\title{
EDUCAÇÃO DO CAMPO: SABERES, DIÁLOGOS E RESISTÊNCIA
}

\author{
ORGANIZADORES \\ Ane Carine Meurer \\ Ivanio Folmer \\ Ricardo Santos de Almeida
}

\section{A $\mathrm{R}$ C 2




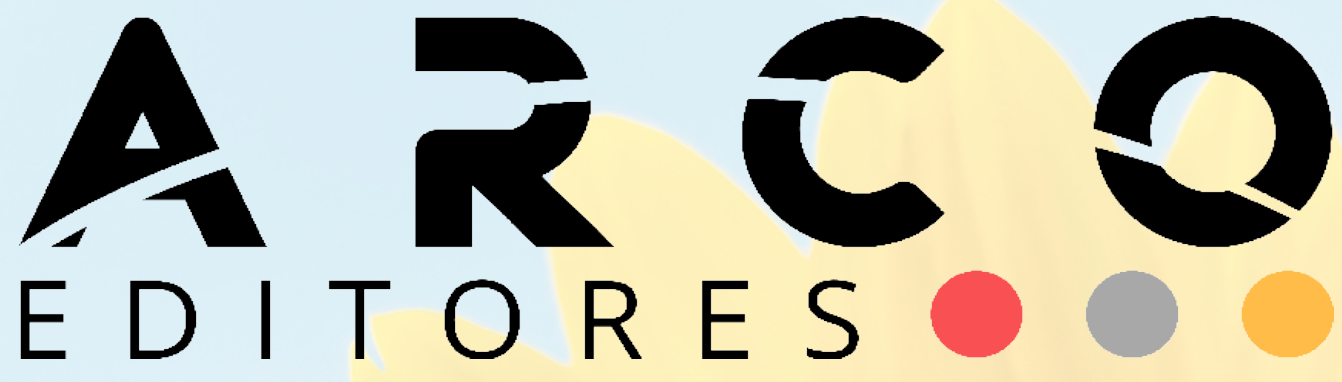

\title{
EDUCAÇÃO DO CAMPO: SABERES, DIÁLOGOS E RESISTÊNCIA
}

\author{
Ane Carine Meurer \\ Ivanio Folmer \\ Ricardo Santos de Almeida \\ [Organizadores]
}


Dados Internacionais de Catalogação na Publicação (CIP) (Câmara Brasileira do Livro, SP, Brasil)

Educação do campo [livro eletrônico] : saberes, diálogos e resistência / organização Ane Carine Meurer, Ivanio Folmer, Ricardo Santos de Almeida. -- 1. ed. -- Santa Maria, RS : Arco Editores, 2021. PDF

ISBN $978-65-994306-7-1$

1. Educação 2. Educação - Finalidade e objetivos 3. Educação rural 4. Escolas do campo 5. Pedagogia 6. Professores - Formação I. Meurer, Ane Carine. II. Folmer, Ivanio. III. Almeida, Ricardo Santos de.

$$
\text { CDD-370.91734 }
$$

\section{Índices para catálogo sistemático:}

1. Educação do campo 370.91734

Aline Graziele Benitez - Bibliotecária - CRB-1/3129

$$
\text { 10.48209/978-65-994306-7-1 }
$$

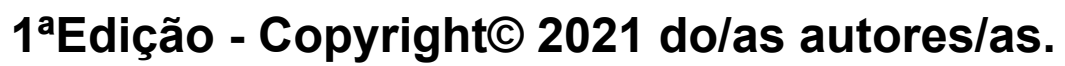




\section{CAPA}

Arco Editores.

\section{DIAGRAMAÇÃO E PROJETO GRÁFICO}

Arco Editores.

\section{REVISÃO}

Dos/as Autores/as.

\section{CONSELHO EDITORIAL}

Prof. Dr. Adilson Tadeu Basquerot e Silva - UNIDAVI/SC

http://lattes.cnpq.br/8318350738705473

Profa. Msc. Jesica Wendy Beltrán -UFCE- Colômbia

http://lattes.cnpq.br/0048679279914457

Profa. Dra Fabiane dos Santos Ramos UFSM- Santa Maria/RS

http://lattes.cnpq.br/0003382878348789

Dr. João Riél Manuel Nunes Vieira de Oliveira Brito -

UAL - Lisboa- Portugal.

http://lattes.cnpq.br/1347367542944960

Profa. Dra. Alessandra Regina Müller Germani -

UFFS- Passo Fundo/RS

http://lattes.cnpq.br/7956662371295912

Prof. Dr. Everton Bandeira Martins UFFS - Chapecó/SC

http://lattes.cnpq.br/9818548065077031

Prof. Dr. Erick Kader Callegaro Corrêa UFN- Santa Maria/RS

http://lattes.cnpq.br/2363988112549627

Prof. Dr. Pedro Henrique Witchs - UFES - Vitória/ES

http://lattes.cnpq.br/3913436849859138

Prof. Dr.Thiago Ribeiro Rafagnin UFOB

http://lattes.cnpq.br/3377502960363268
Prof. Dr. Mateus Henrique Köhler UFSM- Santa Maria/RS http://lattes.cnpq.br/5754140057757003

Profa. Dra. Liziany Müller Medeiros UFSM- Santa Maria/RS

http://lattes.cnpq.br/1486004582806497

Prof. Dr. Camilo Darsie de Souza UNISC-Santa Cruz do Sul/RS

http://lattes.cnpq.br/4407126331414

Prof. Dr. Dioni Paulo Pastorio - UFRGS Porto Alegre/RS

http://lattes.cnpq.br/7823646075456872

Prof. Dr. Leonardo Bigolin Jantsch -

UFSM- Palmeira das Missões/RS http://lattes.cnpq.br/0639803965762459

Prof. Dr. Leandro Antônio dos Santos -UFU- Uberlândia/MG http://lattes.cnpq.br/4649031713685124

Dr. Rafael Nogueira Furtado UFJF- Juiz de Fora/MG http://lattes.cnpq.br/9761786872182217

Dra. Angelita Zimmermann UFSM- Santa Maria/RS http://lattes. cnpq.br/7548796037921237

Profa. Dra. Francielle Benini Agne Tybusch UFN- Santa Maria/RS http://lattes.cnpq.br/4400702817251869 


\section{Prefácio}

Diante da pertinente leitura desta obra, resultante de estudos e pesquisas reflexivas e críticas, em que se evidenciam temáticas necessárias contra o silenciamento ao qual o contexto atual de negações e invisibilidades, insiste em nos colocar, passa a ser uma das vozes que apontam possibilidades e resultados de experiências reais, fatos do cotidiano que se tornaram objetos de estudos e investigações para ressaltar que o campo está vivo e seus sujeitos estão em movimento.

É notório estarmos vivendo o ano do centenário de Paulo Freire, e podermos entre tantas produções, destacar a relevância desta seleção de materiais evidenciando os estudos e pesquisas em Educação do/no campo, enquanto experiência de lutas e resistências, representando a concretização de um projeto de humanização, libertação e participação dos sujeitos na produção das possibilidades de vida digna e igualitária à todas as pessoas, o qual perpassa pela promoção do possível viável na valorização da relação do ser humano, natureza e cultura sob a intencionalidade da existência de homens e mulheres da criança ao idoso, poderem existir em plenitude de direitos e a viver e produzir sua existência de maneira mais humana.

Há de se confirmar, portanto, que o contexto atual, é bom que se registre, soma-se a adversidade de tudo o que se propõe enquanto um projeto democrático, entendendo democracia, como bem nos fundamenta Paulo Freire como forma de vida, consciente de sua existência humana e da problemática de vida cotidiana na qual os sujeitos estão inseridos, portanto é imprescindível fazer a leitura dos textos sob a ótica dos estudos freirianos, os quais revelam a importância destes como marca no tempo e espaço de relações imbricadas por processos de lutas e resistência que nos dizem que o campo está vivo e seus sujeitos continuam a persistir, nos espaços dentro e fora da escola, sejam eles formais ou não-formais, indicando que a construção dos saberes se dá nas mais diversas dimensões das relações humanas.

Construir saberes exige uma reflexão sobre as práticas pedagógicas docentes de seus sujeitos, de sua cultura numa intencionalidade de superação das desigualdades, injustiças e preconceitos que cerceiam as relações sociais humanas. Tal dinâmica, se dá sob a égide do diálogo, categoria pertinente dos estudos freirianos, tão 
necessária à compreensão de que a educação pode sim, acomodar um outro jeito de ver o ser humano considerando sua forma de ser e estar no mundo e com o mundo, onde o campo é uma rica expressão de interrelações pessoais dos movimentos dos seus povos, os povos campesinos com sua cultura transformando-se em suas lutas cotidianas, constituindo-se nas suas subjetividades, especificidades as quais sejam respeitadas.

Os textos encontrados neste livro, representam justamente o esforço bem sucedido da necessidade de explicitar e registrar as mais variadas leituras e percepções em torno da problemática do campesinato e das mais possibilidades da educação do/no campo em suas experiências educativas nos diversos âmbitos, representam a ressignificação do olhar acerca do espaço do campo, espaço de vida e resistência, e seus sujeitos, enquanto sujeitos de direitos. O que nos posiciona na perspectiva de reconhecermos que os povos campesinos pensam o mundo a partir do lugar onde vivem, da sua relação com a terra e os demais seres nela existentes, inclusive se relacionam entre si na intencionalidade da construção de poder ser e viver.

Pensar e fazer um outro mundo não é tarefa fácil, é das mais desafiadoras que se possa desejar, envolve processos formativos dos sujeitos na dinâmica do criar e recriar o mundo em que vive, porque nos fazemos no fazer-se diário, em nossa incompletude pela não conformação do fato dado, imposto e negador da existência humanizada, se fazendo na dialogicidade. Ao que se percebe como parte da dinamicidade da construção deste mundo, não o aceita como se apresenta e permanece na busca de um outro mundo possível, onde homens e mulheres conscientes, fazedores de seu caminho a partir do olhar crítico sobre suas experiências possam fortalecer suas vidas.

É então oportuno registrar, o momento pandêmico imerso em um contexto de políticas negadoras da existência humana em que prevalecem os interesses de um sistema capitalista na sua forma mais cruel, sendo então conveniente ressaltar a educação do/no campo, como possibilidade de mudança, resistência e contra o silenciamento das vozes dos sujeitos históricos que ocupam este espaço social e cultural, representados nestes escritos em que se encontram as pronuncias daqueles que experienciam, vivem a educação do/no campo e suas subjetividades. 
Convido-Ihes, portanto à leitura crítica, no desafio, não de aqui dar-se por satisfeito, mas de quem torna-se desejoso por ir além na busca por saberes que nos dizem da nossa condição humana e do direito de dizer a nossa palavra.

\section{Sara Ingrid Borba}

Lattes: http://lattes.cnpq.br/4761390738481571

ORCID: https://orcid.org/0000-0001-9224-7489

Mestre e doutoranda em Educação - UFPB

Membro do Centro Paulo Freire - Estudos e Pesquisas - UFPE

Marechal Deodoro/AL, 11 de maio de 2021 
A EDUCAÇÃO dO CAMPO E A IDEIa dE CULTURA COMUM DE RAYMOND WILLIAMS.

\section{Amarilson Gordiano de Oliveira}

LICENCIATURA INTERDISCIPLINAR EM EDUCAÇÃO DO CAMPO DA UNIVERSIDADE FEDERAL DE CAMPINA GRANDE: POSSIBILIDADES E DESAFIOS.

\section{Fabiano Custodio de Oliveira}

NOTAS DE UMA ETNOGRAFIA DA PEDAGOGIA DOS POVOS ATINGIDOS POR BARRAGEM: UMA EXPERIÊNCIA DE EDUCAÇÃO DO CAMPO NO AGRESTE PARAIBANO.

\section{Givanilton de Araújo Barbosa}

PROJETOS DE TRABALHO NA EDUCAÇÃO DO CAMPO: A CROMATOGRAFIA DE PFEIFFER COMO POSSIBILIDADE DE (RE) DESENHO AMBIENTAL NO PÓS-PANDEMIa.

\section{Fábio Fernandes Villela}

\section{Oliver Humberto Naves Blanco}

FORMAÇÃO CONTINUADA NA ESCOLA DO CAMPO: $O$ USO DE JOGOS EM AULA DE MATEMÁtICA DO 3 ANO DO ENSINO FUNDAMENTAL.

\section{Ilza Alves Pacheco}

\section{Suely Cristina Soares da Gama}


DO ACAMPAMENTO À FORMAÇÃO DE ASSENTAMENTOS RURAIS: A CONQUISTA DA TERRA E A BUSCA DAS FAMÍLIAS POR MELHORES CONDIÇÕES DE VIDA.

\section{Alessandra Regina Mưller Germani \\ Ana Paula Schervinski Villwock}

SOBERANIA E SEGURANÇA ALIMENTAR: UM RELATO DE PRÁTICA DOCENTE NA MODALIDADE À DISTÂNCIA..........99

\section{Alessandra Regina Mưller Germani}

EDUCAÇÃO dO CAMPO E OS DESMONTES NO PRESENTE GOVERNO BOLSONARO

\section{Sávio Da Silva Aureliano}

Janicleide Vieira Da Silva

Amanda Gomes Dos Santos

EDUCAÇÃO dO CAMPO: MEMÓRIA DAS DISPUTAS DE TERRAS EM NOVA IGUAÇU - RJ

\section{Clodoaldo Ferreira de Oliveira \\ Alexandre Ferreira de Oliveira \\ Cristiano Santos Pimentel}

A ÓTICA DA EDUCAÇÃO DO CAMPO DA UNIVERSIDADE FEDERAL de santa CATARINA SOBRE A EDUCAÇÃo do MUNICÍPIO DE BOM RETIRO/SC. 
EDUCAÇÃO ESCOLAR NO ASSENTAMENTO MENINO JESUS ÁGUA FRIA / BA: DESAFIOS E ENFRENTAMENTOS PARA EFETIVAÇÃO DA EDUCAÇÃO DO CAMPO

\section{Vangilson Ferreira Bispo}

FECHAMENTODEESCOLASNO/DOCAMPO,TERRITORIALIDADE, GESTÃO DEMOCRÁTICA E (AUTO)EDUCAÇÃO DOS POVOS DO CAMPO.

\section{Cláudio Rodrigues da Silva}

ESCOLAS E A EDUCAÇÃO DO CAMPO EM SETE DE SETEMBRO-RS.

\section{Elizandro Luiz Adamski Pauczinski}

CONTRIBUIÇÕES DO “TRABALHO DE CAMPO” (GEOGRAFIA E ANTROPOLOGIA) PARA A FORMAÇÃO ACADÊMICA DE ESTUDANTES DE CIÊNCIAS SOCIAIS

\section{Cláudio Rodrigues da Silva}

A PROdUÇÃo SUCROALCOOLEIRA NA PARAíba E 0 DESENVOLVIMENTO DO TERRIOTÓRIO CAMPONÊS NA PERSPECTIVA DA EDUCAÇÃO DO/NO CAMPO.

\section{Lenira Lins da Silva \\ Juliane Faustino da Silva \\ Edvaldo Carlos de Lima}

(UM) A HISTÓRIA DA PEDAGOGIA DA ALTERNÂNCIA DISCURSIVIZADA PELAS LICENCIATURAS EM EDUCAÇÃO DO CAMPO. 
PERFIL DOS DISCENTES DE UM CURSO DE LICENCIATURA EM EDUCAÇÃO DO CAMPO: UM ESTUDO COMPARATIVO...........24.25

\section{Rita de Cássia Gonçalves}

Natiélia Borges Leal dos Santos

Suzana Gomes Lopes

Tamaris Gimenez Pinheiro

Alexandre Leite dos Santos Silva

EDUCAÇÃO DO CAMPO E EDUCAÇÃO MUSICAL COMO PROJETOS DE EMANCIPAÇAO HUMANA...............................262

\section{Fernando Vieira da Cruz}

Dayana Aparecida Marques de Oliveira Cruz

A INVISIBILIDADE DO CAMPESINATO NA ESCOLA E NO LIVRO DIDÁTICO.

\section{Ana Júlia de Almeida Rosa}

Antonio Miranda de Oliveira

O MONITOR DE EFA: UM RELATO DE EXPERIÊNCIA...............294

\section{Geane Pereira Nunes}

ESCOLAS DO CAMPO E COMUNIDADES: POSSIBILIDADES DE FORTALECIMENTO DIANTE DA AMEAÇA DO FECHAMENTO

\section{Vanessa Dal Canton}

\section{Carine Busatto}


O PROJOVEM CAMPO - SABERES DA TERRA E A EDUCAÇÃO DE JOVENS, ADULTOS E IDOSOS DO CAMPO.

\section{Maria Aparecida Vieira de Melo \\ Marcelo da Fonsêca Santana \\ Ricardo Santos de Almeida}

A POTENCIALIdAde PEdagógica E dE TRANSFORMAÇÃo HUMANA NAS VIVÊNCIAS DE FABRICAÇÃO ARTESANAL DE ERVA-MATE

\section{Moisés da Luz \\ Marcelo Vaz Pupo}

PROCESSOS RESISTENTES NA PERSPECTIVA DA EDUCAÇÃo QUILOMBOLA.

\section{Dilmar Luiz Lopes}

A BNCCE A GEOGRAFIA NA EDUCAÇÃO BÁSICA: AS ESCOLAS DE COMUNIDADES RURAIS DE RESTINGA SECA/RS.

\section{Altair Groff}

\section{Angelita Zimmermann}

Ane Carine Meurer

NOTAS DE UMA ETNOGRAFIA DA PEDAgOGIA DOS POVOS ATINGIDOS POR BARRAGEM: UMA EXPERIÊNCIA DE EDUCAÇÃO DO CAMPO NO AGRESTE PARAIBANO 
OS CENTROS EDUCATIVOS FAMIIIARES DE FORMAÇÃO EM ALTERNÂNCIA E A EDUCAÇÃO DO CAMPO.

\author{
Aline Guterres Ferreira \\ José Vicente Lima Robaina. \\ José Geraldo Wizniewsky
}

SOBRE OS ORGANIZADORES

ANE CARINE MEURER..................................................................417

IVANIO FOLMER.............................................................................418

RICARDO SANTOS DE ALMEIDA...................................................419 


\subsection{9/978-65-CAMPO6-7-2}

\section{A EDUCAÇÃO DO CAMPO E A IDELA DE CULTURA COMUM DE RAYMOND WILLIAMS}

Amarilson Gordiano de Oliveira ${ }^{1}$ 
A população do campo foi marcada historicamente pelo domínio cultural imposto pelos grandes centros. Nas escolas, na mídia, nas mais diferentes instituições, tentou-se disseminar um ideal urbanocêntrico de vida, baseado em um padrão ocidental que subjugava as identidades e os conhecimentos dos sujeitos do campo. Nessa perspectiva, a construção deste artigo se dá com o objetivo de problematizar a cultura do campo em meio a essas relações de poder. Para tal, tomamos como base as ideias de Raymond Williams em dois capítulos do seu livro Recursos da Esperança, uma coletânea de produções do autor entre 1950 e 1980. São estes: "A cultura é algo comum", escrito em 1958, e "A ideia de cultura como algo comum", datado em 1968.

Nesses textos, Williams trata da cultura como algo comum a todos, como um modo de vida baseado em significados comuns, em meio a processos de descoberta e esforços criativos. Para o autor, a cultura é algo inerente a todos de uma sociedade, que constroem e reconstroem significados a partir de modos de pensar individuais. Sendo assim, proponho discutir estas questões relacionando-as com a cultura do campo e seu contexto marcado por lutas históricas, bem como refletir acerca da educação como ferramenta para formar sujeitos mais ativos neste processo de construção de uma cultura comum.

Assim como Williams teoriza questões importantes a partir das suas experiências, o lugar no qual me posiciono neste artigo é marcado por questões que envolvem a cultura do campo. Este lugar é de quem nasceu e foi criado no meio rural, na região do sisal ${ }^{2}$, no qual viveu até os 17 anos, quando ingressou na universidade e, nesse contexto, estudou em escolas do próprio campo até o fim do Ensino Fundamental. Estive em meio a relações de produção rural, com minha família tendo como fonte de renda algumas tarefas ${ }^{3}$ de terra. Voltei à zona rural como professor e, assim como antes, estive em contato com pessoas de diferentes saberes que conseguiam produzir conhecimentos que viriam a facilitar a vida de seus vizinhos do campo. Essas pessoas tinham a capacidade de criar recursos e inclusive aperfeiçoar aqueles

2 Planta que tem como nome científico Agave sisalana, é a principal fonte de renda da região de Conceição do Coité-BA (a $220 \mathrm{~km}$ de Salvador) e cidades vizinhas. Produz uma fibra que pode ser utilizada na fabricação de cordas, fios, tapetes e até na indústria automobilística.

3 Medida agrária utilizada para medir terras na Região do Sisal. 
advindos da cidade com o intuito de superar os problemas rotineiros, como a seca, característica daquela região.

Nessa perspectiva, pensando a partir deste lugar, faz-se relevante discutir a cultura do campo como tendo seus modos de produção e de construção de significados e valores próprios, inserida em uma cultura nacional e que tem contribuições importantes para a sociedade como um todo. Farei isto por meio dos textos acima citados, sempre os confrontando e dialogando com a realidade do campo, a partir das experiências enquanto sujeito do campo, professor e pesquisador.

\section{A IDEIA DE CULTURA COMUM: REPENSANDO A CULTURA DO CAMPO E AS RELAÇÕES DE PODER}

Para que possamos entender como as concepções de Raymond Williams podem servir de instrumento para analisar as relações sociais e de poder atuais, faz-se interessante compreender o lugar no qual se coloca o autor. Foi o que ele mesmo fez em seus trabalhos: posicionar-se enquanto sujeito que tem sua história marcada no meio rural, que estudou na escola da vila, com pai sinaleiro, avô que trabalhou no campo e parentes que trabalhavam na roça. Faz isso ao mesmo tempo em que fala do lugar de escritor, acadêmico, professor, militante de esquerda e crítico literário. Segundo o próprio, "começamos a refletir de onde vivemos" (WILLIAMS, 2015b, p. 49), e a sua experiência particular é relevante no sentido de pensar a própria história sob um outro olhar, um outro lugar, uma outra linguagem.

Aquele lugar onde o autor foi criado tinha sua cultura e seus modos de pensar e produzir. Williams utiliza dessas questões para pensar a cultura como algo comum. Neste trabalho, partiremos dessa ideia para discutir a cultura do campo em meio a relações de poder historicamente construídas por meio da propagação de um ideal urbanocêntrico, que tenta silenciar as vozes das identidades dos povos do campo. Williams (2015) acredita que o fato primordial é que a cultura é algo comum a todos, e a partir desse princípio é que vamos pensar a cultura do campo como tendo sua organização própria, seus modos de produção, de relações em grupo, de articulação de ideias - e estes não são menores que outros.

Nesse sentido, o autor afirma que "toda sociedade humana tem sua própria forma, seus próprios propósitos, seus próprios significados. Toda sociedade humana 
expressa isso nas instituições, nas artes e no conhecimento" (WILLIAMS, 2015a, p. 5). Tomamos o campo como lugar de enfrentamento, cuja organização social é marcada por desafios, como as lutas pela terra, contra a seca, assistência do Estado no que se refere à produção, dentre outras. Contudo, esses desafios são em grande medida superados pela participação ativa de movimentos sociais, cooperativas, associações e sindicatos rurais e outras organizações específicas do campo. São instituições muitas das vezes com economias próprias, que produzem conhecimento e articulam ideias a fim de melhorar a vida no meio rural. Além disso, a cultura camponesa é expressa em movimentos artísticos preservados durante anos, como a literatura, a música, o artesanato, a pintura, dentre outros.

Sabemos que os processos de industrialização acarretaram na centralização do poder na cidade. O ideal urbano foi e continua sendo propagado pelas elites, pela mídia e, por vezes, pelo próprio Estado. Essa disseminação da cultura urbana tem influência na cultura do campo, isso é um fato. É inegável que determinados padrões sejam por vezes adotados, tendo em vista a ampla divulgação da mídia para o consumo de bens e serviços. No entanto, os sujeitos do campo não são meramente influenciáveis, como tal ideal tende a induzir. A metáfora do velho mascate, que Williams (2015a) cita, diz-nos muito acerca dessa questão. O autor, por meio desta, posiciona-se criticamente em relação a como a classe trabalhadora da Inglaterra do século XX é vista, inclusive por meio das próprias áreas do conhecimento.

O velho mascate ainda está lá no mercado, contando os tostões que ganhou dos moleques da zona rural, com seus anéis e relógios de ouro falsificados. Ele pensa que suas vítimas são lerdas e ignorantes, mas elas estão vivas, e cultivam a terra enquanto ele tosse atrás de sua barraquinha. O novo mascate está em escritórios bem decorados, usando resíduos da linguística, da psicologia e da sociologia para influenciar os modos de pensar dos que ele chama de "a massa". Ele também, no entanto, vai ter que desmontar sua barraquinha e ir embora, e enquanto isso não acontece, não devemos nos influenciar por seu linguajar: podemos simplesmente nos recusar a aprendê-lo (WILLIAMS, 2015a, p. 9).

Essa metáfora nos ajuda a entender que as pessoas do campo não são alienadas, que têm seus meios próprios de pensar e rejeitar as coisas e não são meramente influenciáveis. Aqueles que estão na posição de prestígio, da elite, podem imaginar que estão Ihes manipulando, mas na verdade eles rejeitam muito mais do que imaginam e têm seus próprios padrões no seu próprio campo, que vão de encontro aos 
que aqueles da elite urbana tenta impor.

Do mesmo modo, Williams (2015a), em suas considerações sobre a cultura inglesa - que, como já foi dito, diz-nos muito sobre as relações de poder atuais entre campo e cidade, acredita que a classe trabalhadora não deve, de forma alguma, ser pensada como separada da cultura, apesar de estar suprimida de determinados processos às custas da dominação imposta. Nesse sentido, o autor pontua que

Há uma cultura inglesa burguesa, com suas poderosas instituições educacionais, literárias e sociais, em conexão estreita com os centros reais de poder. Dizer que a maioria dos trabalhadores é excluída de tudo isso é dizer o óbvio, embora, sob pressão contínua, estas portas estejam levemente se abrindo. Mas daí dizer que os trabalhadores estão excluídos da cultura inglesa é bobagem: eles têm suas próprias instituições em expansão e, em todo caso, muito da cultura estritamente burguesa eles não iriam mesmo querer (WILLIAMS, 2015a, p. 11).

Isso leva Williams a não aceitar o termo "massa de ignorantes" ao se referir aos trabalhadores, como faziam os marxistas, que ele critica. Ele concorda com o fato de que a cultura de dominação de classe está restrita a uma classe pequena, mas deixa claro que isso não deve acarretar na inferiorização da cultura daqueles que não fazem parte da elite. O modo de vida de uma sociedade, segundo o autor, é marcado por produções e conquistas de diferentes classes, inclusive da própria burguesia. Ele admite que "o tempo livre conquistado pela burguesia nos legou muitas coisas de valor cultural" (WILLIAMS, 2015a, p. 11), porém, esse fato não quer dizer que a cultura burguesa se caracteriza como a própria cultura contemporânea. Existem diferentes obras de arte, de conhecimento e produção de significados naquelas culturas que não estão na posição de prestígio, mas que dizem muito sobre uma cultura nacional.

Nessa perspectiva, cabe pontuar que os trabalhadores do campo não necessariamente vão aceitar e/ou ter desejo por tudo o que venha a ser disseminado como ideal pela classe burguesa urbana atual, embora possam incorporar determinadas coisas, se for de seu interesse. Do mesmo modo, suas produções também estão marcadas no modo de vida da sociedade em geral, apesar de não ser dado o devido valor, assim como Williams (2015a) descreve as relações da cultura inglesa (mais uma vez tomando o duplo lugar de sujeito com suas origens na classe trabalhadora e de acadêmico com modo de vida diferente), na qual encontramos ressonância com a discussão atual. 
Há um modo distinto de vida da classe trabalhadora a que, eu pelo menos, dou muito valor - não porque fui criado nesse modo, uma vez que, de certa forma, agora vivo de um jeito diferente. Penso que esse modo de vida, com sua ênfase na vizinhança, obrigações mútuas e progresso comum, como expresso nas grandes instituições políticas e industriais da classe trabalhadora, é de fato a melhor base para uma sociedade inglesa futura. Quanto às artes e ao aprendizado, são, em um sentido real, uma herança nacional que está, ou deveria estar, disponível para todos (WILLIAMS, 2015a, p. 11-12).

Pensando por outro lado, os avanços acarretados pela globalização, que, apesar de ser uma forma de expansão por todo o mundo de um ideal urbanocêntrico ocidental, são importantes no que se refere às tecnologias e à facilidade de acesso a bens e serviços pela população do campo. Assim como Williams (2015a) pontua sobre a relevância da revolução industrial para os povos do campo daquela época na Inglaterra, devemos reconhecer que tais tecnologias facilitam a vida no campo e contribuem para avanços nos processos de produção na agricultura e na pecuária, a título de exemplo. O autor destaca essa questão por meio de sua própria experiência, quando conta:

[...] em casa estávamos todos muito satisfeitos com a Revolução Industrial e com as mudanças sociais e políticas que ela trouxera. [...] havia uma conquista que sobrepujava a tudo, uma conquista por que pagaríamos qualquer preço, ou seja, a conquista da força motriz, que significava muito para os homens que trabalhavam com as mãos. Demorou para que todas as possibilidades chegassem até nós, mas a máquina a vapor, o motor a óleo, estes e mais uns sem números de produtos, de mercadorias e de serviços associados, nós os aceitávamos assim que nos éramos oferecidos, e estávamos bem satisfeitos. Vi todas essas coisas sendo usadas e vi o que elas substituíam (WILLIAMS, 2015a, p. 14-15).

Hoje, a máquina a vapor e o motor a óleo, aos quais Williams se referia, são as modernas máquinas agrícolas e até aplicativos que facilitam a produção. Obviamente nem todos os produtores do campo têm acesso a esses serviços, mas ao passo que a tecnologia tem avançado, a vida de mais pessoas do campo tem sido facilitada. Da mesma forma, também há pontos negativos nesses avanços. Mas o fato é que os trabalhos manuais, árduos e arriscados têm sido substituídos por equipamentos que tiram o peso do produtor. As instituições, que oferecem serviços de educação, saúde, assistência, dentre outros, também têm avançado no sentido de facilitar o acesso às pessoas do campo. Williams (2015a) faz uma crítica àqueles que, em grande 
medida, são contra determinados avanços para os trabalhadores que vieram com a Revolução Industrial:

Não tenho paciência para ouvir a cantilena de sempre contra tudo isso, a saber, o desprezo com que muitos se referem ao encanamento, aos minicarros, à aspirina, aos contraceptivos, à comida enlatada. Mas respondo a esses fariseus: água suja, latrina, andar cerca de quilômetros todos os dias para chegar ao trabalho, dores de cabeça, mulheres desgastadas, fome e uma dieta monótona. Os trabalhadores, tanto do campo como da cidade, não vão dar ouvidos (e têm todo o meu apoio) a qualquer versão de nossa sociedade que parta do pressuposto de que essas coisas não representam um progresso, e não apenas um progresso mecânico, extrínseco, mas um avanço real da própria vida (WILLIAMS, 2015a, p. 15).

Além dessas questões, o autor também acredita que esse novo contexto para os trabalhadores possibilita uma maior liberdade, uma maior compreensão e uma maior margem para opinar (WILLIAMS, 2015a). Para a população do campo, estar conectada aos avanços possibilita à classe trabalhadora estar em uma interação mais efetiva com o que acontece, pensar e agir criticamente, podendo assim buscar melhorias para além do seu canto de terra.

Nesse sentido, Williams trata da capacidade da classe trabalhadora, descrita como as massas ${ }^{4}$, de fazer uma leitura inteligente e posicionar-se criticamente em meio a produções culturais e opiniões da imprensa. Mais uma vez trazendo o exemplo de sua família, cita a facilidade do seu pai em entender questões complexas da sociedade e confrontar informações por meio da leitura. Ele afirma que essa capacidade do seu genitor "trata-se apenas de inteligência, mesmo que parcialmente formada" (WILLIAMS, 2015a, p. 19-20). Com isso, ele nos diz que, apesar de algumas pessoas terem pouco acesso à educação, são capazes de ler e interpretar fatos de forma crítica, sob um olhar que leva em conta a experiência e o contato com a vida real nas situações mais cotidianas.

Tendo em vista essas questões, a educação se torna um instrumento essencial para formar cidadãos ainda mais críticos. Dessa forma, faz-se primordial facilitar o acesso à educação e promover um currículo contextualizado para a população do campo. Assim, Williams (2015a) pontua que é importante reconhecer que a educação também é algo comum, que se caracteriza como um "[...] processo de dotar todos

4 O autor afirma que "as massas não existem de fato, o que existem são modos de ver pessoas como massas (WILLIAMS, 2015, p. 16). 
os membros da sociedade com a totalidade de seus significados comuns e com as habilidades que lhes possibilitarão retificar esses significados, à luz de suas próprias experiências pessoais e comuns" (WILLIAMS, 2015a, p. 21). Ou seja, os sujeitos do campo devem estar em contato com conhecimentos que são comuns à sociedade, mas trabalhados de forma que dê margem para que possam criticar esses próprios conhecimentos, por meio de suas vivências em seu contexto cultural, e que atenda às suas necessidades. Do mesmo modo, a educação também deve permitir que esses sujeitos também produzam conhecimento no ambiente escolar, assim como o fazem em outras instâncias.

Nessa perspectiva, Williams (2015b) acredita que a criação de significados e valores não pode se restringir a uma minoria. Essa ideia é por muitas vezes disseminada, ao se pensar na elite urbana como a única encarregada dessa criação. Contudo, é preciso reafirmar que a cultura do campo, assim como outras historicamente subjugadas, tem grandes contribuições para a criação dos significados e valores da sociedade em geral. O fato é que, assim como a análise de Williams acerca da Grã-Bretanha contemporânea, essas pessoas eram excluídas pelo próprio sistema educacional, no que se refere aos significados construídos por seus antepassados e à participação ativa na evolução destes e de outros significados (WILLIAMS, 2015b). Isso se dá por conta, dentre outros fatores, da propagação da cultura burguesa urbana e seus significados como aquilo que é ideal. Nesse sentido, as críticas de Williams são pertinentes, quando ele afirma que

Não seria uma cultura comum (embora seja possível chamá-la de cultura em comum) se alguns segmentos existentes de experiência, organizados de uma maneira particular, fossem simplesmente propagados - e ensinados - a outros, de modo que então os tivessem como um domínio comum. Segue-se, a partir da ênfase original, que a cultura de um povo só pode ser o que todos os seus membros se empenham em criar no ato de viver: que a cultura comum não é a disseminação geral do que uma minoria queira dizer e crer, mas a criação de uma condição na qual o povo como um todo participe da articulação de significados e valores e das consequentes decisões entre este e aquele significado, entre este e aquele valor (WILLIAMS, 2015b, p. 54).

À vista disso, o sistema educacional, como destaca o autor, deveria ser ressignificado, ao ponto de deixar de classificar pessoas por meio de um padrão dominante, entre aquelas que são educadas e aquelas consideradas simplesmente como as outras. Ou seja, pensar uma educação em que não haja um pequeno grupo 
que emite significados e outros que apenas os recebem. Seria mudar a lógica de que a cultura urbana produz significados e estes são repassados à população do campo como aquilo que é ideal. Do mesmo modo, seria também colocar essas pessoas do campo como protagonistas da criação de seus próprios significados, que também podem ser emitidos e recebidos por outros. Isto é, para que envolva uma corroboração de todos (WILLIAMS, 2015b).

Por este ângulo, Williams (2015b) afirma que, para que haja uma cultura comum, é preciso uma democracia educada e participativa. Em outras palavras, de acordo com o autor, seria uma educação amplamente disponibilizada, que viesse a fornecer meios para que os sujeitos estivessem qualificados para participar ativamente do processo de construção de significados e valores. A questão é que, no caso da educação do campo, quando disponibilizada para todos de uma determinada região, os sujeitos enquanto aprendizes foram historicamente educados a partir de um padrão urbano, que não Ihes permitia ter voz ativa no processo de aprendizagem. Isso acarretou em uma tentativa de imposição de conhecimentos e pensamentos de uma cultura urbana, que, ensinados como a imagem do ideal, moldaram a ideia de cultura nas escolas do campo. Nesta linha, Williams aborda mais um ponto relevante para esta discussão, quando diz que

\begin{abstract}
Qualquer sociedade rumo à qual possamos nos mover terá, antes de tudo, uma complexidade tão considerável que nesse sentido ninguém poderá possuir "propriedade cultural" da mesma forma, inevitavelmente, as pessoas alcançarão aspectos diferentes da cultura, escolherão aquele em vez deste, prestarão atenção neste e esquecerão aquele. Se for um ato de escolha, é inteiramente bem-vindo; se a decisão do que é acessível e do que é omitido for um ato de escolha alheia, então com certeza desaprova-se (WILLIAMS, 2015b, p. 57).
\end{abstract}

No que diz respeito à educação do campo, o currículo precisa ser pensado a partir deste princípio: em meio a um contexto cultural particular, de modos de produção próprios, os sujeitos na condição de aprendizes não podem estar meramente em contato com aquilo que é selecionado pelo outro como o ideal a ser aprendido. Não pode ser uma escolha alheia, como diz Williams. Os próprios sujeitos, em meio a diferentes formas de conhecimento, vão optar naturalmente pelo que vai ser útil para o seu desenvolvimento enquanto cidadão e o que pode ampliar suas possibilidades, 
podendo ser os conhecimentos advindos da cultura urbana, inclusive, ou simplesmente negando-os.

\section{CONSIDERAÇÕES FINAIS}

No decorrer deste trabalho, dialogamos com a ideia de cultura comum de Raymond Williams, estabelecendo uma conexão com a cultura do campo e as relações de poder existentes em meio a um contexto de propagação de um ideal urbanocêntrico. Tomando dois textos de Williams como apoio, discutimos sobre a importância de tratar os sujeitos do campo como tendo seu próprio modo de vida, inseridos em um contexto específico, mas com contribuições para a formação de uma sociedade.

Desse modo, buscamos ao longo do trabalho levar em consideração o lugar no qual o autor se posiciona, trazendo suas concepções acerca da Inglaterra do século XX e relacionando-as ao contexto atual da relação campo/cidade. Vemos que, da mesma forma que aqueles povos eram subjugados e inferiorizados pela elite inglesa, a população do campo também passa por esse processo, ao vivenciar a tentativa de se ter suas vozes silenciadas por um pensamento elitista urbano. Contudo, entendemos que esses sujeitos não são influenciáveis, como aqueles que estão na posição de prestígio podem pensar, mas sim pessoas com a capacidade de negar o que é transmitido como ideal e produzir seu próprio conhecimento.

Nesse sentido, é preciso que a educação seja instrumento de poder para essas pessoas. Da mesma forma, que o currículo educacional possa prover de meios para que possam participar ativamente de questões da sociedade em geral, criticar o que é imposto, aceitando ou negando aquilo que é do outro, assim como construir e reconstruir significados e valores, não só para o seu contexto em particular, mas para transmitir a outras culturas, assim como lhes é feito.

\section{REFERÊNCIAS}

WILLIAMS, Raymond. A cultura é algo comum. In: . Recursos da Esperança. São Paulo: Editora Unesp, 2015.

WILLIAMS, Raymond. A ideia de uma cultura comum. In: . Recursos da Esperança. São Paulo: Editora Unesp, 2015. 


\section{LICENCIATURA INTERDISCIPLINAR}

EM EDUCAÇÃO DO CAMPO DA UNIVERSIDADE FEDERAL DE

\section{CAMPINA GRANDE:}

\section{POSSIBILIDADES E DESAFIOS}

Fabiano Custodio de Oliveira ${ }^{5}$

$5 \quad$ Fabiano Custódio de Oliveira é doutor em Planejamento Urbano e Regional, pela Universidade Federal do Rio de Janeiro (2017). Mestre em Geografia pela Universidade Federal da Paraíba (2007). Licenciado em Geografia pela Universidade Estadual da Paraíba (2004). Atualmente é professor da Universidade Federal de Campina Grande - UFCG e lotado no Centro de Desenvolvimento Sustentável do Semiárido - CDSA - Sumé/PB. É coordenador do Laboratório de Ensino de Geografia e Educação do Campo (LEGECAMPO). Membro do Núcleo de Pesquisa em Educação do Campo, Formação de Professores/as e Práticas Pedagógicas (NUPEFORP). É professor de Geografia da Licenciatura Interdisciplinar em Educação do Campo na Área das Ciências Humanas e Sociais - fabiano.geografia@gmail.com 
A Educação do Campo é uma política pública que nos últimos anos vem se fortalecendo no Brasil. Essa política pública é caracterizada como o pagamento de uma dívida histórica do Estado aos sujeitos do campo, que tiveram negado o direito a uma educação de qualidade, uma vez que os modelos pedagógicos marginalizavam os sujeitos do campo, já que se vinculavam ao mundo urbano, desconhecendo a diversidade sociocultural do povo brasileiro. Desta forma, Caldart (2002) destaca que os sujeitos do campo têm direito a uma educação pensada, desde o seu lugar e com a sua participação, ligada à sua cultura e às suas necessidades humanas e sociais.

A partir desse direito surgiu o curso de Licenciatura em Educação do Campo, voltado para formar profissionais para atuarem nas escolas do campo, tendo assim uma formação diferenciada das outras licenciaturas, pois o Curso de Licenciatura em Educação do Campo visa formar sujeitos para atuarem por área de conhecimento e não por disciplinas isoladas, gerando assim uma maior amplitude na área de atuação dos profissionais da Licenciatura em Educação do Campo.

Partindo do pressuposto de que a Licenciatura em Educação do Campo tem por objetivo formar professores para atuarem por área de conhecimento, nos surgiu a inquietação de entendermos como se dá o processo formativo do(a) licenciando(a) em Educação do Campo da Universidade Federal de Campina Grande.

Assim sendo, essa pesquisa tem por objetivo apresentar o surgimento e o percurso formativo da Licenciatura Interdisciplinar em Educação do Campo da Universidade Federal de Campina, tendo por base o Projeto Pedagógico do Curso Interdisciplinar em Educação do Campo.

\section{CAMINHOS METODOLÓGICOS}

Nessa pesquisa utilizamos os pressupostos da pesquisa qualitativa, como indica Gil (2012), desenvolvida por diferentes etapas, a primeira etapa consistiu em identificar o objeto a ser pesquisado, na segunda etapa foi realizada uma pesquisa bibliográfica para fundamentação do objeto a ser pesquisado, tendo como base SILVA (2011); SANTOS (2013); AUED e VENDRAMINI (2012); CALDART (2002); MOLINA (2015), PIRES (2012) e RODRIGUES (2002), a terceira etapa consistiu na 
pesquisa no Projeto Pedagógico do Curso Interdisciplinar em Educação do Campo da Universidade Federal de Campina Grande.

Os dados foram analisados a partir de uma abordagem qualitativa, apresentados através de quadros e discutidos de forma descritiva.

\section{RESULTADOS E DISCUSSÃO}

\section{Breve Histórico da Licenciatura em Educação do Campo}

Segundo Silva (2011), a história da implantação de projetos educacionais para os povos do campo sempre esteve ligada aos projetos econômicos de fortalecimento do capital, mostrando assim que a escola faz parte de um todo e tende a incorporar a forma como se estruturam as relações de trabalho na sociedade. Resultando, assim, em uma organização escolar voltada totalmente para a elite do país, deixando a maioria da população marginalizada, ou seja, sem acesso aos direitos políticos, civis, e sociais, destacando principalmente uma negligência à escolarização.

Esse modelo de educação nasceu junto ao conceito de Educação Rural que surgiu na década de 1920, num grande jogo de interesses entre a burguesia industrial, que eram emergentes da oligarquia agrária e o movimento dos pioneiros da educação, passando assim a afirma-se a partir de 1930, pois, segundo o governo da época, era necessário educar as populações rurais, povoar e sanear o interior (SILVA, 2011)

Essa visão da educação como redentora da miséria e da pobreza trouxe para o campo um modelo de escola vinculado ao projeto de modernização conservado$\mathrm{ra}^{6}$, que era patrocinado por cooperativas Norte-Americanas e propagado através do sistema de assistência técnica e extensão rural. Tendo como finalidade adequar a população do campo ao projeto desenvolvimentista, que submeteu a agricultura à industrialização, centralizada na visão de que o Brasil para se desenvolver precisaria se industrializar e urbanizar (SILVA, 2011).

A partir da década de 1950, o discurso sociológico de extinção do rural passa a

$6 \quad$ No campo a expressão clássico da modernização conservadora é a revolução verde, ou Revolução Agrícola, em que a produção agrícola foi modernizada, por meio de implementos agrícolas, pacotes agroquímicos, sementes modificadas, etc., mas a estrutura agrária foi mantida. 
ser predominante dentro e fora da universidade, num ponto de vista de que o campo é uma divisão sociocultural, que deve ser superado e não sustentado. Por isso concordamos com Silva quando a mesma afirma que:

“ (...) na história da educação da classe trabalhadora rural, os anos 1940 representam dois problemas contra os quais ela lutou até hoje: a negação da escola para si e seus filhos, ou seja a impossibilidade real e concreta de acesso ao saber sistematizado e o predomínio de projeto e campanhas pela reprodução ampliada do capital para qualificar mão de obra (SILVA, 2011 pg. 406)

Dessa forma, se compreende que na década de 1940 existia uma grande luta pelo direito à escola, impedindo assim o acesso ao saber estruturado, gerando assim uma repetição do capital para qualificar mão de obra boa e barata.

Ainda segundo Silva (2011), no dia a dia das relações sociais do campo/rural observa-se como os valores da sociedade urbana são impostos de forma acentuada, fazendo uma mistura de velhos e novos elementos como partes do processo de modernização conservadora capitalista, nas relações sociais de produção e vai-se construindo uma concretude e um entendimento do campo sem uma perspectiva de desenvolvimento sustentável, e, portanto, sem gente.

Essas maneiras de avanço do capitalismo no campo juntamente com o modelo de educação rural contribuíram para a desterritorialização e a erradicação dos povos do campo de seu ambiente, e da busca da zona urbana como única perspectiva de vida e de sobrevivência. Essa determinação leva a uma drástica perda de valores de uma cultura, a perda de identidade, por este motivo a escola precisa também ser pensada como lugar de resistência dessa imposição (CALDART, 2002).

De acordo com Molina (2015), as mudanças na ideia de educação rural para educação do campo não se deram unicamente pela verificação da escola rural, mas também pela rejeição ao processo conservador de modernização para o campo, protegido pelo poder político e pelas elites agrárias. A educação do campo é contrária ao modelo de desenvolvimento capitalista que combina latifúndio e agronegócio, pois estes são grandes culpados pela exclusão e morte dos camponeses. A educação do campo numa nova concepção está ligada à reforma agrária e à agricultura camponesa e agroecológica. 
A emergência da educação do campo caracteriza-se pela ausência, pela experiência e pela proposição. O Estado deveria assegurar o direito dos sujeitos do campo à escolaridade, e a uma formação consistente e contextualizada para professores trabalharem nessas escolas do campo. Dessa forma, a experiência que é desenvolvida pelos movimentos sociais e organizações não governamentais foram as bases para a elaboração da proposta da educação do campo (AUDER e VENDERMINI (2012).

A partir de 1980 começaram a surgir Centros de Educação Popular que eram constituídos em sua maioria por militares cristãos, estudantes intelectuais que procuravam recuperar a concepção de educação popular que tiveram seus trabalhos iniciados na década anterior, e tinha a finalidade de ajudar os movimentos sindicais e populares que começavam a se rearticular no país (PIRES, 2012).

Segundo Silva (2011), esses Centros de Educação Populares tiveram uma grande contribuição para a implantação do movimento de Educação do Campo e das práticas educativas desenvolvidas por organizações desde o final dos anos de 1980. Tais centros tinham o trabalho voltado para a "convivência com o semiárido", e já existia o debate sobre a necessidade de se reinventar as escolas localizadas na zona rural, além de se ter formação inicial e continuada para os educadores que iriam atuar no campo, e também trazer a contextualização da educação como forma de mostrar o real significado do ensino/aprendizagem e, principalmente, de colocar a escola em conversa com a realidade, os sujeitos e as organizações sociais.

A declaração de que as pessoas do campo têm direito a uma educação contextualizada com a sua realidade surgiu para oferecer aos sujeitos do campo uma educação voltada para sua vida, sua cultura e sua forma de trabalhar, que hoje em dia conhecemos como Educação do Campo (PIRES, 2012).

Ainda segundo Silva (2011), das argumentações levantadas pelos movimentos da sociedade civil organizada e de iniciativas de instituições de ensino superior, requeridos nos anos de 1990, torna-se questão estratégica e temática a formação de docentes para a educação básica. Algumas iniciativas foram fundamentais na formação e apresentação da Educação do Campo como:

O I Encontro Nacional de Educadoras e Educadores da Reforma Agrária - ENERA, que foi realizado em julho de 1997, a realização da I e II Conferência Nacionais Por uma Educação Básica do Campo, respecti- 
vamente em julho de 1998 e em 2004, a articulação nacional das experiências educativas da Pedagogia da Alternância nos Centros de Formação Familiar por Alternância - CEFFAS em 2000, a articulação da Rede de Educação do Semiárido Brasileiro - RESAB em 2000, a Marcha das Margaridas que reivindicou a criação da Coordenação de Educação do Campo em 2004 (SILVA, 2011 pg. 411).

Essas foram algumas iniciativas nacionais que fortificaram o processo de inclusão da Educação do Campo na agenda política e viabilizaram o debate acerca da prática pedagógica nas Escolas do Campo, denunciando a precariedade das escolas localizadas no campo e também os educadores que não eram profissionais formados para atuarem nessas escolas do campo, gerando assim a necessidade de se ter uma política educacional voltada para o campo.

A elaboração das Diretrizes Operacionais para a Educação Básica nas Escolas do Campo, pelo Conselho Nacional de Educação, que deu resultado na Resolução CNE/CEB $n^{0} 1$, de abril de 2002, foi um processo político no interior do Estado Brasileiro, que conseguiu mobilizar as diferentes organizações e a academia em torno da organização do Movimento da Educação do campo, uma nova nota na legislação brasileira sobre a Educação do campo, abrindo assim espaço para a normatização da Pedagogia da Alternância e o decreto presidencial de 2010, que criou e reconheceu a Educação do Campo e o PRONERA (CALDART, 2002).

Conforme Silva (2011), a partir desse momento, ainda como recurso em construção e como definição não concluída, a Educação do Campo, como direito dos alunos à igualdade do acesso às políticas educacionais e do respeito às diferenças, passa a difundir-se nos diferentes espaços organizativos e acadêmicos do país.

Segundo Silva (2011), em 2004 foi criado, no Ministério de Educação, a Secretaria de Educação Continuada, Alfabetização e Diversidade (SECAD), onde existe uma coordenação de Educação do Campo, e foi organizado ainda no MEC um Grupo Permanente de Trabalho (GPT) sobre educação do campo, virando um espaço de diálogo entre Estado e Sociedade Civil dentro do MEC, e com governantes estaduais e municipais.

Esses procedimentos usados pelas políticas públicas mostram um avanço, no sentido de uma estabilização de políticas educacionais voltadas à realidade do cam- 
po. É de conhecimento público o documento da Coordenação Geral de Educação do

Campo/SECAD/MEC que, dentre outras questões destaca:

a) A necessidade de ações assertivas para corrigir a desigualdade sofrida pelos povos do campo, o que particularmente tirou ao longo dos tempos o direito à educação básica e a precariedade no funcionamentos das escolas do campo, bem com a precariedade presente também na formação dos profissionais que nelas atuam; b) A necessidade de construir políticas de expansão das escolas públicas que ofereçam educação básica no e do campo, entendendo a importância de se criar alternativas de organização dos currículos e do trabalho docente, com a necessidade de mudar o quadro atual principalmente na oferta dos anos finais do ensino fundamental e do ensino médio; c) que considera como "escolas do campo" tanto as escolas localizadas em comunidades rurais como também aquelas que estão localizadas na zona "urbana" e que atendem educandos oriundos do campo; d) Que entende a grande necessidade de se ter uma formação diferenciada e continuada para professores atuarem no campo além de aprenderem a valorizar as potencialidades existentes no campo; e) Que entende a urgência de existirem ações afirmativas que ajudem a transformar a situação educacional que hoje existe no campo. Para isso existe uma necessidade de organizar o trabalho pedagógico, e a formação em uma docência multidisciplinar por áreas de conhecimento. Isso faz necessário uma formação específica para os educadores que irão atuar nestas escolas; f) a amostra de experiências educativas relacionadas ao campo que mostre a necessidade de se pensar uma política voltada para o campo, para que assim se altere o cenário de exclusão educacional que ao longo do tempo os povos do campo vêm sofrendo.

Analisando as questões, verificamos que existe um esforço concentrado para a formação dos profissionais das escolas do campo e tenta atender ao que diz o artigo 67 da Lei n 9.394/96 - Lei de Diretrizes e Bases da Educação Nacional - LBDEN e os artigos 12 e 13 das Diretrizes Operacionais da Educação do Campo, que sugere a formação de professores num ponto de vista de profissionalização docente, o que engloba o direito à formação inicial em todos os níveis, e um processo de formação continuada possibilitando que o professor atue no campo e na cidade com competência.

No dia 23 de novembro de 2005, a "Carta de Gramado", do Conselho Nacional de Secretários de Educação (CONSED), efetuou o compromisso das secretarias estaduais de educação com a "elaboração e implementação de políticas públicas para a educação do campo", destacando como uma das temáticas principais a "formação inicial e continuada de professores", abrindo assim um canal de conversa e amplia- 
ção fundamental para implantação dos futuros profissionais da Educação do campo no mercado de trabalho (SANTOS, 2013).

Através do CONSED, quatro universidades Federais foram convidadas a desenvolver uma experiência piloto, foram ela: Universidade de Brasília - UnB, Universidade Federal de Minas Gerais - UFMG, Universidade Federal da Bahia - UFBA e a Universidade Federal de Sergipe - UFS. Atualmente temos 42 novos cursos de Licenciatura em Educação do Campo, totalizando 46 cursos em todo território brasileiro.

Segundo Molina (2015), o curso de Licenciatura em Educação do Campo tem como alvo a escola de Educação Básica, com destaque na construção da Organização Escolar e do Trabalho Pedagógico para os anos finais do Ensino Fundamental e do Ensino Médio. Os cursos têm como objetivo preparar educadores para irem além da docência e operarem na gestão de processos educativos escolares e na gestão de processos educativos comunitários.

De acordo com a organização da carga horária do mencionado curso, utiliza-se o regime de alternância, isto é, os graduandos alternam períodos presenciais concentrados de aulas na universidade, equivalentes a semestres de cursos regulares. Esses momentos são chamados de "tempo/espaço escola-curso". As atividades a serem desenvolvidas pelos alunos nos seus locais de trabalho e moradia, orientadas pelos professores, ou pela coordenação do curso, ou pelas assembleias dos próprios estudantes serão desenvolvidas no que o curso denomina de "tempo/espaço comunidade-escola do campo" (SILVA, 2011).

A organização curricular estrutura-se, observando a oferta de disciplinas, em três níveis de formação articulados e integrados: a) formação básica; b) formação integradora; c) formação específica. Nesse sentindo, Rodrigues (2002) destaca que a educação do campo requer uma formação que ultrapasse a educação formal, por esta estar ligada às fronteiras que impedem os sujeitos de desenvolverem um projeto histórico de emancipação humana.

\section{LICENCIATURA INTERDISCIPLINAR UFCG - PERCURSO FORMATIVO}

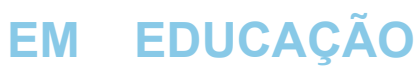

O Curso de Licenciatura em Educação do Campo resulta de um longo processo de debates e diálogo entre movimentos sociais do campo, Ministério da Educação 
e as Universidades Públicas, dentre as quais a UFCG aderiu desde o princípio. O processo de criação deste curso em nível nacional foi romper com a formulação do Programa de Apoio à Formação Superior em Licenciatura em Educação do Campo - PROCAMPO, com o primeiro passo da Secretaria de Educação Continuada, Alfabetização e Diversidade do Ministério da Educação - SECAD/MEC.

"O PROCAMPO tem como finalidade apoiar a implementação de cursos regulares de Licenciatura em Educação do Campo nas Instituições de Ensino Superior em todo o país, voltados especificamente para a formação de educadores (as) para a docência nos anos finais do ensino fundamental e no Ensino Médio nas escolas do campo (PPC do curso de Licenciatura em Educação do Campo, 2011, pg.09)."

A UFCG foi convidada a desenvolver uma experiência piloto juntamente com outras quatro universidades públicas federais: UnB, UFMG, UFBA e UFS. Por questões operacionais do Ministério da Educação, o projeto da UFCG não conseguiu ser executado nesse primeiro momento. No entanto, como a discussão assemelha-se com a aprovação da criação do CDSA - Sumé, que em seu projeto já contemplava esse curso, a comissão de criação do curso deu continuidade a sua definição como um curso regular do CDSA.

Outra ocasião importante foi a apresentação e discussão da proposta inicial do curso em reunião ordinária do Comitê Paraibano de Educação do Campo (12/11/2008), que resultou em importantes contribuições para a elaboração deste projeto. Bem como, e, sobretudo, buscou-se referência, na realidade social, cultural e educacional dos territórios do Semiárido, que serão potencialmente beneficiados pela oferta do Curso, além das orientações do Comitê Paraibano de Educação do Campo, organizado por representantes do Poder Público Estadual e Municipal, das Universidades Públicas do Estado e Movimentos Sociais. Nesse sentido, a Universidade Federal de Campina Grande - UFCG, atendendo à referida demanda, apresenta sua proposta de Curso de Licenciatura em Educação do Campo pautada em toda uma história que reúne a vocação desta Instituição de Ensino Superior para se relacionar com os povos e a série de problemas do campo.

Dessa forma, o objetivo geral do curso da UFCG é formar professoras (es) para a Educação Básica em consonância com a realidade social e cultural específica das populações que trabalham e vivem no e do campo, na diversidade de ações 
pedagógicas necessárias para concretizá-la como direito humano e como ferramenta do desenvolvimento social. O curso tem ainda como objetivos específicos habilitar professores (as) para a docência multidisciplinar na educação do campo nas seguintes áreas de conhecimento: Linguagens e Códigos, Ciências Humanas e Sociais e Ciências Exatas e da Natureza, e formar educadores (as) para atuação na Educação Básica com competências a fazerem a gestão de processos educativos e a desenvolverem estratégias pedagógicas que visem à formação de sujeitos autônomos e criativos capazes de produzir soluções para questões inerentes a sua realidade, vinculadas à construção de um projeto de desenvolvimento sustentável para o país.

A Licenciatura em Educação do Campo se estabelece pela sua especificidade de formar professores (as) para atuar nas escolas básicas do campo, preparando e estimulando educadores para uma atuação que vá além da docência e dê conta da gestão dos processos educativos que acontecem na escola e nos seus arredores. Para isso seu projeto pedagógico se caracteriza para se desenvolver de modo articulado, ensino, pesquisa e extensão para habilitar professores para a docência multidisciplinar nos Anos Finais do Ensino Fundamental e no Ensino Médio por meio de um currículo organizado por áreas de conhecimentos.

O curso está organizado no regime presencial e adotando o sistema de créditos com abordagem na metodologia da alternância, o curso compreende um total de 235 créditos e 3.525 horas, a serem integralizadas, no mínimo, em oito e, no máximo, em doze períodos letivos, com aulas concentradas em três dias da semana: quartas, quintas e sextas.

O trabalho pedagógico, conforme a metodologia da alternância é desenvolvido em dois tempos: tempo escola e tempo comunidade. O tempo academia - que é o tempo de formação na academia, desenvolvido na Unidade Acadêmica de Educação do Campo do CDSA/UFCG na cidade de Sumé. O tempo comunidade - compreendido como o tempo de exercício da prática pedagógica, da pesquisa e da extensão é desenvolvido nos locais de trabalho/moradia dos estudantes.

A matriz curricular está organizada em três dimensões da formação docentes articuladas e integradas: Formação básica, formação específica e formação Integradora. 
A formação básica tendo como base o estudo da literatura pertinente e a análise crítica de distintas realidades educacionais, inclui, entre outros aspectos, a "utilização de conhecimento multidimensional sobre o ser humano, em situações de aprendizagem". Caracteriza-se pela formação geral do alunado, incluindo conhecimentos que subsidiam a docência, quanto às dimensões filosófica, sociológica, histórica, política, psicológica, econômica, cultural etc.

A formação específica está voltada às áreas de atuação profissional e engloba: os conhecimentos básicos para a prática pedagógica em cada área do conhecimento para atuação nos anos finais do ensino fundamental e no ensino médio do campo; e a gestão, coordenação, avaliação do trabalho pedagógico, a criação e uso de textos, materiais didáticos, procedimentos, metodologias e processos de aprendizagem que abrangem a diversidade social e cultural da sociedade brasileira.

Engloba, portanto, conhecimentos designados à capacitação do docente para os conteúdos e metodologias específicas de sua área de atuação, além de conhecimentos desejando uma maior modernização da formação docente frente às transformações de uma sociedade complexa e plural. Dessa forma, são propostas as seguintes áreas de aprofundamento: Ciências Humanas e Sociais, Ciências Exatas e da Natureza e Linguagens e Códigos.

a) Ciências Humanas e Sociais (Geografia, História, Sociologia e Filosofia);

b) Ciências Exatas e da Natureza (Física, Química, Biologia e Matemática); ou

c) Linguagens e Códigos (Língua Portuguesa, Literatura, Língua Estrangeira, Artes e Cultura Corporal).

Cada uma das áreas de aprofundamento é composta por 64 (sessenta e quatro) créditos complementares obrigatórios para a formação específica, com uma carga horária de 960 (novecentos e sessenta) horas, a serem complementadas ao longo do curso a partir do $4^{\circ}$ período, no qual os estudantes farão a opção por uma das áreas e seguir.

A formação integradora, cujo objetivo é propiciar atividades de enriquecimento didático, curricular, científico e cultural. 
O graduando em Licenciatura em Educação do Campo trabalha com um repertório de informações e habilidades composto por pluralidade de conhecimentos teóricos e práticos, cuja consolidação será proporcionada pelo exercício da profissão, fundamentando-se em interdisciplinaridade, contextualização, democratização, pertinência e relevância social, ética e sensibilidade afetiva e estética. Este repertório se constituir por meio de múltiplos olhares, próprios das ciências, das culturas, das artes, da vida cotidiana, que proporcionam leitura das relações sociais e étnico-raciais, também dos processos educativos.

Entre o período de setembro de 2009 a dezembro de 2020 houve algumas mudanças no seu projeto inicial da Licenciatura em Educação do Campo, entre eles podemos destacar: dias do tempo academia, forma de ingressar no curso e inserção de novas disciplinas no percurso formativo. Essas mudanças são frutos de debates entre o NDE, colegiado do curso, alunos e docentes que estão finalizando a elaboração de um novo Projeto Pedagógico do Curso Interdisciplinar em Educação do Campo.

\section{CONSIDERAÇÕES FINAIS}

Com a finalização da pesquisa, identificamos que com a universalização do acesso à escola, a sociedade brasileira - e em especial a escola - tem enfrentado o desafio de incorporar grupos sociais que historicamente foram excluídos dos processos de escolarização. No enfrentamento desse desafio, cabe ao licenciado em Educação do Campo contribuir na tarefa de democratizar o acesso aos conhecimentos visando, entre outros objetivos, a promoção da melhoria nas condições de vida das pessoas.

De modo mais específico, isso implica em ser um profissional capaz de investigar, refletir, gerar conhecimento, gerir e ensinar tanto no âmbito escolar como em espaços não-escolares. Tais competências são coerentes com aquilo que as "Diretrizes Operacionais para a Educação Básica nas Escolas do Campo" estabelecem para a formação de professores para o exercício da docência nas escolas do campo, acentuando: o respeito à diversidade cultural e o protagonismo tendo em vista a interação e transformação do campo; o aprender de forma autônoma e contínua, realizando o duplo movimento de derivar o conhecimento; trabalhando de forma multidisciplinar; pautando-se na ética e na solidariedade enquanto ser humano, cidadão 
e profissional.

Nesse contexto a Licenciatura Interdisciplinar em Educação do Campo da UFCG é de grande relevância para a educação, devido a sua especificidade de formar professores (as) para atuar nas Escolas Básica do Campo, preparando educadores para uma atuação que vá além da docência e dê conta da gestão dos processos educativos que acontecem na escola e no seu entorno. Para tanto seu projeto pedagógico se caracteriza para se desenvolver de modo articulado ensino, pesquisa e extensão para habilitar professores para a docência multidisciplinar nos Anos Finais do Ensino Fundamental e no Ensino Médio por meio de um currículo organizado por áreas de conhecimentos numa perspectiva interdisciplinar, diferenciando das demais licenciaturas que formam por campo disciplinar.

\section{REFERÊNCIAS}

AUED, Bernadete e VENDRAMINI, Célia Regina (Org). Temas e Problemas no Ensino em Escolas do Campo. São Paulo: Outras expressões, 2012.

CALDART. Roseli Salete et al (org). Caminhos para transformação da Educação: Reflexões desde práticas da Licenciatura em Educação do Campo. São Paulo: Expressão Popular: 2002.

CALDART. Roseli Salete. Licenciatura em Educação do Campo e projeto Formativo. In:_. CALDART. Roseli Salete et al (Org). Caminhos para transformação da Educação: Reflexões desde práticas da Licenciatura em Educação do Campo. São Paulo: Expressão Popular: 2002. P. 127-154.

Gil, Antônio Carlos, Métodos e Técnicas de Pesquisa Sociais 6. ed.. São Paulo: Atlas, 2012.

MOLINA, Monica Castagna, Expansão das licenciaturas em educação do campo: Desafios e Potencialidades, UFPR, Curitiba; 2015.

PIRES, Ângela Monteiro Pires. Educação do Campo Como Direito Humano. São Paulo: Cortez, 2012.

Projeto Pedagógico do Curso da Licenciatura em Educação do Campo - UFCG, 2011. 
RODRIGUES. ROMIR. Reflexões Sobre a Organização Curricular por Área de Conhecimento In:__. CALDART. Roseli Salete et al (Org). Caminhos para transformação da Educação: Reflexões desde práticas da Licenciatura em Educação do Campo. São Paulo: Expressão Popular: 2002. P. 101-126

SANTOS, Cláudio Félix dos, 0 "aprender a aprender" na formação de professores do campo, Campinas, SP: Autores Associados; 2013.

SILVA, Maria do Socorro, A Construção da Licenciatura em Educação do Campo: Espaço de Diálogo e Ruptura na Universidade, João Pessoa: Editora UFPB, 2011. 


\section{NOTAS DE UMA ETNOGRAFIA DA}

\section{PEDAGOGIA DOS POVOS ATINGIDOS}

POR BARRAGEM: UMA EXPERIENCIA

DE EDUCAÇÃO DO CAMPO NO AGRESTE

PARAIBANO 7

Givanilton de Araújo Barbosa ${ }^{8}$

$7 \quad$ Apresentei os primeiros resultados deste estudo no "I seminário nacional de educação popular e movimentos sociais do campo: $V$ encontro de pesquisas e práticas em educação do campo da paraíba" realizado no Centro de Educação da UFPB no ano de 2019. Sua primeira versão teve o título: estudo antropológico acerca da "pedagogia dos povos atingidos" por barragem. Já o presente conteúdo se refere a um relatório desta pesquisa que ampliei a sistematização dos dados etnográficos contando com revisão teórica e adequação metodológica conforme o andamento da pesquisa tanto teórica quanto de campo.

$8 \quad$ Mestrando em Antropologia pela UFPB. givaniltonbarbosa10@gmail.com 
A antropologia permite compreender as mudanças sociais e culturais em sociedade, leva em conta a alteridade e particularidades das relações sociais e culturais que foram estabelecidas em um território. Dito isto, o presente conteúdo se refere a um relatório de pesquisa sobre a Pedagogia dos Povos Atingidos do Movimento de Atingidos Por Barragem no Brasil.

Em conformidade este estudo etnográfico objetiva compreender a criação e finalidade da pedagogia dos povos atingidos por barragem, contextualizar a cultura de atingidos por barragem, identificar e traçar o percurso da pedagogia dos povos atingidos por barragem e mapear as práticas pedagógicas articuladas ao movimento social desde seu ponto de vista histórico.

Para este momento ampliei a sistematização dos dados etnográficos que contou com revisão teórica e adequação metodológica conforme o andamento da pesquisa, tanto teórica quanto de campo.

Nos passos metodológicos levo em conta a abordagem qualitativa e analítica acerca dos dados empíricos. A partir da teoria antropológica para o estudo da cultura local, considero especialmente "a experiência etnográfica" (CLIFFORD, 2002), "Argonautas do pacífico ocidental" (MALINOWSKI,1978) e "a interpretação da cultura" (GEERTZ, 1989).

Neste sentido levo em conta a história do Movimento dos Atingidos por Barragem no Brasil, quanto ao avanço no âmbito da criação de sua "Pedagogia dos Povos Atingidos" (MEDEIROS, 2010) enquanto Política Educacional do MAB (2005).

Outro passo metodológico importante é o estudo dos princípios da educação do campo (BRASIL, 2010), (CALDART, 2004) (MANÇANO e MOLINA, 2004) articulados ao conceito de Movimentos Sociais (GONH, 1995) enquanto ações coletivas para entendimento da realidade social da população pesquisada.

Em seguida considero um contexto social apontando três terrenos etnográficos (BARBOSA, 2017) com elementos acerca de uma história mais geral do Movimento dos atingidos por barragem no Brasil, e sua questão social mais local.

Assinalo um breve histórico sobre a pedagogia dos povos atingidos do MAB (2005), e consequentemente a questão local da implantação do Movimento no ano 
de 2000 nas comunidades ribeirinhas atingidas pela barragem de Acauã no Município de Itatuba, agreste do Estado da Paraíba.

Em meio a isso, há também a investigação da abordagem do uso pelo MAB da concepção de Educação do campo (CALDART, 2009) pelo MAB (2005). Ao mesmo tempo investigo a formação e organização coletiva da população atingida no MAB Acauã, e sua configuração enquanto mobilização e resistência social.

Diante do exposto, resta saber, enquanto problemática de pesquisa: Como se constituiu e, ao mesmo tempo vem se revelando, no âmbito nacional e local, a pedagogia dos povos atingidos por barragem, enquanto política pública de educação do movimento dos atingidos por barragem do Brasil?

A justificativa principal desta pesquisa se concentra na identificação de novas práticas educativas associadas aos movimentos sociais na cultura local, em um determinado território brasileiro.

Haja vista, tais novas práticas educativas, ligadas a políticas educacionais, resultam de novas demandas sociais, diante de uma sociedade cada vez mais globalizada e em constante mudanças, especialmente atreladas a populações do campo atingidas por barragem.

\section{DESENVOLVIMENTO}

\section{A cultura local}

Antes de mais nada é importante destacar que um território é construído socialmente, onde culturas e políticas são produzidas constantemente, isto é, atividades produtivas à manutenção social e dinâmica social podem modificar os modos de vida social próprios da localidade (GLUKCMAN, 1987).

Quanto ao estudo interpretativo da cultura local representa um esforço social para "aceitar a diversidade entre várias maneiras que seres humanos tem de construir suas vidas no processo de vivê-las" (GEERTZ, 1997, p. 29).

A cultura não é meramente um sistema de convicções e práticas formais. É essencialmente formada por reações individuais a um padrão tradicionalmente determinado e por variações deste padrão; e, realmente, nenhuma cultura jamais poderá ser entendida se a atenção especial não for dedicada a esta variação de manifestações individuais (VELSEN, 1987, p. 355). 
Geertz (1997, pp. 13-15) explica que ao abandonar a tentativa de explicar fenômenos sociais através de uma metodologia que os tece em redes gigantescas de causas e efeitos, em vez disso teria que tentar explicá-los colocando-os em estruturas locais de saber, por sua vez "a cultura é adquirida, os costumes variam, o mundo é composto por uma variedade de tipos humanos".

Ou seja, a expressão de compreensão da diversidade de culturas implica em considerar um princípio norteador, o da alteridade, outra que para que haja o entendimento da cultura local também implica na aceitação do outro.

Geertz (1997, pp. 29-86) propõe que o estudo interpretativo da cultura representa um esforço para aceitar a diversidade entre várias maneiras que seres humanos tem de construir suas vidas no processo de vive-las, isto é, para o autor é necessário que o antropólogo veja o mundo do ponto de vista dos nativos.

Quanto ao conceito de cultura, (GEERTZ, 1997, p. 115) implica em analisar o senso comum e não necessariamente seu exercício, deve, portanto, iniciar-se por um processo em que se reformule esta distinção com reflexão prévia aos problemas sociais cotidianos.

Logo isso, demonstra a dedicação do pesquisador especialmente o antropólogo no uso de suas atribuições, de um olhar treinado, de uma sensibilização de um olhar para a cultura local, uma vez que o significado é, está para compreender os modos de vida dos sujeitos como eles são e por eles mesmo, isto é, fazendo com que haja a possibilidade que eles falem por eles.

\section{Movimentos Sociais e Educação}

Conforme discutido em Gohn (2011, p. 333) os movimentos Sociais sempre fizeram parte da construção das sociedades, pois são mecanismos vitais ao processo de mudança do meio social. São, portanto, um dos meios de conversão de uma sociedade a uma nova realidade a partir da ação coletiva, a autora também afirma que,

Movimentos sociais são ações coletivas de caráter sociopolítico, construídas por atores sociais pertencentes a diferentes classes e camadas sociais. Eles politizam suas demandas e criam um campo político de força social na sociedade civil. Suas ações estruturam-se a partir de repertórios criados sobre temas e problemas em situações de conflitos, litígios e disputas. As ações desenvolvem um processo social e político-cultural que cria uma identidade coletiva ao movimento, a partir de interesses em comum. Esta identidade 
decorre da força do princípio da solidariedade e é construída a partir da base referencial de valores culturais e políticos compartilhados pelo grupo (GOHN, 1995, p. 44).

Neste sentido os movimentos sociais se caracterizam, sobretudo, pelo senso de coletividade voltado à resolução de problemas, seja de ordem política, econômica ou sociocultural, que são de interesse compartilhado do grupo, há então, a criação de uma percepção acerca de movimentos sociais, a Educação, podendo agir de maneira pedagógica no "processo formativo libertário emancipatório" nos espaços de vivências (FREIRE, 1984).

Para Gohn (1995) é importante perceber o viés marxista de análise crítica sobre as mudanças sociais, isto é, os movimentos sociais podem possibilitar a organização de um grupo social insatisfeito com mudanças que em suma, impostas pelo sistema capitalista.

Portanto, é importante perceber os movimentos sociais do ponto de vista da cultura local, neste caso a análise também pode partir da relação entre comunidade e escola observando suas particularidades e finalidades, se há articulações entre proposta de educação contextualizada e da politização ou sistematização das demandas sociais locais.

\section{A Educação do campo}

A politização das demandas sociais pelos movimentos sociais pode surgir diversas propostas de políticas públicas sociais articuladas aos direitos sociais da Constituição Federal do Brasil (1989), nesta ocasião a modalidade da Educação do campo é uma demanda social oriunda das experiências históricas dos povos do campo (FERNANDES; MOLINA, 2004).

Conforme afirma Caldart (2009, p.36) discutir sobre a Educação do campo hoje, e buscando ser fiel aos seus objetivos de origem, nos exige um olhar de totalidade, em perspectiva, com uma preocupação metodológica, sobre como interpretá-la, combinada a uma preocupação política, de balanço do percurso e de compreensão das tendências de futuro para poder atuar sobre elas.

Segundo Caldart a "Educação rural" situa-se em uma educação eurocêntrica colonizadora, onde seu objetivo principal é de colonizar o outro para que possa aten- 
der suas necessidades para a manutenção do capital estrangeiro e nacional sobretudo desconsiderando os modos de vida dos trabalhadores do campo e tornando-os assalariados, por sua vez, acarretando a desvalorização dos modos de vida do Campo, ou seja,

Pensar a Educação do Campo está em desde ou junto com uma concepção de Campo de significados e assumir uma visão de totalidade dos processos sociais, é reconhecer os processos históricos brasileiros que formou o modelo de sociedade, é garantir avanços institucionais que percebam a valorização da vida cultural e social do Campo, é perceber a exploração da força de trabaIho que resultou na pobreza extrema e desvalorização do campo (CALDART, 2004, p. 5).

Dessa maneira, os modos de vida são revistos por meio da perspectiva de Educação, porém levando em conta todas as esferas da vida social [cultura, economia local, trabalho e renda, saberes tradicionais, território e outros] que abrangem direta e indiretamente as populações do campo em questão.

Trata-se também de acionamentos de dispositivos institucionais do campo jurídico que regulam políticas sociais locais do cenário social em questão, uma vez que envolve a comunidade em sua totalidade considerando seus conflitos e saberes no processo de vivê-los considerando tanto seu passado quanto o presente.

Dito isto, as especificidades da Educação do campo são formas de reaver os modos de vida das famílias, como também faz com que essa população se reconheça como tal podendo permitir a valorização e pertencimento a sua organização social própria,

A Educação do Campo é uma Política Pública que propõe reaver a trajetória dos modos de vida de comunidades, saberes e fazeres do Campo. Revisitar as trajetórias de vida da população camponesa, atenuando para as mudanças sociais devido a inserção da industrialização e que distanciou o Camponês de sua própria identidade e pertencimento enquanto camponês (CALDART, 2004, p. 7).

É necessário reconhecer essas transformações sociais do ponto de vista capitalista e de projeto internacional, por outro lado requer formação humana para situar as pessoas a reconhecerem seu contexto social e possibilitar o acesso da população do Campo ao direito a Universidade, construir o diálogo entre o Campo e Universidade na produção de conhecimento. 
Portanto, ao falar de Educação do Campo, enquanto Política Pública, Nascimento (2009, p. 189) considera "um processo de construção de um projeto Popular Alternativo de desenvolvimento para o Brasil e para a realidade camponesa", sendo assim, especificando novos valores éticos e culturais.

Ou seja, a Educação do campo ocupa-se em pensar o campo e sua gente, seu modo de organização social, do trabalho, espaço geográfico, da organização política, de suas identidades culturais, celebrações e seus conflitos.

Segundo Fernandes e Molina (2004), de 1997 a 2004 aconteceu a especialização da Educação do Campo através de diversos movimentos sociais, discutindo a escolarização das populações do campo, construção de materiais didáticos apropriados, valorizando as práticas dos educandos permitindo maior participação nos seminários locais, regionais e nacionais.

\begin{abstract}
A ideia de criação da Política Educacional de Educação do Campo nasceu em julho de 1997, quando da realização do Encontro Nacional de Educadores da Reforma Agrária - ENERA, na Universidade de Brasília (UnB) promovido pelo Movimento dos Trabalhadores Rurais Sem Terra - MST, em parceria com a UnB, Fundo das Nações Unidas para a Infância - UNICEF, a Organização das Nações Unidas para a Educação, Ciência e Cultura - UNESCO e a Conferência Nacional dos Bispos do Brasil - CNBB no processo de construção partindo de estudos, pesquisas e reflexões realizadas a respeito das diferentes realidades do campo (FERNANDES; MOLINA, 2004, p. 4).
\end{abstract}

Com base em muitos estudos e pesquisas, professores e pesquisadores de diferentes áreas de conhecimento resultou na legalização da modalidade de ensino, a educação do campo, pelo decreto $n^{\circ}$ 7.352, de 4 de novembro de 2010 (BRASIL, 2010) que aprovou a Política de Educação do Campo, por sua vez representa todas as experiências dos povos do campo, sendo indispensável seu Art: $2^{\circ}$ afirmando os Princípios da Educação do Campo.

Já os princípios da Educação do campo se define em: Respeito à diversidade do campo; Incentivo à formulação de projetos político pedagógicos específicos para as escolas do campo; Desenvolvimento de políticas de formação de profissionais da educação do campo; Valorização da identidade da escola do campo por meio de projetos pedagógicos com conteúdo curriculares e metodologias adequadas às reais necessidades dos discentes do campo e Controle social da qualidade da educação 
escolar, mediante a efetiva participação da comunidade e dos movimentos sociais do campo (BRASIL, 2010).

Segundo Fernandes e Molina (2004), o campo da Educação do Campo é analisado a partir do conceito de território como espaço político onde se realizam determinadas relações sociais transformado em projeto de desenvolvimento socioeconômico, cultural e ambiental contribuindo para transformar a realidade.

De tal modo que, "trabalhar na terra, tirar da terra a sua existência, também exige conhecimentos que são construídos nas experiências cotidianas e como também na escola" (FERNANDES; MOLINA, 2004, pp. 4-7).

Quanto as experiências cotidianas, o território é um espaço de relações socioculturais, de disputas e de ligações afetivas, também é um território socialmente construído entre grupo sociais, isto é, "compreender a territorialidade como o conjunto daquilo que se vive pelo conjunto no cotidiano", as relações de trabalho, familiares, comunitárias, de consumo, de tal modo a não homogeneizar a sociedade (SOUZA; PEDON, 2007, p. 136).

Já a construção da identidade no território, Souza e Pedon (2007) afirmam ser um processo que se constrói ao longo do tempo, tendo como principal elemento o sentimento de pertencimento do indivíduo ou grupo com seu espaço de vivência e este sentimento de pertencer ao espaço em que se vive, de conceber o espaço como lócus das práticas sociais e culturais, ou seja onde se tem o enraizamento de sociabilidade ao mesmo tempo dá a esse espaço o caráter de território.

De modo geral, a educação do campo faz parte da política educacional brasileira, é uma modalidade de ensino e aprendizagem para além dos muros da escola, outra que ao longo de sua institucionalização vem sendo implantado cursos de graduação e pós-graduação nos diferentes territórios brasileiros.

Logo, a Educação do campo é resultado de um longo processo histórico dos povos do campo, de suas lutas sociais por direitos, especialmente em resposta às desigualdades educacionais e da ausência de escolas de qualidade e que garantissem o direito desses povos à educação de qualidade, contemplando suas culturas e modos de vida. 


\section{Terreno etnográfico I}

\section{História de atingidos por barragem}

Estudar o tema atingidos por barragem no Brasil implica abordar uma complexa relação da sociedade e meio ambiente como a formas de organização social, uso de recursos naturais, acumulação e desenvolvimento capitalista (BARTH, 2000). Em meio a isso, o Movimento dos atingidos por barragem vem constituindo uma história de luta e resistência social.

De acordo com Maria José Reis (2007, p. 473) estudiosa da área, no Brasil o movimento dos atingidos por barragens teve início por volta no final da década de 1970 na região do alto Uruguai RS/SC devido aos prejuízos de grandes implantações de hidrelétricas objetivando a produção de energia elétrica. De maneira simultânea, comunidades ribeirinhas foram deslocadas de seus lugares e reassentadas distantes do rio, de modo que tiveram seus direitos violados.

Sendo um movimento de luta constante junto aos atingidos, atua na assessoria de organização dos atingidos e em pautas de reivindicação diante de órgãos oficiais do Estado brasileiro objetivando a reconstrução de infraestrutura de educação, saúde, habitação digna para exercício de uma plena cidadania das populações atingidas. Ao longo do tempo de sua atuação junto às populações para consolidação desta causa, elaboraram sua própria política de mobilização (REIS, 2007).

Segundo Santos (2015, pp.115-117) ao discutir o tema com base na teoria de Carlos Wainer, o "conceito de atingido" diz respeito ao reconhecimento e legitimação de direitos de seus detentores. Ou seja, é estabelecer que determinado grupo social, família ou indivíduo é, ou foi atingido por certo empreendimento, significa reconhecer como legítimo o direito de ressarcimento, indenização, reabilitação ou reparação.

Em meio a isso, acontece a realocação de populações ribeirinhas em reassentamentos, na maioria, em lugares áridos, tornando sua principal característica a perda da qualidade de vida, e ao mesmo tempo a perda de qualidade ambiental.

Portanto o surgindo a categoria social de "atingidos por barragem" (SANTOS, 2015), está relacionada a construção de identidades individuais e coletivas de 
interações sociais, políticas e produção de culturais de um povo, isso se constroi ao longo da vida social se configurando numa resistência coletiva.

\section{Terreno etnográfico II \\ A pedagogia dos povos atingidos por barragem}

Considerando os elementos apresentados e ao mesmo diante de uma sociedade cada vez mais globalizada (MARCUS, 2001), surge então, de um lado um outro momento social importante, o de lutas sociais e de organização de movimentos sociais, por outro lado a de considerar o período de redemocratização do Brasil que favoreceu a construção e fortalecimento desses movimentos sociais.

Com base nisso, destaco o Movimento dos atingidos por barragem e suas lutas constantes, entre elas suas contribuições significativas para a construção de sua "pedagogia dos povos atingidos" por barragem (MEDEIROS, 2010).

Em meio a tantas contribuições destaco uma delas, a organização do $1^{\circ}$ Encontro intitulado "Coletivo de Educação" realizado entre os dias 07 a 10 de agosto de 2004 na Cidade de Luziânia no Estado de Goiás, o seminário contou com a participação de 30 colaboradores ligados à Educação de 14 Estados brasileiros incluindo Estados nordestinos como Sergipe, Ceará e Paraíba.

Outro levantamento que considero importante foi a mobilização positiva diante da proposta, de forma coletiva os coordenadores Estaduais se integraram ao Coletivo de Educação com a preocupação de traçar o Projeto inicial de Educação do Movimento dos Atingidos por Barragem do Brasil, dessa maneira, a proposta de pensar uma "Pedagogia dos Povos Atingidos por barragem" consiste substancialmente,

com o propósito de qualificar por meio de práticas educativas o processo de conscientização, participação e organização das pessoas, que direta ou indiretamente sofreram modificações nas condições de vida em consequência da implementação de barragens, e também realizando planejamento para a capacitação nos Estados com viabilidade para o desenvolvimento do processo de formação dos Educadores à nível nacional (MAB, 2005, p. 25-42).

A partir deste encontro um Projeto de Educação foi elaborado com demandas recolhidas, sendo lançado naquele mesmo ano denominado de "A Pedagogia dos Povos Atingidos", com vista aos os princípios da Educação do Campo. 
Com uma pedagogia dos povos atingidos (MEDEIROS, 2010), a Coordenação Nacional do Movimento deAtingidos por Barragem do Brasil sistematizou uma proposta de educação ampla e consistente para ser implantada nas comunidades reassentadas. Assim, os coordenadores Estaduais se articularam com os coordenadores nacionais para a implantação do projeto de educação nas respectivas regiões, ao mesmo tempo foram viabilizadas parcerias com as secretarias dos Estados e Municípios na elaboração de políticas sociais voltadas as populações atingidas.

Um aspecto importante identificado foi a vinculação da proposta educativa do MAB (2005) às questões, desafios e mobilizações em prol também da Educação do Campo (2010), mas com diretrizes e perspectivas próprias, dando respaldo às reivindicações de políticas públicas de desenvolvimento e de educação específicas direcionadas para os camponeses com identidade, trabalho, cultura, história e suas formas e estágios de organização desses povos, visando a abrangência de todos os níveis de escolaridade.

Diante da uma proposta formulada enquanto política pública de educação foram realizados acordos e convênios entre o Movimento dos atingidos por barragem e instituições públicas. Em conformidade passa a ser constituída uma rede de articulação Estadual no intuito de mobilização das comunidades atingidas para o enfrentamento e reivindicações no processo de solucionar os problemas socioeconômicos e ambientais vividos por elas.

Diante disso, também reincide na proposta de Educação do MAB Brasil (2005) o reconhecimento do campo como espaço de vida, moradia e trabalho, resultando a necessidade de justiça e humanização dos povos atingidos que vivem nesse espaço e que foram historicamente excluídos do direito à Educação e à Cultura erudita.

Dessa maneira, tal proposta educativa lista uma série de pretensões como Diretrizes, entre elas: diagnosticar as necessidades de Educação dos povos atingidos; fortalecimento de sua história e cultura; Mapear financiamentos, Editais, convênios e parcerias; Elaboração de Projetos específicos; Elaboração de material didáticometodológicos para o trabalho pedagógico (MAB, 2005).

Um aspecto importante nesse processo são as articulações políticoeducacionais, em meio a isso, iniciativas do MAB diante de Instituições Públicas de Estado, por sua vez podendo consistir em articulações também com Instituições 
privadas.

Por sua vez, a ocorrência mais emblemática foi com o Ministério de Educação e Cultura - MEC, para a aquisição de convênios, especialmente no período de 2004 a 2016, com consecutivas intermitências. Conforme discutido por Medeiros (2010), este tipo de convênio possibilitou que as entidades conveniadas poderiam adotar a linha teórico-metodológica própria principalmente para a Alfabetização de Jovens e Adultos.

Dessa maneira, tendo sido garantidas as condições básicas de financiamento do Projeto, o MAB seguiu a linha própria do Movimento (MEDEIROS, 2010). Com essas iniciativas e reivindicações do MAB nacional foram adquiridos convênios com estatais e desenvolvidas atividades através das Políticas Educacionais, assim, garantindo as especificidades que o Movimento defende.

A Educação de jovens e Adultos (EJA), foi uma das principais pautas da pedagogia dos povos atingidos por barragem, através de um convênio do MAB nacional com o MEC e ELETROBRAS, neste projeto houveram duas etapas de 8 meses cada, contemplando todos os reassentamentos atingidos por barragem.

Diante de uma questão social complexa, há nesse processo justificativas indispensáveis que resultou na criação da Pedagogia dos Povos Atingidos por barragem: de inspiração Freiriana (1984), considera o alto índice de vulnerabilidade socioeconômica, de analfabetismo e escolaridade incompleta.

[...] os atingidos precisam conhecer a História do Brasil dentro do cenário mundial, a organização da estrutura da sociedade para compreender sua conjuntura local, o funcionamento do capitalismo internacional para entender o capitalismo nacional, o poder político das esferas nacional e internacional para compreender o poder político local, dessa maneira, levando em conta o conhecimento por meio da interdisciplinaridade, complementaridade e totalidade (MAB, 2005, pp. 37-40).

Dito isto, seu currículo contempla uma estrutura na perspectiva de circunscrever o indivíduo atingido. Medeiros (2010, p. 209) ao observar os objetivos da pedagogia do MAB, afirma que sua proposta contém: I. Fonte sociocultural; II. Fonte Políticoorganizativa; III. Fonte epistemológica e IV. Fonte Psicossocial. 
Já no ano de 2015 foi desenvolvido o projeto Brasil Alfabetizado, ocorrendo também um importante experiencia, o convênio entre o MAB e o Governo do Estado da Paraíba, desta vez, o projeto também contempla a Educação de jovens e adultos nos reassentamentos, agenciadas pela secretaria de Educação do Estado e o Movimento dos atingidos por barragem, este segundo encarregando-se de fazer a mobilização em cada reassentamento.

De modo geral a coordenação do MAB nacional (2005) considerou que ocorreu um avanço significativo na sua organização como Movimento Social Organizado, inserindo a Educação na sua Agenda Política (MEDEIROS, 2010), concebendo a Educação como um direito social e na disposição para atuar na conquista desse direito.

Ao mesmo tempo o MAB preocupou-se em conquistar espaços próprios de Educação Formal, garantindo Certificação Oficial e com práticas Educativas que consolidem a conscientização dos atingidos num contexto de resistência, organização e luta com populações atingidas por barragens em diferentes territórios do Brasil.

\section{O terreno etnográfico III Os atingidos de Acauã}

Esta pesquisa vem ocorrendo em uma área territorial considerando três reassentamentos agrovilas, são eles: sítio Cajá e sítio Melancia localizados precisamente no município de Itatuba e do distrito de Pedro Velho do município de Aroeiras, todos no agreste do Estado da Paraíba. Nessa região, no ano de 2000 foi instalada a barragem de Acauã, seus efeitos socioculturais, ambientais e econômicos foram inúmeros causando perdas e deslocamento territorial.

Consequentemente, de acordo com o levantamento realizado pela comissão especial de direitos humanos formada para avaliar os impactos negativos no de 2005 (CCEDH, 2005: 2007) constatou que há uma média de 5 mil habitantes atingidos pela represa.

O interesse de estudar esta região se deu por eu ter residido em uma das comunidades atingidas, o Sítio Cajá zona rural de Itatuba-PB. Diante disso, com minha inserção no curso Licenciatura em Ciências Sociais na UFPB, passei a 
estudar o tema atingidos por barragem, a partir da cultura local, especialmente à luz da Antropologia.

Nesta perspectiva, partindo de um olhar antropológico esta pesquisa foi iniciada no ano de 2016 por meio de projeto de extensão universitária na escola do sítio reassentamento Cajá. Ou seja, por meio da prática extensionista permitiu meu retorno a comunidade com um olhar analítico sobre a questão educacional e socioambiental, tais questões provocadas pela implantação da barragem de acauã (BARBOSA, 2017).

Portanto, a partir do momento que identifiquei a proposta da pedagogia dos atingidos na região (MEDEIROS, 2010), enquanto política educacional local e nacional do Movimento dos atingidos por barragem (MAB, 2005) iniciei um mapeamento da população atingida por Acauã, momentos históricos dos movimentos sociais no Brasil, a implantação do MAB nas comunidades, e suas articulações às demandas sociais, especialmente a uma política educacional.

\section{CONCLUSÃO}

Neste artigo reuni resultados iniciais de um relatório de pesquisa sobre a "Pedagogia dos Povos Atingidos por barragem" do Movimento dos Atingidos por barragem do Brasil. Para este momento, foram organizados elementos teóricos e metodológicos que permitiu iniciar o mapeamento sobre uma nova manifestação social, especialmente no âmbito da Cultura e educação do Brasil.

Por conseguinte, tendo em vista da primeira articulação nacional do MAB bastante consistente, a Educação, dos povos atingidos, foi pautada com expressivo caráter protagonista onde se discutiu Políticas Educacionais com vistas a Educação do Campo, o mesmo lembra seu avanço como movimento organizado no campo da Educação e como um todo, tendo como papel revitalizador no processo de instruir seus coordenadores e público alvo diante de instituições públicas e privadas enquanto demanda educacional.

Em conclusão a Pedagogia dos povos atingidos por barragem demonstra conter caráter democrático, pois, analisa, sobretudo, os modos de vida dos atingidos, isto é, suas especificidades culturais individual e coletiva vinculadas ao seu lugar de origem. 
Outra que permite compreender a importância e significado dos Movimentos Sociais organizados, no papel de assegurar às populações atingidas seus direitos.

\section{REFERÊNCIAS}

BARBOSA, G. A. Educação ambiental crítica: experiência em escola de um reassentamento de atingidos por barragem na Paraíba. - João Pessoa, 2017. Monografia (Graduação em Ciências Sociais) - Universidade Federal da Paraíba - Centro de Ciências Humanas, Letras e Artes.

BRASIL. Constituição da República Federativa do Brasil, 1988.

BRASIL. Decreto 7.352, de 4 de novembro de 2010. Política de educação do campo.

BARTH, Fredrik. A análise da cultura nas sociedades complexas. In, Barth, Fredrik. O guru, o iniciador e outras variações antropológicas. Rio de Janeiro. Contracapa Livraria. 2000. p. 107-140.

CALDART, Roseli Salete. Educação do campo: notas para uma análise de percurso. In.: Trab. Educ. saúde [online], v. 7, n. 1p. 35-64, 2009. Disponível em: http://www. epsjv.fiocruz.br/upload/d/Caldart.pdf

. Elementos para construção do projeto político e pedagógico da Educação do Campo. Trabalho Necessário. ano 2 - número 2 - 2004.

CLIFFORD, James. A experiência etnográfica. Antropologia e literatura no século XX. Rio de Janeiro: Editora da UFRJ, 2002.

Dossiê sobre a situação da população atingida: A situação das famílias atingidas pela barragem de Acauã na Paraíba. Campina Grande, dezembro de 2005. In.: Conselho de Defesa dos Direitos da Pessoa Humana Comissão Especial "Atingidos por Barragens. Relatora: Heloisa Elaine Pigatto e relator: João Paulo de Campos Dorini. Brasília, 2007.

FREIRE, Paulo. Extensão ou comunicação? tradução de Rosisca Darcy de Oliveira. prefácio de Jacques Chonchol. $7^{\mathrm{a}}$ ed. Rio de Janeiro, Paz e Terra, 1983. Ação cultural para a liberdade. Rio de janeiro: Paz e Terra, 1976. A educação como prática de liberdade. Rio de janeiro: Paz e Terra, 1967. . Pedagogia do oprimido. Rio de Janeiro. Paz e Terra, 1984. . Pedagogia da autonomia - Saberes Necessários à Prática Educativa. Editora Paz e Terra. 36ª Edição, Coleção Saberes, 1996. 
FERNANDES, Bernardo Mançano, MOLINA, Mônica Castagna. O campo da educação do campo. In: MOLINA, Mônica Castagna; JESUS, Sonia Meire Santos Azevedo de Jesus (Org.). Contribuições para a construção de um projeto de Educação do Campo. Brasília, DF: Articulação Nacional "Por uma Educação do Campo. 2004 (Coleção Por uma Educação do Campo, n 5), 05-Jul-2005.

GLUCKMAN, Max. “Análise de uma Situação Social na Zululândia Moderna. 1987.

GEERTZ, C. A interpretação das culturas. Rio de Janeiro. Editora LTC, 1989. O saber local. Novos ensaios em Antropologia interpretativa. Tradução de vera Mello Joscelyne. 9a ed. Petrópolis, RJ, Vozes, 1997.

GOHN, Maia da Glória. Movimentos e lutas sociais na história do Brasil. São Paulo, Loyola, 1995.

Movimentos sociais na contemporaneidade. Revista Brasileira de Educação v. 16 n. 47 maio-ago. 2011.

Educação, trabalho e lutas sociais. CLACSO, Consejo Latinoamericano de Ciencias Sociales 2000.

INGOLD, Tim. Estar Vivo: ensaios sobre movimento, conhecimento e descrição. Petrópolis: Vozes, 2015. Cap. 1 (pp. 25-41) e 19 (pp. 327-347).

MALINOWSKI, Bronislaw Kasper. Argonautas do pacífico ocidental: um relato do empreendimento e da aventura dos nativos nos arquipélagos da Nova Guiné-Melanésia. Prefácio de Sir james George Frazer; Traduções Anton P. Carr e Lígia Aparecida Cardieri Mendonça; Revisão de Eunice Ribeiro Durham. $2^{a}$ edição; São paulo: Abril Cultural, 1978.

MALINOWSKI, B. K. 1986 [1954]. "A coleta e a interpretação dos dados empíricos". In. E. R. DUHRAN (comp.), Malinowski, Coleção grandes Cientistas Sociais, SP., Ed. Ática, pp. 143-158.

MARCUS, George. "Etnografía en/del sistema mundo. El surgimiento de la etnografía multilocal.” ALTERIDADES, 11 (22): pp. 111-127. 2001.

MEDEIROS, Edileuza Custódio Rodrigues de. Registro da atuação do movimento dos atingido por barragens nos reassentamentos de Acauã: a alfabetização de jovens e adultos. Natal, 2010.

MOVIMENTO DOS ATINGIDOS POR BARRAGEM. Caderno pedagógico. $2^{\text {a }}$ Edição. Org. Gestine Cássia Trindade et. Al. Tamandaí: Ísis, 2005.

MAB. A Organização do Movimento dos Atingidos por Barragem. In:

MAB. $1^{a}$ ed. BrasíliaDF: Secretaria Nacional do MAB, janeiro de 2005. 
NASCIMENTO, Claudemiro Godoy do. Políticas públicas e educação do campo: em busca da cidadania possível? Revista Travessia, v3, n.3. 2009.

REIS, Maria José. O Movimento dos Atingidos por Barragem: atores, estratégias de luta e conquistas. In.: Anais do II seminário nacional: Movimentos Sociais, Participação e Democracia, Florianópolis, 2007.

SOUZA, Edevaldo Aparecido. PEDON, Nelson Rodrigo. TERRITÓRIO E IDENTIDADE. Revista Eletrônica da Associação dos Geógrafos Brasileiros - Seção Três Lagoas Três Lagoas - MS, V 1 - n. ${ }^{\circ} 6$ - ano 4, novembro de 2007.

SANTOS, Mariana Corrêa dos. O conceito de "atingido" por barragens - direitos humanos e cidadania. Revista Direito e práxis. Rio de Janeiro, Vol. 06, N. 11, 2015, p. 113-140.

VELSEN, J. Van. A análise situacional e o método de estudo de caso detalhado. In Antropologia das sociedades contemporâneas, São Paulo: Global, 1987. 


\section{PROJETOS DE TRABALHO NA} EDUCAÇO DO CAMPO:

\section{A CROMATOGRAFIA DE PFEIFFER COMO POSSIBILIDADE DE}

\section{(RE)DESENHO AMBIENTAL NO} PÓS-PANDEMIA

\section{Fábio Fernandes Villela ${ }^{9}$ Oliver Humberto Naves Blanco ${ }^{10}$}

9 Sociólogo, Departamento de Educação, Universidade Estadual Paulista (Unesp), Instituto de Biociências Letras e Ciências Exatas, São José do Rio Preto, e-mail: fabio.villela@unesp.br 10 Engenheiro Agrônomo, formado pela Universidade Estadual Paulista (Unesp), Faculdade de Ciências Agrárias e Veterinárias, Jaboticabal, trabalha na área de Agricultura Orgânica, na coordenação de projetos sociais e capacitação em comunicação rural, e-mail: emporioagricola@gmail. com 
Diversos autores previram que o impacto dos problemas ambientais na saúde do ser humano e na manutenção da vida no planeta Terra haveria de chegar a uma "Sobrecarga" (Cf. Earth Overshoot, 2020). Denunciaram a dinâmica do sistema contemporâneo da seguinte maneira: "terricídio" (Marcuse, 1973), "não verás país nenhum” (Brandão, 1981), “a grande pobre Mãe Terra” (Boff, 2019 e 1993), "progresso destrutivo" (Löwy, 2005), "metabolismo socioecológico" (Clark e Foster, 2006), "cultura ambiental" (Villela, 2016a), "saúde no solo" (Pinheiro, 2018), etc. Tais autores apontaram para a tendência ilimitada da produção pela produção e a contradição entre o caráter limitado dos recursos da Terra e a disposição de se levar as relações capitalistas para os quatro cantos do planeta.

A pandemia do novo Coronavírus ou COVID-19 (Cf. Werneck e Carvalho, 2020) é um novo alerta para a mudança radical que precisa ser feita no modelo "sociometabólico do capital" (Mészáros, 2002). A experimentação dos "limites absolutos do capital" tem um impacto gigantesco sobre o meio ambiente, incrementando, na esfera social, (1) a desigualdade entre as classes, (2) a pobreza extrema, (3) a falta de acesso a serviços de saúde e de educação e, na esfera ambiental, (1) a poluição do ar, água e terra, as chuvas ácidas, (2) o aquecimento global e as mudanças climáticas, entre outros problemas ambientais (Cf. Mészáros, 2002).

Diante do problema da sobrevivência humana em escala planetária, se estabelece o desafio de repensar novas relações de produção, discutir temas relacionados à ecologia, agroecologia, cooperação agrícola, dentre outros, como forma de resistência e construção de uma nova realidade societária. (Cf. Foster, 2005). Nesse sentido, apresentamos alguns resultados da pesquisa intitulada: "Cultura ambiental na educação do campo: paisagem, história e saberes tradicionais do território caipira", realizada entre 2016 e 2019 (Cf. Villela, 2016a), onde foi possível pesquisar a cultura ambiental do noroeste paulista - SP. Neste capítulo iremos abordar uma das metodologias utilizadas no projeto, qual seja, a cromatografia de Pfeiffer. O projeto teve por resultados a articulação dos saberes com as diferentes áreas do conhecimento, possibilitando a vivência de novos valores, o desencadeamento de ações coletivas, 
bem como a elevação de escolaridade associada à qualificação social e profissional, possibilitando novas aprendizagens.

\section{A CROMATOGRAFIA DE (RE)DESENHO AMBIENTAL}

PFEIFFER COMO

Do ponto de vista teórico-metodológico, este projeto fundamenta-se em 4 eixos principais, quais sejam: (1) Cultura Ambiental; (2) Projetos de Trabalho; (3) Educação de Jovens e Adultos (EJA) e (4) Novas Tecnologias Aplicadas à Educação. Uma das motivações desta pesquisa é a necessidade de compreender a "cultura ambiental" dos indivíduos e grupos comunitários do noroeste paulista - SP, tendo como possibilidade o desenvolvimento sustentável. As relações entre homem-sociedade-natureza condicionam e são condicionados pela "cultura ambiental", da qual se deve partir para compreender a consciência dos indivíduos e grupos comunitários. As mudanças de atitudes só podem ser alcançadas com uma cuidadosa investigação da "cultura ambiental" das comunidades, alicerçada em uma estratégia formativa ambientalista (Cf. Villela, 2016a).

Do ponto de vista metodológico, optou-se pelas possibilidades do trabalho com projetos, devido à riqueza de material acumulado sobre comunidades rurais (Cf. MST, 2019). Dentre as diversas opções de trabalho com projetos, destaca-se: "projetos de ensino", "projetos de trabalho", "projetos da aprendizagem", "temas geradores", "metodologia do complexo temático", entre outros (Cf. Hernández 1998). Dessa forma, as metodologias de trabalho com projeto permitem maior flexibilidade de estratégias ao professor e maior liberdade ao educando, viabilizando uma aprendizagem que de fato corresponda às reais necessidades da comunidade.

No final dos anos 90 , ao questionar as práticas pedagógicas que vêm norteando a docência, no campo de debate das concepções dialéticas de educação, com fortes afinidades com a psicologia histórico-cultural, Gasparin (2002) propôs ao educador um modo de ensinar e de aprender, interligando a prática social do aluno com a teoria, no intuito de possibilitar uma formação docente e que, na medida do possível, responda às necessidades dos discentes. O pedagogo defende uma prática de pesquisa e ação fundamentadas nos pressupostos teórico-metodológicos da Pedagogia 
Histórico-Crítica de Saviani, procurando apontar as contribuições do método dialético na elaboração e execução de projetos de trabalho. O processo didático, proposto por Gasparin (2002), foi elaborado a partir de Saviani (2012). Para um exemplo prático dessa proposta, sugerimos a leitura de Villela (2018).

Aliado a essa metodologia, foi utilizada a experiência de EJA desenvolvida no âmbito do "Projeto Unesp de Educação de Jovens e Adultos" (doravante, Peja Unesp). O Peja - Unesp foi criado na Unesp no ano de 2000, na época, vinculado ao Programa Unesp de Integração Social Comunitária, da Pró-Reitoria de Extensão Universitária - PROEX, com o objetivo de estabelecer uma política pública para a educação de jovens e adultos, buscando parcerias comunitárias locais e visando à contribuição de recursos para a formação de cidadãos/leitores críticos e participativos, bem como a de professores com a visão de "educadores populares". Atualmente, o Peja é desenvolvido em oito campus da Unesp (Araçatuba, Araraquara, Assis, Bauru, Marília, Presidente Prudente, Rio Claro e São José do Rio Preto), contando com recursos humanos e materiais da Pró-Reitoria de Extensão Universitária - PROEX para o desenvolvimento de seus trabalhos (Cf. Villela, 2016b e Villela et al., 2007).

Somado a essas duas experiências metodológicas (Projetos de Trabalho e EJA), foi utilizada a desenvolvida em Villela (2014), especificamente o projeto: Centro Virtual de Estudos e Culturas do Mundo Rural. Essa ferramenta foi desenvolvida como recurso didático e ferramenta no ensino de sociologia para os alunos do curso de pedagogia da Unesp de São José do Rio Preto (SP), doravante Rio Preto, e estendido, posteriormente, para escolas que manifestaram interesse em desenvolver tópicos da área de Ciências Humanas e suas Tecnologias. O projeto utiliza a metodologia de blog, um website frequentemente atualizado, por meio do qual os conteúdos aparecem em ordem cronológica inversa. Podem conter textos, imagens, áudios, vídeos e animações. Esta metodologia possibilita a disseminação do conhecimento produzido pela universidade na internet gratuitamente. A comunidade se relaciona através dos conteúdos, possibilitando a transmissão de informação, fazendo da web um espaço de leitura, escrita, participação e reflexão.

O blog de aula, por exemplo, foi utilizado como uma ferramenta do Peja - Rio Preto em um dos trabalhos desenvolvidos no Centro de Convivência do Idoso, do- 
ravante $\mathrm{CCl}$. No Peja - Rio Preto do $\mathrm{CCl}$, o foco central foi o desenvolvimento de práticas de letramento/escrita no contexto da tecnologia digital (Cf. Komesu; Tenani, 2010). Nesse sentido, os jovens, adultos e idosos puderam adquirir conhecimentos básicos de informática (word, internet, facebook, blogs, etc.). ${ }^{11}$ Além do desenvolvimento de práticas de letramento/escrita em contexto da tecnologia digital, os objetivos do Peja - Unesp são: preparar os alunos para ler e escrever na Língua Materna (LM); empregar, com discernimento, o sistema de numeração decimal e as operações fundamentais na resolução de problemas do dia-a-dia; conhecer os direitos, deveres e leis que regem o mundo do trabalho; desenvolver noções de saúde física, psicológica e mental; discutir questões relativas à preservação do meio ambiente. $\mathrm{O}$ trabalho do Peja - Rio Preto no CCl configura-se como uma parceria entre a Unesp e a Secretaria Municipal de Assistência Social de Rio Preto ${ }^{12}$ e tem por objetivos gerais inserir a população da terceira idade ${ }^{13}$, no processo de inclusão digital, considerando as necessidades impostas por uma sociedade tecnológica. Passamos aos resultados e a discussão.

\section{RESULTADOS E DISCUSSÃO}

Diversos cursos de extensão foram organizados entre 2016 e 2019, quando foram experimentados os processos descritos anteriormente. Os cursos atenderam aos alunos do Ibilce/Unesp e a comunidade em geral, que desejavam adquirir formação específica na área de educação do campo, especialmente para desenvolver trabalhos e/ou pesquisas com a interface agroecologia, agrofloresta e saúde no solo. Alguns tópicos do curso foram: 1. Cultura Ambiental (Cf. Villela, 2016a); 2. Saúde no Solo (Blanco, 2020, 2017 e 2013); Agroflorestas (Costa et al., 2014) e 3. Agricultura Sustentável (Nagai e Kishimoto, 2008). Uma primeira elaboração dos resultados desta discussão pode ser recuperada em Villela (2018). A seguir a Figura $1 \mathrm{com}$ alguns

11 Para o desenvolvimento das temáticas relacionadas ao internetês, o projeto contou com a colaboração das professoras Dras. Fabiana Komesu e Luciani Tenani, ambas do Departamento de Estudos Linguísticos e Literários.

12 Essa parceria foi firmada por meio de "termo aditivo" ao convênio em vigor entre a Unesp e a Prefeitura Municipal de Rio Preto, desenvolvido por meio da equipe do Peja - Rio Preto, a partir de 2013.

13 A população é cadastrada no Centro de Referência da Assistência Social (CRASS) para ser selecionada para frequentar o $\mathrm{CCl}$ - Rio Preto, localizado na Av. Philadelpho Manoel Gouveia Neto, 785, Vila Novaes, zona norte da cidade. 
elementos da práxis dos cursos de extensão: fosfito, picumã, caldas minerais, água de vidro, biofertilizantes e a cromatografia de Pfeiffer (Cf. Blanco, 2017).

Figura 1 - Folder com imagens da práxis dos cursos de extensão

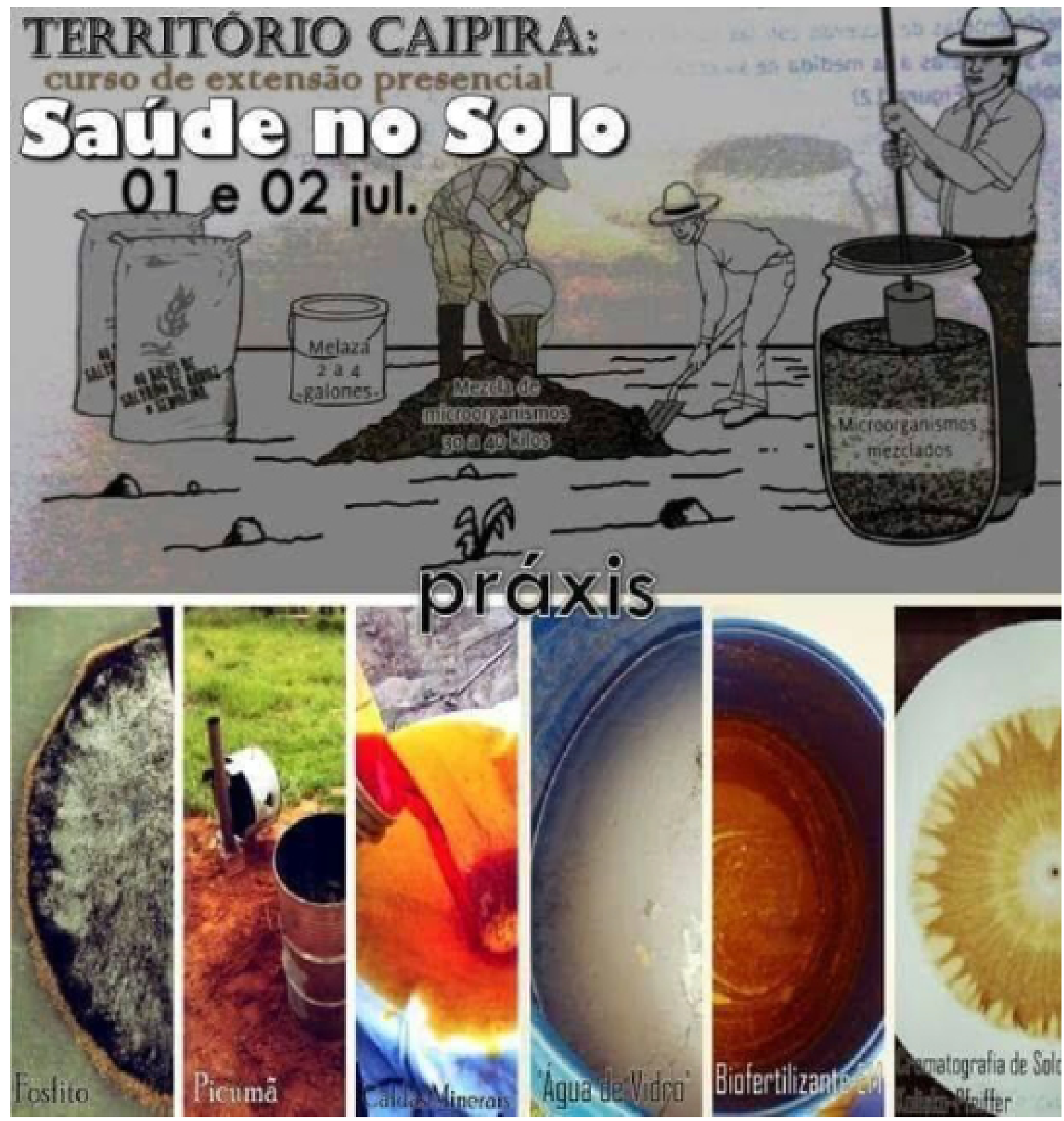

Fonte: Blanco (2017)

Dentre as diversas "práxis" desse processo educativo, destacamos a elaboração da "Cromatografia de Pfeiffer", utilizada para o diagnóstico do estado de saúde do solo (Cf. Blanco, 2017). Recuperamos essa metodologia agora como possibilidade de (re)desenho ambiental no pós-pandemia. Para um aprofundamento da ideia de 
desenho ambiental recomendamos a leitura de Pérez-Rubio (1994 e 2003) e Villela (2016a). Cromatografia, do grego croma, significa "cor" e grafein,"escrever". É o termo coletivo para um conjunto de técnicas laboratoriais para a separação de misturas. A cromatografia foi inventada pelo biólogo italiano, filho de imigrantes russos, Tswett em 1910 e tornou-se um segmento sofisticado da ciência do solo (BLANCO, 2017). O autor nos mostra como elaborar a cromatografia:

O que é um croma? É muito mais que uma análise bioquímica do solo. É um holograma (cada parte contém a informação do todo) dos efeitos do Sol nos ciclos biogeoquímicos metabolizados no solo vivo. Sua harmonia circular (auréola) indica a quantidade de carbono no solo e a glória (fenômeno óptico) da integração à biodiversidade e vida do solo como em um caleidoscópio. Quanto maior a harmonia, maior e constante é a transformação e fluidez de energia, sem perdas neste solo analisado. No microcosmo do cromatograma vemos a luta entre fusão e a gravidade, onde a vida (fusão) é a animação dos minerais, uma força contra a gravidade, conforme Vernadsky. Quanto mais simples e sem vida, as substâncias permanecem mais próximas ao centro gravitacional do cromatograma (caso dos metais/minerais). Quanto mais complexas e vitais as substâncias, mais próximas à superfície ou borda de fusão do cromatograma (BLANCO, 2017).

Conforme Blanco (2017), o cromatograma é uma análise de solo integral, que permite o diagnóstico e acompanha seu tratamento de forma auto-interpretativa, feita pelo próprio agricultor(a). A análise mais precisa e segura nos seres vivos é a genômica (DNA). A cromatografia de Pfeiffer é mais sofisticada, pois além da identificação do DNA incorpora a proteômica, expressão das proteínas dos genes, conforme o ambiente. De forma rápida, fácil e barata permite a leitura pelo próprio agricultor(a) da situação de seu solo, através do tempo-espaço da mesma forma que um pai acompanha o crescimento, desenvolvimento, estado de saúde física e mental do filho, com capacidade de intervenção, quando for necessário (BLANCO, 2017). A seguir uma figura com alguns exemplos de Cromas de Pfeiffer. 
Figura 2 - Cromas de Pfeiffer

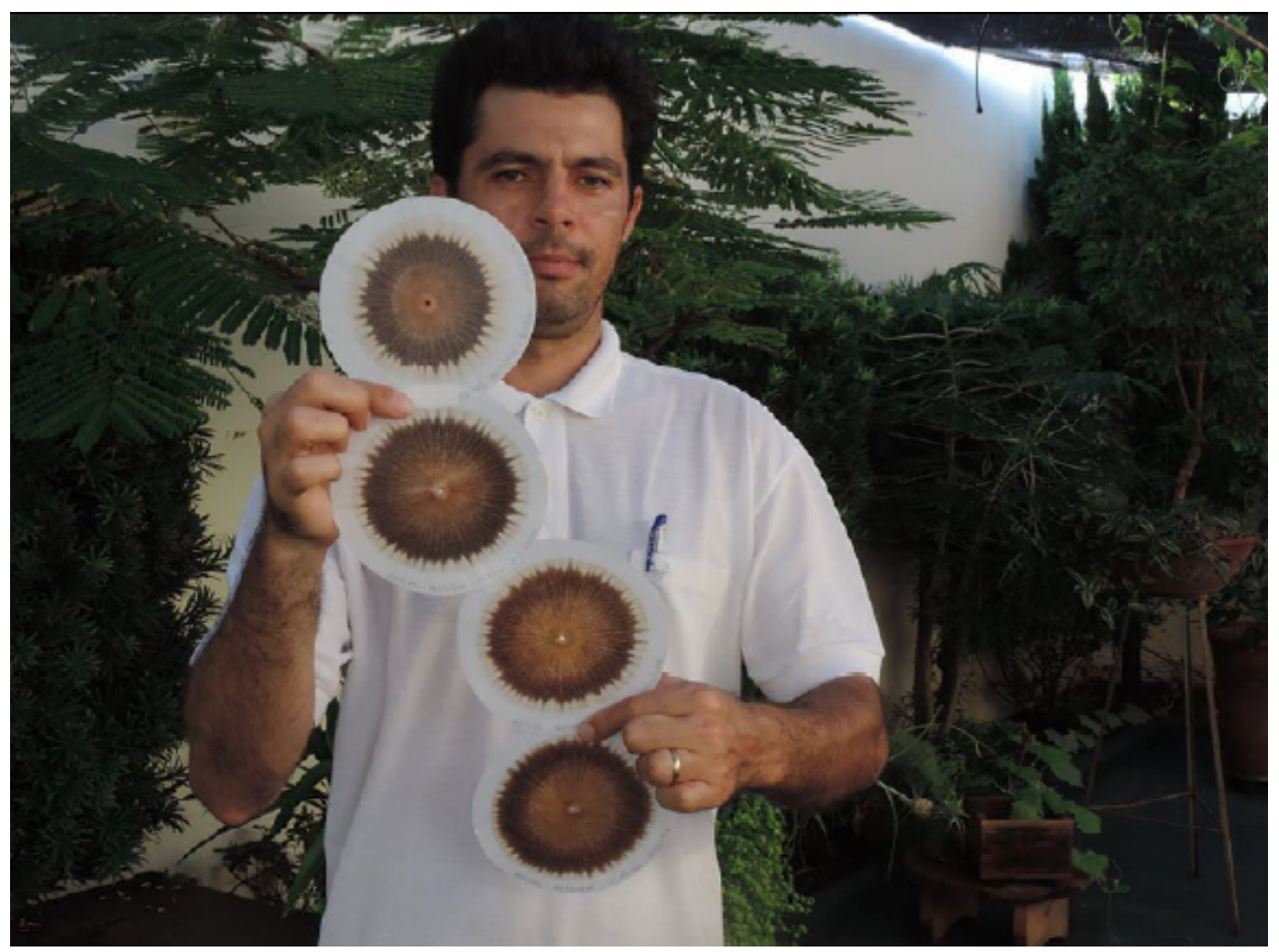

Fonte: Blanco, 2020.

O que se busca em um cromatograma? Para Branco (2017), busca-se a leitura da vida, da qualidade de vida do solo, em determinado momento. Isto é facilmente visualizado em um cromatograma, através da harmonia de cores e desenho entre todos os diferentes componentes mineral, orgânico, energético, eletromagnético do solo. Assim é possível saber se um determinado mineral está em harmonia com a matéria orgânica, $\mathrm{pH}$, biodiversidade de microrganismos ou grau de oxidação/redução de enzimas, vitaminas e proteínas e como se pode alterar positivamente a situação encontrada para alcançar esta meta (BLANCO, 2017).

Cabe lembrar, segundo o autor, que a análise vai depender do aprendizado empírico da natureza de quem o está realizando, o próprio agricultor e sua família. $\mathrm{O}$ cromatograma é uma tomografia do solo e planta que permite saber: (1) qual o manejo do conteúdo de água do solo e (2) qual o manejo dos minerais, plantas adventícias e outras. Ou seja, permite o diagnóstico perfeito da saúde do solo e a avaliação da qualidade dos alimentos nele produzidos (BLANCO, 2017).

A seguir, na Figura 2, apresentamos uma comparação entre cromas de milho crioulo e transgênico. No sentido horário, (1) espigas de milho crioulo e transgêni- 
co; (2) milho crioulo, com preparo mínimo do solo com calagem, farinha de rocha e aplicado biofertilizantes durante seu desenvolvimento, além da utilização do sistema de Milpa (consórcio de milho, feijão-de-corda e abóbora); (3) a mesma semente do milho crioulo anterior, cultivada pelo produtor Aguinaldo (São Pedro/SP). O sistema de produção utilizado foi o convencional.

Segundo Naves (2020), o produtor suspeita que o milho foi contaminado com pólen de milho transgênico. Os "Cromas" na Figura 3, a seguir, nos revelam essa possibilidade: (4) contra prova, do mesmo Croma anterior; (5) milho transgênico, identificado como 2B63PW; (6) milho fresco convencional de Mercado. Nestes Cromatogramas de cereais, fica evidente a diferença de um milho crioulo comparado ao milho transgênico: as conexões do DNA: citosina, guanina, adenosina, parece que são "falhadas"; comprovando que a indústria alterou a proteína do milho, conforme Naves (2020). Sobre os malefícios à saúde do milho transgênico consultar Villela (2014).

Figura 3 - Cromas de Milho Crioulo e Transgênico

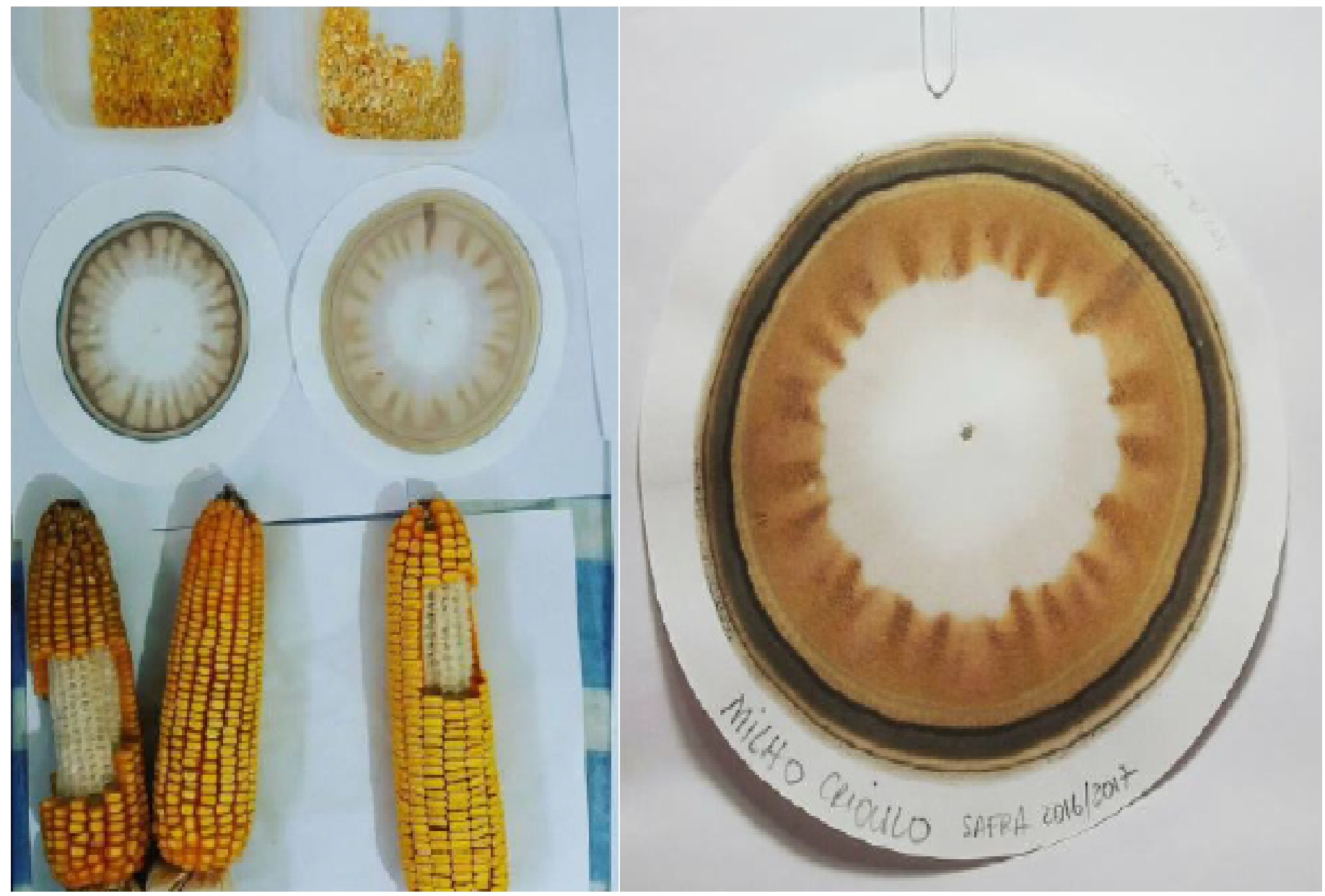



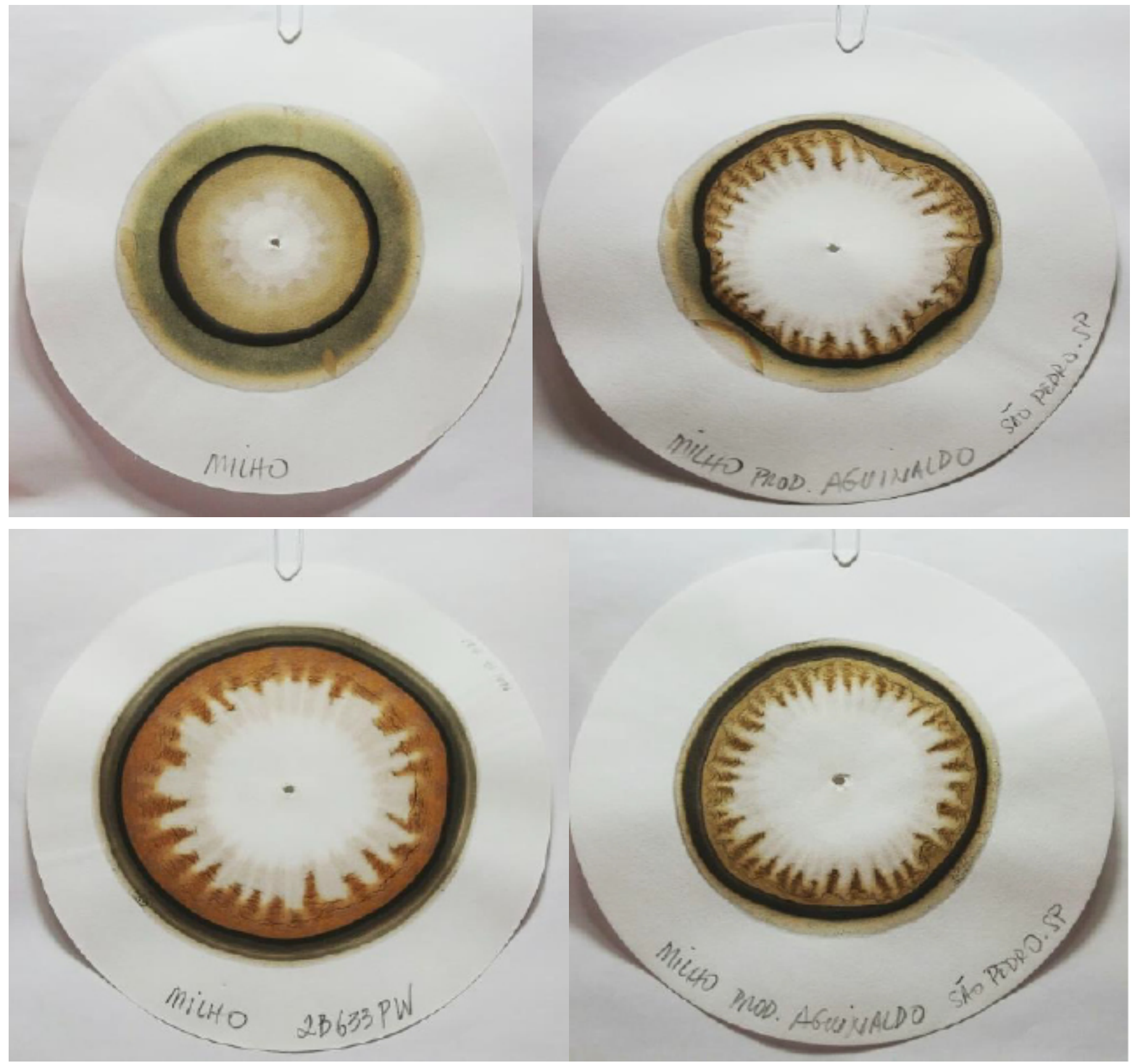

Fonte: Blanco (2020).

Os cursos de extensão, realizados entre 2016 e 2019, foram momentos do desenvolvimento dos projetos de trabalho, baseado na didática da pedagogia histórico-crítica, proposta por Gasparin (2002). Segundo essa perspectiva teórico-metodológica, o ponto de partida diz respeito ao nível de desenvolvimento real do educando, a prática social inicial; o segundo momento, constitui o elo entre a prática social e a instrumentalização, isto é, a problematização; o terceiro relaciona-se às ações didático-pedagógicas para a aprendizagem, denominado instrumentalização; o quarto, a expressão elaborada da nova forma de entender a prática social, a catarse; e o quinto e último, ao nível de desenvolvimento atual do educando, isto é, a prática social 
final. A seguir analisamos a escrita dos participantes dos cursos.

A escrita de participantes dos cursos, nos anos de 2016 a 2019, que se apresenta no Quadro 1, expressa a passagem de uma visão caótica da realidade ao conhecimento científico proporcionado pelo projeto, onde se infere a realidade através de novas formas de pensar (Outras postagens podem ser conferidas em: Villela, 2014). Trata-se da manifestação do aperfeiçoamento intelectual dos participantes, os quais, de forma contínua, se desafiam dialeticamente a transformar a contradição existente entre o velho (prática social inicial) e o novo (prática social final), conforme Gasparin (2002). A escrita presente nas postagens representa um dos pontos de chegada do processo pedagógico do projeto, comprovando que o processo de contra-hegemonia abre espaços de luta e deslocamentos e possibilita a reversão das formas de domínio material e imaterial (Cf. Moraes, 2002). A seguir as postagens dos participantes dos cursos (transcrita exatamente como no original).

Quadro 1 - Postagens dos participantes dos cursos de extensão (2016-2019)

Participante F. 17/07/03 13:22

O curso Território Caipira promovido pela Unesp é uma riqueza inestimável para o conhecimento. No módulo 1, ficou frisado a importância e a prática de elaboração dos fermentados: kobashi, biofertilizante, silo de microrganismos, EM.

Essas práticas mostraram o quanto é facílimo para o produtor agroecológico ser independente de insumos químicos, sem contar a saúde completa que irá disponibilizar para seu solo, para o plantio e também para seus animais.

Palestras e explicações maravilhosas dos fundamentos da agroecologia, feitas pelo mentor Oliver, fundamentam as práticas desenvolvidas de maneira divina.

Sem contar a explanação riquíssima dada pelo prof Fábio, sobre a riqueza sócio/histórico/ cultural das mulheres do campo.

Enfim, tudo lindo e maravilhoso, de estrondoso valor para nossa consciência agroecológica, fazendo que nos finquemos o pé com toda força nessa atitude de preservarmos a saúde do solo.

Participante F. 17/07/03 18:18

No módulo 2 do curso Saúde de Solo aprendemos muita coisa maravilhosa: caldas quentes e frias, fosfito, biochar.

Como sempre, são receitas muito simples e baratas que podem levar a uma produção agroecológica eficiente e saudável.

A prática da cromatografia com certeza elevou o nível do curso mais ainda, mostrando, com simplicidade e arte, como desenhar a sanidade do solo e também dos alimentos.

Cursos como este devem ser uma constante em nossa região e em todo mundo, pois esclarece bem o dever de conscientização que temos para com o solo, pai e mãe de todos os seres vivos.

" SOLO SADIO, POVO SADIO. SOLO DOENTE, POVO DOENTE" 
Participante L. 17/07/12 13:58

Nesta segunda parte do Curso Território Caipira - Saúde do Solo, exploramos de maneira pratica a Cromatografia de Pfeiffer (ou cromatografia circular) que permite ao agricultor ter autonomia com uma visão integral do solo da propriedade, analisando também a evolução do manejo agroecologico que esteja fazendo, acompanhando as sucessivas etapas com aferição dos resultados e progressos.

As Caldas Minerais preparadas tem dupla função. Agem para nutrir e também, em casos emergenciais, podem ter ação nos sintomas/vetores das doenças.

Elas permitem autossuficiência em relação à industria já que a maioria dos insumos são de fácil acesso e outros podem vir da propriedade ou da região.

O uso conjunto das técnicas aprendidas podem dar ao agricultor um grande empoderamento já que o solo revitalizado e remineralizado certamente retribuirá com alimentos saudáveis, geobiodiversos, nutritivos e abundantes.

Participante M. 17/07/04 14:06

Nesse segundo módulo de praticas, nós tivemos muita troca de informação e conhecimento sobre o que é solo vivo e energia. Entramos no fluxo dos sinais e da leitura desses sinais, para intervir de maneira a respeitar os processos de transformação e ciclos biológicos. Usando as receitas de caldas e compostos minerais, cozinhamos e alimentamos a terra, para o controle, reequilíbrio e saúde das culturas e do solo.

O manejo, coleta, observação da matéria em transformação ou estagnada, foi fixada, documentada no tempo/espaço do papel cortado em circulo. Cromatografia, ponto de partida e leitura para futuras ações e avaliações das práticas empregadas.

A porta foi aberta para a formação de uma rede de trocas de conhecimento e experiências. Gratidão.

\section{Participante J. 16/12/19 09:10}

Mais um encontro inspirador, onde aprendemos muito mais do que técnicas focadas sobre a cultura do milho, mas sim, estudos e experiências de Oliver Blanco e pesquisadores sobre manejos na agricultura orgânica.

Apesar de ser produtora e profissional da área, fui surpreendida com várias "novidades" como: a cromatografia aplicada à solos, plantas e compostagens; princípios $3 \mathrm{M}$ e 4M; sideróforos, biochar, peletização alternativa para sementes não convencionais, formulação de fosfito, dentre outras.

A experiência e a humildade de Oliver, fez-me com que eu mergulha-se no passado histórico do milho, passando por descobertas de técnicas, importância de um alimento orgânico para um organismo, impactos dos transgênicos, teoria da trofobiose e tantas outras coisas fantásticas sobre nosso tema.

Precisamos como toda certeza de um tempo a mais com Oliver para tentar "sugar" em todo bom sentido, mais de suas experiências e trazer para mais perto da nossa região tão "carente" informações imprescindíveis para a manutenção e ampliação da nossa agricultura familiar e orgânica.

Fonte: Villela (2014). 
Conforme podemos observar na escrita das participantes acima, a opção teórico-metodológica pela perspectiva da pedagogia histórico-crítica, contribui para a valorização dos conhecimentos científico-culturais, base para a transformação da realidade. Conforme aponta Saviani (2012), a apropriação dos conhecimentos historicamente produzidos pela humanidade deriva do processo de mediação, em decorrência das relações das pessoas entre si e a cultura. A escrita das participantes indica a superação do senso comum em direção à consciência filosófica. A escrita deixa transparecer que o educando reconhece elementos de sua situação, apontando a necessidade de intervir na realidade, transformando-a no sentido de ampliação da liberdade, da comunicação e colaboração entre os homens.

O mérito da reorganização das práticas sociais iniciais das participantes do curso está no processo didático da pedagogia histórico-crítica, cujo método de investigação e de elaboração do conhecimento científico tem por base o desvendamento da teoria do valor-trabalho de Marx. Esse aporte teórico-metodológico contribui para novas relações de ensino e aprendizagem e auxiliam tanto na formação dos alunos, quanto na dos professores. Um projeto de trabalho nessa perspectiva teórico-metodológica é um excelente instrumento didático, tendo em vista o processo dialético presente na sua metodologia de ensino e aprendizagem.

\section{CONCLUSÃO}

Podemos destacar como principais conquistas desse trabalho: (1) levantamento de material de pesquisa através de hipertextos produzidos, no ambiente do blog de aula, pelos participantes do projeto, de modo a propiciar dados qualitativos para pesquisas interessadas na descrição e compreensão da centralidade do valor-trabalho; (2) o desenvolvimento de possibilidades de ações, conforme demonstra a escrita das participantes, para a inclusão produtiva no território caipira, segundo um projeto de trabalho na perspectiva da pedagogia histórico-crítica; (3) a consolidação de redes socioeconômicas da agricultura familiar no âmbito dos territórios rurais, especialmente da região noroeste paulista, considerando as práticas da economia solidária; (4) o fortalecimento de organizações econômicas, contribuindo para a inclusão produtiva e para o desenvolvimento sustentável e solidário do território caipira; (5) desenvolvimento prático da ideia de "cultura ambiental", proposta por Salinas (1988), entre 
outros, possibilitando novos desenhos ambientais para Nuestra América, conforme Pérez-Rubio (2003).

Por fim, cabe destacar: (6) a contribuição para a produção e sistematização de metodologias inovadoras de EJA, na educação do campo; e (7) o aprimoramento de teorias pedagógicas e experiências educativas, no que diz respeito às Tecnologias da Informação e Comunicação (TICs) e outras ferramentas tecnológicas na educação no campo. O projeto foi desenvolvido em um espaço de EJA, conforme Brasil (2000), onde esse ambiente engloba todo o processo de aprendizagem, formal ou informal, no qual pessoas consideradas adultas pela sociedade desenvolvem suas habilidades, enriquecem seu conhecimento e aperfeiçoam suas qualificações técnicas e profissionais, direcionando-as para a satisfação de suas necessidades e as de sua sociedade. No ambiente de EJA, as situações reais devem constituir o núcleo da organização da proposta pedagógica a ser desenvolvida. Para tanto, o desafio da EJA é integrar em sua organização curricular o trabalho e a elevação de escolaridade. $A$ partir dessas ideias, o "arco ocupacional" trabalhado foi a produção rural familiar e a qualificação social e profissional. O resultado desse trabalho é a articulação dos saberes dos educandos com as diferentes áreas do conhecimento, possibilitando a vivência de novos valores, o desencadeamento de ações coletivas, bem como a elevação de escolaridade associada à qualificação social e profissional, possibilitando novas aprendizagens aos educandos no território caipira.

\section{REFÊRENCIAS}

BLANCO, O. H. N. Cromatografia de solo (Kolisko-Pfeiffer): diagnóstico do estado de saúde no solo e alimentos. Flickr website de hospedagem. Net, Araçatuba-SP, 2020. Disponível em: < https://www.flickr.com/photos/raearacatuba/albums > Acesso em: 30 de junho de 2020.

Práticas da agricultura orgânica: saber e fazer em mãos campesinas. Curso de extensão presencial. Território caipira: saúde no solo. SlideShare website para compartilhamento de documentos. Net, Araçatuba-SP, 2017. Disponível: < https:// pt.slideshare.net/OliverBlanco01/territrio-caipira-curso-sade-no-solo-jun-jul-2017 >. Acesso: 30 jun. 2020.

. Milho crioulo "Cunha". Blanco agricultura: consultoria e acompanhamento técnico para o envolvimento dialógico da agricultura orgânica no Brasil. Blogger web- 
site para edição e gerenciamento de blogs. Net, Araçatuba-SP, 2013. Disponível em: < http://oextensionista.blogspot.com.br/2013/05/milho-crioulo-cunha.html\#.Vl6-hr9yzQ9 >. Acesso: 30 jun. 2020.

BOFF, L. Às agressões, como nos responde a Mãe Terra. Website pessoal. Net, Petrópolis-RJ, 2019. Disponível: < https://leonardoboff.org/2019/08/15/as-agressoes-como-nos-responde-a-mae-terra/ >. Acesso em 2 de jul. 2020.

Ecologia, mundialização e espiritualidade: a emergência de um novo paradigma. São Paulo: Ática, 1993.

BRANDÃO, I. de L. Não verás país nenhum: memorial descritivo. Rio de Janeiro: Codecri, 1984.

COSTA, F. M. P. da; OLIVEIRA, T. H.; IRINEU, N. S. O. Sistemas agroflorestais: um olhar sobre o caso da Fazenda Elo Florestal. Cadernos de Agroecologia, [S.I.], v. 9, n. 3, dez. 2014. Disponível em: < http://revistas.aba-agroecologia.org.br/index.php/ cad/article/view/15945 >. Acesso em: 29 jun. 2020.

EARTH OVERSHOOT. Earth Overshoot Day. Website corporativo. Net, Oakland-CA, 2020. Disponível em: < https://www.overshootday.org/ >. Acesso em: 30 de junho de 2020.

FOSTER, J. B. e CLARK, B. Imperialismo ecológico: a maldição do capitalismo. In: PANITCH, L. e LEYS, C. (Org.). O novo desafio imperial. Buenos Aires: CLACSO, 2006.

FOSTER, J. B. A ecologia de Marx: materialismo e natureza. Rio de Janeiro: Civilização Brasileira, 2005.

GASPARIN, J. L. Uma didática para a pedagogia histórico-crítica. 1. ed. Campinas: Autores Associados, 2002.

HERNÁNDEZ, F. Transgressão e mudança na educação: os projetos de trabalho. Porto Alegre: ArtMed, 1998.

KOMESU, F. C.; TENANI, L. E. Práticas de letramento/escrita em contexto da tecnologia digital. Eutomia (Recife), v. 1, p. 1-15, 2010.

LÖWY, M. Ecologia e socialismo. São Paulo: Cortez, 2005. (Coleção questões da nossa época; v. 125).

MARCUSE, H. et ali. Ecologia contra poluição. Lisboa: Dom Quixote, 1973. 
MÉSZÁROS, I. Para além do capital: rumo a uma teoria da transição. São Paulo: Boitempo, 2002.

MORAES, D. de. Imaginário social e hegemonia cultural. Website Gramsci e o Brasil. Net, Rio de Janeiro-RJ, 2002. Disponível em: < http://www.acessa.com/gramsci/?page=visualizar\&id=297 >. Acesso em 26 jan. 2017.

MST. Movimento dos Trabalhadores Rurais Sem Terra (MST). 35 coisas que você precisa saber sobre o MST. Website corporativo. Net, Brasília-DF, 2020. Disponível: < https://mst.org.br/2019/01/18/35-coisas-que-voce-precisa-saber-sobre-o-mst/ $>$. Acesso em 30 jun. 2020.

NAGAI, K.; KISHIMOTO, A. Manejo do solo e adubação: equilíbrio nutricional, meIhoramento do solo e saúde da planta. Instituto de Pesquisas Técnicas e Difusões Agropecuárias da JATAK. Net, Guatapará-SP, 2008. Disponível: < https://docplayer. com.br/22014519-Manejo-do-solo-e-adubacao-equilibrio-nutricional-melhoramento-do-solo-kunio-nagai-akira-kishimoto.html >. Acesso: 3 jul. 2020.

PÉREZ-RUBIO, C.V. el diseño ambiental en nuestra américa: colonización o liberación. Archipiélago. Revista Cultural de Nuestra América. México, v. 11, n. 41, 2003. p. 54-57.

Y el perro ladra y la luna enfria. Fernando Salinas: diseño, ambiente y esperanza. México: UNAM, UAM-A, UIA, 1994.

PINHEIRO, S. Agroecologia 7.0: bombeiro agroecológico, farinhas de rochas, biofertilizantes, biochar, agrohomeopatia e sideróforos. Rio Grande do Sul: Editora da Universidade/UFRGS/Fundação Juquira Candiru Satyagraha/Plataforma Catarse, 2018.

SAVIANI, D. Pedagogia histórico-crítica: primeiras aproximações. 11. ed. rev. reimpr. Campinas: Autores Associados, 2012. (Coleção Educação Contemporânea).

SALINAS, F. La cultura ambiental de nuestra América. Arquitectura y Urbanismo, vol. 13, n. 2, ISPJAE, La Habana, 1992. p. 25-32.

. de la arquitectura y el urbanismo a la cultura ambiental. Guayaquil: Facultad de Arquitectura y Urbanismo, Universidad de Guayaquil, 1988.

VILLELA, F. F. Trabalho, história e saberes tradicionais no território caipira: fundamentos e possibilidades na perspectiva da pedagogia histórico-crítica. Rev. Fac. Educ. (Univ. do Estado de Mato Grosso), Vol. 29, Ano 16, p. 63-80, jan./jun., 2018. Disponível: < https://periodicos.unemat.br/index.php/ppgedu/article/view/3888 >. Acesso em: 
Cultura ambiental no território caipira: história e saberes tradicionais das muIheres do noroeste paulista. Retratos de Assentamentos. v. 19, p. 323 - 350, 2016 a. Disponível em: < http://www.uniara.com.br/nupedor/revista-retratos/ >. Acesso em 2 jul. 2020.

A formação de professores de educação de jovens e adultos no PEJA-Rio Preto: um caleidoscópio de possibilidades. Cadernos da Pedagogia (Ufscar. Online). v.9, p. 2 - 15, 2016b. Disponível em: < http://www.cadernosdapedagogia.ufscar. br/index.php/cp/article/viewFile/862/307 >. Acesso em 3 jul. 2020.

Blog de aula centro virtual de estudos e culturas do mundo rural. Projeto de Extensão Universitária. Pró-Reitoria de Extensão da Unesp - Proex/Unesp. Net, São José do Rio Preto - SP, 2014. Disponível em: < http://www.cecmundorural.com. brl >. Acesso em 27 fev. 2015.

. a escola da justiça global. 2009-2010. Supervisão: Profa. Dra. Liliana Rolfsen Petrilli Segnini. Monografia (Pós-Doutorado). Faculdade de Educação, Universidade Estadual de Campinas.

et al. O Programa Unesp de Educação de Jovens e Adultos - PEJA-UNESP. Projeto de Extensão Universitária. Pró-Reitoria de Extensão da Unesp - Proex/ Unesp, 2007. Net, São José do Rio Preto - SP, Disponível em: < https://www.youtube.com/watch?v=FiHsDxnsO7Y >. Acesso em 3 jul. 2020.

WERNECK, G. L.; CARVALHO, M. S. A pandemia de COVID-19 no Brasil: crônica de uma crise sanitária anunciada. Cad. Saúde Pública, Rio de Janeiro, v. 36, n. 5, e00068820, abr. 2020. Disponível em: < http://cadernos.ensp.fiocruz.br/csp/artigo/1036/a-pandemia-de-covid-19-no-brasil-cronica-de-uma-crise-sanitaria-anunciada >. Acesso em: 30 jun. 2020. 


\title{
FORMAÇO CONTINUADA NA ESCOLA DO CAMPO: 0 USO DE JOGOS EM AULA DE MATEMÁTICA DO 3 ANO DO ENSINO FUNDAMENTAL
}

\author{
Iza Alves Pacheco ${ }^{14}$ \\ Suely Cristina Soares da Gama ${ }^{15}$ \\ Kleide Ferreira de Jesus ${ }^{16}$
}

$14 \quad$ Mestre em Ciências, pela Universidade Federal de Mato Grosso do Sul (UFMS), Educadora/REME/MS, ilza.educ@gmail.com

15 Mestre em Desenvolvimento Local pela Universidade Católica Dom Bosco (UCDB). Especialista em Gestão Escolar/Curso de Gestores UFMS, Pedagoga pela IES, Gestora na Rede Municipal de Campo Grande - Escola Municipal de Educação Infantil (EMEI) - suely.gama@hotmail.com 16 Doutoranda em Educação, Universidade Católica Dom Bosco (UCDB) - kleideferreira@ hotmail.com 
O artigo apresenta um estudo originado a partir de observações e intervenções realizadas em sala de aula de uma escola inserida na área rural. Trata-se de uma pesquisa qualitativa, com base na formação continuada dos professores que atuam nas escolas do campo no ensino de matemática. O objetivo do estudo constitui-se em analisar o uso dos jogos nas aulas do componente curricular de matemática realizadas nos $3^{\circ}$ anos do Ensino Fundamental em uma Escola Polo Municipal Rural no município de Anastácio/MS. Tendo em vista que nessa instituição de ensino, há crianças com dificuldades na aprendizagem da matemática, sentiu-se a necessidade de buscar outros recursos, como os jogos, a fim de contribuir e auxiliar nesse processo, assim como na atuação dos professores desse componente curricular.

\section{BREVE HISTÓRICO DO MUNICÍPIO DE ANASTÁCIO/MS}

O Município de Anastácio situa-se no estado de Mato Grosso do Sul abrangendo uma área de 2.949,206 km² na microrregião do centro-oeste do estado, banhado pelos rios Aquidauana e Taquarussu faz divisa com as cidades de Aquidauana, Nioaque, Bonito, Dois Irmão do Buriti e Maracaju. Possui um lema: Nossa Terra, Nosso Espaço, como é conhecido hoje pela população anastaciana ou sul mato-grossense. Como município formado e independente tem identidade socioeconômica e cultural definida.

Esta distante da capital Campo Grande 127 km pela Rodovia Federal BR 262 Anastácio é considerada o Portal do Pantanal. A história da cidade de Anastácio está intimamente ligada à de Aquidauana, datando sua origem de 15 de agosto de 1892 , quando oficialmente foi fundada sob a coordenação de: Theodoro Rondon, João de Almeida Castro, Augusto Mascarenhas, Manoel Antônio Paes de Barros e Estevão Alves Correa. Distrito criado com a denominação de Anastácio (ex-povoado da margem esquerda), pela lei municipal $n^{\circ}$. 1164, de 20-11-1958, subordinado ao município de Aquidauana.

Em divisão territorial datada de 01-07-1960, o distrito de Anastácio figura no município de Aquidauana, assim permanecendo em divisão territorial datada de 31- 
12-1963. Elevado à categoria de município com a denominação de Anastácio, pela lei estadual $n^{\circ}$. 2143, de 18-03-1964, desmembrado de Aquidauana. Sede no atual distrito de Anastácio. Constituído de 2 distritos: Anastácio e Palmeiras (ex-Jango), ambos desmembrados de Aquidauana.

Instalado em 01-01-1965, o nome de Anastácio foi escolhido em homenagem ao primeiro morador oficial do povoado, o italiano Vicente Anastácio, cuja residência centenária foi à primeira de alvenaria erguida no povoado e ainda hoje se destaca na esquina das avenidas Manuel Murtinho e Porto Geral.

O município é tipicamente agropecuário, formado por chácaras, sítios, fazendas e assentamentos, com uma população de mais de 23.000 habitantes numa área de $2.949,21 \mathrm{~km}^{2}$. O bioma típico é o cerrado.

A agricultura é mais para subsistência temos o arroz, o feijão e o milho. Também há a plantação da mandioca por conta das farinheiras artesanais. A farinha do Pulador é conhecida em todo o estado, daí o nome da Festa da Farinha que já faz parte do calendário cultural de festas do município.

As escolas do campo do município de Anastácio oferecem a Educação Básica nos níveis de Educação Infantil, Ensino Fundamental e Médio, este último com parceria do governo do estado e município em 02 extensões.

Considerando que a realidade do aluno do campo difere muito da realidade do aluno da zona urbana e que a matemática sempre foi um componente curricular na qual muitos alunos têm dificuldades e que trabalhamos há muitos anos com o ensino fundamental e observando o baixo rendimento e dificuldades na aprendizagem desse componente curricular, percebemos que por meio dos jogos e do uso da linguagem concreta, poderíamos contribuir para auxiliá-los a compreender melhor o abstrato; desse modo, muito embora haja muitas pesquisas e estudos dirigidos ao desenvolvimento do processo de ensino e aprendizagem, a escola do campo tem pouco acesso a estes materiais, que estão centrados na arte do brincar como forma de aprender.

Por este motivo, utilizou-se dos jogos com regras criadas e discutidas com as próprias crianças para o desenvolvimento do raciocínio e de atitudes positivas como integração e socialização por meio de atividades realizadas em grupo. 
Em Anastácio há 13 escolas municipais, sendo que 07 dessas escolas são na sede do município e 06 escolas no campo, as escolas estaduais são as 07 que funcionam na sede do município com duas extensões na área rural.

$\mathrm{Na}$ rede municipal há um total de 181 professores, sendo que a maioria dos professores tem formação específica, conforme área do conhecimento que leciona.

Mantida pela Prefeitura de Anastácio, administrada pela Secretaria Municipal de Educação nos termos da legislação em vigor e regulada pelo seu Regimento Escolar, a Escola Pólo Municipal Rural, criada pelo Decreto $n^{\circ} 254 / 97$ de 31 de julho de1997, situa-se em um Assentamento à $35 \mathrm{~km}$ da sede do município.

Partindo dessa constatação, para o trabalho decidimos estudar alternativas que viessem a contribuir para o aprendizado desse componente curricular, pelos alunos da educação do campo, do $3^{\circ}$ ano do Ensino Fundamental.

Aplicamos nos alunos, uma avaliação (sondagem) do conhecimento de matemática, dirigida ao conteúdo referente aos jogos que iríamos fazer, para que depois da construção e aplicação, pudéssemos avaliar e comparar os resultados, verificando o desempenho antes e depois do uso dos jogos como meio de fixação de conteúdo e sua eficácia nesse sentido.

Os jogos se apresentam como alternativa para transmitir informações associados a diversos campos do conhecimento humano, tal decorre do fato eles levam os indivíduos a desenvolver empatia com os conteúdos apresentados ao remover barreiras que possam interferir no aprendizado como medo, insegurança, timidez, etc.

Muitos alunos têm problemas de aprendizado porque não se sentem capazes ou preparados para trabalhar determinados instrumentos, nesse momento ao lançar mão do lúdico, o professor remove essas barreiras por que em tese, pelo menos, da permissão para que o aluno possa errar e expor suas fraquezas sem medo.

Considerando Piaget:

O emprego do lúdico propiciará a capacidade de compreensão nas diversas áreas do conhecimento e atingir o objetivo desejado. Para isto é necessário que o professor enriqueça os ambientes com diversos jogos e os alunos irão descobrir os conceitos inerentes às estruturas dos jogos por meio da manipulação. (1981, p. 190). 
Para o autor, o professor em sua tarefa de transmitir o conhecimento não só precisa como deve usar o lúdico em suas aulas para atingir seus objetivos como educador, mas ele vai ainda mais longe ao dizer que ao "enriquecer o ambiente com diversos jogos", o educador permite aos educandos que estes descubram por si só os conceitos que estão sendo transmitidos ao manipular os jogos compreendendo suas regras e objetivo.

Como essas regras e objetivo podem ser adaptados para atender a praticamente todas as situações de vida, o uso dos jogos para ensinar, se enquadra em qualquer contexto que se deseje usá-los como ferramenta auxiliar de trabalho e fixação de conteúdos.

Apesar dos jogos serem efetivos para ensinar e transmitir conteúdos a alunos de praticamente todas as idades, Petry \& Quevedo (1993, p.33) consideram que eles vão se tornando mais significativos e eficientes na medida em que o aluno vai progredindo pela livre manipulação e uso contínuo deles o que os capacita a construir e reconstruir os contextos e objetos aprendidos através deles, sendo capacitados a criar ou recria-los a partir da sua compreensão.

Isso porque para esses autores um jogo representa uma situação, problema ou contexto a ser compreendido ou resolvido, o que estimula e desafia o raciocínio no sentido de resolver o problema ou entender o contexto, ainda segundo eles, esse processo deve ser concretizado durante a infância consistindo numa síntese progressiva de assimilação com acomodação.

Dessa maneira, representando o jogo uma situação, problema ou contexto a ser compreendido ou resolvido, e a solução a essas indagações devem ser solucionadas de modo prover o aluno de ferramental que proporcione a ele condição de propor respostas não só para o momento imediato, como também para os que se apresentem no futuro.

Nas palavras dos autores:

O jogo em sala de aula é uma ótima proposta pedagógica porque propicia a relação entre parceiros e grupos, e, nestas relações, podemos observar a diversidade de comportamento dos educandos para construir estratégias para a vitória, como também as relações diante da derrota. (PETRY \& QUEVEDO, 1993, p.34-35).

Outro autor que trata desse tema é Oliveira (2004), o qual faz a seguinte propo- 
sição com relação a esse assunto:

Os jogos vêm a ser estratégias que agilizam a autoregulação cognitiva e afetiva, podendo ser utilizados nos mais diversos ambientes. São situações nas quais a criança reorganiza padrões comportamentais regredidos e inadequados, inclusive em seus aspectos socioculturais e morais. (OLIVEIRA, 2004, p.34).

Nesse sentido, jogos usados como estratégia e ensino têm o objetivo de agilizar a aprendizagem. A aplicação dessa estratégia ocorre para acentuar a autoestima, a cognição e inclusive a afetividade dos envolvidos no processo. Em geral nessas ocasiões há um redimensionamento da estrutura comportamental dos alunos e outros aspectos, pois afloram condutas que em situações normais não seriam expostas.

Ainda segundo Oliveira (2004), o lúdico contribui para o desenvolvimento do ser humano com o uso de jogos por estimular a interação entre as pessoas por impor regras que possibilitam ao jogo transcorrer sem conflitos insolúveis entre os participantes.

As regras, inseridas no contexto lúdico, passam a ser vistas realmente como o meio que possibilita o desenvolvimento do jogo, como o melhor jeito de se conduzir um trabalho em grupo. Longe de paralisar e inibir a criança serve de suporte ao bom relacionamento e à criatividade. (OLIVEIRA, 2004, p.72).

Uma das áreas onde os jogos têm se mostrado bastante eficiente no auxílio ao aprendizado, é a matemática, onde uma diversidade deles pode ser usada como apoio ao aprendizado.

\section{JOGOS COMO UM RECURSO A APRENDIZAGEM DO ENSINO DA MATEMÁTICA}

Os jogos podem ser usados como recurso para a transmissão dos conteúdos de diversos componentes curriculares, como: história, geografia, português, etc, entretanto é especialmente no ensino da matemática onde a maior parte dos alunos tem dificuldades para compreender e reter os conteúdos que eles podem ajudar.

Principalmente no Ensino Fundamental, existem diversas maneiras de usar os jogos com o objetivo de facilitar de jogos como o Baralho da Multiplicação, o Jogo da Argola, a Corrida da Bicicleta, o Jogo Linha-Coluna, o Dominó da Adição o ensino de 
matemática. Alguns exemplos de jogos que podem ser usados com alunos.

Cada jogo pode ser usado para demonstrar como se operacionaliza determinado cálculo, um jogo de soma e subtração, demonstra aos alunos não só como se realiza cada operação como também fixa o resultado de somas e subtrações por repetição continuada das operações. Eles também ajudam a desenvolver o raciocínio lógico, pois, obrigam o aluno a fazer relacionamentos entre as operações efetuadas e os resultados obtidos.

Assim:

$2+3=>3+2=>4+1 \Rightarrow 1+4=>$ resultam na quantidade 5 indicando aos alunos que um determinadO valor pode ser obtido e várias formas diferentes.

Nesse sentido, os jogos precisam ser operacionalizados levando em consideração desde o objetivo que se deseja alcançar e as séries onde serão aplicados, até a metodologia, dessa forma, percebemos que desde que adaptados, os jogos podem ser usados em uma grande variedade de situações e séries para transmitir o conteúdo, ou desenvolver uma habilidade desejada nos alunos.

No contexto da sala de aula, une-se o lúdico ao concreto, transformando o brinquedo, a festa, o jogo, a brincadeira em algo sério onde se aprende, constrói o saber, sem, contudo, forçar o compreender, pois o conhecimento é introduzido de uma forma natural em um contexto inerente à própria natureza humana.

Noutros termos, partindo se de uma visão onde o jogo mais do que brincadeiras puras, são ferramentas para o aprendizado, servem para tornar prazerosa a investigação e o aprendizado, principalmente da matemática, matéria que maioria dos alunos considera complicada de entender.

Os jogos permitem nesse caso, que a matemática seja inserida no contexto do dia a dia dos alunos, pode-se, por exemplo, usar matérias que eles tenham a disposição como latas e garrafas descartadas após o uso de seu conteúdo, podem usar materiais característicos da região e cultura que vivem trazendo a eles o sentido de que ela os cerca e faz parte de suas vidas.

De certo modo, esta foi a razão pela qual se escolheu realizar um trabalho focando nessa forma aprendizado, pois os alunos poderiam usar materiais que en- 
contram cotidianamente em suas casas e no campo para confeccionar os jogos que usariam em sala de aula para desenvolver os conteúdos que os professores queriam transmitir. Nesse sentido adequamos a seguinte definição de Kalhil (2003) "O conjunto de tarefas ou ações previamente planificadas que conduzem ao cumprimento de objetivos preestabelecidos baseados numa metodologia elaborada para tal fim durante o processo pedagógico". (KALHIL, 2003, p.40)

Assim os professores (re)construíram sua própria metodologia para desenvolver a aplicação dos jogos no contexto do ensino de matemática, criando, adaptando e planejando de modo que os alunos se sentissem envolvidos e participantes do processo.

Nesse processo, tal como preconizado em textos de Vygotsky, percebemos que além de uma excelente forma para transmitir conteúdos, os jogos também proporcionam maior adequação emocional e social aproximando do grupo, mesmo aqueles alunos mais tímidos e arredios, proporcionando um espaço de interação e troca de experiências onde as barreiras se desfaziam e os indivíduos se aproximavam uns dos outros deixando medos ou preconceitos de lado.

Em meio a tudo isso, vê-se como disse Moreira que:

Aprendizagem deve ser não só significativa, mas também crítica [...] uma estratégia necessária para sobreviver na sociedade contemporânea. Aprendizagem significativa crítica é aquela perspectiva que permite ao sujeito fazer parte de sua cultura e, ao mesmo tempo estar fora dela [...] um ensino centrado na interação entre professor e aluno enfatizando o intercâmbio de perguntas tende a ser crítico e suscitar a aprendizagem significativa crítica. (MOREIRA, 2000)

Cumpre-nos dizer ainda que considerando Vaziro (2001), que o aprendizado dos conceitos da matemática não se dá pela memorização das fórmulas e definições, ou aceitando passivamente o que é dito pelos professores, mas sim, pela compreensão de como eles estão presentes no dia a dia de cada um a partir da experiência, observação e descoberta pessoal. 
Formamos um grupo de estudo de matemática composto por professores do $3^{\circ}$, sendo os encontros realizados aos sábados. Após os estudos realizados por meio de leituras de livros, artigos e analise de apostilas, discutiu-se qual seria as dificuldades dos alunos e verificamos os conteúdos, posteriormente cada professor pesquisou e verificou as necessidades de seus alunos e quais seriam os jogos que poderiam contribuir e colaborar para auxiliar a aprendizagem, assim ficou definido que seria elaborado um projeto de jogos.

Na reunião de pais foi explicado como seria desenvolvido o projeto de jogos e que contaria com a colaboração deles, pois seria necessário de materiais recicláveis e também de recursos naturais, sendo assim seria de fundamental importância a contribuição deles e os professores desenvolveriam juntamente com sua turma um joguinho utilizando esses materiais que os próprios alunos e famílias colaboraram em levar para a escola.

Em primeiro lugar foi explicado quais seriam os conteúdos a serem trabalhados com o auxílio dos jogos, depois se discutiu quais os materiais mais adequados para confeccioná-los e quais seriam suas regras, explicamos para as crianças, que elas iriam realizar a confecção dos jogos, com o apoio e supervisão dos professores, sentimos que se interessavam pela perspectiva de construir os jogos que usariam para desenvolver os conteúdos de matemática que estavam sendo desenvolvidos na sala de aula.

Os alunos que nunca haviam tido uma experiência como essa ficaram entusiasmados e curiosos, tanto que se envolveram profundamente com o processo procurando e coletando o material necessário para a confecção dos jogos, após a qual, excitados com a perspectiva de usá-los, mal podiam esperar pelo momento em que os usariam nas aulas para desenvolver os conteúdos da matéria.

A confecção dos jogos escolhidos foi de acordo com a realidade do assentamento, usando materiais do dia a dia dos alunos como garrafas PET, papelão de caixas descartadas, cartolina e sulfite, o uso de materiais descartados, além do uso 
didático, também teve o objetivo de trabalhar a consciência ecológica dos alunos, demonstrando que alguns itens que são descartados podem ser reaproveitadas de forma produtiva preservando-se o meio ambiente ao mesmo em que se constrói alternativas de aproveitamento.

Também os jogos foram usados considerando a realidade diária dos alunos resolvendo questões do tipo: - A porca teve seis leitõezinhos. Foram vendidos quatro a $R \$ 22,00$ cada um. Em quantos reais importou o total da venda ?; minha mãe comprou uma galinha por $R \$ 10,00$. A galinha teve seis pintinhos, que foram vendidos por $\mathrm{R} \$ 3,00$ cada um. Quanto minha mãe ganhou?

Após alguns dias usando os jogos dessa maneira com os alunos, observou-se que tanto o desempenho, como o rendimento de cada aluno no momento de resolver as atividades melhorou, continuando nesse processo, o resultado para alguns alunos que ainda encontravam dificuldades para resolver contas de adição, subtração e multiplicação, logo mais percebeu-se que estavam começado a resolver os exercícios sozinhos sem precisar de interferência.

Os alunos contribuíram com a confecção dos jogos levando para a escola garrafas Pet de dois litros e papelão para a confecção dos jogos, eles estavam ansiosos para começar. Combinamos que duas vezes na semana, que a última aula seria exclusivamente para a confecção dos jogos. Percebemos que até o rendimento em sala melhorou, pois eles estavam ansiosos para dar início a confecção. A sala era arrumada com os materiais à disposição e antes de dar início à confecção de cada jogo explicávamos qual seria o objetivo daquele jogo. Observamos que durante o trabalho havia interação, socialização, união e participação de todos. Percebeu- se que quando eles confeccionam o seu próprio material de estudo valorizam muito mais. Atividade realizada, nas fotos 01 e 02 :

Material necessário: 10 garrafas pet de 2 litros, cheias de areia e numeradas de 1 a 10, argolas feitas de garrafas plásticas cortadas em tiras ou mangueira, caneta atômica e papel sufit.

Regras do jogo: 1 aluno para marcar; quantas jogadas irá fazer por exemplo: (determinar 5 jogadas para cada participante). $O$ aluno que for escolhido para marcar, deverá apontar as jogadas que cada aluno acertar. Ganha o jogo quem acertar mais. 
Objetivos: Estimular atenção e a concentração do calculo mental.

Foto 01: Jogo das garrafas (argolas)

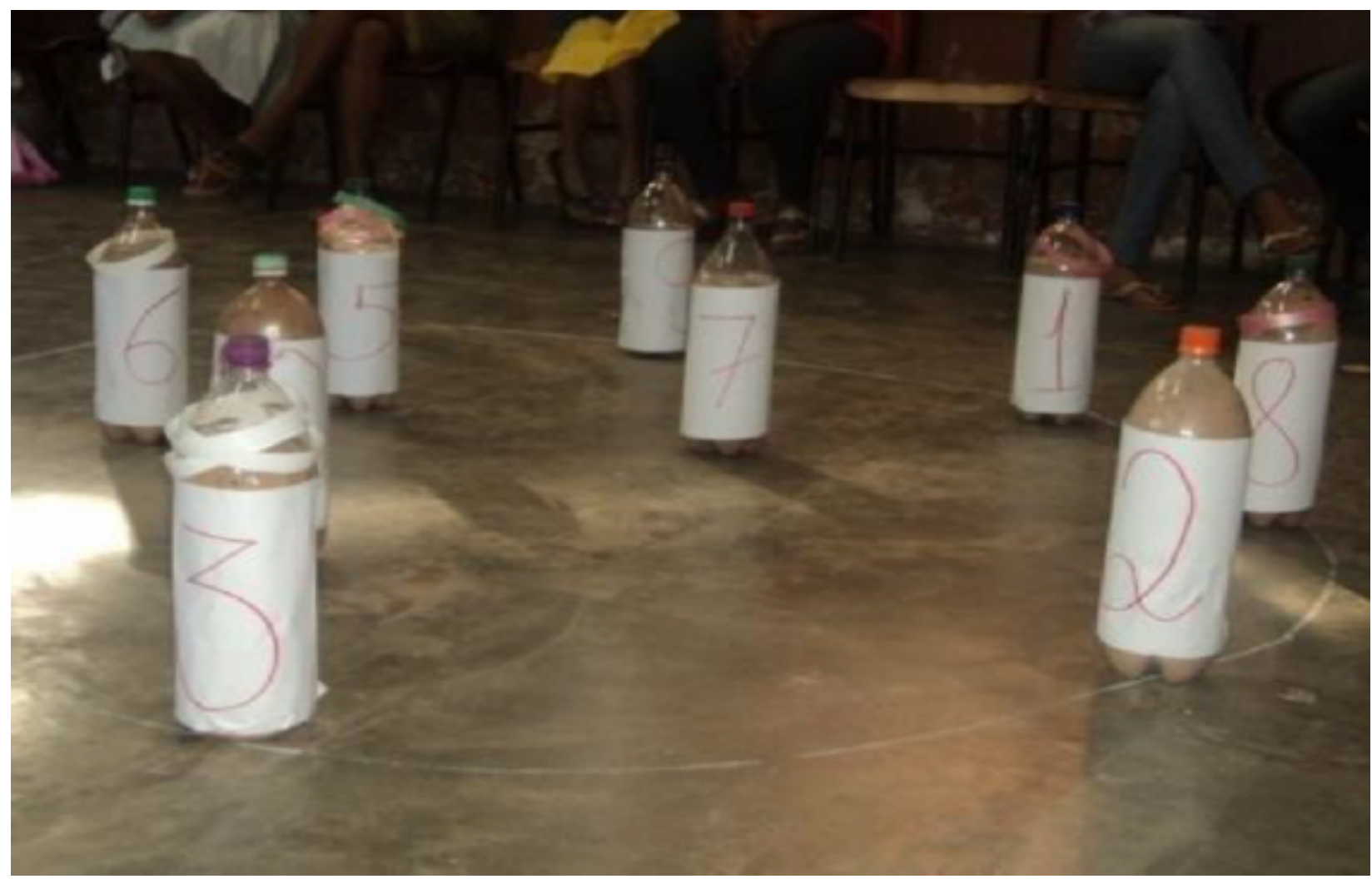

Fonte: professora Benedita (2018)

Foto 02: Jogo das garrafas (argolas)

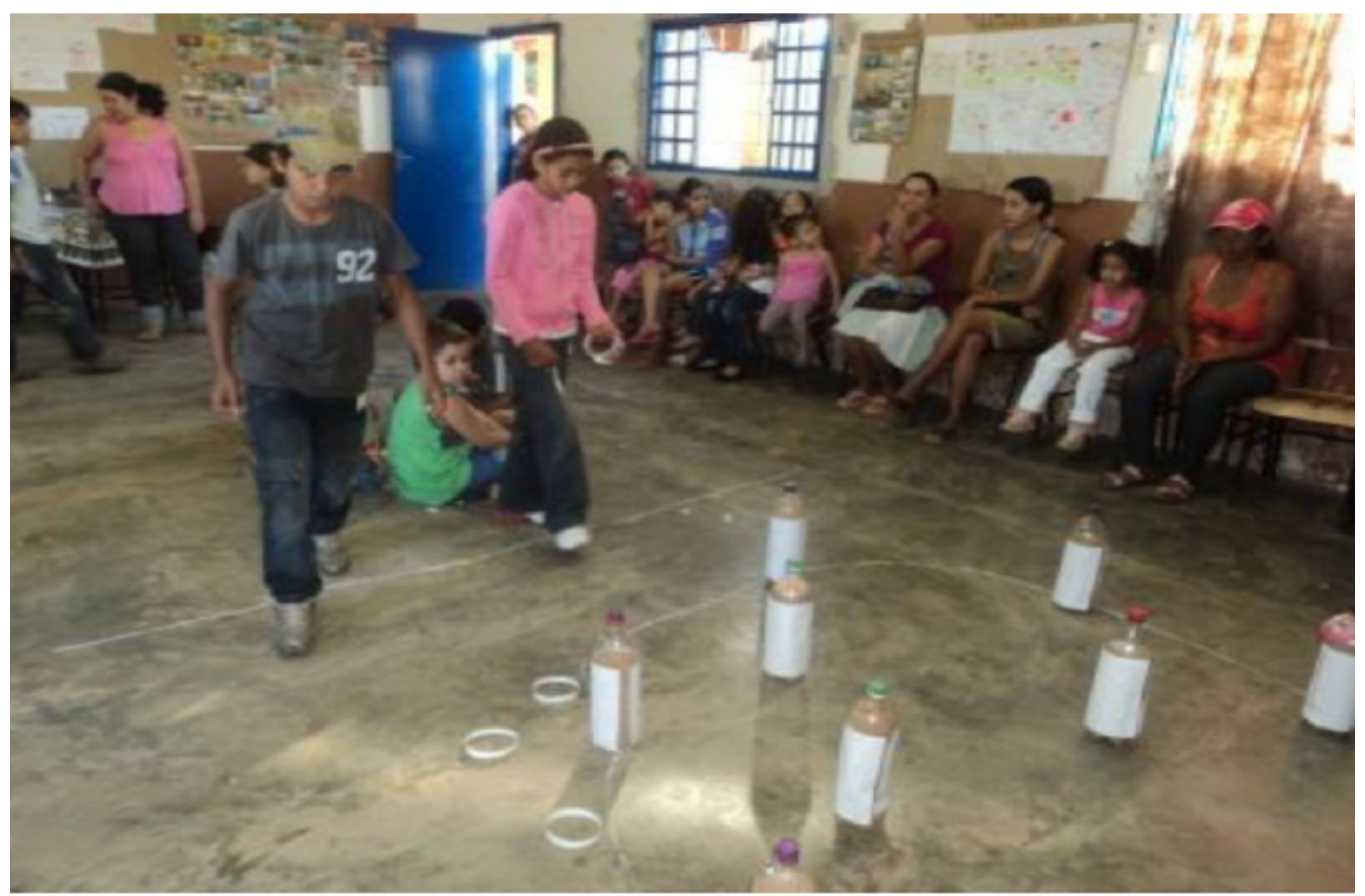

Fonte: Professora Benedita (2018) 


\section{Calculo Mental (cartas)}

Objetivo: estimular o cálculo mental e o raciocínio lógico-matemático.

Material necessário: papel manilha ou cartolinas para confecção dos cartões, fita crepe para plastificar as peças, pincel atômico para escrever os números, como pode ser visto nas fotos 03 e 04 :

Foto 03: Jogo: Calculo Mental (cartas).

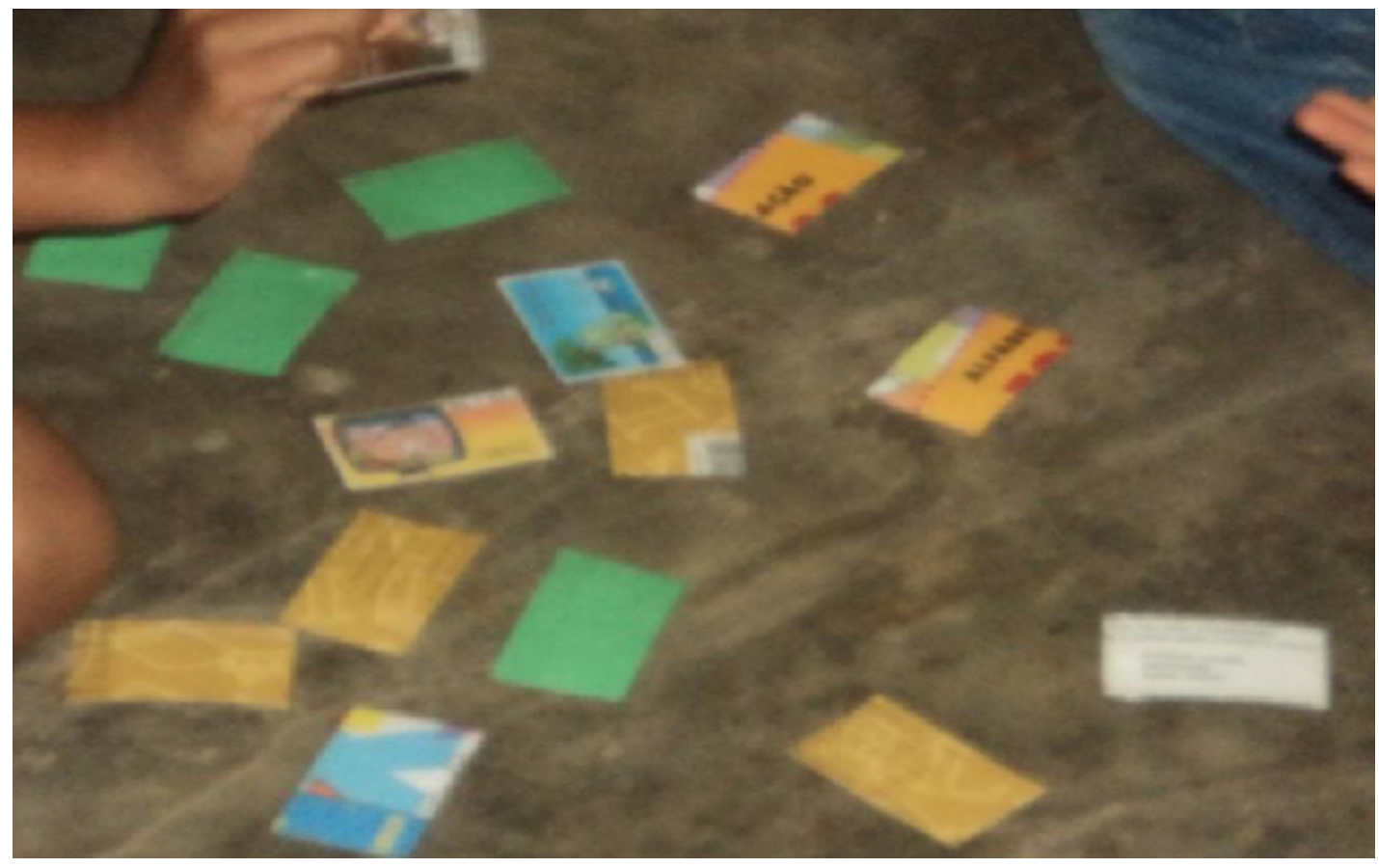

Fonte: Helenara Correia Teixeira (2018)

Foto 04: Jogo: Calculo Mental (cartas).

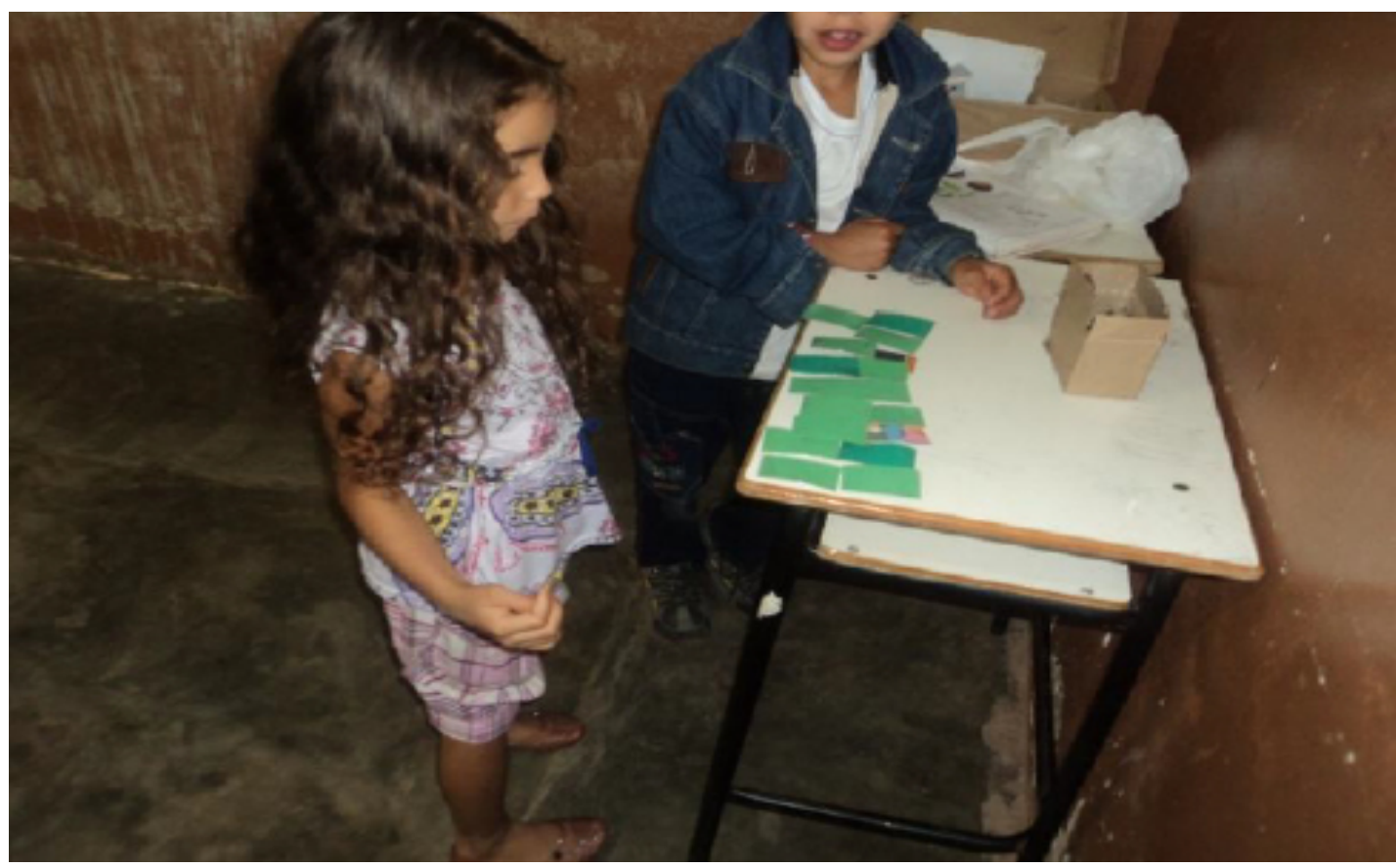

Fonte: Helenara Correia Teixeira (2018) 


\section{Jogo da tabuada(baralho)}

Objetivo: estimular o cálculo mental e o raciocínio lógico-matemático e auxilia o aluno em seu processo de aprendizagem de Matemática, foto 05 :

Foto 05: Jogo da tabuada(baralho).

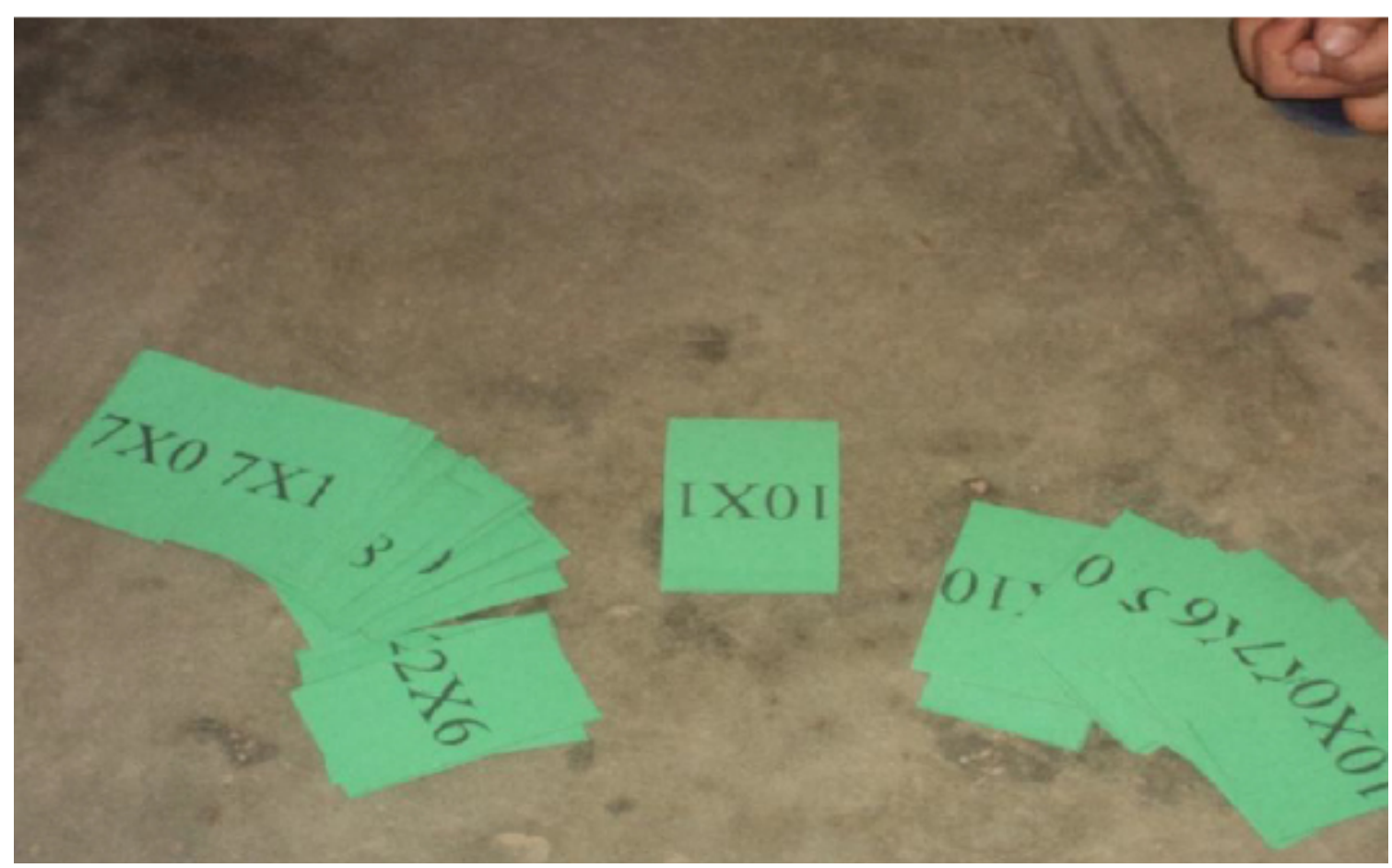

Fonte: Helenara Correia Teixeira (2018)

\section{Jogo Linha-Coluna}

Objetivo: conhecer linha e coluna além de estabelecer relação de ordem entre os números e calculo metal, como ser visto na foto 06 :

Foto 06: Jogo Linha - coluna

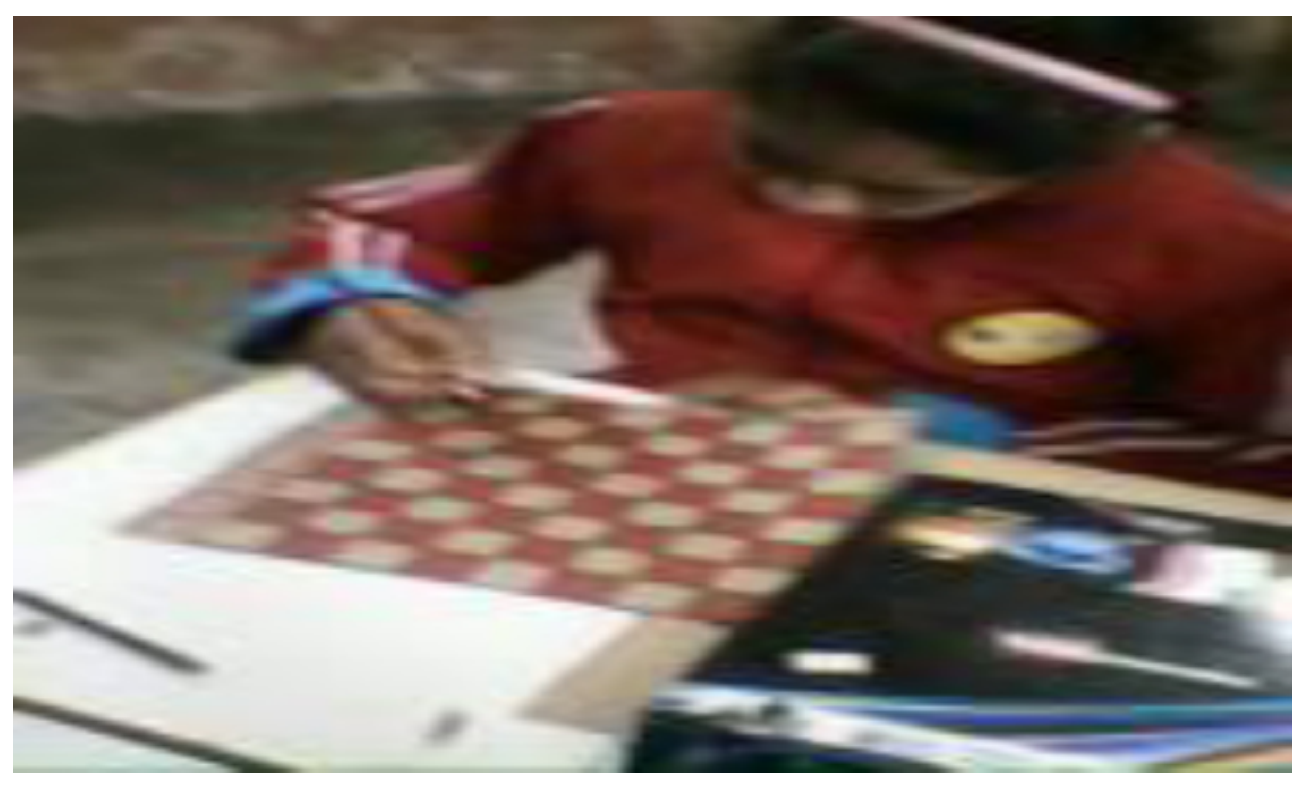

Fonte: Helenara Correia Teixeira (2018) 


\section{Dominó da adição}

Objetivo: estimular o cálculo mental e o raciocínio lógico-matemático e auxilia o aluno em seu processo de aprendizagem de Matemática, podemos observar na foto 07 :

Foto 07: Dominó da adição.

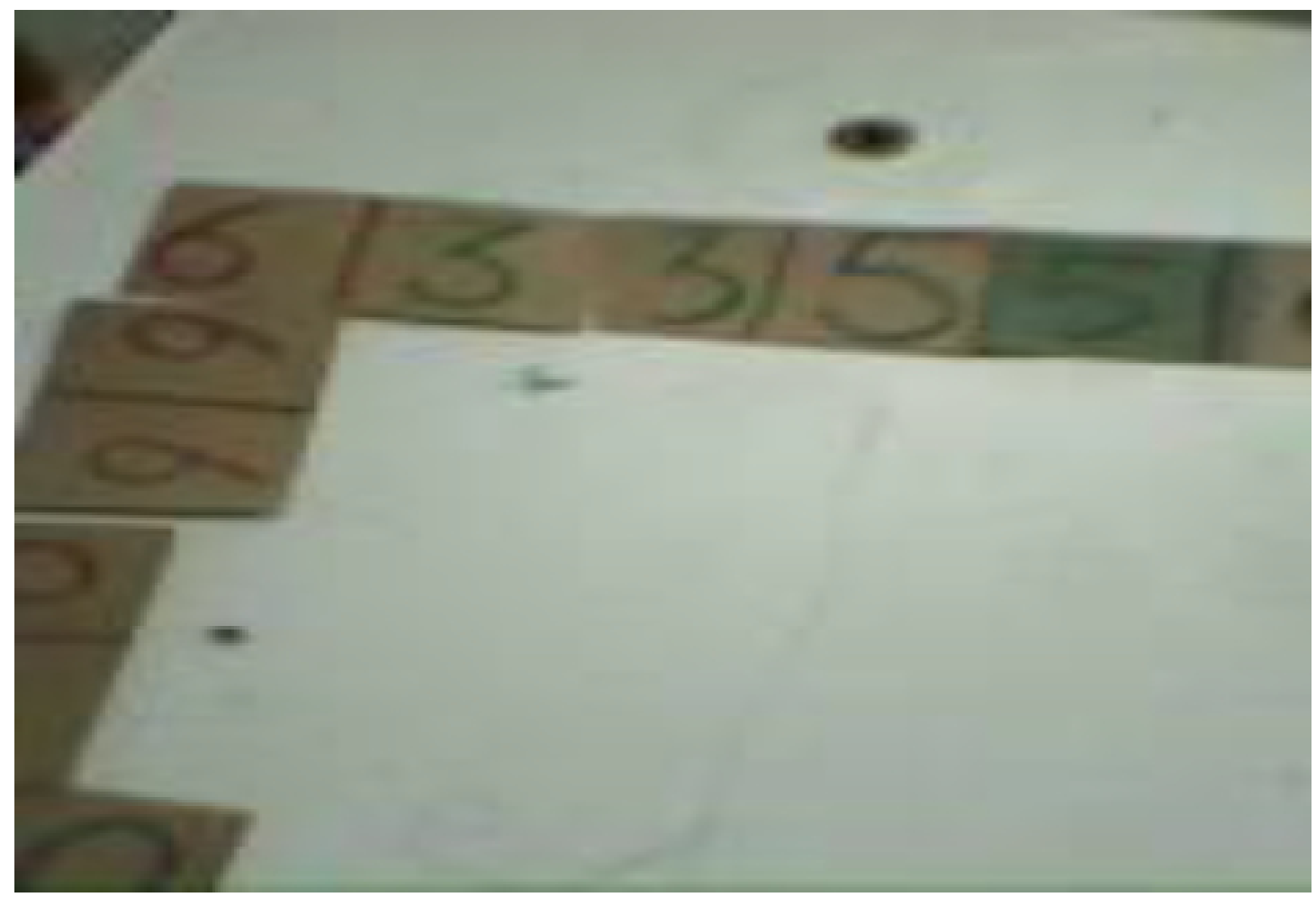

Fonte: Helenara Correia Teixeira (2018)

Ao termino do projeto dos jogos realizou-se uma exposição na escola para toda a comunidade escolar. E pelos ótimos resultados do projeto, realizou-se uma reunião na escola para escolher os trabalhos os quais seriam apresentados na Mostra de Ciência e Artes de Anastácio.

\section{CONSIDERAÇÕES FINAIS}

Observando que os alunos estavam com dificuldades e pouco rendimento no componente curricular de matemática, buscou-se como subsídio a confecção de jogos como o baralho da multiplicação, o jogo das garrafas (argola), e outros jogos, como fonte de experiência para ensiná-los contar somar, subtrair, dividir e multiplicar, o qual percebemos juntamente com os professores, que por meio dos jogos e a ludicidade os alunos tiveram realmente um aprendizado e ainda gostarem de matemática.

Todas as atividades foram desenvolvidas de forma a trabalhar com a realidade local da comunidade, ou seja, com conteúdos direcionados a dificuldade de cada 
aluno e que também proporcionasse interesse nesses alunos, o rendimento da turma do $3^{\circ}$ ano mudou e até os alunos das outras salas queriam participar das atividades.

Percebemos que por meio de jogos e desafios, os alunos foram estimulados a desenvolver o raciocínio lógico, estabelecendo a criatividade na busca por estratégias diferenciadas que colaboram para o seu aprendizado.

Pode-se notar que há carência de jogos na escola e evidentemente nas salas de aulas, bem como a necessidade de conhecer novos jogos, além de proporcionar aos alunos maior aprendizagem e rendimento, auxiliando no desenvolvimento do raciocínio lógico, da criatividade, da interação e da socialização.

Nesse sentido foi gratificante trabalhar com os professores e os alunos na elaboração e na confecção dos jogos, pois, o interesse e estimulo pelo novo e pelo material que todos ajudaram a criar trouxe novas perspectivas para eles e que também estimulou o raciocínio criando outras regras para o jogo.

Comparando a avaliação que foi realizada a (sondagem) antes da construção dos jogos e a avaliação após a construção verificou-se que houve um melhor rendimento dos alunos do $3^{\circ}$ ano.

Observou-se que no dia da Exposição e Apresentação do trabalho em questão houve interação, socialização, união, descontração e envolvimentos de todos dos pais, alunos, professores e de toda a comunidade escolar.

Assim, percebeu-se que a utilização de materiais alternativos para construir os jogos usados nas aulas, quando avaliado no contexto do ensino da matemática, proporcionou aos alunos um a melhor compreensão dos conceitos desenvolvidos nas aulas teóricas, tornando-os interessantes e agradáveis, desenvolvendo sua capacidade de observação e reflexão, uma maior aproximação com a Região e sua cultura, sendo que permitiu a interação entre alunos e professores, transformando-se em um espaço de construção coletiva do conhecimento, como também demonstrou que nesse espaço a situação de aprendizagem pode-se utilizar de materiais alternativos que deixam sua função primária e passam a ser didáticos, transmitindo informação com a intenção de provocar, por meio do desafio, o uso da intuição, para a partir dela, fazer com que o aluno questione, procure regularidades, tome decisões mas, principalmente, que tenha coragem de resolver os problemas a ele apresentados por si só. 
Dessa forma, conclui-se que há uma necessidade em se trabalhar com jogos e principalmente direcionando para o componente curricular de matemática, pois amplia o conhecimento dos alunos, possibilitando que eles tenham um senso de fortalecimento da autoestima a partir do momento em que conseguem compreender o abstrato, por meio do lúdico é possível mostrar a criança um universo de possibilidades para a construção do conhecimento.

\section{REFERÊNCIAS}

BOGDAN, R.; BIKLEN, S. Investigação qualitativa em educação: uma introdução à teoria e aos métodos. Lisboa: Porto Editora, 1994.

CABRAL, Silas. CABRA, C. e ANGELO, R. Anastácio. Campo Grande, MS: Gráfica Editora Alvorada, 2003.

FLICK, U. Qualidade na pesquisa qualitativa. Porto Alegre: Artmed, 2009.

KALHIL, J.B. Estratégia Pedagógica para el desarrollo de habilidades investigativas en la Disciplina Física de Ciências Técnicas. Tese de Doutorado em Ciências Pedagógicas. Universidade de Havana, Havana, 2003.

LDB, Lei de Diretrizes e Bases da Educação Nacional. Lei 9.394/96 de 20 de dezembro de 1996, Diário Oficial da União 23/12/96. Disponível em: https://www.planalto.gov.br/ccivil_03/Leis/L9394.htm, acessado em: 19/07/2019.

MOREIRA, Marco Antônio. A Teoria da aprendizagem significativa e sua implementação em sala de aula. Brasília: Editora Universidade de Brasília, 2006.

OLIVEIRA, Patrícia. Coleção Tendências em Educação Matemática. Belo Horizonte: Editora Autêntica, 2006.

PIAGET, J. A formação do símbolo na criança: imitação, jogo e sonho, imagem e representação. 3ed. Rio de Janeiro: Zahar, 1981.

PETRY, Mary Rose; QUEVEDO, Zelia Rodrigues. A magia dos jogos na alfabetização. Porto Alegre: Kuruap, 1993.

RIBEIRO, Flávia Dias., Jogos e modelagem na educação matemática/ Flávia Dias Ribeiro. Curitiba: Ibpex,2008.124p.:i Ibpex,2008.124p.:II 
VAZIRO, Z.C.M. Laboratório de Matemática Escolar - Série Laboratório de Matemática Escolar - Caderno 0. Goiânia: Gráfica e Editora Vieira, 2001.

VYGOTSKY, L.S. A formação social da mente. São Paulo: Martins Fortes, 1984. 


\section{DO ACAMPAMENTO À FORMAÇO DE ASSENTAMENTOS RURAIS: A CONQUISTA DA TERRA E A BUSCA DAS FAMÍLIAS POR MELHORES CONDICOOES DE VIDA}

Alessandra Regina Muller Germani ${ }^{17}$ Ana Paula Schervinski Villwock ${ }^{18}$

$17 \quad$ Enfermeira. Professora do Magistério Superior na Área de Saúde Coletiva na Universidade Federal da Fronteira Sul - UFFS, Campus Passo Fundo/RS. Doutora em Extensão Rural pelo Programa de Pós-Graduação em Extensão Rural da Universidade Federal de Santa Maria - UFSM.E-mail: alessandragermani@hotmail.com

18 Engenheira Agrônoma. Professora do Magistério Superior no Departamento de Engenharia Agronômica da Universidade Federal de Sergipe. Doutora em Extensão Rural pelo Programa de Pós-Graduação em Extensão Rural da Universidade Federal de Santa Maria - UFSM. E-mail: ana. agronomia@gmail.com 
A formação dos assentamentos no país tem sido uma das principais respostas do Estado aos conflitos relacionados às lutas populares e as demandas sociais pelo direito de acesso à terra. É uma ação pontual e localizada, que não enfrenta a desigualdade social existente no campo, mas que contribui timidamente para atenuar conflitos e modificar lentamente a estrutura agrária do Brasil. Contudo, apesar dos percalços, vários estudos apontam que os assentamentos apresentam resultados bastante significativos (SAUER, 2005; BERGAMASCO e FERRANTE, 2005; MEDEIROS e LEITE, 2009; DE FREITAS COCA, 2013; FIGUEIREDO E PINTO, 2014).

Os assentamentos rurais representam, portanto, um novo momento no contexto da luta pela terra desenvolvida pelos diferentes movimentos sociais. Significa que a terra já foi conquistada, dando início a uma nova etapa da caminhada que envolve a organização das famílias a serem assentadas e a estruturação de uma nova comunidade rural.

Desta maneira, este capítulo apresenta os resultados encontrados a partir de uma pesquisa bibliográfica realizada na perspectiva de reunir subsídios teóricos para sustentar nossas reflexões em sala de aula e em outros espaços de debate acerca do tema. Os dados foram coletados e sintetizados durante o primeiro semestre de 2018, utilizando-se diferentes fontes bibliográficas. Sendo selecionadas produções de autores reconhecidos no cenário nacional e que se destacam na produção de conhecimentos sobre o tema.

\section{DESENVOLVIMENTO}

Analisando os dados disponíveis no Instituto Nacional de Colonização e Reforma Agrária - INCRA referentes aos programas de assentamentos rurais identifica-se que, entre 1961 e 2009, foram implantados no Brasil, 8.637 assentamentos e que até maio de 2016 foram assentadas 1.346.798 famílias. Já, o estudo de Spavorek (2003), nos mostra que até 2008 existiam no Brasil 4 milhões de famílias sem-terra; 1,6\% dos proprietários controlavam até $78 \%$ das terras, existiam 130 milhões de terras ociosas e 30 empresas transnacionais controlavam a produção, a industrialização, a distribuição, e a comercialização dos produtos agrícolas no país (SPAVOREK, 2003; 
BERGAMASCO e FERRANTE, 2005; MATTEI, 2013; GUERRERO, BERGAMASCO e ESQUERDO, 2016).

Esses dados mostram que independente de ter viabilizado para as populações excluídas acesso à terra, por meio do aumento do número de assentamentos e de famílias assentadas, em nada alterou o quadro geral de concentração da propriedade da terra no cenário nacional, evidenciando que há muito para se fazer em relação a desconcentração e a ociosidade da terra no Brasil (SPAVOREK, 2003; BERGAMASCO e FERRANTE, 2005; MATTEI, 2013; GUERRERO, BERGAMASCO e ESQUERDO, 2016).

A obtenção de terras para o assentamento se dá por meio da desapropriação de terras, regularização fundiária, reconhecimento de projetos já existentes, reassentamento de atingidos por grandes obras de infraestrutura, entre outros. Não são assentados somente camponeses sem-terra, mas também comunidades tradicionais, posseiros, colonos, parceiros, seringueiros, trabalhadores urbanos vivendo de ocupações temporárias e à margem do mercado de trabalho formal, entre outros, demonstrando a diversidade dos assentamentos rurais e seus beneficiários. Os assentamentos são implantados não só para aqueles que querem entrar na terra, mas para aqueles que nela querem permanecer, com condições dignas de vida (SOUZA-ESQUERDO e BERGAMASCO, 2011; DE FREITAS COCA, 2013).

Neste sentido, a literatura sobre a diversidade dos atores envolvidos nos processos de criação e consolidação dos assentamentos no país é vasta, além dos demandantes pela terra, que também se apresentam sob diferentes formas (assalariados, parceiros, posseiros, etc), estão presentes outros, como: governo federal, o INCRA, o Poder Judiciário, os governos estaduais e seus respectivos órgãos de terra, as secretarias estaduais de agricultura e seus organismos de assistência técnica, prefeituras, organizações não-governamentais, entidades vinculadas às igrejas, entidades de representação como sindicatos, Movimento dos Trabalhadores Rurais Sem Terra - MST, Via Campesina, associações de produtores, cooperativas, entidades patronais, entre outros. Cada um expressando seu pensamento e força política em relação à implementação dos assentamentos (MEDEIROS e LEITE, 2009). 
Frente à diversidade deste contexto, as formas de luta pela terra e pela Reforma Agrária no país se configuram de diferentes formas, sendo que a partir da década de 1990, num contraponto as tradicionais estratégias de resistência que foram desenvolvidas pelos camponeses frente à expropriação pelo capital na década de 1950 e, sobretudo entre 1970 e meados da década de 1980 na fase de apogeu do avanço do capital sobre a agricultura brasileira, e com as ações do MST, a ocupação seguida da construção de acampamentos ganham visibilidade e consequentemente, projeção política e jurídica (MEDEIROS, 2004; SOUZA-ESQUERDO e BERGAMASCO, 2011).

A foto abaixo retrata a ocupação realizada na Fazenda Annoni que ocorreu na madrugada de 29 de outubro de 1985 e contou com o envolvimento de 1.500 famílias. Essa ocupação é reconhecida como um marco da retomada da luta pela terra no fim da ditadura militar e também como berço da organização do Movimento dos Trabalhadores Sem Terra - MST no país.

Figura 2 - Registro fotográfico da Área 10, local do Acampamento da Annoni

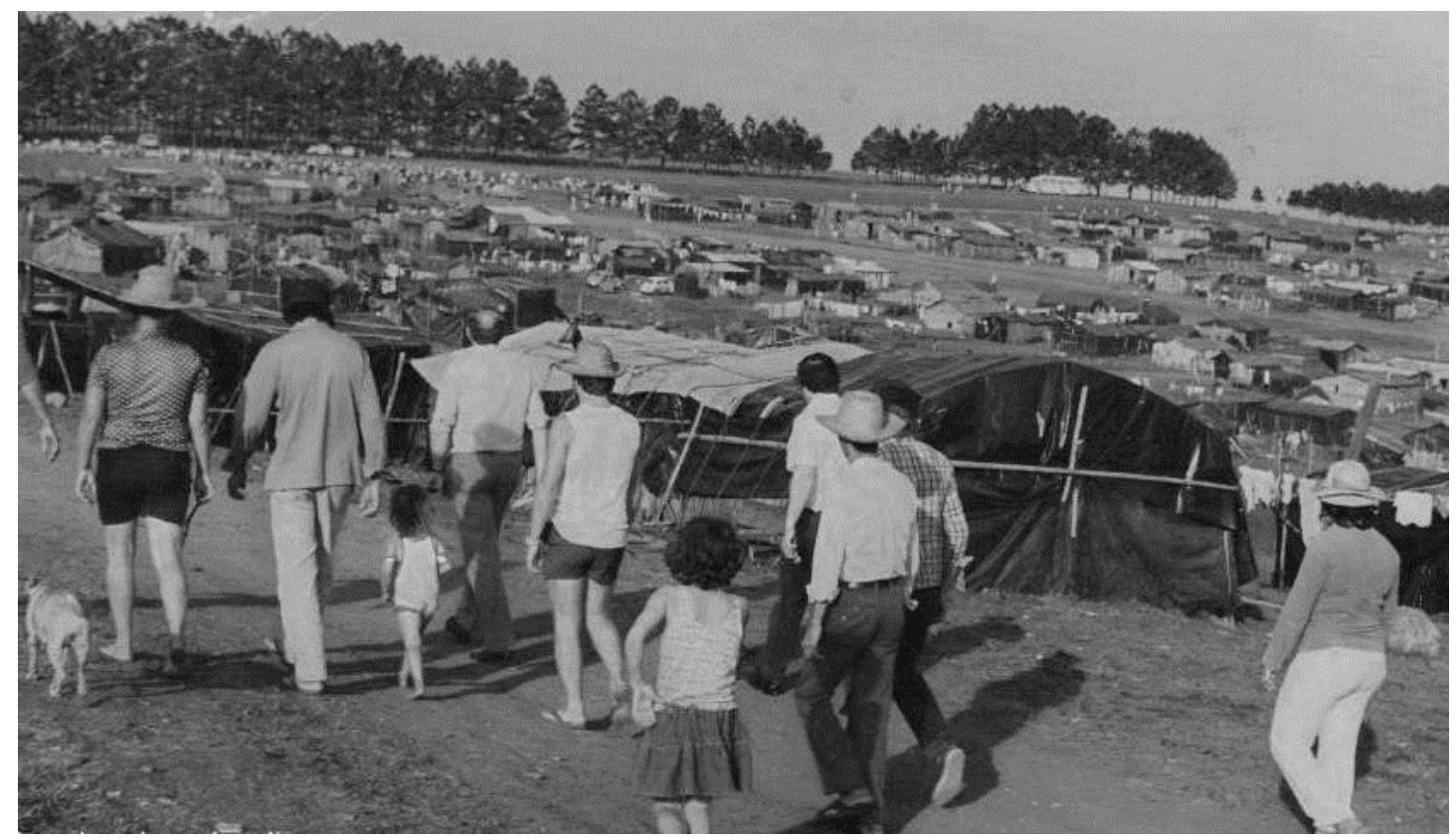

Fonte: Acervo de José Leal. Disponível em: http://www.mst.org.br/2015/10/30/aprendemos-a-sonhar-e-a-conquistar-sonhos-e-ainda-sonhamos-com-o-socialismo-afirma-sem-terra-sobre-a-1-ocupacao-do-mst.html

Os acampamentos são caracterizados como um momento de transição, de passagem construídos em áreas que se pretende transformar em assentamentos ou do lado de fora de fazendas, à margem das rodovias. Organizam-se internamente 
na forma de Coletivos, que são instâncias coletivas de decisão, sobre os diversos assuntos pertinentes ao funcionamento dos acampamentos, pois os acampados enfrentam muitas dificuldades neste período, tais como: doenças, fome, exposição às intempéries, a fragilidade dos barracos, violência, entre outras. Este é um período, na qual as pessoas, pelo convívio, rompem com as suas identidades anteriores, recriando relações e valores, práticas sociais e formas organizativas. Como ainda não chegaram ao seu lugar definitivo, ainda não alcançaram a sua nova identidade: o de ser assentado (SAUER, 2005; MARTINS, 2009; FIGUEIREDO E PINTO, 2014).

Neste sentido, abaixo segue um dos registros fotográficos do barraco em que estava alojado a família do Sr. JoséEstevão da Silva durante o período do acampamento na Fazenda Annoni, em 1985. Salienta-se que nesta realidade, os barracos foram sendo montados com madeiras, taquaras, algumas retiradas do mato e cobertas com lonas pretas. Como eram muitas as famílias, elas foram se organizando por proximidade e conforme os municípios de origem, sendo os barracos erguidos um próximo ao outro, porque não se tinha muito espaço disponível naquela área.

Figura 3 - Registro fotográfico da família do Sr. José Estevão da Silva em frente ao barraco no Acampamento da Annoni.

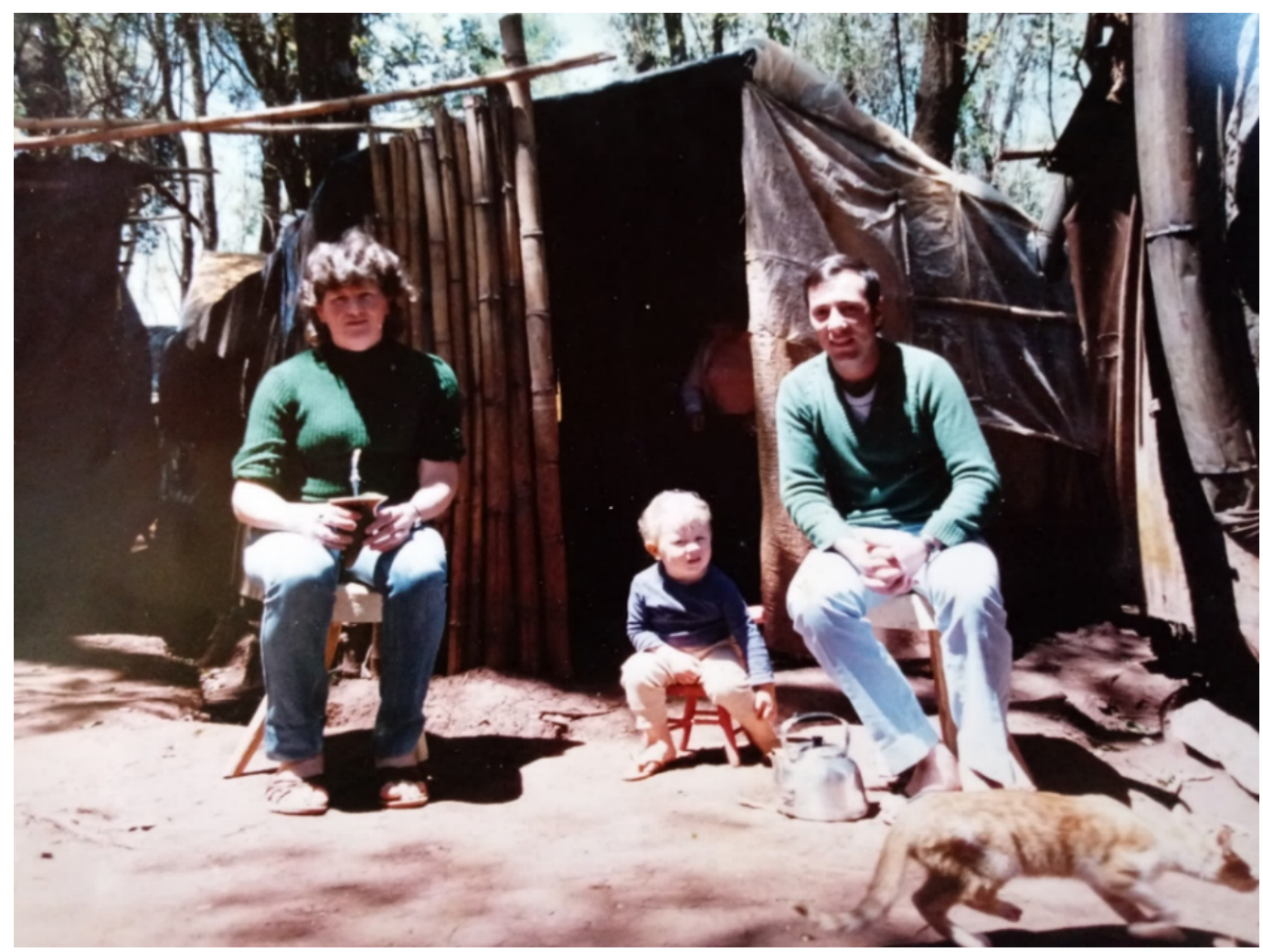

Fonte: Acervo pessoal do Sr. Zé Estevão - liderança no Acampamento 
As pessoas lutavam em busca de uma perspectiva que seja capaz de garantir-Ihes, através do trabalho e da produção, a liberdade, a sobrevivência e a continuidade da vida (reprodução social). A busca pelo trabalho é parte fundante do processo de luta e conquista da terra. $\mathrm{O}$ direito ao trabalho significa muito mais que um emprego ou ocupação, pois viabiliza liberdade e fartura no sustento da família. Lutam, portanto, por melhores condições de vida e por um lugar que lhes permita enraizamento e pertencimento. O acesso à terra representa, portanto, um lugar de trabalho, de produção e de vida, um novo momento na experiência de vida dos assentados (SAUER, 2005; BERGAMASCO e FERRANTE, 2005; FIGUEIREDO E PINTO, 2014).

Neste sentido, os assentamentos podem ser compreendidos como um lugar onde diferentes histórias de vida se cruzam se encontram ou, decorrentes dos acampamentos, se reencontram. Desse momento, surge a construção de novos processos sociais de interação que dão origem a identidade social de assentado. Esses atores sociais e políticos terão a possibilidade de desenvolver processos organizativos internos que podem resultar na criação de associações, cooperativas, grupos de produção, roças ou investimentos comunitários, etc. Também a criação de outros mecanismos que permitam a interação do grupo social, como igrejas, escolas, centros comunitários e de lazer, grupos de trabalho, entre outros, que contribuem para a organização e sustentabilidade dos projetos de assentamento. Mesmo que no interior do assentamento haja conflitos e diferenças culturais, isso não se constitui em aspectos desmobilizadores (SAUER, 2005).

Abaixo segue a foto de alguns dos lugares onde as famílias se reúnem, ginásio e igreja, na Comunidade 16 de Março, no Assentamento da antiga Fazenda Annoni. 


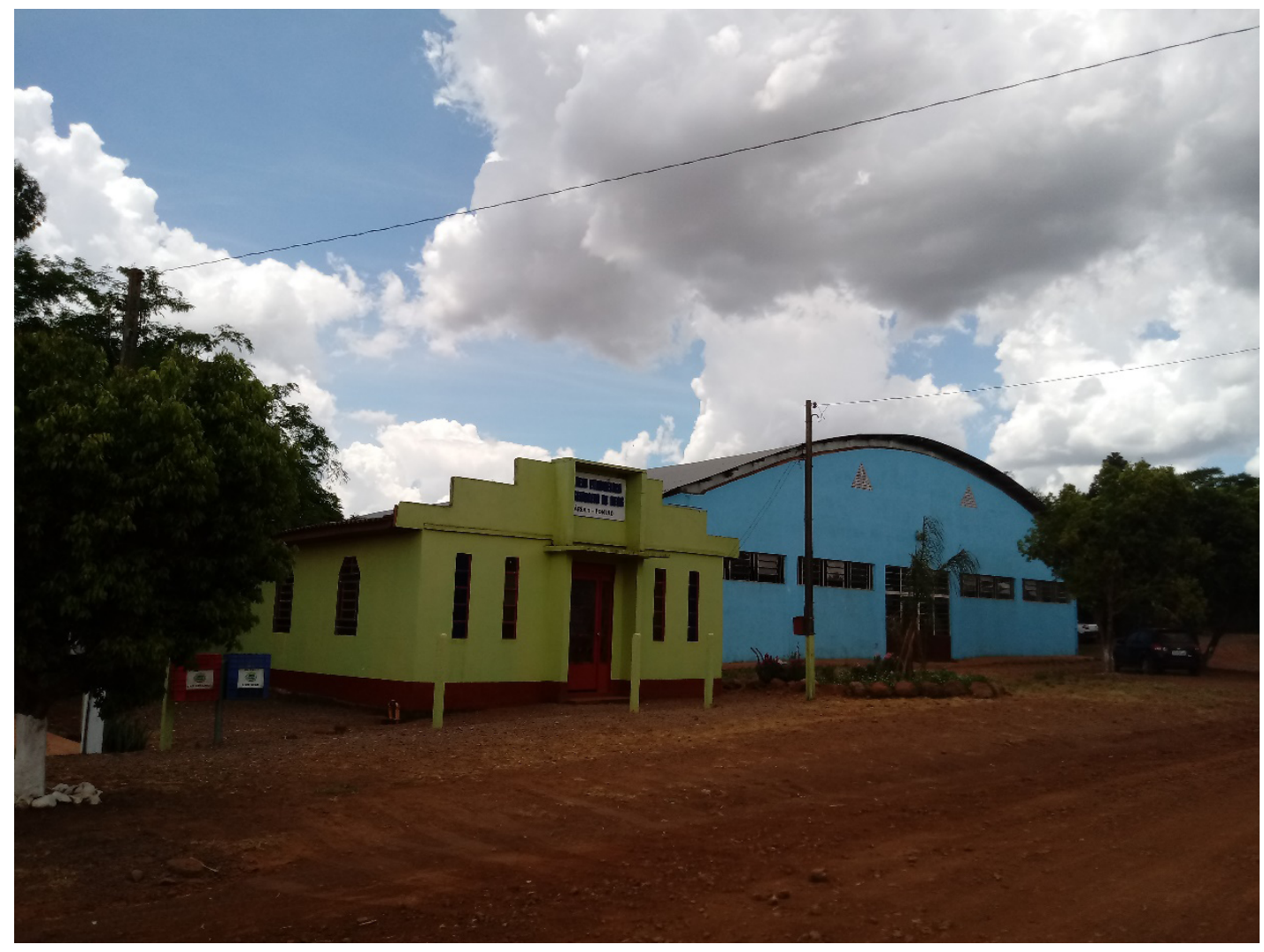

Fonte: Arquivo pessoal das autoras (2017).

Em termos de conceituação, a referência à palavra assentamento surge pela primeira vez no cenário político e social, em 1960, no contexto da Reforma Agrária venezuelana, e se difundi por inúmeros países, inclusive no Brasil. De uma forma geral, os assentamentos rurais podem ser definidos como um espaço social e geograficamente delimitado, de continuidade da luta pela terra, criado por meio de políticas governamentais visando o reordenamento do uso da terra em benefício de trabalhadores rurais sem terra ou com pouca terra. A criação dos assentamentos, inclusive como lugares existenciais - geram uma nova organização social, econômica e política (BERGAMASCO e NORDER, 1996; SAUER, 2005; MARTINS, 2009; MEDEIROS e LEITE, 2009)

Do ponto de vista institucional, a Portaria MDA no 80 de 24/04/2002, conceitua assentamento como sendo a unidade territorial que é obtida pelo programa de Reforma Agrária do Governo Federal, ou em parceria com os Estados ou Municípios, por meio da desapropriação, arrecadação de terras públicas, aquisição direta, doação, reversão do patrimônio público, ou por financiamento de créditos fundiários; que será destinada aos indivíduos que são selecionados pelos programas de acesso à terra. $\mathrm{E}$ 
como assentados, todo o candidato que se inscreve e após entrevista é selecionado para ingressar no Programa de Reforma Agrária, sendo concedido, portanto, o direito ao uso de terra identificada, incorporada ou em processo de incorporação ao Programa (BRASIL, 2002; RAMIRO, 2008).

O esforço para padronizar os conceitos e ajustá-los à legislação faz emergir uma definição meramente técnica do que seja assentamento e assentados. Neste sentido, sobre os assentados, Guerrero, Bergamasco e Esquerdo (2016), fazem questão de mencionar que o assentado é também a pessoa que busca seus direitos, coloca em risco a sua vida e a de seus familiares na luta pela terra. Luta, portanto, por um pedaço de terra e pela conquista de seus direitos.

A constituição dos assentamentos no país não foi acompanhada de um planejamento prévio de localização e de oferta de bens sociais, de equipamentos e serviços públicos por parte do Estado. Muitos enfrentaram e enfrentam situações adversas em relação às condições de sua instalação, que dispersos geograficamente, desencadearam uma série de reinvindicações ligadas principalmente à infraestrutura básica, como construção e/ou melhorias de estradas, saúde e educação, condições para escoamento da produção, entre outros. Com isso, fica evidente que a criação e manutenção dos assentamentos vêm caminhando de forma lenta e fortemente dependente da vontade política dos governantes, gerando consequências por vezes negativas na vida dos assentados e reforçando a necessidade de se manterem organizados e em luta constante pelos direitos e justiça social (MEDEIROS e LEITE, 2009; FIGUEIREDO E PINTO, 2014).

\section{CONCLUSÃO}

Assim, conclui-se com a realização dessa pesquisa bibliográfica, que para os assentados a conquista da terra não significa o fim da luta, mas sim um ponto de partida, pois a estruturação dos assentamentos significa uma nova etapa, a da conquista por condições plenas de vida e de produção; é um momento de (re)criar a vida em comunidade e de seguir resistindo e lutando pela transformação do modelo de desenvolvimento econômico e social no país. 
BRASIL. Portaria MDA n 80, de 24 de abril de 2002. Adota as denominações e os conceitos aplicáveis ao Ministério do Desenvolvimento Agrário e sua entidade vinculada, o Instituto Nacional de Colonização e Reforma Agrária. Diário Oficial da União, Brasília, DF, 25 abr de 2002.

BERGAMASCO, Sonia Maria Pessoa Pereira; FERRANTE, Vera Lúcia Silveira Botta. A qualidade dos assentamentos da reforma agrária: a polêmica que nunca saiu de cena. Brasília: NEAD, 2005.

BERGAMASCO, Sonia Maria Pessoa Pereira; NORDER, Luís Antônio C. O que são os assentamentos rurais? São Paulo: Brasiliense, 1996.

DE FREITAS COCA, Estevan Leopoldo. Identidades dos camponeses assentados no Território Cantuquiriguaçu, Paraná - Brasil. Revista Mercator, Ceará, CE, v.14, n. 1, p. 77-88, 2015.

FIGUEIREDO, Gislayne Cristina; PINTO, José Marcelino de Rezende. Acampamento e assentamento: participação, experiência e vivência em dois momentos da luta pela terra. Revista Psicologia \& Sociedade, v. 26, n. 3, 2014.

GUERRERO, Iris Cecilia Ordóñez; BERGAMASCO, Sonia Maria Pessoa Pereira; ESQUERDO, Vanilde Ferreira de Souza. Reforma Agrária: contribuições para o debate. Revista Eletrônica Retratos de Assentamentos, v. 19, n. 1, p. 351-380, 2016.

MARTINS, José de Souza. Travessias: a vivência da reforma agrária nos assentamentos. 2 ed. Porto Alegre: Editora da UFRGS, 2009.

MATTEI, Lauro. A reforma agrária brasileira: evolução do número de famílias assentadas no período pós-redemocratização do país. Estudos Sociedade e Agricultura, v. 2, 2013.

MEDEIROS, Leonilde Servolo de; LEITE, Sérgio. A formação dos assentamentos rurais no Brasil: processos sociais e políticas públicas. 2 ed. Porto Alegre: Editora da UFRGS, 2009.

MEDEIROS, Leonilde Servolo de. As novas faces do rural e a luta por Terra no Brasil Contemporâneo. Nómadas, n. 20, p. 210-219, 2004.

SAUER, Sérgio. O significado dos assentamentos de reforma agrária no Brasil. In: Caio FRANÇA, Galvão de; SPAVOREK, Gerd. Assentamentos em debate. Brasília: NEAD, 2005. 
SPAROVEK, Gerd. A qualidade dos assentamentos da reforma agrária brasileira. São Paulo: Páginas \& Letras. Editora e Gráfica, 2003.

SOUZA-ESQUERDO, Vanilde Ferreira; BERGAMASCO, Sonia Maria Pessoa Pereira. Reforma Agrária e Assentamentos Rurais: perspectivas e desafios. V Jornada de Estudos em Assentamentos Rurais, 2011. Campinas/SP. Anais V Jornada de Estudos em Assentamentos Rurais. Campinas/SP: Feagri/Unicamp, 2011. p.01-23.

RAMIRO, Patrícia Alves. Assentamentos rurais: o campo das sociabilidades em transformação: o caso dos assentados do Nova Pontal. 2008. 156f. Tese (Doutorado em Sociologia) - Universidade Federal de São Carlos, São Carlos, 2008. 

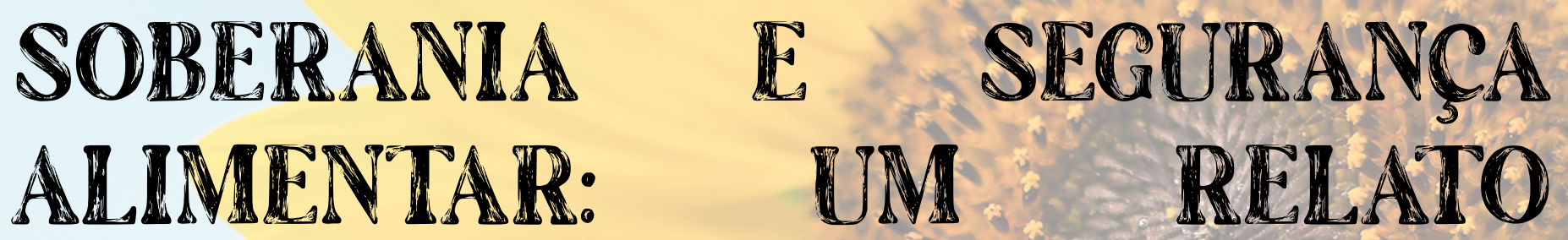
DE

Alessandra Regina Muller Germani ${ }^{19}$

19 Enfermeira. Professora do Magistério Superior na Área de Saúde Coletiva na Universidade Federal da Fronteira Sul - UFFS, Campus Passo Fundo/RS. Doutora em Extensão Rural pelo Programa de Pós-Graduação em Extensão Rural da Universidade Federal de Santa Maria - UFSM.E-mail: alessandragermani@hotmail.com 
O Curso de Licenciatura em Educação do Campo, da Universidade Federal de Santa Maria - UFSM, ofertado na modalidade à distância, foi implantado em 2017, e conta com o apoio dos Polos dos seguintes municípios: Agudo, Balneário Pinhal, Cerro Largo, Itaqui, Novo Hamburgo, Santana do Livramento, São Sepé, São Lourenço do Sul, Seberi e Sobradinho (PPC, 2017).

O referido Curso tem como objetivo principal proporcionar uma formação que contemple uma nova demanda da sociedade, gerada pelas populações do campo, que historicamente lutam por uma educação diferenciada e de qualidade, que respeitem as especificidades do seu modo de viver que tem profunda ligação com a terra (PPC, 2017).

Neste contexto, a disciplina Soberania e segurança alimentar, foi disponibilizada para os 99 educandos matriculados, no segundo semestre de 2020 , tendo como finalidade conhecer e compreender os marcos legais da Soberania e da segurança alimentar no cenário nacional e internacional, destacando que o direito a soberania alimentar diz respeito aos direitos inerentes aos agricultores de produzirem seus alimentos (PPC, 2017).

Por ser uma disciplina ministrada a distância, torna-se uma prática desafiadora a prática docente, pois exige que sejam adotadas estratégias de ensino-aprendizagem que permitam despertar no educando o interesse e a adesão as atividades propostas no decorrer do semestre. Desta forma, para despertar, redescobrir, incrementar ou ativar os estudos, na perspectiva de propiciar uma formação crítica da realidade, considerando que serão futuros educadores do campo, essas estratégias não podem ser somente de cunho teórico, mas sim de interação entre teoria e prática, promovendo assim a interligação com o contexto social, econômico, cultural, de pluralidade e diversidade presentes nas escolas do campo.

Tendo em vista estas questões, elaborou-se um cronograma de aulas constituído por sete etapas para a disponibilização, via Plataforma moodle, dos conteúdos teóricos, das atividades de interatividade e de aprofundamento dos temas estudados, tais como, sugestão de filmes, documentários, leituras de textos e exercícios de análise de situações que envolvem a realidade do campo voltadas para a Soberania e segurança alimentar. Assim, a cada etapa foram liberados conteúdos e atividades a serem realizadas pelos educandos, seguindo o ementário da disciplina. 
Para a operacionalização das aulas, além de um docente para a mediação do conhecimento, a disciplina contou com o apoio de um tutor pedagógico do Curso, o qual tinha a responsabilidade de estar fomentando e acompanhando os educandos durante o desenvolvimento das atividades previstas no cronograma.

Neste sentido, o presente capítulo tem a finalidade de apresentar a experiência de estruturação de um cronograma de aulas da disciplina de Soberania e segurança alimentar, na perspectiva de socializar essa forma de organização didático-pedagógica adotada na modalidade de ensino à distância. Cabe salientar que as temáticas da Soberania e da segurança alimentar surgem de maneira inter-relacionadas na realidade, porém por uma questão didático-pedagógica desenvolveu-se uma divisão em unidades de aprendizagem para facilitar o aprofundamento de cada um dos subtemas que envolvem o conjunto de conteúdos da disciplina.

\section{DESENVOLVIMENTO}

É padrão iniciarmos a disciplina na Plataforma moodle com uma apresentação inicial, indicando os objetivos, metodologia e disponibilizando o plano de ensino para acesso e acompanhamento dos educandos, conforme ilustração abaixo.

Figura 1 - Registro da apresentação da disciplina

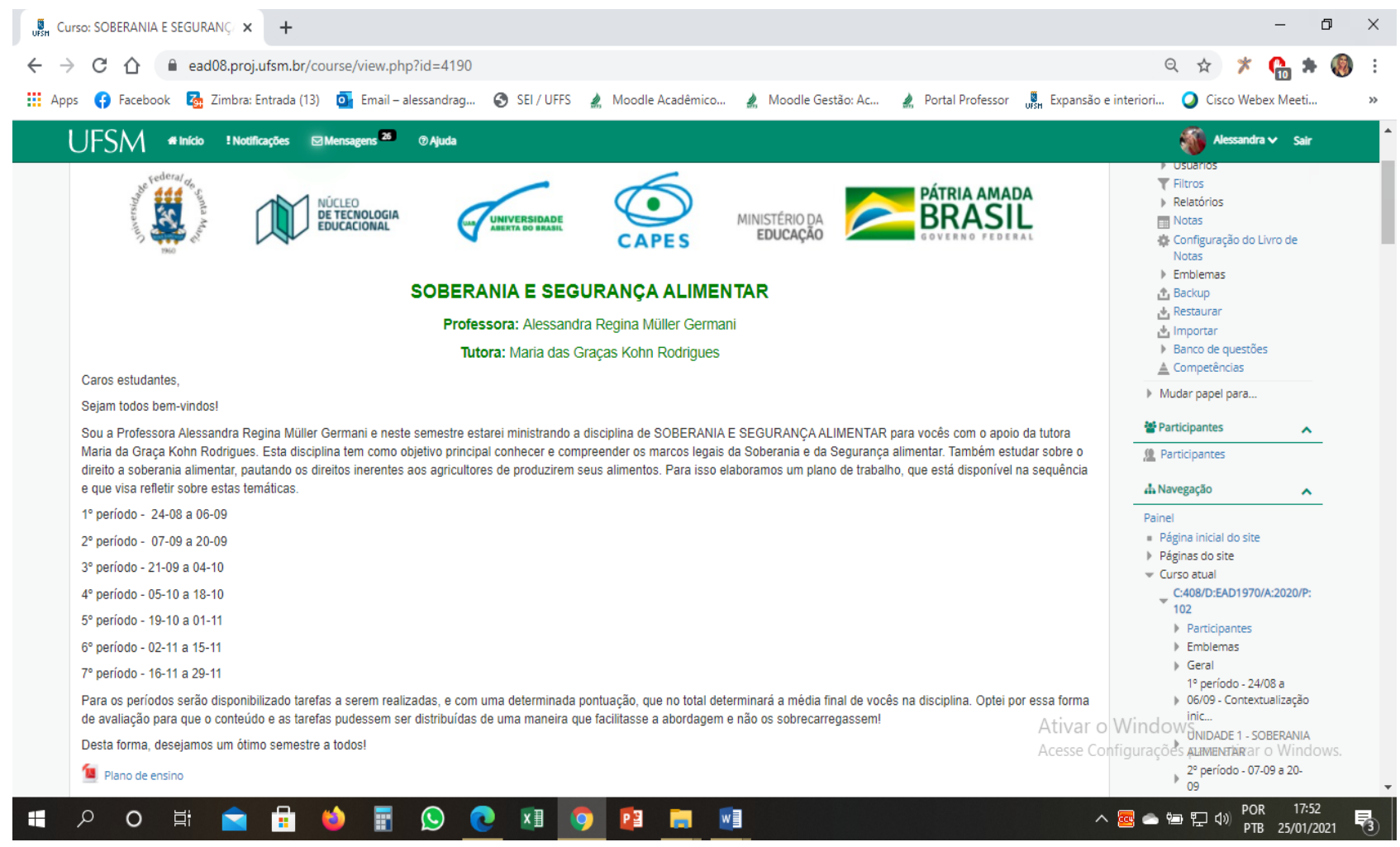

Fonte: Plataforma moodle, 2021. 
A primeira etapa do cronograma de aula ocorreu no período de $24 / 08 / 2020$ a 06/09/2020, e teve a intenção de desencadear o processo educativo-reflexivo sobre o tema da Soberania e segurança alimentar trazendo à tona a realidade da produção dos alimentos que consumimos no país. Para isso, disponibilizou-se dois filmes/ documentários para os educandos, sendo o primeiro chamado "O Veneno está na mesa I - 2011" e o segundo denominado "O Veneno está na mesa II - 2014", ambos com direção de Silvio Tendler.

Para apoiar a apreensão dos conteúdos propiciados pelos filmes/documentários, também se disponibilizou um estudo dirigido contendo questões relacionadas aos pontos essenciais em que os educandos deveriam se ater em cada um dos filmes/documentários, que após preenchidos deveriam ser postados na Plataforma moodle.

Neste sentido, no estudo dirigido foram realizados os seguintes questionamentos aos educandos: De onde vêm os alimentos que consumimos diariamente? Como os alimentos eram produzidos no Brasil até a década de 1940? Quais as técnicas agrícolas utilizadas para a produção desses alimentos? Em que quantidade esses alimentos eram produzidos? Quais mudanças ocorreram na produção de alimentos em nosso país a partir da segunda metade do século XX? Quais as técnicas agrícolas passaram a ser utilizadas para a produção desses alimentos? Em que quantidade esses alimentos são produzidos na atualidade? Essa nova forma de produzir a partir da segunda metade do século $X X$ trouxe sérias repercussões para a vida humana e para a natureza. De acordo com os filmes/documentários quais seriam as possibilidades de mudanças frente a essa nova forma de produzir alimentos? Explique, a partir dos estudos que vocês têm desenvolvido no Curso e dos filmes/documentários, qual o seu pensamento sobre essas mudanças ocorridas na produção de alimentos no país?

Abaixo segue registro ilustrativo da Plataforma moodle, de como estes materiais pedagógicos foram postados e disponibilizados para os educandos. 
Figura 2 - Registro da primeira etapa do cronograma da disciplina

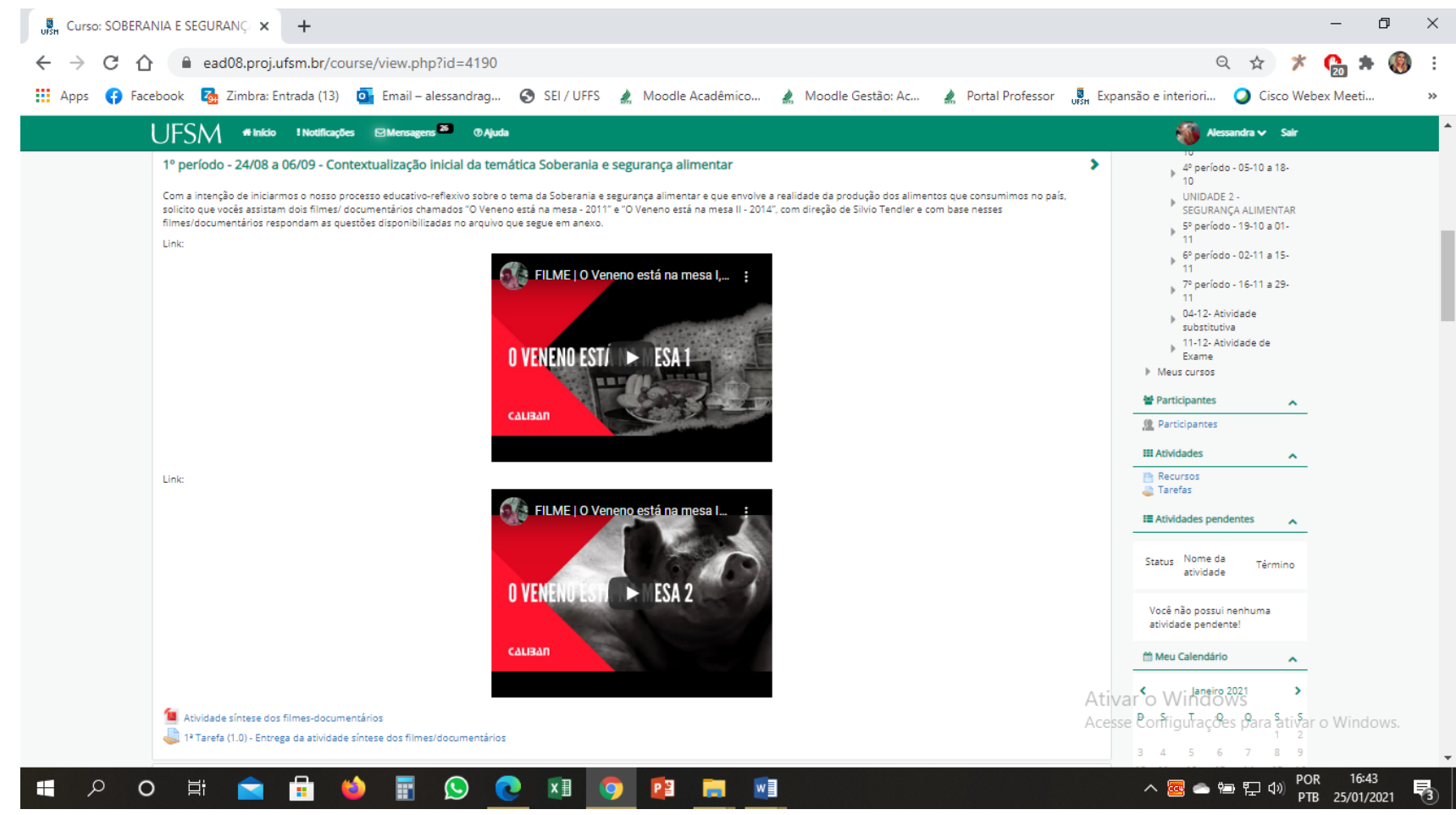

Fonte: Plataforma moodle, 2021.

Ao final desta primeira etapa da disciplina, dos 99 educandos matriculados, 79 fizeram a entrega dessa primeira atividade. Importante destacar que este primeiro exercício teve a intenção de aproximar e contextualizar a temática que seria aprofundada no decorrer do semestre, sendo as questões respondidas pelos educandos de maneira coerente com o que estava sendo proposto. Alguns educandos enviaram mensagens a fim de destacar a relevância desse momento inicial, no qual os vídeos permitiram um "choque de realidade" sobre a temática a ser estudada. Ao mesmo tempo lançando o desafio a eles de como agregar esse assunto em suas futuras práticas como educadores do campo.

Após esse primeiro momento de contextualização geral, passamos para a segunda etapa, desenvolvida no período de 07/09/2020 a 20/09/2020, na qual abordou-se os conteúdos referentes a Unidade 1 - Soberania alimentar, especificamente o item 1.1 Conceito e princípios de soberania alimentar. Neste sentido, os autores Oliveira e Castro (2013) referem que o termo soberania alimentar e nutricional emerge dos intensos debates internacionais, a partir da década de 1990, sendo seu conceito desenvolvido a partir daí. No Brasil, o Artigo $5^{\circ}$, da Lei 11.346/2006, que dispõe sobre 
a Lei Orgânica da Segurança Alimentar e Nutricional (Losan) estabeleceu o conceito de soberania alimentar vigente no país. Sendo assim estabelecido:

A consecução do direito humano à alimentação adequada e da segurança alimentar e nutricional requer o respeito à soberania, que confere aos países a primazia de suas decisões sobre a produção e consumo de alimentos (BRASIL, 2006).

Partindo desse entendimento, foram disponibilizados três artigos científicos que apresentavam conteúdos relacionadas aos desafios alimentares frente ao contexto de combate à fome e o surgimento das estratégias de ação vinculadas a soberania alimentar no mundo, na América Latina e no Brasil. E de maneira complementar, e para auxiliar na realização do estudo dirigido, disponibilizou-se o link de dois filmes/ documentários, o primeiro chamado “Josué de Castro - Cidadão do Mundo”, de 1994 e direção de Silvio Tendler, que retrata a vida e a obra do médico, filósofo, sociólogo e geógrafo pernambucano que dedicou sua vida aos estudos sobre a fome

E o segundo chamado "Agricultura Tamanho Família", de 2014 e direção de Silvio Tendler, demonstra que o agronegócio não é a única modalidade de produção existente no campo, e que também não é o mais importante para o abastecimento interno e a garantia da soberania e segurança alimentar da população do país. Aliado aos filmes/documentários "O Veneno está na Mesa I e II", esse filme/documentário forma uma trilogia chamada "Trilogia da Terra", cujos conteúdos promovem a socialização de conhecimento que visam sustentar a realização de um projeto de desenvolvimento rural sustentável e solidário, pautado no fortalecimento da agricultura familiar e na democratização do acesso à terra.

Abaixo segue o registro ilustrativo da disposição desses conteúdos na Plataforma moodle. 
Figura 3 - Registro da segunda etapa do cronograma da disciplina

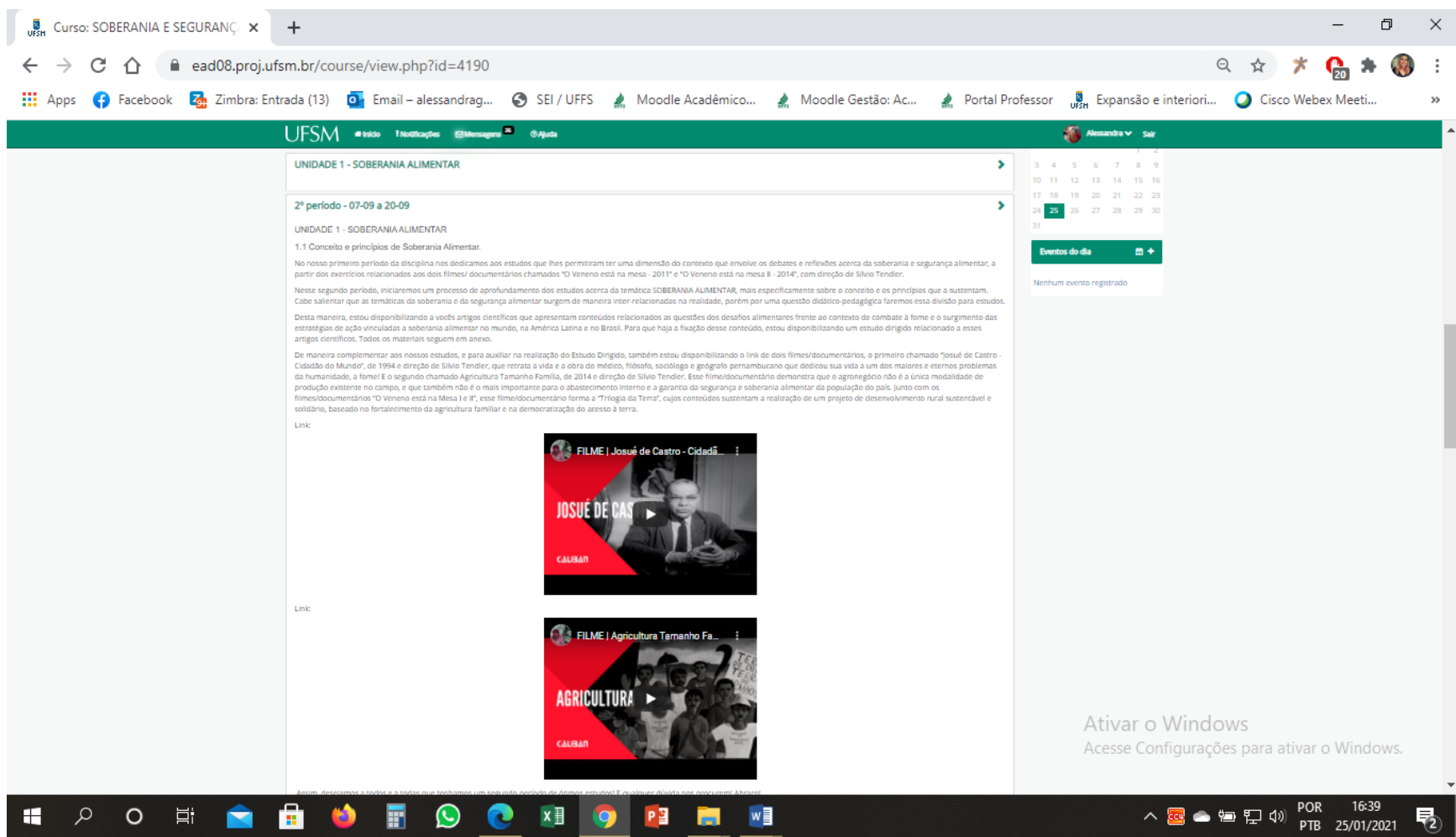

Fonte: Plataforma moodle, 2021.

Para que houvesse a fixação desse conteúdo, os educandos contaram com o apoio novamente de um estudo dirigido relacionado aos artigos e também sobre os filmes/documentários, contendo as seguintes questões: Contextualize historicamente e a partir da sua interpretação (com as suas palavras) a situação da fome no mundo, na América Latina e no Brasil, especificando/argumentando neste contexto qual foi a contribuição do autor Josué de Castro para o debate do combate à fome. Elabore uma linha do tempo contendo os principais marcos históricos em que foram abordados a temática da soberania alimentar e quais as principais mudanças identificadas em relação a soberania alimentar em cada um desses marcos.

Nesta etapa da disciplina, dos 99 educandos matriculados, 66 fizeram a entrega da atividade. Ao analisar os materiais que foram recebidos identifica-se o uso da criatividade e de outras fontes de pesquisa para a elaboração das respostas ao estudo dirigido, demonstrando o interesse e a dedicação dos educandos na realização desta atividade de síntese de conteúdo. Um destaque especial a composição da linha de tempo que foram expressas de diferentes formas, tais como: tabelas, linhas 
temporais, diagramas, entre outras. As dúvidas presentes nesta etapa de construção do conhecimento dos educandos foram resolvidas mediante mensagens enviadas via Plataforma moodle para a tutoria e para a docente.

A terceira etapa, realizada no período de 21/09/2020 a 04/10/2020, tratou-sedos conteúdos relacionados ao item 1.2 Soberania alimentar e movimentos sociais, o qual ocorreu por meio da disponibilização de dois artigos científicos e um estudo dirigido. Assim, a partir da leitura dos artigos científicos, bem como apoiado nos demais conteúdos estudados, os educandos foram estimulados a pesquisar em seus municípios ou na região que residem, um exemplo de atividade que envolvesse os movimentos sociais e a prática da promoção da soberania alimentar, apresentado na forma de um resumo expandido com até 1.000 palavras, e contendo: título, introdução, desenvolvimento e conclusão.

Nesta atividade foram citados os mais diversos exemplos de experiências com vistas a promoção da soberania e segurança alimentar tanto nos municípios, como na região onde os polos educacionais se encontram fixados. Dos 99 educandos, 59 fizeram a entrega do estudo dirigido. Porém, alguns mencionaram no decorrer desta etapa que estavam encontrando dificuldades em visualizar experiências dessa natureza nos seus municípios, bem como na região, sendo orientado para que então fossem apresentadas outras experiências, de cunho institucionais, como de prefeituras, escolas, etc e que pudessem traduzir, de certo modo, a realidade daquele determinado local.

No período de 05/10/2020 a 18/10/2020, ocorreu a quarta etapa das aulas, na qual abordou-se o item 1.3 Direito à Soberania Alimentar. Para esse período, disponibilizou-se um artigo científico intitulado Direito humano à alimentação adequada e responsabilidade, de autoria de Juliane Caravieri Martins Gamba e Zélia Maria Cardoso Montal, publicado na Revista Semina: Ciências Sociais e Humanas em 2009, no qual as autoras evidenciam a importância do direito humano à alimentação adequada e destacam a responsabilidade internacional na implementação de políticas públicas para a geração de alimentos saudáveis. 
Aos educandos coube a tarefa de desenvolver uma leitura investigativa desse material, elencando os pontos que mais Ihes chamaram a atenção. Sendo que as dúvidas a respeito desse conteúdo foram resolvidas por mensagens via Plataforma moodle. E como se tratava de um texto de síntese, foram poucos os questionamentos acerca dessa etapa da disciplina.

$\mathrm{Na}$ sequência dos conteúdos, realizou-se a quinta etapa, no período de 19/10/2020 a 01/11/2020, na qual iniciou-se a UNIDADE 2 - SEGURANÇA ALIMENTAR, mais especificamente o item 2.1 Conceito e princípios da Segurança Alimentar. Assim, como material pedagógico desse período, disponibilizou-se dois artigos científicos que apresentavam os conteúdos relacionados a conceituação e princípios que regem a Segurança Alimentar. E na perspectiva de orientar a apreensão dos conteúdos, disponibilizou-se um estudo dirigido, contendo duas questões norteadoras a serem respondidas e postadas na Plataforma moodle.

$\mathrm{Na}$ primeira questão os educandos tinham que apresentar e argumentar de maneira sintética a evolução conceitual da Segurança Alimentar e Nutricional - SAN, considerando que esta ocorre em nível internacional e nacional e caracteriza-se como um processo contínuo que acompanha as diferentes necessidades de cada povo e de cada época. A forma de apresentação ficou a critério de cada educando, podendo ser na forma textual ou em esquemas, diagramas, linhas de tempo, entre outras.

E na segunda questão, eles tinham que apresentar a relação desta temática da evolução conceitual da Segurança Alimentar e Nutricional - SAN com a sua futura prática como educadores do campo. A intenção era que os educandos pudessem interligar com a realidade da docência os conhecimentos apreendidos até esse momento. Podendo para isso se apoiar em autores para subsidiar essa resposta.

Dos 99 educandos, 64 postaram as suas atividades. E ao realizar a leitura e análise das produções dos educandos, evidenciou-se uma certa fragilidade em relação a segunda questão, principalmente em relação a inserção desse tema no cotidiano do fazer docente. Além disso, a maioria não se apoiou em autores para subsidiar seus argumentos. Essa fragilidade encontrada foi apontada aos educandos via mensagem na Plataforma moodle. 
A sexta etapa ocorreu de 02/11/2020 a 15/11/2020, na qual desenvolveu-se o item 2.2 Segurança alimentar como tentativa de erradicação da fome. Para isso, disponibilizou-se outro documentário, intitulado "Por Uma Vida Melhor", de Thereza Jessouroun, cujo registro fotográfico segue abaixo, e que retrata a realidade da segurança alimentar e nutricional no Brasil.

Figura 4 - Registro da sexta etapa do cronograma da disciplina

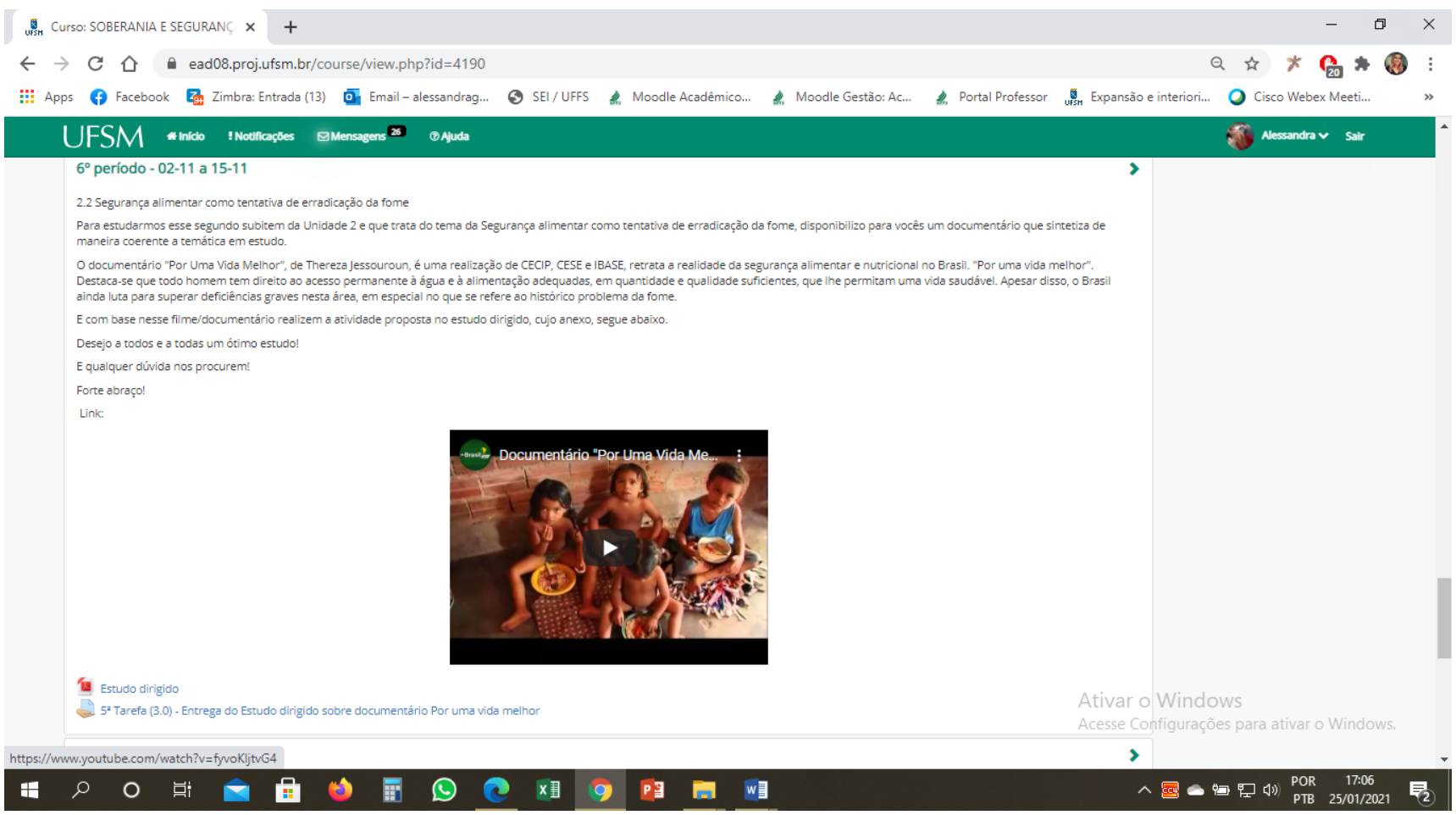

Fonte: Plataforma moodle, 2021.

Neste documentário destaca-se que todo homem tem direito ao acesso permanente à água e à alimentação adequadas, em quantidade e qualidade suficientes, que lhe permitam uma vida saudável. Apesar disso, o Brasil ainda luta para superar deficiências graves nesta área, em especial no que se refere ao histórico problema da fome.

E para refletir sobre o que foi apresentado, os educandos foram estimulados, por meio de um estudo dirigido, a elaborar uma síntese deste documentário, ressaltando os aspectos que mais Ihes chamaram a atenção, e relacionando estes aspectos com os conteúdos que já foram abordados na disciplina. Sendo esta síntese estruturada contendo uma introdução, desenvolvimento, conclusão e referências (opcional), e apresentado no máximo em duas laudas. 
Essa atividade foi postada na Plataforma moodle pelos educandos, sendo que dos 99 matriculados, 61 fizeram a entrega. Ao analisar as atividades foi possível identificar que eles conseguiram captar a essência do conteúdo que estava sendo posto no documentário, porém alguns educandos apresentaram certas fragilidades no modo de estruturação da apresentação escrita, mas que acabou não comprometendo significativamente a leitura da síntese como um todo.

E por fim, a sétima etapa, desenvolvida no período de 16/11/2020 a 29/11/2020, onde tratou-se do item 2.3 As leis de Segurança Alimentar. Para isso, disponibilizou-se dois materiais pedagógicos para o desenvolvimento de uma leitura investigativa, reforçando que a legislação tem uma característica de ir sendo modificada ao longo das diferentes gestões governamentais. No primeiro documento apresenta-se a legislação básica que compõe o marco legal do Sistema Nacional de Segurança Alimentar e Nutricional (Sisan) e regulamenta o funcionamento do Consea, sendo este publicado em 2017. A intenção desta publicação naquele período era de servir como manual de consulta rápida as conselheiras, conselheiros, agentes públicos e observadores, contribuindo para uma participação ativa e informada no Conselho.

O segundo documento trata do Plano Nacional de Segurança Alimentar e Nutricional, vigência 2016-2019. O Plano é o principal instrumento da Política Nacional de Segurança Alimentar e Nutricional - PNSAN, instituída pelo Decreto $n^{\circ} 7.272 / 2010$ e nele estão previstas as diferentes ações do governo federal que se propõem a respeitar, proteger, promover e prover o Direito Humano à Alimentação Adequada para todas as pessoas que estão no Brasil.

E assim, encerramos a disponibilização gradativa do conjunto de conteúdos aos educandos, ressaltando que a avaliação do processo de ensino- aprendizagem, neste caso, se deu por meio da análise dos estudos dirigidos apresentados de maneira individual pelos educandos, e que tinham uma pontuação valorativa e um prazo para serem postados na Plataforma moodle. Os três primeiros estudos dirigidos valiam um ponto cada um; o quarto estudo dirigido valia quatro pontos e por fim, o quinto estudo valia três pontos, totalizando dez pontos.

Considerando o quantitativo de postagens e os contatos realizados no decorrer da disciplina, identificamos uma adesão significativa dos educandos as atividades propostas, sendo que na maioria os prazos e combinações de postagens foram cum- 
pridos. Ao final, disponibilizou-se ainda mais duas datas para que os educandos que tivessem estudos dirigidos em atraso pudessem fazer a devida entrega.

Nesse período de desenvolvimento das etapas de organização da disciplina, destaca-se também como ponto positivo a interação dos educandos com o tutor e com o docente, via mensagens da Plataforma moodle, para a retirada de dúvidas e também para que demais comunicações pudessem ser feitas sempre que necessário, permitindo que o fluxo de informações pudesse circular de maneira clara entre todos os participantes da disciplina, tendo em vista que se trata de uma disciplina que ocorre na modalidade a distância, e a fluidez da comunicação se torna essencial.

\section{CONCLUSÃO}

Ao final, percebe-se que o uso de diferentes recursos didáticos-pedagógicos tais como os filmes/documentários, leitura e síntese de artigos científicos, entre outros, serviram para estimular e despertar nos educandos a curiosidade e o interesse pelo conteúdo, facilitando assim o aprendizado, vindo ao encontro do que Freire (2000) reforça em suas obras, de que o processo de mudança de percepção se dá por meio da análise da realidade, de questionar o que se apresenta, levando as pessoas a adotarem, posições indagadoras, inquietas e criadoras, uma postura de criticidade sobre a realidade.

Desta maneira, entende-se que o processo educativo-reflexivo desenvolvido na disciplina de Soberania e segurança alimentar foi gradativo, intenso e profundo, servindo para que pudéssemos nos aproximar e refletir junto aos educandos sobre as profundas transformações que ocorrem no cenário da produção de alimentos no país e que tem relação direta com os debates e discussões sobre a soberania e segurança alimentar, contribuindo assim para que que os educandos pudessem reunir subsídios para sustentar a sua futura prática profissional, como educadores do campo.

\section{REFERÊNCIAS}

BRASIL. Lei $n^{\circ} 11.346$ de 15 set. 2006. Lei Orgânica de Segurança Alimentar e Nutricional. Cria o Sistema Nacional de Segurança Alimentar e Nutricional SISAN com vistas em assegurar o direito humano à alimentação adequada e 
dá outras providências. Diário Oficial da União. 18 set 2006. [internet]. [acesso em 27 de jan 2021]. Disponível em: https://www.planalto.gov.br/ccivil 03/ ato20042006/2006/lei/l11346.htm

FREIRE, Paulo. Política e educação. 4 ed. São Paulo: Cortez, 2000. OLIVEIRA, Luiz Felipe Candido de; CASTRO, Sérgio Duarte de. Soberania Alimentar. Revista de Ciências Ambientais e Saúde, v. 40, n. 3, p. 311-320, 2013.

PPC - Projeto Pedagógico de Curso. Curso de Educação do Campo - Licenciatura (a Distância). Universidade Federal de Santa Maria - UFSM, 2017. 


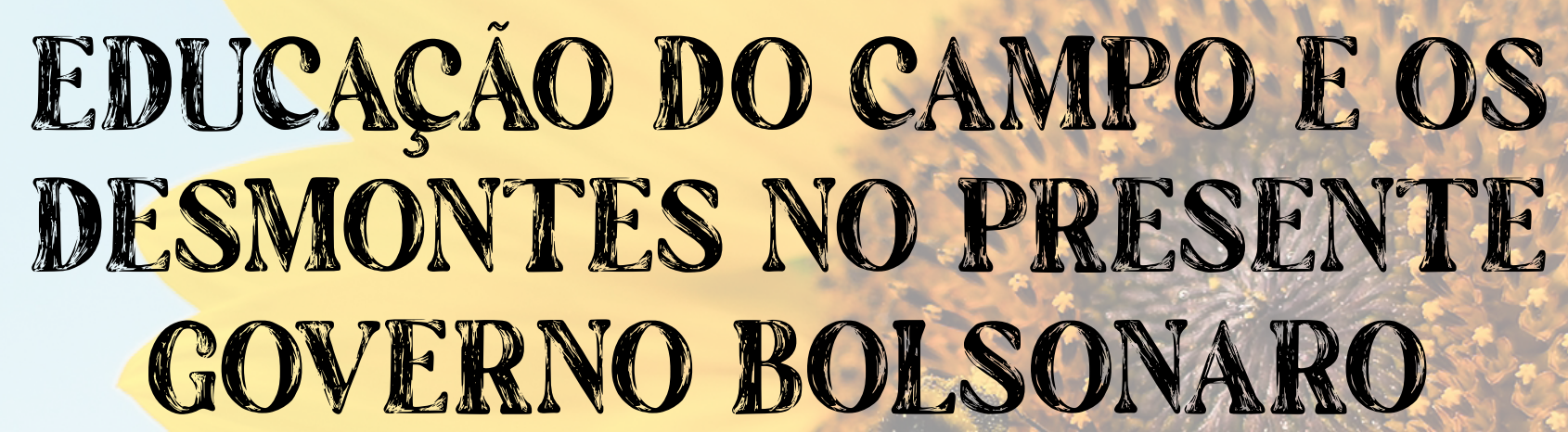

Sávio Da Silva Aureliano ${ }^{20}$ Janicleide Vieira Da Silva ${ }^{21}$ Amanda Gomes Dos Santos ${ }^{22}$

20 Graduado pelo curso de Geografia da Universidade Estadual da Paraíba - UEPB, savio. ds@outlook.com.

21 Graduanda pelo curso de Geografia da Universidade Estadual da Paraíba - UEPB, Janicleide397@gmail.com

22 Graduanda pelo curso de Geografia da Universidade Estadual da Paraíba - UEPB, amanda.ag260@gmail.com. 
Atualmente, observa-se no cenário brasileiro e no atual governo um desmonte da Educação do Campo, o qual afeta a milhares de camponeses(as), proferindo ainda mais as desigualdades sociais existentes, e compromentendo os avanços sociais presentes no campo através da educação. Deste modo, o governo vigente e seu atencessor, como foi o caso do governo de Michel Temer, buscaram atingir os principais programas, projetos, e ações educacionais do campo, para estagnar e desestabilizar os avanços e conquistas obtidas.

O governo Temer tinha como condutas de interesses, alterar o ensino médio e diminuir os recursos destinandos à educação em suas diferentes esferas, visto que seu projeto de governo era voltado para ações liberais. Uma das várias propostas do governo Michel Temer, segundo a reportagem da REL UITA (2018), era que, por meio de resolução que atualiza as Diretrizes Curriculares, liberar até $40 \%$ da carga horária total do Ensino Médio para que esta pudesse ser realizada à distância, e que a Educação de Jovens e Adultos pudesse ser feita 100\% à distância.

Sendo assim, temos com as questões observadas a desestruturação da educação, no qual interliga ao problema gerador e com as questões do campo. Em retratação do trabalho a ser abordado, pondera-se que, o desmonte da Educação do Campo vem ocorrendo em meio as ações dos governantes. Como o foco deste trabalho é o atual governo Bolsonaro, as colocações estão sendo pautadas no presente momento de sua gonvernância, mas fazendo menções aos outros governantes que também contribuiram negativamente ou positivamente para a Educação do Campo.

Portanto, para elucidar todo um questionamento vigente, é necessário traçar objetivos quem venham a corresponder com a inquietação do problema, sendo assim, logo foram elaborados nesta perspectiva. Sendo eles, analisar os desmontes realizados pelo governo Bolsonaro na Educação do Campo através do Pronera ${ }^{23}$, identificar as ações de fechamento das escolas do campo, e Compreender como os desmontes na educação do campo afeta negativamente sua atuação. 
Deste modo, com as informações adquiridas e estudadas, o desenvolvimento do trabalho será alçado, com reflexões acerca da temática proposta. O primeiro subtópico trata a respeito do desmonte do Pronera, programa este, essencial para o fortalecimento da Educação do Campo, no qual ela está indo por ruínas. o segundo subtópico vem mostrando a ações de fechamento das escolas do campo, tal fato traz inúmeras consequências negativas para os camponeses, e esse fechamento vem se acirrando ainda mais. O terceiro subtópico, traz uma reflexão na preponderância de como o desmonte na Educação do Campo afeta a sua atuação, diante os camponeses e o campo brasileiro, por meio de medidas do atual governo.

O presente trabalho traz como metodologia a pesquisa bibliográfica, sendo ela realizada através de livros, artigos, noticias, sites, entre outros meios, ela contribuiu para um leque de informações e conhecimentos valiosos para a pesquisa, leitores e pesquisadores.

Portanto, os descasos vêm aumentando gradativamente, e ao chegar no governo Bolsonaro existem medidas ainda mais perversas, pois os movimentos sociais do campo são atacados, bem como o ensino, os investimentos destinados à Educação do Campo, e as estruturas educacionais. Os resultados vão confirmar essas condutas destruídora da Educação do Campo, contra os camponeses, com os dados levantados e por meio da bibliografia, este conjunto de informações dão uma resposta plausível para responder as inquietações.

\section{DESEN VOLVIMENTO}

Desmonte na Educação do Campo pelo governo Bolsonaro através do Pronera

As medidas tomadas pelo atual governo vem ratificar o arruinamento do Pronera, e como cabe salientar, o presente governo busca atingir a todos que estão presentes no campo. Portanto, os regressos realizados atribuim-se, principalmente, dentro da educação no que tange ao Pronera, desta forma, se abre em uma cadeia de desfechos negativos.

Quando os recursos são reduzidos, afetam desde os professores até os camponeses, universidades e etc.., pois há uma interligação entre estes setores, visto 
que foi conseguida uma ligação entre eles ao longo do fortalecimento do programa. Podemos observar como esses sujeitos estão interligados de acordo com os projetos educacionais, no qual Santos (2012) afirma que:

Os projetos educacionais do Pronera envolvem alfabetização, anos iniciais e finais do ensino fundamental e ensino médio na modalidade de educação de jovens e adultos (EJA), ensino médio profissional, ensino superior e pós-graduação, incluindo neste nível uma ação denominada Residência Agrária (SANTOS, 2012, p. 631).

De acordo com essa afirmação de Santos (2012), se tem o envolvimento de todos que se fazem presentes na Educação do Campo através do Pronera, os camponeses, professores da rede básica e do ensino superior e universidades. No entanto, é sabido que o governo atual se articula demonstrando objetivar o regresso das universidades, da educação, dos movimentos sociais e dos camponeses, atentando de forma pertinente suas principais estruturas.

Consequentemente, a paralização deste programa, efetivada pelo governo Bolsonaro, se choca com essa realidade dos camponeses, professores e universidades, paralisando o ensino para milhares de jovens e adultos. Segundo Stédile (2019):

Paralisação do PRONERA. O programa estimulava às universidades públicas construírem cursos especiais, na forma de alternância, realizando vestibular específico para filhos de camponeses. Isso permitia que eles ficassem dois meses em aulas e dois meses de volta às suas comunidades. Milhares de jovens do interior tiveram a acesso à universidade, se formaram e permaneceram no campo, graças a esse programa (Stédile, 2019).

Seguindo essa afirmação de Stédile, conota-se o quanto será afetado todos esses que fazem parte do processo educacional do campo, além de outras ações efetivadas pelo atual governo contra aqueles que se encontram no campo, vivem, moram e dependem dele. Contudo, estas ações não afetarão os grandes latifundiários, o agronegócio, e os ruralistas, estes últimos formam a bancada rural no congresso brasileiro, que é defendida pelas próprias ações contra os povos do campo, vindo dos governantes. 
O fechamento das escolas do campo vem se alogando em meio aos governos petistas, após o golpe com Temer, e atualmente no governo Bolsonaro. Entretanto, as ameaças de fechamentos das escolas se acentuam e se agravam durante o atual governo, pois a sua proposta radical de fechamento dessas escolas acarretará na saída de milhares de camponeses do seu território para as escolas urbanas, e escolas nucleadas.

Os ataques do governo Bolsonaro às escolas do campo se concernem a ações como a redução dos recursos financeiros destinados ao Pronera, a imposição na sua campanha eleitoral para o fechamento de escolas, além da criminalização do $\mathrm{MST}^{24}$, como bem afirma a Brasil de fato (2019) em sua publicação:

Desde a campanha eleitoral o presidente Jair Bolsonaro (PSL) já atacava as escolas do campo afirmando que iria fechá-las. Em entrevista à revista Veja o secretário especial de Assuntos Fundiários, Luiz Antônio Nabhan Garcia, afirmou que pretende fechar as escolas do Movimento dos Trabalhadores Rurais Sem Terra (MST), e chamou as escolas públicas do campo de "fabriquinhas de ditadores" (BRASIL DE FATO, 2019).

Perante a exposicação destes fatos relatados pela Brasil de Fato (2019), mostra-se um governo despreocupado em relação ao campo, camponeses, e à Educação do/no Campo. Vislumbra-se uma imagem nefasta de um governante que ignora e menospreza o quão importante é uma escola no campo, e o quão transformadora é a educação perante os povos do campo.

Todo esse conjunto de ações e pensamentos do governo Bolsonaro se alinha quando se levantam dados para proceder como é colocada a questão das matrículas nas escolas do campo, e compreende-se essa relação quando o Censo Escolar de 2019 foi divulgado. De acordo com a reportagem da Brasil de Fato (2020):

As escolas rurais brasileiras estão menos frequentadas, com ensino integral enfraquecido e majoritariamente sob o poder dos municípios, conforme aponta o Censo Escolar 2019, divulgado pelo Ministério da Educação, em 30 de dezembro. No último ano, de acordo com o levantamento, o campo teve queda de 145.233 matrículas na soma de todas as modalidades de ensino foram 5.195.387 registros em 2018, contra 5.050.154 em 2019 (BRASIL DE FATO, 2020). 
Assim, observa-se nessa relação que as matrículas nas escolas rurais diminuíram no ano de 2019. Ou seja, as implementações do atual governo surtiram efeitos negativos no campo, deixado a margem milhares de crianças, jovens e adultos com uma educação sucateada e regredindo por medidas de um desgoverno. No entanto, as escolas, a educação e os camponeses resistem contra todas essas retaliações.

\section{Como os desmontes na Educação do Campo no governo Bolsonaro afeta negativamente a sua atuação}

Para que a Educação do Campo seja efetivada de forma ativa, coerente, positiva, crítica e abragente, se faz necessário uma série de ações que vislumbre positivamente em suas condutas. O fortalecimento desta, irá se refletir perante os camponeses, milhares de jovens, crianças e adultos por todo o Brasil, com uma educação voltada ao interesse camponês, disvinculado de um mercado avassalador tanto educacional quanto econômico.

Como perspectiva de alcance aos objetivos da Educação do Campo, busca-se uma transformação social dos presentes camponeses, a educação como promotora da ruptura de uma desigualdade social no Brasil. Como no campo brasileiro se encontram índices elevados do contraste desigual, os camponeses e universidades federais e estaduais do Brasil se vinculam por um educação promotora de rupturas. Porém, em contra-mão, vem o governo federal atual com suas ações negligenciadoras, como no caso do decreto 10.252/2020.

Segundo o FONEC 25 (2020), o governo Bolsonaro publicou, no dia 21 de fevereiro de 2020, o Decreto 10.252/2020 que altera a estrutura regimental do Instituto Nacional de Colonização e Reforma Agrária - Incra. O governo alterou a estrutura regimental e de cargos, o Decreto muda profundamente as competências do órgão, desta forma serão exercidas as competências do INCRA com outro viés, ao qual se adeque as ações do governo, neste contexto o INCRA passou por profundas mudanças e banalizações.

No que tange a afetação na Educação do Campo, podemos citar o referido caso da extinção da Coordenação-Geral de Educação do Campo e Cidadania, esta 
responsável pelo Pronera. Portanto, se vê em total desestruturação. Como bem afirma o FONEC (2020):

Entre tantas extinções de políticas então coordenadas pelo Incra, o referido Decreto extingue a Coordenação-Geral de Educação do Campo e Cidadania, responsável pela gestão do programa Nacional de Educação na reforma Agrária-PRONERA. Depois de 20 anos, extingue o lugar político da elaboração e gestão de uma das maiores políticas públicas de educação, no Brasil (FONEC, 2020).

Diante desta afirmação, pontua-se que tal extinção se coloca em desavença com a sociedade brasileira, em especial do campo, pois está assegurada na constituição braseileira de 1988 que a educação é direito de todos e, é dever do Estado manter e assegura-la para todos, porém no atual governo se observa que este direito não é cumprido, já que a Educação do Campo é afetada diretamente pelas atuais atitudes do governo federal.

Perante as ações refletidas no Pronera, reitera-se os descasos com as escolas do campo por todo o Brasil, e a conjuntura social política vivenciada mostra um momento de regressão na educação, pois suas conquistas foram banalizadas e estão sendo atacadas por um governo que se coloca contra os avanços educacionais.

Deste modo, as escolas do campo são alvos do processo de nucleação e da municipalização, segundo Pavani, Andreis (2017), o processo chamado de "nucleação escolar" consiste em reunir os alunos das escolas desativadas, fechadas, geralmente em áreas rurais, deslocando-os para centros maiores. Concentra-se o maior número de alunos em uma única escola, seja ela da cidade ou do campo. Com a municipalização o poder das escolas públicas do ensino fundamental fica nas mãos dos municípios brasileiros, essa prática utilizada do fechamento das escolas do campo se deve a questões como falta de políticas públicas implementadas.

Entretanto, os movimentos sociais do campo vão em contrapartida pois, como defensores da Educação do Campo, não comungam de tal relação dos governantes para com as escolas do campo. Com a nucleação das escolas e, transferindo os alunos do campo para o urbano, o modo de tratar, viver e observar as escolas no território camponês são diferentes daqueles que fazem parte do urbano. Nota-se que os politícos fazem projetos pensando no econômico, na redução de escolas, cortes de gastos, entre outros pontos, e deixam de lado as escolas rurais e a educação dos 
camponeses. Portanto, o MST (2005) ratifica:

A escola é um lugar de estudo, trabalho e organização. É também um lugar para aprender a DEMOCRACIA. Este aprendizado não se faz estudando sobre o que é democracia. A democracia se aprende através do relacionamento diário dos alunos com os alunos, dos alunos com os professores, dos professores com os professores, da Escola com o assentamento. (MST, 2005, p. $35)$.

Sendo assim, essa afirmação do MST pondera a relação da escola com os alunos e o assentamento, este tríplice conjunto interligado, desta forma, a escola deve estar dentro do assentamento e não fora dele. O que o processo de nucleação faz é retirar as escolas e alunos de dentro do seu território, compreendendo-se que não há um estado vigente democrático, há uma quebra na relação entre escola, alunos e assentamento.

\section{RESULTADOS E DISCUSSÃO}

Verifica-se ao longo da atuação da Educação do Campo no território brasileiro uma série de lutas dos camponeses, e dos movimentos socias do campo para alcançarem as conquistas. Todos eles batalharam para que se estabelecesse, de fato, uma educação que seja voltada para o campo no Brasil, pois a luta nunca parou, busca-se sempre melhorias para a educação, principalmente tratando-se de educação no Brasil, onde a disparidade educacional é gritante.

Desta maneira a educação também é sujeita à desigualdade, e o campo brasileiro está diretamente interligado nesta questão, nele se encontram níveis de escolaridade muito baixos em relação ao urbano, como infraestrutura, transporte, deslocamento, dentre outras questões que são bem mais amplas no campo. Esses fatores fazem com que uma educação do e no campo seja essencial e obtenha avanços.

A desigualdade educacional entre o campo e o meio urbano é claramente observada com a retratação dos dados correlatados no mapa 1 em 2010. Identifica-se que as regiões Norte e Nordeste do país possuem os menores índices de IDHM ${ }^{26}$ da

$26 \quad$ Índice de Desenvolvimento Humano Municipal foi desenvolvido por meio de parceria entre o Programa das Nações Unidas para o Desenvolvimento (PNUD) Brasil, a Fundação João Pinheiro (FJP) e o Ipea, a partir de metodologia adaptada do Índice de Desenvolvimento Humano (IDH) Global. 
educação no meio rural, entretanto, o IDHM do meio urbano supera o rural em todos os estados brasileiros, mas não chega a ser o ideal para um nível educacional de ótima qualidade.

Figura 1 - Mapa do IDHM Educação: rural e urbano (2010)

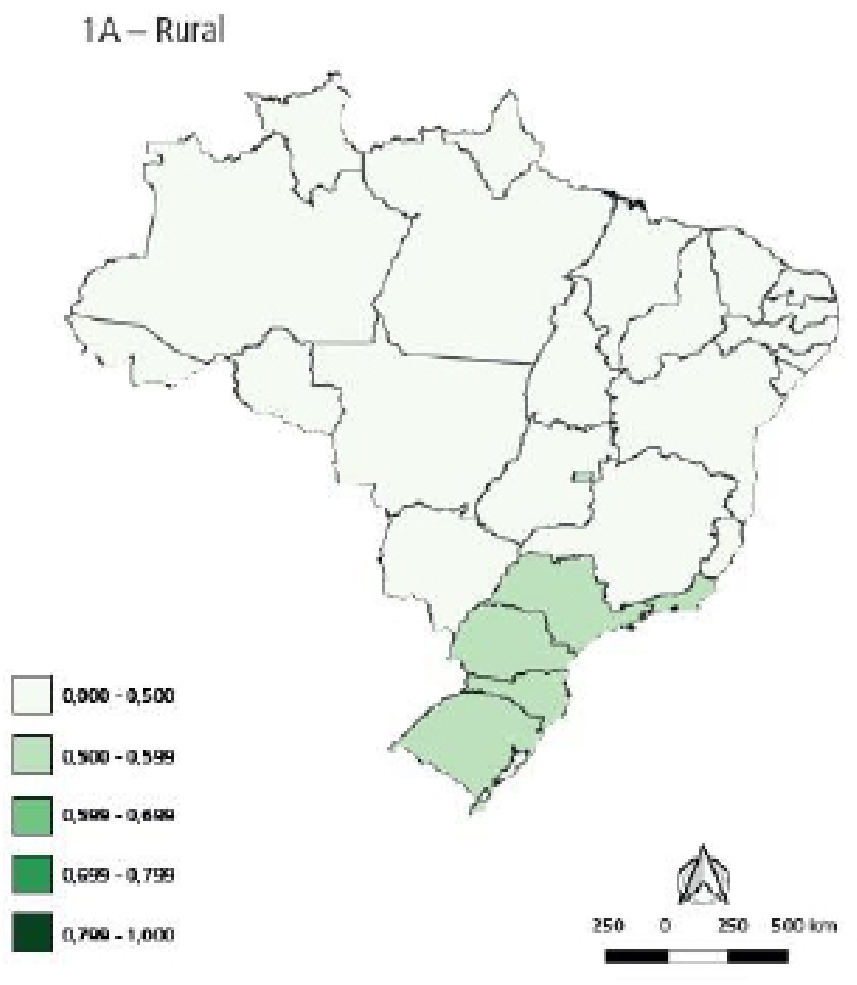

$1 \mathrm{~B}-$ Urbano

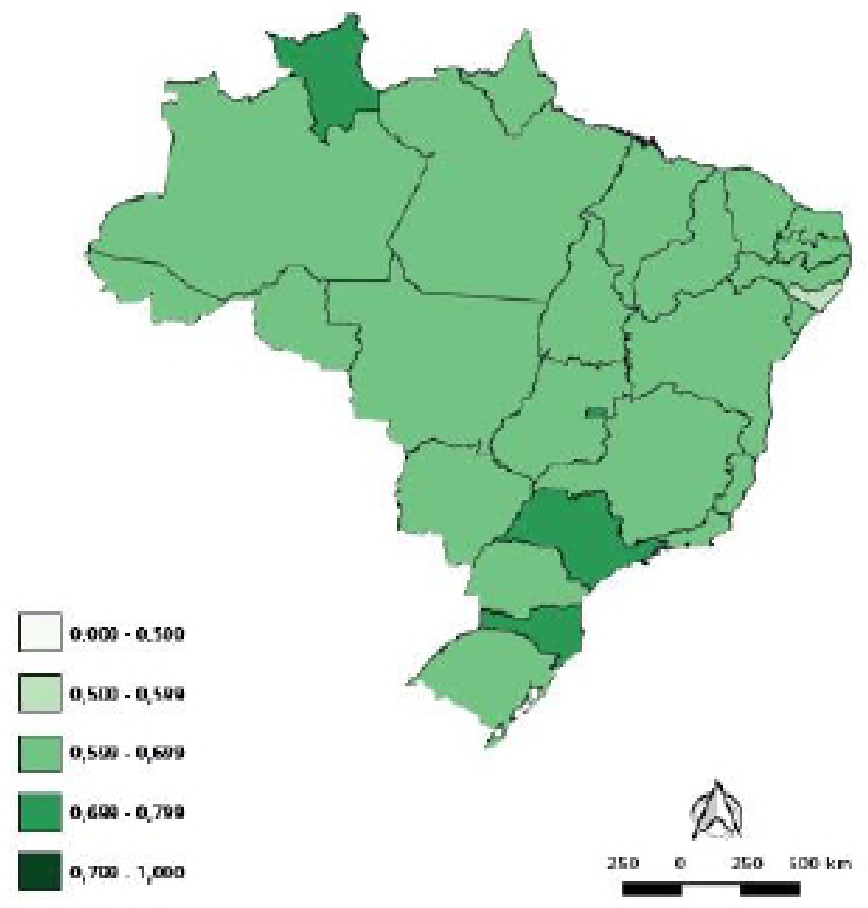

Fonte: Atlas do Desenvolvimento Humano no Brasil, 2013. Elaboração dos autores.

De acordo com Pereira, Castro (2019).

O IDHM Educação possui valores considerados muito baixos na área rural da maioria dos estados brasileiros, com exceção de Paraná, Santa Catarina, Rio Grande do Sul, São Paulo e Rio de Janeiro, que apresentaram IDHM Educação baixo nessa área. Os dados para o meio urbano são visivelmente meIhores (mapa 1B). A maioria dos estados apresentou IDHM Educação médio no urbano, com exceção de Alagoas, que apresentou valor baixo. Os únicos estados que apresentaram valor alto nesse índice para o meio urbano foram São Paulo, Santa Catarina e Roraima (PEREIRA; CASTRO, 2019, p. 65).

Diante do que foi exposto no mapa do IDHM de 2010 e na retratação de Pereira e Castro, já se observa que há uma necessidade de investimentos na Educação do Campo, investimentos esses ao qual perpassam por uma série de ações dos governantes na melhoria da infraestrutura de escolas, transporte, alimentação, nos salários dos professores, e políticas públicas em todos os campos ao qual a educação 
necessite.

Porém, durante os anos de governo do $\mathrm{PT}^{27}$, a Educação do Campo conseguiu conquistas e avanços no meio educacional camponês, fruto de lutas dos movimentos sociais do campo e dos camponeses, reivindicando políticas públicas as quais beneficiassem a educação nesta área. De fato, pode-se dizer que houve evolução no presente meio em que os governos petistas estavam presentes, ações em prol dos camponeses e da educação foram colocadas em prática. Como bem afirma Souza (2013):

A caminhada por uma Política Pública de Educação do Campo completa 16 anos. Dessa luta algumas conquistas podem ser contabilizadas, embora elas tenham ficado bem aquém do que se reivindica. Pode-se relacionar a criação do Programa Nacional de Educação na Reforma Agrária - PRONERA; as Diretrizes Operacionais para a Educação Básica das Escolas do Campo Resolução CNE/CEB N 1/2002; A Licenciatura em Educação do Campo (PROCAMPO); o Saberes da Terra; as Diretrizes Complementares Resolução CNE/CEB N² 2/2008; a criação dos Observatórios de Educação do Campo; e o Decreto Presidencial de Decreto $n^{\circ} 7.352$, de 4 de novembro de 2010 (SOUZA, 2013, p. 20).

Contudo, percebe-se que ainda existem muitas lacunas para serem fechadas e muitos desafios para serem superados. Os governos do PT, em seus anos de atuação, propiciaram progressos para a Educação do Campo, embora poderiam ter realizado muito mais. Todavia, ressalta-se que, após o golpe de 2016 e no atual governo Bolsonaro, os retrocessos na Educação do Campo estão se efetivando amargamente e parecem estar aumentando gradativamente.

No período de atuação do governo Temer, a Educação do Campo sofreu com muitos retrocessos os quais impactaram diretamente em sua estrutura. Como o congelamento de investimentos públicos nas áreas de saúde e educação por 20 anos, aprovação das reformas do ensino fundamental e médio, além das questões trabaIhistas que afetam também os trabalhadores do campo.

Ou seja, a continuidade do desmonte segue em execução perante a Educação do Campo, como bem mostra os dados de fechamento das escolas rurais na tabela 1 entre os anos de 1997 a 2018, e o número de matrículas nestas escolas entre os

27 Partido dos Trabalhadores, o PT surgiu como agente promotor de mudanças na vida de trabalhadores da cidade e do campo, militantes de esquerda, intelectuais e artistas. 
anos de 2016 a 2019 na tabela 2, eles refletem o descaso perante a educação.

Tabela 1 - Número de estabelecimentos de ensino - Educação Básica

\begin{tabular}{|c|c|c|c|}
\hline Ano & Total & Urbanos & Rurais \\
\hline 1997 & 225.520 & 87.921 & 137.599 \\
\hline 2018 & 181.939 & 124.330 & 57.609 \\
\hline Diferença & -43.581 & +36.409 & -79.990 \\
\hline
\end{tabular}

Fonte: Censo Escolar - INEP.

Os dados da tabela 1 mostram a grande quatidade de escolas do campo que foram fechadas, durante 21 anos, e mesmo diante de anos dos governos petistas no poder, os fechamentos das escolas do campo aconteceram. Em todos esses governos, escolas foram fechadas no urbano e no campo, no entanto, foi no campo o maior número de fechamento. Esta relação também prossegue com os números da tabela 2 sobre as matrículas nas escolas do campo entre 2016 e 2019.

Tabela 2 - PROGRAMA: 2080 - Educação de qualidade para todos

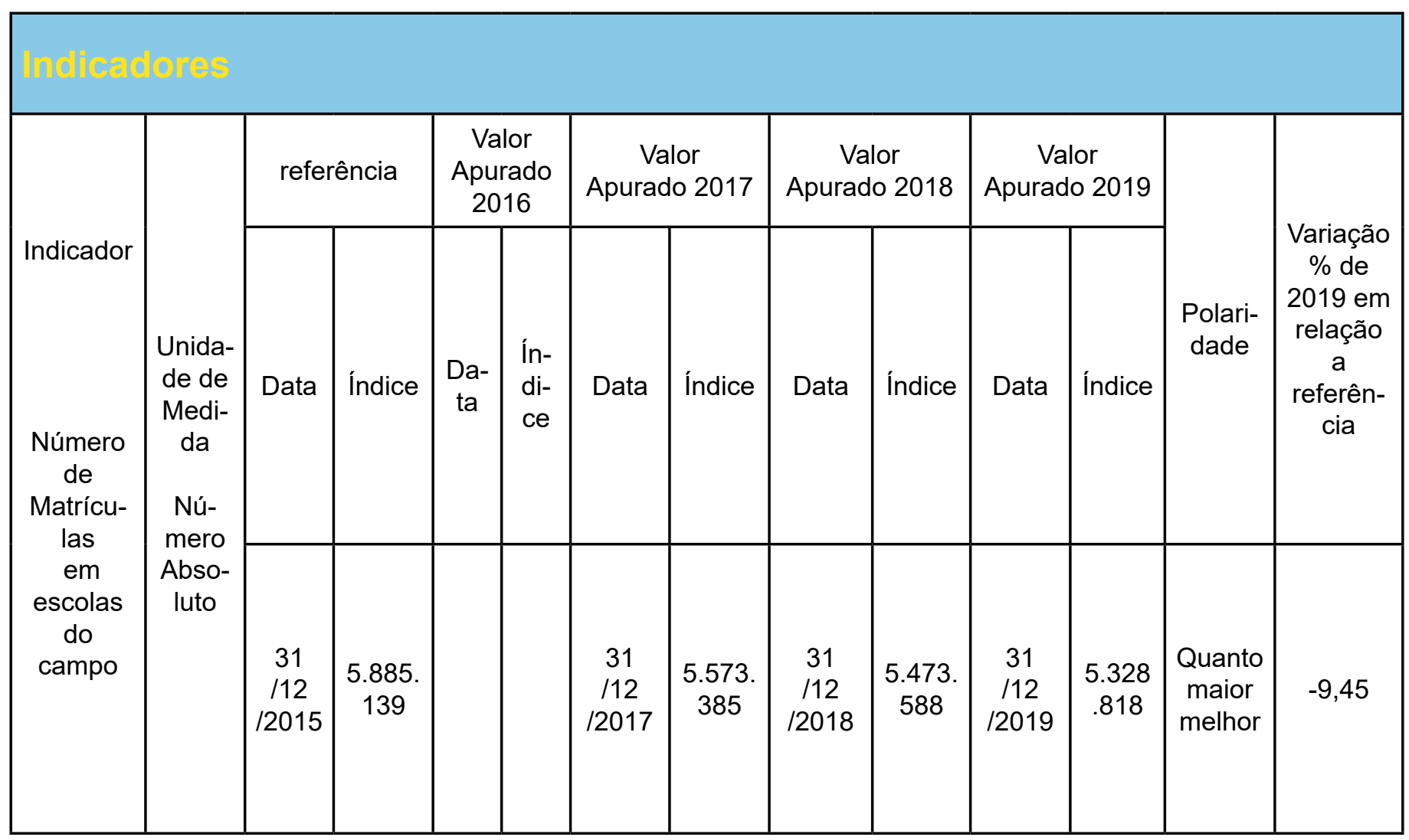


A tabela 2 mostra que, no campo, entre 2016 e 2019, o número de matrículas nas escolas foi sendo gradualmente menor, chegando a um resultado negativo. Durante este período ocorreu o golpe de 2016 e a eleição do presidente Bolsonaro. Portanto, o fechamento das escolas do campo ganhou continuidade no governo Temer e Bolsonaro, bem como os ataques bem mais acentuados contra a educação, camponeses, e os movimentos sociais.

Mesmo diante de todos esses desmontes na Educação do Campo, sabe-se o quão frutífera é a educação para os camponeses e os resultados positivos que ela exerce. Desta forma, segundo o MST (2020).

são mais de 2 mil escolas públicas construídas em acampamentos e assentamentos, 200 mil crianças, adolescentes, jovens e adultos com acesso à educação garantida, $\mathbf{5 0}$ mil adultos alfabetizados, 2 mil estudantes em cursos técnicos e superiores, e mais de 100 cursos de graduação em parceria com universidades públicas por todo o país (MST, 2020).

Como tal afirma o MST em sua colocação, observa-se que muitos camponeses(as) foram beneficiados por ações das lutas por melhores condições educacional no campo. Isto perpassa por construção de escolas no território camponês, acesso à educação e alfabetização, jovens camponeses em cursos técnicos e superiores com apoio das universidades públicas, todo esse conjunto de conquistas só é possível por meio da união, luta, e articulação de todos que se fazem presente na busca por uma educação melhor e de qualidade.

E não para só com essas conquistas, a Educação do Campo reflete nas produções acadêmicas feita pelos camponeses(as) nas suas pesquisas e estudos, ou seja, além de vivenciarem uma educação voltada para eles, produzem conhecimento sobre a situação real do campo. De acordo com Santos (2019):

Destacam-se a produção acadêmica gerada pelos próprios camponeses/ as em processos de estudos e pesquisas em nível de graduação e pós-graduação ou ainda por outros pesquisadores/as. A II PNERA apontou que o PRONERA resultou em 5.920 produções acadêmico científicas. Foram 2.747 Monografias/Trabalhos de Conclusão de Curso, 180 artigos científicos e 136 livros. O PRONERA passou a ser objeto de estudos acadêmico-científicos, registrando a existência, por exemplo, de 260 dissertações, 63 teses, 51 livros e 469 artigos científicos sobre o Programa. 
A produção acadêmica a respeito do Pronera como citado acima, revela a importância em que os camponeses tratam este programa, bem como a Educação no Campo brasileiro. Sendo assim, colaborando para o conhecimento cientifico com uma produção diversificada, dentre elas temos: monografias, artigos científicos e livros, todos à disposição da sociedade brasileira para leitura e obtenção de conhecimento.

Em virtude dos aspectos analisados, conclui-se que, a procedência no desmonte da Educação do Campo no governo Bolsonaro ganha conotável atenção por meio de suas ações retrocedoras. As conquistas obtidas pelos camponeses, e movimentos sociais do campo ao qual conseguiram em prol da Educação do Campo, estão sendo regredidas e atacadas com medidas e retaliações do governo, sendo elas prejudiciais ao fornecimento da educação no campo brasileiro. Deste modo, a afirmação de que a educação é direito de todos e dever do Estado fornece-lá, ela não é cumprida, pois vislumbra-se no campo a negação do direito à educação. Logo os camponeses necessitam da educação, porém com uma atuação deles, para eles, e vinda deles, ou seja, estando presente neste processo, com os governantes fornecendo apoio e subsídio para tal conduta, fato que não se observa no governo Bolsonaro.

\section{REFERÊNCIAS}

BRASIL DE FATO. Resultados. Disponível em: https://www.brasildefato.com. br/2019/03/28/proposta-de-educacao-no-campo-de-bolsonaro-esta-alinhada-com-o-agronegocio. Acesso em 20/jun/2020.

. Resultados. Disponível em: https://www.brasildefato.com.br/2020/01/07/ diminuicao-de-matriculas-e-fechamento-de-escolas-em-zonas-rurais-preocupam-movimentos. Acesso em 20/ Jun/2020.

FONEC. EM DEFESA DO PRONERA E DO DIREITO À EDUCAÇÃO DO CAMPO. Disponível em: https://mst.org.br/2020/02/28/forum-nacional-de-educacao-do-campo-denuncia-extincao-do-pronera/ Acesso em 30/jun/2020.

MARCONI, M. A; LAKATOS, E. M. Fundamentos de metodologia científica. 5. ed. - São Paulo : Atlas 2003. 
MST. Dossiê MST Escola: documentos e estudos, 1990-2001. São Paulo: Expressão Popular, 2005. jun/2020.

. Resultados. Disponível em: https://mst.org.br/educacao/ Acesso em 22/

PAVANI, G. A; ANDREIS, A. M. O PROCESSO DE NUCLEAÇÃO E FECHAMENTO DE ESCOLAS NO CAMPO E A LUTA DOS MOVIMENTOS SOCIAIS PELA EDUCAÇÃO DO CAMPO. VIII Simpósio Internacional de Geografia Agrária e IX Simpósio Nacional de Geografia Agrária GT 14 - Educação do/no campo. 13p.

PEREIRA, C. N; CASTRO, C. N. EDUCAÇÃO: CONTRASTE ENTRE O MEIO URBANO E O MEIO RURAL NO BRASIL. Boletim Regional, Urbano e Ambiental | 21 | jul.-dez. 2019

REL UITA. Resultados. Disponível em: http://rel-uita.org/br/contra-o-desmonte-da-educacaol Acesso em junho/2020.

SANTOS, C. A. Programa Nacional de Educação na Reforma Agrária (PRONERA). In: CALDART, R.S. et al. (Org.) Dicionário da Educação do Campo. Rio de Janeiro, São Paulo: Escola Politécnica de Saúde Joaquim Venâncio, Expressão Popular, 2012. 788p.

STEDILE, J. P. Os retrocessos do governo na política agrária, agrícola e ambiental - por Stédile. Disponível em: https://www.poder360.com.br/opiniao/brasil/os-retrocessos-do-governo-na-politica-agraria-agricola-e-ambiental-por-stedile/ Acesso em: 30/ jan/2020.

SOUZA, R. L. EDUCAÇÃO DO CAMPO: ANÁLISE DAS REIVINDICAÇÕES DOS TRABALHADORES DO CAMPO E DAS PROPOSTAS DOS GOVERNOS DE LUIZ INÁCIO LULA DA SILVA E DILMA ROUSSEFF. Rev. Tamoios, São Gonçalo (RJ), ano 09, n. 2, pags.5 - 28, jul/dez. 2013. 


\subsection{9/978-10-CAMPO6-7-2}

\section{EDUCACAOO DO CAMPO: MEMÓRIA DAS DISPUTAS DE TERRAS EM NOVA IGUACU - RJ}

Clodoaldo Ferreira de Oliveira ${ }^{28}$ Alexandre Ferreira de Oliveira ${ }^{29}$ Cristiano Santos Pimentel ${ }^{30}$

28 Mestre em Educação pela Universidade Federal Rural do Rio de Janeiro (PPGEA/UFRRJ). E-mail: clodoaldohistoria@gmail.com

29 Mestrado Profissional em Avaliação pela Fundação Cesgranrio - RJ. E-mail: alexandrehistoria2804@gmail.com

30 Mestrado Profissional em Avaliação pela Fundação Cesgranrio - RJ. E-mail: cecprof2018@ gmail.com 
“(...) aprendendo dos lutadores que vieram antes, cultivando a memória de sua própria caminhada. A história se faz assim: projetando o futuro a partir das lições do passado cultivadas no presente". (Caldart, 2003, p.56).

De acordo com o argumento defendido pela autora Roseli Salete Caldart, observa-se claramente a relação existente, por ela exposto, a respeito da importância de buscar-se e preservar-se às memórias contidas nas demandas da historicidade de um determinado grupo social.

Ao trazer à tona as especificidades dos cidadãos e cidadãs do campo, inexoravelmente, torna-se necessário aprofundarmo-nos sobre a persistente e contumaz luta destes sujeitos, através da mobilização promovida pelos movimentos sociais do campo, os quais dentre incontáveis questões, requerem, persistentemente, a garantia de seus direitos, respeito às peculiaridades, bem como a valorização da identidade campesina.

Analisando este contexto de disputas, o campo personifica-se num território de constantes enfrentamentos e repleto de profusas reflexões. Para entendê-las é de suma importância compreender a composição de seus sujeitos, que se diferenciam, de maneira peculiar, dos sujeitos das cidades, uma vez que é representada por diversos agentes (agricultores, ribeirinhos, indígenas, quilombolas, sem-terra, entre outros), cada qual com suas singularidades. Nesta dinâmica, o conceito da Educação do Campo proporciona recursos teóricos e metodológicos fundamentais que contribuem para compreensão das demandas referentes às particularidades do campo.

Assim, o conceito de memória está a todo o momento presente nos discursos referentes à história da luta dos sujeitos do campo, na medida em que, estes, trazendo consigo inúmeras reminiscências que corroboram com as demandas que justificam as suas mobilizações sociais que marcaram, não apenas a luta pela terra, bem como a luta por uma educação voltada para os sujeitos do campo, devendo este ser entendido para além de um mero espaço de produção agrícola e sim de produção de vida e de novas relações, sejam elas sociais, naturais, rurais ou urbanas. (MOLINA, 2006). 
Inegavelmente, a colonização do Brasil, realizada pelos portugueses, proporcionou uma série de consequências, na sua grande maioria, negativas em diversos setores da sociedade. No que diz respeito ao trabalho e à educação, devido à implementação do emprego da mão de obra escrava, do desenvolvimento das grandes lavouras, da prevalência da monocultura e da ausência de acesso ao conhecimento às camadas mais pobres da população, transformaram o campo em um território, tradicionalmente, marcado por disputas, uma vez que o seu acesso era, e ainda é, extremante limitado, fazendo com que os grupos mais abastados determinassem os rumos sociais e econômicos. Este controle manteve-se durante o período imperial e avançou no decorrer da República, pois já estava arraigado em nossa sociedade desde o século XVI como constatou Barbosa (2011, p.7):

O engenho, na época colonial, consagrou o poder dos senhores de engenho, assim como a fazenda de café e de gado, no Império e na República Oligárquica (1889-1930) o fez com os senhores do café; e os senhores do gado. Estes senhores tiveram papel importante nas diversas formas de desenvolvimento que a agricultura proporcionou ao país. Seu poder econômico e político se constituíram em grande impedimento ao desenvolvimento autônomo das classes de pequenos e médios produtores. Formou-se uma sociedade com hierarquia social rígida, deixando as outras classes com poucas possibilidades de promoção social. Muito contribuíram o engenho e a fazenda - de café e de gado - lócus preferencial da sociedade brasileira, funcionando como núcleo que além de concentrar a produção, tornava possível executar funções que demandavam outras atividades que configuravam a sociedade rural, visto que através deles realizava-se, ao mesmo tempo a inclusão e a exclusão dos indivíduos.

A estreita relação político-econômica entre os grandes produtores, bem como a dificuldade de permanecerem fixos ao meio rural que foram impostas aos pequenos, médios e, mais adiante, aos que não possuíam terras, ocasionou a exclusão de milhares de homens e mulheres do campo para outras regiões do país. Este modelo de colonização, introduzido, inicialmente, pelos portugueses e adotado, posteriormente, pelos brasileiros, baseado na exploração impetuosa, a princípio dos escravizados, em seguida dos trabalhadores rurais, gerou a construção de uma visão preconceituosa em torno da população que vive e trabalha no campo, em virtude de um imaginário 
constituído em torno de um trabalho extenuante, árduo, sofrido e mal remunerado.

Durante a primeira metade do século $X X$, a economia brasileira passou a adquirir novas características pertinentes ao processo do capitalismo industrial, o qual indicava a necessidade de uma maior especialização da classe operária. Ao ponto em que o meio urbano crescia, paralelamente ao avanço da mecanização, exigindo, na visão do patronato, um maior investimento nos moldes de uma educação direcionada para o mercado de trabalho, coube, apenas, a um percentual exíguo da população do meio rural, a oferta, de uma educação basicamente instrumental, elementar e formadora de mão de obra. Com a priorização do urbano, o rural permaneceu desassistido de políticas efetivas e específicas para o atendimento das necessidades de seus sujeitos. Vale ressaltar que até a década de 1950 não havia, por parte do Estado Brasileiro, um investimento significativo para o desenvolvimento educacional do meio agrário o objetivo fundamental era o de formar pessoas para o mercado de trabalho nos centros urbanos que surgiram paulatinamente ao avanço tecnológico, fato este preponderante para a incidência do êxodo rural, marcante na biografia da população brasileira, bem como para a desvalorização da cultura camponesa, provavelmente, consequência do silenciamento da memória desses agentes ao longo da nossa história. (RODRIGUES; BONFIM, 2017).

Devido ao vertiginoso crescimento populacional, houve um inchaço dos grandes centros urbanos despertando as atenções governamentais para o desenvolvimento de políticas públicas voltadas para as populações periféricas das grandes cidades e das zonas rurais. A década e 1960 foi marcada pelo desenvolvimentismo industrial, mais acentuado e acelerado do que as décadas anteriores, o que intensificou o fluxo migratório Campo/Cidade exigindo do Estado a elaboração de medidas que contivessem esse deslocamento visto com preocupação pelas elites brasileiras como afirma (RICARDO et al, 2007, p.11):

$\mathrm{Na}$ década de 60, a fim de atender aos interesses da elite brasileira, então preocupada com o crescimento do número de favelados nas periferias dos grandes centros urbanos, a educação rural foi adotada pelo Estado como estratégia de contenção do fluxo migratório do campo para a cidade. A Lei de Diretrizes e Bases da Educação Nacional de 1961, em seu art. 105, estabeleceu que "os poderes públicos instituirão e ampararão serviços e entidades que mantenham, na zona rural, escolas capazes de favorecer a adaptação do 
Além de converter-se numa tentativa governamental de manter a população campesina atrelada à vida rural, a medida também alinhavava-se aos interesses das demandas industriais como a mecanização do campo, a introdução de novos insumos e o uso de agrotóxicos provenientes da denominada Revolução Verde ${ }^{31}$. Este modelo iniciou-se, de maneira embrionária, no Brasil, a partir da segunda metade da década de 1940, com o fim da Segunda Guerra Mundial (1939-1945), durante os anos 50 adquiriu a força e o status de "revolução", pois foi com o desenvolvimento da indústria química, bem como a ampla valorização das ciências, associada à mecanização do campo, que o movimento, dito "revolucionário", que convergia aos interesses das elites rurais e urbanas, adquiriu forças, encontrando assim, alguns anos à frente, durante o regime de Ditadura Empresarial-Militar (1964-1985), o cenário propício à sua consolidação. (LAZZARI; SOUZA, 2017). O falacioso discurso de desenvolvimento e empregabilidade do/no meio rural, adjunto ao regime ditatorial, dentro de uma política industrial, marcante nos países, considerados, subdesenvolvidos encontrou um cenário favorável, em razão de atender à ambição do poder hegemônico brasileiro. Sobre este fato os autores afirmam ainda que:

A Revolução Verde irrompe no Brasil com a promessa de modernização do campo, de erradicação da fome, de aumento da produção, e, sobretudo como a nova era da agricultura e a busca de desenvolvimento aos países subdesenvolvidos. É aqui que começam a ser delineados os bem pensados traços do agronegócio com a difusão de tecnologias agrícolas que, (...), procuravam espaço no mercado de consumo como os agrotóxicos e fertilizantes químicos. (LAZZARI; SOUZA, 2017, p.4).

Todavia, este processo, não serviu apenas como pano de fundo para o fortalecimento das lutas pela terra, iniciadas na segunda metade da década de 1940 com as Ligas Camponesas ${ }^{32}$, como também, potencializou a mobilização da

31 Foi denominada de Revolução Verde as inovações tecnológicas que ocorreram na agricultura, a partir da década de 1940, com o objetivo de obter uma maior produtividade através do desenvolvimento de pesquisas em sementes, fertilização do solo, utilização de agrotóxicos e mecanização no campo atendendo os anseios do capitalismo industrial no aumento pelo lucro e redução dos custos com a mão de obra humana. (LAZZARI; SOUZA, 2017).

32 Devido à imensa dificuldade de abertura de um sindicato rural - precisando da aprovação do Estado, as primeiras Ligas Camponesas nascem em 1945 como forma de associação civil sob iniciativa do recém- legalizado Partido Comunista Brasileiro (PCB). A formação das Ligas foi uma tentativa de estabelecer uma aliança entre proletários e camponeses contra o latifúndio e o impe- 
sociedade civil urbana na busca por direitos. Nos anos finais do regime ditatorial, diante do processo de abertura política e após anos de luta contra a repressão o sistema educacional brasileiro passou a adquirir novos atributos diante do discurso de redemocratização do país. A década de 80 , além de marcar o fim do regime militar, culminou com a promulgação da Constituição, em 1988, alcunhada como "Constituição Cidadã", devido ao seu caráter universal e democrático, a qual garantiu o direito à cidadania as pessoas que outrora não eram reconhecidos na sociedade, como analfabetos, indígenas e trabalhadores rurais. Vale ressaltar a importante participação de diversos movimentos sociais que buscavam, além do direito a moradia digna, o acesso à terra, e a incessante busca por uma educação de qualidade como cita Ricardo (2007, p.12):

Destacam-se nesse momento as ações educativas do Movimento Nacional dos Trabalhadores Rurais Sem Terra (MST), da Comissão Pastoral da Terra (CPT), da Confederação Nacional dos Trabalhadores na Agricultura (Contag) e do Movimento Eclesial de Base (MEB). Outras iniciativas populares de organização da educação para o campo são as Escolas Famílias Agrícolas (EFAs), as Casas Familiares Rurais (CFRs) e os Centros Familiares de Formação por Alternância (CEFAs).

É notório que, através de um olhar mais apurado, as lutas no meio rural traduziram-se, neste momento, em um avanço nas políticas públicas em diversos rincões do Brasil, porém observar as desigualdades políticas, econômicas e sociais que marcam a história nacional evidenciam e justificam os constantes conflitos pelo acesso e posse à terra existentes em nossa nação.

\section{OS CONFLITOS PELA TERRA EM NOVA IGUAÇU}

Antes de adentrarmos nos conflitos que marcaram a Baixada Fluminense, mais especificamente o município de Nova Iguaçu ${ }^{33}$, é oportuno contextualizar, em linhas gerais, as lutas dos agricultores em sua amplitude na busca de compreender o

rialismo. A proposição do PCB era a de um inicial pacto entre operários, camponeses e burguesia nacional a fim de superar o feudalismo existente no campo, para então poder estabelecer uma luta contra o capitalismo e a sua superação via o comunismo. (BRITO, 2015, p. 75-76).

33 O Município de Iguaçu, Estado da Guanabara (Rio de Janeiro) foi criado no dia 15 de janeiro de 1833, com sua sede instalada às margens do Rio Iguassú, que serviu durante muito tempo como rota comercial para o escoamento de produtos. (Sacramento, 2018). 
cerne do movimento camponês no Brasil. Tendo como marco inicial a política industrial promovida por Getúlio Vargas, a partir da década de 1930, observa-se uma reconfiguração não só dos aspectos políticos e econômicos, como também nos sociais. A inexistência de uma justiça que defendesse os interesses dos trabalhadores rurais permitia com que a produção, principalmente, dos pequenos agricultores, fosse, praticamente, expropriada pelo grande capital e centros urbanos, de maneira a tornar o trabalho no campo algo excessivo e exploratório. Além disso, essa massa de trabalhadores se tornou, na medida em que a industrialização avançava, numa grande fonte de mão de obra operária para o trabalho nas indústrias e nos centros urbanos cabendo-Ihes, assim, baixos salários. Como consequência deste modelo houve um aumento da superexploração das classes trabalhadoras tanto na cidade quanto no campo produzindo uma violenta e previsível luta de classes. (BRITO, 2015).

Diante deste contexto paradoxal, típico do capitalismo, o qual, no momento, dependia da exploração da classe trabalhadora para o sucesso da implantação da industrialização, os trabalhadores rurais constataram que havia a necessidade de se organizarem, todavia, as representações Estatais da época dificultavam a criação de sindicatos rurais. Foi neste universo, como citado anteriormente, que surgiram as primeiras Ligas Camponesas em 1945, este sistema de associação civil ganhou forma com o apoio e a influência do, então, legalizado Partido Comunista Brasileiro (PCB) que tinha como objetivo superar a exploração no campo a partir do acerto, num primeiro momento, entre operários, camponeses e burguesia nacional, para então sistematizar a luta contra o capitalismo e, assim, a tão inspirada superação pelo caminho do comunismo. Contudo esta aliança entre trabalhadores rurais e PCB sofreu algumas transformações devido ao retorno, por força do Estado, do partido à ilegalidade forçando as Ligas Camponesas a se rearranjarem, sem, porém, deixarem de exercer o seu caráter insurgente.

O PCB absorve as reivindicações rurais e consegue mobilizar as massas camponesas, ampliando a sua presença no campo até o ano de 1947, quando entra novamente na ilegalidade, sendo as Ligas desarticuladas e extintas após forte repressão.

Entre os anos de 1948 e 1954 os conflitos se mantiveram de forma constante e cotidiana, consolidando a luta de classes a experiência de classe campo- 
nesa, levando a existência de associações ligadas ou não ao PCB (então na ilegalidade) e ocorrendo também congressos rurais, que iniciavam timidamente um retorno às mobilizações e criavam um vocabulário comum de luta e práticas de resistência. (BRITO, 2015, p. 76).

As circunstâncias transcorridas, a partir do final da década de 1940 e nos anos posteriores, desencadearam na Baixada da Guanabara (atualmente, Baixada Fluminense $)^{34}$, uma sucessão de eventos relacionados ao processo de transição da produção da laranja (citricultura) ${ }^{35}$ para o loteamento. Concluindo que ambos os eventos estão diretamente ligados à lógica capitalista e aos interesses tanto públicos quanto privados, encontravam, e ainda encontram, nestes setores arcabouço para a sua manutenção. A expansão urbana em direção à Baixada, aliada a crise agrícola e em acordo com a especulação imobiliária, levou milhares de pessoas a uma intensa procura por lotes de terras nos municípios que compunham a região. Na medida em que os anos seguiam esta dinâmica transformou-se não só no quesito mercadológico com no quesito social, ao passo em que as disputas entre posseiros e grileiros ${ }^{36}$ expuseram a tônica deste embate.

A viabilização de obras de infraestrutura na Baixada da Guanabara implementadas vigorosamente a partir da década de 1930, tinham como interesse diversificar a produção agrícola, bem como criar condições de manter o agricultor atrelado ao território, GRYNSZPAN (1987, p.27) afirma que é a partir desta década que se intensificam os interesses governamentais sobre a região: "Este quadro não se havia modificado até a década de 1930 quando o Governo Federal iniciou a implementação de um amplo programa de recuperação da Baixada que incluía obras de saneamento e drenagem". O referido programa, iniciado nos anos 30 , possibilitou a valorização territorial, entretanto não conseguiu, mais a frente, perpetuar o almejado desejo governamental de transformar aquela área em um espaço de produção rural. Ao contrário

$34 \quad$ Baixada Fluminense, Periferia, Região Metropolitana, Grande Iguassu ou Recôncavo da Guanabara são termos utilizados para se referir a um pedaço de chão e a escolha de um destes conceitos implica em se filiar a um conjunto de referências e sentidos, também eles transmutados ao longo do tempo. (SILVA, 2013, p. 48).

35 A partir de 1915 a laranja tornou-se num novo produto para a economia municipal. Este fato denotou a importância que a citricultura adquiriu para a economia nacional tanto ao mercado interno quanto ao mercado internacional, carregando consigo, ainda na memória do município, a alcunha de "Cidade Perfume", em uma alusão ao aroma exalado pelo fruto que era cultivado nas inúmeras propriedades. (BARROS, 2004).

36 Pessoa que se apodera ou procura se apossar de terras alheias, mediante falsas escrituras de propriedade. 
do imaginado, as terras da Baixada se tornaram em um campo de intensas disputas advindas da dicotomia existente entre os interesses dos agricultores (posseiros e lavradores), frente aos dos especuladores (grileiros e administradores).

Além do cenário nacional que desenhava-se, a partir da influência do desenvolvimento das Ligas Camponesas, da ascendência do PCB e dos diversos agentes sociais como militantes, políticos e membros da Igreja Católica, os quais marcaram a organização e luta dos trabalhadores do campo no Estado do Rio de Janeiro, os conflitos por terras na Baixada possuíam, também, em sua essência o imaginário da "posse", ou seja, o ideal de quem teria realmente o "direito" sobre uma determinada propriedade. Aquele que há tempos vivia e/ou sobrevivia do que produzia tendo toda uma relação de afetividade não só com a terra como também com a localidade? Ou aquele que de alguma forma se dizia proprietário, por ter em suas mãos um documento, muitas das vezes espúrio, marcado pela grilagem, atestando-lhe o direito sobre a terra reclamada? Diante deste contexto, os conflitos se intensificaram e adquiriram amplitude como explica GRYNSZPAN (1987, p. 84).

A valorização das terras da Baixada e o consequente surgimento dos grileiros, muitas vezes diversos deles reivindicando uma mesma área, contribuíram para o enfraquecimento dos já não muito fortes laços de subordinação que prendiam os lavradores. Se estes não se sentiam donos das terras, eles iriam, aos poucos, relativizando sua situação, e desconfiando de que aqueles que se diziam donos também não o eram. Os lavradores tornavam-se, assim, propensos a lutar por uma terra que julgava ser um direito seu e a sua sobrevivência, contra os despejos que lhes pareciam, cada vez mais, injustos e ilegítimos. Destarte, a quebra da subordinação provocada, em grande parte, pela interposição de um terceiro elemento na relação - o grileiro - foi fundamental para que as lutas dos lavradores se iniciassem a partir da Baixada, e tivessem, ali, seu foco de maior intensidade até o ano de 1964.

Foi em torno desta complexa combinação de sentidos e de interesses que os embates pela aquisição de terras configuraram-se na Baixada colocando de um lado os lavradores, que dependiam diretamente da terra para sua sobrevivência, e de outro os que viviam da negociação, ou seja, especulação delas para enriquecer (negociantes, famílias tradicionais, grileiros, agentes públicos e privados entre outros).

Organizados, os lavradores, lutavam constantemente contra a onda de despejos que assolavam o município de Nova Iguaçu. Tais desapropriações se caracteriza- 
vam pela extrema violência como o uso desproporcional da força, da queimada das lavouras, da derrubada de propriedades, da prisão e do assassinato de posseiros. Um caso emblemático deste período foi a associação dos lavradores de Pedra Lisa, atualmente pertencente ao município de Japeri, no Estado do Rio de Janeiro. Antes de emancipação da cidade, em 1991, a localidade fazia parte das terras iguaçuanas, sendo marcada por uma série de contendas entre posseiros e especuladores, por este motivo os trabalhadores do campo se organizaram de maneira a fazer frente ao poder hegemônico tanto local como estadual, tendo na figura do agricultor Bráulio Rodrigues ${ }^{37}$ uma emblemática liderança.

Natural da cidade mineira de Januária, nascido no ano de 1922, o "Seu Bráulio", como é conhecido, ficou órfão aos quatro anos de idade, sendo, por este motivo, internado em um asilo de menores na capital, Belo Horizonte. Durante sua juventude desempenhou diversas atividades profissionais, como sapateiro, jornaleiro e vendedor de laranjas, na cidade de Volta Redonda. Neste período, durante meados da década de 1930, exerceu a profissão de apontador na Companhia Siderúrgica Nacional (CSN), devido a sua personalidade combativa ao protestar contra as injustiças, as quais os operários eram submetidos na fábrica foi demitido trocando o trabalho na fábrica pelo trabalho no campo em Nova Iguaçu, na região da Pedra Lisa como descreveu em entrevista ao Jornal da Baixada no ano de 1979.

"Trabalhei um tempo em Volta Redonda assistia muita injustiça lá. Eu achava aquilo muito desumano e comecei a protestar. Aí me puseram para fora. E eu vim pra Nova Iguaçu. Fui pro campo, em Pedra Lisa. Fui pra lá porque soube que estavam distribuindo terra”. (Jornal da Baixada, Edição n5, 1979, p.5).

As palavras do agricultor ratificam o desenvolvimento do processo de loteamento da baixada, analisado anteriormente, e evidenciam a tônica dos conflitos que giram em torno do controle pela terra. No final da década de 1940 e início dos anos 50 , no período em que as disputas entre posseiros e grileiros/especuladores se consolidaram, os lavradores de Pedra Lisa se reuniram em torno de uma associação ${ }^{38}$.

$37 \quad$ Líder comunitário e conhecido agricultor. Responsável pela resistência dos agricultores de Pedra Lisa, atual município de Japeri, antes da emancipação o território fazia parte do município de Nova Iguaçu.

38 É comum em um estudo sobre memória que o entrevistado cometa algumas imprecisões com lugares, nomes ou datas como no caso da fundação da Sociedade dos Lavradores e Posseiros de Pedra Lisa, data de 1948, foi fundada a Sociedade dos Lavradores e Posseiros de Pedra Lisa. 
Sociedade dos Lavradores e Posseiros de Pedra Lisa desempenhou um papel importante na resistência dos agricultores, pois além se comprometer na luta pelo direito à posse da terra, possuía o papel de conscientizar o trabalhador e seus familiares de que aquele era o seu local e por isso deveriam se mobilizar:

"Não era sindicato, era Associação. Mas eu só comecei a participar da Associação quando o seu presidente fundador, Zé Matias, foi assassinado pelos fazendeiros da época. Isso foi em 1949, 50. Nós continuamos a distribuir terras, mas para ter direito à terra, tinha que ser sócio da Associação. Por dois motivos: primeiro porque era uma maneira de dar consciência à pessoa que estava ali. E, segundo, porque era uma maneira da associação sobreviver. Eram mais ou menos 300 sócios.

Era Preciso se comprometer a morar ali. Agente pedia que construísse logo o barraco para consolidar a ocupação. E plantasse bens de raízes, como laranjeiras, bandeiras". (Jornal da Baixada, Edição n5, 1979, p.5).

A fala do personagem evidencia o clima tenso diante dos diversos interesses que envolviam o cenário de certame na Baixada, mais especificamente em Nova Iguaçu. Em seu relato consta o assassinado de um dos líderes dos lavradores da época, Zé Matias, bem como a necessidade da organização dos camponeses frente à concorrência dos interesses de grupos que representavam a elite iguaçuana. A Associação de Pedra Lisa contou com apoio de alguns sindicatos que solidarizavam com a causa operária da cidade e do campo, o que proporcionou um apoio à sua manutenção na luta, em diversos conflitos, contra grupos do capital iguaçuano. Mas, com a instauração da Ditadura Empresarial-Militar no Brasil, em 1964, a Associação foi fechada, Bráulio Rodrigues e muitos lavradores, foram presos, condenados pela justiça da época e/ou tiveram que deixar as suas terras, tendo que resistir, praticamente, de maneira solitária ou clandestina por conta da repressão:

"Depois de 64, acabou a Associação. Fecharam o posto médico, metralharam a escola e ficaram acampados lá durante quase um ano. Prenderam muitos lavradores, prisões de poucos dias. Depois tornavam a prender. Durante todo esse período, fui preso 32 vezes pelo Exército. Fui julgado em três inquéritos e absolvido em todos eles. Mas o Exercito achava que eu não podia ser absolvido, que eu tinha que pagar alguma coisa. Aí começaram a me perseguir. Eu ia pro campo, eles iam lá e me prendiam. Isso de 66 a 74". (Jornal da Baixada,

A área vinha sendo ocupada desde o começo dos anos de 1940 e passou a ter a entrada e saída de lavradores regulada por uma comissão formada pelos que ali viviam e trabalhavam e que estavam organizados na Sociedade. Um de seus fundadores foi José Teodoro, conhecido como José Matias, assassinado anos mais tarde por grileiros locais. (MAIA, 2015, p. 251). 
O contexto de repressão transformou não só o cotidiano de Bráulio Rodrigues como também de inúmeros outros agricultores de Nova Iguaçu, mesmo em meio ao Estado de exceção estabelecido no país muitos lavradores permaneceram ligados a terra e a atividade agrícola, fruto do período de conscientização e embates por direito à posse dos lotes e contra os despejos compulsórios. O próprio Bráulio, que era constantemente convocado a prestar contas com o Exército e coagido a largar a sua propriedade, como forma de sobrevivência tornou-se comerciante: "Comprei uma carroça e passei a fazer feira num lugar onde os próprios lavradores fazem feira. Comprava a mercadoria em Tinguá. Assim estava sempre em contato com os lavradores, ouvindo, conversando, trocando idéias". Apesar de desenvolver uma atividade alternativa, porém muito próxima ao campo, o trânsito entre diferentes distritos agrícolas, como Tinguá, e o contato com os agricultores, fizeram com que a memória da resistência do campo permanecesse viva no imaginário da população local mesmo numa conjuntura adversa.

Algumas regiões de características agrícolas, como a de Tinguáa ${ }^{39}$, apesar de reduzirem-se com o passar dos anos, ainda resistiram às constantes transformações que marcaram as cercanias iguaçuanas fruto da resiliência dos sujeitos do campo diante frente aos interesses da elite hegemônica estabelecida na cidade, desde a colonização portuguesa até a contemporaneidade. Na Baixada Fluminense, não obstante, esses eventos manifestaram-se a todo instante, pois refletiam as circunstâncias histórico-sociais estabelecidas no Brasil. Entretanto, respeitados as suas especificidades, a história de Nova Iguaçu fez, e ainda faz, parte desse processo marcado por incontáveis disputas políticas, econômicas e sociais que resultaram nas reflexões propostas nesta parte da discussão. Vale relembrar que as transformações que ocorreram, e ainda ocorrem no campo, foram possíveis graças à confluência de diversos sujeitos sociais que, organizados ou não, fizeram ecoar as vozes das classes oprimidas.

39 Esta alcunha, Tinguá, é proveniente do idioma Tupi-Guarani, (Tin-gua), o qual significa pico em forma de nariz, este termo foi utilizado pelos indígenas em alusão ao formato pontiagudo característico da descrição fisionômica do maciço formado por tinguaíto, espécie de rocha alcalina, presentemente marcante na Serra do Tinguá, distrito da Cidade de Nova Iguaçu - RJ. (NIMA, 2010). 
O contexto de luta, evidenciado por este trabalho, no município de Nova Iguaçu remete ao congênere cenário de conflitos existente no Brasil. O diálogo com a história da resistência camponesa traz à luz do debate os diversos interesses conflitantes que estão contidos no seu universo.

Estudos históricos voltados para a análise e compreensão da memória coletiva passaram a destacar à extrema riqueza, no que diz respeito ao armazenamento da história, tanto material, quanto humano. Com isso, o domínio desta memória coletiva adquiriu um status de dominação passando a exercer um papel de aparelho de poder. (LE GOFF, 2003).

Para que a reminiscência coletiva desempenhe uma função libertadora, torna-se necessário reinterpreta-la e, assim, reinterpretar a própria história como afirma Le Goff (2003, p.471) “A memória, na qual cresce a história, que por sua vez a alimenta, procura salvar o passado para servir o presente e ao futuro. Devemos trabalhar de forma que a memória coletiva sirva para a libertação e não para a servidão dos homens".

O relato do agricultor Bráulio Rodrigues traduz o cenário conflitante da disputa territorial na Baixada Fluminense e que dialoga com a constante busca pela libertação concretizada pelo acesso à terra. Desta forma, através do campo conceitual da Educação do Campo é possível compreender que as conquistas campesinas foram fruto da ação dos movimentos sociais, interessados em afirmar a identidade dos sujeitos do campo e que refletisse valorização dos seus saberes. (SANTOS, 2011).

Assim, a Educação do Campo configura-se, neste sentido, num campo científico que representa a luta dos povos do campo por sua identidade, ou seja, pela sua própria existência. Em Nova Iguaçu, não obstante às demais realidades do Brasil, o mesmo processo de resistência ocorre, salvo suas especificidades, apontando caminhos relevantes num sentido de se compreender e valorizar a luta dos movimentos sociais, em especial a dos sujeitos do campo. 
ALENTEJANO, Paulo Roberto Raposo. A Evolução do Espaço Agrário Fluminense. Niterói: GEOgraphia / UFF, v. 13, 2005. (p. 49-70).

BARBOSA, Francisco Benedito da Costa. Formação da Sociedade Rural e seus Reflexos no Desenvolvimento do Brasil. Rio de Janeiro: Instituto de Pesquisa Aplicada em Desenvolvimento Econômico Sustentável - IPADES, 2011.

BARROS, Ney Alberto Gonçalves. A Vila de Iguaçu. In: Baixada Fluminense: a construção de uma história: sociedade, economia, política. São João de Meriti RJ: IPAHB Editora, 2004. (p. 96-108).

BRITO, Ricardo José Braga Amaral de. A Luta Camponesa e a Repressão Durante a Ditadura Empresarial-Militar (1964 -1985). Rio de Janeiro: Revista Habitus, volume 13, n 1, jul, 2015. (p. 72-87).

CALDART, Roseli Salete [et. AL]. Dicionário da Educação do Campo. São Paulo: Escola Politécnica de Saúde Joaquim Venâncio, Expressão Popular, 2012.

Pedagogia do Movimento Sem Terra. Petrópolis: Vozes, 2000.

Movimento Sem Terra: Lições de Pedagogia. Instituto Técnico de Capacitação e Pesquisa da Reforma Agrária (ITERRA): Currículo sem Fronteiras, v.3, n.1, 2003. (p. 50-59).

GRYNSZPAN, M. Mobilização Camponesa e Competição Política no Estado do Rio de Janeiro: 1950-1964. 2 v. Dissertação (Mestrado). Programa de Pós-Graduação em Antropologia Social, MN/UFRJ, Rio de Janeiro, 1987.

INSTITUTO MULTIDISCIPLINAR. Jornal da Baixada. Repositório/UFRRJ, $n^{\circ} 5$, 1979. Disponível em: < http://repositorio.im.ufrrj.br:8080/jspui/handle/1235813/88>. Acesso em: 18/02/21.

LAZZARI, Francini Meneghini; SOUZA, Andressa Silva. Revolução Verde: Impactos sobre os Conhecimentos Tradicionais. Rio Grande do Sul: Universidade Federal de Santa Maria, 2017.

LE GOFF, Jacques. História e Memória. Campinas: Ed. Unicamp, 2003.

MAIA, Aline Borghoff. Conflitos fundiários em Duque de Caxias e Nova Iguaçu: repressão e formas de resistência. In: Conflitos por Terra e Repressão no Campo no Estado do Rio de Janeiro (1946-1988). Rio de Janeiro: CPDA-UFRRJ, 2015. 
MOLINA, Mônica (org). Educação do campo e pesquisa: questões para reflexão. Brasília, MDA, 2006.

NIMA. Núcleo Interdisciplinar de Meio Ambiente Educação Ambiental: formação de valores étnico-ambientais para o exercício da cidadania no Município de Nova Iguaçu. Rio de Janeiro: PUC-Rio, 2010.

RICARDO, Henriques [et. al]. Educação do Campo: diferenças mudando paradigmas. Brasília: Ministério da Educação, 2007.

RODRIGUES, Hanslilian Correia Cruz; BONFIM, Hanslivian Correia Cruz. A Educação do Campo e seus Aspectos Legais. Curitiba: Revista Educare, 2017. (p. 13731387).

SACRAMENTO, C. F. de O. Escolas do Campo, memórias, paisagem geográfica em Nova Iguaçu e Reserva Biológica de Tinguá. Seropédica, RJ: UFRRJ. Dissertação de Mestrado, 2018.

SANTOS, Ramofly Bicalho. Histórico da Educação do Campo no Brasil. In: II Seminário de Pesquisa em Educação do Campo: desafios teóricos e práticos. Florianópolis: UFSC, volume 1, 2011. (p. 1-14).

SILVA, Lúcia Helena Pereira. De Recôncavo da Guanabara à Baixada Fluminense: Leitura de um Território pela História. Rio de Janeiro: Revista Recôncavo, volume $3, n^{\circ} 5,2013$. 
A ÓTICA DA EDUCAÇÁO DO CAMPO DA UNIVERSIDADE FEDERAL DE SANTA CATARINA SOBRE A EDUCACAO DO
MUNICIPIO DE BOM RETIRO/SC

Silvio Domingos Mendes da Silva ${ }^{40}$

$40 \quad$ Professor do Departamento de Educação do Campo - EDC/UFSC; formado em Geografia; e-mail: silvio.mendes@ufsc.br 
Este artigo foi possível a partir de pesquisa realizada por alunos do primeiro ano do Curso de Licenciatura em Educação do Campo (LEdoC) da Universidade Federal de Santa Catarina (UFSC), polo de Alfredo Wagner, sob coordenação de um professor orientador nas disciplinas de Vivência Compartilhada I e II.

O curso de Licenciatura em Educação do Campo funciona em regime de alternância, estratégia curricular de fazer com que a LEdoC esteja organizada em momentos pedagógicos, que interagem, chamados de "tempo universidade" e "tempo comunidade". Na UFSC estes momentos, no primeiro ano do curso, são viabilizados pela disciplina de Vivência Compartilhada, que contempla planejamento, preparação, realização, acompanhamento e supervisão, assim como a avaliação. A disciplina Vivência Compartilhada objetiva envolver o acadêmico num processo educativo uno, buscando articular a experiência escolar propriamente dita, a ocorrer no interior da universidade, neste caso no município de Alfredo Wagner, com a experiência de trabalho e vida no seio da comunidade onde convive e trabalha o estudante.

O objetivo principal deste trabalho é estabelecer uma perspectiva de práxis entre "tempo universidade e tempo comunidade", apresentando resultados concretos à luz da pedagogia da alternância. De maneira geral, a pesquisa permitiu além de uma análise concisa do território bom retirense, um diagnóstico preliminar da educação desse município.

O trabalho de pesquisa de campo iniciou-se a partir de leitura preliminar do Decreto Federal 7.352 (BRASIL, 2010). A discussão em torno de uma educação para as escolas do campo que contemple os anseios dos sujeitos que vivem nesse espaço, não seria efetiva se não fosse considerado o processo de formação de professores. Sendo assim, em 2007, as primeiras experiências de LEdoC foram realizadas em quatro universidades: Universidade Federal de Brasília (UNB), Universidade Federal da Bahia (UFBA), Universidade Federal de Minas Gerais (UFMG), Universidade Federal de Sergipe (UFS).

A escolha de Bom Retiro se deve ao fato de o território compor a oitava turma da UFSC - polo de Alfredo Wagner, com a presença de dez estudantes. As atividades 
foram desenvolvidas no ano de 2017, aprofundando a pesquisa em vários aspectos, tais como: sociais, econômicos, políticos, estrutura fundiária, saúde e educacionais.

$\mathrm{Na}$ perspectiva de desenvolver no educando a sensibilidade e a competência para análises de um território (em geral, um município), entendido como um espaço geográfico sobre ação antrópica, considerando-se as relações sociais nele existentes, bem como as determinações que elas geram, buscou-se aprimorar uma metodologia participativa em todas as etapas de trabalho, de forma a preparar paulatinamente um “Diagnóstico do Município”, com aspectos voltados à ação em Educação do Campo.

Buscou-se promover a articulação com - e entre - as diferentes disciplinas que compõem o primeiro e o segundo semestre do curso de Educação do Campo, bem como uma facilitação na relação com as instituições/organizações dos territórios/municípios em que foram realizados os Tempos Comunidade.

O ponto de partida foi a construção de forma autônoma e participativa dos Planos de Estudos (PA), por meio do envolvimento dos estudantes na indicação das temáticas a serem pesquisadas, com base em seus conhecimentos sobre o território. Os PA são os alicerces do desenvolvimento do trabalho de pesquisa e da análise dos pesquisadores (professor e estudantes) durante o tempo comunidade. É preciso lembrar que no processo de construção de um diagnóstico, o educador do campo deve considerar pontos mínimos do território: história e economia, questão agrária/estrutura fundiária, movimentos sociais/organização da sociedade civil; meio ambiente e impactos ambientais da ação humana; educação e escolarização; saúde; sujeitos do campo, mulheres, dentre outros.

Ao longo dos semestres foram realizados oito tempos comunidade, com três visitas intermediárias em cada semestre para acompanhar e orientar os estudantes na coleta de dados da pesquisa e para estabelecer e reforçar as relações institucionais com parceiros locais. Resumidamente, a metodologia utilizada constituiu-se de entrevistas com sujeitos chaves das comunidades, atores do poder público, estudantes das redes municipal e estadual e professores, nas quais os pesquisadores procuravam colocar em prática os métodos aprendidos durante os tempos universidade.

Em relação à localização geográfica da área de estudo, o município de Bom Retiro, localiza-se no estado de Santa Catarina (latitude $27^{\circ} 47^{\prime} 50^{\prime \prime}$ sul e longitude 
49²9'21" oeste), na região serrana, com população estimada em 10.060 habitantes, segundo dados do Instituto Brasileiro de Geografia e Estatística - IBGE (2020). Sua população, segundo IBGE (2010), entre 2000 e 2010, cresceu a uma taxa média anual de $1,16 \%$, enquanto no Brasil foi de 1,17\%, no mesmo período. Nessa década, a taxa de urbanização do município passou de 66,98\% para 71,76\%. Entre 1991 e 2000, a população do município cresceu a uma taxa média anual de 1,17\%, no estado esta taxa foi de 1,85\%; já no Brasil foi de 1,63\%. Na década, a taxa de urbanização do município passou de $56,42 \%$ para $66,98 \%$.

De maneira geral, Bom Retiro pode ser considerado um município pequeno, com atividades econômicas voltadas para o setor primário, porém a maioria de sua população vive na região urbana do território. Esse fato é corroborado pelo processo migratório interno (migração rural-urbana e inter-regional) para esta cidade que foi intenso nos últimos anos.

\section{EDUCAÇÃO DO CAMPO, ESCOLA, TERRITÓRIO E SUAS RELAÇÕES}

Cabe aqui uma pequena reflexão sobre o entendimento que tenho sobre esta questão. Parto do princípio de que o município tem a obrigação de conhecer suas necessidades e seus limites, seus recursos humanos, naturais, econômicos, financeiros, entre outros. Assim, acredito que nos municípios há fontes de produção de conhecimentos às quais os mesmos devem dar oportunidades por intermédio das escolas. As escolas, por sua vez, têm condições de construir o conhecimento sobre cada bairro, comunidade, cada recurso natural (solo, vegetação, água, sementes, etc.), produção e abastecimento.

Por outro lado, tem-se um dilema: como fazer estudos sobre a realidade local se há um currículo para cumprir? Começo partindo da premissa de que o conhecimento do currículo não é algo diferente do conhecimento da realidade. Neste sentido, a metodologia usada na Educação do Campo permite fazer com que o currículo possa ser o estudo da realidade através das disciplinas. Essa opinião vai corroborar a ideia de Educação Popular (EP), apresentada por Moura (2003, p.67), de que "A EP é a que tem em seu bojo, em sua filosofia, em seus currículos, em sua finalidade, preparar as pessoas para um projeto de sociedade". 
Pensar em como colocar em prática essa forma de conjeturar e agir, exige do professor reflexões sobre o processo educacional que tem na avaliação um caráter permanente de acompanhamento, monitoramento, uma vez que a educação é um processo no qual as pessoas não se formam de uma só vez, em saltos grandes. Pode-se pensar na mesma linha de raciocínio sobre o conhecimento. Nele não existe somente o limite entre o certo e o errado, mas sim a compreensão inicial, incompleta, dos conceitos e da realidade, que vai amadurecendo, tomando formas mais aperfeiçoadas e completas. O produto final do conhecimento, de uma ação é, por vezes, o resultado inesperado desse processo. Assim, faz sentido pensar a avaliação como um processo antes, durante e depois das ações. Avaliação dos valores, das atitudes, dos conhecimentos, dos processos e dos conteúdos.

Discorrer a respeito da realidade do território por essa ótica é refletir sobre a vida, o trabalho e a escola dos sujeitos. Nosso trabalho enquanto educadores do campo só faz sentido quando temos condições críticas de perceber que essas realidades se apresentam para as famílias rurais e urbanas, assim como para os estudantes, como se tudo tivesse a ver entre si, e não como mundos distintos, isolados. De tal sorte, que a vida é o campo maior do conhecimento, o trabalho e a escola são partes e dimensões da vida, em condições de interagir, de apoiar e manter relações uma com as outras (MOURA, 2003). Ainda, em conformidade com o autor:

[...] A vida precisa de conhecimento. Historicamente as pessoas aprenderam para melhorar a vida, para facilitar o uso das energias humanas; a escola apareceu para otimizar esse estágio de aprendizagem que as pessoas tinham diante da vida, de modo que muitas sociedades viveram e outras ainda vivem sem escola no desenho que têm hoje (MOURA, 2003, p.91).

Mediante esta reflexão, tratar a realidade local passa a ser uma missão do educador do campo. O olhar ao território é uma condição sine qua non, na qual o rural e o urbano, que na maioria das vezes nos são apresentados como dimensões bipolares, como se houvesse uma lacuna nítida entre os dois e como se a separação pudesse ser definida pela prefeitura ou pelo legislativo local, que decidem onde começa e termina o limite urbano/rural, ou mesmo, como se as realidades fossem meramente espaciais e físicas. Também, nessa toada, existe a conotação cultural de que o rural é sinônimo de atraso, "matutice", de lugar distante e isolado; onde as pessoas falam 
errado ou mesmo onde as relações são livres com a natureza e os animais. E há a conotação social, com a pobreza, moradias precárias, falta de higiene, de lazer. Todas essas características em oposição à cidade, que se apresenta como sendo o lugar onde tem luz, médico, emprego, escolas, pessoas que falam correto.

Neste território de hoje, as relações entre rural e urbano transcendem todas essas conotações. As contribuições de Veiga (2002), no livro "Cidades Imaginarias", ao analisar os números oficiais do Estado, nos dão essa dimensão. A partir do autor, vê-se que esses modos de vida se transcendem, interpenetram-se, interagem. $O$ rural não se identifica somente como agrícola e o urbano com o arruados de casas, com postos de saúde e escolas. Os meios de comunicação, as TVs a cabo estão em todos os espaços, os modos e costumes estão se influenciando de uma dimensão a outra. Ou seja, ser do campo não é mais um estigma, e ser da cidade não é mais um status social. Pode-se viver muito bem ou muito mal em qualquer um dos espaços.

De maneira geral, a pesquisa proposta aos estudantes pautava-se não somente em um resgate da cidadania, da história dos sujeitos do campo, mas também por uma redefinição de espaço rural a partir das noções que englobam as dimensões cultural, produtiva, territorial e ambiental. Que não opõe cidade e campo, mas em que ambos se completam e, quanto mais harmoniosos e valorizados forem suas funções e relações, mais desenvolvimento será alcançado no território. Os conceitos de territórios que estão sendo tratados no Brasil atualmente por diversos autores (HAESBAERT, 2007; SAQUET, 2006; SANTOS, 2005) inspiram relações complementares e não opostas.

\section{UM OLHAR SOBRE A EDUCAÇÃO DE BOM RETIRO - SC}

A educação no município teve início em 1907, com uma escola privada adventista, em funcionamento até os dias atuais. O sistema público de ensino se iniciou em 1941, com o Grupo Escolar Alexandre de Gusmão, hoje Escola de Educação Básica Alexandre de Gusmão. No interior havia escolas isoladas e multisseriadas só até a $4^{\mathrm{a}}$ série. Atualmente, todas as escolas do meio rural são municipais e com a nomenclatura de "Escola do Campo", porém, apesar do nome indicar que a escola é do campo, o ensino reproduz a realidade urbana, quando deveria beneficiar e atender às realidades locais (do campo) dos educandos. 
Em relação ao transporte escolar, há uma frota terceirizada e outra própria do município, que atende apenas seis localidades. Foi perceptível, a partir das entrevistas com estudantes usuários, que as condições dos ônibus utilizados para o transporte não são adequadas, sendo que eles chegam a perder aulas por este motivo.

A alimentação é feita nas próprias escolas. A Secretaria de Educação faz a compra dos alimentos através de licitação (30\% da verba é destinada para compra de produtores da agricultura familiar). Apesar de esta ser uma cota legal, a prefeitura prioriza comprar alimentos de origem da agricultura familiar.

Na rede municipal há três creches (duas na zona urbana e uma na zona rural). Há cinco escolas no meio urbano e oito no meio rural, conforme a Tabela 1. Algumas dessas escolas ainda são multisseriadas.

Tabela 1 - Escolas municipais e número de alunos matriculados em 2017

\begin{tabular}{|c|c|c|}
\hline ESCOLAS MUNICIPAIS & Alunos & tipologia \\
\hline Creche Professor Alosir Moretti & 95 & Normal \\
\hline Creche Municipal Irmã Paula & 59 & Normal \\
\hline Creche Municipal Patrícia Deucher & 15 & Normal \\
\hline Pré-escolar Municipal Capistrano & 60 & Normal \\
\hline Escola do Campo Barbaquá (pré-escolar) & 9 & \multirow{2}{*}{ Multisseriada } \\
\hline Escola do Campo Barbaquá (ensino fundamental) & 17 & \\
\hline $\begin{array}{l}\text { Escola do Campo Cambará (pré-escolar) } \\
\text { Escola do Campo Cambará (ensino fundamental) }\end{array}$ & $\begin{array}{c}8 \\
18\end{array}$ & Multisseriada \\
\hline E. do Campo Costão do Frade (ensino fundamental) & 17 & Multisseriada \\
\hline $\begin{array}{l}\text { Escola do Campo Paraíso da Serra (pré-escolar) } \\
\text { E. do Campo Paraíso da Serra (ens. fundamental) }\end{array}$ & $\begin{array}{c}9 \\
26\end{array}$ & Multisseriada \\
\hline Escola do Campo Três Pontas (ensino fundamental) & 9 & Multisseriada \\
\hline $\begin{array}{l}\text { Núcleo Municipal Henrique Hemkmaier } \\
\text { (ensino fundamental) }\end{array}$ & 83 & Normal \\
\hline
\end{tabular}




\begin{tabular}{|c|c|c|}
\hline $\begin{array}{l}\text { Núcleo Municipal São José (pré-escolar) } \\
\text { Núcleo Municipal São José (ensino fundamental) }\end{array}$ & $\begin{array}{r}68 \\
219 \\
\end{array}$ & Normal \\
\hline Escola do Campo Sapato & 3 & Multisseriada \\
\hline Escola do Campo Rio Sincero & 3 & Multisseriada \\
\hline $\begin{array}{l}\text { Escola do Campo Canoas (pré-escolas) } \\
\text { Escola do Campo Canoas (ensino fundamental) }\end{array}$ & $\begin{array}{c}7 \\
21\end{array}$ & Multisseriada \\
\hline TOTAL DE ALUNOS MATRICULADOS & 746 & \\
\hline
\end{tabular}

Fonte: Elaborada pelo autor, com dados extraídos de Bom Retiro (2017)

Além das escolas de ensino municipal, o município conta com o Núcleo Avançado de Ensino Supletivo - NAES, que atende 28 estudantes com idades entre 15 e 50 anos; conta também com a Associação de Pais e Amigos dos Excepcionais APAE, que atende 98 alunos a partir dos três meses de vida. $E$ também tem a Escola de Ensino Infantil Beija Flor, com 72 crianças em idades entre dois anos e meio a seis anos.

Diariamente, 117 estudantes vão a Lages para estudar em universidades locais e cursos técnicos, utilizam transporte escolar e fazem parte de uma associação organizada por eles que recebe auxílio da prefeitura. Dez estudantes vão a Alfredo Wagner (polo UFSC) com transporte particular, sem ajuda de custo da prefeitura. Há, ainda, 15 estudantes que vão para uma escola particular em Urubici, município vizinho. No município, há, também, uma escola particular de idiomas que atende cerca de 190 alunos e dois polos de ensino superior (à distância-Ead).

Bom Retiro conta também com duas escolas estaduais, uma de ensino fundamental e outra de ensino médio. Na escola de Educação Básica Alexandre de Gusmão, que oferece o ensino fundamental, estudam 795 alunos, sendo 597 que moram no perímetro urbano e 198 que vem do perímetro rural, entre seis e quinze anos de idade. Alguns alunos que tinham distorção idade/série foram transferidos para o NAES. Na escola Alexandre de Gusmão atuam 56 professores, mas nem todos são habilitados, e a maioria é Admitido em Caráter Temporário - ACT. 
A Escola de Ensino Médio Valmir Omarques Nunes tinha 247 estudantes em 2017. Devido à recente inauguração (no ano de 2017) não se tem dados oficiais pelo IDEB (Índice de Desenvolvimento da Educação Básica), sendo que os dados de acompanhamento são estimativas da própria escola, onde o índice estimado de reprovação está em 3\%, o que deixa o índice de aprovação em torno dos 95\% a 97\%. Conta com 27 professores, sendo apenas quatro efetivos e os demais ACTs. Apenas dois professores não atuam na sua área de formação.

A faixa etária dos estudantes é de 14 a 18 anos. Tem duas grades curriculares (ensino médio convencional de primeiro ao terceiro ano e cursos técnicos em Agropecuária e Informática). A partir do ano de 2018 conta também com ensino integral, que é uma proposta do Governo Federal e tem novos cursos técnicos na área têxtil e pós-médio.

Além desses dados, a pesquisa permitiu inferir números gerais do município referentes a distorção idade/série. A Tabela 2 mostra essa distorção idade/série em todas as escolas do município.

Tabela 2 - Distorção Idade/série de estudantes de escolas públicas em 2016

\begin{tabular}{|c|c|c|c|c|c|}
\hline \multicolumn{2}{|c|}{$\begin{array}{c}\text { Anos Iniciais } \\
\left(1^{\circ} \text {. ao } 5^{\circ} \text {. Ano E. Fundamental) }\right.\end{array}$} & \multicolumn{2}{|c|}{$\begin{array}{c}\text { Anos finais } \\
\left(6^{\circ} \text { ao } 9^{\circ} \text {. Ano E. Fundamental }\right)\end{array}$} & \multicolumn{2}{|c|}{$\begin{array}{l}\text { Ensino Médlio } \\
\left(1^{\circ} \text {. ao } 3^{\circ} \text {.) }\right.\end{array}$} \\
\hline Ano & Porcentagem & Ano & Porcentagem & Ano & Porcentagem \\
\hline $1^{\circ}$ & 12 & $6^{\circ}$. & 45 & $1^{\circ}$. & 31 \\
\hline $2^{\circ}$. & 1 & $7^{\circ}$ & 41 & $2^{\circ}$. & 52 \\
\hline $3^{\circ}$. & 2 & $8^{\circ}$ & 39 & $3^{\circ}$. & 18 \\
\hline $4^{\circ}$. & 15 & $9^{\circ}$. & 27 & & \\
\hline $5^{\circ}$ & 15 & & & & \\
\hline
\end{tabular}

Fonte: Elaborado pelo autor, com dados extraídos de http://qedu.org.br (2017)

Nas entrevistas realizadas com os estudantes, ao serem indagados sobre a questão da avaliação de aulas, professores e escola, os alunos do ensino fundamental se mostraram pouco satisfeitos. Grande parte deles afirmaram que faltam aulas práticas. Já os do ensino médio confirmaram que os professores fazem o que podem 
para que as aulas sejam de excelência.

Sobre o futuro em relação a qual curso querem fazer após o ensino médio, foram apresentadas inúmeras opções. Chama a atenção um baixo índice de alunos que querem fazer cursos de licenciatura. Além disso, é expressiva a quantidade de estudantes que estão no último ano do ensino médio, mas que ainda não sabem o que querem cursar no ensino superior.

A Tabela 3 mostra os dados sobre todas as escolas do município em relação a aprovação, reprovação e desistência de estudantes.

Tabela 3 - Índice total de aproveitamento das escolas públicas do município, em 2016.

\begin{tabular}{|c|c|c|c|}
\hline \multicolumn{4}{|c|}{ Índices gerais } \\
\hline Etapa escolar & Reprovação & Abandono & Aprovaçäo \\
\hline $\begin{array}{c}\text { Anos Iniciais } \\
\text { (Ensino Fundamental) }\end{array}$ & $8,2(58)$ & $0,3(3)$ & $91,5(117)$ \\
\hline Anos Finais (Ensino Fundamental) & $28,9(168)$ & $3,2(19)$ & $67,9(134)$ \\
\hline Ensino Médio & $5,9(17)$ & $8,2(23)$ & $85,9(243)$ \\
\hline \multicolumn{4}{|c|}{ Anos Iniciais (Ensino Fundamental) } \\
\hline Anos iniciais & Reprovaçao & Abandono & Aprovaçao \\
\hline $1^{\circ}$. Ano & $1,7(3)$ & $0,0(0)$ & $98,3(243)$ \\
\hline $2^{\circ}$. Ano & $2,2(3)$ & $0,0(0)$ & $97,8(243)$ \\
\hline $3^{\circ}$. Ano & $16,6(26)$ & $0,0(0)$ & $83,4(128)$ \\
\hline $4^{\circ}$. Ano & $0,7(1)$ & $0,8(2)$ & $98,5(134)$ \\
\hline $5^{\circ}$. Ano & $16,6(27)$ & $0,6(1)$ & $82,8(131)$ \\
\hline \multicolumn{4}{|c|}{ Anos Finais (Ensino Fundamental) } \\
\hline Anos finais & $\begin{array}{l}\text { Reprovação } \\
\%\end{array}$ & $\begin{array}{c}\text { Abandono } \\
\%\end{array}$ & $\begin{array}{l}\text { Aprovaçăo } \\
\qquad \%\end{array}$ \\
\hline $6^{\circ}$. Ano & $37,3(65)$ & $3,7(7)$ & $59,0(103)$ \\
\hline $7^{\circ}$. Ano) & $34,2(56)$ & $1,9(4)$ & $1,9(4)$ \\
\hline $8^{\circ}$. Ano 22,3 & $22,3(29)$ & $3,1(5)$ & $74,6(97)$ \\
\hline $9^{\circ}$. Ano & $13,9-(14)$ & $4,9(5)$ & $81,2(79)$ \\
\hline \multicolumn{4}{|c|}{ Ensino Médio } \\
\hline Ensino Médio & Reprovaçao & Abandono & Aprovaçaco \\
\hline $1^{\circ}$. Ano & $6,6(8)$ & $13,2(15)$ & $80,2(87)$ \\
\hline $2^{\circ}$. Ano 9,1 & $9,1(4)$ & $12,1(4)$ & $78,8(27)$ \\
\hline $3^{\circ}$. Ano & $4,6(7)$ & $3,0(4)$ & $92,4(132)$ \\
\hline
\end{tabular}


Como se pode observar, há muitas reprovações nos anos finais do ensino fundamental, o que contribui para o aumento da distorção idade/série. Não se pode deixar de destacar que os índices de aprovação são bons nos anos iniciais do ensino fundamental e no ensino médio, porém nos anos finais do ensino fundamental o índice é bem baixo, deixando o município entre os cinco piores índices do estado, de acordo com sítio eletrônico do QEdu. De modo geral, como mostra a tabela 3, o índice de abandono é baixo, o que significa afirmar que são poucos estudantes com idade escolar fora da escola.

Quanto ao IDEB dos anos iniciais do ensino fundamental, Bom Retiro, em 2015, apresentou média de 5,1 na rede estadual de educação, a qual se encaixa dentro das metas estabelecidas pelo Governo Federal. Em relação aos anos finais do ensino fundamental, a média que em 2005 estava entre 4,0 e 4,9, em 2015 baixou para 3,8.

\section{RESULTADOS E DISCUSSÕES PRELIMINARES}

O resultado final da pesquisa foi um diagnóstico do território do município de Bom Retiro, porém aqui se dará ênfase aos aspectos relacionados à educação pública como elemento integrador. De acordo com os dados do Índice de Desenvolvimento da Educação Básica (IDEB), o município se manteve nos últimos anos com o índice de 5,1, conforme cálculos do fluxo escolar e com base no aprendizado em Português e Matemática.

Atualmente Bom Retiro possui um total de 14 escolas públicas, dentre estas, nove são consideradas escolas do campo, em conformidade com o Decreto Federal 7.352/2010, por estarem localizadas na área rural ou por atenderem a maior parte de estudantes que moram no interior e utilizam o transporte escolar. Todas as escolas localizadas em área rural são multisseriadas.

Fator interessante a ser destacado é que as escolas localizadas no centro do município (com exceção do colégio de ensino médio) padecem mais com a falta de estrutura do que àquelas do interior, principalmente as creches. Isto porque muitas turmas estão superlotadas, fazendo com que as salas se tornem pequenas, além de apresentarem faltas de carteiras. Este fator deve-se principalmente à ocorrência de, nos últimos anos, os anos finais do ensino fundamental estarem concentrados no centro da cidade, fazendo com que muitos estudantes se desloquem de suas comu- 
nidades para estudarem na sede municipal.

Assim, temos alguns dados sobre o quadro atual da educação de Bom Retiro (escolas, quantidade de alunos e tipografia), tendo como base a educação pública.

Na Tabela 1, chama atenção o fato de duas escolas terem três alunos, apenas, em suas equipes, número extremamente pequeno, mesmo sendo escolas do interior do município. Inevitável são as perguntas: quais são os motivos que impulsionam um número tão pequeno de estudantes nessas escolas? O que move professores e alunos a se manterem ativos com uma quantidade tão pequena de estudantes? Por que o poder local não as fechou, nucleando-as? Contraditoriamente, por outro lado, temos uma escola com 287 estudantes. O que explica essa quantidade é o processo de nucleação que vem ocorrendo nos últimos anos no território, acompanhando uma tendência estadual de fechamento de escolas do campo.

A nucleação das escolas, segundo a secretaria de educação, iniciou-se no ano de 1998, com o intuito de diminuir o grande número de escolas isoladas, a qual, na visão dos administradores locais passaram a "dar prejuízos" aos cofres públicos. Para viabilizar essa ação, foram determinados os locais onde seriam implantados os núcleos (conforme Tabela 1), de tal forma que alunos de comunidades vizinhas poderiam "facilmente" se deslocar até a escola, utilizando o transporte do município como meio. Para atender essa demanda de estudantes, o município conta com um total de 108 profissionais na área da educação, sendo eles professores, monitores e estagiários (Professores - 87; Monitores - 9; Estagiários - 12).

Além das unidades de ensino municipais, Bom Retiro conta também com duas escolas estaduais que desempenham papel fundamental dentro da educação do município. Merece destacar a quantidade de estudantes da Escola Alexandre de Gusmão, bem como seu quadro de professores. Tradicional na cidade, por longo tempo abrigou os ensinos fundamental e médio. Hoje, a função de oferecer ensino médio cabe à Escola Valmir Omarques Nunes, onde, além do ensino médio normal, também oferece cursos técnicos à comunidade regional.

Somando todas as escolas do município, o número total de alunos matriculados é de 1.943 e, para esta demanda, o total de professores é de 178. Além de professores, outros profissionais trabalham na área da educação ocupando cargos de diretores, coordenadores, merendeiras, motoristas, serviços gerais, entre outros. 
Para gerenciar a educação do município, o poder público local pode contar com convênios e verbas advindas dos dois entes (federal e estadual) e fundos voltados à educação. O município tinha, no período da pesquisa, um investimento de $\mathrm{R} \$$ $3.744 .736,73$, que ultrapassava $25 \%$ da renda total. No quadro a seguir estão listados os valores de benefícios recebidos pelo município para a educação.

Tabela 5: Valores gastos com educação de janeiro a outubro de 2017

\begin{tabular}{|c|c|}
\hline Valor FUNDEB & $\mathrm{R} \$ 2.809 .318,68$ \\
\hline Valor PNAE & $\mathrm{R} \$ 334.146,18$ \\
\hline Valor PDDE & $\mathrm{R} \$ 36.800,00$ \\
\hline Valor Salário Educação & $\mathrm{R} \$ 235.710,95$ \\
\hline Valor Transportes & $\mathrm{R} \$ 882.243,25$ \\
\hline VALOR TOTAL_APLICADO & $\mathrm{R} \$ 3.744 .736,73$ \\
\hline
\end{tabular}

Fonte: Elaborado pelo autor, com dados extraídos de Bom Retiro (2017).

Chama a atenção os gastos com o transporte escolar e o valor recebido do Fundo Nacional da Educação Básica (FUNDEB). No caso do primeiro, relatos da secretaria de educação do município corroboram dados de outros municípios de Santa Catarina, no qual a maior despesa da Educação do município provém do setor de transportes.

\section{COMENTÁRIOS SOBRE A SITUAÇÃO DA EDUCAÇÃO EM BOM RETIRO}

De acordo com a pesquisa, a educação no município de Bom Retiro vem numa melhora nos últimos anos, apesar do investimento financeiro não ser o adequado para a demanda, assim como o processo de nucleação aparentemente ter acelerado. As maiores dificuldades encontradas para se manter o nível de ensino estão na parte financeira, nos quais os valores mensais obrigatórios e via projetos que são repassados pelos governos (federal, estadual e municipal) para a educação não são suficientes para arcar com as demandas e investimentos. Segundo dados do próprio governo municipal o maior investimento/gasto é na área de transporte, já que muitos alunos são dependentes deste meio para chegar às escolas, além dos aluguéis de frota, reposição de peças, dentre outros. 
Segundo Brasil (2016), o valor mínimo aplicado em educação deve ser de $25 \%$ do orçamento da prefeitura e, de acordo com as informações da Secretaria de Educação do município, de janeiro até outubro de 2017, o valor aplicado já ultrapassava $29 \%$ do seu orçamento, chegando à cifra de quase quatro milhões de reais.

Outro fator importante que a pesquisa aponta é que há uma defasagem no quadro de professores habilitados para ministrar as disciplinas curriculares normais. Parte dos professores não é habilitada e a grande maioria é ACT. Além disso, em uma escola pesquisada, pôde-se observar que a relação aluno/professor é conturbada, e o uso de entorpecentes, no entorno da unidade escolar, é um fator que prejudica e preocupa a ainda mais esta relação.

Em relação às metodologias de ensino/aprendizagem, notou-se que alguns professores oferecem resistência aos novos métodos de ensino, mostrando, então, que o procedimento tradicional é o que prevalece. Cabe, porém, considerar que a dificuldade encontrada por esses docentes, às vezes, decorre de salas de aula lotadas, muitos alunos sem materiais, desinteressados, desestimulados e, em alguns casos, obrigados, por lei, a frequentar a escola. Estes motivos, aliados à falta de estrutura das escolas, à carga horária excessiva e à falta de materiais, acabam desmotivando os professores e contribuem para que as aulas não sejam estimulantes.

A principal reclamação dos entrevistados (professores, técnicos e alunos) foi a falta de recursos em suas escolas. Muitos deles queriam poder fazer mais pela educação, porém se deparam com essa dificuldade. Por fim, a pesquisa mostrou ser o transporte escolar a principal preocupação dos administradores públicos. Os dados colhidos com representantes da Secretaria de Educação corroboram que a municipalidade tem um gasto bem maior com transportes escolares (aluguéis, reposição de peças quebradas, manutenção de frota, dentre outros), do que manter uma escola multisseriada no interior do município. Assim, cabe refletir se não seria mais prudente e viável manter as escolas na área do campo, ao invés do processo de nucleação. Para além das questões financeiras, manter as escolas do campo significa também primar por questões culturais e pela preocupação com o bem-estar dos alunos, já que muitos ônibus usados para transportar os estudantes encontram-se em péssimas condições de trafegabilidade. 
Ao realizar essa pesquisa com estudantes do curso de Educação do Campo, polo Alfredo Wagner, constatamos que o objetivo foi cumprido, ou seja, o acadêmico pôde colocar em prática grande parte da bagagem adquirida em sala de aula, diretamente em campo de trabalho. Nesse contato inicial, um choque de realidade, faz-se necessário, pois é este o ambiente onde nossos egressos irão atuar.

Associando o trabalho desenvolvido à metodologia adotada, a partir da pedagogia da alternância, pode-se afirmar que esta pedagogia compreende uma metodologia de organização do ensino escolar para a educação do campo, que conjuga diferentes experiências formativas distribuídas ao longo de tempos e espaços distintos, tendo como finalidade uma formação profissional. Assim, o trabalho tratou de uma proposta pedagógica que procura articular diferentes espaços e tempos formativos, alternando momentos de atividade no meio sócio profissional, acadêmico, e momentos de atividade escolar propriamente dita, nos quais se focaliza o conhecimento acumulado nos tempos universidades, considerando sempre as experiências concretas dos alunos. Desse modo, como pontua Silva (2006, p. 6), "a alternância, enquanto princípio pedagógico, mais que característica de sucessões repetidas de sequências, visa a desenvolver na formação dos jovens situações em que o mundo escolar se posiciona em interação com o mundo que o rodeia".

Por último, apontamos a Educação do Campo como um modelo alternativo ao vigente, com proposições para fixação do jovem do campo em suas comunidades, mantendo uma tradição necessária, que é de áreas rurais como fornecedoras de alimentos de qualidade, além de um modo de vida peculiar e autossustentável.

\section{REFERÊNCIAS}

BOM RETIRO. Matrículas e Infraestrutura. 2017. Disponível em: <http://www qedu.org. $\mathrm{br} /$ cidade/641-bom-retiro/censo=-escolar?year2016=\&dependence $0=\&$ localization0\&education_stage $=0 \&$ item $=$. Acesso em 20/08/2018.

BRASIL. DECRETO NN 7.352. DISPÕE SOBRE A POLÍTICA DE EDUCAÇÃO DO CAMPO E O PROGRAMA NACIONAL DE EDUCAÇÃO NA REFORMA AGRÁRIA - PRONERA. Brasília, 2010. Disponível em: <https://www2. camara.leg.br/legin/fed/ decret/2010/decreto-7352-4-novembro-2010-609343-publicacaooriginal-130614-pe. html>. Acesso em 23 de ago. 2018. 
EMENDA CONSTITUCIONAL N 95. Altera o Ato das Disposições Constitucionais Transitórias, para instituir o Novo Regime Fiscal, e dá outras providências. Brasília, 2016. Disponível em: <http://www.planalto.gov.br/ccivil_03/constituicao/ emendas/emc/emc95.htm>. Acesso em 23 de ago. 2018.

HAESBAERT, R. O mito da desterritorialização: do fim dos territórios à multiterritorialidade. 3 ed. Rio de Janeiro: Bertrand Brasil, 2007.

IBGE. População Estimada. 2020. Disponível em: <https://cidades.ibge.gov.br/brasil/ sc/bom-retiro/panorama>. Acesso em 12 de fev. de 2021.

. Censo demográfico. 2010. Disponível em: <https://cidades.ibge.gov.br/brasil/ sc/bom-retiro/panorama>. Acesso em 23 de out. de 2018.

MOURA, Abdalaziz. Princípios e fundamentos da proposta educacional de apoio ao desenvolvimento sustentável-PEADS: uma proposta que revoluciona o papel da escola diante das pessoas, sociedade e do mundo - Glória de Goitacá, PE: Serviço de Tecnologia Alternativa, 2003.

SANTOS, Milton. O retorno do território. En: OSAL: Observatório Social de América Latina. Buenos Aires: CLACSO, Año 6 no. 16, 2005. ISSN 1515-3282. Disponível em: <:http://bibliotecavirtual.clacso.org.ar/ar/libros/osal/osal16/D16Santos.pdf>. Acesso em 07 de out. de 2018.

SAQUET, Marcos A. Por uma abordagem territorial das relações urbano-rurais no Sudeste paranaense. In: SPOSITO, Maria Encarnação Beltrão; WHITACKER, Arthur Magon (orgs.). Cidade e Campo: relações e contradições entre urbano e rural. São Paulo: Expressão Popular, 2006.

SILVA, M. do S. Da raiz à flor: produção pedagógica dos movimentos sociais e a escola do campo. In: MOLINA, Mônica Castagna. Educação do Campo e Pesquisa: questões para a reflexão. Brasília: Ministério do Desenvolvimento Agrário, 2006, p. 61-9.

VEIGA, José E. Cidades Imaginarias: o Brasil é menos urbano do que se calcula. Campinas, São Paulo, Editora Autores Associados, 2002.

Sítio eletrônico pesquisado:

h t t p : / / q ed u . org.br/cidade / 641 - b o m-retiro/dis tor cao-idadeserie?dependence=0\&localization=0\&stageld=initial_years\&year=2016. Acesso em 25 de out. de 2018. 


\section{EDUCACÃO ESCOLAR NO}

ASSENTAMENTO MENINO JESUS ÁGUA FRIA / BA: DESAFIOSE

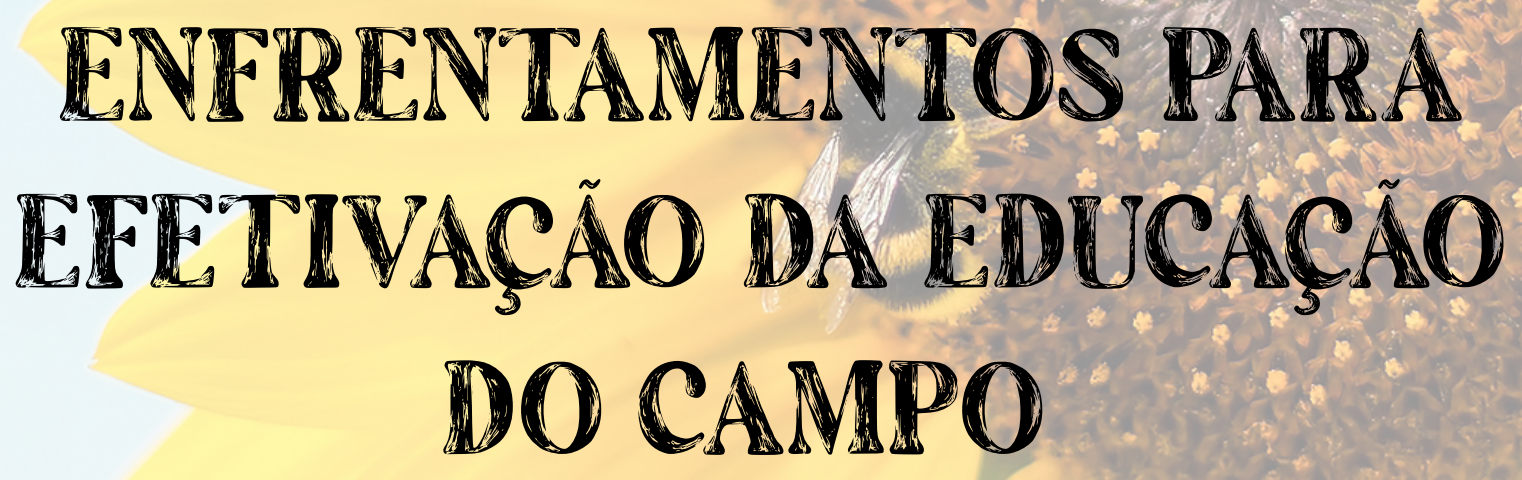

Vangilson Ferreira Bispo ${ }^{41}$

$41 \quad$ Vangilson Ferreira Bispo especialista em educação do campo pela universidade Federal de São Carlos, mestrando em Educação do Campo pela Universidade Federal do Recôncavo da Bahia. Email vangilsonmst@hotmail.com 
A educação do campo possui singularidades e especificidades particulares do seu povo, sua cultura, seus interesses e sua história, e estas precisam ser respeitadas e valorizadas. Assim, este artigo visa levantar uma discussão sucinta a partir da realidade do estudante do curso de especialização de educação do campo, no enfrentamento dos desafios para a efetivação de uma educação de qualidade valorizando a historia de luta e cultura no Assentamento Menino Jesus, situado no município de Água Fria Bahia, discutindo as concepções e as efetivações das políticas públicas ou estatais. Para melhor organizarmos a discussão iremos dividir da seguinte forma: histórico do Assentamento Menino Jesus; desafios enfrentados no período de acampamento; análise da situação educacional, especificamente, da Escola municipal Fabio Henrique de Cerqueira, as concepções de educação do campo, buscando estabelecer uma diferenciação da Educação do Campo e no campo, e as políticas públicas efetivadas. Para que haja melhor embasamento das discussões irei trazer alguns autores para dialogar com os assuntos que proponho discutir tais como: Rosili Salete Caldart, Claudemiro Godoy do Nascimento, Maria do Socorro Pinheiro entre outros.

\section{1- O ASSENTAMENTO MENINO JESUS}

A história da comunidade Menino Jesus, foi iniciada no dia 20 de dezembro de 1998, quando 120 famílias vinda das cidades circunvizinhas ocuparam a fazenda Paracatu, antiga fábrica de artefatos de sisal falida há 12 anos. $O$ assentamento Menino Jesus localiza-se no município de Água Fria, aproximadamente a $160 \mathrm{~km}$ de Salvador. Possui uma área de 13009 hectares de terra, chegou a ter 500 famílias no período de acampamento (época em que ainda não havia o reconhecimento pelo Instituto Nacional de Colonização e Reforma Agrária (INCRA)). Após a avaliação e desapropriação da terra feita pelo INCRA em 2003, foi assentado 185 famílias neste momento, sendo que a área tem capacidade para assentar 212 famílias, ficando cada assentado com uma média de 40 hectares para o lote de produção e 0,36 hectares para construção da casa na agrovila. 
O Assentamento está estruturado em uma agrovila com aproximadamente 212 casas, construídas a margem da Avenida Brasil, via que corta o assentamento, sendo o acesso principal e outras construídas em ruas secundarias. A velha estrutura da fazenda foi muito utilizada pelos assentados como sede da associação, salão de festas, posto de saúde, escola, almoxarifado, salão de atividades culturais entre outros. O assentamento possui setores específicos (Produção, Educação, Saúde, Juventude, Frente de massa, gênero entre outros), seguindo a mesma linha do MST responsável pela organização do assentamento juntamente como a Associação e os coordenadores de núcleos.

Atualmente o assentamento Menino Jesus possui uma escola com seis salas de aula construída pelo poder publico estadual porem é utilizada também pelos alunos matriculados na rede publica municipal. Isso depois de muitos enfrentamentos para liberação desse espaço pois, o mesmo foi conquistado através de muitas lutas e mobilizações pelas famílias da comunidade. O prédio funciona duas escolas: $O$ Colégio Estadual do Campo Menino Jesus e a Escola Municipal Fabio Henrique de Cerqueira. A gestão é compartilhada e existe um diretor pelo estado e outro pelo município onde o mesmo é assentado e residente na comunidade. Os professores da escola municipal são todos da cidade e não tem vínculo nenhum com a luta do MST e nem com a Educação do Campo. Há grande dificuldade em trabalhar as especificidades da escola do campo geralmente trazem os mesmos métodos e conteúdos trabalhados na cidade.

\section{1 - A EDUCAÇÃO NO ASSENTAMENTO MENINO JESUS}

A Escola municipal Fabio Henrique de Cerqueira, está localizada no Assentamento Menino Jesus, município de Água Fria/ Ba. A mesma iniciou suas atividades no ano de 1999 quando começou a luta do Movimento dos trabalhadores rurais sem terra pela desapropriação da fazenda Paracatu, antiga fábrica de artefato de sisal e celulose. Logo após a ocupação da área, no início do ano subsequente, a direção do movimento se preocupou em articular as aulas para as crianças e adolescentes em idade escolar participante do acampamento. Foi quando a direção do MST marcou uma reunião com o atual prefeito do município de Água Fria, o Sr. Balbino Leão de 
Almeida, e o secretário de educação, Sr. Fernando Cunha, para discutir a questão da educação das crianças sem-terra, que estavam no acampamento. Porém os mesmos não aceitaram abrir escola para atender essa demanda, alegando que não haveria uma garantia destas famílias permanecerem na área. Mesmo sem aceitação do poder público municipal, a escola foi criada com duas turmas multisseriadas, tendo como professores voluntários Vangilson Bispo e Eliana Silva.

Durante este período, a direção do movimento continuou insistindo e revindicando juntamente com as famílias a abertura da escola e efetivação das turmas. Diante de muita luta, vinculou-se os estudantes à escola municipal Everaldo Pinheiro dos Reis localizada na Fazenda Serrado no município de Água Fria. A direção desta escola ficou por conta de uma diretora que administrava varias escolas pequenas no distrito de Paraíba. Nesse período houve um aumento significativo de educando, devido a chegada de muitas famílias no acampamento, e nessa mesma medida foi aparecendo professores formados para acampar e se ingressava na educação para dar conta da demanda da escola.

Em 2005 foi aprovada na câmara de vereadores a mudança do nome da escola para Escola Municipal Fabio Henrique de Cerqueira, nome este discutido na comunidade e aprovada por maioria por ser um militante do MST que lutava por educação de qualidade para as famílias sem-terra. A partir desse momento foi nomeado um professor assentado para a direção da Escola o qual trabalhava com toda equipe de professores e agentes públicos participante do MST. Houve um longo período em que os serviços de limpeza e merenda da escola seriam realizados por pais voluntários bem como a ciranda infantil que desde o início das atividades da escola vinha acontecendo. O poder público não dava a assistência necessária para o bom funcionamento da escola. As aulas funcionavam em casas velhas da antiga fazenda na maioria das vezes deteriorada, sem banheiro adequado, telhado, piso e portas estragadas, quadro de giz e cadeiras velhas que já haviam sido usadas por outras escolas. Diante de todas essas dificuldades enfrentadas, o MST sempre fazia reivindicação da construção de uma escola de qualidade ao poder público municipal e estadual, porem sempre negada pelos órgãos públicos. Somente em 2009 foi aprovado o projeto da escola pelo poder público estadual e finalmente a obra foi concluída 
em novembro de 2010. Apesar da conclusão das obras, chegou o período de iniciar o ano letivo 2011, e ainda não havia sido inaugurado o prédio da escola. Dessa forma a comunidade se uniu e discutiu que deveria ocupar a escola devido a precariedade dos espaços que estavam sendo utilizados como salas de aula. Educadores, pais e educandos entraram para escola, iniciaram o desenvolvimento das atividades do ano letivo e continuam até os dias atuais sem a inauguração.

Em 2008 aconteceu um concurso público no município para professores com vagas exclusivas para a escola municipal Fabio Henrique de Cerqueira, sendo que nenhum dos educadores do assentamento ficou entre as vagas, devido a uma falha na comunicação sobre a prova de título. A partir de 2009, houve grandes mudanças na educação escolar dos educandos da escola municipal Fabio Henrique de Cerqueira, com a chegada dos novos professores vindos da cidade e a saída dos professores do assentamento, os quais conheciam e viviam toda realidade dos educandos. No período em que o quadro de professores da escola era composto por participante do MST, havia a participação dos encontros de formação promovidos pelo setor de educação do Movimento, e isso colaborava na implementação da pedagogia do movimento sem-terra, baseado no método de Paulo Freire, trabalhando e valorizando a realidade dos educandos. Dessa forma, havia o canto do hino, músicas do movimento sem-terra, apresentação de mística, trabalhava-se os símbolos do movimento, participavam do concurso de arte e desenho promovido pelo setor de educação, participação da horta escolar entre outras atividades. As crianças da escola participaram de diversos encontros dos sem terrinha a nível estadual, regional e de brigada. Havia uma sintonia entre a escola, comunidade e movimento sem-terra. A partir do momento em que os educadores da cidade chegaram a escola se tornou uma extensão da educação da cidade, porque não houve mais um trabalho voltado para realidade dos educandos, e os professores não tinham nenhum interesse em participar de nenhuma atividade ligado ao movimento sem-terra principalmente se ocorresse fora do seu turno de trabalho.

Outra dificuldade que a escola enfrenta é a rotatividade de professores que acontece quase todos os anos, que acabava dificultando o trabalho de formação dos educadores e estudantes. A coordenação pedagógica da escola passou a ser com- 
partilhada com outras do município, deixando de lado as especificidades da comunidade. Atualmente a escola funciona atendendo da ciranda infantil ao fundamental I, com 120 educandos matriculados, 5 professores de 20 horas, um diretor (núcleo), um vice diretor, um secretário, um porteiro, 3 agentes públicos e uma ajudante de ciranda. A escola trabalha com os programas Mais Educação nas modalidades de canteiro sustentável, letramento, capoeira e esporte escolar. Tem ainda o programa mais cultura na modalidade de samba de roda, e tem a parceria com o Pibid Diversidade com os estudantes do curso de Licenciatura em Educação do Campo da Universidade do Estado da Bahia (Uneb) de Itaberaba onde são desenvolvidas oficinas ligadas a leituras, escrita, matemática e arte.

\section{3- CONCEPÇÃO DE EDUCAÇÃO DO CAMPO OU NO CAMPO}

A concepção de educação do campo surge e ganha força através dos movimentos sociais camponeses que vem discutindo e implementando uma educação voltada para os interesses da classe trabalhadora do campo onde possa ser valorizado o meio e as formas de vivência deste povo. De acordo com Molina (2012),

O movimento histórico de construção da concepção de escola do campo faz parte do mesmo movimento de construção de um projeto de campo e de sociedade pelas forças sociais da classe trabalhadora, mobilizadas no momento atual na disputa contra-hegemônica( Molina, 2012, p 324).

A Educação no Brasil sempre foi direcionada a determinada camada da sociedade (que é a camada economicamente dominante) e o homem do campo, nunca foi prioridade para os governantes no que se refere a escolarização, como afirma Pinheiro, no seu artigo que discute concepção de educação do campo:

“... é pertinente ressaltar que a concepção de educação que vem sendo empregada pela cultura dominante e elitista, não tem favorecido satisfatoriamente para combater o analfabetismo, elevar a escolaridade dos sujeitos, sua cultura e seu padrão de vida".

Portanto está claro que não é prioridade para a elite dominante que está a frente da Educação resolver o problema do analfabetismo no Brasil nem tão pouco elevar o nível de escolaridade da classe trabalhadora principalmente do povo do campo. 
Para que haja uma escola no Campo, os movimentos sociais tem se organizado e lutado muito na defesa de uma educação de qualidade voltado para a realidade dos sujeitos que ali atua. De acordo com Caldart:

O MST, como organização social de massas, decidiu, pressionado pela mobilização das famílias e das professoras, tomar para si ou assumir a tarefa de organizar e articular por dentro de sua organicidade esta mobilização, produzir uma proposta pedagógica específica para as escolas conquistadas, e formar educadoras e educadores capazes de trabalhar nesta perspectiva (Caldart, 2003, p. 03).

Dessa forma o movimento social através de muitos esforços e experiências acumuladas ao logo dos anos, criou sua própria pedagogia para direcionar os trabaIhos dos educadores que é a "Pedagogia do Movimento Sem Terra". De acordo com Caldart:

\begin{abstract}
A Pedagogia do Movimento, enquanto reflexão específica sobre as matrizes pedagógicas postas em movimento na formação dos Sem Terra, e ao tratar em formação como um processo educativo, expressa e reafirma uma concepção de educação, de formação humana, que não é hegemônica na historia do pensamento ou das teorias sobre educação: trata-se de uma concepção de base histórico-materialista-dialética para a qual é preciso considerar centralmente as condições de existência social em que cada ser humano se forma: a produção da existência e a produção ou formação do ser humano são inseparáveis, ou seja, as pessoas se formam pela inserção em um determinado meio, sua materialidade, atualidade, cultura, natureza e sociedade, fundamentalmente através do trabalho que lhe permite a reprodução da vida e é a característica distintiva do gênero humano, é a própria vida humana na sua relação com a natureza, na construção do mundo (Caldart, 2011, p. 65).
\end{abstract}

Atualmente já é percebível algumas conquistas, e uma das importantes na luta dos movimentos sociais pela construção desta concepção de escola do campo foi o seu reconhecimento em marcos legais, o que se deu somente após muitos anos de experiências e práticas concretas de Educação do campo (Molina, 2012). Podemos citar um dos marcos mais importante foram as Diretrizes operacionais para educação básica das escolas do campo de abril de 2002.

Com essa legislação em vigor é possível debater e exigi que o poder público tenha um olhar diferenciado para um povo que historicamente foi desprovido de certos conhecimentos para além de podermos implementar uma educação diferenciada. 
Afirma Andréa (2011, p 87) "os fazeres docentes, assim como as práticas familiares e as demais relações sociais estabelecidas, não estão descolados de uma realidade social e cultural que os conformam".

Para Nascimento a educação básica do campo possui três características fundamentais: é um projeto político-pedagógico da sociedade civil que busca intervir nos fundamentos da educação brasileira; é um projeto popular alternativo para o Brasil e um projeto popular de desenvolvimento para a realidade campesina. Baseado ainda nessas características Nascimento ainda afirma que a concepção de escola do campo procura defender os interesses, a política, a cultura e a economia da agricultura camponesa.

\section{4- AS POLÍtICAS PÚBLICAS EDUCACIONAIS DE EDUCAÇÃO DO}

A Educação do Campo tem sido uma das maiores política pública para a classe trabalhadora no meio rural, onde através de alguns programas tais como: Pro-Jovem Campo - Saberes da Terra escolarizou milhares de jovens agricultores/as familiares em nível fundamental na modalidade de Educação de Jovens e Adultos (EJA), integrado à qualificação social, profissional em Agricultura Familiar e Sustentabilidade em diversas regiões do Brasil. De acordo com Nascimento o curso é organizado assim:

A execução da proposta pedagógica e curricular acontece por meio da realização de atividades educativas em diferentes tempo e espaços formativos. Os jovens iniciam a escolarização pelo "Tempo Escola" que corresponde ao período no qual os jovens permanecem efetivamente na unidade escolar com atribuições de aprendizagens sobre os saberes técnico científicos dos eixos temáticos, planejamento e execução de pesquisas, atividades de acolhimento e organização grupal, entre outras atividades pedagógicas. Outro momento de organização do tempo e espaço formativo do Programa é o "Tempo Comunidade" correspondente ao período no qual os educandos realizam pesquisas, estudos e experimentações técnico-pedagógicas nas comunidades, com o objetivo de partilharem seus conhecimentos e suas experiências adquiridas na escola com as famílias ou instâncias de organização social.

Esse programa teve seus avanços no que se refere a escolaridade e oportunidade aos jovens continuar seus estudos, principalmente porque a metodologia da 
alternância facilitava o acesso de muitos jovens. Uma das dificuldades enfrentada na escola que participo era falta de material, falta de alguns educadores e atraso no pagamento.

Outro programa ligado às políticas de educação do campo importante é o Programa de Apoio à Formação Superior em Licenciatura em Educação do Campo Procampo. Segundo Nascimento:

É uma iniciativa do Ministério da Educação, por intermédio da Secretaria de Educação Continuada, Alfabetização e Diversidade (SECAD), em cumprimento às suas atribuições de responder pela formulação de políticas públicas de combate às desvantagens educacionais históricas sofridas pelas populações rurais e valorização da diversidade nas políticas educacionais.

Esse programa tem como objetivo apoiar a implementação de cursos regulares de Licenciatura em Educação do Campo nas Instituições Públicas de Ensino Superior de todo o país, voltados especificamente para a formação de educadores para a docência nos anos finais do ensino fundamental e ensino médio nas escolas rurais. Sua principal missão é promover a formação superior dos professores em exercício na rede pública das escolas do campo e de educadores que atuam em experiências alternativas em educação do campo (Nascimento).

Esse programa tem beneficiado milhares de jovens do campo de diversos movimentos sociais inclusive do Assentamento Menino Jesus onde 07 assentados e filhos de assentados estão concluindo esse curso acima citado, pela Universidade do Estado da Bahia (UNEB) campos de Itaberaba. Uma preocupação que já existe com esses jovens, é a forma que será inserida nas escolas porque geralmente muitos são capacitados, mas não tem a oportunidade de atuar em suas comunidades devido as contratações serem através de concursos púbicos.

A política púbica que engloba todos os programas ligados a Educação do Campo é, o Programa Nacional de Educação da Reforma Agrária (PRONERA) que tem como concepção a educação do campo como um direito de todos e se realiza por diferentes territórios e práticas sociais que incorporam a diversidade do campo. É, ainda, uma garantia para ampliar as possibilidades de criação e recriação de condições de existência da agricultura familiar/camponesa. Portanto, o PRONERA quer fortalecer o mundo rural como território de vida em todas as suas dimensões: econômicas, 
sociais, ambientais, políticas e éticas (Nascimento). Nascimento afirma ainda que:

O PRONERA realiza práticas e reflexões teóricas da Educação do Campo, tendo como fundamento a formação humana como condição primordial, e como princípio a possibilidade de todos e todas serem protagonistas da sua história, criando novas possibilidades para descobrir e reinventar, democraticamente, relações solidárias e responsáveis no processo de reorganização socioterritorial em que vivem.

É nesse sentido que muitos jovens e adultos estão sendo formado em diversos cursos espalhados pelo Brasil em diversas áreas do conhecimento. O assentamento Menino Jesus já tem pessoas que foram beneficiadas nos cursos de Direito, Agronomia, Pedagogia, Letras e cursos técnicos em Agropecuária e Gestão.

As políticas de Educação do campo vêm sendo implementadas no país no tocante à formação dos camponeses. Porém, ainda há um limite no que se refere a garantia da atuação desses profissionais nas suas comunidades para que possa implementar a aprendizagem que adquiriu com os cursos que the foi oferecido.

Os educadores que trabalham no município de Água Fria, grande parte vem das cidades circunvizinhas de outra realidade, portanto não se importa com a realidade do município, e nem das especificidades das comunidades como garante a LDB no seu artigo 28. Enquanto isso muitos filhos dos trabalhadores do assentamento Menino Jesus estão qualificados e não consegue ser contratado para trabalhar na escola.

Um dos grandes problemas enfrentado na Escola Municipal Fabio Henrique são os conteúdos iguais os da cidade, os professores despreparados pra lhe dar com o púbico da reforma agrária, a falta dos professores, o atraso do transporte que conduz os professores, a não valorização da luta do MST entre outros. É preciso que os movimentos sociais continuem a luta de novas turmas pelo PRONERA, mas também que intensifique a luta para garantir os profissionais formados exercendo suas funções nas suas comunidades de origem.

\section{CONSIDERAÇOES FINAIS}

Na medida em que foi sendo discutida a educação de maneira geral foi observado que já houve grandes mudanças na educação escolar do Assentamento Menino Jesus. Uma das questões bem visíveis é o espaço físico que antigamente eram espaços improvisados e atualmente tem seu próprio prédio. O ensino aprendizagem 
também mudou porque antes quando os professores eram moradoras da comunidade conseguiam discutir melhor as questões especificas da melhoria da comunidade além de participarem das atividades promovidas pelo MST no intuito de conquistar mais benefício para as pessoas residentes no assentamento Menino Jesus. Com o quadro de professores atual está muito difícil discutir as questões relacionadas com o luta dos trabalhadores e da educação do campo. Os educadores não tem disponibilidade para participar dos cursos de formação promovido pelo setor de educação local ou estadual do MST. As pessoas que já se capacitaram através dos cursos formais ou não formais promovidos pelo MST ligados a política do PRONERA muitas vezes ainda não tiveram oportunidade pra colocar seus conhecimentos em pratica devido às burocracias do estado no que se refere aos concursos públicos. Ainda há uma grande distância entre o que o movimento social prega na questão de formação para seu povo especialmente os estudantes de suas escolas e o que é ofertado pelo poder púbico municipal. Na verdade, o Secretaria de educação do município não respeita a Lei de Diretrizes e Base que no seu artigo 28 garante adaptação às peculiaridades da vida rural e de cada região.

Já houve várias tentativas de implementação do art. 28 da LDB no que se refere aos conteúdos curriculares, as metodologias apropriadas, organização escolar própria incluindo adequação do calendário e outras especificidades, mas sempre houve resistência pela secretaria municipal de educação de Água Fria.

\section{REFERÊENCIAS}

CALDART, Rosili Salete; Fetzner ... et al. Caminhos para transformação da escola: reflexões desde praticas da licenciatura em educação do campo. 1 ed. São Paulo Expressão Popular 2011. 248 p.

CALDART, Rosili Salete; PEREIRA, Isabel Brasil et al. Dicionário da Educação do Campo. 2. Ed. Rio de Janeiro, são Paulo; Escola Politécnica de Saúde Joaquim Venâncio, Expressão Popular, 2012.

CALDART, Roseli Salete A ESCOLA DO CAMPO EM MOVIMENTO. Currículo sem Fronteiras, v.3, n.1, pp.60-81, Jan/Jun 2003 http://www.ia.ufrrj.br/ppgea/conteudo/conteudo-2009-1/Educacao-MII/3SF/A_ESCOLA_DO_CAMPO_EM_MOVIMENTO.pdf Acessado em 30/06/2016 
NASCIMENTO, Claudemiro Godoy do. POLÍTICAS "PÚBLICAS" E EDUCAÇÃO DO CAMPO: EM BUSCA DA CIDADANIA POSSÍVEL? Acessado em 20/06/2016: http:// www.unioeste.br/prppg/mestrados/letras/revistas/travessias/ed_007/EDUCACAO/ Pol\%C3\%ADticas\%20p\%C3\%BAblicas.pdf

PINHEIRO, Maria do Socorro Dias. A concepção de educação do campo no cenário das políticas públicas da sociedade brasileira. http://www.anpae.org.br/congressos antigos/simposio2007/289.pdf. Acessado em 19/06/2016.

Lei de Diretrizes e Base. Acessado 20/06/2016 https://www2.senado.leg.br/bdsf/bitstream/handle/id/70320/65.pdf?sequence $=3$ 


\section{FECHAMENTO DE ESCOLAS NO/DO CAMPO, TERRITORIALIDADE,}

\section{GESTÃO DEMOCRÁTICA E (AUTO) EDUCAÇA DOS POVOS DO CAMPO}

Cláudio Rodrigues da Silva ${ }^{42}$ 
Neste capítulo apresentam-se problematizações acerca da questão da política de fechamento de escolas no/do ${ }^{43}$ campo e implicações para a gestão democrática do ensino público e para a (auto)educação dos povos do campo.

A Educação do Campo é uma modalidade da educação escolar brasileira, que visa propiciar uma educação contextualizada aos povos do campo (BRASIL, 1996; 2002).

A conquista da Educação do Campo foi decorrência principalmente de demandas e mobilizações desses povos, por intermédio de suas organizações, visando garantir uma educação escolar que atenda às suas especificidades políticas, econômicas e culturais. Destaca-se que esses povos foram historicamente preteridos pelo Estado brasileiro, em termos de políticas de educação escolar (FOLMER; MEURER, 2019; MORAES, 2019; SANTOS; PALUDO, 2020).

A década de 1990 configura-se como um marco em termos de mobilizações e ações de variadas ordens, que resultaram, posteriormente, na conquista da Educação do Campo como uma política educacional no Brasil. No entanto, em contraposição a essa conquista legal, nessa mesma conjuntura passa a se intensificar uma política de fechamento de escolas no/do campo. Essa política tem diversos impactos negativos diretos e indiretos para o direito à educação escolar dos povos do campo (FOLMER; MEURER, 2019; TAFFAREL; MUNARIM, 2015).

Assim, tem-se por objetivo, neste capítulo, apresentar problematização sobre a inter-relação entre fechamento de escolas no/do campo, a territorialidade, gestão democrática e a (auto)educação dos povos do campo. Argumenta-se que essa política impacta negativamente na questão da territorialidade e da gestão democrática do ensino público, o que, por sua vez, pode inviabilizar avanços na implementação ou na execução de projetos de (auto)educação dos povos do campo em conformidade com suas especificidades políticas, econômicas e culturais.

$43 \quad$ Nem toda escola instalada no campo é uma escola do campo, na acepção crítica de Educação do Campo, porém, uma escola do campo precisa, necessariamente, ser instalada no campo. Educação para, no ou do campo é uma temática que gera polêmicas entre diversos setores da sociedade brasileira, inclusive no âmbito acadêmico (BEZERRA NETO, 2016; CALDART, 2012; CASSIN; NALLI, 2016; MORAES, 2019). 
Trata-se de uma temática relevante e atual, uma vez que essa política tem diversas implicações - diretas e indiretas, imediatas e mediatas, individuais e coletivas - para o direito à educação escolar dos povos do campo. Além disso, a educação (a ser) propiciada aos povos do campo é um tema debatido tanto da perspectiva do tempo presente quanto da perspectiva do tempo passado, em âmbitos nacional e internacional (CELESTE FILHO, 2020; MORAES, 2019).

Para a realização deste estudo, documental e bibliográfico, analisaram-se documentos oficiais do governo federal brasileiro relacionados ao tema em tela, à luz de bibliografias atinentes às temáticas do fechamento de escolas no/do campo, da Educação do Campo, da educação em movimentos sociais e da gestão democrática.

\section{FECHAMENTO DE ESCOLAS NO/DO CAMPO}

Educação do Campo, por conseguinte, escola do campo, implica uma educação contextualizada, conforme as especificidades políticas, econômicas e culturais dos povos do campo. As Diretrizes Curriculares Nacionais da Educação Básica (DCNs) (BRASIL, 2013, p. 225) possibilitam compreender o entendimento oficial acerca dos povos do campo:

$O$ [...] Decreto $n^{\circ} 7.352 / 2010$ [...] Dá um entendimento abrangente ao conceito de populações do campo, diversificadamente constituídas pelos agricultores familiares, extrativistas, pescadores artesanais, ribeirinhos, assentados e acampados da reforma agrária, trabalhadores assalariados rurais, quilombolas, caiçaras, povos da floresta, caboclos e outros que produzam suas condições materiais de existência a partir do trabalho no meio rural.

Portanto, povos do campo é uma categoria ampla, que abrange vários povos com singularidades diversas, porém, com uma característica comum, qual seja, vivem no e do campo.

Conforme as DCNs (BRASIL, 2013, p. 125), "[...] a Educação do Campo, tratada como educação rural na legislação brasileira, incorpora os espaços da floresta, da pecuária, das minas e da agricultura e se estende também aos espaços pesqueiros, caiçaras, ribeirinhos e extrativistas [...]". 
No entendimento de Caldart (2012, p. 259, grifos da autora),

A Educação do Campo nomeia um fenômeno da realidade brasileira atual, protagonizado pelos trabalhadores do campo e suas organizações, que visa incidir sobre a política de educação desde os interesses sociais das comunidades camponesas. Objetivo e sujeitos a remetem às questões do trabalho, da cultura, do conhecimento e das lutas sociais dos camponeses e ao embate (de classe) entre projetos de campo e entre lógicas de agricultura que têm implicações no projeto de país e de sociedade e nas concepções de política pública, de educação e de formação humana.

A Lei no 12.960, de 2014 (BRASIL, 2014b), que altera a LDBEN (BRASIL, 1996), determina critérios básicos para o fechamento de escolas no/do campo:

O fechamento de escolas do campo, indígenas e quilombolas será precedido de manifestação do órgão normativo do respectivo sistema de ensino, que considerará a justificativa apresentada pela Secretaria de Educação, a análise do diagnóstico do impacto da ação e a manifestação da comunidade escolar.

Taffarel e Munarim (2015, p. 47), fazendo referência a essa lei, apontam que ela foi instituída "[...] em 27 de março do mesmo ano [2014] para coibir esse ato [de fechamento de escolas] autoritário, abusivo, discricionário e, por fim, criminoso, que vem sendo praticado por autoridades educacionais em quase todos os estados e municípios brasileiros." Ainda segundo esses autores,

Essa lei foi conquistada pelo Movimento Nacional de Educação do Campo, com o mote 'Fechar Escola é Crime', e contrariou os interesses de gestores locais de educação (estados e municípios). Em geral, esses gestores contrariados, como quem faz de conta que não sabe da lei, continuam com a mesma prática. E é regra também não cumprirem a lei e dizerem que não o fazem por pura incapacidade orçamentária, visto que o custo/aluno/qualidade das escolas do campo é mais alto que a média. E na sequência muitos tentam convencer o interlocutor - do Movimento Social, quando o diálogo ocorre - de que a culpa do crime praticado é do sistema federativo, que impõe aos governos locais as obrigações sem a devida cobertura orçamentária. (TAFFAREL; MUNARIM, 2015, p. 48)

Não obstantes os critérios estabelecidos pela LDBEN, fechamentos de escolas continuam a ocorrer em diferentes pontos do território brasileiro. Porém, registram-se diversas iniciativas de resistências, levadas a termo por movimentos sociais de povos do campo contrários a essa política (FOLMER; MEURER, 2019; TAFFAREL; 
MUNARIM, 2015; TORRES; SILVA; MORAES, 2015).

Ainda que implementada de forma, em tese, pontual e dispersa, ao se considerar os dados gerais referentes a essa política, constata-se expressiva quantidade de escolas no/do campo fechadas em diferentes localidades do território nacional. Segundo Taffarel e Munarim (2015, p. 46), "[...] os dados do Censo Escolar Inep/MEC, assim como os dados do II PNERA [...] demonstram que ao longo da última década, o número de escolas do campo brasileiras fechadas é enorme. As escolas foram reduzidas em $31,46 \%$, ou seja, 32.512 unidades foram fechadas." Esses autores destacam, ainda, que "A última lista divulgada pelo MEC (INEP) aponta que 4.084 escolas municipais e estaduais foram fechadas no decorrer de 2014, quase absolutamente todas no campo." (TAFFAREL; MUNARIM, 2015, p. 47).

A política de fechamento de escolas no/do campo está relacionada a diversos fatores, principalmente econômicos, que envolvem os âmbitos internacional, nacional, estadual e municipal. Tanto esses fatores quanto esses âmbitos são, em alguma medida e em determinados casos, imbricados entre si. Essa política, como apontado, gera vários impactos negativos para o direito à educação escolar dos povos do campo (MARTINS, 2004; TORRES; SILVA; MORAES, 2014, SILVA; MORAES; TORRES, $2015)^{44}$.

Além dos desdobramentos mencionados por esses e por outros autores, a política de fechamento pode ter outros impactos, como, por exemplo, na territorialidade e na gestão democrática das escolas públicas no/do campo.

\section{TERRITORIALIDADE}

A LDBEN, no artigo 28, reconhece as especificidades educativas dos povos do campo e determina que devem ser garantidas adequações da organização e do funcionamento da escola do campo às especificidades desses povos:

Na oferta de educação básica para a população rural, os sistemas de ensino promoverão as adaptações necessárias à sua adequação às peculiaridades da vida rural e de cada região, especialmente:

I - conteúdos curriculares e metodologias apropriadas às reais necessidades e interesses dos alunos da zona rural;

$44 \quad$ Esses e outros autores mencionados neste capítulo detalham vários desses impactos em seus textos. 
II - organização escolar própria, incluindo adequação do calendário escolar às fases do ciclo agrícola e às condições climáticas;

III - adequação à natureza do trabalho na zona rural. (BRASIL, 1996)

O Estatuto da Criança e do Adolescente, no artigo 53, determina que "A criança e o adolescente têm direito à educação [...]" e ao "[...] acesso à escola pública e gratuita, próxima de sua residência [...]" (BRASIL, 1990).

No que se refere ao território, as DCNs, tratando da Educação Quilombola, apontam que "[...] é no território que as clivagens culturais e sociais, dadas pela geografia e pela história, se estabelecem e se reproduzem; e é na perspectiva do desenvolvimento que se visualizam e se constituem as interfaces entre a educação e outras áreas de atuação do Estado." (BRASIL, 2013, p. 233).

No que tange à escola do campo, segundo as Diretrizes Operacionais para a Educação Básica nas Escolas do Campo, artigo 2², parágrafo único,

A identidade da escola do campo é definida pela sua vinculação às questões inerentes à sua realidade, ancorando-se na temporalidade e saberes próprios dos estudantes, na memória coletiva que sinaliza futuros, na rede de ciência e tecnologia disponível na sociedade e nos movimentos sociais em defesa de projetos que associem as soluções exigidas por essas questões à qualidade social da vida coletiva no país. (BRASIL, 2013)

Sem pretensão de esgotar essa temática, constata-se que a legislação federal brasileira reconhece e, no plano formal, assegura um conjunto de direitos aos povos do campo, direitos esses que remetem à questão do território e da territorialidade.

Na concepção de Zibechi (2003, p. 3), “El território es el espacio en el que se construye colectivamente una nueva organización social, donde los nuevos sujetos se instituyen, instituyendo su espacio, apropiándoselo material y simbolicamente."

Considerando-se apontamentos de Fernandes (2012), inserem-se também nos debates acerca do território os assentamentos e acampamentos da reforma agrária, dentre outros. Conforme Fernandes (2012, p. 749), “[...] território camponês é um conceito importante para entender a sua existência. Inseparáveis, são destruídos e recriados pela expansão capitalista, mas também se fazem na secular luta pela terra, na qual o camponês luta para ser ele mesmo." Dessa forma, segundo esse autor, 
[...] o território camponês é uma unidade espacial, mas também é o desdobramento dessa unidade, caracterizada pelo modo de uso desse espaço que chamamos de território, por causa de uma questão essencial que é a razão de sua existência. A unidade espacial se transforma em território camponês quando compreendemos que a relação social que constrói esse espaço é o trabalho familiar, associativo, comunitário, cooperativo, para o qual a reprodução da família e da comunidade é fundamental. A prática dessa relação social assegura a existência do território camponês, que, por sua vez, promove a reprodução dessa relação social. Essas relações sociais e seus territórios são construídos e produzidos, mediante a resistência, por uma infinidade de culturas camponesas em todo o mundo, num processo de enfrentamento permanente com as relações capitalistas. (FERNANDES, 2012, p. 746, grifos do autor)

O território enseja a questão da territorialidade. Considerando-se apontamentos das DCNs (BRASIL, 2013, p. 438), “[...] a territorialidade é um princípio fundamental. Não se trata de segregação e isolamento. A terra é muito mais do que possibilidade de fixação; antes, é condição para a existência do grupo e de continuidade de suas referências simbólicas [...]."

Folmer e Meurer (2019, p. 25) apontam que a territorialidade "[...] vem a somar em um conjunto de relações que se estabelece diante de um sistema que integra três dimensões: Sociedade, Espaço e Tempo, onde se busca a implantação da autonomia de um sistema."

Assim, no caso dos povos do campo, há que se considerar as inter-relações necessárias entre a territorialidade, o território e a terra, que se configura como fator-chave dessa tríade.

Por um lado, houve avanços, em termos de reconhecimento do direito ao território e a uma educação contextualizada. Porém, por outro lado, a política de fechamento de escolas afeta essas conquistas.

Apontamentos de Cassin e Nalli (2016, p. 367) contribuem para exemplificar alguns desafios enfrentados por povos do campo de determinadas localidades:

[...] a população assentada do Mário Lago se depara, ainda hoje, com problemas de transporte, na manutenção dos ônibus, na conservação das vias no interior do assentamento, no tempo de deslocamento das crianças de suas casas à escola, na dispersão das crianças assentadas atendidas em cinco escolas diferentes, na resistência das crianças dos bairros em aceitar as assentadas, a dificuldade dos pais em atender aos chamados das escolas e na participação desses e das crianças nas atividades escolares fora do horário de aula. 
Com base nos apontamentos apresentados, considera-se que o fechamento de escolas no/do campo e, por conseguinte, a transferência dos seus estudantes para escolas em áreas urbanas ou para outras escolas no/do campo, porém, em comunidades distantes de suas residências, resulta em deslocamentos diários, não raramente envolvendo trajetos longos e demorados, o que implica, em determinados casos, para além dos desdobramentos enunciados, desterritorialização desses estudantes, ainda que em tempo parcial (MARTINS, 2004; SILVA; MORAES; TORRES, $2015)^{45}$.

Apontamentos de Folmer e Meurer (2019, p. 26-27) contribuem para a compreensão de impactos da desterritorialização, bem como da problematização realizada neste texto: "[...] a desterritorialização significa o desarraigamento de povos, atividades sociais e econômicas que envolvem a comunidade, significando uma perda de cultura que outrora estava ligado àquele espaço."

Por isso considera-se que ocorre a desterritorialização, pois estudantes são deslocados dos respectivos territórios e enviados a outros territórios, fenômeno que tem implicações políticas, econômicas e culturais, não só para esses estudantes, mas também para suas famílias e outros membros das suas comunidades. Dessa perspectiva, mesmo as escolas localizadas no campo e que concentram os estudantes oriundos de escolas fechadas incorrem, em determinadas circunstâncias, em algum nível de desterritorialização.

No entendimento de Folmer e Meurer (2019, p. 30), "Não só há um fechamento. Há uma desarticulação e por sua vez uma desterritorialização da Escola do Campo."

Além dos impactos anteriormente enunciados, a desterritorialização, decorrente da política de fechamento, afeta, também, o dispositivo legal da gestão democrática.

\section{GESTÃO DEMOCRÁTICA}

A Constituição Federal, no artigo 205, inciso VI, determina a "gestão democrática do ensino público, na forma da lei" (BRASIL, 1988).

45 Para determinados estudantes, como, por exemplo, público-alvo da Educação Especial, os impactos do fechamento de escolas tendem a ser ainda mais sensíveis. Aliás, a interface entre Educação do Campo e Educação Especial é outra condição adversa para a escolarização de pessoas que demandam essa interface (NOZU; RIBEIRO; BRUNO, 2018; TORRES et al, 2015). 
A LDBEN, consoante com a Constituição determina no artigo $3^{\circ}$, que "O ensino será ministrado com base nos seguintes princípios: [...] VIII - gestão democrática do ensino público, na forma desta Lei e da legislação dos sistemas de ensino;" (BRASIL, 1996). No artigo 14, a LDBEN diz que

Os sistemas de ensino definirão as normas da gestão democrática do ensino público na educação básica, de acordo com as suas peculiaridades e conforme os seguintes princípios:

I - participação dos profissionais da educação na elaboração do projeto pedagógico da escola;

II - participação das comunidades escolar e local em conselhos escolares ou equivalentes. (BRASIL, 1996)

As Diretrizes Operacionais para a Educação Básica nas Escolas do Campo, no artigo 10, também abordam a questão da gestão democrática:

O projeto institucional das escolas do campo, considerado o estabelecido no artigo 14 da LDB, garantirá a gestão democrática, constituindo mecanismos que possibilitem estabelecer relações entre a escola, a comunidade local, os movimentos sociais, os órgãos normativos do sistema de ensino e os demais setores da sociedade. (BRASIL, 2002)

O Estatuto da Criança e do Adolescente, no parágrafo único do artigo 53, determina que "É direito dos pais ou responsáveis ter ciência do processo pedagógico, bem como participar da definição das propostas educacionais." (BRASIL,1990).

Portanto, considerando-se a legislação federal, as escolas públicas, inclusive as no/do campo, devem ser geridas democraticamente, ou seja, com a participação das comunidades nos processos decisórios.

Considera-se que a mencionada lei 12.960/2014, que altera a LDBEN, em alguma medida, é consoante com o princípio da gestão democrática, ao determinar a necessidade da manifestação da comunidade escolar. Porém, conforme Taffarel e Munarim (2015), a existência dessa lei não implica que ela seja cumprida.

A gestão democrática, não sem contradições e condições adversas decorrentes de fatores sociais estruturais e conjunturais, apresenta potencial de contribuição para avanços no que se refere à participação popular em alguns aspectos da educa- 
ção escolar em âmbito local, isto é, em questões da alçada decisória da escola.

Partindo do que apontam Dal Ri e Vieitez (2008) e Silva e Dal Ri (2019b), dentre outros autores, a gestão democrática, não sem contradições, tem, também, potencial de contribuir para avanços na implementação de projetos contra-hegemônicos de (auto)educação, como, por exemplo, os levados a termo por movimentos sociais de povos do campo.

Assim, retrocessos no dispositivo legal da gestão democrática tendem a repercutir na possibilidade do tensionamento da educação oficial, com vistas a democratizá-la, ainda que dentro da lógica institucional. Dessa forma, torna-se oportuno e necessário que seja (re)colocada em tela, a partir de outro patamar e de perspectivas das classes trabalhadoras, a questão da gestão democrática do ensino público, pois, enquanto as classes trabalhadoras estiverem à margem dos processos decisórios, a tendência é de que a educação continue a ser concebida, executada e gerida exclusivamente - ou seja, sem disputas em âmbito institucional - da perspectiva das classes dominantes.

Considerando-se apontamentos de Caldart (2012), Bezerra Neto (2016), Moraes (2019), dentre outros autores, constata-se que a educação escolar propiciada aos povos do campo foi historicamente concebida, executada e gerida por instituições, organizações, intelectuais ou profissionais alheios ao campo e/ou às classes trabalhadoras, a exemplo do que aponta Moraes (2019) sobre os ruralistas do ensino.

Esses apontamentos históricos remetem a debates contemporâneos sobre a educação para, no e do campo ${ }^{46}$.

O dispositivo da gestão democrática propicia aporte legal e ético-político para que as classes trabalhadoras - não sem contradições - reivindiquem e exerçam o direito à participação nos processos decisórios da escola.

Iniciativas do MST de ocupação ou de posse são uma forma de disputar com o Estado e com as classes dominantes, nos planos teórico e empírico, a educação das classes trabalhadoras (MARTINS, 2004; SILVA; DAL RI, 2019a; 2019b). Dal Ri e Vieitez (2008, p. 317, grifo dos autores) consideram o projeto educativo do MST

46 Por um lado, não se desconsidera que a Educação do Campo é recente na educação brasileira. Por outro lado, considera-se que, ainda que com outros termos e especificidades das diferentes conjunturas e sujeitos, gérmens desses debates já estavam presentes, há décadas, em pautas de movimentos populares. 
[...] uma posição política e educacional de primeira grandeza por suas conotações sociais inclusivas, ou seja, o MST é partidário incondicional da escola pública e gratuita. Ao que devemos acrescentar o termo de democráticas, por nosso prognóstico decorrente da análise.

Destaca-se, no entanto, que essas disputas - que registram casos exitosos não ocorrem apenas no plano da execução, mas também no âmbito da concepção das políticas educacionais, como se pode constatar, por exemplo, em documentos oficiais relativos à Educação do Campo. Porém, partindo do que apontam Santos e Paludo (2020), há que se considerar implicações decorrentes da incorporação e da transformação dessa demanda dos povos do campo em uma política pública.

Essas iniciativas são, também, formas de tensionar o dispositivo da gestão democrática, com vistas a impulsionar avanços na efetivação desse dispositivo legal, porém, da perspectiva do trabalho, e não da perspectiva do capital ${ }^{47}$. Esse tensionamento apresenta potencial de contribuição para avanços também no que se refere a outra bandeira histórica de alguns movimentos, qual seja, a educação dos trabalhadores sob a gestão das classes trabalhadoras (DAL RI; VIEITEZ, 2008; SILVA; DAL RI, 2019b). Isso remete aos diversos debates e iniciativas, pretéritas e atuais, de (auto) educação levadas a termo por organizações das classes trabalhadoras (AGUIRRE ROJAS, 2017; BARBOSA, 2016; LOUREIRO; 2010, 2017; 2019; OLIVEIRA, 2020; SILVA, 2019) ${ }^{48}$.

Portanto, a política de fechamento de escolas no/do campo, além dos impactos mais relacionados diretamente à desterritorialização, configura-se como mais uma condição adversa, que inviabiliza a implementação da gestão democrática em escolas do campo, pois longas distâncias entre as escolas e as residências dos estudantes tendem a inviabilizar a participação das famílias e de outros membros das comunidades de origem dos estudantes desterritorializados.

47 Destaca-se que, ainda que com outros termos e com significativas diferenças entre si, a gestão democrática é um princípio transcendente e comum a projetos educativos de alguns dos principais movimentos sociais das classes trabalhadoras, desde meados do século XIX, com destaque para o cartismo britânico, o marxismo, o socialismo utópico e, na atualidade, o MST e o Zapatismo, além de outras iniciativas de menor repercussão na literatura acadêmico-científica (SILVA; DAL RI, 2019b).

48 Ressalta-se que iniciativas de resistência e auto-organização de determinadas frações das classes trabalhadoras, desde o momento histórico da Revolução Industrial até a atualidade, tendem a incluir projetos de (auto)educação (SILVA; DAL RI, 2019b). 
Considera-se pertinente a análise da política de fechamento de escolas no/do campo para além da dimensão local e dos aspectos mais pontuais, o que não significa desconsiderar sua relevância. Assim, faz-se necessário analisá-la desde uma perspectiva mais abrangente, para além da alegação de baixo número de estudantes matriculados nessas escolas e/ou das restrições orçamentárias dos entes federados. Aliás, essas razões, pautadas pela lógica do custo-benefício, são históricas e recorrentes na produção discursiva de governantes e gestores estatais para explicar o fechamento de escolas (FOLMER; MEURER, 2019; MUNARIM; TAFFAREL, 2015; TORRES; SILVA; MORAES, 2015; SILVA; DAL RI, 2019b).

Assim, há que se considerar questões atinentes à geopolítica internacional, à divisão internacional da produção, em especial no que se refere à divisão social hierárquico-vertical do trabalho, às concepções de campo e de cidade (e as inter-relações entre ambos, para além dos aspectos geográficos), entre outros quesitos, em última instância, indissociáveis da concepção de sociedade e, por conseguinte, do modo de produção dominante (MORAES, 2019; MUNARIM; TAFFAREL, 2015).

A educação escolar dos povos do campo implica diversas disputas e desafios, sendo que alguns perpassam a história da educação brasileira (BEZERRA NETO, 2016; MORAES, 2019). Outros desafios assumem novas configurações, pois são típicos da atualidade ou, então, apresentam-se como uma tendência (BARCELLOS et al, 2020; NOZU; RIBEIRO; BRUNO, 2018; TORRES et al, 2015; TORRES; SILVA; MORAES, 2015). Com base nos dados levantados, os indicativos são de que a política de fechamento terá continuidade ou será intensificada, haja vista os progressivos cortes nos investimentos estatais - que já eram insuficientes - na área da educação.

As tentativas de enfrentamento - ainda que sem garantias de êxito - desses desafios demandam auto-organização e mobilizações populares de vários tipos e diferentes instâncias, não só para evitar retrocessos, como também para demandar a implementação adequada dos direitos constantes na legislação. Concomitantemente, há que se considerar, também, a necessidade da conquista de novos direitos, 
que propiciem as condições adequadas, materiais e simbólicas, de vida aos povos do campo. A existência e o funcionamento adequado - em termos de quantidade e de qualidade - de equipamentos públicos de uso coletivo são fundamentais para a qualidade de vida dos povos do campo. A escola do campo - portanto, no campo - é um dos equipamentos públicos de uso coletivo mais estratégicos para a viabilidade de determinados projetos dos povos do campo (SILVA; MORAES; TORRES, 2015; TORRES; SILVA; MORAES, 2015). Folmer e Meurer (2019, p. 29) contribuem para exemplificar a relevância da escola do campo para povos do campo, em especial para assentados da reforma agrária:

Os assentados entendem a Escola Do Campo como ferramenta de luta e articulação da educação com movimento social. Assim, poderá transformar a vida das crianças e jovens que desde cedo participam do movimento. Também compreendem a mesma como necessária à vida dos educandos por possibilitar um ensino voltado às condições de suas próprias vivências.

A conquista de direitos na legislação é importante e necessária, porém, por si só, é insuficiente para a sua adequada efetivação. Ao longo da história da educação brasileira constatam-se vários direitos ou determinações legais que, por diversas razões, não passaram do plano formal, noutras palavras, não saíram do papel (MORAES, 2019).

Os direitos à educação escolar, a uma educação contextualizada (a Educação do Campo) e à participação nos processos decisórios da escola (a gestão democrática) são decorrentes de históricas mobilizações populares. A sua efetividade e a sua manutenção dependem eminentemente de correlação de forças favorável aos povos do campo, suficiente para fazer com que governantes e gestores estatais cumpram, adequadamente, o que determina a legislação. Na atualidade, esses e outros direitos estão em iminente risco ou em efetivo retrocesso, em decorrência das políticas que vêm sendo implementadas pelo Estado brasileiro, o que tem vários impactos negativos para a educação escolar das classes trabalhadoras. 
A política de fechamento de escolas no/do campo implica vários impactos negativos para a educação escolar dos povos do campo. Um desses impactos é a tendência à desterritorialização dos estudantes das escolas fechadas, o que afeta negativamente não só o processo de ensino-e-aprendizagem dos componentes curriculares, mas, também, o dispositivo da gestão democrática, o que dificulta ou inviabiliza a participação dos povos do campo afetados nos processos decisórios da escola.

Essa política é resultado e, ao mesmo tempo, gera implicações políticas, econômicas e culturais, envolvendo não só fatores nacionais, mas também questões relacionadas à geopolítica internacional, dentre elas, a divisão internacional da produção e as diversas hierarquizações sociais verticais dela decorrentes.

Reitera-se, em consonância com o objetivo deste texto, que o fechamento de escolas no/do campo e a desterritorialização de estudantes, além dos diversos impactos negativos para o processo de ensino-e-aprendizagem, afetam, também, o dispositivo da gestão democrática, o que implica dificuldades ou inviabilidade de participação dos povos do campo e de suas organizações na gestão da escola. Isso tende a resultar em maiores desafios para a conquista da hegemonia em escolas públicas e, por conseguinte, para a execução de projetos contra-hegemônicos de (auto)educação no âmbito dessas escolas.

\section{REFERÊNCIAS}

AGUIRRE ROJAS, Carlos Antonio. Artes, ciencias y saberes neozapatistas. Nascer desde abajo el nuevo mundo no capitalista. Contrahistorias, Ciudad de México, n. 12, p. 133-154, 2018. Disponível em: <https://ojs.uv.es/index.php/kamchatka/article/ view/13416/12695>. Acesso em: 5 fev. 2021.

BARBOSA, Lia Pinheiro. Educación, resistencia y conocimiento en América Latina: por una teoría desde los movimientos sociales. De Raíz Diversa, Ciudad de México, v. 3, n. 6, p. 45-79, jul./dez., 2016. Disponível em: <http://www.planalto.gov.br/ccivil_03/constituicao/ConstituicaoCompilado.htm>. Acesso em: 5 fev. 2021.

BARCELLOS, Luis Henrique dos Santos et al. Limites e desafios da educação inclusiva no campo: a experiência do projeto educativo do MST. Rev. Bras. Educ. Camp., 
Tocantinópolis, v. 5, e10660, 2020. Disponível em: <http://dx.doi.org/10.20873/uft. rbec.e10660>. Acesso em: 14 fev. 2021.

BEZERRA NETO, Luiz. Educação rural no Brasil: do ruralismo pedagógico ao movimento por uma Educação do Campo. Uberlândia: Navegando, 2016.

BRASIL. Constituição (1988). Constituição da República Federativa do Brasil. Disponível em: <http://www.stf.jus.br/arquivo/cms/publicacaoLegislacaoAnotada/anexo/ Completo.pdf>. Acesso em: 15 abr. 2013.

BRASIL. Diretrizes Curriculares Nacionais Gerais da Educação Básica. Brasília: MEC, SEB, DICEI, 2013.Disponível em: <http://portal.mec.gov.br/index.php?option=com_content\&view=article\&id=12663\&Itemid=1152>. Acesso em: 04 out. 2014.

BRASIL. Documento-Referência. Conferência Nacional de Educação, 2014a. Disponível em: <http://conae2014.mec.gov.br/images/pdf/doc_referencia_conae2014. pdf>. Acesso em: 04 out. 2014.

BRASIL. Estatuto da Criança e do Adolescente (1990). <http://www.planalto.gov.br/ ccivil_03/leis/L8069compilado.htm >. Acesso em: 5 fev. 2021.

BRASIL. Lei $n^{\circ}$ 12.960, de 2014. Altera a Lei no 9.394, de 20 de dezembro de 1996... 2014b. Disponível em: <http://www.planalto.gov.br/ccivil_03/_Ato2011-2014/2014/ Lei/L12960.htm>. Acesso em: 04 out. 2014.

BRASIL. Lei $n^{\circ}$ 9.394, de 1996. Estabelece as diretrizes e bases da educação nacional. 1996. Disponível em:<http://www.planalto.gov.br/ccivil_03/Leis/L9394compilado. htm>. Acesso em: 5 fev. 2021.

CALDART, Roseli Salete. Educação do campo. In: CALDART, Roseli Salete et al (org.). Dicionário da educação do campo. Rio de Janeiro, São Paulo: Escola Politécnica de Saúde Joaquim Venâncio; Expressão Popular, 2012. p. 259-267.

CASSIN, Marcos; NALLI, Laura. Assentamento Mário Lago: espaço de formação política, qualificação técnica e educação escolar. Revista HISTEDBR On-line, Campinas-SP, v. 16, n. 68, p. 358-370, 2016. Disponível em: <https://periodicos.sbu.unicamp. br/ojs/index.php/histedbr/article/view/8643760>. Acesso em: 5 jan. 2021.

CELESTE FILHO, Macioniro. A educação rural delineada por organismos interna- 
cionais de cultura e suas repercussões no Brasil nas décadas de 1960 e 1970. In: CELESTE FILHO, Macioniro; CHALOBA, Rosa Fátima de Souza; MESQUITA, Ilka Miglio. (org.). História e memória da educação rural no século XX. São Paulo: Cultura Acadêmica, 2020. p. 231-267.

FERNANDES, Bernardo Mançano. Território camponês. In: CALDART, Roseli Salete et al (org.). Dicionário da educação do campo. Rio de Janeiro, São Paulo: Escola Politécnica de Saúde Joaquim Venâncio; Expressão Popular, 2012. p. 746-750.

FOLMER, Ivanio; MEURER, Ane Carine. A territorialização do MST a partir da Educação do Campo nos assentamentos Fazenda Annoni e Bela Vista. Rev. NERA, Presidente Prudente, v. 22, n. 48, p. 14-37, 2019. Disponível em: <https://revista.fct.unesp. br/index.php/nera/article/view/5587/4844>. Acesso em: 14 jan. 2021.

LOUREIRO, Bráulio Roberto de Castro. O ativismo de rappers e o "progresso intelectual de massa": uma leitura gramsciana do rap no Brasil. Rev. Histedbr On-Line, Campinas, v. 17, n. 2 [72], p. 419-447, abr./jun. 2017. Disponível em: <https://periodicos.sbu.unicamp.br/ojs/index.php/histedbr/article/view/8645849/16926>. Acesso em: 29 ago. 2020.

LOUREIRO, Bráulio Roberto de Castro. Formação política via autoeducação no movimento hip-hop: experiências de rappers ativistas no Brasil. Educação, Santa Maria, v. 44, p. 1-29, 2019.Disponível em: <https://periodicos.ufsm.br/reveducacao/article/ view/34976/pdf>. Acesso em: 20 mar. 2020.

LOUREIRO, Bráulio Roberto de Castro. Política e educação na construção do cursinho popular "Nós Por Nós". Rev. Ed. Popular, Uberlândia, v. 17, n. 1, p. 136-144, jan./abr. 2018. Disponível em: <http://www.seer.ufu.br/index.php/reveducpop/article/ view/42847/22331 . Acesso em: 14 mar. 2020.

MARTINS, Fernando José. Gestão democrática e ocupação da escola: o MST e a educação. Porto Alegre: EST, 2004.

MORAES, Agnes lara Domingos. A circulação das ideias do Movimento pela ruralização do ensino no Brasil (1930-1950). 2019. 272 f. Tese (Doutorado em Educação) - Faculdade de Filosofia e Ciências, Universidade Estadual Paulista.

NOZU, Washington Cesar Shoiti; RIBEIRO, Eduardo Adão; BRUNO, Marilda Moraes 
Garcia. Interface entre Educação Especial e Educação do Campo: a produção científica em teses e dissertações. Interfaces da Educação, Paranaíba, 9(27), p. 317349, 2018. Disponível em: <https://doi.org/10.26514/inter.v9i27.3002>. Acesso em: 29 mar. 2019.

OLIVEIRA, Ivan Thomaz Leite. Educação racionalista e sindicalismo de intenção revolucionária na prática política do anarquismo paulista (1900-1919). Revista Espaço Acadêmico, Maringá, n. 221, mar./abr., p. 91-102, 2020.Disponível em: <http://periodicos.uem.br/ojs/index.php/EspacoAcademico/article/view/51333/751375149737>. 15 fev. 2021.

SANTOS, Magda Gisela Cruz dos; PALUDO, Conceição. Contribuições do estado da questão na pesquisa sobre política pública, Educação Rural e Educação do Campo. Revista Brasileira de Educação do Campo, Tocantinópolis, v. 5, p. e7365, 30 abr. 2020. Disponível em: <https://sistemas.uft.edu.br/periodicos/index.php/campo/article/view/7365>. Acesso em: 15 jan. 2020.

SILVA, Cláudio Rodrigues. Educação em movimentos sociais: princípios educativos comuns ao Movimento Zapatista e ao Movimento dos Trabalhadores Rurais Sem Terra (MST). 2019. 430 f. Tese (Doutorado em Educação) - Faculdade de Filosofia e Ciências, Universidade Estadual Paulista, Marília.

SILVA, Cláudio Rodrigues; DAL RI, Neusa Maria. A posse da Escola de Ensino Fundamental Construindo o Caminho pelo MST: contradições, potencialidades e limites. In: DAL RI, Neusa Maria et al. Educação democrática, trabalho e organização produtiva no Movimento dos Trabalhadores Rurais Sem Terra (MST). Marília: Oficina Universitária; São Paulo: Cultura Acadêmica, 2019a. p. 116-140.

SILVA, Cláudio Rodrigues; DAL RI, Neusa Maria. Princípios educativos comuns e transcendentes em movimentos sociais de trabalhadores: owenistas, cartistas britânicos e Movimento dos Trabalhadores Rurais Sem Terra. Revista e-Curriculum, São Paulo, v. 17, n. 2, p. 699-725, abr./jun., 2019b. Disponível em: <http://dx.doi. org/10.23925/1809-3876.2019v17i2p699-725>. Acesso em: 14 nov. 2019.

SILVA, Cláudio Rodrigues; MORAES, Agnes lara Domingos; TORRES, Julio Cesar. Fechamento de escolas e implicações para a educação dos povos do campo. In: SICCA, Natalina Aparecida Laguna; DAVID, Alessandra. (org.). Diálogos na educação básica: políticas, currículo e discurso. Curitiba: CRV, 2015. p. 29-53. 
TAFFAREL, Celi Zulke; MUNARIM, Antonio. Pátria educadora e fechamento de escolas do campo: o crime continua. Revista Pedagógica, Chapecó, v. 17, n. 35, p. 41-51, maio/ago. 2015. Disponível em: <https://bell.unochapeco.edu.br/revistas/index.php/ pedagogica/article/view/3053>. Acesso em: 25 ago. 2019.

TORRES, Julio Cesar et al. Educação inclusiva no projeto educacional do MST. Comunicações, Piracicaba, v. 22, n. 2, p. 149-164, jul./dez., 2015. Disponível em: <https://www.metodista.br/revistas/revistas-unimep/index.php/comunicacoes/article/ view/2203>. Acesso em: 5 jan. 2021.

TORRES, Julio Cesar; SILVA, Cláudio Rodrigues; MORAES, Agnes lara Domingos. Escolas públicas no campo: retrospectiva e perspectivas em um contexto de projetos políticos em disputa. Revista Eletrônica de Educação, São Carlos, v. 8, n. 2, p. 262-272, jul./dez., 2014. Disponível em: <http://www.reveduc.ufscar.br/index.php/reveduc/article/view/962>. Acesso em: 5 jan. 2021.

ZIBECHI, Raúl. Los movimientos sociales latinoamericanos: tendencias y desafíos. OSAL - Observatorio Social de América Latina, Buenos Aires, n. 9, jan. 2003. Disponível em: <http://bibliotecavirtual.clacso.org.ar/ar/libros/osal/osal9/zibechi.pdf>. Acesso em: 15 mar. 2013. 


\section{ESCOLAS E A EDUCACAO DO CAMPO EM SETE DE SETEMBRO RS}

Elizandro Luiz Adamski Pauczinski ${ }^{49}$ 
Sete de Setembro está localizado no noroeste do estado do Rio Grande do Sul, são municípios limítrofes Santo Ângelo, Giruá, Guarani das Missões e Senador Salgado Filho. De acordo com dados do COREDE Missões (2016), a área territorial do município é de $130 \mathrm{~km}^{2}$ e sua população soma aproximadamente 2.169 habitantes, os quais em sua maioria habitam o meio rural, em torno de 1630, enquanto 494 pessoas vivem na área urbana. Este fato denota que a principal base da economia do município é a agricultura familiar. Entre os produtos cultivados os mais expressivos são as hortaliças, em torno de $28 \%$; a criação de gado leiteiro, somando $41 \%$ (COREDE Missões, 2012).

Levando em conta os aspectos populacionais apresentados, o presente ensaio tem por objetivo geral analisar a participação das escolas rurais do município nas comunidades rurais e urbana. Assim como: a) mapear as escolas do município da área urbana e rural; b) descrever a infraestrutura de cada escola; c) analisar as propostas pedagógicas das escolas rurais, na perspectiva da educação do campo; d) compreender a importância das escolas do meio rural para a comunidade local.

A metodologia do trabalho foi estruturada nas seguintes etapas: a primeira destina-se ao levantamento bibliográfico; a segunda refere-se ao levantamento in loco (campo) e por fim a terceira constituiu-se na análise e interpretação dos dados alcançados, assim como, para a redação do texto final da pesquisa. O município possui quatro escolas ao total, uma no perímetro urbano e as demais localizam-se na área rural, são elas: a Escola Estadual de Ensino Médio São Roque, localizada na área urbana, oferece Ensino Fundamental e Ensino Médio; A Escola Municipal de Ensino Fundamental Gaúcha, da Linha Gaúcha, área rural; A escola da Linha Boa Vista, Escola Municipal de Ensino Fundamental Sargento Pedro Krinski e a Escola Estadual de Ensino Fundamental Nossa Senhora do Carmo da comunidade da Linha Barreira. (Secretária da Educação do Município Sete de Setembro, 2018).

As escolas possuem boa infraestrutura com bibliotecas, salas de vídeo, refeitórios, sala de informática (apenas na Escola Estadual de Ensino Médio São Roque), espaço para o lazer como: parquinhos e quadras de vôlei e futebol. A importância das escolas das áreas rurais do município se dá por inúmeros fatores, porém o mais cita- 
do pelos depoentes é o deslocamento, observam que a escola na comunidade facilita o acesso à educação, além de estar localizada no espaço de vivência dos alunos, promovendo, de certa forma, a valorização do local, dos hábitos e costumes dessas comunidades em que estão inseridas. Mas, nem sempre a escola desenvolve métodos de ensino que estimulam os alunos a valorizarem as experiências vivenciadas por eles e seus familiares, como destaca o depoente A, "a escola da comunidade da Linha Boa Vista não aborda assuntos referente a lida no campo, muito menos sobre a nossa cultura. São valores que vão se perdendo, pois, as nossas crianças observam outra forma de viver, mais fácil, do que o trabalho na lavoura e na horta". (Diário de Campo, 2018). "Os professores também não ajudam, poucos são os do nosso município, e nem um é daqui da comunidade, muitos vêm de outros municípios da região para lecionar no Sete de Setembro", destaca o depoente B. (Diário de Campo, 2018). "Uma das preocupações da comunidade da Linha Barreira é o reduzido número de crianças em idade escolar, e a Secretaria de Educação do Município está cogitando a hipótese de nucleação", revela o depoente C (Diário de Campo, 2018).

Os espaços rurais geralmente são territórios com pouca densidade demográfica, porém essa característica não se aplica ao município de Sete de Setembro/RS, onde a população rural aumentou nos últimos anos. Fenômeno pouco valorizado e explorado, tanto pelo poder público como pelos munícipes, pois essas sociedades/ comunidades produzem paisagens específicas, por meio do trabalho cotidiano e estabelecem relações recíprocas entre os membros dessas comunidades com a escola. Assim, a escola do campo poderia constituir-se como representante e reprodutora das histórias, memórias do espaço em que está inserida, ou seja, incluir no processo de ensino e aprendizagem as formas, cores, estruturas, cheiros, processos, funções e sabores, ou seja, os traços daqueles e daquelas que construíram/produziram o espaço geográfico rural de Sete de Setembro (RS).

\section{IMPORTÂNCIA DA EDUCAÇÃO DO CAMPO DENTRO DAS ESCOLAS}

O presente trabalho tem como objetivo principal realizar uma analise da educação do campo no município de Sete de Setembro, onde as escolas não demonstram um trabalho sobre o assunto, fazendo com que torne necessário a realização de um estudo apurando os fatores que demonstre a não aplicação do ensino sobre o recor- 
rente assunto.

A educação do campo deve ser implementada nas escolas onde o município apresente um número elevado de moradores camponeses, com isso o ensino levará para os alunos a importância de compreender o trabalho que é realizado no meio rural.

É importante destacar que a população do campo e a educação do campo tem objetivos de produzir e reproduzir a realização de bens que agrega valores para o município. De acordo com O Decreto $7352 / 2010 \mathrm{em}$ seu artigo $1^{\circ}$ conceitua população de campo e escola do campo:

Populações do campo: agricultores familiares, os extrativistas, os pescadores artesanais, os ribeirinhos, os assentados e acampados da reforma agrária, os trabalhadores assalariados rurais, os quilombolas, os caiçaras, os povos da floresta, os caboclos e outros que produzam suas condições materiais de existência a partir do trabalho no meio rural.

Escola do campo: aquela situada em área rural, conforme definida pela Fundação Instituto Brasileiro de Geografia e Estatística - IBGE, ou aquela situada em área urbana, desde que atenda predominantemente a populações do campo (BRASIL, 2010).

Nesse contexto, o município de Sete de Setembro apresenta quatro escolas, sendo duas municipais e duas estaduais, e dentro delas, apenas uma possui o ensino médio, sendo a única localizada na área urbana. Dentro dessa escola que possui o ensino médio, os alunos que terminam o ensino básico ou fundamental nas escolas rurais, para continuar os estudos transferem-se para está escola, portanto, isso faz com que ela possua um número elevado de alunos do campo, trazendo fatores que colocam que a educação do campo deve ser aplicada dentro dela.

De acordo com o Decreto $7352 / 2010$ em seu artigo $2^{\circ}$ conceitua os princípios da educação do campo:

I - Respeito à diversidade do campo em seus aspectos sociais, culturais, ambientais, políticos, econômicos, de gênero, geracional e de raça e etnia;

II - Incentivo à formulação de projetos político-pedagógicos específicos para as escolas do campo, estimulando o desenvolvimento das unidades escola- 
res como espaços públicos de investigação e articulação de experiências e estudos direcionados para o desenvolvimento social, economicamente justo $e$ ambientalmente sustentável, em articulação com o mundo do trabalho;

III - desenvolvimento de políticas de formação de profissionais da educação para o atendimento da especificidade das escolas do campo, considerando-se as condições concretas da produção e reprodução social da vida no campo;

IV - Valorização da identidade da escola do campo por meio de projetos pedagógicos com conteúdos curriculares e metodologias adequadas às reais necessidades dos alunos do campo, bem como flexibilidade na organização escolar, incluindo adequação do calendário escolar às fases do ciclo agrícola e às condições climáticas;

V - Controle social da qualidade da educação escolar, mediante a efetiva participação da comunidade e dos movimentos sociais do campo.

Nessa perspectiva, a educação do campo traça a valorização da identidade dos camponeses, levantando pontos que devem ser colocados em pratica nas escolas, para conscientizar aos alunos a se colocarem na vida rural, junto com suas famílias.

\section{AS ESCOLAS DO MUNICÍPIO DE SETE DE SETEMIBRO}

O município de Sete de Setembro conta com quatro escolas, sendo três na área rural e apenas uma na área urbana e dentre elas, duas são municipais e duas estaduais. E dessas apenas uma conta com o ensino médio completo.

As escolas são Escola Estadual de Ensino Médio São Roque; A Escola Municipal de Ensino Fundamental Gaúcha, da Linha Gaúcha; Escola Municipal de Ensino Fundamental Sargento Pedro Krinski e a Escola Estadual de Ensino Fundamental Nossa Senhora do Carmo; a última com possibilidades de fechar por possuir um baixo número de alunos.

Única escola que está localizada no perímetro urbano, sendo a que possui o maior número de alunos. 
Figuras 1 e 2: Escola Estadual de Ensino Médio São Roque

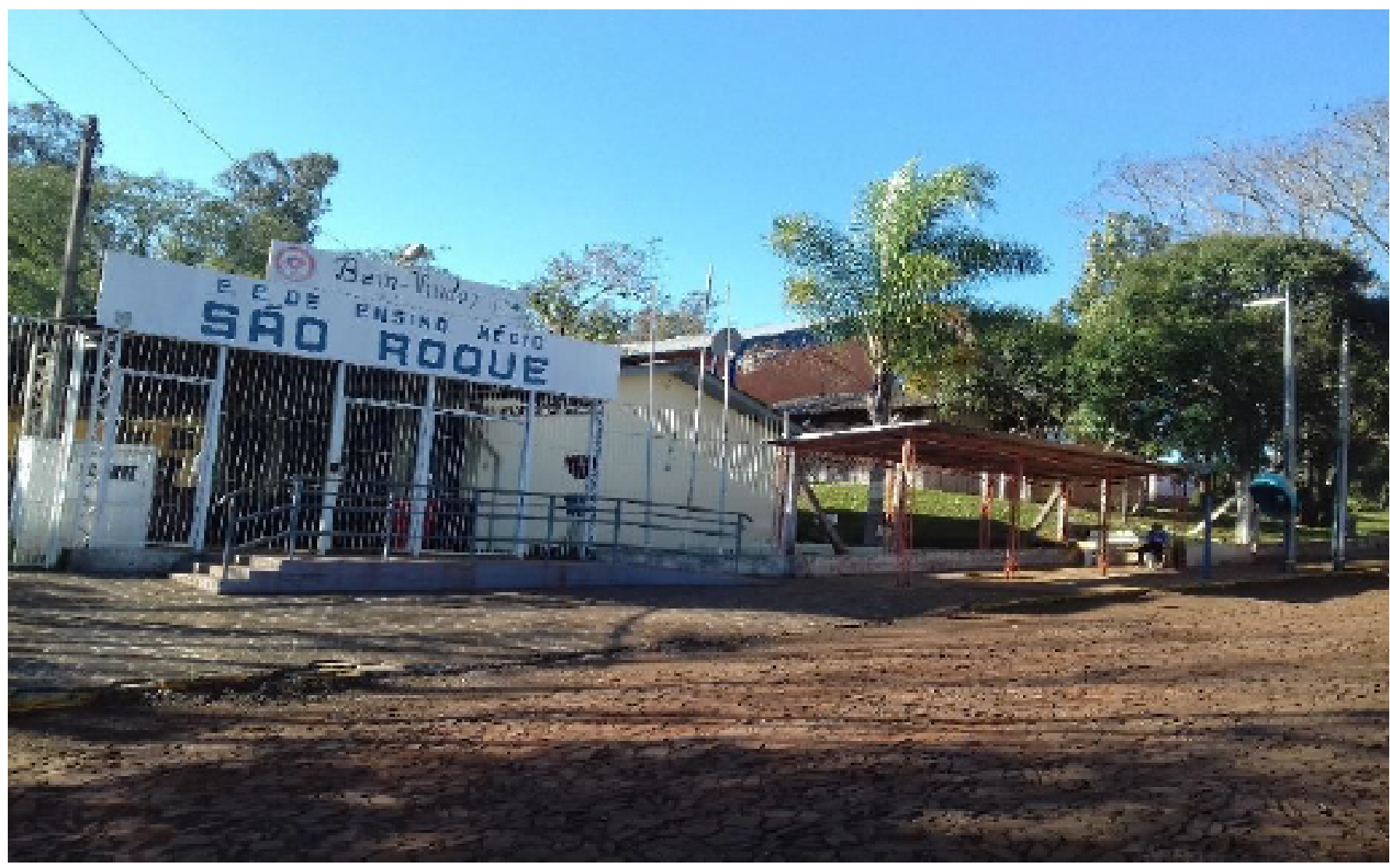

Fonte: Pauczinski, 2018

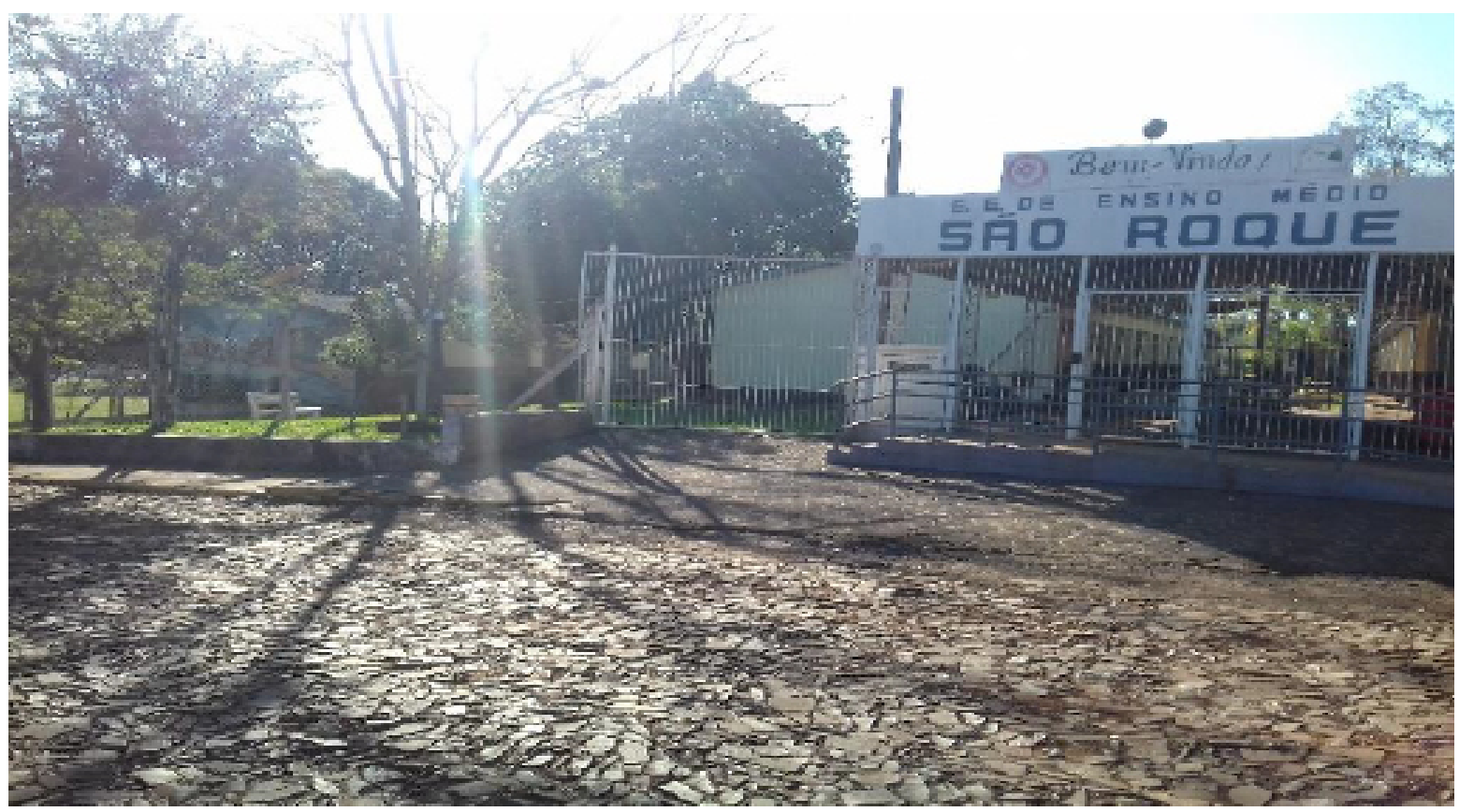

Fonte: Pauczinski, 2018.

Escola que se encontra no perímetro rural, na comunidade da linha Gaúcha, possui apenas o ensino básico. 
Figuras 3 e 4: Escola Municipal de Ensino Fundamental Gaúcha

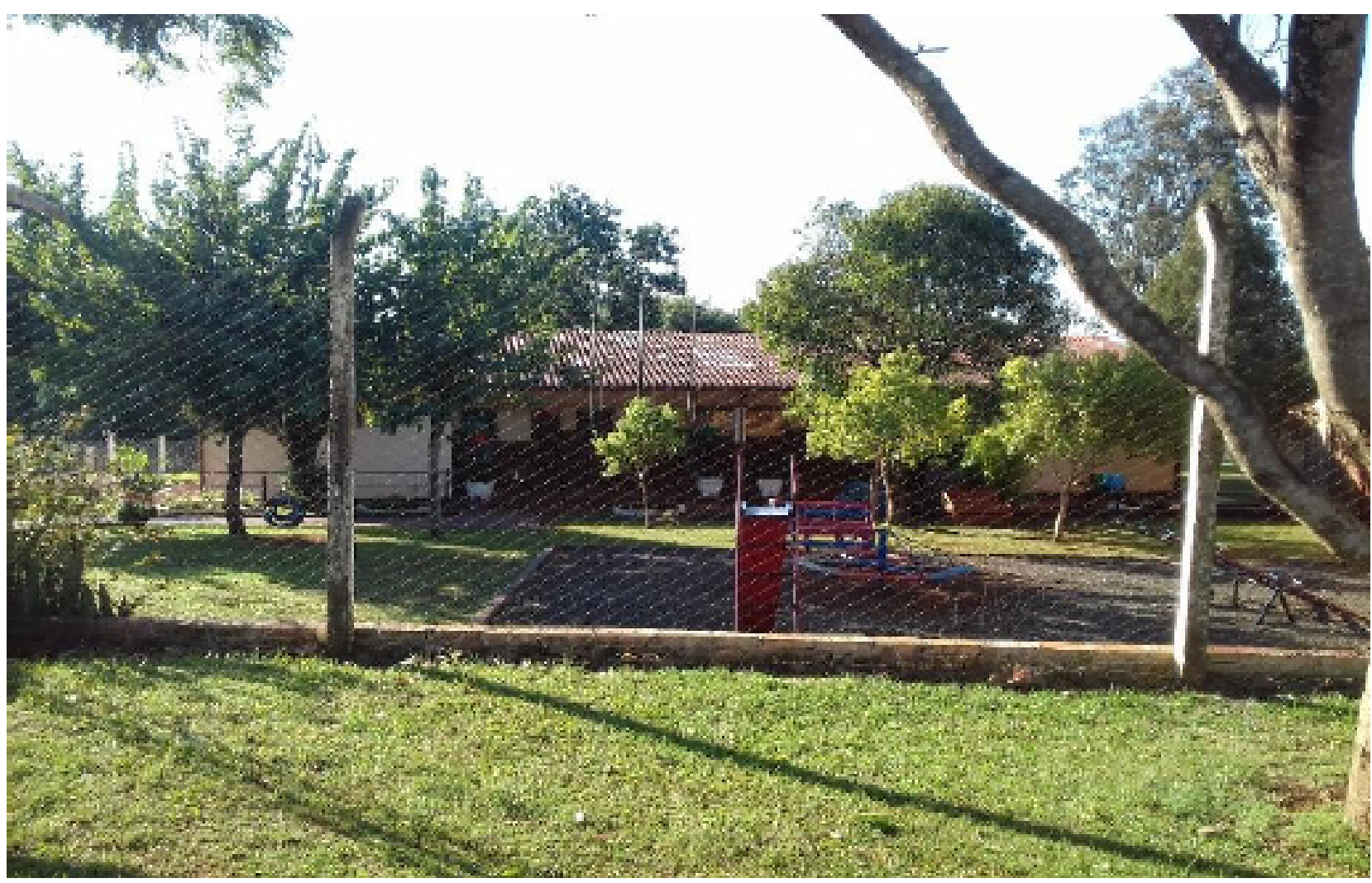

Fonte: Pauczinski, 2018.

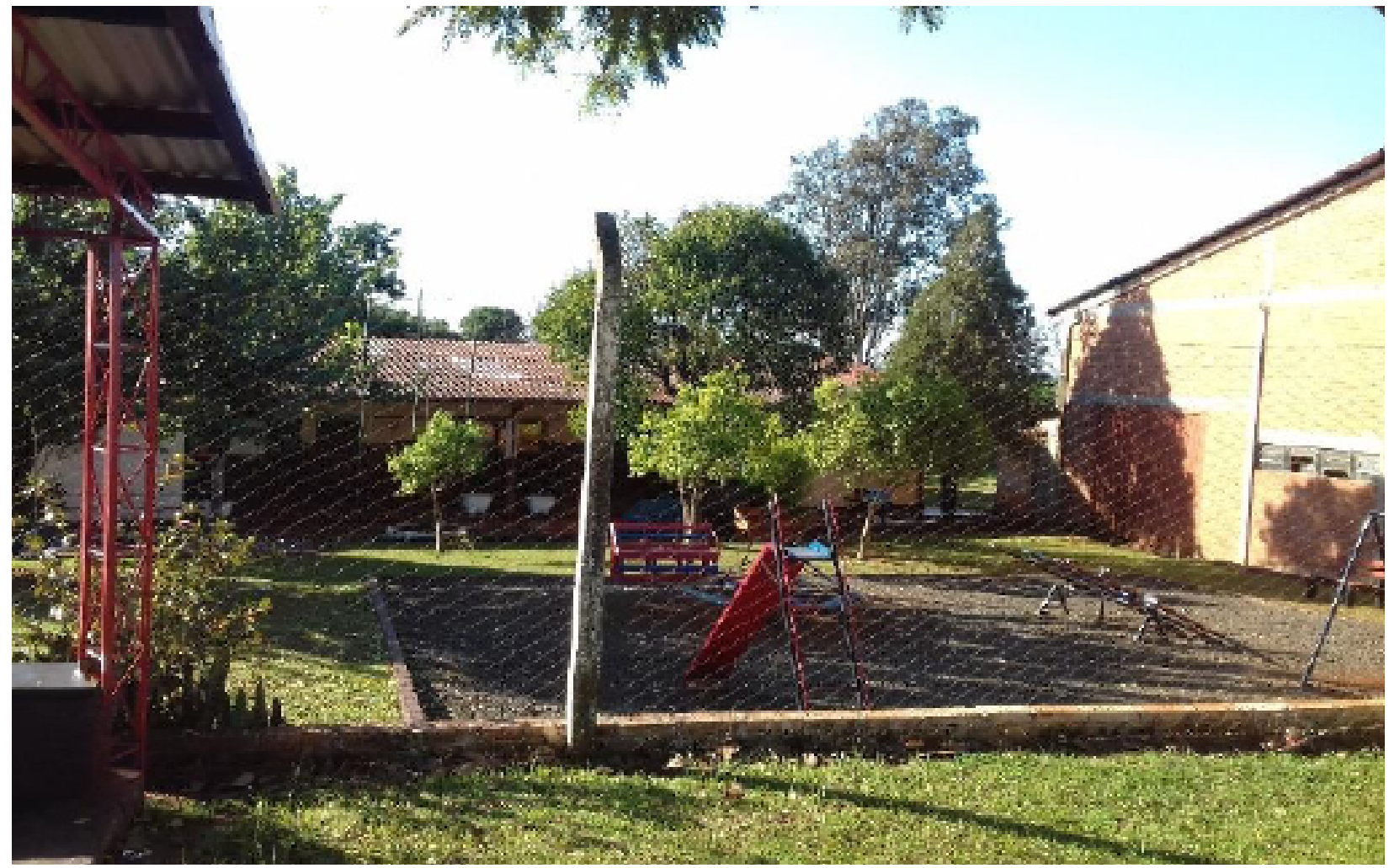

Fonte: Pauczinski, 2018.

Escola localizada no perímetro rural, na comunidade da linha Boa Vista e possui apenas o ensino básico. 
Figuras 5 e 6: Escola Municipal de Ensino Fundamental Sargento Pedro Krinski

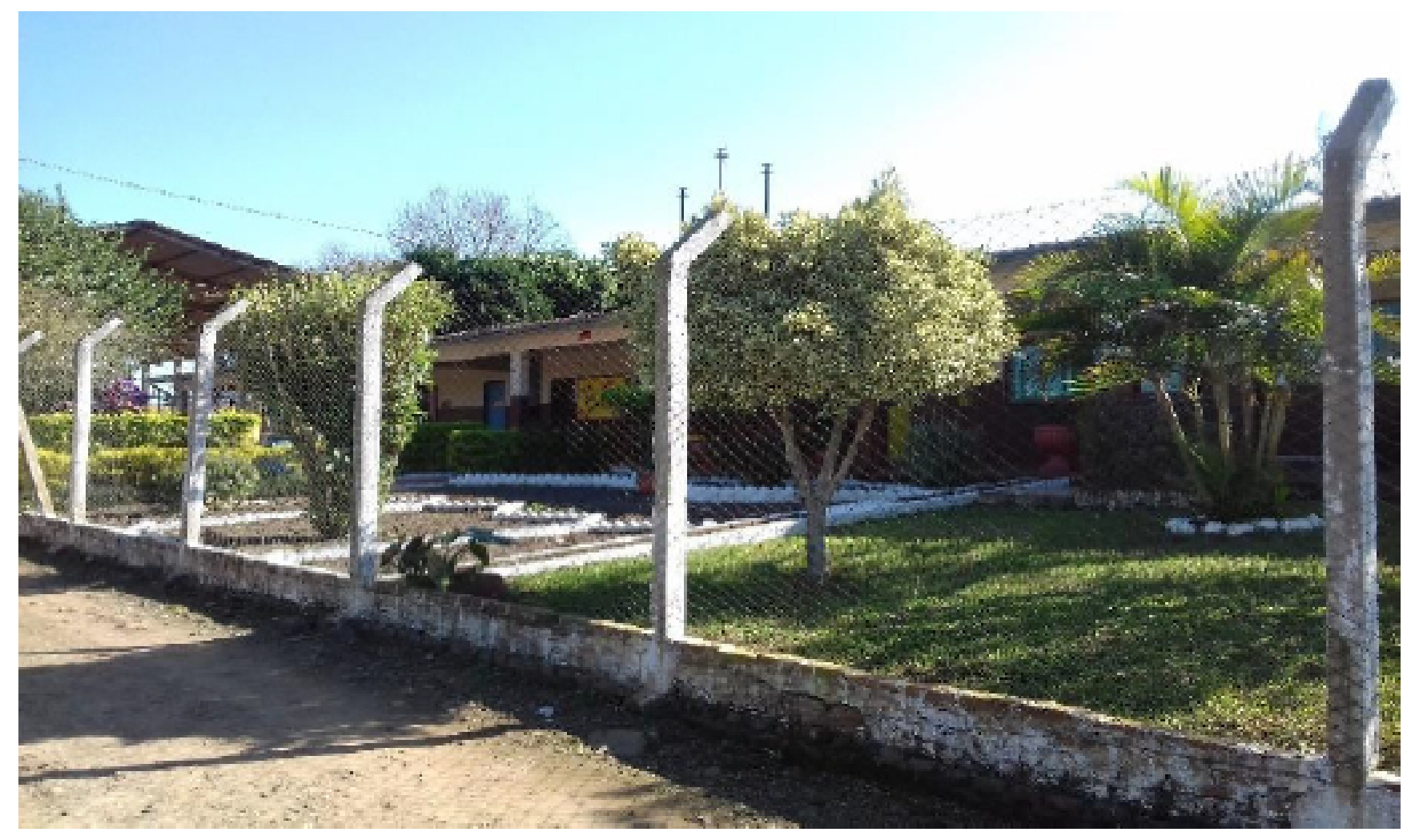

Fonte: Pauczinski, 2018.

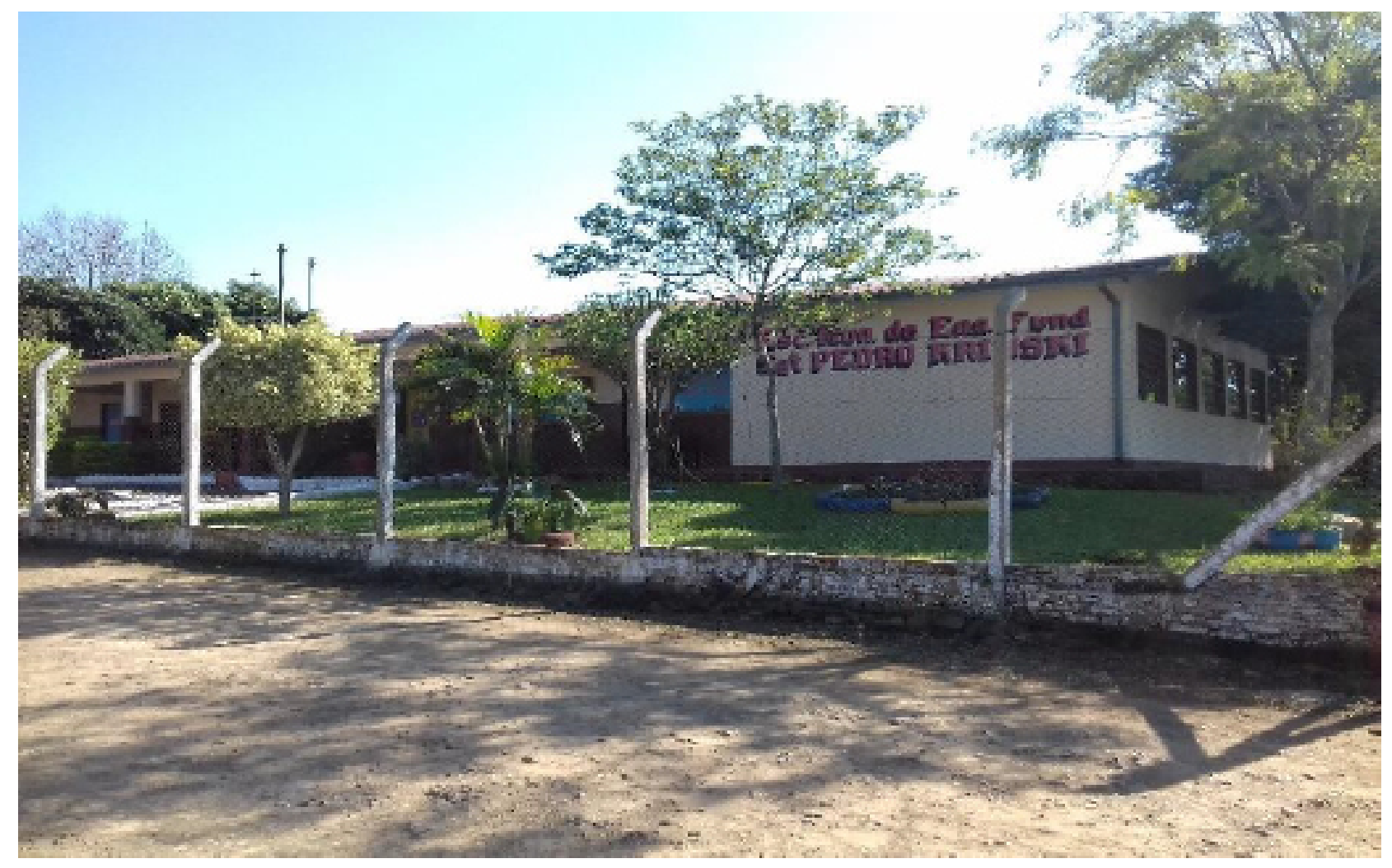

Fonte: Pauczinski, 2018.

Escola localizada no perímetro rural, comunidade da Linha Barreira e sendo a única das escolas no meio rural que possui o ensino fundamental completo. 
Figuras 7 e 8: Escola Estadual de Ensino Fundamental Nossa Senhora do Carmo

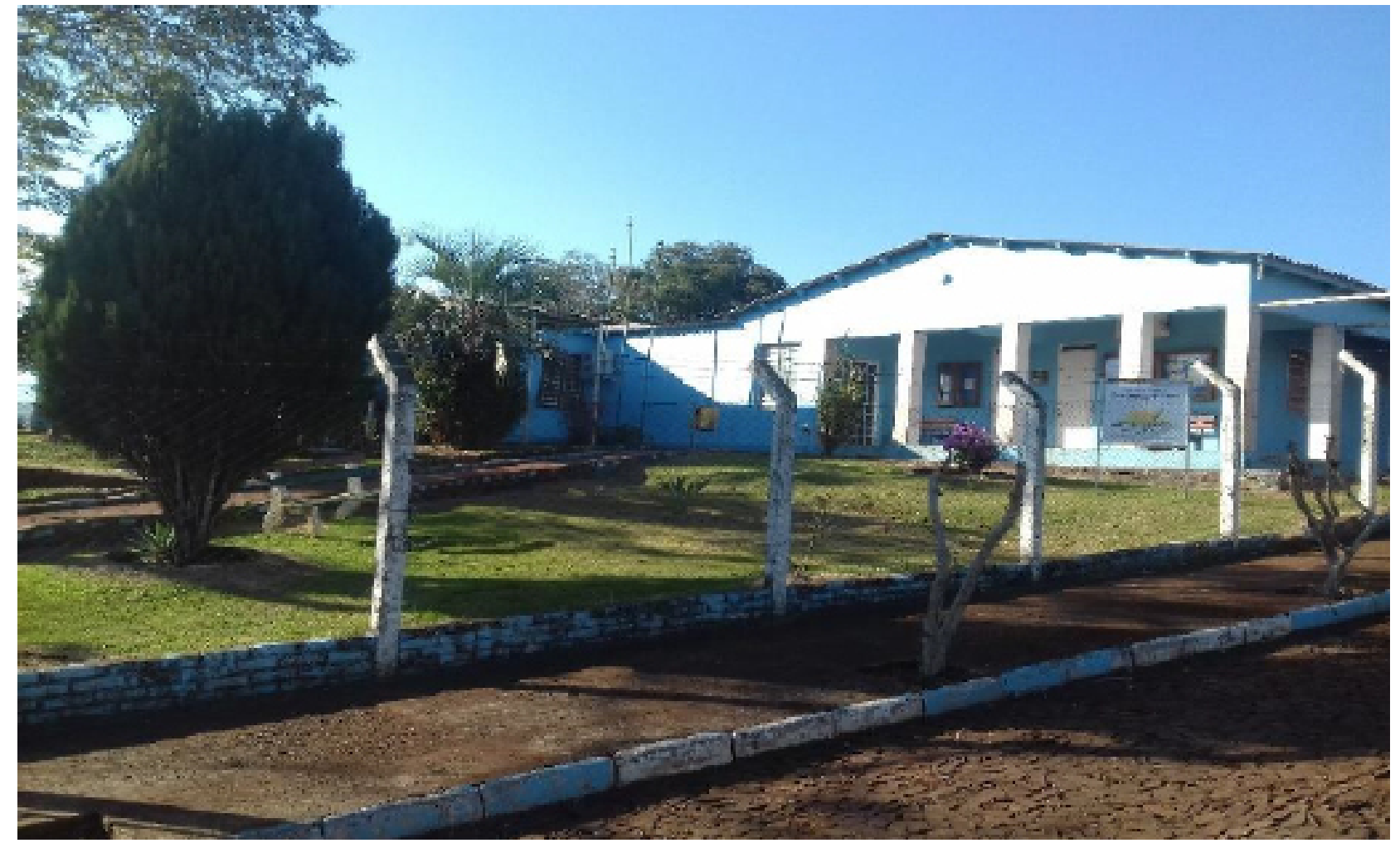

Fonte: Pauczinski, 2018.

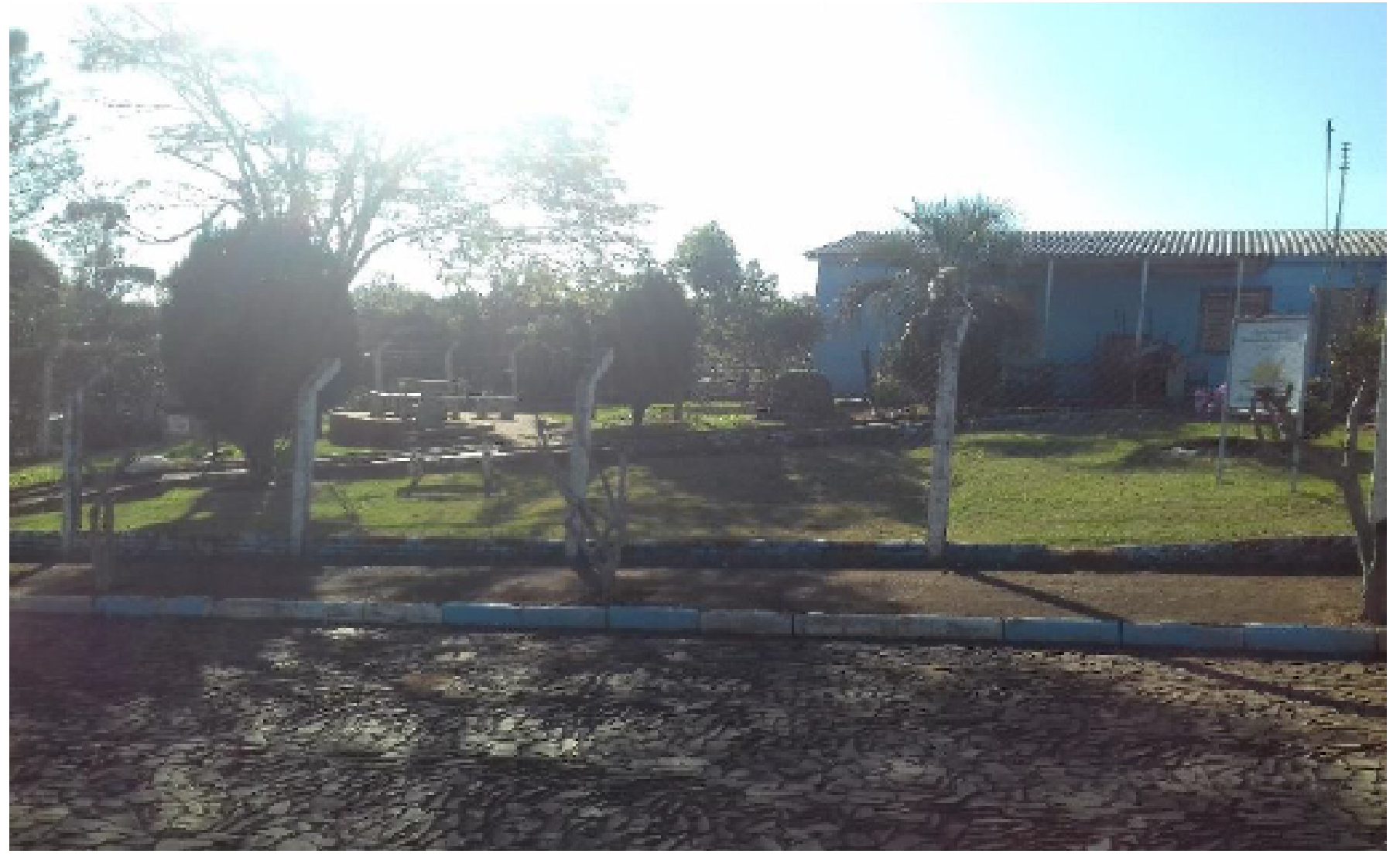

Fonte: Pauczinski, 2018. 
BRASIL. Instituto Brasileiro de Geografia e Estatística (Ed.). IBGE. Disponível em: <https://www.ibge.gov.br/>. Acesso em: 14 jul. 2018.

FEE. COREDE. Disponível em: <https://www.fee.rs.gov.br/perfil-socioeconomico/coredes/>. Acesso em: 14 jul. 2018.

SETE DE SETEMBRO. PREFEITURA MUNICIPAL. (Org.). Prefeitura Municipal de Sete de Setembro. Disponível em: <https://www.setedesetembro.rs.gov.br>. Acesso em: 14 jul. 2018.

BRASIL. Decreto 7352 de 04 de novembro de 2010. Disponível em: http://portal.mec. gov.br/docman/marco-2012-pdf/10199-8-decreto-7352-de4-denovembro-de-2010/ file. Acesso em: 11 set. 2018. 


\section{CONTRIBUIÇÓES DO TRABALHO DE CAMPO"}

\section{(GEOGRAFIA E ANTROPOLOGIA)}

PARA A FORMAÇÃO ACADEMICA DE ESTUDANTES DE CIENCLIAS SOCIAIS Cláudio Rodrigues da Silva ${ }^{50}$ 
Neste capítulo tem-se por objetivo apresentar aspectos das contribuições do "trabalho de campo" para a formação acadêmico-científica de estudantes de Graduação em Ciências Sociais da Faculdade de Filosofia e Ciências da Universidade Estadual Paulista, campus de Marília.

"Trabalho de campo" era ${ }^{52}$ a denominação formal de uma atividade integrante do currículo da disciplina de Fundamentos da Geografia, do $2^{\circ}$ ano do curso em referência. Essa atividade, realizada há vários anos e de periodicidade anual, consistia em uma estadia de dois dias em um acampamento e em um assentamento da reforma agrária, ambos no município de Promissão, no Estado de São Paulo. As edições de 2011 e 2012 dessa atividade, móbeis de problematização deste texto, foram realizadas no Assentamento "Reunidas" e no Acampamento "Augusto Boal". O Assentamento "Reunidas" é, segundo Olivier e Percassi (2012, p. 6), é o "mais antigo do estado de São Paulo". Conforme Fernandes et al (2016, p. 32),

O Assentamento Reunidas foi um dos primeiros assentamentos no estado [...]. [é] Oriundo da luta dos movimentos sociais e sindicais pelo acesso à reforma agrária nos anos 1980 [...]. Está organizado em dez agrovilas: Agrovila São Pedro, Agrovila de Penápolis, Agrovila de Birigui, Agrovila de José Bonifácio, Agrovila de Campinas, Agrovila Central e Agrovila dos 44, Agrovila de São Bento, Promissãozinha e Agrovila dos 12.

Na edição de 2011 do trabalho de campo houve interlocução ${ }^{53}$ com a disciplina de Fundamentos da Antropologia, integrando, dessa forma, as atividades também dessa disciplina. É importante ressaltar isso, haja vista que, no curso em referência, a interlocução entre disciplinas, de maneira oficial e efetiva, não era praxe. Também não era praxe a realização de atividades formalmente vinculadas às disciplinas fora dos ambientes da universidade. Não raramente, a única atividade curricular reali-

51 Singelamente dedicado à Profa. Dra. Mirian Cláudia Lourenção Simonetti, que dedicou parte significativa de sua vida à educação pública e à questão da terra (e da Terra!).

52 Em determinados casos, por cautela metodológica, utilizam-se verbos no pretérito, pois este trabalho apresenta dados com base em um momento específico do curso. Destaca-se, porém, que o uso do pretérito de forma alguma sugere que essa situação tenha perdurado ou mudado após aquele momento.

53 Opta-se por utilizar o termo interlocução - e não interdisciplinaridade -, pois, partindo do entendimento de Fazenda (2003), interdisciplinaridade extrapolaria uma aproximação pontual de disciplinas, como ocorreu com a atividade mencionada, o que não afeta a sua relevância. 
zada fora desses ambientes eram os estágios curriculares obrigatórios, no caso de estudantes que optam pela licenciatura. Portanto, essas atividades ocorriam não por iniciativa de docentes ou da universidade, mas, por força da legislação. Havia, também, projetos de extensão, porém, com configurações diferenciadas em relação ao trabalho de campo.

Durante o trabalho de campo, os estudantes, comumente organizados em grupos, entrevistaram assentados e acampados sobre questões relacionadas, dentre outros aspectos, ao cotidiano nesses territórios, sendo as formas de encaminhamento e as temáticas das entrevistas e observações previamente definidas. Além disso, os estudantes participaram de atividades culturais concebidas e executadas pelos assentados. Entre as atividades desenvolvidas estiveram a apresentação da história do Assentamento, que incluiu o processo de conquista daquelas terras, por intermédio do projeto de reforma agrária; manifestações artístico-culturais; visitas a lotes, a espaços e instalações de produção, além de outros momentos de interação, individual ou coletiva, com assentados.

Os dados apresentados neste texto são decorrentes de observação participante, entrevistas semiestruturadas e de formulários (GIL, 1987) respondidos por estudantes que participaram da atividade em tela. Considera-se pertinente a apresentação do ponto de vista discente, pois - recorrendo a palavras de Munakata (2012), ao tratar da questão do livro didático -, os estudantes são sujeitos quase sempre em elipse na educação escolar.

\section{CONTRIBUIÇÕES DO TRABALHO DE CAMPO}

Um dos pontos destacados pelos participantes refere-se à dimensão mais prática dessa atividade. Ressalta-se que era recorrente entre estudantes a realização de críticas em relação ao caráter - recorrendo a palavras de integrantes desse segmento - "puramente teórico", "distante da realidade" e "abstrato" desse curso. Aliás, é típica desse curso a predominância de disciplinas eminentemente teóricas. Apresentam-se, a seguir, alguns posicionamentos de participantes: 
Acredito que o papel do cientista social não é apenas teórico, deve ser também prático, empírico. A ida a campo durante a formação, por este motivo, é de extrema importância para a nossa formação. (ESTUDANTE I)

Além de ser uma [iniciativa] interessante e bastante importante para a formação acadêmica, [...] foi uma experiência de conhecimento de uma realidade um tanto velada para nós alunos urbanos. (ESTUDANTE A)

Acho fundamental que os estudantes saiam do espaço somente da universidade e conheçam as outras realidades que existem. (ESTUDANTE C)

[...] a gente lê muito no curso, mas [...] quando chega na prática, é difícil. Aquele texto de Antropologia ${ }^{54}$ teve outro sentido pra mim, depois do assentamento, porque, além de ser um texto difícil, pra mim ele era muito abstrato. [...] Acho que, agora, quanto eu ler textos da Antropologia, eu vou saber juntar as peças, porque antes eu ficava me perguntando sobre [o] para quê ler alguns textos dessa disciplina [...]. (ESTUDANTE J)

[...] fundamental, pois não ficamos só na teoria e conseguimos ver na realidade questões postas no nosso curso. (ESTUDANTE G)

A relação entre teoria e prática é uma polêmica histórica e recorrente na área da educação no Brasil, especialmente em se tratando de cursos de licenciaturas, cujos debates assumem configurações específicas, típicas dessa área (GATTI, 2010; MELLO, 1981; PIMENTA, 2010).

Alguns estudantes disseram que se tratou da sua primeira experiência de campo até aquele momento do curso.

Além de ser um trabalho coletivo, com a turma toda, todos os recursos, de estadia para a pesquisa e exploração do assentamento foram providos para uma primeira experiência de campo dos alunos. (ESTUDANTE A)

[...] iniciativas como esta, tão importantes e [que nas outras disciplinas] não se dão da mesma forma. (ESTUDANTE H)

[...] uma atividade muito importante para a nossa formação enquanto cientistas sociais. A considero desta forma, por tratar-se da primeira atividade empírica realizada após um ano e meio de curso. (ESTUDANTE I)

54 Argonautas do Pacífico Ocidental, de Bronislaw Malinowski. 
Para mim foi, de verdade, a primeira vez que eu participo de uma atividade como essa. Me apaixonei ainda mais pelo curso. Eu já adorava o curso, mas essa atividade prática me deu uma outra noção, deu outro sentido para mim, para poder ver como eu aplico o que aprendo nas disciplinas. (ESTUDANTE K)

A (con)vivência e a observação, principalmente em sala de aula, permitiram constatar, especialmente entre estudantes do primeiro e do segundo anos, indícios de dificuldades, expressas verbalmente por alguns deles, em relação ao acompanhamento do curso ou mais especificamente de algumas disciplinas. Entretanto, estudantes em fase de finalização, bem como egressos desse curso também relataram dificuldades para acompanhamento (com o desejado aproveitamento) quando cursaram o primeiro e o segundo anos especialmente. Com base nos dados levantados em estudos sobre leituras acadêmico-científicas na Graduação (SILVA, 2018; 2021), destaca-se que nem todos os estudantes conseguem, de forma espontânea e/ou sem a mediação docente, estabelecer conexões entre diferentes disciplinas do curso e/ou entre essas disciplinas e a realidade social.

Vale destacar que alguns estudantes consideraram reduzido ou insuficiente o tempo destinado à realização da atividade em campo, isto é, no acampamento e no assentamento. Ressalta-se que o trabalho de campo envolveu preparativos em sala de aula antes e depois da atividade em campo e, durante aulas precedentes, foi reiterado pelos docentes que o objetivo era propiciar uma oportunidade de um contato inicial com o trabalho empírico, com a mediação docente e para além dos ambientes da universidade.

Porém, para a realização de atividades como essa, são demandados trabalhos e empenhos extras - tanto de docentes, quanto de discentes -, se comparados às demandas para aulas no formato habitual e preponderante no curso, isto é, unicamente dentro da sala de aula ou no espaço do campus universitário e sem interlocução entre diferentes disciplinas do curso.

Há que se considerar, ainda, que a realização de atividades como o trabalho de campo e que não tenham um caráter de obrigatoriedade institucional ou legal tende a se tornar cada vez mais desafiadora, devido principalmente às crescentes demandas, sejam em termos de procedimentos administrativos, sejam em termos de 
produtividade colocadas aos docentes. O trabalho de campo requer condições adequadas, tanto para estudantes (vários realizam trabalho remunerado e/ou não têm disponibilidade para ausências mais prolongadas do trabalho e/ou da família, dentre outras situações adversas), quanto para docentes (tempo, outros compromissos acadêmicos, verbas, equipamentos etc.).

Outro ponto destacado foi a interlocução entre as disciplinas de Fundamentos da Geografia e de Fundamentos da Antropologia, durante uma das edições do trabalho de campo. Apresentam-se, a seguir, pontos de vista de alguns estudantes:

Creio [que] a interlocução entre as duas disciplinas [...] é muito produtiva, considerando que o ambiente visitado, pela sua idiossincrasia político-territorial e de ser um lugar onde as relações sociais ocorrem de forma diferente, tornou um terreno muito fértil para o trabalho nas duas disciplinas. (ESTUDANTE A)

Ótima, pois foram duas visões sobre o trabalho de campo. (ESTUDANTE D)

Durante a pesquisa de campo, as questões antropológicas e geográficas por muitas vezes se misturavam. Desta forma, sob meu ponto de vista, o conhecimento em campo se tornou mais enriquecedor. Questões como identidade, estereótipos entre outros, estavam diretamente ligados à questão da terra. (ESTUDANTE H)

Importante [pois] [...] dá para relacionar as duas matérias. (ESTUDANTE G)

Eu avalio como sendo boa a interlocução entre as disciplinas de Fundamentos de Geografia e de Antropologia durante o trabalho de campo. Principalmente no momento anterior à ida a campo, nas aulas em que trabalhamos os textos $^{55}$ de Malinowski e Foote-Whyte sobre como fazer e as dificuldades do trabalho empírico. (ESTUDANTE I)

Com base no que foi expresso pelos participantes, considera-se que a interlocução entre as disciplinas propiciou maior aporte teórico-prático aos estudantes, tanto para e durante a realização do trabalho de campo, quanto posteriormente, para a realização, em sala de aula, das atividades pedagógicas decorrentes desse trabalho. Estudantes que participaram das duas edições do trabalho de campo, isto é, da de

55 Esse estudante faz referência aos textos estudados na disciplina de Fundamentos de Antropologia com vistas especificamente ao trabalho de campo, quais sejam, Argonautas do Pacífico Ocidental, de Bronislaw Malinowski, e Treinando a observação participante, de William Foote-White. 
2011, na qual ocorreu a interlocução, e da de 2012, na qual não ocorreu a interlocução, disseram que eram perceptíveis e significativas as diferenças decorrentes da não interlocução, tanto em relação aos seus próprios desempenhos, quanto em relação aos desempenhos de outros estudantes. Isso porque, como apontado, na edição de 2011, houve, em ambas disciplinas, uma preparação específica para a realização do trabalho de campo.

Quanto à pertinência e à viabilidade da realização de atividades análogas ao trabalho de campo, porém, envolvendo outras disciplinas do curso, todos os participantes responderam afirmativamente. Alguns posicionamentos são apresentados a seguir:

Sim, o trabalho de campo entre outras disciplinas romperia, em certa medida, com as 'fronteiras' que separam a instituição acadêmica (a teoria) do mundo, da realidade que nos cerca e muitas vezes nos é desconhecida. [...] um ponto positivo [...] desta interlocução [...] seria a percepção de que a separação de disciplinas que vemos no sistema educacional pode não se dar na prática, pois várias questões são interligadas e fazem parte de nosso cotidiano. (ESTUDANTE H)

Claro, a disciplina de política, por exemplo, está bem relacionada ao tema, devido ao amplo estudo dos movimentos sociais. Embora exista a possibilidade de envolvimento com outras disciplinas, isso fica um tanto delicado, devido às particularidades destas. (ESTUDANTE A)

Estamos nos formando em um curso de Ciências Sociais e a interlocução entre as matérias é indispensável. A interlocução, na verdade, deveria ser entre todas as matérias do curso e não somente entre Geografia e Antropologia. Devido à especialização presente em nossa sociedade, é difícil fazer a interlocução, mas vejo essa dificuldade como algo produtivo e fundamental no curso. (ESTUDANTE B)

Acho que um trabalho conjunto que envolva todas as áreas do curso é importante, já que as disciplinas têm uma ligação. (ESTUDANTE C)

Seria bastante interessante um diálogo entre as diferentes disciplinas [...] há muitos pontos de convergência e uma tem muito a acrescentar a outra. [...] uma formação ampla e multidisciplinar ocorreria não apenas do ponto de vista teórico, como também empírico. (ESTUDANTE I) 
Entretanto, alguns estudantes apresentaram ressalvas em relação à pertinência e à viabilidade de realização de atividades análogas ao trabalho de campo envolvendo outras disciplinas desse curso:

Sim, porém, deve-se considerar quais disciplinas. $O$ fato de ir ao campo literalmente a fim de estudar as questões de aula, creio eu, devem estar condizentes com o tema estudado pela matéria, caso contrário ficará algo um tanto deslocado. (ESTUDANTE A)

[...] eu adoraria, mas acho que não daria tão certo como esta, porque seriam muitos professores a serem envolvidos. $E$ também acho que nem toda disciplina dá certo para isso, por exemplo, Filosofia e Psicologia. (ESTUDANTE L)

Sim, se conseguir que seja agradável e que seja levado a sério, tanto para quem coordena o trabalho de campo, quanto para o aluno. (ESTUDANTE F)

Penso que o envolvimento de várias disciplinas em uma pesquisa de campo seria inviável tendo em vista uma maior organização que esta necessitaria, apesar de [...] a separação de disciplinas serem formas de 'arranjos' institucionais para aplicação de conhecimento. (ESTUDANTE H)

O "Projeto Político Pedagógico" do curso em tela, que coloca dentre os seus objetivos a articulação entre "pesquisa, ensino e extensão", diz que

O objetivo principal do Curso de Ciências Sociais da UNESP, Campus de Marília, é proporcionar uma formação teórica básica dos fundamentos das Ciências Sociais, bem como a compreensão das metodologias das diversas áreas do conhecimento, de modo a proporcionar aos profissionais, tanto do Bacharelado como da Licenciatura, uma visão interdisciplinar, múltipla e mais próxima da realidade que todo cientista social e docente deve ter e compreender. (UNESP, 2018, p. 2, grifos nossos)

É recorrente em projetos político-pedagógicos, na literatura acadêmico-científica e na produção discursiva docente a defesa da interdisciplinaridade ou mesmo da transdisciplinaridade, em contraposição à perspectiva disciplinar (FAZENDA, 2003).

Porém, ações no sentido de superação de abordagens disciplinares pareciam incomuns e incipientes, pois requerem, entre outros fatores, a disponibilidade de docentes (a serem) envolvidos ou mesmo alterações estruturais no curso.

Assim, o fato de o trabalho de campo integrar formalmente as atividades da disciplina de Fundamentos da Geografia configura-se como um diferencial. Isso por- 
que não são incomuns visitas de estudantes a acampamentos e assentamentos da reforma agrária, inclusive nos mencionados neste texto, porém, não raramente, são atividades sem vínculo formal curricular ou então são organizadas por estudantes ou suas entidades.

O trabalho de campo teve repercussões para além dos aspectos mais pedagógicos, isto é, voltados para as finalidades das disciplinas. Alguns participantes destacaram outras contribuições dessa atividade para a sua formação:

Foi uma experiência boa. É um trabalho muito importante, pois nos permite conhecer a verdadeira realidade do movimento dos sem-terra. (ESTUDANTE C)

Foi interessante no sentido da vivência apreendida durante o [trabalho] de campo, entender a luta dos integrantes do MST e até simpatizar pela causa. (ESTUDANTE F)

A experiência, não só acadêmica, mas pessoal. (ESTUDANTE G)

[...] uma lição de vida, de solidariedade, de garra, de organização etc. Também de respeito, outras culturas, outros jeitos de viver [...]. Isso não faz parte da minha realidade do dia a dia. Se não fosse por esse trabalho, provavelmente eu jamais teria conhecido esse espaço, essas pessoas [...]. (ESTUDANTE M)

Vários estudantes relataram que, anteriormente ao trabalho de campo, nunca estiveram em um acampamento ou em um assentamento da reforma agrária. Alguns disseram também que nunca estiveram em áreas rurais.

[...] acho que para vocês, que são do interior, pode até parecer estranho, mas, eu sou muito urbanoide, eu nunca tive oportunidade de estar numa área rural. Eu ia muito para o litoral, mas, ruralzão, como aqui, nunca. Eu via o rural quando passava pelas rodovias, mas nunca pude parar, conversar com eles, pisar na terra, respirar esse ar [...]. (ESTUDANTE K)

[...] você viu quando [nome citado suprimido intencionalmente] falou sobre o que a sua mãe disse, quando ele falou que ia no assentamento? A minha situação é bem parecida com essa. Eu imaginava totalmente o contrário do que eu vi. [...] Quando eu contar pra minha mãe que eu estive lá, ela vai ter um ataque [...]. (ESTUDANTE J)

Alguns estudantes relataram, também, que, até o momento do trabalho de cam- 
po, suas informações acerca da questão da reforma agrária, dos movimentos sociais do campo e assuntos correlatos eram pautadas pela mídia hegemônica. Outros abordaram a imagem difundida por essa mídia:

[...] o trabalho de campo foi a atividade com a qual [...] mais e melhor [...] pude aprender, conhecendo empiricamente sobre reforma agrária e Movimento dos Trabalhadores Rurais Sem Terra [...], rompendo com pré-noções e estereótipos. (ESTUDANTE I)

[...] foi importante como forma de conhecermos a realidade da luta do MST e dos diversos indivíduos e suas famílias. [...] de certa forma, nos aprofundar na questão agrária que se apresenta tão distorcida nos meios de comunicação. (ESTUDANTE H)

[...] no caso dos sem terra foi ótima a troca de experiências e a desconstrução de estereótipos criados pelas diversas mídias. (ESTUDANTE B)

[...] a visão que eu tinha deles era toda estereotipada, porque tudo o que eu sabia deles era pelo Jornal Nacional [...] Na faculdade, meus assuntos de interesse são outros, então, diferente de algumas pessoas aqui, eu não estudo essas questões [...]. Eu saí com uma outra visão sobre eles [...]. (ESTUDANTE K)

Segundo Jezus (2010, p. 332), “[...] ideias reacionárias e conservadoras, que normalmente se opõem às propostas de reforma agrária e, muitas vezes, ainda criminalizam os legítimos movimentos sociais de luta pela terra, especialmente o Movimento de Trabalhadores Rurais Sem-terra (MST), prevalecem na mídia."

Assim, o trabalho de campo propicia condições para que os estudantes avancem inclusive no processo de formação acadêmica, especialmente no que se refere à autonomia intelectual, ao posicionamento crítico e à metodologia da pesquisa científica.

[...] foi marcante para mim. E não só para mim, acho que para todo mundo. Oportunidade única. Eu nunca me imaginei em um acampamento de pessoas sem-terra. [...] Aprendi pra caramba. Eu quero ir para a Antropologia e esse trabalho está me ajudando a entender a parte metodológica, porque quando a gente lê a bibliografia, parece fácil, mas quando a gente 'cai no campo', aí a coisa pega, porque é preciso colocar a teoria na prática [...]. (ESTUDANTE M) 
[...] eu achei importante, porque vai me ajudar bastante, porque no próximo ano eu quero submeter minha bolsa de iniciação científica e tem bastante coisa que eu tenho dúvidas. Aqui, por exemplo, eu consegui esses detalhes metodológicos, do como fazer na prática, do como explicar no projeto, enfim, essas coisas burocráticas que a gente precisa fazer. (ESTUDANTE L)

Pontos positivos: o diálogo entre as duas áreas de conhecimento. As orientações de como nos portarmos em campo, observar, entrevistar, vindas sobretudo da disciplina de Fundamentos de Antropologia foram de grande valia para o trabalho como um todo. (ESTUDANTE I)

Para Silva Júnior (1996, p. VII), "[...] espera-se ainda e principalmente que a universidade não se reduza à tarefa da formação profissional sem colocar em questão os rumos dessa formação e sem analisar criticamente as determinações que envolvem a formação pretendida e oferecida." Dessa perspectiva, o compromisso da universidade extrapola a dimensão estritamente pedagógica.

Simonetti (2011, p. 7) argumenta que "A demanda por terra dos Sem Terra e suas experiências realizadas nos acampamentos e assentamentos, clama por compreensão visto que nenhuma sociedade pode pensar em mudanças sem refletir profundamente sobre todos os seus segmentos sociais."

Ressalta-se o potencial educativo dos movimentos sociais contra-hegemônicos, inclusive para fins de constituição de uma visão crítica acerca da sociedade (AGUIRRE ROJAS, 2012; BARBOSA, 2016; DAL RI; VIEITEZ, 2008), bem como das atividades de extensão para a formação dos estudantes (FERNANDES et al, 2016; LOUREIRO, 2010).

Conforme Cassin e Goldschmidt (2014, p. 12),

[...] com relação aos assentamentos rurais, inferimos que os ataques que eles têm sofrido pela elite e também pela classe média são a potencialidade educativa e formativa que carregam. Do ponto de vista educativo, em seu sentido mais amplo, de processos de introjeção e incorporação das experiências vivenciadas nos acampamentos com as ocupações, as assembleias, formação de coletivos, as marchas e atos, como também cursos e oficinas que os movimentos sociais possibilitam para os acampados e apoiadores vão constituir um conjunto de ações educativas tácitas e intencionais que elevam o nível de consciência política dos envolvidos. 
Considera-se que o trabalho de campo propiciou elementos que contribuíram para uma noção mais ampla e aprofundada de um dos mais prementes e históricos problemas sociais no Brasil, qual seja, a questão do latifúndio, que tem várias implicações políticas, econômicas e culturais. Contribuiu, ainda, para uma melhor compreensão de outras questões históricas e relevantes que afetam a sociedade brasileira e que implicam algum tipo de imbricação com o latifúndio, como, por exemplo, a relação entre campo e cidade, a reforma agrária, a questão ambiental, a migração, o agronegócio (e seu contraponto, a agroecologia), a educação no/do ${ }^{56}$ campo, os equipamentos públicos de uso coletivo, os conflitos sociais no campo, dentre outros temas que afetam principalmente (mas não somente) acampados e assentados da reforma agrária e também, em alguma medida, outros segmentos de povos do campo.

\section{CONSIDERAÇÕES FINAIS}

O trabalho de campo foi avaliado positivamente pelos estudantes participantes deste estudo, que destacaram as suas contribuições para avanços na articulação entre o currículo e aspectos da realidade social, mais especificamente aqueles atinentes à questão da terra (e da Terra) no Brasil. A interlocução entre as disciplinas de Fundamentos da Geografia e de Fundamentos da Antropologia durante o trabalho de campo foi destacada como potencializadora do processo de ensino-e-aprendizagem.

No entanto, a realização de atividades como essa implica, cada vez mais, diversos desafios, decorrentes de variados fatores, em especial a crescente precarização das condições de trabalho docente e as dificuldades materiais para a sua consecução equipamentos, transporte, dentre outros -, que implicam ônus financeiros, em uma conjuntura de intensificação de corte de verbas para a educação pública.

Considera-se oportuno ressaltar uma questão atualmente em discussão no âmbito acadêmico, qual seja, a implementação da carga horária referente a atividades de extensão no currículo. Vale destacar que a extensão é uma demanda histórica de

56 Por um lado, nem toda escola instalada no campo é uma escola do campo, na acepção crítica de Educação do Campo. Por outro lado, uma escola do campo precisa ser, necessariamente, instalada no campo. Educação para, no ou do campo é uma questão que gera polêmicas entre diversos setores da sociedade brasileira, inclusive no âmbito acadêmico (CALDART, 2012; CASSIN; NALLI, 2016; MORAES, 2019). 
segmentos da universidade mais vinculados a movimentos populares e defensores de uma maior inter-relação entre a universidade e a sociedade. Entretanto, por outro lado, o pensamento hegemônico no Ensino Superior brasileiro tem, cada vez mais, impulsionado perspectivas que prejudicam a indissociabilidade entre ensino, pesquisa e extensão.

\section{REFERÊNCIAS}

AGUIRRE ROJAS, Carlos Antonio. Movimientos antisistémicos: pensar lo antisistémico en los inicios del Siglo XXI. Rosario: Prohistoria Ediciones, 2012.

ALMEIDA, José Luís Vieira de. As atividades de ensino: equívocos e perspectivas. In: UNESP. $V$ Circuito PROGRAD: as atividades de seu curso atendem ao perfil do profissional a ser formado? São Paulo: UNESP PROGRAD, 1996. p. 3-12.

BARBOSA, Lia Pinheiro. Educación, resistencia y conocimiento en América Latina: por una teoría desde los movimientos sociales. De Raíz Diversa, Ciudad de México, v. 3, n. 6, p. 45-79, jul./dez., 2016. Disponível em: <http://revistas.unam.mx/index. php/deraizdiversa/article/view/58425>. Acesso em: 30 dez. 2020.

CALDART, Roseli Salete. Educação do campo. In: CALDART, Roseli Salete et al (org.). Dicionário da educação do campo. Rio de Janeiro, São Paulo: Escola Politécnica de Saúde Joaquim Venâncio; Expressão Popular, 2012. p. 259-267.

CASSIN, Marcos; GOLDSCHIMDT, Mírian Helena. Notas sobre os assentamentos rurais na reforma agrária e seu papel na qualificação, formação e educação dos assentados. Aurora, Marília, v. 8, p. 1-15, 2014. Disponível em: <https://revistas.marilia. unesp.br/index.php/aurora/article/view/4714>. Acesso em: 13 nov. 2020.

DAL RI, Neusa Maria et al. Educação democrática, trabalho e organização produtiva no Movimento dos Trabalhadores Rurais Sem Terra (MST). Marília: Oficina Universitária; São Paulo: Cultura Acadêmica, 2019.Disponível em: <https://ebooks.marilia. unesp.br/index.php/lab_editorial/catalog/book/160>. Acesso em: 27 nov. 2020.

DAL RI, Neusa Maria; VIEITEZ, Candido Giraldez. Educação democrática e trabalho associado no Movimento dos Trabalhadores Rurais Sem Terra e nas fábricas de autogestão. São Paulo: Ícone: FAPESP, 2008.

FAZENDA, Ivani Catarina Arantes. Interdisciplinaridade: qual o sentido? São Paulo: Paulus, 2003.

FERNANDES, Silvia Aparecida de Sousa et al. Cinema, juventude e ruralidades: for- 
mação crítica e educação geográfica no meio rural. Revista Anekumene, Bogotá, v. 1, p. 285, 2016. Disponível em: <https://revistas.pedagogica.edu.co/index.php/anekumene/article/view/8358/6433>. Acesso em: 9 mai. 2019.

GATTI, Bernardete Angelina. Formação de professores no Brasil: características e problemas. Educ. Soc., Campinas, v. 31, n. 113, p. 1355-1379, out.-dez., 2010. Disponível em <http://www.cedes.unicamp.br>. Acesso em: 6 jun. 2014.

GIL, Antônio Carlos. Métodos e técnicas de pesquisa social. 2. ed. São Paulo: Atlas, 1987.

JEZUS, Luiz Alberto de. A questão agrária no Brasil. In: MARQUES, Rosa Maria; FERREIRA, Mariana Ribeiro Jansen (org.). O Brasil sob a nova ordem: a economia brasileira contemporânea: uma análise dos governos Collor a Lula. São Paulo: Saraiva, 2010. p. 331-351.

LOUREIRO, Braulio Roberto de Castro. O Projeto Hip-Hop Com/ciência: ação político-educacional na periferia de Marília. Arma da Crítica, Fortaleza, a. 2, dez., p. 294-301, 2010. Disponível em: <http://www.armadacritica.ufc.br/phocadownload/relato_1.pdf >. Acesso em: 14 mar. 2020.

MELLO, Suely Amaral. A teoria, na prática, é outra? Um estudo das mediações teoria e prática na ação educativa - Supletivo Caaso: um estudo de caso. 1981. 128 f. Dissertação (Mestrado em Educação) - Centro de Educação e Ciências Humanas, Universidade Federal de São Carlos, São Carlos.

MORAES, Agnes lara Domingos. A circulação das ideias do Movimento pela ruralização do ensino no Brasil (1930-1950). 2019. 272 f. Tese (Doutorado em Educação) - Faculdade de Filosofia e Ciências, Universidade Estadual Paulista.

MUNAKATA, Kazumi. O livro didático: alguns temas de pesquisa. Revista Brasileira de História da Educação, Campinas, v. 12, n. 3 (30), p. 179-197, set./dez., 2012. Disponível em: <http://www.periodicos.uem.br/ojs/index.php/rbhe/article/view/38817>. Acesso em: 25 jul. 2014.

OLIVIER, Ramiro; PERCASSI, Jade. Assentamento Reunidas comemora 25 anos e homenageia Seu Luiz Beltrame. Jornal Sem Terra, São Paulo, set./out./nov., p. 6-6, 2014.

PIMENTA, Selma Garrido. O estágio na formação de professores: unidade, teoria e prática?. 9. ed. São Paulo: Cortez, 2010.

SILVA, Cláudio Rodrigues da. Leituras acadêmicas em curso de formação de pro- 
fessores: o que dizem os estudantes? In: LEAL, Luciana Ferreira; MORAES, Agnes lara Domingos (org.). Literatura, leitura e escrita: interfaces. Porto Alegre: Editora Fi; Tupã: Editora Faccat, 2018. p. 41-69. Disponível em: <https://www.editorafi.org/439literatura>. Acesso em: 19 jun. 2019.

SILVA, Cláudio Rodrigues da. Leituras das bibliografias básicas das disciplinas por estudantes de cursos de graduação: o que dizem docentes do ensino superior? In: OLIVEIRA, Daniele Ramos de; MORAES, Agnes lara Domingos (org.). Diálogos pertinentes sobre educação: o ensino fundamental de nove anos em foco. Porto Alegre, RS: Editora Fi, 2021. p. 220-255. Disponível em: <https://drive.google.com/file/d/ 12suocZv7e8GYbJpQuwKVYks6tk1hpYhd/view>. Acesso em: 15 fev. 2021.

SILVA JÚNIOR, Celestino Alves da. Apresentação. In: UNESP. V Circuito PROGRAD: as atividades de seu curso atendem ao perfil do profissional a ser formado? São Paulo: UNESP PROGRAD, 1996. p. VII-VIII.

SIMONETTI, Mirian Cláudia Lourenção. Apresentação. In: SIMONETTI, Mirian Cláudia Lourenção. (org.). Assentamentos rurais e cidadania: a construção de novos espaços de vida. São Paulo: Cultura Acadêmica; Marília: Oficina Universitária, 2011. p. 7-11.

SIMONETTI, Mirian Cláudia Lourenção et al. Pesquisa de opinião publica: movimentos sociais e reforma agrária. Boletim DATALUTA, Presidente Prudente, v. 54, p. 02-05, 2012. Disponível em: <https://repositorio.unesp.br/bitstream/handle/11449/115143/ ISSN21774463-2012-00-52-02-05.pdf?sequence=1\&isAllowed=y>. Acesso em: 10 set. 2016.

UNESP. Projeto Político Pedagógico do curso de Ciências Sociais - Modalidades: Bacharelado e Licenciatura. 2018. Disponível em: <https://www.marilia.unesp.br/Home/ Graduacao/CienciasSociais/projeto_politico_pedagogico-2018.pdf>. Acesso em: 20 abr. 2019. 


\title{
A PRODUÇÃO SUCROALCOOLEIRA NA
} PARAÍBA E O DESENVOLVIMENTO DO TERRIOTÓRIO CAMPONES NA PERSPECTIVA DA EDUCACAO DO/NO CAMPO

\author{
Lenira Lins da Silva ${ }^{57}$ \\ Juliane Faustino da Silva ${ }^{58}$ \\ Edvaldo Carlos de Lima ${ }^{59}$
}

$57 \quad$ Graduanda em Geografia pela Universidade Estadual da Paraíba Campus III - Guarabira. Membro do Centro de Estudos Agrários e do Trabalho (CEAT), sob orientação do Professor Dr. Edvaldo Carlos de Lima, e-mail: leniralins.gba@gmail.com

58 Graduanda em Geografia pela Universidade Estadual da Paraíba Campus III- Guarabira. Membro do Centro de Estudos Agrários e do Trabalho. Bolsista PIBIC com apoio do CNPq, sob orientação do Professor Dr. Edvaldo Carlos de Lima, e-mail: julianefaustino12@gmail.com 59 Professor do Departamento de Geografia da Universidade Estadual da Paraíba - Campus III - Guarabira. Coordenador do Centro de Estudos Agrários e do Trabalho (CEAT); orientador e-mail: edvaldo.edvlima@gmail.com 
O Brasil é considerado o maior produtor de cana-de-açúcar em nível mundial e se tornou um dos pilares da economia brasileira impulsionado, principalmente, pela demanda do etanol no mercado internacional. Inicialmente o açúcar era o principal produto produzido nos antigos engenhos, entretanto, na década de 70, o Programa Nacional de Álcool (PROÁLCOOL) e os incentivos governamentais trouxeram uma nova demanda para a cadeia produtiva da cana no país, com novas visões econômicas voltadas para produzir etanol e bioenergia.

No discurso a respeito da utilização de energias alternativas renováveis, a redução da emissão de gazes poluentes vem acentuando a produção de etanol proveniente da cana destilada. $O$ investimento em tecnologia para o biocombustível proveniente da cana-de-açúcar, decorrente da crise do petróleo, e a expectativa de ampliar a exportação para o mercado internacional foram essenciais para expandir a produção do biocombustível decorrente da expansão do mercado de automóveis flex a partir de 2003.

O estado da Paraíba é considerado o terceiro maior produtor de cana-de-açúcar do Nordeste, em extensão de área plantada. Na Zona da Mata paraibana, também chamada de Zona da Cana, predomina a monocultura. A cana foi um dos primeiros produtos cultivados na Paraíba, desde o período colonial, por ser propícia para o desenvolvimento da agricultura, que, inicialmente, foi voltada, sobretudo, para o cultivo da cana direcionada à produção do açúcar.

Considerando esse contexto, pode-se afirmar que as relações capitalistas de produção vêm se territorializando no espaço agrário brasileiro em forma de agronegócio. Isso resulta em concentração de terras e dificulta o desenvolvimento da agricultura familiar. Nesse cenário, a educação do/no campo, junto com os movimentos sociais, é uma ferramenta importante na luta dos trabalhadores/as e dos pequenos agricultores familiares contra o avanço do agronegócio sucroalcooleiro. Essa articulação é organizada em nível nacional, estadual e local, influenciada, principalmente, pelo Movimento dos Trabalhadores Rurais Sem Terra - MST.

Devido às intempéries que permeiam a questão agrária no Brasil, um fator 
que continua em evidência são os conflitos de classes entre os grandes produtores agroindustriais e a população campesina, que é usada como mão de obra barata e explorada nos canaviais e nas destilarias em trabalhos análogos à escravidão. Porém isso não acontece somente na Paraíba, mas em todo o Brasil e, com mais força, no Centro-Sul.

Partindo desse contexto de conflitos, o objetivo central deste trabalho é de analisar o antagonismo territorial existente entre dois territórios distintos: o território do agronegócio canavieiro e o território camponês. Atrelada a esse descompasso, a educação do campo surge como um instrumento de resistência e de reinvindicação dos/as trabalhadores/as rurais. Portanto, reuniram-se informações com o propósito de responder ao seguinte problema da pesquisa: Como a educação do campo pode influenciar diretamente o projeto de desenvolvimento do campo?

Nessa perspectiva, é necessário compreender o papel da educação do/no campo para o desenvolvimento territorial dos assentamentos de reforma agrária em relação ao avanço do capital agroindustrial da cana-de-açúcar no estado na Paraíba. Visivelmente nos leva a analisar de que forma as práticas de ensino e os conteúdos trabalhados nas unidades escolares existentes nos assentamentos podem contribuir para uma formação que ultrapasse as barreiras do capital.

O estudo territorial sobre a produção sucroalcooleira pode contribuir para que possamos compreender a atual realidade da questão agrária na Paraíba e a luta pela terra e pela educação do/no campo. É importante não apenas para o meio acadêmico, mas também para os/as trabalhadores/as do campo, em sua luta histórica e espacial, por meio da articulação dos movimentos sociais para ter acesso à terra. Com esse intuito, apresentamos os resultados das nossas pesquisas, desenvolvida na Universidade Estadual da Paraíba, Campus III - Guarabira-PB, na Iniciação Cientifica (PIBIC), cota 2019/2020, com apoio do Conselho Nacional de Desenvolvimento Científico e Tecnológico (CNPq).

Os resultados contidos neste trabalho são relevantes para que possamos entender as contradições existentes na expansão da agricultura capitalista, por meio da produção da monocultura da cana na Zona da Mata paraibana. Diante dessa realidade, as escolas que trabalham na perspectiva da educação do/no campo assumem 
o desafio de desenvolver uma educação nas unidades escolares que transforme e forme para além dos interesses capitalistas. Uma educação direcionada para um projeto maior voltado para o desenvolvimento territorial do campo.

Para dar respaldo ao objetivo proposto, utilizou-se como procedimento metodológico uma pesquisa bibliográfica, baseado em uma pesquisa teórica, através de leituras realizadas na Iniciação Científica. A leitura das obras de autores como Fernandes (2012), Lima (2013), Feliciano (2006), Caldart (2012), Oliveira (2007), entre outros, que trabalham com temas relevantes como desenvolvimento territorial, reforma agrária, questão agrária e educação do campo foi muito importante para fundamentar este artigo.

Para desenvolver a contento o tema proposto, foi necessário, além de consultar as bibliografias citadas, recorrer a sites renomados, como CONAB, NOVACANA, UNICA e IBGE. Esses canais de pesquisas são ferramentas importantes para o acesso a informações e dados estatísticos, com o objetivo de expor resultados organizados em tabelas satisfatórios para se entender a pesquisa.

No que diz respeito à estrutura, este artigo foi dividido em três subtítulos. No primeiro, apresenta-se o desenvolvimento, que traz alguns conceitos importantes para se entender o tema proposto; no segundo, aborda-se o contexto da produção sucroalcooleira na Paraíba, com foco na Zona da Mata, destacando os principais municípios e a quantidade de cana processada entre os anos de 2010 e 2020; no terceiro item, apresentam-se os resultados e as discussões a respeito da importância das lutas históricas dos movimentos sociais para se ter acesso à terra e, principalmente, os conteúdos que devem ser trabalhados nas escolas do campo, com o objetivo de manter a identidade campesina e como plano para o desenvolvimento territorial do campo e a soberania alimentar na contramão da monocultura da cana-de-açúcar.

\section{DESENVOLVIMENTO}

As leituras realizadas durante as pesquisas desenvolvidas no Programa de Iniciação Científica possibilitaram a compreensão da dialética que envolve as questões agrárias no Brasil, sobretudo na Paraíba, em suas diversas dimensões. $\mathrm{Na}$ atual conjuntura, que envolve o mercado nacional e o internacional, o território do agrone- 
gócio canavieiro, com seus impactos socioambientais, tem se expandido com muita rapidez.

No Brasil, a forte atuação do setor sucroalcooleiro tornou-se um dos temas mais debatidos por grandes estudiosos da questão agrária brasileira, porque seus impactos não abrangem somente a grande concentração de terras, mas também a expropriação dos camponeses e dos indígenas e a exploração da força de trabalho em situações precárias semelhantes ao trabalho escravo. Além desses problemas, podemos citar os sérios impactos ambientais provocados pela monocultura da cana-de-açúcar. Para Fernandes (2008), no contexto atual, a questão agrária envolve uma disputa territorial entre a agricultura familiar e a agricultura capitalista como diferentes totalidades.

Em seus estudos, Oliveira (2007) assevera que, por meio do processo de modernização, a agricultura se tornou submissa ao modo de produção capitalista. $O$ mais preocupante, contudo, é constatar que, para efetivar a estrutura agrária contemporânea, é necessário concentrar terra com base em grandes latifúndios, concentrar renda, sujeitar os camponeses ao trabalho assalariado e acumular capital. Não é exagero afirmar que, nesse contexto, as transformações ocorridas com a entrada do capital no campo começaram a dar forma à estrutura agrária atual, que visa monopolizar a agricultura. Em todo esse processo, houve mudanças nas relações socioeconômicas no espaço rural.

Conforme explicado acima, é interessante afirmar que o modo de produção capitalista é o grande responsável pela divisão de classes, que se configura como uma ampla desigualdade. Preocupa o fato de que o paradigma do capitalismo agrário visa destruir o campesinato, e transformá-lo de acordo com sua lógica de produção seria uma espécie de metamorfose, em que o camponês passa a ser agricultor familiar, segundo Fernandes (2008), porque, à medida que os camponeses adentram a lógica do capital, sua identidade e características próprias vão sendo perdidas.

Uma questão que precisa ser compreendida é o fato que, em meio ao processo contraditório de desenvolvimento do capitalismo, a agricultura familiar se enquadra na ótica do capitalismo porque é capaz de entrar no mercado e de se modernizar e negociar. Trata-se inegavelmente da diferença entre a agricultura camponesa e a 
agricultura familiar. A primeira entende o campo como uma forma de vida e de liberdade e demonstra um vínculo com a terra. Já a segunda apresenta uma dimensão voltada para se integrar ao mercado e à comercialização na busca por resultados (FELICIANO, 2006). O autor deixa claro que seria um erro não admitir que a visão de desenvolvimento do campesinato apresenta dimensões que assumem sentidos totalmente diferenciados para o desenvolvimento do campo.

Ressalte-se, entretanto, que o modelo de desenvolvimento baseado no agronegócio é totalmente excludente e serve como máquina de manobra para o capitalismo organizar o espaço agrário visando aos seus interesses meramente comerciais. Para isso, é necessário ocupar outros territórios, o que gera conflitos (FERNANDES, 2008). Esse processo ocorre com a territorialização do agronegócio no território camponês e indígena, inserção de máquinas, sementes transgênicas, agrotóxicos para expandir a produção da monocultura para a exportação.

O modelo de desenvolvimento baseado no agronegócio é totalmente excludente e serve como máquina de manobra para o capitalismo organizar o espaço agrário visando aos seus interesses mercadológicos com incentivos políticos governamentais. "Para isso, é necessário ocupar outros territórios. Desse modo, as políticas promovem o fortalecimento das relações capitalistas em detrimento das não-capitalistas" (FERNANDES, 2008, p. 53). Esse processo ocorre com a territorialização do agronegócio, no território camponês e no indígena, a inserção de máquinas, sementes transgênicas e agrotóxicos, com o objetivo de expandir a produção da monocultura para a exportação, que aumentam consideravelmente o desemprego.

Em tese, o Nordeste brasileiro é parte importante da questão agrária atual, porque foi uma das primeiras regiões colonizadas no país, razão por que é palco de conflitos e de resistência de vários movimentos sociais, ao longo da história, e cujos trabalhadores lutam contra a dominação do agronegócio. Esse embate dos movimentos sociais ocorre em forma de acampamentos e assentamentos. De acordo com Lima (2011),

Essa perspectiva analítica nos leva a indagar de forma mais aprofundada os desdobramentos do modelo de desenvolvimento do capitalismo monocultor para a classe trabalhadora, especificamente para os trabalhadores rurais na luta por terra e acampados na zona da cana, que ao tempo são explorados 
e precarizados no trabalho de corte da cana nas usinas de açúcar e etanol (LIMA, 2011, p.111).

O autor deixa claro a problemática do capital sucroalcooleiro. No Nordeste, os principais produtores de cana-de-açúcar são os estados de Alagoas, Pernambuco e Paraíba. Julgamos pertinente trazer à baila que a produção canavieira vem provocando uma série de problemas nesses estados, perceptíveis nas transformações da paisagem, a qual tem vários hectares de terras cobertas de cana, totalmente homogênea, conhecida como Zona da Mata Atlântica e, agora, "Zona da cana", quase extinta, devido à exploração dos recursos naturais para a produção de açúcar e de etanol.

A Paraíba é considerada o terceiro maior produtor de cana-de-açúcar do Nordeste, de acordo com a União da Indústria de Cana-de-açúcar (UNICA). Esse processo não é resultado de um fenômeno recente, porque esse estado foi uma das primeiras áreas a serem colonizadas no país, e sua estrutura agrária é marcada pela concentração de terras e renda. A cana faz parte do desenvolvimento socioeconômico desde o período colonial, quando era usada para produzir açúcar. Atualmente o etanol é seu principal derivado e um dos pilares da economia que intensificou a tomada de territórios para sua expansão. Sobre essa prerrogativa, as relações sociais, culturais, políticas, ambientais e econômicas se modificaram.

A Paraíba continua sendo palco de conflitos entre trabalhadores sem-terra por causa do avanço do setor sucroalcooleiro. Por isso, não podemos deixar de lado a mobilização de alguns movimentos importantes ao longo da história, como as Ligas Camponesas, e os mais recentes, como o MST e o CPT, como agentes importantes para ${ }_{a}$ manutenção do território camponês.

Devido aos conflitos territoriais, a educação do campo vem assumindo um papel imprescindível na luta dos trabalhadores sem-terra como uma das várias dimensões para o desenvolvimento camponês. Todavia, considerando os aspectos distintos entre o território do agronegócio e o território camponês, a educação também deve ser diferenciada. Para isso, os métodos, as teorias e os conteúdos a serem trabalhados nas escolas do/no campo devem corresponder aos aspectos próprios desse contexto (FERNANDES, 2008). Consequentemente, o resultado será um ensino e uma aprendizagem diferenciados. 
A educação do campo é um paradigma erguido a partir da questão agrária, portanto, é um território imaterial, que foi se constituindo como parte das políticas ideológicas pautadas na visão campesina, como refere (CAMACHO, 2013). Contudo, o debate sobre essa concepção de educação concretiza-se em uma percepção de campo como território em disputa, entre o modo de viver do camponês e as formas de territorializar o agronegócio. Na verdade, a educação do campo opta por uma luta que envolve liberdade e emancipação dos sujeitos, com elementos socioeducativos que prezem pela manutenção da identidade e da cultura camponesa, em contraposição à ideia destrutiva dessas particularidades pelo capital agroindustrial.

Convém enfatizar que, na Paraíba, a produção de etanol vem expandindo a produção de cana-de-açúcar. Dessa forma, o capital em forma de agronegócio também expande seus territórios. Essa realidade vem causando sérios problemas ambientais e sociais decorrentes de sua forma exploratória e destrutiva. Consequentemente, a complexidade da realidade contraditora imposta no campo vem gerando conflitos liderados pelos movimentos sociais em contraposição ao avanço do capital. Assim, com sua proposta de emancipação, o "paradigma da educação do campo" concebe a educação como um instrumento de reivindicação e de resistência. Nesse sentido, seu objetivo é de lutar para desterritorializar o agronegócio e, por conseguinte, territorializar o camponês.

\section{RESULTADOS E DISCUSSÃO}

\section{A PRODUÇÃO SUCROALCOOLEIRA NO ESTADO DA PARAÍBA}

Atualmente, o Brasil é considerado o maior produtor de cana-de-açúcar, em âmbito mundial, a Índia ocupa a segunda posição, e a República Popular, na China, a terceira. Nesse contexto, o Brasil vem se destacando em relação à produção de etanol e de sucroenergético. O etanol faz parte de um dos vetores da economia brasileira intensificado com o Programa Nacional do Álcool (PROÁLCOOL), em 1975, por meio de um decreto do governo federal.

Nas últimas décadas, o PROÁLCOOL vem expandindo consideravelmente o uso do biocombustível como alternativa para reduzir a dependência do país do petróleo, principalmente no período da crise nos anos de 1970, conhecido como o Primei- 
ro Choque do Petróleo (FAPESP). De certo modo, a gasolina derivada do petróleo foi substituída pelo etanol. Isso foi considerado uma das maiores conquistas. Assim, um aspecto sobremaneira importante a ser ressaltado é a geração de energia "sustentável" com a produção sucroenergética, cuja matéria-prima é o bagaço da cana, visto também como estratégia para reduzir a emissão de CO2.

De acordo com o Levantamento Sistemático da Produção Agrícola (LSPA) disponível no IBGE, o Brasil produziu cerca de 667.532.475 toneladas de cana-de-açúcar em 2019 e reduziu a produção de 1.0\% em relação a 2018. Entretanto, isso não influenciou a economia, que resultou em 31,1 toneladas de açúcar na safra de 2018/2019, com estimativa de crescimento de 3,8 \%, na safra de 2019/2020. Quanto ao etanol derivado da cana-de-açúcar, foram produzidos 33.8 bilhões de litros na safra de 2018/2019, com estimativa de crescimento de 4,6\% para a safra de 2019/2020, segundo a CONAB.

Esse crescimento é resultado do clima e das chuvas favoráveis, porém esses percentuais são confrontados pelos pesquisadores da UNICA, que contesta as informações divulgadas pela Conab por considerá-las otimistas, pois o período de estiagem, em algumas regiões, pode reduzir a produção nacional da cana e comprometer sua qualidade na próxima safra.

De acordo com o levantamento de dados referentes à produção de cana-de-açúcar publicados pela UNICA, a cultura está presente em cerca de 1,2\% do território nacional, concentrada, principalmente, na Nas Regiões Centro-Sul e Nordeste. Esse quadro se deve à presença da lavoura em $30 \%$ dos municípios do país.

Vale mencionar que o Nordeste é considerado a segunda maior região produtora de cana-de-açúcar, e os principais estados que a produzem são Alagoas, segundo Pernambuco e Paraíba. Na Paraíba, a Zona da Mata é principal área produtora. Isso é resultado do processo de territorialização pelos colonizadores e por ser uma área litorânea próxima à capital, João Pessoa, onde se concentram as atividades econômicas e é fácil escoar mercadorias.

Lima (2011), em sua tese de Doutorado, refere-se à Zona da Mata utilizando outro termo - "Zona da Cana" - pois o que antes era Zona da Mata Atlântica hoje praticamente não existe, em prol do desenvolvimento do capital agroindustrial. Na Paraíba, ela é composta de 30 municípios e ocupa uma extensão territorial de 5.232.396 
$\mathrm{Km}^{2}$. Seis principais municípios vêm se destacando, demonstrando uma produção canavieira significativa destinada à produção de açúcar e de etanol: Pedras de Fogo, Santa Rita, Mamanguape, Rio Tinto, Sapé e Cruz do Espírito Santo.

Por esse motivo, conforme explicado acima, todas as usinas ativas estão situadas na Zona da Mata. A tabela 2 mostra o total de usinas, os grupos empresariais, os municípios onde estão localizadas e o tipo de produto.

Tabela 1- usinas produtoras de açúcar e etanol no estado da paraíba

\begin{tabular}{|c|c|c|c|}
\hline Grupo Empresarial & $\begin{array}{l}\text { Unidades } \\
\text { ativas na } \\
\text { Paraíba }\end{array}$ & Municipios & Produtic \\
\hline Miriri Alimentos e Bioenergia S.A & Destilaria Miriri & Santa Rita & Álcool \\
\hline Grupo Japungu & Unidade Agroval & Santa Rita & Açúcar \\
\hline Grupo Japungu & Unidade Japungu & Santa Rita & Álcool \\
\hline Agroindustrial Tabu & Destilaria Tabu & Caaporã & Álcool \\
\hline Biosev & Unidade Giasa & Pedras de Fogo & Álcool \\
\hline Grupo UNA & Unidade Sapé & Sapé & Álcool \\
\hline D’Pádua & Usina D’Pádua & Rio Tinto & Álcool \\
\hline Companhia Usina São João & Usina São João & Santa Rita & $\begin{array}{l}\text { Álcool e } \\
\text { açúcar }\end{array}$ \\
\hline Grupo Soares de Oliveira & Usina Açúcar Alegre & Mamanguape & $\begin{array}{l}\text { Álcool e } \\
\text { açúcar }\end{array}$ \\
\hline
\end{tabular}


A tabela 3 nos mostra também, o processo de territorialização do agronegócio canavieiro na Zona da Mata Paraibana, com 8 grupos empresariais, 9 unidades sucroalcooleiras ativas, produtoras de açúcar e álcool. Uma trabalha exclusivamente na produção de açúcar (Agroval), duas são mistas produzem açúcar e álcool (São João e Açúcar Alegre), as outras cinco apenas álcool (Giasa, Tabu, Japungu, Miriri e Unidade Sapé) (JORNAL DA PARAIBA, 2019). Na tabela 2, apresenta-se a evolução da produção da cana-de-açúcar, etanol e de açúcar, entre 2010 e 2020, na Paraíba, demonstrando algumas oscilações na produção, entre 2013 e 2014 e 2016 e 2017.

Tabela 2 - Paraíba: produção de cana-de-açúcar, açúcar e etanol - desempenho das safras entre 2010 e 2020

\begin{tabular}{|c|c|c|c|c|c|}
\hline Ano & $\begin{array}{l}\text { Cana-de-açúcar } \\
\text { (mil toneladas }\end{array}$ & $\begin{array}{l}\text { Açúcar } \\
\text { (mil toneladas) }\end{array}$ & $\begin{array}{l}\text { Etanol Anidro } \\
\qquad\left(\mathrm{mil} \mathrm{m}^{3}\right.\end{array}$ & $\begin{array}{c}\text { Etanol } \\
\text { Hidratado } \\
\left(\mathrm{mil} \mathrm{m}^{3}\right)\end{array}$ & $\begin{array}{l}\text { Etanol } \\
\text { Total } \\
\text { (mil m³ }\end{array}$ \\
\hline 2010-2011 & 5.246 & 183 & 124 & 174 & 298 \\
\hline 2011-2012 & 6.723 & 270 & 150 & 208 & 357 \\
\hline 2012-2013 & 5.293 & 209 & 151 & 155 & 3060 \\
\hline 2013-2014 & 4.981 & 77 & 191 & 191 & 324 \\
\hline 2014-2015 & 6.723 & 148 & 214 & 206 & 421 \\
\hline 2015-2016 & 5.586 & 129 & 175 & 170 & 344 \\
\hline 2016-2017 & 4.856 & 187 & 139 & 145 & 284 \\
\hline $2017-2018$ & 5.900 & 159 & 184 & 187 & 370 \\
\hline 2018-2019 & 5.589 & 118 & 153 & 229 & 382 \\
\hline $2019-2020$ & 6.599 & 138 & 205 & 237 & 442 \\
\hline
\end{tabular}

Fonte: União da Indústria de Cana-de-açúcar (UNICA)/ORG: Lenira Lins da Silva

Os dados apresentados na tabela 2, ilustram com muita clareza oscilações no desempenho da safra da cana-de-açúcar, na última década, resultando em uma retração na produção do açúcar, entre 2013/2014, demonstrando uma recuperação considerável nos anos subsequentes. A produção de etanol anidro e hidratado, da mesma forma, demonstram algumas oscilações, porém, mantiveram à média. Essa instabilidade, representa não somente problemas econômicos para a Paraíba, mas também sociais, causando aumento no índice de desemprego, por conseguinte, impulsionando a migração da população para as cidades. Essas oscilações ocorrem, 
provavelmente, por falta de políticas públicas voltadas para o desenvolvimento dos estados do Nordeste (TARGINO; MAIA FILHO; MOREIRA, 2010).

Segundo o IBGE, a cana ainda é o principal produto cultivado na Paraíba. Em 2018, ocupava uma área de 125,29 mil hectares, com a participação do seu potencial produtivo de $1,37 \%$ da produção brasileira, e ultrapassa outros produtos essenciais para a sobrevivência dos paraibanos, como batata doce, feijão, macaxeira, fava etc. A pesar dos reflexos negativos com a seca do ano anterior, entre 2017 e 2018, a produção cresceu. A tabela 2, apresenta uma expectativa de crescimento para 2019 e 2020 e demonstra um grande potencial produtivo, pois a Paraíba tem solo e clima favoráveis para o seu desenvolvimento.

Entretanto, segundo o IBGE a cana ainda é o principal produto cultivado na Paraíba. Em 2018 e 2019, ocupava uma área de 125,29 mil hectares e 5.589 milhões de toneladas processadas apresentando uma leve queda em relação a 2017/2018, com 5.900 milhões de toneladas processadas (CONAB, 2019). A participação do seu potencial produtivo é de $1,37 \%$ da produção brasileira e ultrapassa outros produtos de subsistência como: batata-doce, feijão, macaxeira, fava. Porém, para a safra de 2019 e 2020, a produção atingiu 6.599 milhões de toneladas de cana-de-açúcar processada, provavelmente, a quantidade de chuvas, investimentos em irrigação e fertilização podem ser a causa do aumento na produção (JORNAL DA PARAÍBA, 2019).

Como sabemos, o Brasil é o pioneiro na tecnologia voltada para a produção do etanol e seu uso e considerado como uma alternativa altamente renovável. Todavia, o país tem uma grande extensão territorial de terras direcionadas ao cultivo da cana. Fica evidente que houve pontos positivos, como a redução de emissão de gases e a geração de emprego para o corte da cana, por exemplo. No Nordeste, o corte ainda é feito manualmente, e a matéria-prima para a geração de energia é o bagaço da cana. Entretanto, é um processo contraditório, pois provoca sérios danos ambientais e a exploração dos recursos naturais de nosso país.

Outro aspecto a ser considerado é a necessidade de muita terra para o cultivo, que suscita uma grande concentração fundiária e contribui para expandir o agronegócio, principalmente com o evento da modernização. Isso leva a outras consequências sérias, como a drástica redução das lavouras de alimentos e a expropriação e 
a expulsão dos camponeses e indígenas do seu território. Infelizmente essa é uma realidade presente no Brasil desde o período colonial. Seguindo essa premissa, o setor sucroalcooleiro é um dos que mais representa a superexploração da força de trabalho em condições análogas às do escravo nos canaviais durante o eito do corte. Além dos péssimos salários, as formas degradantes durante o corte acarretam sérios problemas de saúde.

Portanto, como destacamos anteriormente, a retração da produção de alimentos em detrimento do cultivo da cana, é resultado da expansão do setor sucroalcooleiro que contribui, indiscutivelmente, para essa atual tendência. Doravante, essa expansão canavieira na Paraíba e no Brasil, deixou sequelas irreparáveis provocando graves problemas ambientais com a retirada da vegetação nativa em áreas florestais, poluição dos rios e grandes problemas sociais provocando um número elevado de expulsão dos trabalhadores de suas terras (EGLER, TAVARES, 1984).

Nesta atual conjuntura, é importante destacar a pressão social feita pelos movimentos sociais, no campo da Reforma Agrária, e a resistência às relações de dominação do capital sucroalcooleiro. Uma das formas de lutar é ocupando terras que não cumprem sua função social. O MST é um dos principais movimentos que lideram essas ocupações em todo o país. Nesse embate, a educação do campo assume um papel importante - o de formar sujeitos emancipados capazes de lutar pelos direitos ligados ao projeto de desenvolvimento territorial utilizando a agroecologia como alternativa sustentável nos acampamentos e nos assentamentos. Esses aspectos serão tratados com mais detalhes no item a seguir.

\section{A EDUCAÇÃO DO/NO CAMPO E O DESENVOLVIMENTO TERRITORIAL} NA PARAÍBA

É importante entender que a educação do campo não deve ser pensada apenas como uma política voltada para o processo de alfabetização, pois sobretudo os saberes adquiridos na escola devem comportar outras dimensões do conhecimento e envolver assuntos como reforma agrária, meio ambiente, economia, política, cultura, cidadania e identidade, para que o campo seja entendido a partir de suas várias dimensões, e não, apenas, como um espaço de produção do agronegócio. Ora, um 
território que conglomera todas essas dimensões deve considerar que o processo de desenvolvimento territorial precisa estar atrelado, principalmente, à valorização da soberania alimentar ${ }^{60}$ em uma perspectiva voltada para a sustentabilidade. Nesse sentido, a prática agroecológica é uma ótima possibilidade para o desenvolvimento socioeconômico.

De acordo com Fernandes (2008), existem duas visões antagônicas de desenvolvimento: o agronegócio, que concebe o campo como um lugar para produzir mercadoria, que é atrasado, precisa se modernizar para produzir agricultura capitalista e é visto como território homogêneo, sem relações sociais, e a agricultura camponesa, que entende o campo como um modo de viver e de produzir alimentos.

As relações sociais fazem parte das dimensões territoriais, isto é, educação, saúde, cultura, organizações políticas e comerciais etc. É importante ressaltar que, como a educação está dentro do território, precisa comportar suas particularidades. Camacho (2013, p.342) assevera que "A escola tem que ter a territorialidade camponesa. Se a escola não se atentar para estas especificidades, será um 'corpo estranholl' no território camponês". É possível compreender que a educação do campo faz parte da dialética camponesa visando criar e recriar seu modo de viver.

Nesse contexto, a educação é uma ferramenta de luta, porque a educação do/ no campo não deve ser dissociada dos movimentos sociais e da reforma agrária, porquanto foi na luta por terra que ela surgiu. Isso implica afirmar que a educação do campo influencia diretamente o projeto de desenvolvimento do campo. Assim, preocupa-nos o teor dos conteúdos que vêm sendo trabalhados nessas escolas, porque devem ser transformados, adaptados ao contexto local e valorizar as práticas e a cultura dos sujeitos do campo. Entretanto, isso não é o que vem acontecendo, pois a educação do campo faz parte do sistema educacional brasileiro que é engessado e padronizado com o intuito de formar para o mercado de trabalho.

Para Camacho (2013), a educação do campo não precisa de um ensino padronizado, mas de lápis, caderno, enxada, trator e professores capacitados para lidar com essa realidade e preparar o conhecimento para a vida. Então, conteúdos como

60 Soberania alimentar é o conjunto de políticas públicas e sociais que deve ser adotado por todas as nações, em seus povoados, municípios, regiões e países, a fim de se garantir que sejam produzidos os alimentos necessários para a sobrevivência da população de cada local (DICIONÁRIO DA EDUCAÇÃO DO CAMPO P,714, 2012). 
movimentos sociais, reforma agrária, ocupação de terras, agroecologia, desenvolvimento sustentável e contradições do capitalismo são adequados e devem ser trabaIhados nas unidades escolares levando em consideração as especificidades regional e local. Outro aspecto que deve ser ressaltado é que os livros didáticos distribuídos nas escolas públicas não contemplam as complexidades do campo, aliás, são os mesmos utilizados nas escolas urbanas, e a maioria dos professores também são urbanos.

Então, considerando esse cenário, como a educação do/no campo pode ser uma ferramenta de desenvolvimento territorial na Paraíba? Responder a essa pergunta não é fácil, porque, na estrutura agrícola desse estado, a produção de cana-de-açúcar domina e, consequentemente, gera dependência na população para trabalhar nas usinas, nas destilarias e, sobretudo, no eito do corte da cana.

Em contrapartida, na Paraíba, as escolas lideradas pelo MST, depois de erguer seus acampamentos e de conquistarem seus assentamentos, não se opuseram a cobrar da Secretaria da Educação dos respectivos municípios a construção de escolas. O objetivo do MST é de ofertar um ensino que articule o trabalho, a educação e a terra, com o propósito de educar sujeitos emancipados, por meio de uma formação crítica (CALDART, 2012). Para isso, é imprescindível desenvolver políticas educacionais que contemplem as múltiplas diversidades, a fim de atender à população campesina paraibana como protagonista de sua realidade não apenas como escopo de manobra dos usineiros.

\section{CONCLUSÃO}

Neste trabalho, foram analisados dois territórios antagônicos: a agricultura capitalista canavieira, entendida como agronegócio, e o campesinato, os quais vivem em constantes conflitos. Devido às contradições no avanço da monocultura da cana-de-açúcar, a educação do/no campo surgiu como instrumento de resistência e de reivindicação. Contudo o estudo mostrou que as unidades escolares do campo devem trabalhar conteúdos adequados à realidade campesina e assumir a responsabilidade de formar cidadãos comprometidos como o desenvolvimento territorial camponês. 
De modo geral, no Brasil, a cana-de-açúcar é a principal matéria-prima para a produção do etanol. Com o PROÁLCOOL e incentivos governamentais, sua produção tende a crescer, principalmente se os biocombustíveis forem ampliados, e o $\mathrm{CO} 2$ for reduzido. Na Paraíba, a cana ainda é o principal produto agrícola, em que os grandes e os pequenos produtores enxergam uma oportunidade de adquirir mais renda. Entretanto, a agricultura capitalista canavieira é o setor que mais explora a força de trabalho em condições degradantes. Por outro lado, os movimentos sociais continuam a lutar contra o avanço do capital no campo e por acesso a terra.

Assim, devido à importância do tema, a educação do campo está vinculada ao projeto de desenvolvimento do campo na Paraíba e no Brasil como um todo. Nesse sentido, a educação é vista como dimensões necessária para transformar os sujeitos em pessoas emancipadas, porque, a escola é considerada um espaço de compartiIhamento de conhecimentos que devem ser utilizados para manter e desenvolver o território dos camponeses.

\section{REFERÊNCIAS}

ASPLAN - Associação de Plantadores de Cana da Paraíba. PB faz estimativa que safra 2019/2020 de cana-de-açúcar deve superar seis milhões de toneladas. Disponível em:<http://www.paraibanoticia.net.br/asplan-pb-faz-estimativa-que-safra-2019-2020-de-cana-de-acucar-deve-superar-seis-milhoes-de-toneladas/>. Acesso em: 20 dez.2020.

CALDART, Roseli Salete. Pedagogia do Movimento sem Terra. 4. ed. São Paulo: Expressão Popular, 2012, 448 p.

CAMACHO, Rodrigo Simão. Paradigmas em disputa na educação do campo. 2014.809 f. Tese (Doutorado em Geografia) - Faculdade de Ciências e Tecnologia, Universidade Estadual Paulista, Presidente Prudente, 2014.

DICIONÁRIO DA EDUCAÇÃO DO CAMPO. Rio de Janeiro: Expressão Popular, 2012. $788 \mathrm{p}$.

FELICIANO, Carlos Alberto. Movimento camponês rebelde: a Reforma Agrária no Brasil. São Paulo: Contexto, 2006. 178 p. 
FERNANDES, Bernardo Mançano. Educação do campo e território camponês no Brasil. In: SANTOS, Clarice Aparecida (org.). Por uma educação do campo: Campo Políticas Públicas - Educação. 7ª.ed. Brasília: INCRA/MDA, p.39-65. 2008.

JORNAL DA PARAÍBA. Paraíba deve alcançar 6,5 milhões de toneladas de cana-de-açúcar em na safra 2019/2020. Disponível em: https://www.jornaldaparaiba.com.br/ economia/paraiba-deve-alcancar-65-milhoes-de-toneladas-de-cana-de-acucar-na-safra-2019-2020.html.Acesso em:10 jun.2020.

LIMA, Edvaldo Carlos de. Dissidência e fragmentação da luta pela terra na "Zona da cana" nordestina: o estado da questão em Alagoas, Paraíba e Pernambuco. 2011. 266 f. Tese (Doutorado em Geografia) - Universidade Federal de Pernambuco, Recife, 2011.

OLIVEIRA, Ariovaldo Umbelino. Modo de produção capitalista, agricultura e reforma agrária.7a ed. São Paulo: Labur Edições, 2007. 184 p.

IBGE. Instituto Brasileiro de Geografia e Estatística. Levantamento Sistemático da Produção Agrícola. Disponível em:<https://www.ibge.gov.br/estatisticas/economia/ agriclturaepecuaria/92011levantamento-sistematico-da-produção-eagricola.html?>. Acesso em: 01 de março de 2020.

NOVACANA. <https://www.novacana.com/usinas Brasil/estados/paraíba> Acesso em 28 de fevereiro de 2020

ÚNICA. União da Indústria da Cana-de-açúcar. < http://unicadata.com.br/> Acesso em 25 de fevereiro de 2020. 


\section{(UM)A HISTÓRIA DA PEDAGOGIA DA ALTERNÂNCIA DISCURSIVIZADA PELAS LICENCIATURAS EM EDUCAÇAO DO CAMPO}

Lucas Martins Flores ${ }^{62}$

$61 \quad$ Uma primeira versão deste texto foi apresentado no SIFEDOC 2018 - Seminário Regional de Educação do Campo da Região Centro do Rio Grande do Sul e encontra-se publicado nos Anais desse Evento, disponível em: < https://www.ufsm.br/app/uploads/sites/369/2018/11/Anais-SIFEDOC-2018..pdf > Acesso em 22 mar. 2021. p. $388-401$.

62 Professor no Instituto Federal Farroupilha (IFFar) Campus Jaguari. Licenciado em Letras, Português, Inglês e respectivas Literaturas, Mestrado em Letras (UCPEL) e Doutorado em Letras (UFSM). lucas.flores@iffar.edu.br 
Stories matter. Many stories matter.

Stories have been used to dispossess and to malign but stories can also be used to empower and to humanize.

Stories can break the dignity of the people, but stories can also repair that broken dignity ${ }^{63}$.

Chimamanda Adichie: O perigo da história única.

Em Expansão das licenciaturas em Educação do Campo: desafios e potencialidades (2015), texto produzido pela Professora Mônica Castagna Molina, da Universidade de Brasília, a autora apresenta, a partir do Observatório da Educação de Aperfeiçoamento de Pessoal de Nível Superior (CAPES), a pesquisa intitulada "Políticas da Expansão da Educação Superior no Brasil", cujo período de execução é de 2013 a 2017. Nessa publicação, além de apresentar um panorama geral sobre a Educação de Ensino Superior no país, ela discorre sobre o histórico de criação da Licenciatura em Educação do Campo, sobre os princípios que orientam a matriz político-pedagógica deste curso, sobre os desafios e potencialidades que podem vir a serem objetos de estudos e de acompanhamento.

De acordo com Molina, de 2008 em diante, 42 cursos de Licenciatura em Educação do Campo foram implantados no Brasil por Universidades Federais e Institutos Federais de Educação, Ciência e Tecnologia. No Rio Grande do Sul, algumas instituições ofertaram essa Licenciatura, tais como: Universidade Federal da Fronteira Sul (Campus Erechim e Laranjeiras do Sul), Universidade Federal do Pampa, Universidade Federal do Rio Grande do Sul, Universidade Federal do Rio Grande e Instituto Federal Farroupilha ${ }^{64}$.

É com base nesse percurso de constituição dos Cursos de Licenciatura em Educação do Campo - e do levantamento feito por Molina - que proponho, neste texto, por meio da leitura e análise dos Projetos Pedagógicos dos Cursos (PPC) das Licenciaturas em Educação do Campo ofertados no Rio Grande do Sul quando do

63 Tradução: Histórias importam. Muitas histórias importam. Histórias têm sido usadas para desapropriar e tornar maligno, mas histórias também podem ser usadas para empoderar e humanizar. Histórias podem ser usadas para destruir com a dignidade das pessoas, mas histórias também podem reparar essa dignidade perdida. Vídeo completo da palestra da escritora Nigeriana Chimamanda Ngozi Adichie disponível em: < https://www.youtube.com/watch?v=EC=-b1hYARsc\&t1075s > Acesso em 22 mar. 2021.

64 Estes dados referem-se ao segundo semestre de 2016, período em que tal trabalho começou a ser desenvolvido. 
lançamento do edital de oferta desses cursos no Brasil (2012), refletir sobre (um)a história da Pedagogia da Alternância, "metodologia65" adotada nesses cursos, e da forma como ela é discursivizada nos PPC em questão.

Refletir sobre a Educação do Campo, sobre a Pedagogia da Alternância, enfim, sobre os Projetos de Curso que desenvolvem essas noções - práticas - se faz importante ${ }^{66}$ como constituição de um arquivo a ser lido e interpretado. Penso arquivo como "campo de documentos pertinentes e disponíveis sobre uma questão" (PÊCHEUX, [1975] 1994, p. 57), para então, fazer recortes desse arquivo para poder reconhecer as evidências práticas que organizam essas leituras e, nas palavras de Pêcheux (1994) "mergulhar a leitura literal (enquanto apreensão do documento) numa leitura interpretativa", constituindo assim, um trabalho de relação do arquivo com ele mesmo, em uma série de conjunturas, ao mesmo tempo em que se dá um trabalho da memória, da história e da língua.

Interessante observar que essa "escolha" de trabalhar com os Projetos Políticos Pedagógicos do Curso de Licenciatura em Educação do Campo das instituições do Rio Grande do Sul, já é um recorte realizado para a constituição desse arquivo. Na posição que assumo - na Análise de Discurso de perspectiva pecheuxtiana - isso se justifica, porque o que me interessa não é a abrangência de leitura sobre o arquivo, nem a quantidade de fontes consultadas, mas o tratamento que esse arquivo e essas fontes merecem. O que me interessa não são todas, nem a quantidade de histórias contadas, mas as possibilidades de se contar uma ou outra história a partir daquilo que lemos, enxergamos e/ou analisamos.

Orlandi (1984, p. 14) afirma que "recorte é uma unidade discursiva". E por unidade discursiva, "entendemos fragmentos correlacionados de linguagem-e-situação". "Assim, um recorte é um fragmento da situação discursiva”. Desse modo, um segundo recorte que faço para apresentar tal trabalho, está direcionado ao que me proponho a ler nestes Projetos Políticos Pedagógicos, que se trata sobre a proposta

65 A Pedagogia da Alternância é tratada pelos Marcos Normativos da Educação do Campo (2012) como uma "metodologia pedagógica", normatizada por meio do Parecer n 01/2006 (BRASIL, 2012, p. 41).

66 Se faz importante, sobretudo, porque a partir desta retomada dos saberes dos PPC, trazemos à baila muitas vozes daqueles que estão atualmente (2021) esquecidos: os povos do campo. (Re)memorar Educação do Campo, Pedagogia da Alternância, trabalhos desenvolvidos pelos PPC e pelos cursos (seus docentes, seus discentes, suas instituições) é um forma de "saber, dialogar e, principalmente, resistir". 
de funcionamento do Curso de Licenciatura em Educação do Campo: a Pedagogia da Alternância. Esses recortes que ora realizo se dão pelo fato de meu interesse em descrever o funcionamento do discurso sobre a Pedagogia da Alternância nesses documentos, compreendendo que o lugar em que situo tal reflexão não se baseia em uma descrição do texto, mas sim, uma teorização sobre o discurso, observando o seu funcionamento a partir de um quadro epistemológico em que se unem o histórico, o linguístico, atravessado por uma teoria psicanalítica em que enquadra a noção de sujeito.

Nesse sentido, constituo o corpus deste trabalho pelos recortes discursivos (RD), compreendendo: a) os critérios vinculados à questão de pesquisa; b) que essas materialidades discursivas pertencem a espaços e tempos discursivos distintos; c) que esses recortes projetam gestos de interpretação que permitem a compreensão de sentidos além de uma memória institucionalizada, mas especialmente, efeitos de sentido nesse espaço tempo e d) que esses recortes - regularidades entre os PPC - compreendem uma totalidade ilusória dos sentidos sobre a Pedagogia da Alternância.

Assim, por meio de um gesto interpretativo, reflito sobre como os Projetos Pedagógicos dos Cursos de Licenciatura em Educação do Campo do Rio Grande do Sul apresentam e descrevem a Pedagogia da Alternância. A partir dessa reflexão, projeto delinear o horizonte de retrospecção da Pedagogia da Alternância, com base em Sylvain Auroux (2008), traçando (um)a história de como ela foi/ está sendo implantada no Brasil.

\section{(UM)A HISTÓRIA DA LICENCIATURA EM EDUCAÇÃO DO CAMPO...}

A Licenciatura em Educação do Campo é um "novo" curso de graduação, que vem sendo implantada desde 2007 pelas universidades, com o apoio do Ministério de Educação ${ }^{67}$. "O curso propõe-se atender a uma nova demanda, as populações do campo, que historicamente lutam por uma educação diferenciada de qualidade, que respeite as especificidades da vida neste contexto", afirma o PPC da Universidade

67 Observo que esse apoio do Ministério da Educação inexiste atualmente (2021). Decidi demarcar esse posicionamento da época de escrita do trabalho primeiro, porque, indiretamente, ele demarca a necessidade de os Cursos de Licenciaturas em Educação do Campo serem tratados como uma Política de Estado e não somente uma política governamental. 
Federal do Rio Grande do Sul.

De acordo com Caldart (2011, p. 96), o curso nasceu das proposições da II Conferência Nacional por uma Educação do Campo, realizada em 2004. Por meio de uma comissão instituída pelo Grupo Permanente de Trabalho de Educação do Campo da Secretaria de Educação Continuada, Alfabetização e Diversidade (Secad) e com representante do Iterra, a proposta específica começou a ser construída no MEC, em 2005, mas, a autora afirma que foi em novembro de 2006, que o MEC decidiu convidar universidades para a realização de projetos-piloto do curso.

Caldart (2011, p. 96) menciona que quatro projetos-piloto foram desenvolvidos: o primeiro, uma parceria entre Iterra e UnB, com aprovação da criação institucional do curso realizada em julho de 2007, com o vestibular e início da primeira etapa ainda em setembro de 2007. Ela explica que essa turma aconteceu em Veranópolis, RS, na sede do Iterra, com uma organização curricular de etapas constituídas pela alternância entre Tempo Escola e Tempo Comunidade. Os outros projetos-piloto são da Universidade Federal de Minas Gerais (UFMG), Universidade Federal da Bahia (UFBA) e Universidade Federal de Sergipe (UFS) (CALDART, 2011).

A partir do início das turmas dos projetos-pilotos, o MEC criou um programa específico de apoio à implantação de cursos de Licenciatura em Educação do Campo (o Procampo), lançando anualmente editais de convocação às Instituições de Ensino Superior públicas para que apresentem projetos de criação da nova Licenciatura, dentro dos mesmos parâmetros da proposição inicial. Isso é exposto no PPC da Licenciatura em Educação do Campo de todas as instituições analisados, como por exemplo, o Instituto Federal Farroupilha Campus Jaguari que afirma: "a proposta está em consonância com o Edital de Chamada Pública $N^{\circ} 02$, de 31 de agosto de 2012, chamada pública para seleção de Instituições Federais de Educação Superior - IFES, objetivando a criação de cursos de Licenciatura em Educação do Campo".

Nesse edital (2012), é claramente exposto como devem ser apresentados os projetos de cursos para serem aprovados pelo edital, no que diz respeito ao seu funcionamento:

3.5 - Os projetos apresentados deverão:

c) apresentar organização curricular por etapas equivalentes e semestres 
regulares cumpridas em Regime de Alternância entre Tempo-Escola e Tempo-Comunidade. Entende-se por Tempo-Escola os períodos intensivos de formação presencial no campus universitário e, por Tempo-Comunidade, os períodos intensivos de formação presencial nas comunidades camponesas, com a realização de práticas pedagógicas orientadas (BRASIL ${ }^{68}, 2012$, p. 2).

Nesse momento, em que descrevo o processo de constituição das Licenciaturas em Educação do Campo, a partir de um edital do MEC, tentando lançar-me a um gesto interpretativo sob os PPCs dos Cursos ofertados por esse edital no RS, chama-me atenção o modo como a UFRG "responde às orientações básicas propostas pelo Edital" (PPC UFRGS, p. 8):

c) organizar metodologicamente o currículo por alternância entre Tempo/Espaço e Universidade e Tempo/Espaço Comunidade, de modo a permitir o necessário diálogo entre saberes teóricos-tecnológicos e saberes tradicionais culturais oriundos das experiências de vida no campo (PPC UFRGS, p. 9).

Nessa "resposta às orientações", assim posta no projeto do curso, o currículo organiza-se nomeando diferentemente do Edital. As orientações do edital trazem a nomeação "regime de alternância". No entanto, nessa "resposta", há um apagamento da nomeação "regime". Nesse processo discursivo, os sentidos podem ser um, mas também podem ser outros. A não presença da nomeação "regime" ou "alternância", como se apresenta no decorrer do PPC da UFRGS, provoca efeitos de sentidos que merecem ser compreendidos. Que memórias discursivas entram nesse jogo de palavras que significam igualmente, mas de modo diferente?

\section{(UM)A HISTÓRIA DA PEDAGOGIA DA ALTERNÂNCIA...}

Considerando que "existem muitas formas de aplicar e, portanto, de compreender a Alternância" (CALVÓ e GIMONET, 2013 p. 42) na Pedagogia da Alternância ou no Regime de Alternância, nesta seção apresento um caminho histórico sobre a Pedagogia da Alternância, levando em consideração também como ela é apresentada nos Projetos de Cursos de Licenciatura em Educação do Campo no Rio Grande do Sul. Não me é tarefa fácil refletir sobre o funcionamento da alternância, tendo em

68 Edital organizado pela Secretaria de Educação Superior (SESU), Secretaria de Educação Profissional e Tecnológica (SETEC) e Secretaria de Educação Continuada, Alfabetização, Diversidade e Inclusão (SECADI). 
vista que preciso distanciar-me de minha prática cotidiana no Curso de Licenciatura em Educação do Campo do Instituto Federal Farroupilha Campus Jaguari.

A distância é grande entre a ideia ou o conceito e a prática de alternância, e aqueles que percorrem logo o percebem (Gimonet, 2007, p. 19). Nas Maisons Familiales Rurales (MFR) na França, elaborou-se "uma metodologia progressiva" no tempo e ajustada em função dos contextos, da evolução das formações, dos públicos recrutados, até mesmo das exigências administrativas. E de lá para cá, conhecimentos teóricos práticos foram sendo constituídos e transformados. Como se vê, o público da Pedagogia da Alternância em suas origens eram públicos específicos, o que vemos hoje, é essa prática sendo aplicada em cursos de formação de professores do/no/para o campo em Universidades e Institutos Federais brasileiros.

Desse modo, Auroux (2008) explica que o ato de saber (a produção do conhecimento) "não é ele mesmo algo sem relação à temporalidade", ou seja, é necessário tempo para saber sobre um conhecimento instantâneo. É a partir de um horizonte de retrospecção, isto é, conjunto de conhecimentos antecedentes que fazem com que se represente a Pedagogia da Alternância hoje, talvez, diferentemente, do modo como era em outros lugares e momentos. Isso não significa afirmar que uma ou outra está certa ou errada. "É necessário tempo para saber" (AUROUX, 2008, p. 141).

Da mesma maneira que o horizonte de retrospecção constitui saberes anteriores, segundo Auroux, o horizonte de projeção antecipa, idealiza, imagina, uma projeção do que está por vir. Na França, quando da criação das MFR, criaram-se alguns traços fundamentais de uma identidade comum, mas evidentemente que previa parâmetros constantes e evolutivos (Gimonet, 2007, p. 14). O que se tem hoje, em termos da legislação da Pedagogia da Alternância é a última Nota Técnica Nº 3/2016 da SECADI que afirma que:

As Licenciaturas devem integrar programas institucionais de ensino, pesquisa e extensão, sendo ofertados na modalidade presencial, com a garantia da infraestrutura adequada e desenvolvimento pelo Regime de Alternância, com vivências dos tempos educativos - Tempo Escola (TE) e Tempo Comunidade (TC) (BRASIL, 2016).

Essa produção do conhecimento sobre a Pedagogia da Alternância vai além de onde dizem nascer seus marcos iniciais, nesse percurso é que me interessa também 
compreender como se dá esse funcionamento do processo discursivo que vem da "pedagogia da alternância" para "regime de alternância", como mencionado na última nota técnica em que, em nenhum momento, nomeia-se "pedagogia", mas sim "regime". Isso justifica meu interesse em refletir sobre essa memória da/ na atualidade nesse processo discursivo. No Edital (2012), como apresentado anteriormente, utiliza-se "regime", na literatura e nos PPCs dos Cursos, utiliza-se "pedagogia", na última nota técnica (2016), "regime". Entre "regime" e "pedagogia", os sentidos não estão somente nas palavras, mas também na relação com a exterioridade, nas condições em que elas são produzidas. "Regime" e "pedagogia" significam pela história e pela língua.

Sobre esses marcos iniciais da Pedagogia da Alternância, Calvó e Gimonet (2013) observam que a Pedagogia da Alternância "não é monopólio" no que diz respeito a sua criação, porque já tem séculos. Eles destacam nesse processo, os Compagnos du devoir ou aprendizes-companheiros e seu Tour de France, construindo castelos, palácios e catedrais; os monges e a construção de monastérios na idade média que já aplicavam uma forma de alternância trabalho-escola; os irmãos das escolas cristãs e suas escolas dominicais.

O livro Educação do Campo: origens da Pedagogia da Alternância no Brasil de Paolo Nosella (2012) conta as origens da Pedagogia da alternância no Brasil, e é uma obra de caráter documentativo, de acordo com o autor, em que se publica a dissertação de mestrado, defendida na Pontifícia Universidade Católica de São Paulo, em março de 1977, cujo título é: Uma nova educação para o meio rural: sistematização e problematização da experiência educacional das escolas da família agrícola do Movimento de Educação Promocional do Espírito Santo. O autor não é apenas um historiador observador das origens dessa experiência pedagógica, sobretudo, participou diretamente, desde 1968, do trabalho de criação das primeiras Escolas da Família Agrícola (EFAS) da Pedagogia da Alternância no Brasil (NOSELLA, 2012, p. 18).

Nosella para introduzir sobre a vida do Padre Granereau, afirma que "A história de uma ideia é também é história de um homem e, de certa forma, é também a história da época e dos problemas vividos por ele" (2012, p. 45). O Padre Granereau, nascido em 1885, na França, desde a sua juventude, o padre preocupou-se com o desinteresse, por parte do Estado e da Igreja, frente ao problema do homem do cam- 
po. Na época, acreditava-se que para os filhos de agricultores se tornarem sábios e instruídos, deveriam necessariamente mudar para os grandes centros urbanos, observa Nosella. Dessa necessidade de traçar um novo olhar para os homens do campo, para a escola rural, surgiu a Pedagogia da Alternância. Vê-se claramente o funcionamento da ideologia sendo posta em evidência: dois "aparelhos ideológi$\cos ^{\prime 69}$ : a) de estado e b) religioso funcionando sob um sujeito padre. Que movimentos escolares da época na França proporcionaram esse processo de valorização ao que está na cidade e ao que está no campo de forma diferenciada? Que políticas aí estão em jogo? Qual a relação da igreja nesse processo? O que ela pregava? E seria o que a igreja pregava a mesma posição do padre ${ }^{70}$

A Europa, nesse período pós-primeira guerra mundial, vivia uma efervescência de pensamentos liberais, socialistas, nacionalistas, e social cristão, corroboram Andrade e Andrade (2012, p. 63). De acordo com os autores,

Em 1891, o papa Leão XIII (1878-1903), sensibilizada pela "condição dos operários" lança a encíclica Rerum Novarum. Com esse documento a Igreja Católica Apostólica Romana - ICAR assume a questão social. Nesse momento, a questão agrária e a situação dos camponeses não constitui a preocupação principal da Igreja. Pouco depois, o papa Pio XI (1922-1939), com a encíclica social Quadragesimo anno, contribui para o surgimento da Ação Católica Geral e na sequência com a Ação Católica Especializada. Esse é um período que a ação da Igreja vai de encontro à situação dos camponeses. A Ação Católica Especializada no Brasil vai ser fundamental na formação de lideranças e organização dos camponeses no período entre 1950 a 1970, principalmente a Juventude Agrária Católica - JAC (ANDRADE e ANDRADE, 2012, p. 63).

Como se percebe as primeiras MFR teve grande contribuição dos setores progressistas da Igreja Católica e no Brasil não foi diferente. Em 1968, uma organização filantrópica e sem fins lucrativos de inspiração cristã constitui o Movimento de Educação Promocional do Espírito Santa (MEPES) liderado pelo padre jesuíta Humberto Pietrogrande, sacerdote de Anchieta - ES, afirmam Andrade e Andrade (2012, p. 64),

69 ALTHUSSER, Louis. Ideologia e Aparelhos Ideológicos de Estado. Martins Pontes ([1970] 1980).

70 Tais questionamentos referem-se a tomada de posição do sujeito que é interpelado pela ideologia para dizer o que diz. O sujeito padre pode ser plenamente identificado a ideologia religiosa a que ele pertence como pode tomar outra posição, a partir de uma outra formação ideológica, inclusive religiosa - entre as tantas crenças religiosas existentes. De acordo com Indursky (2019, p. 118) "os sujeitos podem identificar-se (inscrever-se em uma posição sujeito) plenamente e contraidentificar-se (desinscrever-se da referida posição-sujeito, sem romper com a formação discursiva". 
de acordo com Nosella. Esse movimento de criação dessa fundação pode ser visualizado no fragmento abaixo em que Nosella (2012, p. 64) apresenta um fragmento dos Cadernos (1970), demonstrando os envolvidos: estado e igreja:

No dia 25 de abril de 1968, na Câmara Municipal de Anchieta, uma Assembleia de agricultores dos municípios assinava a ata constitutiva do Movimento de Educação Promocional do Espírito Santo (MEPES), que tinha como finalidade a promoção de pessoa humana, através de uma ação comunitária que desenvolva a mais ampla atividade inerente ao interesse da agricultura e principalmente no que tange à elevação cultural, social e econômica dos agricultores. Na Junta Diretora do MEPES se encontram os representantes da Companhia de Jesus, dos Vigários dos Prefeitos, da Associação dos Amigos Italianos e da ACARES (Associação de Crédito e Assistência Rural do Espírito Santo) (NOSELLA, 2012, p. 64).

Além do MEPES, fundado em 1968, de acordo com Araújo (2005, p. 90), fundou-se também a Associação dos Amigos do Estado Brasileiro do Espírito Santo AES, Organização não governamental, criada na Itália, para ajudar no processo de implantação, assinatura de convênios e arrecadação de recursos para a manutenção das escolas que, além de dar esse suporte, viabilizou intercâmbios entre brasileiros e italianos. Vale ressaltar que esse processo de implantação dessas escolas no Brasil se deu no auge da ditatura militar no Brasil, que de acordo com Araújo (2005)

[...] período em que o campo sofreu um processo de tal abandono por parte dos poderes públicos, excluindo a agricultura familiar. As políticas públicas para o campo, naquela época, estavam centradas na grande produção agropecuária, no modelo de agricultura patronal, voltado para as monoculturas e o mercado externo, associado à sofisticação tecnológica, conhecida como modernização conservadora (ARAÚJO, 2005, p. 91).

Traçado esse percurso do processo histórico de implantação das primeiras atividades com a proposta pedagógica da alternância em escolas familiares rurais, passamos a ler sobre a Pedagogia da Alternância como posta pelos Cursos de Licenciatura em Educação do Campo.

\section{(UM)A HISTÓRIA DISCURSIVIZADA PELOS PROJETOS DE CURSOS} ANALISADOS...

Em A Historicidade das Ciências, Sylvain Auroux (2008), traça um percurso filosófico para explicitar que a produção de saber como conhecimento, faz-se necessá- 
rio distinguir saberes tácitos dos saberes que configuram formas de representação.

O filósofo francês observa que

a relação do ser humano com seu ambiente (sobrevivência, produção de bens, organização) passa necessariamente pela colocação em funcionamento de elementos cuja construção e conservação dependem de externalidades e/ou são externalidades; tanto quanto estes elementos referem-se à representação, trata-se do que se chama "conhecimento" ou "saber" (AUROUX, 2008, p. 125).

Nesse sentido, os saberes tácitos constituem nossas práticas cotidianas, de acordo com Auroux (2008, p. 125), "não há saber sem transmissão" e o saber tácito pode ser ocultado, mas "transmissível". Essa transmissão se dá pelas técnicas. "Assim, as técnicas têm sido primeiro conhecimentos não representados, transmitidos por aprendizagens e imitação". São esses saberes tácitos que a Pedagogia da Alternância enfatiza como um processo de inicialização da produção do conhecimento dentro do curso, a partir de seu funcionamento em dois tempos: tempo escola, ou "tempo universidade" (como chamado pelo PPC do UFRGs) e tempo comunidade. A seguir, trago um recorte discursivo de um PPC, que demonstra essa valorização, enquanto necessidade de "esforço na apropriação" dos docentes de que seja desse modo e não de outro, dos tempos e espaços no processo formativo da proposta da alternância no Curso:

Esta opção, para além de metodológica, se traduz em uma opção política, exigindo por parte dos professores do curso um esforço na apropriação, problematização e proposição do próprio método. Desse modo, serão delineados momentos específicos para planejamento, elaboração e organização dos chamados Tempos Educativos: Tempo Escola (TE) e Tempo Comunidade (TC) que fundamentam a Metodologia da Alternância (UFFS, p. 41).

O PPC apresenta como uma "opção" a escolha pela Alternância, no entanto, como visualizamos anteriormente, isso foi politicamente definido pelo edital, como se explica adiante no próprio excerto "opção política", isso demonstra o funcionamento da interpelação pelo estado na manutenção de uma proposta de ensino. Além disso, esse recorte discursivo apresenta a Pedagogia da Alternância como uma metodologia, definindo os espaços de "tempo" e "espaço" ocupados que permitem um diálogo entre os saberes "técnico-tecnológicos" e os saberes "das experiências de 
vida". Importa-me aqui refletir brevemente sobre essa "representação" dos saberes enquanto discursivização produzida por sujeitos em diferentes espaços: a) de um lado, o sujeito que produz conhecimento científico, o da academia e b) de outro, um sujeito do campo, no campo (rural) que discursiva saberes para os seus, através da transmissão de aprendizagens e imitação. Encontra-se aí, talvez, a preocupação como apontada no PPC da UFFS (RD2), de que exige "por parte dos professores" "um esforço na apropriação, problematização e proposição do próprio método".

Essas preocupações apontam para o que Auroux (2008, p. 126) corrobora, [...] "sabe-se que se sabe aquilo que se sabe. Evidente, às vezes não é absurdo dizer que se sabia, mas que não sabia o que se sabia", demonstrando que nesse jogo de representações, o sujeito precisa ser encarado não como um sujeito biológico, objetivo, que sabe tudo, que sempre quer ter todas as respostas e que quando não as tem, representa tê-las, mas um sujeito que representa (no inconsciente) e é representado (no real) a todo momento, um sujeito sócio histórico que interpela e é interpelado pela língua e pela ideologia em seus processos discursivos nos seus diferentes tempos e espaços, que falha, que se contradiz. É nesse sentido, que concordo com Petri (2004, p. 25), quando afirma que a representação está sempre sujeita à opacidade da linguagem e dos sentidos.

No recorte do PPC que trago abaixo, demonstra-se como se dá o funcionamento prático das organizações dos tempos escola e comunidade no Curso de Dom Pedrito. Ao contrário das outras organizações, o PPC da Licenciatura em Educação do Campo de Dom Pedrito/RS utiliza-se unicamente da nomeação "regime" como se percebe no recorte abaixo:

A Organização curricular em regime de alternância, com base no Parecer CNE/CEB n. 1/2006 - prevê dias letivos organizados em tempo escola e tempo comunidade, com etapas presenciais (equivalentes a semestres de cursos regulares) e etapas vivenciadas no próprio ambiente social e cultural dos estudantes. Sendo assim, neste projeto o TE, desenvolvido nos meses de fevereiro e julho, será realizado presencialmente na universidade, configura-se como um momento no qual os educandos possuem aulas teóricas e práticas com o grupo de docentes efetivos do curso e colaboradores, participam também de atividades culturais, e exercitam a capacidade de auto-organização: momentos de organização do ambiente, trabalho em grupo, resolução de exercícios, leituras, ou seja, cada acadêmico, de acordo com as suas necessidades organiza o seu tempo individual de acordo com a avaliação das suas prioridades e de acordo com o seu planejamento individual e coletivo. No TC 
os educandos realizam atividades em suas comunidades de origem, sejam elas escolas, acampamentos, assentamentos de reforma agrária, propriedades rurais. Entre algumas das atividades previstas para o TC estão: pesquisa sobre a realidade, registro destas experiências, implementação de ações pedagógicas, vivências que possibilitem a partilha de conhecimentos, desenvolvimento de projetos de aprendizagem. Todas as atividades são orientadas no TE, e acompanhadas pelos professores mediadores nos meses de julho a dezembro e nos meses de março a junho (Unipampa, 2013, p. 29).

Nesse movimento de sentidos, entre o mesmo e o diferente, entre a "pedagogia" e o "regime" da alternância, entre os saberes da Universidade e os saberes do campo se constituem discursos que assumem diferentes posições que se assumem como as mesmas, em um caminho que perpassa o científico e o popular, inconscientemente atravessado ideologicamente por relação de forças. É nesse percurso entre os tempos e espaços pré-definidos da escola e da comunidade que a produção do conhecimento da Educação do Campo vem se constituindo, enquanto proposta educacional para aqueles localizados no campo.

\section{CONSIDERAÇÕES FINAIS - UM THE END DE (UM)A HISTÓRIA}

Neste texto (em sua primeira versão apresentado no SIFEDOC em 2018), discorro sobre o processo formativo de uma proposta pedagógica que nasceu nos anos 60 com influência da igreja e que vem desde lá, através de uma luta dos movimentos sociais em prol de uma educação diferenciada àqueles que vivem no e do campo, buscando espaço em meio à produção do conhecimento acadêmico de universidades e institutos federais brasileiros.

Para tanto, utilizo-me de Projetos Pedagógicos de Cursos de Licenciatura em Educação do Campo do Rio Grande do Sul ofertados via Edital proposto pelo MEC em 2012, para descrever uma relação entre o que é demandado politicamente por um edital e o que é apresentado pelas instituições ofertantes, no que diz respeito à proposta de funcionamento dos cursos.

Essa proposta, ora nomeada como Pedagogia da Alternância, ora como Regime de Alternância, como construída e apresentada nos Projetos Pedagógicos dos Cursos de Licenciatura em Educação do Campo do RS não atribui diferenças de sentidos entre a "pedagogia" e o "regime", pois eles centram suas explicações no funcionamento das práticas do curso, em seus diferentes tempos, o da escola e o da 
comunidade, a fim de atender a um Edital e poder ofertar o curso nessas instituições.

No entanto, uma vez que caminhamos teoricamente alicerçados por uma teoria discursiva de interpretação que busca compreender a língua fazendo sentido, enquanto trabalho simbólico-social, constitutivo do sujeito e respectivamente de sua história, é importante descrever o funcionamento dos discursos que institucionalizam saberes sobre essa proposta nos cursos, às vezes, nomeando "regime", outras "pedagogia", interpelados ideologicamente em uma memória de saberes que entra em funcionamento, inconscientemente, para "optar" dizer de um modo que não de outro.

"Usar uma palavra não é usar outra, e fazer recortes em regiões de sentidos sem ter nenhuma garantia de um entendimento absoluto é inscrever-se em redes de filiações de sentidos, memórias e esquecimentos constitutivos do dizer" (FLORES, 2019 , p. 65). Essas filiações de sentidos, entre o "regime" e a "pedagogia", remetem a memórias e a circunstâncias que mostram que os sentidos não estão somente nas palavras, mas em uma relação com as condições em que elas são produzidas, com uma relação com a exterioridade e com a historicidade que nelas se constitui.

\section{REFERÊNCIAS}

ALTHUSSER, Louis. Aparelhos Ideológicos de Estado. Tradução Joaquim José de Moura Ramos. Lisboa; São Paulo: Presença; Martins Fontes, [1970] 1980.

ANDRADE, Gilmar dos Santos. ANDRADE, Edjane de Souza. Historiando a Pedagogia da Alternância e a Escola Família Agrícola do Sertão da Bahia. In: Entrelaçando: Revista Eletrônica de Culturas e Educação. N. 6. V. 2. p. 61-72. 2012.

ARAÚJO, Sandra Regina Magalhães. Escola para o trabalho, escola para a vida: o caso da Escola Família Agrícola de Angical - Bahia. 2005. Dissertação (Mestrado em Educação e Contemporaneidade) - Universidade do Estado da Bahia, Salvador, 2005.

AUROUX, Sylvain. A questão da origem das línguas seguido de A historicidade das ciências. Campinas, Editora RG, 2008.

BRASIL. Ministério da Educação. Secretaria de Educação Continuada, Alfabetização, Diversidade e Inclusão - SECADI. Educação do Campo: marcos normativos. Brasília: SECADI, 2012.

BRASIL. Ministério da Educação. Secretaria de Educação Continuada, Alfabetiza- 
ção, Diversidade e Inclusão - SECADI. Nota Técnica Conjunta $\mathbf{N}^{\circ}$ 3/2016/GAB/ SEACADI. 2016. Disponível em: < http://portal.mec.gov.br/index.php?option=com docman\&view=download\&alias=39261-nt-conjunta-03-2016-setec-sesu-secadi-pdf\&category slug=abril-2016\&ltemid=30192 > Acesso em 19 de junho de 2016.

CALDART, Roseli Salete. Licenciatura em Educação do Campo e projeto formativo: qual o lugar da docência por área?. In: Molina, Mônica Castagna; Sá, Laís Mourão. (Org.). Licenciaturas em Educação do Campo. 1. ed. Belo Horizonte: Autêntica, 2011, v. 5, p. 95-121.

CALVÓ, Pedro Puig. GIMONET, Jean-Claude. Aprendizagens e relações humanas na Formação por Alternância. In: BEGNAMI, João Batista e BURGHGRAVE, Thierry (Orgs.) Pedagogia da Alternância e sustentabilidade. Orizona, UNEFAB, 2013.

FLORES, Lucas Martins. A militância na/ da produção do conhecimento científico: uma análise discursiva do Dicionário da Educação do Campo. 2019. Tese (Doutorado em Letras) - Programa de Pós-Graduação em Letras, Universidade Federal de Santa Maria, Rio Grande do Sul. 2019.

GIMONET, Jean-Claude. Praticar e compreender a Pedagogia da Alternância dos CEFFAs. Tradução de Thierry de Burghgrave. Petrópolis, RJ: Vozes, Paris: AIMFR Associação Internacional dos Movimentos Familiares de Formação Rural, 2007.

INDURSKY, Freda. O Discurso do/sobre o MST: movimento social, sujeito, mídia. Campinas, SP: Pontes Editores, 2019.

MOLINA, Mônica Castagna. Expansão das licenciaturas em Educação do Campo: desafios e potencialidades. Educar em Revista, Curitiba, Editora UFPR: Brasil, n.55, jan./mar., 2015.

NOSELLA, Paolo. Educação do Campo: origens da pedagogia da alternância no Brasil. Vitória: EDUFES, 2012.

ORLANDI, Eni. Pulcinelli. Segmentar ou recortar. In: Série Estudos. № 10. Faculdades Integradas de Uberaba (linguística: Questões e Controvérsias), 1984.

PÊCHEUX, Michel. Ler o arquivo hoje. In: Orlandi, Eni P. (Org.) Gestos de leitura: da história no discurso. Tradução Bethania S. C. Mariani. Campinas, SP: Unicamp, [1975] 1994.

PETRI, Verli. Imaginário sobre o gaúcho no discurso literário: da representação do mito em Contos Gauchescos, de João Simões Lopes Neto, à desmitificação em Porteira Fechada, de Cyro Martins. 2004. Tese (Doutorado em Letras). Porto Alegre: UFRGS. 2004. 


\section{Projetos de Cursos}

INSTITUTO FEDERAL FARROUPILHA. Projeto Pedagógico do Curso Licenciatura em Educação do Campo. Jaguari, RS, 2012.

UNIVERSIDADE FEDERAL DO PAMPA. Projeto Pedagógico do Curso de Licenciatura em Educação do Campo. Dom Pedrito, RS, 2013.

UNIVERSIDADE FEDERAL DA FRONTEIRA SUL. Projeto Pedagógico do Curso Interdisciplinar em Educação do Campo. Erechim, RS, 2013.

UNIVERSIDADE FEDERAL DO RIO GRANDE DO SUL. Projeto Pedagógico do Curso de Graduação Licenciatura em Educação do Campo. Porto Alegre, RS, 2013. 


\title{
PERFIL DOS DISCENTES DE UM CURSO DE LICENCIATURA EM
}

\author{
EDUCACÃO DO CAMPO: \\ UM ESTUDO COMPARATIVO
}

\author{
Rita de Cássia Gonçalves ${ }^{71}$ \\ Natiélia Borges Leal dos Santos ${ }^{72}$ \\ Suzana Gomes Lopes ${ }^{73}$ \\ Tamaris Gimenez Pinheiro ${ }^{74}$ \\ Alexandre Leite dos Santos Silva ${ }^{75}$
}

71 Graduada em Educação do Campo, Ciências da Natureza e Pós-Graduandas (lato sensu) em Ensino de Ciências da Natureza pela Universidade Federal do Piauí, campus Senador Helvídio Nunes de Barros. Fazem parte do Grupo de Pesquisa Ensino de Ciências e Educação do Campo. 72 Graduada em Educação do Campo, Ciências da Natureza e Pós-Graduandas (lato sensu) em Ensino de Ciências da Natureza pela Universidade Federal do Piauí, campus Senador Helvídio Nunes de Barros. Fazem parte do Grupo de Pesquisa Ensino de Ciências e Educação do Campo. c.goncalves2014@hotmail.com; natieliaborges06@gmail.com

73 Doutora em Biotecnologia pela Universidade Federal do Maranhão. Docente do Curso de Licenciatura em Educação do Campo, Ciências da Natureza, da Universidade Federal do Piauí, campus Senador Helvídio Nunes de Barros. Atua nas áreas de Parasitologia Animal, Ensino de Biologia, Ensino de Ciências e Educação do Campo. suzanagms.lopes@gmail.com

74 Doutora em Ciências Biológicas - Zoologia pela Universidade Estadual Paulista "Júlio de Mesquita Filho" (UNESP), campus de Rio Claro/SP. Docente do Curso de Licenciatura em Educação do Campo, Ciências da Natureza, da Universidade Federal do Piauí, campus Senador Helvídio Nunes de Barros. Atua nas áreas de ecologia e parasitologia de moluscos aquáticos do semiárido além de temas transversais e ensino de ciências. tamarisgimenez@ufpi.edu.br

75 Doutor em Educação pela Universidade Federal de Uberlândia. Docente do Curso de Licenciatura em Educação do Campo da Universidade Federal do Piauí, campus Senador Helvídio Nunes de Barros. Atua nas áreas de Ensino de Ciências e Educação do Campo. alexandreleite@ ufpi.edu.br 
A população do campo tem sofrido historicamente a marginalização no aspecto educacional, inclusive quanto à Educação Superior (SANTOS, 2017). Nesse contexto, foram criadas as Licenciaturas em Educação do Campo (LEdoCs), que se enquadram como ações afirmativas, pois são medidas que procuram

[...] eliminar desigualdades historicamente acumuladas, garantindo a igualdade de oportunidade e tratamento, bem como de compensar perdas provocadas pela discriminação e marginalização, por motivos raciais, étnicos, religiosos, de gênero e outros. (BRASIL, 1996a, p. 10).

As LEdoCs são cursos regulares destinados à formação de professores para a docência nos anos finais do Ensino Fundamental e Ensino Médio nas escolas localizadas em áreas rurais. Seu objetivo é contribuir para a expansão da oferta da Educação Básica nas comunidades rurais e para a superação das históricas desvantagens educacionais experimentadas pelas populações do campo (BRASIL, 2012), sendo estas constituídas por coletivos diversos, como agricultores familiares, extrativistas, pescadores artesanais, ribeirinhos, assentados e acampados da reforma agrária, trabalhadores assalariados rurais, quilombolas, caiçaras, povos da floresta, caboclos e outros que vivem a partir do trabalho no meio rural (BRASIL, 2010).

O objetivo deste trabalho é discutir o alcance e o potencial do desenvolvimento de uma LEdoC da Universidade Federal do Piauí (UFPI), a partir do estabelecimento de um comparativo do perfil entre turmas de ingressantes e concluintes. $O$ estabelecimento da relação entre turmas, além do contexto, agrega ineditismo à pesquisa, já que não foi encontrado algo similar na revisão de literatura realizada, especialmente nos trabalhos de Cancelier et al. (2018) e Brito e Molina (2019).

Cancelier et al. (2018) fez um estudo sobre o perfil de uma turma de ingressantes de uma LEdoC, na modalidade de Educação à Distância (EAD) e na área de Ciências Humanas, da Universidade Federal de Santa Maria (UFSM). O perfil dos sujeitos investigados foi traçado a partir de um conjunto de características como a escolaridade, a idade, o polo em que está matriculado, o grau de instrução, o município de origem, a área de atuação e formação, a relação com o campo e os movimentos sociais, assim como os motivos que os levaram a optar pelo Curso. O seu objetivo foi 
entender se o Curso está indo ao encontro das pessoas inseridas ou que têm o desejo de se inserir na Educação do Campo, para assim traçarem metas e estratégias para a construção do perfil do egresso almejado no Projeto Pedagógico.

As implicações do estudo para o perfil do egresso demonstram que o sujeito ingressante no curso de Licenciatura em Educação do Campo deve ter clareza da formação que receberá traçada no perfil do egresso sendo necessária a aproximação com os ideais formadores do curso, identificando-se com os mesmos (CANCELIER et al., 2018, p. 12).

Os resultados obtidos pelos autores supracitados, por meio de questionários, indicaram, dentre outras coisas, que parte significativa dos ingressantes já possuíam graduação e poucos tinham vínculos com os movimentos sociais campesinos.

Brito e Molina (2019), sob a perspectiva do materialismo histórico-dialético, construíram uma pesquisa em que um dos objetivos foi traçar o perfil dos concluintes de uma LEdoC da Universidade de Brasília (UnB). Para isso, usaram como instrumentos o questionário e a análise documental. Os resultados da sua pesquisa mostraram que a maioria dos concluintes eram mulheres que viviam no campo e, inseridas nos movimentos sociais e/ou sindicais, trabalhavam na área do Curso. Por isso, concluíram que o perfil levantado as permitiu "afirmar que os concluintes do curso de LEdoC estão correspondendo ao perfil de formação apontado pelo projeto piloto do curso em relação à permanência em seu território e possibilidades de transformação na forma escolar" (BRITO; MOLINA, 2019, p. 8).

$\mathrm{Na}$ direção dos trabalhos anteriores, os autores deste texto consideram que conhecer os estudantes ingressantes e concluintes pode ser um ponto essencial no processo de acompanhamento do desenvolvimento da LEdoC e para se obter subsídios para o planejamento de ações futuras. A partir da descrição e da análise do perfil dos estudantes, buscou-se as respostas às questões: quem é o aluno do Curso? Que mudanças no lapso temporal representado pelas duas turmas tem ocorrido nos sujeitos que compõem o corpo discente do Curso?

Para tratar dessas questões, este texto será apresentado da seguinte forma: primeiro, fará considerações sobre o quadro teórico em torno da relação das LEdoCs com o paradigma da Educação do Campo, como ações afirmativas. Depois, apresen- 
tará a metodologia adotada. Em seguida, trará os resultados e discussões e, consecutivamente, as considerações finais.

\section{Licenciaturas sob o paradigma da Educação do Campo}

As LEdoCs são frutos de ações afirmativas das políticas públicas vinculadas ao Programa Nacional de Educação do Campo (Pronacampo) e, em especial, ao Programa de Apoio à Formação Superior em Licenciatura em Educação do Campo (Procampo). Emergiram em meio a reivindicações dos trabalhadores rurais e sob o paradigma da Educação do Campo (CALDART, 2012).

A Educação do Campo é um termo cunhado nos anos 1990 (CALDART, 2012), que concebe um ensino construído com o sujeito do campo e voltado para a sua realidade. É resultado da contribuição de diversos referenciais pedagógicos, como a pedagogia do oprimido, a pedagogia do movimento e a pedagogia socialista (CALDART, 2011).

Os princípios da Educação do Campo são: (i) educação de qualidade como direito da população camponesa, com respeito à sua cultura, seus valores e seus conhecimentos; (ii) educação construída com respeito às organizações comunitárias e a seus saberes; (iii) educação organizada no espaço camponês; (iv) educação produtora de uma cultura mediada pelo trabalho na terra e para terra; (v) educação para o desenvolvimento sustentável; (vi) educação contextualizada, com respeito à heterogeneidade dos povos do campo (BRASIL, 2007).

Esse paradigma educacional (MOLINA; JESUS, 2004) tem apoio na Lei de Diretrizes e Bases da Educação Nacional (BRASIL, 1996b), nas Diretrizes Operacionais para a Educação Básica das Escolas do Campo (BRASIL, 2002) e nas Diretrizes Curriculares Nacionais para a Educação Básica (BRASIL, 2013). Esses documentos apontam para um ensino articulado com os saberes e as vivências das populações do campo, considerando os seus contextos e heterogeneidade.

Alicerçados no paradigma da Educação do Campo, as LEdoCs foram criadas desde 2007 com experiências pilotos em quatro universidades (MOLINA, 2017) e, depois, se expandiram em projetos de licenciaturas com turma únicas (BRASIL, 2008; 2009) até se tornarem política permanente, sendo atualmente mais de 40 cursos espalhados pelo país (MOLINA, 2015). 
Os cursos de LEdoC funcionam em regime de alternância entre tempos formativos presenciais na universidade (tempo universidade) e nas comunidades e escolas rurais (tempo comunidade), de modo a propiciar a integração entre os conteúdos acadêmicos e a realidade dos estudantes e ao mesmo tempo não reforçando a alternativa de saírem do campo para estudar na cidade (MOLINA, 2015; 2017).

Além da alternância, as LEdoCs são cursos multidisciplinares, formando para a docência por área de conhecimento, de forma a ampliar a oferta dos níveis de escolarização nas escolas do campo (MOLINA, 2015). Assim, foram criados cursos para as áreas: Artes, Literatura e Linguagens; Ciências Humanas e Sociais; Ciências da Natureza e Matemática e Ciências Agrárias.

As LEdoCs possuem o caráter de ação afirmativa, pois contribuem para diminuir a histórica desigualdade de acesso à Educação Superior dos povos do campo.

Iniciativas institucionais que tem por objetivo a implantação de novos cursos de licenciatura específicos para a formação de professores para atuarem no segundo segmento do ensino fundamental e ensino médio nas escolas do campo. As propostas deverão ter como base a realidade social e cultural específica dos povos do campo e diagnóstico sobre o Ensino Fundamental e Ensino Médio das comunidades rurais a serem beneficiadas com os cursos. Serão apoiadas preferencialmente propostas de cursos elaboradas em parceria com as comunidades do campo a serem beneficiadas (BRASIL, 2012, p. 2)

Por isso, a condição para o ingresso nesses cursos é que os seus candidatos tenham vínculo com o campo, como professores ou outros profissionais da educação sem formação superior na modalidade licenciatura em exercício nas escolas do campo, nos centros de alternância, em experiências educacionais alternativas de Educação do Campo, em instituições da sociedade civil ou entidades não governamentais que atuam na defesa de direitos das populações do campo, jovens e adultos de comunidades do campo que tenham o Ensino Médio concluído e ainda não tenham formação em nível superior; participantes de instituições e movimentos sociais que atuam no espaço socioterritorial do campo, que tenha o ensino médio concluído e ainda não tenham formação em nível superior (UFPI, 2018).

Essas exigências se fazem para garantir a formação integral desses sujeitos que habitam, trabalham e vivem no e do campo, na busca de sua identificação enquanto sujeitos de direitos (FERNANDES; CERIOLI; CALDART, 2004; SANTOS, 2012). 
Conforme apresenta Silva Júnior e Netto (2011) a Educação do Campo não deve ser entendida como uma proposta de educação, mas sim como uma crítica a uma realidade historicamente determinada e por uma concepção de educação e de campo. Essa constante luta vem proporcionando avanços significativos que marcam e solidificam os ideais não só por educação, mas por condições de vida digna para esses povos (SANTOS, 2012). Tal luta mobiliza a população camponesa em prol de uma escola e de uma educação que seja de fato do campo e para o campo, com currículo próprio e, principalmente, profissionais que entendam e vivenciam a realidade do campo.

\section{DESENVOLVIMENTO}

\section{Contexto e sujeitos}

A Universidade Federal do Piauí (UFPI), mais especificamente, o Centro de Ciências da Educação, do campus Ministro Petrônio Portela, visando atender às demandas sociais do estado quanto a educação campesina, apresentou uma proposta para a oferta do Curso de Licenciatura em Educação do Campo com ênfase em Ciências da Natureza, para os municípios de Teresina, Picos e Floriano, e Ciências Sociais em Bom Jesus ao Edital de seleção № 02/2012 Secretaria de Educação Superior (SESU)/Secretaria de Educação Profissional e Tecnológica (SETEC)/Secretaria de Educação Continuada, Alfabetização, Diversidade e Inclusão (SECADI)/ Ministério da Educação (MEC) (UFPI, 2017). O referido Edital consistia na "Chamada Pública para seleção de Instituições Federais de Educação Superior - IFES e de Institutos Federais de Educação, Ciência e Tecnologia - IFET, para criação de cursos de Licenciatura em Educação do Campo, na modalidade presencial” (BRASIL, 2012).

Assim, em 2014, a UFPI lançou um edital para a primeira seleção de 240 discentes para ingresso nos referidos Cursos, 60 alunos cada. Atualmente o ingresso nesses cursos ocorre anualmente de forma diferenciada, ou seja, não fazendo uso da nota do Exame Nacional do Ensino Médio (ENEM) como instrumento e sim a classificação obtida em um processo seletivo especial, em que os candidatos são submetidos a uma prova objetiva, para a avaliação de conhecimentos, e à análise documental, para a comprovação da ligação com o campo (UFPI, 2018). 
Além da seleção diferenciada, o Curso também possui uma sistemática de funcionamento exclusiva na Instituição de Ensino, ocorrendo no modo de alternância, adaptado às condições de vida dos povos campesinos, de modo que consigam aliar sua formação com seu espaço de trabalho. A alternância no Curso é organizada da seguinte maneira: durante os meses de janeiro, parte de fevereiro, julho e parte de agosto, acontece em tempo integral o tempo universidade; e nos meses de fevereiro, março, abril, agosto, setembro, outubro é realizado o tempo comunidade.

A pesquisa foi realizada de setembro de 2017 a janeiro de 2018 com 76 estudantes de uma LEdoC da UFPI, no campus Senador Helvídio Nunes de Barros, na cidade de Picos, Piauí. A turma de concluintes ingressou no Curso no ano de 2014 e a de ingressantes em 2018. O Curso é organizado em oito blocos. Possui enfoque na área de Ciências da Natureza, contemplando, por isso, em sua matriz curricular, componentes referentes aos conhecimentos físicos, químicos e biológicos, além de componentes pedagógico-didáticos, conforme as diretrizes curriculares para as licenciaturas. Também contempla componentes que tratam da história, da organização e dos fundamentos teóricos e metodológicos da Educação do Campo, bem como a sua relação com os movimentos sociais camponeses.

\section{Instrumentos de coleta e análise dos dados}

Os dados foram coletados por meio de questionários e documentos do Curso. Foram utilizados dois questionários mistos com questões que trouxeram elementos que permitiram traçar o perfil desses alunos quanto aos seguintes assuntos: i) municípios de origem; ii) meios pelos quais tiveram conhecimento sobre o Curso; iii) grau de escolaridade ao ingressar no Curso; iv) vínculo empregatício; e v) interesse pelo Curso. A escolha pelo questionário como instrumento de coleta de dados se deve à sua propriedade de poder atingir uma quantidade maior de sujeitos em um tempo mais curto e à sua maior objetividade em relação a outras técnicas (MARCONI; LAKATOS, 2003).

Quanto aos documentos do Curso analisados, foi realizada também a pesquisa do Projeto Pedagógico vigente desde 2017, focando no público-alvo do referido Curso. Foram também analisados os editais de seleção das LEdoCs lançados pelo 
Ministério da Educação (MEC) e que foram a base para a delimitação dos perfis de concluintes e dos projetos pedagógicos dos Cursos desde a sua implantação. A pesquisa documental seguiu as orientações de Cellard (2008) sobre como levar em conta as condições de produção dos documentos e o cuidado com a sua autenticidade, sendo estes obtidos em páginas institucionais da UFPI e do MEC.

As questões objetivas do questionário foram tabuladas em planilhas no software Excel para a construção de gráficos comparativos. As questões discursivas foram submetidas à análise categorial, conforme Creswell (2008). Dessa forma, a análise contemplou as dimensões qualitativa e quantitativa.

A análise dos dados do questionário conjuntamente com os documentos permitiu confrontar as características dos ingressantes e concluintes, permitindo inferências sobre mudanças no perfil dos sujeitos que são atendidos.

\section{RESULTADOS E DISCUSSÃO}

A partir dos procedimentos descritos no tópico anterior, os resultados dos questionários foram digitados e compilados, inferidos com o auxílio da análise documental.

Participaram da pesquisa um total de 21 alunos concluintes, cuja faixa etária variou de 23 a 63 anos. Destes, $86 \%$ são do sexo feminino e $14 \%$ são do sexo masculino. $\mathrm{O}$ grupo de ingressantes pesquisado foi composto por 55 sujeitos que apresentaram idade média inferior aos da primeira turma, variando de 16 a 59 anos, sinalizando uma diminuição na idade média dos alunos do curso pesquisado. Desse total de ingressantes, $73 \%$ são do sexo feminino e $27 \%$ são do sexo masculino, número que indica uma redução na proporção de licenciandos do sexo feminino quando comparadas as duas turmas.

Constata-se com esses dados sobre a faixa etária que, com o passar do tempo, a LEdoC tem contado com a presença de um público mais jovem. Ao passo que essa mudança foi se conformando à expectativa expressa pela Plano de Desenvolvimento da Educação (BRASIL, 2001), no sentido de prover a Educação Superior para uma significativa parcela do público jovem, na faixa etária entre 18 e 24 anos, também atende às aspirações que levaram à criação das LEdoCs, isto é, "garantir a formação, no âmbito da educação superior, para os educadores que já atuam nas escolas 
do campo, bem como para a juventude camponesa que nelas possa vir a atuar" (MOLINA, 2017, p. 594).

Quanto ao gênero dos educandos, mesmo com a sua redução com o tempo, a presença feminina ainda é majoritária na LEdoC. Embora isso seja o esperado de uma licenciatura, conforme atestam outras pesquisas (BRITO; MOLINA, 2019), representa no contexto da Educação do Campo uma vitória, pois a presença e liderança da mulher nas atividades educativas escolares e comunitárias, alavancada pela formação na LEdoC, pode ser um indicativo da diluição da cultura patriarcal camponesa e de empoderamento da mulher do campo (FALEIROS; FARIAS, 2017).

Dezenove municípios puderam ser identificados como tendo sujeitos atendidos pela LEdoC (FIG. 1). Nove municípios da região sudeste piauiense foram apontados como local de residência dos concluintes: Campo Grande do Piauí, Geminiano, Inhuma, Itainópolis, Jaicós, Massapê do Piauí, Picos, Valença do Piauí e Vila Nova do Piauí (FIG. 2). Quanto aos ingressantes, 16 municípios foram destacados (FIG. 2), alguns localizados muito próximo à Picos, cidade sede do campus Senador Helvídio Nunes de Barros, onde é ofertada a LEdoC, como Geminiano (distante cerca de 18 km de Picos) (FIG. 1). No entanto, há alunos oriundos de municípios relativamente distantes, como Palmeirais (situado a $261 \mathrm{~km}$ de distância de Picos), São Miguel do Fidalgo (a 167 km de Picos) e Patos do Piauí (a 99 km de Picos) (FIG. 1). 
Figura 1 - Mapa da distribuição dos municípios do estado do Piauí com destaque para aqueles atendidos pelo Curso de Licenciatura em Educação do Campo, Ciências da Natureza, campus Senador Helvídio Nunes de Barros, Universidade Federal do Piauí.

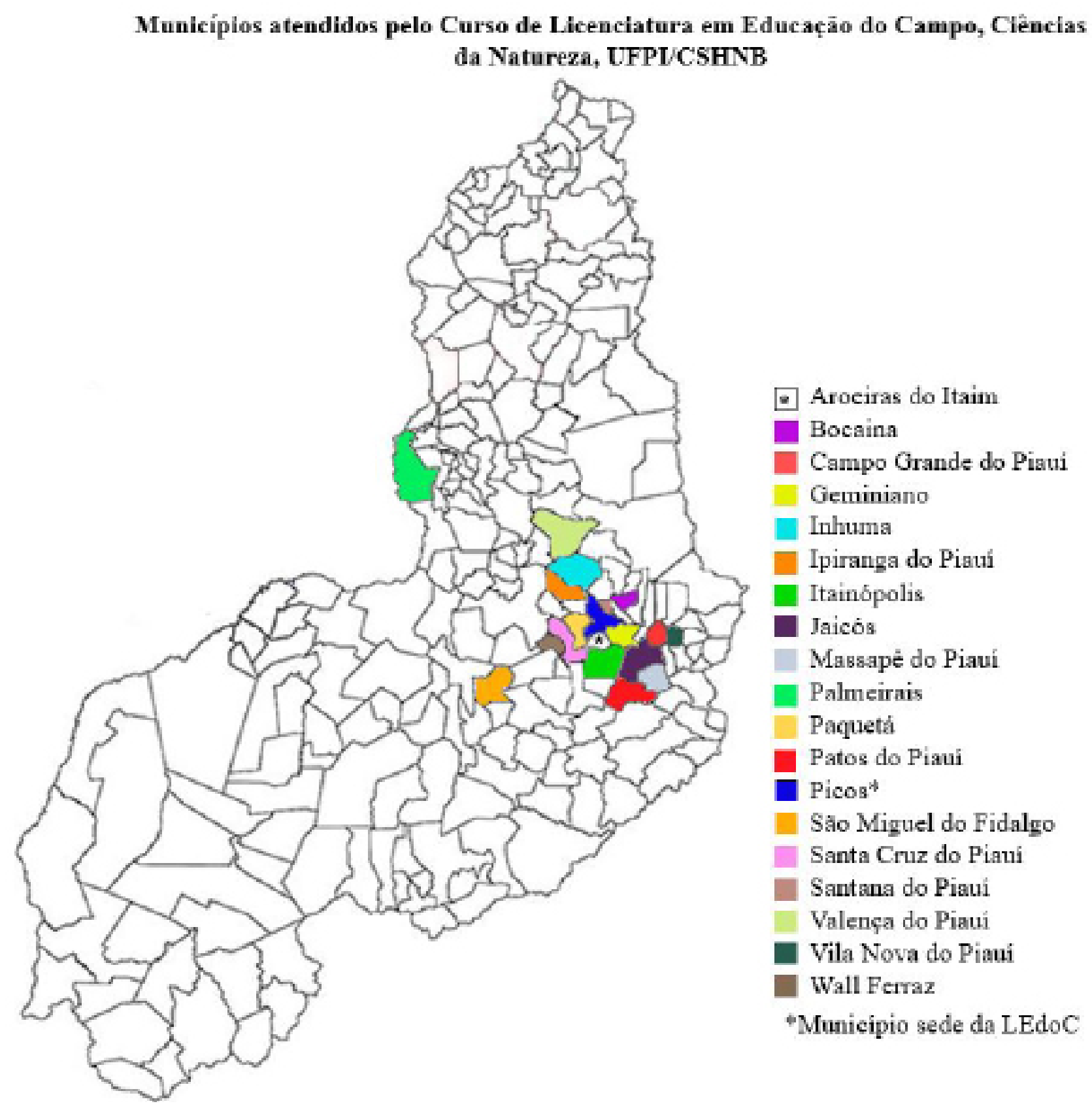

Fonte: Elaborado pelos autores (2020). 
Figura 2 - Municípios em que residem os sujeitos da pesquisa

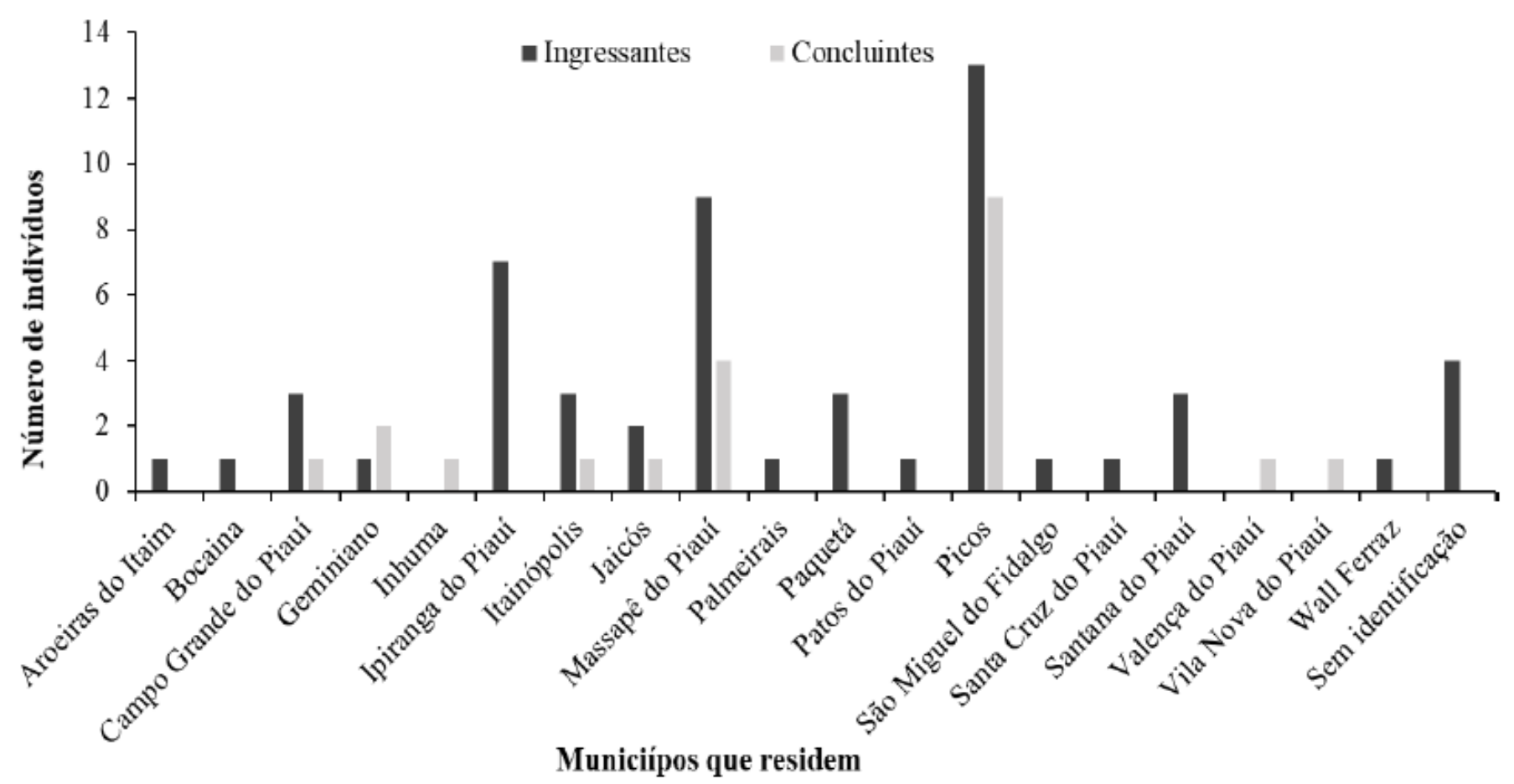

Fonte: Elaborado pelos autores (2020).

Nota-se que em quatro anos de atuação, o Curso quase dobrou o número de municípios atendidos, o que indica uma ampliação no alcance dele, que passou a contar com alunos de locais diversos e distantes da sede. Esse fato aponta que, apesar das limitações, as políticas públicas afirmativas para a população campesina têm surtido efeitos positivos no sentido do acesso à Educação Superior a um coletivo diverso. Dessa forma, vê-se um movimento da população camponesa regional para afirmarem o seu lugar nos espaços do conhecimento (ARROYO, 2014), com reflexos na produção cultural e intelectual. Um exemplo disso pode ser visto no livro de Pacheco et al. (2017), oriundo de um trabalho dos estudantes da LEdoC em escolas da educação básica. A obra, toda ilustrada, contém uma coletânea de contos populares e regionais e inclui sugestões pedagógicas de temas, de atividades e de conteúdos conceituais, procedimentais e atitudinais que podem ser trabalhados no ensino de Ciências da Natureza, em articulação com outros campos do conhecimento, como os das Ciências Humanas e Sociais.

Quanto como ficaram sabendo do Curso, $42,8 \%$ dos concluintes afirmaram ter tido conhecimento por meio de indicação de outras pessoas, 33,3\% por meio da internet, 19,1\% pelos jornais e 4,8\% pela rádio. Quanto aos ingressantes, 81,9\% ficaram sabendo da oferta do Curso por indicação de outras pessoas, 14,5\% por meio 
da internet e 3,6\% por meio de notícia em jornal. A menor proporção de indicação por outras pessoas para os alunos concluintes é justificável pois estes, que ingressaram em 2014, possuíam apenas como referência os estudantes das duas turmas das LEdoCs, uma na cidade de Oeiras e outra em Jaicós, oferecidas com base em editais específicos (BRASIL, 2008; 2009), em projetos especiais de turmas únicas (MOLINA, 2017). Assim, o fato de o Curso, agora como política permanente e regular na instituição (BRASIL, 2012), fez com que os próprios estudantes contribuíssem para a sua divulgação, permitindo que pessoas dos mais distintos lugares tivessem acesso e interesse no ingresso.

Com relação à formação em Ensino Superior, 76,2\% dos concluintes declararam já ter concluído algum curso de graduação, enquanto $23,8 \%$ possuíam o Ensino Médio completo. Para os ingressantes essa relação foi representativamente diferente pois, apenas $3,6 \%$ possuíam formação superior, enquanto $96,4 \%$ apenas o Ensino Médio. Essa informação é mais uma evidência da eficácia dos mecanismos institucionais de ação afirmativa, pois um dos requisitos para o ingresso na LEdoC é que o estudante ainda não tenha formação em nível superior. Um dos objetivos do Curso, previsto no seu Projeto Pedagógico (UFPI, 2017, p. 23, grifo nosso) é "habilitar profissionais em exercício na educação fundamental e média, que ainda não possuam a titulação mínima exigida pela legislação educacional em vigor". Embora reduzido, o ingresso ainda contínuo de alunos com formação em nível superior indica a necessidade de mais medidas para que a seleção de candidatos tenha realmente caráter de ação afirmativa.

Sobre o exercício de alguma atividade laboral, $61,9 \%$ dos concluintes declararam trabalhar e $38,1 \%$ não exerciam nenhuma função no mercado de trabalho. Dentre os que trabalhavam, 61,5\% eram professores da Educação Básica em escolas públicas, enquanto $38,5 \%$ trabalhavam em outras atividades, como o sindicalismo, o radialismo, a gestão escolar, dentre outros. Com relação ao trabalho dos ingressantes, apenas $29,1 \%$ deles afirmaram desenvolver alguma atividade remunerada. Destes, 56,3\% declararam trabalhar em atividades ou setores diversos, como babá, aula de reforço, técnico em áudio, lava jato, escola, vendedora, network e prefeitura. Além deles, 37,5\% declararam trabalhar no campo, seja na "roça" ou com irrigação ou como técnico agrícola; e apenas um sujeito $(6,3 \%)$ declarou ser professor. 
Esses resultados representam uma mudança no perfil do ingressante no Curso, tendo em vista que a maior parte da primeira turma, a dos concluintes, era constituída pelo profissional que atuava nas escolas do campo sem formação em licenciatura ou com licenciatura em outra área do conhecimento. Os ingressantes, por sua vez, além de não possuírem formação superior, na sua grande maioria, não atuam nas escolas do campo, sendo constituída por uma significativa quantidade de trabalhadores do campo.

Essa mudança pode ter implicações para o planejamento do Curso, cujo calendário e tempos de alternância foram organizados para possibilitar o ingresso de educadores na Educação Superior sem que precisem abandonar o trabalho na escola básica para elevarem sua escolarização (MOLINA, 2017). Agora, a preocupação, com essa mudança de perfil, é evitar que o ingresso de jovens e adultos do campo na LEdoC reforce a alternativa de deixarem a vida no território rural (MOLINA, 2017).

A pesquisa também buscou identificar as expectativas que motivaram os sujeitos a optarem pela LEdoC. A alternativa com o maior número de respostas dada pelos concluintes foi a identificação com um curso de licenciatura voltado para o campo $(61,9 \%)$, seguida pela possibilidade de ingresso no Ensino Superior (14,3\%). Outras respostas foram atribuídas, como: aperfeiçoar conhecimentos e adquirir habilidades para atuar com alunos do campo; estudar em uma instituição reconhecida pela qualidade de ensino; precisar de uma licenciatura por estar em sala de aula; por falta de opção; por já trabalhar em escola do campo. Cada uma delas foi dada por um concluinte, representando $23,8 \%$ da amostra.

A escolha da LEdoC para os ingressantes também ocorreu pela identificação com um curso de licenciatura voltado para o campo (36,4\%); pelo fato do curso proporcionar o estudo em uma instituição reconhecida (32,7\%); pela possibilidade de ingresso no ensino superior (29,1\%); e pela identificação com a docência (1,8\%). Esse resultado indica que o Curso, além de contar com um público que ingressa pela afinidade à proposta, constitui uma grande oportunidade, se não a única, de ter acesso à universidade. Essa expectativa está consonância com o propósito da criação das LEdoCs na esteira do Procampo (Molina, 2015). 
A pesquisa mostrou que no lapso temporal entre as duas turmas analisadas ocorreu uma mudança no perfil, com um público mais jovem, embora ainda predominantemente feminino. O número de municípios atendidos e representados pelo corpo discente também se expandiu, assim como o papel da divulgação por meio de semelhantes. Houve a redução de discentes atuantes como educadores em escolas do campo para aqueles envolvidos diretamente com o trabalho na terra, embora ainda haja quem já possua outra graduação. Quanto às expectativas que os levaram a optar pelo Curso, em ambas as turmas foi significativa a identificação com a formação voltada para a Educação do Campo.

Os dados revelam que o Curso tem seguido um caminho que vai ao encontro dos documentos oficiais quanto ao público que atinge, constituído por educadores e outros trabalhadores do campo. No entanto, mostram a necessidade de melhorias no processo de divulgação e seleção de forma a atingir os grupos que realmente façam jus a tal ação afirmativa, isto é, aqueles envolvidos com o campo e que não possuam ainda formação em nível superior.

Embora mais municípios sejam atendidos pela LEdoC, ainda há margens para expansão e para que representantes de outros locais e comunidades da região sejam atingidos, o que pode requer uma maior divulgação por meios diversos.

A redução no público feminino entre as duas turmas deve ser acompanhada para se verificar se as mulheres do campo da região têm optado por outros cursos de graduação, se tem chegado até elas informações sobre o Curso e/ou se têm encontrado obstáculos para o acesso ao Ensino Superior.

O impacto de um público mais jovem deve ter reflexos nas metodologias e estratégias de ensino. Além disso, a maior presença de discentes envolvidos com o trabalho na terra sinaliza a necessidade de se repensar na organização da alternância do Curso, estabelecida inicialmente para atender professores de escolas do campo.

O trabalho mostrou a importância do estudo dos perfis das turmas e do estabelecimento de comparações como meios de evidenciar mudanças e continuidades e, dessa forma, apontar ajustes que precisam ser realizados na divulgação, no processo 
de seleção, na matriz curricular, no calendário e na organização didático-pedagógica do Curso. Enfim, o estudo do perfil de ingressantes e concluintes tem um importante papel para assegurar o desenvolvimento da LEdoC como uma ação afirmativa para a população do campo da região.

\section{REFERẾNCIAS}

ARROYO, M. G. Outros sujeitos, outras pedagogias. 2. ed. Petrópolis: Vozes, 2014.

BRASIL. Ministério da Justiça. Secretaria de Estado dos Direitos Humanos. Relatório do Grupo de Trabalho Interministerial População Negra. Brasília, DF: 1996a.

. Lei $n^{\circ}$ 9.394, de 20 de dezembro de 1996. Estabelece as Diretrizes e Bases da Educação Nacional. Diário Oficial [da República Federativa do Brasil], Brasília, DF, v. 134, n. 248, 23 dez. 1996. seção 1, p. 27834-27841.

. Lei no 10.172, de 9 de janeiro de 2001. Aprova o Plano Nacional de Educação e dá outras providências. Diário Oficial [da República Federativa do Brasil], Brasília, DF, n. 248, 09 jan. 2001. seção 1, p.

. Câmara de Educação Básica. Resolução n 1, de 03 de abril de 2002. Estabelece as diretrizes para a Educação Básica nas escolas do campo. Diário Oficial [da República Federativa do Brasil], Brasília, DF, n. 67, 09 abr. 2002. seção 1, p. 32.

Educação do Campo: diferenças mudando paradigmas. Brasília, DF: 2007. 81 p. Disponível em: http://portal.mec.gov.br/secad/arquivos/pdf/educacaocampo. pdf. Acesso em: 08 jun. 2020.

. Secretaria de Educação Continuada, Alfabetização, Diversidade e Inclusão. Edital de convocação $N^{\circ} 02$, de 23 de abril de 2008. Chamada pública para seleção de projetos de instituições públicas de ensino superior para o PROCAMPO. Diário Oficial [da República Federativa do Brasil], Brasília, DF, n. 78, 24 de abr. 2008. seção 3, p. 30.

Secretaria de Educação Continuada, Alfabetização, Diversidade e Inclusão. Edital de convocação $N^{\circ}$ 09, de 29 de abril de 2009. Diário Oficial [da República Federativa do Brasil], Brasília, DF, n. 81, 30 de abr. 2009. seção 3, p. 57-59.

Decreto $N^{\circ} 7.352$, de 04 de novembro de 2010. Dispõe sobre a política de educação do campo e o Programa Nacional de Educação na Reforma Agrária - PRONERA. Diário Oficial [da República Federativa do Brasil], Brasília, DF, n. 212, 05 nov. 2010. seção 1, p. 1-3. 
. Secretaria de Educação Continuada, Alfabetização, Diversidade e Inclusão. Edital de chamada pública $N^{\circ} 02$, de 31 de agosto de 2012. Diário Oficial [da República Federativa do Brasil], Brasília, DF, n. 173, 05 set. 2012. seção 3, p. 59-60.

Diretrizes Curriculares Nacionais Gerais da Educação Básica. Brasília, DF: 2013. 562 p. Disponível em:

http://portal.mec.gov.br/index.php?option=com_docman\&view=download\&alias=13448-diretrizes-curiculares-nacionais-2013-pdf\&ltemid=30192. Acesso em 17 set. 2020.

BRITO, M. M. B.; MOLINA, M. C. Reflexões sobre os egressos do curso de Licenciatura em Educação do Campo da Universidade de Brasília: os elementos para "Transformar (ação) Pedagógica" na Educação Superior. Revista Brasileira de Educação do Campo, Tocantinópolis, v. 4, e6291, p. 1-29, maio. 2019.

CALDART, R. S. Por uma educação do campo: traços de uma identidade em construção. In: ARROYO, Miguel González.; CALDART, Roseli Salete; MOLINA, Mônica Castagna (Org.). Por uma educação do campo. 5. ed. Petrópolis: Vozes, 2011. p. 147-160.

. Educação do campo. In: CALDART, R. S. et al. (Org.). Dicionário da Educação do Campo. 2. ed. Rio de Janeiro/São Paulo: Escola Politécnica de Saúde Joaquim Venâncio, Expressão Popular, 2012. p. 257-265.

CANCELIER, J. W. et al. Perfil dos alunos ingressantes no Curso de Licenciatura em Educação do Campo habilitação em Ciências Humanas na Universidade Federal de Santa Maria/UAB. In: CONGRESSO INTERNACIONAL DE ENSINO SUPERIOR À DISTÂNCIA, 4., 2018, Natal. Anais ... Natal: UFRN, 2018. P.1-13.

CELLARD, A. Análise documental. In: POUPART, J. et al. (Org.). A pesquisa qualitativa: enfoques epistemológicos e metodológicos. Tradução de Ana Cristina Arantes Nasser. Petrópolis: Vozes, 2008. p. 295-316.

CRESWELL, J. W. Educational research: planning, conducting, and evaluating quantitative and qualitative research. 3. ed. Columbus: Pearson, 2008.

FALEIROS, W.; FARIAS, M. N. Educação do campo: entre a expansão política e o Estado neoliberal. Revista Educação Popular, Uberlândia, v. 16, n. 1, p. 22-37, jun. 2017.

FERNANDES, B. M.; CERIOLI, P. R.; CALDART, R. S. Primeira Conferência Nacional por uma educação básica do campo: texto preparatório. In: ARROYO, M. G.; 
CALDART, R. S.; MOLINA, M. C. Por uma educação do campo. Petrópolis: Vozes, 2004, p. 19-62.

MARCONI, M. A.; LAKATOS, E. M. Fundamentos de metodologia científica. 5. ed. São Paulo: Atlas, 2003.

MOLINA, M. C. Expansão das licenciaturas em Educação do Campo: desafios e potencialidades. Educar em Revista, Curitiba, n. 55, p. 145-166, jan./mar. 2015.

Contribuições das licenciaturas em Educação do Campo para as políticas de formação de educadores. Educação \& Sociedade, Campinas, v. 38, n. 140, p. 587-609, jul./set. 2017.

MOLINA, M. C.; JESUS, S. M. S. A. (Org.). Contribuições para a construção de um projeto de Educação do Campo. Brasília, DF: Articulação Nacional Por Uma Educação do Campo, 2004. (Coleção Por Uma Educação do Campo, n. 5).

PACHECO, A. C. L. et al. (Org.). Costurando pontos e amarrando pontos: tecendo o Piauí pelo imaginário popular. Teresina: Edufpi, 2017.

SANTOS, S. P. A concepção de alternância na licenciatura em educação do campo na universidade de Brasília. 2012. 161f. Dissertação (Mestrado em Educação) - Faculdade de Educação, Universidade de Brasília, Brasília, 2012.

SANTOS, R. B. História da Educação do Campo no Brasil: o protagonismo dos movimentos sociais. Teias, Rio de Janeiro, v. 18, n. 51, p. 210-224, out./dez. 2017.

SILVA JÚNIOR, A. F.; NETTO, M. B. Por uma educação do campo: percursos históricos e possibilidades. Entrelaçando. Revista Eletrônica de Culturas e Educação Caderno temático: Cultura e Educação do Campo, n. 3, p. 45-60, nov. 2011.

UNIVERSIDADE FEDERAL DO PIAUÍ. Projeto Pedagógico do Curso de Licenciatura em Educação do Campo. Picos: 2017. Disponível em:

https://www.sigaa.ufpi.br/sigaa/verProducao?idProducao $=2472104 \& k e y=-$ 95681897701346cebc5135c08393129d. Acesso em: 10 out. 2020.

. Edital $\mathbf{N}^{\circ} . \mathbf{0 8}$, de 24 de julho de 2018. Processo Seletivo para o Curso de Licenciatura em Educação do Campo (LEdoC) - 2019.1. Teresina: 2018. Disponível em: https://www.in.gov.br/materia/-/asset_publisher/Kujrw0TZC2Mb/content/ id/34576143. Acesso em: 25 set. 2020. 


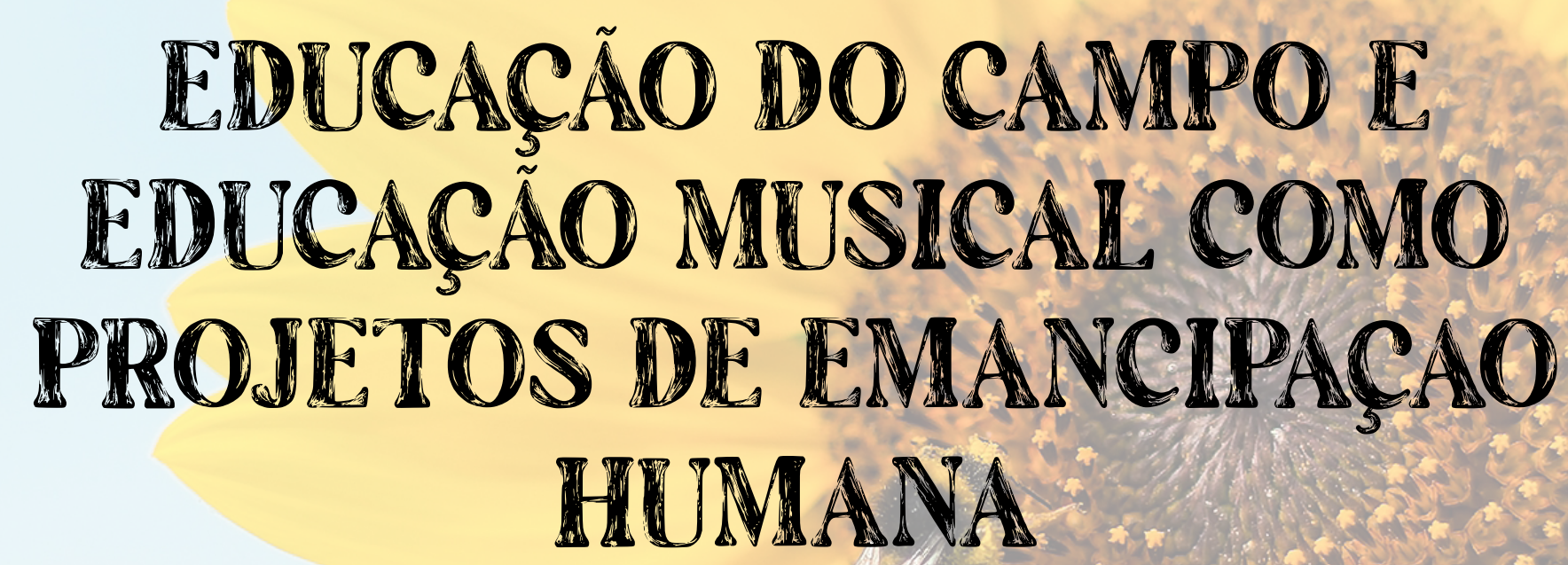

Fernando Vieira da $\mathrm{Cruz}^{76}$ Dayana Aparecida Marques de Oliveira $\mathrm{Cruz}^{77}$

$76 \quad$ Mestre e Doutorando em Música pela Unicamp. Supervisor Educacional no Projeto Guri. E-mail: fvccruz@hotmail.com

77 Graduada, Mestra e Doutora em Geografia pela FCT/Unesp. Professora no Instituto Federal de São Paulo (IFSP/Registro). E-mail: d.dayana@hotmail.com 
Diferentes concepções educacionais vêm denunciando a necessidade de o debate em educação não ficar restrito ao pensamento pedagógico, mas atentar-se as relações sociais, contextos de vida dos estudantes e modelos de sociedade que os subsidiam. A educação do campo e diferentes propostas da educação musical que surgiram a partir do século XX são exemplos pertinentes a este texto. O surgimento destas propostas, as quais pretendemos colocar em diálogo, convergem com alguns princípios gerais como o do desenvolvimento integral do sujeito, o protagonismo do estudante, o contexto de vida como materialidade de conhecimento, e de modo mais basilar, a necessidade das transformações no pensamento pedagógico, na realidade de vida dos estudantes na intenção de uma sociedade mais igualitária. Firmes em contrapor os paradigmas que as antecederam, estas propostas vêm sendo desenvolvidas com fortes discussões das contradições que as cercam. Estas contradições emergem, muitas vezes, do perigo das dicotomias presentes no embate das ideias postas em discussão. Elas denunciam a necessidade do adensamento e alargamentos de tais discussões com um olhar sempre voltado aos princípios geradores das propostas em voga.

A perspectiva teórica que assumimos é a da concepção de música como linguagem pelas contribuições de Silvia Cordeiro Nassif Schroeder gestada na leitura da filosofia da linguagem de Mikhail Bakthin. Nesta perspectiva a linguagem, portanto também a linguagem musical, pode ser entendida através dos discursos e enunciados postos em prática em um contexto social comum aos interlocutores, sendo que, cada enunciado ou discurso musical ocorre em resposta e em direção a outro discurso. Assim, a noção de diálogo em VOLÓCHINOV/BAKHTIN (2017) está posta em qualquer tipo de resposta imediata ou não, falada, escrita, em concordância ou contrapondo, e até mesmo por uma simples fruição. Por depender do contexto social, a significação dos discursos se dá em interação nos coletivos sociais chamados de Sistemas Ideológicos (a religião, a política, a ciência e assim por diante). Assim, entre ideologias cotidianas (aquelas das conversas do dia a dia) e ideologias já formadas (aquelas em prevalência nos sistemas ideológicos), ocorrem contínuos processos de transformação (ressignificações) de cada discurso e também dos interlocutores 
envolvidos. Estes processos de mútuas transformações são chamados de refração. Esta breve exposição do aporte teórico e alguns conceitos que utilizaremos durante o texto é feita apenas para cumprir a clareza de onde partimos as discussões. Cumpre ainda dizer, que este aporte teórico se funda no materialismo histórico dialético com certa clareza de onde partem também as concepções de educação do campo com as quais dialogaremos.

Seguindo, a partir da perspectiva anunciada trazemos o objetivo deste texto em discutir as possíveis aproximações e diálogos presentes em concepções da educação musical e da educação do campo observando alguns princípios norteadores presentes em ambas. Dentre os princípios, ressaltamos a convergência das discussões sobre uma educação mais igualitária que considera o estudante como protagonista de seu processo de ensino-aprendizagem. Portanto, encontramos em autoras que discutem a educação do campo como Caldart (2004) e Freitas (2011), alguns pontos de contato com o debate realizado no âmbito da educação musical por Penna (2008, 1999), Souza (2004) e Schroeder (2005). Identificamos profícuos diálogos para a formação integral do ser, para uma educação mais igualitária e integradora, para o reconhecimento das diversidades e valorização da cultura, dos saberes e das formas de expressões locais.

Para cumprir o objetivo proposto utilizamos da revisão bibliográfica sobre educação do campo e educação musical pelos autores apontados anteriormente. O texto está organizado em duas partes. A primeira apresenta o apontamento de algumas dicotomias limitantes em ambas as áreas em discussão. Na segunda parte aprofundamos a discussão sobre a superação de tais dicotomias a partir do arcabouço teórico adotado. Por fim, trazemos as considerações finais sobre as possibilidades de diálogo levantadas durante o texto.

\section{A PROBLEMÁTICA DAS DICOTOMIAS LIMITANTES}

O debate acerca da superação das visões dicotômicas é recorrente em diferentes abordagens educacionais e abundante nas discussões da educação do campo e da educação musical. Em pauta, entram a promoção da igualdade social, garantia da autonomia dos sujeitos e reconhecimento das diversidades. Aqui, pretendemos focalizar nossas discussões da representatividade que tem esta discussão para a 
superação da verticalidade impositiva da cultura instrumentalizada por uma visão excludente de educação.

No caso da educação do campo, busca-se a superação da antinomia rural e urbano na qual se reafirma estereótipos acerca dos modos de vida no campo como antiquado/atrasado e na cidade como moderno/avançado. Essa dicotomia foi reforçada nas propostas que ficaram conhecidas como educação rural com início no Brasil na década de 1930. O discurso em prol da "modernização" do campo subjugava-o como sinônimo de atraso por não se adequar ao sistema produtivo imposto de forma verticalizada (FREITAS, 2011). As transformações no campo impactaram a organização do território brasileiro culminando em mudanças não só no campo, mas também nas cidades (SANTOS, 1998). Tais transformações estiveram baseadas no modelo de desenvolvimento agroindustrial adotado como referência a partir da Revolução Verde da década de 1970. Este modelo atenuou os conflitos e contradições existentes no campo a partir da disputa de poder entre os grandes latifundiários e os movimentos sociais, trazendo à tona a discussão sobre a questão agrária no debate político nacional.

A resistência protagonizada pelos movimentos sociais do campo, como no caso do Movimento dos Trabalhadores Rurais Sem Terra (MST), aprofundou as discussões sobre a concentração fundiária e a produção no campo brasileiro através da luta pela reforma agrária e pela adoção de novas práticas de cultivo como a agroecologia (FERNANDES, 2019). Tais embates abarcaram diferentes aspectos da vida no campo, incluindo o reconhecimento da necessidade da luta pelo direito à educação gestada numa concepção multidimensional do próprio campo (FERNANDES, 2006). Neste sentido, a educação do campo busca reconhecer as identidades e valorizar os saberes do campo, sendo contrária à velha premissa da educação rural que impôs, durante muito tempo, a perpetuação das desigualdades sociais no campo buscando adequar-se às demandas da modernidade urbana e industrial (FREITAS, 2011).

Podemos apontar também a velha dicotomia entre a educação em espaços formais e informais discutida por Caldart (2007), diretamente relacionada à persistência das citadas abordagens (tradicionais) de ensino. Embora os movimentos sociais reconhecem e reivindicam para o campo a formação escolar, eles também advertem para a necessidade da escola estar pautada na materialidade do campo. Em outras 
palavras, a escola precisa atender as particularidades dos sujeitos sociais concretos do campo tendo como referência um recorte de classe, abrangendo também a universalidade da educação e no empenho em "construir uma educação do povo do campo e não apenas com ele, nem muito menos para ele" (CALDART, 2004, p. 3 grifos da autora). Tais reivindicações faz valer a função da escola enquanto espaço coletivo de construção do saber (CRUZ, 2020b).

Enfim, por mais que o embate pelo fim das dicotomias, muitas vezes, denuncie a necessidade de tratamento de fortes contradições, a discussão precisa avançar em densidade e amplitude. É preciso encarar tais contradições para não cair ou se render ao modelo liberal de sociedade amparada pela repetição de projetos educacionais impositivos e instrumentalizados. Pois, enquanto a educação não coloca em pauta a emancipação humana da população historicamente oprimida, ela estará a mercê deste mesmo modelo de sociedade, conforme discutido por Caldart (2007).

A mesma necessidade de superação das dicotomias também se faz presente no âmbito da educação musical. Uma situação já bem conhecida é aquela advinda da contraposição entre música popular e música de tradição europeia (destarte, música erudita). Esta visão dicotômica supervaloriza o padrão europeu de cultura, música e repertório em detrimento das manifestações populares e locais. Ela vem sendo historicamente reforçada pela reprodução do ensino de música que visa a formação profissional de instrumentistas voltados à performance da música erudita, vigente e predominante até meados do século XIX. Este ensino (destarte, ensino tradicional) ainda é predominante em escolas de música especializadas, conservatórios e cursos de graduação em música, bacharelado (PENNA, 1999). As práticas que comumente mais as caracterizam estão ligadas ao desenvolvimento das habilidades técnicas instrumentais, referidas como uma forma de treinamento automatizado da execução do repertório da música erudita.

O embate a este modelo vem sendo protagonizado por diferentes propostas de educação musical surgidas a partir do início do século XX. De modo geral, elas trazem a ideia da participação ativa dos estudantes em seu processo de formação e a educação musical atrelada a um projeto de formação integral do sujeito. Por isso, o reconhecimento dessas propostas como "métodos ativos em educação musical" (FONTERRADA, 2008). Em sua maioria, estas propostas são visitadas pelas ideias 
da Escola Nova (SCHROEDER, 2005). No entanto, algumas delas, sobretudo aquelas praticadas nas escolas de educação básica, penderam para uma prática que enfatiza a "liberdade criativa e a expressão pessoal". Essa mudança ocorreu em detrimento do esvaziamento dos conteúdos específicos da linguagem musical, os quais na maioria das vezes são supervalorizados verticalmente no ensino tradicional (PENNA, 1999, p. 60). Chamamos essas propostas de propostas de vanguarda, assim como foram denominadas por Schroeder e Schroeder $(2011)^{78}$. Em suma, os métodos ativos são diversos sendo que alguns ainda continuam fortemente atrelados à execução instrumental como é o caso da proposta de Shinichi Suzuki. As propostas de vanguarda estão mais atreladas ao esvaziamento dos conteúdos da música tonal como é o caso da proposta do compositor Murray Schafer. Logo, estão postas diferentes dicotomias que se entrelaçam: música erudita e música popular; ensino tradicional e o ensino de vanguarda; música tonal e estéticas de vanguarda (serialismo, música concreta, eletrônica entre outras); e assim por diante.

O caminho para a superação dessa dicotomia ainda está em disputa e precisa equilibrar-se para não cair na supervalorização dos conteúdos em detrimento de processos pedagógicos mais igualitários, nem tampouco no esvaziamento dos processos pedagógicos em função da supervalorização dos conteúdos (PENNA, 1999). Neste sentido, é preciso considerar as propostas que dão espaço a cultura, música e repertório local, ligadas ao cotidiano dos estudantes. Expressões de ampla gama de possibilidades incluindo, inclusive, a música de massa (PENNA, 2008). Estas produções, presentes no cotidiano dos estudantes, não se limitam ao entretenimento como é afirmado pelo senso comum. Elas estão relacionadas à construção de identidade dos sujeitos, bem como aos diferentes modos de vida e de significação musical vivenciadas por eles (SOUZA, 2004).

Observamos a busca por um processo de ensino emancipatório que inclua e valorize a vivência e as demandas dos estudantes tanto nestas propostas de educação musical intencionadas como na educação do campo. Por isso, em ambas estão presentes a resistência, a contestação e o questionamento do paradigma hegemônico imposto historicamente pelos países centrais como referência de cultura e sociedade, representados pelos velhos modelos dicotômicos. 
As concepções que intencionamos dialogar neste texto apresentam algumas características que podem nos ajudar a pensar a superação das dicotomias limitantes apresentadas anteriormente, tanto na educação do campo quanto na educação musical. Partimos das concepções desta última, nelas vimos a possibilidade de extrapolar a visão do ensino tradicional, sobretudo para o afastamento de práticas que reforçam a imposição de um modelo de cultura eurocêntrica. De fato, o que nos instiga nestas proposições é a possibilidade do não esvaziamento completo dos conteúdos históricos da linguagem artística musical e ao mesmo tempo não se limitar a elas. Vale ressaltar que nosso foco está nas possibilidades dos contextos de vida dos estudantes, ao nosso ver, mais próximos da música popular, incluindo a música de massa.

A compreensão das práticas sociais dos alunos e suas interações com a cidade, o lugar como espaço do viver, habitar, do uso, do consumo e do lazer, enquanto situações vividas, são importantes referências para analisar como vivenciam, experimentam e assimilam a música e a compreendem de algum modo (SOUZA, 2004, p. 10).

Considerar as vivências musicais cotidianas dos estudantes inclui uma aproximação com o entendimento de que o desenvolvimento individual está atrelado ao desenvolvimento dos grupos sociais presentes em seus cotidianos. Na citação anterior, Souza (2004) se refere a grupos urbanos que, na maioria das vezes, têm suas práticas invalidadas pela sociedade de modo geral. Por isto, reclamam uma outra sociedade na qual tenham garantidos os seus direitos e espaços. Assim, identificados com seus espaços de vivências cotidianas buscam a valorização e transformação de seus espaços, bem como o reconhecimento de suas produções enquanto conhecimento e cultura.

No âmbito da educação musical, é nítida a contradição das práticas do ensino tradicional cujos treinamentos de habilidades e entendimento de esquemas teóricos (leitura de partituras, por exemplo) ganham espaços nas aulas em detrimento da própria experiência musical (SCHROEDER, 2005). Ou seja, a imposição de padrões musicais validados em uma realidade social distante da realidade dos estudantes e de suas práticas musicais. Em tempo, refletindo sobre a citação de Souza (2004) 
inferimos que seja possível adicionamos o campo igualmente "como espaço do viver, habitar, do uso, do consumo e do lazer" de modo digno como pauta a ser discutida na educação musical. O que se mostra nos discursos e na própria construção identitária dos sujeitos.

\begin{abstract}
Um sujeito social coletivo se refere à associação de pessoas que passam a ter uma identidade de ação na sociedade, e, portanto, de formação e organização em vista de interesses comuns e de um projeto coletivo [...] E sujeitos coletivos se formam, não são dados pelas condições objetivas que os definem, exatamente porque seus membros partilham mais do que uma condição: partilham objetivos construídos ou tornados conscientes no movimento histórico em que se afirmam ou são reconhecidos pela sociedade. Em nosso tempo, os movimentos sociais estão sendo reconhecidos como espaços importantes de formação de sujeitos coletivos (CALDART, 2012. p. 550).
\end{abstract}

No bojo do aporte teórico que nos apoia, Volochinóv/Bakhtin (2017), encontramos o diálogo entre as ideologias cotidianas (que se referem às conversas do dia a dia) continuamente sendo transformadas e transformando as ideologias constituídas (aquelas tomadas de posição, interpretações e significações predominantes de modo mais coletivo nos diferentes campos de atividades). Os coletivos nos quais predominam determinadas ideologias constituídas são chamados de Sistemas Ideológicos por Volóchinov/Bakhtin (2017) e exemplificados pelos campos da ciência, política, artísticos e outros. Este movimento mútuo de transformação dos processos de significação dos sujeitos nos sistemas ideológicos soa para nós como aquilo que vai além das simples condições objetivas de um coletivo apontadas por Caldart (2004). Ou seja, abarcam as intencionalidades coletivas construídas historicamente, incluem a luta e as ações práticas em busca da concretização dos mesmos, geram valores e formas de significação coletivamente predominantes dos objetivos, lutas e ações práticas. Aí está o imbricar das ideologias constituídas que são persuadidas e persuadem as ideologias cotidianas. Nesta interação reside a intersecção do desenvolvimento do sujeito e de seus coletivos em um movimento dialético de construção concreta e histórica de suas identidades.

No campo e na participação nos movimentos sociais rurais, como o MST por exemplo, se entrelaçam as lutas compartilhadas coletivamente com a própria intencionalidade da formação e desenvolvimento humano. Os desdobramentos destes 
discursos se materializam no diálogo com as teorias pedagógicas que ajudam a construir a concepção de Educação do Campo reafirmando a materialidade, a historicidade e o movimento dialético na formação e desenvolvimento humano (CALDART, 2012). Tal concepção busca superar o ensino pautado em esquemas de transmissão de conhecimento, treinamento e domínio de habilidades técnicas, conceituações e práticas mais próprias de vertentes verticalizadas do campo educacional. Estas propostas são representações alinhadas às concepções de educação projetadas em outros lugares e oportunizada à população do campo de modo alheio à sua realidade, necessidades e lutas. Essa dinâmica acontece no contexto de sociedade capitalista no qual a educação ofertada ao camponês visa a formação instrumentalizada de mão de obra para o agronegócio. Todavia, encontra a resistência protagonizada pela sociedade civil organizada pelo direito à terra e à vida digna (CALDART, 2004).

As teorias pedagógicas com as quais a educação do campo dialoga são as seguintes: pedagogia socialista, pedagogia do oprimido, pedagogia do movimento. De acordo com Caldart (2004), a pedagogia socialista indica a necessidade de pensar a realidade dos sujeitos do campo, da organização coletiva, e do entendimento da cultura como um processo histórico. A necessidade de pensar a realidade dos sujeitos do campo aparece também como preocupação central na pedagogia do oprimido, cuja base teórico-epistemológica advém da prática da educação popular como projeto emancipador, discutido por Paulo Freire (CALDART, 2004). Por fim, a pedagogia do movimento também aglutina alguns pontos comuns indicados na pedagogia socialista e pedagogia do movimento, todavia, ela só pode ser entendida a partir da observação do próprio processo de formação da educação do campo por meio das contribuições dos movimentos sociais, sobretudo os movimentos sociais do campo (CALDART, 2004). Logo, sob a ótica da pedagogia do movimento é impossível desassociar a educação do campo da luta pela terra e do reconhecimento das populações nele territorializadas (camponeses, indígenas, quilombolas e ribeirinhos). Para a educação do campo, pensada em diálogo com estas teorias pedagógicas, é basilar a valorização dos modos de vida e de interação com a natureza, incluindo formas de produção não-hegemônicas como a agroecologia popular. Em outras palavras, a valorização do lugar, dos sujeitos e da cultura como processo histórico é a única 
possibilidade da efetivação de um projeto de educação.

Logo, superar as velhas dicotomias é uma forma de ampliar e aprofundar as discussões do fazer educacional tanto na educação do campo quanto na educação musical. É importante salientar que entendemos os diferentes extratos das duas áreas educacionais. Enquanto a educação do campo representa as condições, objetivos e lutas construídas na especificidade da vida no campo, a educação musical se faz presente em diferentes contextos de vida como possibilidade discursiva. Porém, nas duas áreas e dentro das perspectivas aqui postas, ambas apontam para a superação das dicotomias excludentes da diversidade tanto dos modos de vida quanto dos discursos nelas presentes.

Para a superação dos processos de imposição cultural presentes nas velhas dicotomias é preciso enxergar então as necessidades específicas da realidade de vida dos estudantes levando em conta sua pluralidade de contextos. O caminho possível que apontamos está no imbricar da concepção de música como linguagem com alguns princípios apontados na Educação do Campo. Entendemos que as dicotomias presentes em ambas as áreas tem em sua base a mesma raiz da imposição do padrão europeu de modernidade que é referência na comparação entre manifestações culturais e formas de vida distintas a fim de hierarquizá-las. A resistência à hierarquização da cultura, dos saberes e dos modos de vida é um ponto profícuo para o diálogo entre a educação do campo e a educação musical.

Pela concepção de educação musical adotada, o aprendizado musical ocorre a partir dos seus discursos postos em prática em um contexto social comum aos interlocutores. Os discursos são refratados (transformados e ressignificados) a cada diálogo, provocam outros discursos e diálogos que os respondem e trazem consigo as transformações dos seus interlocutores. Assim, os discursos, diálogos, sujeitos e grupos sociais são continuamente transformados. O uso da linguagem musical é tanto resultante do sujeito histórico quanto motivo de suas transformações de vida. Esta forma de entendimento se aproxima de como a formação do sujeito é vista também na educação do campo: 
mação das circunstâncias e autotransformação. É a atividade que forma o ser humano; mas a atividade que humaniza mais radicalmente é aquela que exige a autotransformação que passa pela compreensão teórica da realidade (CALDART, 2012. p. 552).

A constituição do humano na práxis (em termos marxistas a atividade pela qual os sujeitos transformam e são transformados pela realidade coletiva na qual se afirmam) se aproxima da ideia de como o sujeito se transforma por seus discursos e processos dialógicos. Pois, nos discursos e processos dialógicos os sujeitos se construindo histórica e coletivamente. A centralidade dessa aproximação está na prática discursiva e transformadora que persuade a própria realidade dos sujeitos de modo contínuo.

Assim, pela perspectiva assumida, o ensino de música torna-se significativo para os estudantes à medida que ocorre contextualizado de suas vivências musicais cotidianas, dos espaços que frequentam, dos coletivos que compõem e de todas as formas as quais os estudantes se identificam em suas práticas diárias (musicais e não-musicais). Neste sentido inclui-se o papel da música popular e/ou música de massa tão presente no cotidiano dos estudantes:

Nessa cultura "experimentam o sentimento de legitimação na sua vida de exclusões", trazida por um discurso que reivindica os direitos sociais e denuncia as dificuldades da vida na periferia para a qual tenta mobilizar a sociedade (SOUZA, 2004, p. 8).

A educação musical que não se desvincula da vida social dos estudantes pode atrelar-se aos seus projetos de vida e de sociedade, para além disto, pode contribuir com o protagonismo do sujeito em seu processo de desenvolvimento.

A materialidade de origem da Educação do Campo projeta/constrói uma determinada totalidade de relações que lhes são constitutivas. Antes (ou junto) de uma concepção de educação ela é uma concepção de campo: porque, neste caso, como pensamos o campo pensamos a educação; [...] o vínculo de origem da educação, ou de um projeto educativo, com um projeto político, com um projeto social. A teoria pedagógica historicamente surgiu para dar conta da intencionalidade da formação do ser humano capaz de ser sujeito construtor de um determinado projeto de sociedade (CALDART, 2004, p. 4-5).

Assim como a educação do campo toma a própria concepção de campo como subsídio fundamental, o ensino de música na perspectiva que adotamos vê na pró- 
pria concepção discursiva da música como forma de linguagem o seu fundamento de aprendizado. Antes de ensinar a música é preciso ter em mente qual música se intenciona ensinar. Sendo a música a ser ensinada aquela que é compreendida nas situações reais de diálogos musicais, é na realidade da vivência dos alunos que reside seu êxito. Portanto, a educação musical pensada no campo precisa incluir o sujeito camponês como seu protagonista e a cultura, trabalho, costumes e valores do campo como sua materialidade concreta. Para além dos limites das discussões teóricas e pensamentos mais próprios do campo educacional são estes protagonismos e materialidades que colocam diferentes propostas em contato, por apontarem em uma mesma direção da intencionalidade de seus ensinos.

\section{CONSIDERAÇÕES FINAIS}

Portanto, as concepções de educação musical e de educação do campo aqui discutidas suscitam os seguintes questionamentos: Qual a serventia da prática de padrões musicais e culturais distantes da realidade de vida dos estudantes? Como isto poderia se conectar com o modo de vida camponês? Parafraseando, qual a utilidade de se aprender um idioma fora do país onde é falado? Mais especificamente, qual a utilidade do desenvolvimento técnico de habilidades instrumentais para execução de um repertório "alienígena"? Ou por que supervalorizar os sistemas teóricos e de grafias musicais em detrimento das múltiplas possibilidades discursivas musicas existentes na cultura camponesa? Por fim, para além das concepções de ensino pautadas em verticalização, imposição e hierarquização da do conhecimento, da cultura e da música é possível encontrar propostas que dão luz sobre estas questões como buscamos expor na breve reflexão deste texto.

A potencialidade da aproximação proposta entre a educação musical e a educação do campo feita neste texto se mostra, sobretudo, no poder emancipador de tornar o sujeito do campo como protagonista de seu aprendizado. As ideias da educação do campo se mostram permeáveis por um ensino de música dado por sua concepção discursiva e poroso para os discursos advindos da cultura camponesa. Conceber a música como linguagem discursiva abre caminhos para que seu ensino se concretize no ato de rebelar-se contra as imposições culturais historicamente predominantes do ensino tradicional. Neste imbricar, enquanto as convicções da educação do campo 
iluminam as necessidades da educação a ser pensada no contexto camponês a concepção de música como linguagem se mostra pertinente para fazer força no embate pelas transformações intencionadas no campo e na resistência de sua cultura.

\section{REFERÊNCIAS}

CALDART, R; PEREIRA S; FRIGOTTO, G (Orgs.). Dicionário da educação do campo. São Paulo. Expressão popular, 2012.

CALDART, R. Elementos para a construção de um projeto político e pedagógico da Educação do Campo. In: MOLINA, M. C.; JESUS, S. M. A (Org.). Educação do Campo: contribuições para a construção de um projeto de Educação do Campo. Brasília: Articulação Nacional por uma Educação do Campo, 2004. p. 13-52.

CRUZ, D. A. M. O. Entre limites e possibilidades da geografia escolar. Revista Ensino de Geografia (Recife), v. 3, n. 2, p. 19-33, 2020b. Disponível em: <https://periodicos.ufpe.br/revistas/ensinodegeografia/article/view/243768/36592>, acesso em 18 de fevereiro de 2021.

CRUZ, F. V. O material didático para bandas de música: reflexões e possibilidades de uso. In: GUILHERME, W. D. Educação no Brasil: Experiências, Desafios e Perspectivas. Ponta Grossa: Editora Atena, p.243-252, 2019a. Disponível em: <https:// www.atenaeditora.com.br/arquivos/ebooks/educacao-no-brasil-experiencias-desafios-e-perspectivas-3>, acesso em 15 de fevereiro de 2021.

A (Re)Construção Da Banda De Música: Repertório e Ensino. Dissertação (Mestrado em Música). 2019b. Instituto de Artes da Unicamp, Universidade Estadual de Campinas. Disponível em: <http://repositorio.unicamp.br/handle/REPOSIP/333950>, acesso em 15 de fevereiro de 2021.

Banda de música e identidade cultural. In: ALBORNOZ, J. Estudos Latino-Americanos Sobre Música. Ponta Grossa: Editora Atena, p.159-170, 2020a. Disponível em: <https://www.editoraartemis.com.br/artigo/31815/>, acesso em 20 de fevereiro de 2021.

CRUZ, F. V; CRUZ, D. A. M. O. Reflexões da prática pedagógica voltada à criação musical. Reflexão e Ação, v. 26, n. 2, p. 267-282, 2018. Disponível em: <https://online.unisc.br/seer/index.php/reflex/article/view/4852/pdf>, acesso em 18 de fevereiro de 2021.

FERNANDES, B. M. Movimentos socioterritoriais na América Latina: campesinato, terra e comida. In: ALVES, F. D (et. al). A dimensão política do espaço: conflitos e 
desigualdades territoriais na sociedade contemporânea. Alfenas: Editora Universidade Federal de Alfenas, 2019, p. 38-59.

. Os campos da pesquisa em Educação do Campo: espaço e território como categorias essenciais. In: MOLINA, M. C. (Org.) Educação do Campo e pesquisa: questões para reflexão. Brasília: Ministério do Desenvolvimento Agrário, 2006. p. 27-39.

FREITAS, H. C. de A. Rumos da Educação do Campo. Em Aberto, Brasília, v. 24, n. 85 , p. 35-49, abr. 2011

PENNA, M. Música(s) e seu ensino. Porto Alegre, 2008.

SANTOS, M. A urbanização brasileira. 4. ed. São Paulo: Editora Hucitec,1998

SCHROEDER, S. C. N. Reflexões sobre o conceito de musicalidade: em busca de novas perspectivas teóricas para a educação musical. Tese (Doutorado em Educação). 2005. Universidade Estadual de Campinas.

SOUZA, J. Educação musical e práticas sociais. Revista da ABEM, Porto Alegre, v. 10, 7-11, mar. 2004.

VOLOCHINÓV, V.; BAKHTIN, M. Marxismo e filosofia da linguagem: Problemas fundamentais do método sociológico na ciência da linguagem. 10 ed. São PauIo/SP: EDITORA 34, 2017. 


\subsection{9/978-20-CAMPO6-7-2}

\section{A INVISIBILIDADE DO CAMPESINATO NA ESCOLA E NO LIVRO DIDÁTICO}

Ana Júlia de Almeida Rosa ${ }^{79}$ Antonio Miranda de Oliveira ${ }^{80}$

79 Pedagoga, egressa do Curso de Pedagogia da UFT-Campus de Miracema; email: anajuliaalmeidadarlei@gmail.com.

80 Docente do Curso de Pedagogia da UFT-Universidade Federal do Tocantins-Campus de Miracema. Doutor em Geografia; Líder do Grupo de Pesquisa Educação Cultura e Mundo Rural-EDURURAL. Email: miranda@uft.edu.br. 
Nosso objetivo neste texto é apresentar os resultados das leituras e reflexões que fizemos acerca da educação de crianças, filhas de camponeses, que vivem no campo, no município de Miranorte-TO e são transportadas para a escola urbana ${ }^{81}$. Além de autores que discutem a condição camponesa, fez-se uma pesquisa de campo, com o uso da entrevista com integrantes da escola, bem como uma análise do livro didático da área de Geografia utilizado pela escola.

Nos últimos cinquenta anos o Brasil viveu conflitos próprios de uma sociedade capitalista que se urbaniza, com mudanças importantes nos modos de viver, trabalhar e estudar dos diferentes grupos sociais que fazem parte da sociedade brasileira, mesmo aqueles que ao longo da história foram excluídos, mas insistem em continuar existindo. Este é o caso específico dos camponeses, haja vista ser um dos sujeitos sociais que contraditoriamente, insistem em se recriar, mesmo considerando que a sociedade capitalista os domina, mas não tem conseguido eliminar as diferentes lógicas constituintes das relações sociais capitalistas. Essa lógica dominante não é favorável, aos camponeses, mas eles estão ai, se reproduzindo material e simbolicamente, mesmo quando são invisibilizados.

Compreendemos que é importante entender melhor os problemas oriundos desse processo e suas relações contraditórias com o campo e com os camponeses que não se deixam dominar por completo e tomam consciência do seu abandono nas periferias das pequenas e médias cidades. Os camponeses insistem em enfrentar esse processo, produzindo material e simbolicamente novos modos de existência, territorializando-se quantas vezes forem necessárias, como já demonstraram ao longo de suas lutas camponesas por terra em todas as regiões do Brasil. A escola e a educação tem sido um instrumento importante neste processo.

Em sua origem, o conceito de camponês está relacionado à realidade da idade média européia, mas a formação do campesinato brasileiro possui as suas especificidades. Entre nós, o campesinato se constituiu no seio de uma sociedade desigual e capitalista, mas também no interior e à margem do latifúndio escravista.

$81 \quad$ Um debate mais aprofundado dessa questão pode ser verificado no Trabalho de Conclusão de Curso de Ana Júlia de Almeida Rosa, realizado em 2020, com o título: Campesinato e Livro Didático em Miranorte. 
O campesinato brasileiro tem como característica importante, desde sua origem, uma forte mobilidade espacial, ele "zanza a procura de terra", enquanto o camponês europeu tem no enraizamento territorial sua característica mais forte.

A história da formação e do desenvolvimento da sociedade brasileira vem demonstrando que o mundo rural não acabou e que também o campesinato está ai, Moura (1986, p. 17-18) diz que "é mais correto falar em recriação, redefinição e até diversificação do campesinato do que fazer uma afirmação finalista. Nem mesmo nas sociedades socialistas é possível falar numa abolição do trabalho familiar camponês". Portanto, precisamos buscar elementos para enfrentar essa história de frente sem excluir quem tem muito a contribuir.

Martins (1981), diz que esse conceito foi introduzido em nosso contexto a partir da segunda metade do século XX. Para este autor, até pouco tempo, quando se falava de camponês era comum se recorrer a palavras como "caipira", "caiçara, "tabaréu", "caboclo", "roceiro", entre outras dependendo da região a que se referia, diz o seguinte:

Consciente de sua condição subalterna, o camponês se vê como o pobre e o fraco; reservando o antônimo destas categorias para os proprietários de grandes extensões de terra, os profissionais que representam as agências do Estado, e de modo mais ou menos genérico, os habitantes do meio urbano (MOURA, 1986, p. 16).

Vemos, no entanto, que ao longo da história brasileira, essa designação de pobre, fraco foi superada todas as vezes que o campesinato se apresentou socialmente nas importantes lutas políticas e sociais, inclusive gerando contribuições importantes para a sociedade nacional em especial nos processos de luta pela reforma agrária.

Alguns autores quando descrevem o campesinato e as suas relações sociais de produção, o definem como o "conjunto daqueles que trabalham a terra e possuem seus meios de produção: ferramentas e a própria terra" (BOTOMORE, 1988, p. 42). Ou ainda: "cultivadores de pequenas extensões de terra, às quais controla diretamente com sua família" (MOURA, 1986, p. 12); ou ainda: "o cultivador que trabalha a terra, opondo-o àquele que dirige o empreendimento rural” (MOURA, 1986, p. 13).

No Brasil, o predomínio de sistemas de posse precária da terra, para esta classe social, tem resultado numa condição de instabilidade estrutural, que faz da busca de 
novas terras uma importante alternativa de recriação social do campesinato. Neste sentido, temos observado que no caso do campesinato, mais do que a terra, há uma importante herança deixada que é o seu modo de vida, como patrimônio que tem sido de fato transmitido (Wanderley, 1996).

Um aspecto importante dessa herança imaterial é a educação. Um autor que aborda a conjuntura de direito e contextualização da educação é Sérgio Haddad (2012). Segundo o autor, idealizar a educação como direito de um indivíduo, corresponde a entender que a educação deve se fazer presente em meio aos direitos imprescindíveis ao desenvolvimento da dignidade de todo ser humano de forma íntegra. Sendo assim, o direito à educação precisa ser garantido a todos os indivíduos, independentemente de qualquer outro fator ou território, seja urbano ou rural. Concordamos com Haddad, pois

Por meio da educação, são acessados os bens culturais, assim como normas, comportamentos e habilidades construídas e consolidadas ao longo da história da humanidade. Tal direito está ligado a características muito caras à espécie humana: a vocação de produzir conhecimentos, de pensar sobre sua própria prática, de utilizar os bens naturais para seus fins e de se organizar socialmente (HADDAD, 2012, p.215).

Compreende-se que esta é uma perspectiva importante de pensar a educação nos tempos atuais, especialmente quando ela assume seu caráter escolar no atendimento a populações específicas. De acordo com Haddad (2012), a educação escolar é o alicerce na construção do desenvolvimento formativo dos indivíduos, norteando-os de forma que esses possam compreender que são seres que devem lutar pela conquista de outros direitos.

Ribeiro (2012) enfatiza que os educandos filhos de camponeses são inseridos no processo de trabalhar e estudar quando ainda criança, isto porque a grande maioria desses educandos precisa através de seu trabalho, auxiliar no sustento da família. Diante desse contexto, observa-se a grande relevância do papel a ser desenvolvido pela escola com o propósito de motivar esse educando a dar continuidade aos estudos. Mas segundo as discussões da autora, o que acontece na realidade é uma prática totalmente equivocada, pois na instituição de ensino apenas se estuda, e o contexto analisado não apresenta uma relação com o trabalho ou com a rotina 
do dia-a-dia do educando. Ou seja, há um corte entre o que a escola ensina, pensa e faz e a vida das crianças e de suas famílias, principalmente no caso de crianças que estudam em escola rurais, ou que vivem no campo e são transportadas para a escola urbana.

A autora relata sobre as dificuldades deparadas quanto à habilidade dos educadores em desenvolverem um trabalho que possibilite que os educandos sintam-se correspondidos na ação educativa, principalmente em relação ao trabalho e contexto escolar, ou seja, a permanência dos alunos está intrinsecamente associada ao que Ihe é proposto. Mas é imprescindível notar que os profissionais da educação não são preparados e qualificados em uma formação que lhes proporcione um desenvolvimento formativo para ministrar um trabalho coerente de acordo com a realidade do aluno camponês, o que ocasiona ao educador um desprendimento em exercer suas atividades nas instituições localizadas nas áreas rurais. Isso coloca uma responsabilidade maior para as instituições que formam professores para os anos iniciais, como é o caso da formação do pedagogo.

\section{DESENVOLVIMENTO: DO PROJETO DA ESCOLA Á ESCOLA REAL}

A literatura da área, mas também as práticas no ambiente escolar dão conta de que o Projeto Político Pedagógico é um processo que precisa ser discutido, elaborado e assumido coletivamente para alcançar os objetivos da escola. Nesse contexto, a escola deve ser pensada como fruto da sociedade, levando em conta os saberes construídos socialmente e culturalmente pelas pessoas que estão fora e dentro dela. Assim, torna-se fundamental pensar em mudanças dentro da unidade de ensino, refletindo uma proposta pedagógica que seja construída a partir do cotidiano dos alunos. Veiga (1995) complementa citando uma análise de como deveria ser organizada uma proposta pedagógica, diz essa autora que,

O projeto busca um rumo, uma direção. É uma ação intencional, com um sentido explicito, com um compromisso definido coletivamente. Por isso, todo projeto pedagógico da escola é, também, um projeto político por está intimamente articulado ao compromisso sócio-político com os interesses reais e coletivos da população. (VEIGA, 1995, p. 13).

Portanto, percebe-se que as escolas já assumiram a ideia de que a construção de uma proposta pedagógica deve ser coletiva e que possa ser um documento que 
norteia as ações desenvolvidas pela escola, tornando-se um desafio, por exigir esforço e participação coletiva da equipe escolar. Segundo Vasconcelos (2004, p. 43) "o projeto político pedagógico é um instrumento teórico metodológico que visa ajudar a enfrentar os desafios do cotidiano da escola, só que de uma forma refletida, consciente, sistematizada, orgânica e o que é essencial participativa".

Assim, a escola é responsável pela promoção do desenvolvimento do cidadão, no sentido pleno da palavra. Então, cabe a ela definir-se pelo tipo de cidadão que deseja formar, de acordo com a sua visão de sociedade. Cabe-lhe também a incumbência de definir as mudanças que julga necessário fazer nessa sociedade, através das mãos do cidadão que irá formar. Veiga (1995, p. 56), alerta que "no que diz respeito à escola, é preciso que as decisões institucionais, para que se efetivem, partam da prática cotidiana, sendo, portanto, necessário conhecê-las, identificando suas características e formas de expressão".

Portanto, é no projeto educativo da escola que reside parte significativa dos desencontros, bem como os motivos dessa relação. É no projeto da escola que se anuncia a formação intencionada. Sabe-se que há dificuldades de realizar de forma coerente essa formação cumprindo o projetado, inclusive porque a instituição escolar é abandonada pelo poder público que, não coloca à disposição dos trabalhadores da escola e das comunidades internas e externas, os recursos necessários para o desenvolvimento de suas atividades.

Especificamente no caso da escola de ensino fundamental, objeto desse estudo, buscando o seu PPP percebemos alguns elementos da história da Escola Municipal de Tempo Integral Antônio Pereira de Sousa. A mesma foi criada pela Lei $\mathrm{N}^{\circ}$ 007-89 em 25 de outubro de 1989 e recebeu esse nome em homenagem a um dos principais pioneiros do Município de Miranorte -TO.

Os alunos atendidos por esta unidade de ensino são pessoas vindas de várias regiões do Brasil, sendo bem diversificada a condição social dos alunos, sendo mais proeminentes famílias de média e baixa renda e filhos de camponeses, residentes na periferia da cidade e no campo e que são transportados todos os dias para a escola.

É muito evidente o esforço da instituição em realmente cumprir seu papel tanto educacional como social. Porém, mais evidentes ainda são as falhas tanto da esco- 
la-instituição, como de profissionais (professores, coordenadores, diretores), é nítida em determinados casos, a falta de conhecimento e de preparo da escola como um todo no atendimento aos alunos e as famílias oriundas do campo.

Compreende-se também que há outros elementos que jogam "contra" a escola e a comunidade nesse processo, por isso que somente parte dos (des)encontros estão no seu projeto educativo. O que pensar/dizer acerca da formação de professores no Tocantins e em Miranorte? Que papel desempenha, no contexto do trabalho escolar, as condições de trabalho dos trabalhadores da escola (são contratados, indicados por políticos, são concursados)? A formação dos professores nos cursos de formação inicial das instituições de ensino superior ${ }^{82}$ no Tocantins indica que rumos na constituição das identidades Docentes? E como aparece em seus projetos de cursos a educação de crianças do campo?

Consideramos importante neste processo o debate acerca do currículo. Apropriando-se do debate da obra de Arroyo (2011), "Currículo, território em disputa" compreende-se que as classes populares, assim como os docentes no contexto do seu trabalho compreenderam que há disputas não somente por direitos mais amplos na sociedade, mas que também o próprio projeto de escola e educação faz parte desse processo, como diz o autor:

Se há muita vida lá fora, também há muita vida disputada nas salas de aula. Há muitas disputas lá dentro e muitas disputas fora sobre a função da escola e sobre o trabalho de seus profissionais. Sinal de que o território da escola ainda é importante para a sociedade e, sobretudo, para as crianças, os adolescentes, os jovens e adultos populares e para seus professores (as). A escola é disputada na correlação de forças sociais, políticas e culturais. Nós mesmos, como profissionais da escola, somos o foco de tensas disputas (ARROYO, 2011, p. 12-13).

Por outro lado é importante considerar as reflexões de Martins (2004/2005) no sentido de ter clareza que a crise é da escola que temos e que não é somente a criança que vive no campo e estuda na cidade que sofre processos de marginalização, embora esse processo seja negado pela escola em estudo. Esse autor diz,

$82 \quad$ A maioria dos cursos de graduação da UFT- Universidade Federal do Tocantins são de licenciatura. O Câmpus de Miracema oferta o Curso de Pedagogia e somente agora (2019) aparece na proposta pedagógica desse curso (com definição de disciplinas especificas) preocupação com a formação de populações indígenas e do campo. 
O ensino deveria ser mais flexível e culturalmente adaptado do que é, tanto no campo quanto na cidade. A educação básica na cidade é quase que apenas projeção da ideologia de classe média do educador. O mesmo acontece no campo. Prevalece ainda entre nós a concepção de que o educador não precisa ser educado, não precisa ser ressocializado para a sua missão de educar.

Nesse sentido, quase que se pode considerar a escola urbana, inadaptada, como um campo de concentração onde se realiza o trabalho forçado da aculturação compulsória dos educandos, tendo por referência uma cultura urbana em grande parte postiça, mais ficção do ideário urbano do professor e da política educacional do que expressão da realidade urbana em que o aluno vive (MARTINS, 2004/2005, p. 31-32).

Especificamente em relação ao trabalho com crianças que vivem no campo e à escola onde as mesmas estudam, diz este autor,

O mesmo acontece no campo e, talvez, de modo agravado em consequência de uma ideologia educacional que desvaloriza o mundo rural e o trabalho rural. A ideologia do educador, no campo, é via de regra a ideologia que considera a cultura, os costumes, o saber da população que ele quer educar como cultura primitiva de povos ignorantes, formas incivilizadas de conhecer a vida e interpretar o mundo. Não raro, o educador é o grande responsável por abrir um amplo abismo cultural entre as gerações do mundo rural.

A escola deveria ser uma instituição do diálogo cultural com sua clientela, com os circunstantes, e deveria considerar clientela não só o aluno burocraticamente matriculado, como preferem os educadores burocratas, mas também a comunidade de referência, a que pertencem os alunos (MARTINS, 2004/2005, p. 32).

Considerando essas questões podemos ver que estamos distante de ter uma escola que se constitua como um espaço de diálogo voltado para seu público interno e externo. Há muito que se fazer para que a escola articule um trabalho que não seja somente reprodutor de ideologias que dominam.

A seguir apresenta-se discussão acerca do livro didático e o modo como integrantes da escola pensam sobre as crianças filhos e filhas de camponeses transportados para estudar todos os dias na escola urbana localizada na cidade. 
No contato com a escola realizamos entrevistas com a Diretora, a Coordenadora e a professora de uma turma de terceiro ano do ensino fundamental. Fez-se dois questionamentos: o primeiro sobre o que elas entendem por camponês, suas características. Na sequência, foram realizados questionamentos acerca do livro didático utilizado na escola. As questões tinham o objetivo geral de saber o que essas pessoas, responsáveis pelo processo pedagógico pensam sobre o camponês e o livro didático utilizado na escola.

Sobre quem é o camponês, as respostas da professora, coordenadora e diretora, foram as seguintes:

São trabalhadores/as que vivem no campo e trabalham na roça com a família (Professora).

São trabalhadores/as que vivem no campo e trabalham na roça com a família. São trabalhadores assentados da reforma agrária (Diretora).

São produtores rurais que praticam uma agricultura moderna e que tem como base a comercialização de seus produtos. São pequenos produtores, pobres, sem conhecimento de técnicas agrícolas e são responsáveis pelo atraso na agricultura nacional (Coordenadora).

Analisando o conteúdo das entrevistas, vemos que a docente expressa uma visão bem diferente do modo como pensam a Diretora e a Coordenadora da Escola quando são solicitadas a indicar o que elas entendem por camponês. Podemos perceber ainda nestas respostas concepções equivocadas criadas pela escola baseado nas respostas das entrevistadas. É importante discutirmos algumas visões equivocadas ou generalizadas sobre o camponês. A escola não deveria reproduzir uma imagem equivocada a respeito desses povos, devemos ressaltar as dificuldades encontradas por eles e refletir seu papel diante de todos os impasses enfrentados, para que dessa forma, as crianças tenham consciência do que vem a ser um camponês. Como demonstra a indicação da coordenação da escola acerca dos camponeses afirmando que estes "são produtores rurais que praticam uma agricultura moderna e que tem como base a comercialização de seus produtos". 
Esse modo de pensar sobre o camponês pode ajudar a entender alguns problemas vividos pela escola, mas também pelos camponeses. Compreendemos que essa diversidade de opiniões é saudável, mas também é algo problemático se pensarmos no ponto de vista de inclusão do aluno campesino. Pois são estes profissionais que no dia a dia da escola precisam trabalhar pela integração positiva e assertiva destes estudantes, o que fica muito complicado sendo que não possuem nem ao menos um conceito de camponês ajustado entre si. Felizmente concordam que a terra é o principal instrumento de trabalho do camponês.

Solicitou-se que as integrantes da escola indicassem características que se aplicam ao camponês. Eis as respostas:

A terra é seu principal instrumento de trabalho (Professora)

A terra é seu principal instrumento de trabalho (Diretora)

Tem fácil acesso a crédito e apoio de políticas públicas para continuar produzindo alimentos. E tendo em vista o desenvolvimento do capitalismo e da produção no campo, o campesinato é uma classe em extinção (Coordenadora).

Mais uma vez, com base nas respostas das entrevistadas, percebemos o equívoco da escola em relação ao modo como pensa acerca do camponês e como esse pensar se propaga no ambiente escolar, ao afirmarem, Por exemplo: que devido ao desenvolvimento do capitalismo o "campesinato é uma classe em extinção" ao mesmo tempo em que se tem inúmeros alunos residentes do campo nas salas de aula, nos fazendo refletir sobre o quanto esses sujeitos são invisibilizados, pouco conhecidas, suas culturas, seus modos familiares, o compromisso e a dedicação ao seu trabalho.

Segundo a diretora, coordenadora e professora, os camponeses têm fácil acesso a crédito e apoio de políticas públicas para continuar produzindo alimentos; porem a realidade é bem diferente, a começar que não é fácil ter acesso a esse credito, sem mencionar as altas taxas de juros. A Coordenadora indica que tendo em vista o desenvolvimento do capitalismo e da mecanização da produção no campo, o campesinato é uma classe em extinção. Porém, esta é uma afirmação demasiada exagerada. Embora tenha havido enorme êxodo rural, os camponeses ainda são responsáveis pela maior parte da produção de alimento no Brasil. 
Quando perguntou-se se existem alunos filhos de camponeses que estudam na escola e foi solicitado que falassem sobre a presença deles na escola, a professora respondeu que "Sim e que há uma parceria entre a unidade escolar e os alunos". Já as respostas da coordenadora e diretora foram assim:

Sim. Em relação a presença infelizmente é uma situação complicada, as faltas são constantes, em função do transporte escolar (Diretora da Escola).

Sim. Devido à distância percorrida pelo transporte escolar para trazê-los, achamos cansativo, mas são iguais as demais (Coordenadora da Escola).

Sendo assim, não dá para dizer que a escola tem uma parceria com os alunos do campo. Pois, é nítido que a questão da distância atrapalha, tanto que a assiduidade dos alunos não é a mesma porque eles chegam cansados. Às vezes muitos profissionais pedagogos que estão dentro da escola poderiam fazer algo a mais para ajudar, buscando uma solução para esse tipo de problema. Muitos simplesmente se acomodam e ficam esperando que outras pessoas venham de fora para fazer o que é papel deles, ou seja, lutar pelos direitos dos alunos camponeses.

Buscando trazer para as reflexões, o cotidiano da sala de aula e as impressões da professora acerca das crianças do campo neste espaço, foram feitas as seguintes questões: como o professor pode ajudar um aluno camponês?; Quais as orientações que a escola ou a Secretaria Municipal de Educação oferta aos professores para trabalhar com as crianças do campo? e ainda se a realidade do aluno do campo e da cidade é a mesma?. A professora respondeu que a melhor forma de ajudar o aluno do campo é "Trabalhando sua realidade" e que "não há orientações para os professores"; disse ainda "Que a realidade do campo e da cidade é a mesma e que usando as tecnologias não há diferença".

Já a Diretora e Coordenadora pensam semelhante ao que foi informado pela professora, pois as mesmas disseram que "Não há uma orientação especifica que separe os alunos do campo e os da cidade e que eles recebem a mesma forma de trabalho que os demais". E que em relação aos alunos que vivem no campo ou na cidade, "Não há diferenças, poucas hoje em dia. Apenas diferença comportamental quase inexpressiva".

Ficou evidente nestas respostas as dificuldades tanto da Secretaria Municipal de Educação de Miranorte -TO, como também da escola e do corpo docente para a 
efetividade de um trabalho pedagógico que leve em conta a diversidade do seu público. Orientações especificas para se trabalhar com esses alunos são essenciais e imprescindíveis; outro ponto a ser visto como preocupante é que não é possível um corpo docente acreditar que as realidades do campo e da cidade são as mesmas, trabalhar a realidade do aluno campesino supõe ter noção disso. Definitivamente não dá! É necessário que o município crie políticas e ações pedagógicas que qualifiquem as ações das escolas e de seus profissionais.

Muito do que se viu nas falas dos integrantes da escola, está intrinsecamente ligado a ação de intolerância social e cultural, a falta de respeito para com os colegas que vivem no meio rural, e a falta de apoio tanto dos governantes que não conseguem inserir verdadeiramente na sociedade, políticas públicas que busquem uma melhor inserção destes alunos vindos do campo, como também dos professores que muitas vezes por falta de preparo e recursos pedagógicos são incapazes de proporcionar uma melhor interação entre os alunos que vem do campo com costumes e culturas diferentes dos alunos que já estão inseridos nos espaços urbanos.

Questionadas sobre o acolhimento aos alunos do campo pela escola ou se já houve caso de marginalização, a Diretora disse: "Os alunos são muito bem acolhidos, não há diferença entre o tratamento dos alunos do campo e os da cidade". Já a Coordenadora informou que "Nunca são excluídos; são tratados de igual forma".

Porém, o que se pôde constatar com as visitas de observação na escola é que os alunos são sim alvo de preconceitos e brincadeiras de mal gosto. Existe o bullying, existe a exclusão, existe conceitos errôneos, tudo isso entre os alunos; não por maldade, mais sim, por falta de instrução e pela reprodução de uma visão dominante marginalizadora sobre os camponeses.

Em relação ao livro didático a professora, a coordenadora e a diretora colocaram as seguintes informações, quando questionadas sobre como é feita a escolha/ seleção do livro didático utilizado na escola. A professora simplesmente informou que a escolha é feita "Pelos professores", sem mais informações. Já a coordenação e direção disseram o seguinte: "Vários livros de várias editoras são expostos na escola e num dia $(x)$ todos os professores através do manuseio, escolhem os livros" (Diretora). "É feita uma analise de exemplares no final do ano para escolha do livro didático" (Coordenadora). 
Retomando o que fora afirmado pelas integrantes da escola, Miranda e Luca (2004, p. 126) afirmam que com a criação do PNLD, “... progressivamente foram sendo incluídas no programa as distintas disciplinas componentes do currículo escolar e o programa foi se delineando no sentido de incorporar os professores no processo de escolha dos livros didáticos". É apropriado afirmar, concordando com Fernandes (2011, p. 2), que:

O PNLD - Programa Nacional do Livro Didático - criado em 1985, é um programa de referência para a compreensão do processo de redemocratização brasileira, no campo da política educacional, posto que vem atravessando todos os governos nos últimos 25 anos da história da educação brasileira. (FERNANDES, 2011, p.2)

Já no século XXI, a escola progressivamente democratizada participa efetivamente da escolha dos livros didáticos que chegam a ela, desfocando o problema da quantidade de material para a qualidade do material na escola, pois, mesmo com um programa responsável por selecionar os livros possíveis de serem escolhidos pelos professores, ainda assim chegam às escolas livros didáticos descontextualizados da realidade social na qual o aluno está inserido. Frequentemente o professor acaba utilizando este material como currículo único aplicado em sala de aula.

O livro didático de Geografia utilizado pela professora do $3^{\circ}$ (terceiro) ano do ensino fundamental é Conectados Geografia, tendo como autores Edilson Adão e Laercio Furquim JR, os quais são mestres em educação, ambos atuando no ensino médio e superior. A obra foi publicada pela editora FTD, $1^{a}$ (primeira) edição, em São Paulo, no ano de 2018.

O livro integra o PNLD, do FNDE-MEC para os anos de 2019 a 2022. Na apresentação os autores falam de suas expectativas com o uso do livro: "Esperamos que ele seja tão importante como as outras fontes de estudo para o auxiliar a identificar e reconhecer os lugares onde você vive".

Perguntou-se à professora como aparecem retratados no livro didático as populações camponesas e como o livro didático de Geografia é trabalhado com as crianças? A mesma respondeu que o "Livro didático só mostra a verdadeira realidade deles e que é lido e explicado em sala".

Sobre os conteúdos trabalhados em sala, a professora menciona "que trabalha 
os livros didáticos apenas lendo com os alunos e explicando as temáticas". Destaca-se que não foram registrados nenhuma outra forma de se trabalhar os conteúdos, o que representa uma falha da instituição. Embora a professora afirme que os camponeses são retratados nos livros assim como são no seu cotidiano, é sabido que estes são retratados de forma muito superficial e na maioria das vezes de forma errada e preconceituosa. O livro de fato não mostra a realidade da vida no campo a partir da condição do camponês.

Copatti e Callai (2018, p. 241) argumentam que muitos dos conteúdos dos livros didáticos que chegam a estas escolas são elaborados para atender de modo geral a todas as instituições de educação pública do Brasil, e não há uma tradição de produção de livros específicos para as escolas do campo. Considerando a extensão territorial e a diversidade brasileira, Callai questiona se "[...] É possível um livro único que oriente todos os alunos de todo o território brasileiro considerando a nossa diversidade geográfica numa perspectiva global, mas também em escala local?" (COPATTI; CALLAI, 2016, p. 295). Diante disso, como estabelecer o que é mais adequado para determinado lugar/determinada região?

No livro utilizado pela escola não vimos muito esforço para trazer os modos de vida dos alunos filhos de camponeses e que moram no campo para a realidade da sala de aula. Não aparecem os contextos em que vivem as crianças e os jovens do campo, algumas peculiaridades que poderiam ser mais bem expostas no sentido de contemplar as vivências destes grupos. Por exemplo que experiências têm estas crianças e jovens do campo? Que diversões experimentam? O que é significativo para eles?

Os autores do livro didático ao debaterem as transformações nas paisagens no campo o fazem mostrando duas imagens, ambas do Estado de São Paulo. A primeira com trabalhadores na colheita manual do café, em 1902, na cidade de Ribeirão Preto. A segunda, com uma máquina (trator) sendo utilizada na colheita do café na cidade de Alvinlândia, em 2016. Na sequência das imagens os autores fazem o seguinte questionamento: "quais são as diferenças entre as duas paisagens mostradas nas fotos?". E pede para assinalar a resposta, dentre as seguintes indicações: "presença de cultura de trigo; uso de máquinas; existência de silos; quantidade de trabalhadores". Infere-se que os autores esperam a marcação de duas alternativas como corre- 
tas: “Uso de máquinas e Quantidade de trabalhadores" (Silva e Junior, 2018, p. 74).

Muitos outros elementos poderiam ser explorados para trazer esse debate para o espaço onde a escola e os alunos estão articulados, mas também para trazer mais aprofundamento para essa discussão, por exemplo, discutindo a natureza do trabaIho manual no campo, não somente com a cultura do café e a introdução do uso de maquinas para o processo produtivo no campo e suas consequências para as pessoas.

Que implicações esse processo trouxe ou está trazendo para o uso da terra e as pessoas na região de Miranorte? Sabe-se que esses elementos podem ser levantados pelo trabalho do professor. Isso significa buscar outras referências de leituras e análises desses processos na sociedade brasileira. No entanto também é preciso se questionar se o pedagogo em sua formação básica está habilitado a trabalhar com os conteúdos geográficos levando em conta essas possibilidades. A nosso ver não é isso que vemos em nossa formação inicial.

Dando sequência aos questionamentos com os profissionais de ensino da escola, foi solicitado que avaliassem o transporte escolar dos alunos do campo. As respostas merecem reflexão, pois a professora simplesmente informou que "A avaliação é ótima". Já a diretora e a coordenadora buscaram trazer mais elementos para o debate. A diretora disse: "Os pontos negativos são porque os ônibus são velhos, além do mais, os alunos residem bem distante da escola/zona urbana". E por fim, acabou dizendo que "quando os antigos ônibus se quebram todos são informados". A coordenadora disse que "Os pontos negativos não se aplicam ao transporte, mas sim, às rotas que são longínquas e com vias bastante deterioradas".

O transporte escolar é uma política pública no campo da educação que está articulada, por um lado com as lutas das populações que vivem no campo para garantir educação para seus filhos, mas por outro lado também é utilizada como instrumento para atender aos interesses políticos dos grupos locais a serviço da apropriação dos recursos públicos e dos seus interesses econômicos e políticos.

Em nossa região, e o caso de Miranorte não está excluído desse processo, acrescenta-se a isso as dificuldades relacionadas às grandes distâncias, estradas ruins, veículos velhos e sem manutenção e outros problemas próprios quando se fala do atendimento a população que vive no campo. 
Sabemos que o abandono e a marginalização das populações rurais é o que sobressai nas relações com o poder público. O testemunho dos integrantes da escola demonstra isso, embora também revelem uma concepção de naturalização dessa situação. Não acreditamos que essa situação seja natural ou que não existe outra forma de funcionamento.

\section{CONSIDERAÇÕES FINAIS}

É urgente que a comunidade escolar, pais e todos os envolvidos avaliem se o investimento que o governo municipal e as famílias estão fazendo para a educação de suas crianças é o necessário para garantir uma educação que possa contribuir para a superação dos problemas vividos pela comunidade.

Compreendemos ainda que os alunos do campo são sim excluídos, marginalizados por diversos fatores, inclusive pela negligencia! Principalmente por parte do governo.

Tomando uma expressão muito cara e repetida pela burguesia política, urbana e rural no Brasil e também no Tocantins, com a qual não concordamos: o campo é o lugar do atraso, pois ainda hoje fundamos nossas relações com o campo baseados em estereótipos, vindos da cidade e projetados sobre o homem do campo que o coloca na condição de réu e condenado a extinguir-se, como nos indica Oliveira (2013). Essas "são visões idealizadas, baseadas largamente num culto partilhado entre marxistas e liberais, pelo progresso, pelo urbano-fabril, como imagem única da nova época da existência humana” (LINHARES; SILVA, 1999, p. 33). Daí a importância de se "compreender que o campo e seus sujeitos construíram e continuam construindo muitas especificidades e é exatamente esta condição que requer e exige que se pense uma educação que atenda a esses elementos que distinguem o camponês de outros sujeitos" (OLIVEIRA, 2013, p. 141).

Mesmo considerando as transformações que ocorreram no campo e na cidade ao longo dos anos, isso não permite pensa-los como espaços separados, estanques e com lógicas distintas. Ambos são criados e recriados o tempo todo na lógica de uma sociedade capitalista, embora isso também não queira significar que seja absoluto e por isso sempre há alguma possibilidade de rompimento com a lógica dominante. 
O campo é tão dinâmico quanto o espaço urbano. É lógico que não é a mesma coisa, mas isso não significa que vamos negar às pessoas do campo (especialmente às crianças filhos de camponeses) conhecimento sobre a vida urbana e também dificultar as possibilidades de realizar diálogos mais proveitosos entre as crianças do campo e da cidade quando as mesmas dividem o mesmo espaço de sala de aula. A paisagem da escola também vive processos de mudanças significativos e um deles poderia se articular com o fortalecimento da diversidade cultural existente dentro dela e da sociedade, portanto, um espaço onde pode frutificar muitos saberes e resistências dos diferentes sujeitos ali articulados.

\section{REFERENCIAS}

ARROYO, Miguel G. Curriculo, território em disputa. Petropólis, RJ: Vozes, 2011.

ARROYO, Miguel Gonzalez; FERNANDES, Bernardo Mançano. A educação básica e o movimento social do campo. Brasília: Peres, 2006.

BOTOMORE, 1988, p.13 BOTTOMORE, Tom, etalli. Dicionário do pensamento Marxista.Trad. Waltensir Dutra. Zahar: Rio de Janeiro, 1988.

CALLAI, H. C e MORAES, M. M. Educar para a Formação Cidadã Na Escola. Scripta Nova Revista electrónica de geografía y cienciassocialesUniversidad de BarceIona. ISSN: 1138-9788. Depósito Legal: B. 21.741-98 Vol. XVIII, núm. 496 (02), 1 de diciembre de 2014 [Nueva serie de Geo Crítica. Cuadernos Críticos de Geografía Humano.

COPATTI, Carina; CALLAI, Helena Copetti. O ensino de Geografia em educação do campo e o livro didático. Revista Contexto \& Educação. Unijuí: v. 33, n.105, 2018: p. 222-247.

HADDAD, Sérgio. Direito à educação. In: CALDART, Roseli Salete. et al.(Org). Dicionário da Educação do Campo. Rio de Janeiro, São Paulo: Escola Politécnica de Saúde Joaquim Venâncio: Expressão Popular, 2012. P. 215222.

LINHARES, Maria Yedda Leite, SILVA, Francisco Carlos Teixeira da.Terra Prometida: uma história da questão agrária no Brasil. Rio de Janeiro: Campus, 1999.

MARTINS, José de Souza. (1981) (organizador). Introdução Crítica à Sociologia Rural. São Paulo: Hucitec. 1981. 
MARTINS, José de Souza. Cultura e Educação na roça, encontros e desencontros. REVISTA USP, São Paulo, n.64, p. 28-49, dezembro/fevereiro 2004/2005.

MIRANDA, Sonia Regina; LUCA, Tania Regina de. O livro didático de história hoje: um panorama a partir do PNLD. Revista Brasileira de História, v. 24, n. 48, dez. 2004, p. 123-144.

MOURA, Margarida Maria. Camponeses. São Paulo: Ed. Ática: 1986.

OLIVEIRA, Antonio Miranda de. Territorialidades camponesas na educação de assentados: assentamento Brejinho em Miracema do Tocantins. Tese (doutorado) Universidade Federal de Uberlândia - Programa de Pós-Graduação em Geografia: Uberlândia-MG, 2013.

PPP - Projeto Politico Pedagógico da Escola Municipal de Tempo Integral Antonio Pereira de Sousa, Miranorte, 2019.

RIBEIRO, Marlene. Educação Rural. In: CALDART, Roseli Salete. et al.(Org). Dicionário da Educação do Campo. Rio de Janeiro, São Paulo: Escola Politécnica de Saúde Joaquim Venâncio: Expressão Popular, 2012. P. 293 - 299

SILVA, Edilson Adão Cândido da; JUNIOR, Laércio Furquim. Conectados Geografia, $3^{\circ}$ ano: Componente curricular: Ensino fundamental, anos iniciais. 1. Ed. São Paulo: FTD, 2018.

VASCONCELOS, Celso dos Santos. Planejamento: Projeto de Ensino-Aprendizagem e Projeto Político-Pedagógico.12. ed. São Paulo: Libertad, 2004.

VEIGA, Ilma Passos Alencastro (org.). Projeto político-pedagógico da escola: uma construção possível. São Paulo: Papirus, 1995.

WANDERLEY, Maria de Nazareth B. Raízes históricas do campesinato brasileiro. Caxambu, 1996. (texto apresentado no XX Encontro Anual da ANPOCS, GT 17- Processos Sociais Agrários). 


\subsection{9/978-21-CAMPO6-7-2}

\section{O MONITOR DE EFA:}

\section{UM RELATO DE EXPERIENCIA 83}

Geane Pereira Nunes ${ }^{84}$

83 Este relato de experiência foi submetido em formato de resumo expandido no IV Congresso de Educação e Formação Docente: perspectivas e possibilidades (CONEF), na Universidade Estadual de Montes Claros (UNIMONTES).

84 Atuou como monitora na Escola Família Agrícola Tabocal e também como professora designada na Rede Estadual de Ensino Básico de Minas Gerais. Mestranda em Educação pela Universidade Estadual de Montes Claros (UNIMONTES), licenciada em Educação do Campo com Habilitação em Ciências Sociais e Humanidades, pela Universidade Federal de Minas Gerais (UFMG). geanepn2014@gmail.com 
Este artigo relata uma experiência de monitoria em uma Escola Família Agrícola (EFA), a partir dos princípios teórico-metodológicos da Pedagogia da Alternância (PA).

A Pedagogia da Alternância é uma metodologia educativa que une tempos e espaços diversos por meio dos instrumentos pedagógicos: Plano de Estudo (PE); Atividade de Retorno; Colocação em Comum; Síntese Coletiva; Visita e Viagem de Estudo; Intervenção Externa; Tutoria; Caderno de Acompanhamento; Caderno da Realidade; Estágio e Projeto Profissional do Jovem (PPJ). Nesse processo, os estudantes permanecem duas semanas na escola em sistema de internato e duas semanas com a família em suas comunidades e, nesses tempos e espaços, recebem o acompanhamento dos monitores e das famílias.

A Escola Família Agrícola adota essa Pedagogia e, com base em seus princípios e instrumentos pedagógicos, oferece uma formação integral e libertadora, principalmente para os filhos de camponeses, valoriza a agricultura familiar e a agroecologia, por meio de um projeto de Campo e de sociedade emancipadores (AMEFA, 2018).

O texto encontra-se organizado em 4 partes; no primeiro e segundo itens, é apresentado o conceito de EFA, as especificidades da atuação profissional e os desafios do monitor nos tempos e espaços que permeiam a Pedagogia da Alternância. Em seguida, são sistematizados os resultados e discussão desse estudo, revelando a complexidade da profissão monitor de EFA e suas nuanças e, por fim, são tecidas as considerações finais, que apontam a necessidade de outras reflexões, tais como sobre o lugar ocupado pelo monitor de EFA na sociedade, na política e na Educação do Campo.

São objetivos deste relato de experiência discutir a relação do monitor com a Pedagogia da Alternância e identificar os desafios enfrentados pelos educadores na atuação profissional. Atendendo ao propósito deste trabalho, adotou-se a metodologia de sistematização da experiência vivida pela autora na Escola Família Agrícola Tabocal, localizada no município de São Francisco, Minas Gerais. A discussão teórica baseia-se em leituras feitas em Veiga (1998), Begnami (2003), Marirrodriga e 
Calvó (2010), Cruz (2014), Freitas (2015) e AMEFA (2018). A escolha desses textos pauta-se pela relevância do conteúdo para a discussão sobre o monitor de EFA e as especificidades da profissão, pois apresentam um diálogo que permeia a relação do monitor com a Pedagogia da Alternância em diferentes tempos, espaços e contextos, discute a profissionalização docente, atuação e a importância desses educadores para as EFA e a Educação do Campo.

Por meio desse relato, é possível identificar elementos que sustentam a importância dos monitores para as EFA, a Educação do Campo e demais educadores e espaços formativos, revela os desafios e enfrentamentos diários desses profissionais que buscam a materialidade de uma educação numa nova perspectiva de formação humana e profissional.

\section{A INSTITUIÇAO EDUCACIONAL ESCOLA FAMÍLIA AGRÍCOLA}

A EFA é uma instituição de ensino que adota a Pedagogia da Alternância, oferece o Ensino Médio integrado ao curso técnico em agropecuária, objetiva atender principalmente jovens camponeses e, em algumas dessas escolas, existem outras modalidades de ensino, como o Ensino Fundamental e a Educação de Jovens e Adultos (EJA). Trata-se de uma instituição de cunho associativo, na qual a gestão acontece por meio de uma coletividade formada por famílias, comunidades, movimentos sociais e sindicais, na busca de promover a formação integral e emancipação dos sujeitos, em articulação com os princípios da Educação do Campo, tendo em vista um novo projeto de sociedade (AMEFA, 2018).

A EFA funciona com base nos quatro pilares, que são princípios fundamentais das Escolas Famílias Agrícolas e que as caracterizam e diferenciam das instituições de ensino convencional (FREITAS, 2015).

O princípio da alternância dá sustentação para o funcionamento das escolas e busca atender ao objetivo geral dos Centros Familiares de Formação por Alternância (CEFFA) ${ }^{85}$. Marirrodriga e Calvó (2010, p. 65) sublinham que esse princípio visa "[...] a promoção e o desenvolvimento das pessoas e de seu próprio meio social a curto, médio e longo prazo, através de atividades de formação integral, principalmente, de

85 O CEFFA é o Centro Educativo Familiar de Formação por Alternância. Ele agrega as EFA, Casas Familiares Rurais (CFR) e Escolas Comunitárias Rurais (ECOR) [...]. (AMEFA, 2018). 
adolescentes, mas também, de jovens e adultos".

Os 4 pilares fundamentais dos CEFFA são classificados em dois princípios-meios, a associação e a alternância, e dois princípios fins, a formação integral e o desenvolvimento do meio. Os primeiros, intitulados meios, proporcionam a materialidade dos considerados finalidades, e assim são tidos como indissociáveis, pois dialogam entre si e não funcionam de forma fragmentada.

No cumprimento da sua função social, a EFA, sustentada pelos princípios da Pedagogia da Alternância, proporciona para os jovens e adultos uma formação que perpassa as áreas técnica, profissional, humana, intelectual, ética e espiritual, que se tornam mecanismos para concretizar o desenvolvimento do espaço onde vivem.

AEFAé um espaço educativo com princípios, ideologias e práticas que a caracteriza e faz tornar possível uma formação humana, crítica e que busca a emancipação, sobretudo dos camponeses que, na história, foram invisibilizados pelas políticas educacionais.

\section{O MONITOR DE EFA: A ATUAÇÃO PROFISSIONAL E SEUS DESAFIOS}

O universo de vivências profissionais do monitor de uma EFA é bastante complexo, fazendo-se necessário direcionar dialeticamente o olhar para que se possa compreender suas nuanças.

As especificidades metodológicas e curriculares da EFA exigem que os seus educadores sejam diferenciados em relação aos saberes docentes e habilidades profissionais (FREITAS, 2015). Isso significa que a função do monitor nessa realidade vai para além da responsabilidade de dar aulas, perpassando por diversas atribuições no processo formativo dos estudantes, a partir da proposta da Pedagogia da Alternância.

Marirrodriga e Calvó (2010, p. 74 ) salientam que "o trabalho do monitor não começa ou termina num determinado horário porque não se reduz aos tempos de conversa pessoal com os alunos ou com as aulas para o grupo". Ele recebe o jovem na escola e o acompanha durante o internato, construindo e mantendo um diálogo com o aluno e sua família. É um profissional que está a serviço em tempo integral, atendendo e acompanhando os alunos, dentro e fora da sala de aula, sendo considerado o (a) pai (mãe), o (a) amigo (a) e o(a) psicólogo(a) do estudante no internato. É 
ele quem apoia e contribui com cada jovem, convertendo-se em seu amigo fiel, orientador no âmbito intelectual, profissional e humano (MARIRRODRIGA; CALVÓ, 2010).

Dessa forma, para atuar como monitor é necessário que se tenha habilidades múltiplas que não se limitam ao saber pedagógico e técnico, uma vez que deve considerar a totalidade e a complexidade da Pedagogia da Alternância. "O monitor deve ser capaz de suscitar a vocação formadora das famílias e responsáveis de alternância durante a estadia dos alunos no meio socioprofissional. Portanto, é um formador de adultos, além de um formador de jovens" (MARIRRODRIGA; CALVÓ, 2010, p.75).

Diante dessas considerações é importante entender por que o uso do termo monitor e não professor.

O termo monitor

[...] resulta de sua construção histórica a partir da denominação de uma prática que exigia atribuições no sentido de acompanhar os alunos em diversos momentos do processo educativo em Alternância. Monitor é um nome universal no âmbito das escolas da Alternância (FREITAS, 2015, p.145).

As funções e responsabilidades caracterizam a titulação construída e dada aos educadores das Escolas Famílias Agrícolas. "O Monitor é concebido como aquele que orienta, motiva, aguça curiosidades, provoca, problematiza, ajuda a construir ou reconstruir conhecimentos, facilita aprendizagens e, quando necessário, também ensina" (BEGNAMI, 2003, p.49). Mas, cabe ressaltar que a denominação "monitor", a importância desses profissionais e do trabalho desenvolvido por eles, não os fazem melhores ou mais importantes do que os professores, e não propõe a fragmentação do grupo de profissionais que atuam na EFA. Ao contrário, busca inspirar e fortalecer a luta por uma nova forma de ensinar e aprender, por meio da contextualização do ensino e de práticas e ações pedagógicas interdisciplinares, em contraposição ao ensino com disciplinas isoladas. E, nesse processo, considera-se relevante no ensino e aprendizagem a aproximação do educador com a realidade do aluno e o estreitamento do vínculo com as famílias (FREITAS, 2015).

Ao encontro com essa ideia, Cruz (2014, p.100) sintetiza que "[...] o assumir a EFA pelo monitor está além de ser um simples funcionário [...]”, pois é necessário estar envolvido em muitas atividades da alternância dedicando-se ao processo de contextualização das suas aulas, responsabilizando-se em conjunto com a equipe de 
monitores pela organicidade da sessão escolar, que consiste em dividir e acompanhar as tarefas (atividades práticas) diárias a serem desempenhadas pelos alunos, tais como os cuidados e limpeza do espaço escolar. Também é função do monitor acompanhar a organização dos dormitórios, supervisionar os horários a serem cumpridos pelos estudantes que compreendem os momentos de acordar, de realizar as atividades práticas, de estar em sala de aula e de manter silêncio no período noturno. Além disso, ele deve acompanhar a disciplina dos alunos e orientá-los no cumprimento das normas internas da instituição.

A equipe de monitores também se ocupa das atividades que envolvem os instrumentos pedagógicos, que são elementos essenciais para a concreticidade da Pedagogia da Alternância, como a Tutoria que é o acompanhamento personalizado feito pelos monitores a um grupo de alunos, o que permite o estreitamento do vínculo com as famílias dos jovens por meio do Caderno de Acompanhamento e a construção do Plano de Estudo. Esse Plano consiste na organização e elaboração dos enfoques de pesquisa, assim como a sistematização das informações da pesquisa, em conjunto com os estudantes por meio da colocação em comum e síntese coletiva.

Outra atividade sob responsabilidade dos monitores é o planejamento e acompanhamento dos estudantes na Visita e Viagem de Estudo, tendo em vista o tema do Plano de Estudo trabalhado. Nessa atividade, eles buscam parceiros para promover a Intervenção Externa, momento de troca de experiências acerca do tema do Plano de Estudo. As orientações e acompanhamento do Estágio, do Projeto Profissional do Jovem, e do Caderno da Realidade, são outras funções atinentes ao monitor (MARIRRODRIGA; CALVÓ, 2010).

Diante disso, percebe-se que "a concepção de espaço e tempo do monitor da EFA e do 'professor tradicional' é diferente, incluem atribuições e um comportamento diferenciado diante da proximidade com os alunos e suas famílias, comunidades que ocorre na escola de Alternância" (FREITAS, 2015, p.145).

Considerando-se as atribuições e o papel do monitor da EFA, "a seleção e a formação dos formadores é um problema considerável" (MARIRRODRIGA; CALVÓ, 2010, p.70), tanto a inicial quanto a continuada, para o movimento das EFA, a Educação do Campo, os estudantes e famílias. Desse modo, é pertinente enfatizar que a formação inicial do monitor para atuar na Educação Básica é mediante a formação 
em curso superior de licenciatura (VEIGA,1998), assim como para os demais professores.

Nesse sentido, Veiga (1998, p. 84) acentua que "a profissionalização do magistério implica necessariamente ressaltar a importância da articulação entre a formação inicial e a continuada. [...] e ambas complementam-se como elementos essenciais à construção da identidade profissional". Diante do exposto, é oportuno considerar: como a formação inicial e continuada dos monitores é percebida pelas EFA?; a formação inicial em curso de licenciatura tem sido considerada como um fator importante para docência nas EFA? Essas são provocações que demandam reflexões importantes para a comunidade escolar e a Educação do Campo.

Cruz (2014, p.102) ressalta que

[...] ser monitor na EFA e cumpridor de seu papel de formador crítico vai muito além de ministrar disciplinas e aplicar os instrumentos da pedagogia da alternância, na medida em que exige o seu compromisso pessoal, ético e política com a vida dos estudantes e suas famílias [...].

Nessa perspectiva, atentar-se para formação inicial e continuada desses profissionais é, dentre outras finalidades, buscar a profissionalização dos educadores, repensar e ampliar as habilidades, os saberes, as ações e fazeres docentes.

E os desafios e possibilidades na atuação profissional dos monitores de EFA não se resumem a essas questões expostas, eles se apresentam na carga horária excessiva de trabalho, nos recursos didáticos limitados, nos atrasos de salário e na baixa remuneração. Entende-se que cada EFA tem suas especificidades e organização, e os fatores que influenciam as realidades, em alguns casos, independem das EFA, e perpassam pela negação dos direitos dessas instituições e das famílias e alunos, no que diz respeito às políticas educacionais e ao compromisso político, social e econômico por parte da sociedade e do governo.

As discussões propostas revelam que o monitor de EFA é um profissional polivalente, devendo possuir habilidades, saberes e práticas educativas que permitam a articulação e o desenvolvimento das suas diversas funções na escola. Seu contexto de trabalho e sua atuação se apresentam num movimento de complexidade. 
As reflexões apresentadas possibilitam-nos perceber que para exercer a função de monitor de EFA é necessário pensar a educação para além da sala de aula, entendendo que os espaços ocupados pelos jovens e adultos, as pessoas que convivem na sessão escolar, no meio socioprofissional, são detentores de saberes e contribuem com o processo formativo em alternância.

As teorias em diálogo com a experiência vivida pela autora revelam que as responsabilidades do monitor exigem muitas capacidades e habilidades que são construídas a partir da formação inicial e continuada de professores, da experiência da docência, da relação com a equipe de trabalho, da busca constante pelo conhecimento, do intercâmbio com as outras EFA, da troca de saberes com os estudantes, famílias e comunidades. E assim, é evidenciada a materialidade dos 4 pilares fundamentais das EFA, os princípios da Pedagogia da Alternância, a formação humana, integral, critica e emancipatória dos sujeitos.

Entretanto, os monitores de EFA são profissionais pouco conhecidos e valorizados na sociedade e nos espaços acadêmicos. São invisibilizados pelas políticas educacionais, programas de formação de professores, além de lhes ser negado o direito a uma remuneração digna. Nesse sentido, é pertinente ressaltar a importância que esses profissionais representam para a Educação, sobretudo para a Educação do Campo. As produções acadêmicas, as pesquisas, os debates sobre esses atores da Pedagogia da Alternância avançam lentamente, tendo em vista a representatividade das EFA na luta pela educação popular, nos enfrentamentos com os movimentos sociais e sindicais pela conquista de direitos, pela valorização da agricultura familiar, da agroecologia, entre outras ações e embates na busca pela igualdade e justiça social.

Nota-se que os monitores enfrentam diariamente desafios atinentes às responsabilidades e à função que desempenham na EFA, e que impactam sua condição física e saúde mental. Diante dessa realidade, fica evidente a necessidade de avanços e mudanças para esses profissionais, o que demanda o fortalecimento da identidade, além de debates, reflexões e ações coletivas nas EFA, nos cursos de formação de professores, nos movimentos sociais e sindicais, na Educação do Campo e nos demais espaços políticos junto aos governos em suas respectivas esferas. 
É interessante sublinhar, também, que na atuação do monitor na EFA, por meio do convívio diário, constrói-se o vínculo afetivo entre a equipe de trabalho com os alunos, as famílias, e existe uma troca e uma aprendizagem contínua nos espaços e nas relações construídas através do movimento da Pedagogia da Alternância.

Há, portanto, possibilidades e provocações que propõem debates e reflexões acerca da Educação do Campo, das EFA e dos monitores, no que diz respeito aos saberes, as lutas e a resistência desses espaços e sujeitos.

\section{CONCLUSÃO}

A atuação do monitor em uma Escola Família Agrícola é direcionada pela Pedagogia da Alternância e pelos instrumentos pedagógicos que buscam efetivar a proposta educativa dessa escola, enquanto instituição que proporciona formação humana, profissional e integral dos estudantes. É evidente a relevância desse profissional no processo formativo dos jovens e adultos, pois o compromisso que tem com a formação na EFA se revela em um movimento que transcende a vida profissional e técnica dos estudantes, para as capacidades humanas, ética, social e espiritual, o que se desdobra na formação integral desses sujeitos.

A EFA se revela como um espaço com muitas possibilidades de aprendizagem coletiva, em seus tempos e espaços, permeados pela Pedagogia da Alternância e pelas atividades promovidas e organizadas. De acordo com este estudo, percebe-se que a instituição de ensino busca no processo educativo a materialidade da práxis, entendendo que, a partir da consciência, envolvem a prática, a reflexão e uma nova prática para promover uma transformação, e os monitores são protagonistas na orientação e na mediação desse método.

Constata-se que os desafios são diários na vida do monitor, atinentes à sala de aula, aos recursos didáticos, à condição de trabalho, à remuneração, à saúde mental, à invisibilidade na sociedade e às políticas educacionais, e que esses profissionais reinventam as suas ações diante das dificuldades e da realidade existente nos espaços que ocupam.

Tendo em vista os assuntos discutidos neste texto, percebe-se a importância deste estudo para os educadores em geral, as EFA, a Educação do Campo, os acadêmicos e pesquisadores em educação, pois abrem um leque de possibilidades para 
debates e (re) construção de concepções acerca do profissional monitor, sua atuação e sua importância. E, para outras discussões, é relevante indagar "qual lugar é ocupado pelo monitor de EFA na sociedade, na política e na Educação do Campo? " O que demanda outras reflexões.

\section{REFERÊNCIAS}

ASSOCIAÇÃO MINEIRA DAS ESCOLAS FAMÍLIAS AGRÍCOLAS, 2018. À serviço da educação e formação camponesa. [Belo Horizonte: AMEFA], 2018. 1 folder.

BEGNAMI, J. B. Formação pedagógica de monitores das Escolas Famílias Agrícolas e alternância: Um Estudo Intensivo dos Processos Formativos de cinco Monitores. 2003. 319 f. Dissertação (Mestrado em Educação) - Faculdade de Ciências e Tecnologias da Educação, Universidade Nova de Lisboa, Portugal; Departamento de Ciências da Educação e Formação, Universidade François Rabelais de Tours - França, 2003. Disponível em: HTTPS://RUN.UNL.PT/BITSTREAM/10362/391/1/ BEGNAMI_2003.PDF. Acesso em: Mar/2021.

CRUZ, N. A. da. A práxis da Escola Família Agrícola: continuidades e permanências na vida de egressos camponeses. 2014. 224 f. Tese (Doutorado em Educação) - Instituto de Educação, Universidade Federal de Mato Grosso, Cuiabá, 2014.

FREITAS, G. V. Formação em Pedagogia da Alternância: um estudo sobre os processos formativos implementados pela AMEFA junto aos monitores das EFAs do Médio Jequitinhonha-MG. 2015. 253 f. Dissertação (Mestrado em Educação do Campo) - Centro de Formação de Professores, Universidade Federal do Recôncavo da Bahia, Amargosa, 2015.

MARIRRODRIGA, R. G.; CALVÓ, P. P. Características Gerais Definições, Fins e Meios dos CEFFA. In: MARIRRODRIGA, Roberto Garcia; CALVÓ, Pedro Puig. Formação em Alternância e Desenvolvimento Local: o movimento educativo dos CEFFA no mundo. Tradução: João B. Begnami. Belo Horizonte: O Lutador, 2010. cap. 2, p. 59-106.

VEIGA, IIma Passos Alencastro. Avanços e equívocos na Profissionalização do Magistério e a Nova LDB. In: VEIGA, Ilma Passos Alencastro (Org.). Caminhos da Profissionalização do Magistério. 2 ed. Campinas-SP: Papirus, 1998, p.75-97. (Coleção Magistério: Formação e Trabalho Pedagógico). 


\section{ESCOLAS DO CAMPOE COMUNIDADES: POSSIBILIDADES DE FORTALECIMENTO DIANTE DA AMEACGA DO FECHAMENTO}

Vanessa Dal Canton ${ }^{86}$ Carine Busatto ${ }^{87}$ Adivane Bresolin ${ }^{88}$

86 Extensionista Rural Social. Licenciada em Pedagogia pela URI. Pós-graduada em Desenvolvimento Rural e Agricultura Familiar. Mestre em Educação. Licencianda em Educação do Campo pela UFSM. E-mail: vanessadalcanton@hotmail.com

87 Professora. Licenciada em Pedagogia pela URI. Pós-graduada em Atendimento Educacional Especializado - AEE e em Autismo. E-mail: carine_busatto@hotmail.com

88 Professora. Licenciada em Pedagogia pela UFPEL, Letras pela UNOPAR e Educação do Campo pela UFSM. Pós-graduada em Educação Inclusiva. E-mail: adivane.uabseberi@gmail.com 
A temática do fechamento das escolas do campo apresenta-se atualmente como grande inquietação dos profissionais, pais, alunos e municípios onde estão inseridas. Tendo em vista a observação de alguns casos da região norte do Rio Grande do Sul, em que projetos relacionados ao campo e a comunidade local tiveram força para sensibilizar lideranças e evitar o fechamento de escolas, é que este trabalho busca responder ao problema de pesquisa: "quais ações estão presentes ou podem ser fomentadas na comunidade escolar para o fortalecimento das escolas do campo diante da ameaça do fechamento?"

Neste sentido, o presente estudo se origina de um projeto desenvolvido na disciplina de Seminário Integrador II do curso de Licenciatura em Educação do Campo da UFSM e foi apresentado no Seminário Regional de Educação do Campo da Região centro do Rio Grande do Sul - SIFEDOC (2018). Objetiva conhecer as ações desenvolvidas nas escolas de campo e o fortalecimento junto à comunidade local, na busca por estratégias de fortalecimento diante da ameaça de fechamento. A pesquisa foi realizada em três municípios, nos quais as alunas pesquisadoras estão inseridas profissionalmente e/ou pessoalmente, sendo: Iraí, Frederico Westphalen e Liberato Salzano.

As três primeiras escolas visitadas aceitaram participar da pesquisa e serão referenciadas no decorrer do texto como: Escola 1, Escola 2 e Escola 3, sendo respectivamente dos municípios de: Iraí, Frederico Westphalen e Liberato Salzano. O que se dispôs a estudar refere-se a uma temática bastante complexa e atual que envolve diferentes atores. Para tanto, o universo da pesquisa compreendeu o corpo docente, o corpo discente e a comunidade escolar mediante Termo de Consentimento Livre e Esclarecido.

Assim, as entrevistas com o corpo docente envolveram o (a) diretor (a); o (a) coordenador (a) pedagógico (a) e um professor (a) de cada escola. Teve como objetivo saber que alternativas o corpo docente pensa ser importante para o não fechamento das escolas do campo. A escolha do professor (a) foi por convite. Já o corpo discente respondeu sobre a representatividade da escola para suas vidas 
e formação. Participou da pesquisa um aluno de cada ano $\left(5^{\circ}, 6^{\circ}, 7^{\circ}, 8^{\circ}\right.$ e $\left.9^{\circ}\right)$ a partir da aprovação da direção das escolas e convite aos mesmos que se reuniram em sala separada dos demais para responder ao questionário. Como membros da comunidade, foi entrevistada uma pessoa do Círculo de Pais e Mestres, o presidente da comunidade, dois pais e/ou mães de alunos da respectiva escola e um membro da comunidade que não tenha filho estudando na escola. O objetivo da entrevista era ter a opinião destas pessoas quanto à representatividade da escola para o desenvolvimento e/ou manutenção da comunidade.

Para compor o quadro teórico da pesquisa utilizou-se de um estudo bibliográfico acerca das concepções básicas da Educação do Campo, com o objetivo de contextualizar, compreender e balizar a realidade a ser estudada. Num segundo momento do trabalho foi realizada a coleta, análise e interpretação dos dados que expressaram a realidade pesquisada, no intuito de conhecer o desenho da educação do campo nos municípios de Frederico Westphalen, Iraí e Liberato Salzano. Assim também está organizado este trabalho.

A pesquisa de cunho qualitativo buscou responder a inquietação inicial deste projeto trazendo para dentro do processo os atores que fazem parte dele e assim, buscar possibilidades juntos, pois, a resposta deve vir do interior sendo trabalhada de forma horizontal. Teve-se como preocupação inicial levar à comunidade a discussão sobre a importância de se permanecerem abertas as escolas do campo, já que elas se incluem num projeto maior que configura a manutenção das comunidades e da vida no meio rural. Além disso, as entrevistas e questionários responderam de forma positiva, na sua grande maioria, alternativas de fortalecimento das escolas do campo.

\section{A CONSTRUÇÃO DA EDUCAÇÃO DO CAMPO: UM TERRITÓRIO MARCADO POR LUTAS DOS MOVIMENTOS SOCIAIS}

Os movimentos sociais incorporam as angústias de um grupo ou comunidade que perpassam por tensões e contradições de aceitação pelo seu modo de vida em um determinado local da sociedade. Surgem os mesmos, pois, são forçados a seguirem valores e ações que não condizem com a realidade social deste grupo. Para chegar até a modalidade de Educação do campo não foi diferente, muitas movimentações 
sociais foram realizadas em busca de dar visibilidade à importância deste modo de vida e modalidade de ensino.

Os movimentos se organizavam em torno de um objetivo, criar uma política que favorecia e defendia a identidade desse grupo para garantir uma Educação que seja no Campo e do Campo. Pois, estavam convictos de que "No Campo", teriam suas escolas no lugar onde viviam, e "Do Campo", teriam uma metodologia pensada e planejada para essa realidade. Como exemplifica Caldart (2002, p. 26): "No, o povo tem direito a ser educado no lugar onde vive. Do, o povo tem direito a uma educação pensada desde seu lugar e com a sua participação, vinculada à sua cultura e às suas necessidades humanas e sociais."

É neste sentido que a educação do campo continua sendo um desafio para o Brasil, pois existe uma diferença social e política da educação rural. O movimento de busca por uma educação adequada à realidade dos sujeitos do campo iniciouse basicamente pela luta ao acesso a terras, já que no Brasil, a disparidade em quantidade de área de terras é enormemente assustadora. A questão educacional vem em seguida para reforçar esse movimento, criar mais sustentação e resistência para manter essa estratégia do modo de vida.

A educação do campo trabalha através do diálogo, está vinculada aos valores da participação e democracia. São ações exercidas pelo povo e para todos. A educação do campo é vinculada a uma forma de vida específica que foi conquistada através de muitas lutas e mobilizações sociais. Para tanto, é uma modalidade de educação pensada, criada e planejada pelos indivíduos do campo para o educando que vive no campo. Certamente com um propósito único e direcionado para essa população que apresenta constantes situações de dificuldades no modo de vida e de produção em geral.

Conforme a Secretaria da Educação do Rio Grande do Sul - SEDUC/RS (2018), a educação do campo envolve diversos níveis e modalidades de ensino, possui legislação própria e está vinculada a um projeto de desenvolvimento sustentável, articulado com outras instituições ligadas ao meio rural. O objetivo é qualificar os espaços escolares e garantir o acesso à educação, contribuindo para a permanência dos jovens no meio rural. 
Para garantir que este projeto de educação do campo se desenvolva com efetividade é fundamental que os profissionais tenham acesso à formação específica para trabalhar com tal realidade. Não é possível estabelecer relação entre educação e trabalho quando não se consegue adentrar na realidade daqueles com quem se trabalha. Preocupado com esta dificuldade, Pinto (1981 apud RIBEIRO, 2012, p. 296) refere-se aos professores justificando que eles "não recebem uma formação adequada para lidar com a realidade do campesinato, por isso seu desinteresse em estabelecer relações com as comunidades, quando encaminhados a trabalhar nas áreas rurais."

De fato, a formação dos profissionais deveria estar na base de um plano ou projeto da educação do campo. Se não existe formação adequada, também não pode haver interrogações sobre um trabalho educativo que não vá ao encontro de práticas em favor do campo. No entanto, tem-se conhecimento de exemplos de escolas do campo que conseguem fazer a diferença mesmo enfrentando uma série de dificuldades. Exemplos estes que têm conseguido força suficiente para evitar o fechamento de escolas.

Toda vez que a escola desconhece ou desrespeita a história de seus alunos,
toda vez que se desvincula da realidade dos que deveriam ser sujeitos, não
os reconhecendo como tal, ela escolhe ajudar a desenraizar e a fixar seus
educandos num presente sem laços. E se isto acontecer com um grupo social
desenraizado ou com raízes muito frágeis, isto quer dizer que estas pessoas
estarão perdendo mais uma de suas chances (e quem garante que não a úl-
tima?) de serem despertadas para a própria necessidade de voltar a ter raiz,
a ter projeto. Do ponto de vista do ser humano isto é muito grave, é violenta-
mente desumanizador. (CALDART, 2001, p. 141).

Reitera-se a fundamental contribuição da escola comprometida e responsável na formação de sujeitos do campo. As palavras de Caldart (2001) fazem pensar e reafirmar o sentido de lutar juntos pelo respeito às raízes dos educandos do campo. Contudo salienta-se que não é somente a formação dos professores que levará as escolas do campo ao âmago do desenvolvimento. O que contribuirá é um conjunto de ações que envolvem: políticas públicas, infraestrutura, construção de um projeto político pedagógico, uma proposta que dialoga com a necessidade da comunidade, acesso à escola e estruturação ampla da comunidade e do governo, entre outros 
fatores. Com todos os pontos ressaltados pode-se sim haver uma grande transformação na educação do campo.

As Diretrizes Complementares da Educação Básica do Campo (2008) afirmam o oferecimento das condições para a viabilidade de quaisquer atividades com respeito às diversidades dos sujeitos do campo. As diretrizes asseguram ainda que as escolas do campo devem oferecer todo acervo pedagógico e de infraestrutura, o qual seria nada mais que um direito de qualquer aluno usufruir. Porém, como mencionado nas entrevistas das escolas pesquisadas, não é assim que acontece na realidade. As escolas têm dificuldade para manter estruturas físicas básicas, pois, são poucos os recursos devido ao baixo número de alunos e o repasse ocorre a partir da quantidade de matrículas.

Conforme observado nos relatos, nos últimos anos, escolas do campo são ameaçadas por políticas que afirmam "reduzir gastos" e pela diminuição do número de alunos. Políticas que não consideram que os alunos têm direito de acessar uma educação de qualidade com propósitos afins a sua realidade. A Lei de Diretrizes e Bases da Educação Nacional (LDB 9.394/96) garante em seu Artigo 28 a oferta de um sistema de ensino diferenciado para o campo que promova as adaptações necessárias à sua adequação, levando em consideração às peculiaridades do campo. Neste sentido, os conteúdos e metodologias são organizados de acordo com a realidade levando em consideração o ciclo agrícola e as condições climáticas de cada região.

Observa-se nos municípios das escolas entrevistadas que comunidades que não possuem escolas em funcionamento são comunidades com menos moradores e com participação reduzida em qualquer que for o evento. Pode-se dizer então que uma escola fechada contribui para o enfraquecimento da comunidade na qual está inserida. São notáveis as diferenças de comunidades que possuem escola funcionando, pois, são mais ativas, mais participativas e organizadas. Parece que existe um ânimo diferente, algo que move as pessoas a se empenharem por uma mesma causa. Este é um bom motivo pela luta de permanência das escolas do campo.

Neste sentido, as escolas podem colaborar para a permanência dos jovens no campo, utilizando-se de ferramentas que venham contribuir, incentivar, fortalecer o 
gosto pelas atividades agrícolas, que deem embasamento para o cultivo de alimentos, a geração de empregos, renda e qualidade de vida no campo.

Com relação ao papel das comunidades no enfrentamento da ameaça de fechamento das escolas do campo, pode ser citada a lei 12.960/2014 que acrescenta ao artigo 28 da LDB 9394/96 o seguinte:

Parágrafo único: O fechamento de escolas do campo, indígenas e quilombolas será precedido de manifestação do órgão normativo do respectivo sistema de ensino, que considerará a justificativa apresentada pela Secretaria de Educação, a análise do diagnóstico do impacto da ação e a manifestação da comunidade escolar. (LEI No 12.960/2014).

É nesta ótica que a comunidade se faz muito importante na luta contra atos de governos que pretendem fechar escolas do campo. Se a lei deixa claro que as escolas juntamente com suas comunidades podem reivindicar adaptações e melhoras para incentivar o aluno a permanecer no campo, acredita-se que as escolas serão fechadas se a comunidade escolar não estiver preparada para lutar pelo direito de permanência no campo.

\section{A REALIDADE DA AMEAÇA E DO FECHAMENTO DAS ESCOLAS DO CAMPO}

A primeira pergunta do questionário aplicado aos profissionais da educação das escolas do campo buscou conhecer as atividades que as mesmas promovem que seguem na direção do intuito da permanência dos jovens no campo. Sendo assim, duas escolas - Escolas 1 e 3 - desenvolvem ações que envolvem o preparo do solo, o plantio e os cuidados necessários até a colheita, resultando em: horta, pomar, jardinagem, estufa, produção de mandioca, amendoim, batata-doce e morango, principalmente. Conforme relato da Escola 3, os alunos vivenciam na prática a importância da agricultura familiar para a sustentabilidade.

Destaca-se a relevância destes cultivos em espaço escolar, pois, além de contribuírem para a valorização do campo e a produção de alimentos feita pelos agricultores familiares em sua maioria, estes produtos colhidos servem em primeiro lugar para abastecer e enriquecer a merenda escolar. Para exemplificar esta questão, chama-se atenção à resposta da coordenadora pedagógica da Escola 1: "Sim. Desenvolvemos projetos permanentes de jardim, horta e estufa. Os produtos cultivados são 
utilizados na merenda escolar. Como o terreno da escola é muito extenso, cultivamos batata-doce, milho, amendoim, feijão e mandioca, além de árvores frutíferas."

A Escola 2 afirma que quando possível desenvolve ações voltadas à permanência do jovem no campo. Aborda como exemplos, a participação em Feiras, Dias de Campo e outras atividades em parceria com a Emater/RS ASCAR. Com relação à aproximação com esta entidade de extensão rural, as outras duas escolas também afirmam sua contribuição, mas é enfatizada pela Escola 3 que afirma ter a presença dos extensionistas durante todas as ações principais que dizem respeito à agricultura.

As Escolas 1 e 3 já sofreram ameaças de fechamento. Os principais motivos são: o baixo número de alunos e corte de gastos. Conforme relato dos profissionais da Escola 3, no início do ano (2018) a mesma foi informada pela SEDUC - Secretaria da Educação do Rio Grande do Sul - que funcionaria em apenas um turno, porém, com a mobilização e o apoio da comunidade, foi revertida esta situação. Os docentes reiteram que o que teve grande influência para o não fechamento foram as ações desenvolvidas através do projeto voltadas a atividades do campo e isto levou a um comprometimento ainda maior da equipe escolar com a comunidade em geral.

É possível perceber a influência de projetos como os citados acima e a presença da comunidade no momento de tomar a decisão de fechar uma escola do campo. Assim, o exemplo da Escola 1 demonstra a força do povo unido por uma mesma causa já que a escola foi ameaçada de fechamento em duas ocasiões, conforme explica:

[...] Na primeira, o principal motivo foi o baixo número de alunos (fechamento total) e na segunda, neste ano (2018) foi fechado um turno, alegando que o número de salas é suficiente para o atual número de alunos. Situação esta que foi revertida pela comunidade escolar, juntamente com a $20^{\mathrm{a}} \mathrm{CRE}$ e Prefeito Municipal. (Professor 1, 2018).

A manifestação da comunidade, conforme a Lei 12.960/2014 que altera o artigo 28 da LDB 9.394/96 se faz importante instrumento de análise antes que seja tomada a decisão de fechar uma escola do campo. Nesse sentido, reconhecendo as fragilidades de cada Escola visitada, mas também, percebendo a luta por continuarem sua jornada apoiadas pela comunidade, os docentes enalteceram as alternativas que pensam ser importantes para o fortalecimento das instituições que viriam ao encontro do não fechamento. Para tanto, dentre as alternativas mais citadas, o desenvolvimento de 
projetos e/ou práticas voltadas à realidade do campo é a que mais se destaca seguida de uma formação adequada aos profissionais e o aumento do número de alunos.

Correlacionada ao baixo número de alunos, realidade enfrentada pela maioria das escolas do campo, está a dificuldade financeira e a falta de recursos humanos, o que por vezes acarreta na sobrecarga de trabalho como relata a Coordenadora Pedagógica da Escola 1: "Por ser uma escola com um número baixo de alunos, dispusemos de poucos recursos humanos, uma vez que são vários projetos desenvolvidos, sobrecarregando alunos, professores, funcionários e, principalmente, direção". Sobre a dificuldade financeira, a Diretora da mesma escola complementa: "[...] O que mantém financeiramente nossa escola é a Nota Fiscal Gaúcha que desenvolvemos um grande trabalho e a produção de alimentos na própria escola, também tenho que ressaltar a contribuição dos pais."

Abaixo são relacionadas todas as alternativas que os docentes afirmam ser importantes para o fortalecimento das escolas do campo e as dificuldades que estas enfrentam. Em negrito, as respostas que apareceram com mais frequência.

Figura 1: Alternativas de fortalecimento e dificuldades das escolas do campo

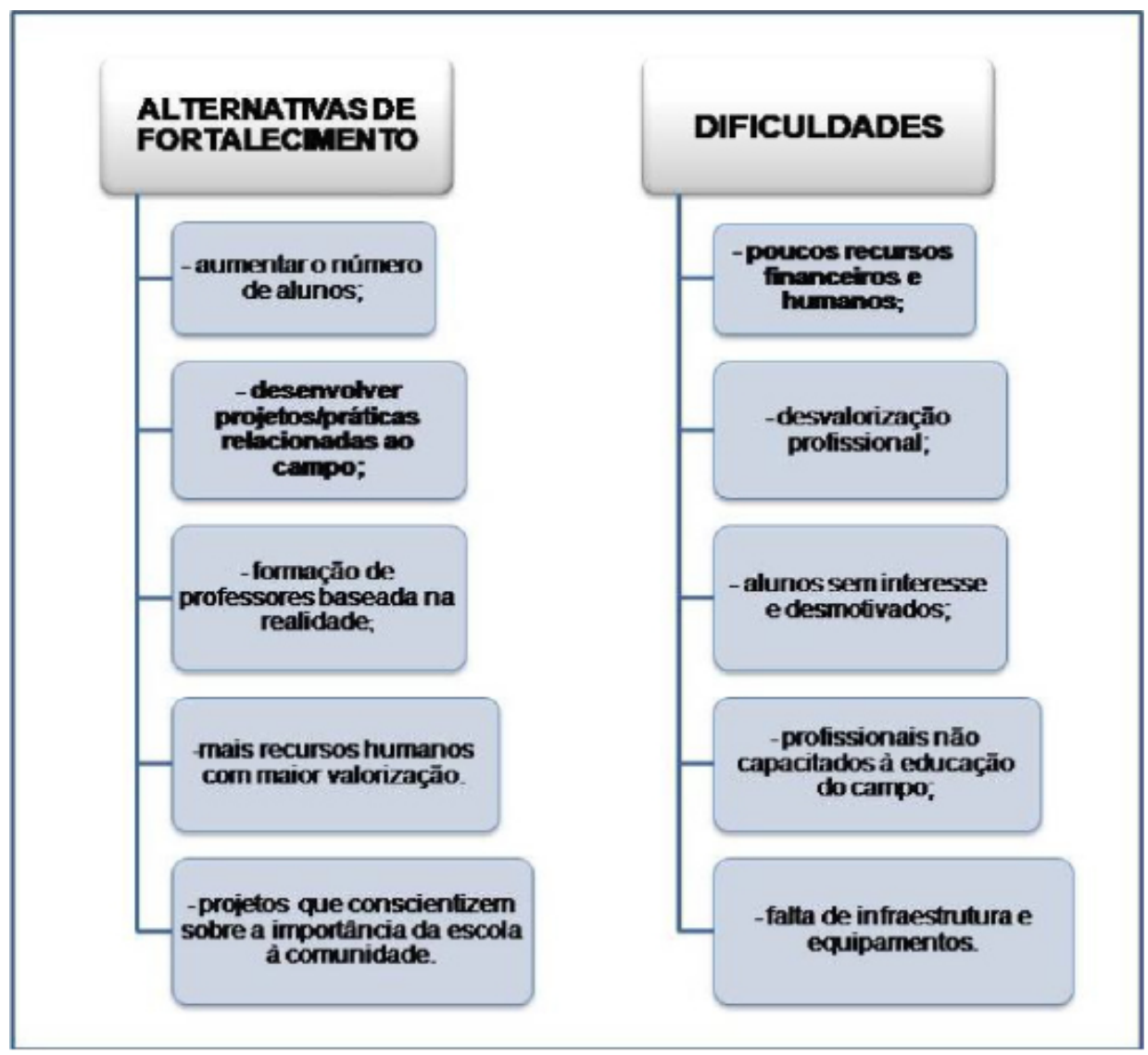

Fonte: Elaborada pelas autoras. 
As escolas que relataram terem sofrido ameaça de fechamento, enfatizaram o baixo número de alunos como principal motivo para esta atitude de governantes. De fato, isto é uma dificuldade real das escolas, haja vista, o campo possui menos gente e as famílias têm menos filhos. Reunir alunos de duas escolas do campo é uma alternativa apresentada por uma moradora da Comunidade 1. No município existem duas escolas próximas, porém, uma estadual (Escola 1 que participou da pesquisa) e outra municipal. A sugestão dela é que os alunos da municipal (são em menor quantidade) viessem estudar na estadual. Esta é uma possibilidade já enunciada pela Administração Municipal aos docentes da escola, porém, estes rejeitaram de imediato até o presente momento.

Conforme docentes da Escola 2, outra dificuldade que enfrentam é a desmotivação e desinteresse dos alunos. Segundo eles, a maioria dos pais delega suas funções para a escola, não cumprindo seu papel primordial em casa. A escola responsabilizada por este e outros tantos compromissos, não consegue dar conta, fazendo aquilo que pode com o que tem, convivendo ainda com a desvalorização profissional.

No que tange a participação da comunidade na vida escolar, a Escola 1 enfatiza sua realidade como bastante positiva, relatando a participação ativa dos pais quando convidados para virem à escola e fazem muitas doações de alimentos, principalmente. Avaliam como excelente e de suma importância o envolvimento das famílias na vida escolar. A Escola 2 entende que a comunidade poderia participar mais e a Escola 3, comenta que ainda algumas famílias não se envolvem na vida escolar, outras têm resistência em participar, mas quando solicitadas, a maioria participa.

Em face do exposto, salienta-se que o espaço rural apresenta-se como um espaço de possibilidades. Sobre isto, Arroyo et al (2004, p.15) diz que:

Esta visão do campo como um espaço que tem suas particularidades e que é ao mesmo tempo um campo de possibilidades da relação dos seres humanos com a produção das condições de sua existência social, confere à educação do campo o papel de fomentar reflexões sobre um novo projeto de desenvolvimento e o papel do campo neste projeto. Também o papel de fortalecer a identidade e a autonomia das populações do campo e ajudar o povo brasileiro a compreender que não há uma hierarquia, mas uma complementaridade: cidade não vive sem campo que não vive sem cidade. 
A educação do campo precisa ser pensada a partir das singularidades de cada espaço valorizando os saberes populares e a cultura dos seus sujeitos. Assim, é que a proposta pedagógica de cada escola precisa ser configurada como práticas educativas em favor dos sujeitos do campo a partir das suas realidades diversas, pois, torna-os atores e autores do próprio processo educativo relacionando seus conhecimentos empíricos com saberes científicos que impulsionam a transformação do espaço onde vivem e produzem.

A entrevista com discentes buscou conhecer a representatividade da escola para suas vidas e formação. Para elucidar as respostas dos alunos, apresenta-se abaixo a figura que aborda a partir de palavras-chave o que mais ficou saliente nas respostas de acordo com as respectivas interrogações:

Figura 2 - Entrevista com corpo discente das escolas do campo

\section{Entrevista com corpo discente das escolas do campo:}

\begin{tabular}{|c|c|c|c|}
\hline O que mais gosta: & O que representa: & $\begin{array}{c}\text { Colabora para sua } \\
\text { permanência no } \\
\text { campo: }\end{array}$ & $\begin{array}{l}\text { Se a escola fosse } \\
\text { fechada: }\end{array}$ \\
\hline $\begin{array}{l}\text { - Espaço; } \\
\text { - Alimentação; } \\
\text { - Atividades; } \\
\text { - Professores. }\end{array}$ & $\begin{array}{l}\text { - Segunda casa; } \\
\text { - Lugar de } \\
\text { aprender, } \\
\text { - Diversāo; } \\
\text { - Amizades. }\end{array}$ & $\begin{array}{l}\text { - Sim(Escolas } 1 \\
\text { e 3): aulas } \\
\text { práticas; } \\
\text { valorizaçăoe } \\
\text { vínculo como } \\
\text { campo; } \\
\text { alfabetizaçăo } \\
\text { nutricional. } \\
\text { - Näo (Escola } \\
\text { 2): năo } \\
\text { desenvolve } \\
\text { açōes voltadas } \\
\text { ao meio rural. }\end{array}$ & $\begin{array}{l}\text {-Protesto; } \\
\text { - Reunião com a } \\
\text { comunidade; } \\
\text {-Rádio; } \\
\text {-Abaixo } \\
\text { assinado; } \\
\text {-Advogado. }\end{array}$ \\
\hline
\end{tabular}

Fonte: Elaborado pelas autoras.

Com vistas a exemplificar ainda mais o contexto da escola na primeira questão, destaca-se a resposta do Aluno do $6^{\circ}$ ano da Escola 1 ao justificar o que mais gosta na sua escola: 
Na resposta do aluno é possível ver o desenho da sua escola e a impressão que ele tem da mesma. Assim, outras respostas apontam para a tranquilidade do lugar, as atividades práticas de produção de alimentos e a satisfação em comer estes alimentos na merenda. Para tanto, destaca-se a representatividade das escolas para os alunos, independente da idade escolar. A escola constitui-se como um lugar de importância infinita, pois, é comparada a uma segunda casa, uma segunda família, devido às amizades cultivadas e aprendizados vivenciados. Quanto mais próxima a realidade das famílias (de vida e de produção) estiver do contexto escolar, maior a valorização e o reconhecimento dos alunos para com o espaço onde vivem.

Assim, a resposta do aluno do $6^{\circ}$ ano da Escola 1 salienta esta importante aproximação de contextos e aprendizados quando afirma que a escola colabora para a sua permanência no campo: "Sim, pois aqui nós criamos um vínculo com o local e se nós mudarmos de escola, por exemplo, for para a cidade, nós perdemos o vínculo com o campo e passaremos a não valorizar mais a zona rural". Outro aluno do $8^{\circ}$ ano da Escola 3 complementa:

A escola colabora com nossa permanência no campo porque é ali que aprendemos como devemos trabalhar para poder em casa praticar, onde aumenta o amor pela terra, é na escola que aprendo que devo comer alimentos saudáveis e sem agrotóxico através de palestras e de práticas.

Neste sentido, pode se afirmar que as escolas do campo representam aos alunos um espaço de construção de conhecimentos validados na realidade de suas famílias, um lugar bom de estudar onde muitas amizades são cultivadas e diversas experiências são vivenciadas cotidianamente. Nas respostas, ficou claro que os alunos têm consciência sobre a importância da escola e o que ela representa em suas vidas e formações. Ainda, apresentam possibilidades de luta contra o fechamento das escolas. Possivelmente, estas alternativas já foram experimentadas em face de ameaça de fechamento das duas escolas no início deste ano.

É nesta direção que se desenvolve um processo educativo que tem como princípio balizador o trabalho. Trabalho este que leva em conta a realidade dos educandos e volta-se para ela de maneira ressignificada, revisitada, agora com uma 
bagagem de conhecimentos ampliada. Além disso, "'educar é humanizar', é cultivar os aprendizados de ser humano". (CALDART, 2003, p. 52). As pessoas aprendem umas com as outras, aprendem fazendo, lutando, produzindo e reproduzindo cultura, afirma a autora.

Em conversa com membros das comunidades, envolvendo pais/mães de alunos, representante do Círculo de Pais e Mestres e presidente da comunidade, buscou-se compreender qual a representatividade da escola para o desenvolvimento e/ou manutenção da comunidade. De maneira geral, pode ser afirmada a grande importância de uma escola para a comunidade. Os entrevistados reconhecem que na relação de troca que há entre uma e outra, acontece a valorização e reconhecimento das pessoas e do lugar onde vivem. A escola representa vida ativa das pessoas que a constituem e estas por sua vez, envolvem-se com as causas da escola de maneira comprometida e atuante.

$\mathrm{Na}$ figura abaixo, é possível visualizaras as principais respostas que foram obtidas durante entrevistas.

Figura 3 - Entrevista com as comunidades das escolas do campo

\section{Entrevista com as comunidades das escolas do campo:}

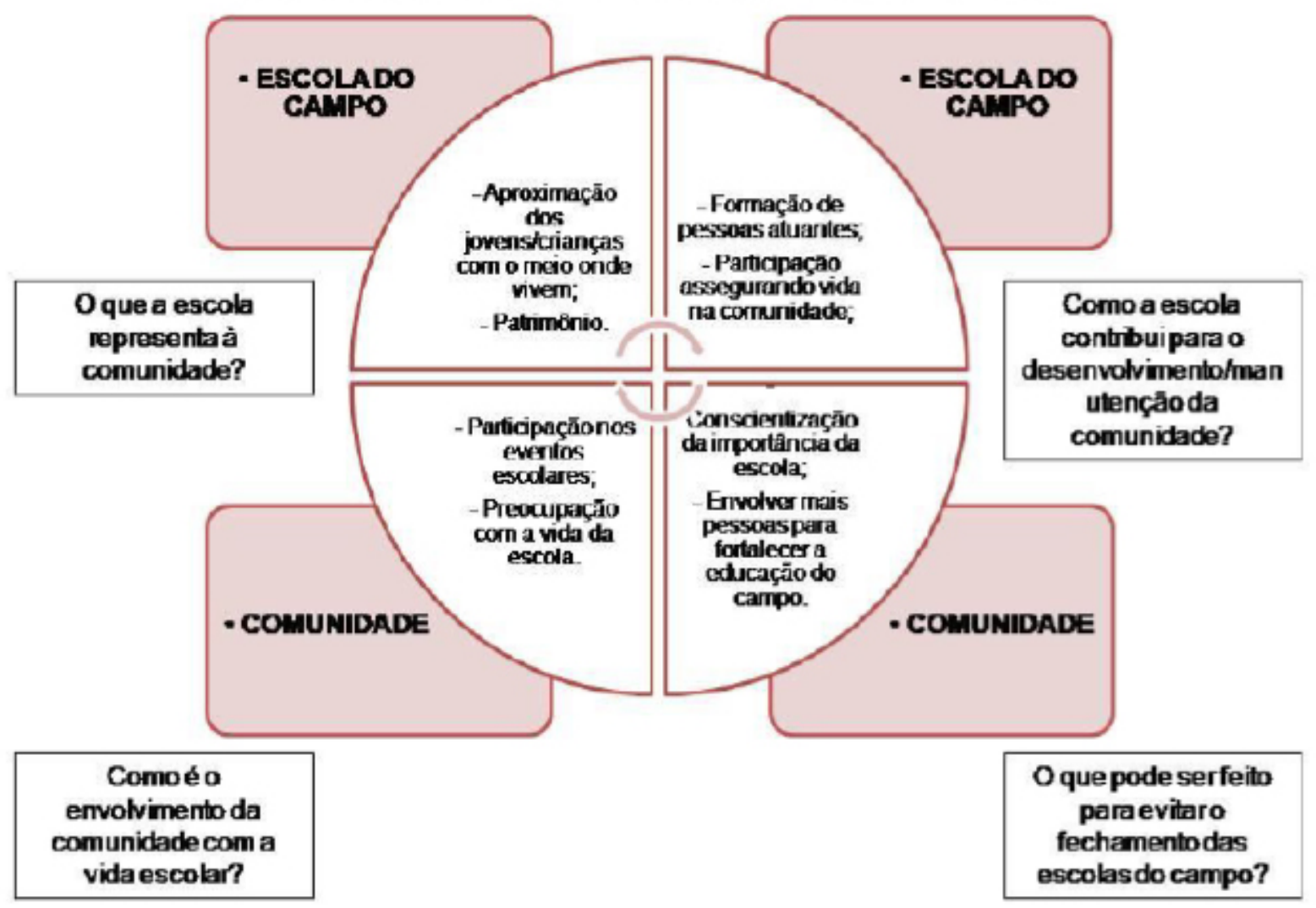

Fonte: Elaborado pelas autoras. 
Nas três escolas, há a ocorrência de respostas que afirmam a participação da comunidade em eventos organizados pela escola. Na Escola 1, por exemplo, acontece o envolvimento de uma para com a outra, ou seja, quando acontecem eventos na comunidade, a escola colabora nos trabalhos, assim, a escola pode também contar com a ajuda dos membros da comunidade em suas programações. "Na escola a gente se sente em casa", afirma um membro do Conselho da comunidade da Escola 1.

Vale ressaltar as colocações do presidente do Conselho Escolar e de um membro da comunidade da Escola 1 quando afirma que essa aproximação que existe entre comunidade e escola depende muito das pessoas que fazem a gestão de cada um dos locais. "O gestor carrega os demais para o mesmo rumo" - afirmam. O exemplo disso é a premiação que a escola ganhou com o trabalho feito acerca da Nota Fiscal Gaúcha e a colaboração da comunidade com a merenda escolar. Outra iniciativa é a oferta de cursos ministrados pela Emater/RS ASCAR dentro da escola, oportunizando a participação não só de alunos, mas também da comunidade.

A escola contribui para o desenvolvimento ou a manutenção da comunidade
pois acredito que seja um local de muito aprendizado e isso colabora para
podermos manter as pessoas na comunidade, pois se não tivermos a escola
em nosso meio, os alunos vão se deslocar para a cidade, onde muitos pais
mudam para lá e as comunidades acabam diminuindo e muitas vezes aca-
bando [...] (PAI/MÃE DE ALUNO DA ESCOLA 3, 2018).

"Poderia haver mais incentivo por parte do governo às escolas do campo, assim os jovens se motivariam a ficar no campo ao invés de ir até a cidade para estudar", sugere um pai/mãe de aluno da Escola 1. Uma proposta educativa para o campo precisa se preocupar com o desenvolvimento deste espaço como um todo não o visualizando como um mero instrumento de reprodução do sistema capitalista vigente. Assim, a educação do campo configura-se como importante instrumento, mas não o único, para desenvolver este espaço em seus aspectos sociais, econômicos e ambientais. 
O estudo que se apresenta buscou conhecer quais ações estão presentes ou podem ser fomentadas na comunidade escolar para o fortalecimento das escolas do campo diante da ameaça de fechamento. O universo da pesquisa compreendeu escolas do campo de: Frederico Westphalen, Iraí e Liberato Salzano e seus atores, sendo eles: o corpo docente, o corpo discente e a comunidade local.

Assim, diante das realidades pesquisadas, de modo geral, pode se afirmar que não é possível visualizar uma proposta de educação do campo que não esteja ligada a um projeto popular de educação e desenvolvimento para o país, ampliando assim, o leque de debates acerca dos problemas existentes no meio rural. É preciso políticas setoriais de combate à exclusão social, ao êxodo rural, ao analfabetismo funcional, à agricultura familiar, à formação do professor, para que a luta por uma educação do campo não caia em medidas meramente paliativas (NASCIMENTO, 2004).

Desse modo, a educação do campo se diferencia da educação rural, haja vista, a educação do campo se preocupa com a formação humana do educando, se envolve na vida cotidiana da comunidade com o intuito de apoiar com ações voltadas à sustentabilidade das famílias que se encontram no campo e para o bem comum de todos. Já na educação rural, a escola está localizada no meio rural, mas não são desenvolvidas atividades relacionadas a este espaço, ou seja, o espaço, o lugar de onde vêm os alunos. Pode-se resumir dizendo que o pensar pedagógico não é voltado para a realidade dos sujeitos que ali se encontram.

As diferenças teóricas entre educação do campo e educação rural se fazem presente na realidade pesquisada. Das três escolas visitadas, uma delas, não desenvolve ações voltadas ao campo, afirma apenas desenvolver quando possível por meio de visitas a Feiras, Dia de Campo, isto é, a escola demonstra responder aos convites que recebe e afirma estas serem as ações voltadas a sua realidade. A resposta de seus alunos quando questionados sobre a colaboração da escola para sua permanência no campo comprova a ausência de práticas nesta direção.

Por outro lado, destacam-se as práticas que fortalecem as escolas do campo e já demonstrou sua força aliada a presença da comunidade no enfrentamento de 
ameaças de fechamento. Os projetos que envolvem os alunos em ações com horta, pomar, estufa, jardinagem entre outros cultivos, demonstraram ser instrumentos colaboradores no fortalecimento de vínculo com a terra, com a origem, com o lugar, enfim, pode-se resumir em vínculo de pertencimento. As respostas quanto à representatividade da escola aos alunos pode comprovar esta afirmação. Mesmo pequenos, reconhecem a escola como "segunda casa" e já apresentam alternativas de luta contra o fechamento. Isto significa preocupar-se com uma instituição que é importante na vida deles.

A comunidade por sua vez reconhece e enaltece o valor de uma escola no e do campo. As pessoas se mostram mais ativas, organizadas, comprometidas, preocupadas com uma causa maior, ou seja, com a formação e permanência dos jovens no campo. Talvez, ainda seja necessário, buscar mais pessoas para a luta, não só da comunidade, mas também lideranças e/ou representantes de entidades que possam colaborar com projetos que venham ao encontro do fortalecimento de práticas educativas que somem num plano de permanência das escolas do campo.

Diante disso, tem-se o reconhecimento do papel fundamental dos profissionais da educação que promovem todas estas ações. Mesmo com dificuldades de falta de recursos humanos e financeiros, com lacunas na formação, as escolas conseguem fazer a diferença e integrar a comunidade escolar em suas ações. Sabe-se que o educador do campo precisa cada vez mais se comprometer com a educação e com os sujeitos que ali se encontram conhecer as peculiaridades culturais, sociais, econômicas e políticas do campo.

A educação do campo é fruto de muitas lutas, principalmente dos movimentos sociais, para tanto não pode cair no esquecimento de governos e lideranças, pois ela está inserida num projeto maior que engloba o desenvolvimento das pessoas e do lugar onde vivem e produzem. Cada vez mais, se faz necessária a articulação entre escola e comunidade local, entre os conhecimentos científicos e saberes/fazeres do campo.

Práticas de fortalecimento são importantes pontos de apoio da escola do campo. Inicialmente, a legislação específica assegura direitos, assim, a escola precisa fazer sua parte ou continuar fazendo, com ações voltadas ao campo com a integração 
cada vez maior da comunidade. Tais práticas de fortalecimento só serão desveladas dentro do próprio processo e movimento feito por seus atores sociais. Por isso, a importância de olhar para si e para os arredores contrastando tal realidade com um projeto global.

\section{REFERÊNCIAS}

ARROYO, Miguel Gonzalez; CALDART, Roseli Salete; MOLINA, Mônica Castagna. (Org.). Por uma educação do campo. Petrópolis, RJ: Vozes, 2004.

BRASIL. Lei № 12.960 de 27 de março de 2014. Disponível em: http://www.planalto. gov.br/ccivil_03/_ato2011-2014/2014/lei/l12960.htm. Acesso em 19 de março de 2018.

BRASIL, Lei n. 9.394/96. Lei de Diretrizes e Bases da Educação Nacional. Ministério da Educação. Brasília, 1996.

CALDART, R. S. Educação do Campo: notas para uma análise de percurso. In: Trabalho, Educação e Saúde, vol. 7, n. ${ }^{\circ}$. Rio de Janeiro: Fundação Oswaldo Cruz, Escola Politécnica de Saúde Joaquim Venâncio, março - junho de 2009.

CALDART, Roseli Salete. Educação do Campo. In: Caldart, R.S.; Pereira, I.B.; Alentejano, P.; Frigotto, G. (org). Dicionário da Educação do Campo. Rio de Janeiro, São Paulo: Escola Politécnica de Saúde Joaquim Venâncio, Expressão Popular, 2012.

CALDART, Roseli Salete. Movimento Sem Terra: lições de Pedagogia. Revista Currículo sem Fronteiras. V. 3, nº 1, p. 50-59. 2003.

CALDART, R. S. Por uma educação do campo: traços de uma identidade em construção. In: Educação do campo: identidade e políticas públicas- Caderno 4. Brasília: Articulação Nacional "Por Uma Educação Do Campo", 2002.

MOLINA, Mônica Castagna; SÁ, Lais Mourão. In: Caldart, R.S.; Pereira, I.B.;Alentejano, P.; Frigotto, G. (org). Dicionário da Educação do Campo. Rio de Janeiro, São Paulo: Escola Politécnica de Saúde Joaquim Venâncio, Expressão Popular, 2012.

NASCIMENTO, Claudemiro Godoy do. A Educação Camponesa como espaço de resistência e recriação da cultura: um estudo sobre as concepções e práticas educativas da Escola Família Agrícola de Goiás - EFAGO. Dissertação de Mestrado (Educação). Campinas: FE/Unicamp, 2004. 
RIBEIRO, Marlene. Educação Rural. In: Caldart, R. S.; Pereira, I. B.; Alentejano, P.; Frigotto, G. (org). Dicionário da Educação do Campo. Rio de Janeiro, São Paulo: Escola Politécnica de Saúde Joaquim Venâncio, Expressão Popular, 2012.

SECRETARIA DA EDUCAÇÃO. Escolas do Campo. Disponível em: http://www. educacao.rs.gov.br/escolas-do-campo. Acesso em 20 de março de 2018.

BRASIL. Resolução No 2 de 28 de abril de 2008. Disponível em: http://pronacampo. mec.gov.br/images/pdf/mn_resolucao_2_de_28_de_abril_de_2008.pdf. Acesso em 02 de maio de 2021. 


\section{O PROJOVEM CAMPO SABERES DA TERRA E A EDUCACAO DE JOVENS. ADULTOS E IDOSOS DO CAMPO}

Maria Aparecida Vieira de Melo ${ }^{89}$

Marcelo da Fonsêca Santana ${ }^{90}$

Ricardo Santos de Almeida ${ }^{91}$

89 Docente da Universidade Federal do Rio Grande do Norte. Doutora em Educação pela Universidade Federal da Paraíba. Caicó/RN. ORCID: https://orcid.org/0000-0001-6288-9405, Lattes: http://lattes.cnpq.br/6705733173478276, m_aparecida_v_melo@hotmail.com.

90 Graduação em Física pela Universidade Federal da Paraíba (UFPB). Graduação em Pedagogia pela Universidade Federal da Paraíba (UFPB). Mestrado em Educação pela Universidade Federal da Paraíba (UFPB). João Pessoa/PB. Lattes: http://lattes.cnpq.br/7067072831352386, ORCID: https://orcid.org/0000-0002-5497-0147, marfonsecas@hotmail.com

91 Docente do Instituto Federal de Ciência e Tecnologia de Alagoas Campus Marechal Deodoro e da rede pública municipal de Porto Calvo/AL. Doutorando em Geografia pela Universidade Federal de Santa Maria, Estudiante del Doctorado en Ciências de la Educación pela Universidad Interamericana. Maceió/AL, Brazil, ORCID: https://orcid.org/0000-0003-1266-2557, Lattes: http:// lattes.cnpq.br/5955679764505968, ricardosantosal@gmail.com 
A presente pesquisa parte da análise da coletânea dos livros do programa ProJovem Campo - Saberes da Terra. A qual teve por finalidade escavar os enunciados acerca da profissionalização dos sujeitos do campo, bem como descrever a formação técnica específica para a cultura dos camponeses. Metodologicamente foi desenvolvida pelo procedimento da análise arqueológica do discurso (AAD) de Michel Foucault (2010). A curiosidade que assenta a esta pesquisa é: como está presente a ordem do discurso da qualificação para os camponeses? Foi possível considerar que há um enunciado neoliberal nas coletâneas, quando trata os camponeses como produtores, agricultores, pecuaristas. Tais enunciados dizem respeito que o paradigma da educação do campo ainda não subverteu a subalternização que historicamente foi evidenciado no paradigma da educação rural. Sendo assim, é preciso defender um projeto social e emancipatório para que os povos do campo sejam valorizados em sua natureza de homem lavrador da terra.

A abordagem sobre o Programa Projovem Campo - Saberes da Terra (2005) visa evidenciar os feixes de relações presentes ao que concerne a qualificação técnica dos jovens e adultos do campo. É um programa recente que tem por finalidade promover ações educacionais e de cidadania voltadas a jovens que, por diferentes fatores, foram excluídos do processo educacional, de modo a reduzir situações de risco, desigualdade, discriminação e outras vulnerabilidades sociais, fomentando a participação social e cidadã, favorecendo a permanência e a sucessão dos jovens na agricultura familiar (BRASIL, 2018). Em sendo assim, a especificidade deste programa é a escolarização e a qualificação dos jovens para atuarem na agricultura familiar.

É importante ressaltar que este programa faz jus ao que está enunciado no Plano de Metas Compromisso Todos pela Educação, pois para aderir ao ProJovem, primeiramente foi aderido ao plano de metas compromisso todos pela educação (DECRETO, Nº. 6.629/2008).

É sabido que o ProJovem Campo - Saberes da Terra é um programa de escolarização de jovens agricultores/as familiares em nível fundamental na modalidade 
de Educação de Jovens e Adultos (EJA), integrado à qualificação social e profissional (BRASIL, 2018). Desta maneira, é um programa específico para os jovens da modalidade da educação de jovens e adultos, entretanto se exclui os adultos do Programa, uma vez que o limite da idade é de 18 aos 29 anos de idade.

Para fazer jus a problematização que subsidia a presente pesquisa, qual seja, como está presente a ordem do discurso da qualificação para os camponeses? Lançamos mão da metodologia que foi desenvolvida pelo procedimento da análise arqueológica do discurso (AAD) de Michel Foucault (2010). Para fins de escavar os enunciados acerca da profissionalização dos sujeitos do campo, bem como descrever a formação técnica específica para a cultura dos camponeses. Em sendo assim, o Programa será analisado destacando os enunciados sobre a profissionalização e formação técnica, correspondente à qualificação dos jovens e adultos do campo.

Por conseguinte, o programa é uma iniciativa interessante que promove a inclusão social dos jovens e adultos do campo, entretanto o seu modus operandi tal como enunciado "tempo escola e tempo comunidade" o tempo comunidade apresenta especificidades lacunares que promova a qualificação dos jovens para atuarem melhor nos manejos cultivares.

\section{O FAZER PEDAGÓGICO DO PROGRAMA PROJOVEM CAMPO - SABE- RES DA TERRA}

A especificidade pedagógica do Programa ProJovem Campo - Saberes da Terra é na perspectiva freiriana, pois se defende a educação popular, os círculos de cultura e as jornadas pedagógicas.

A metodologia do círculo de cultura na perspectiva de Paulo Freire o diálogo fomenta e historiciza a essencial intersubjetividade humana; ele é relacional e, nele, ninguém é iniciativa absoluta. Revive a vida em profundidade crítica. A consciência emerge do mundo vivido, objetiva-o, problematiza-o, compreende-o como projeto humano. O Círculo de Cultura é o espaço coletivo de diálogo horizontalizado, onde o exercício da fala e da escuta é praticado e respeitado. É um legado freiriano de encontro de pessoas para combater a educação bancária e partilhar saberes, é o 
respeito da identidade individual, das diferenças e singularidades. É um espaço democratizado e de autonomia do protagonismo dos sujeitos em sua diversidade.

Para Freire em educação como prática da liberdade, declara que o círculo de cultura promove a liberdade a participação, assim é definido que:

A visão da liberdade tem nesta pedagogia uma posição de relevo. É a matriz que atribui sentido a uma prática educativa que só pode alcançar efetividade e eficácia na medida da participação livre e crítica dos educandos. É um dos princípios essenciais para a estruturação do círculo de cultura, unidade de ensino que substitui a "escola", autoritária por estrutura e tradição. Busca-se no círculo de cultura, peça fundamental no movimento de educação popular, reunir um coordenador a algumas dezenas de homens do povo no trabalho comum pela conquista da linguagem. $O$ coordenador, quase sempre um jovem, sabe que não exerce as funções de "professor" e que o diálogo é condição essencial de sua tarefa, "a de coordenar, jamais influir ou impor" (FREIRE, 1967, p. 3, grifos nossos).

Desse modo o círculo de cultura permeia a participação livre, o diálogo horizontalizado, onde não há quem saiba mais ou menos, há saberes diferentes, que expostos tornam-se saberes de todos os participantes do círculo, isso pelo movimento da educação popular, por ser uma prática pedagógica essencialmente democrática, tal como é enunciado por Freire, a saber:

O movimento de educação popular, uma prática educativa voltada, de um modo autêntico, para a libertação das classes populares. Não obstante, se podemos encontrar, ao nível da educação, uma unidade real da teoria e da ação, ela não se dá ao nível da política, terreno onde a ideologia serviu à criação de uma atmosfera de luta, mas não chegou a instaurar-se de maneira organizada na ação (1967, pp. 25-26, grifos nossos).

É justamente baseado neste movimento que o Projovem Campo-Saberes da Terra se assenta, ao ser assim sistematizado pedagogicamente, para promover a elevação do nível de escolarização e a qualificação social e profissional, como podemos visualizar: 
Quadro 1: estrutura pedagógica do caderno do programa ProJovem Campo - Saberes da Terra

\begin{tabular}{|c|c|c|c|}
\hline Percurso formativo & Atividades & Conteúdos & Avaliação \\
\hline $\begin{array}{l}\checkmark \text { Tempo escola de } \\
\text { acolhida } \\
\checkmark \text { Base conceitual e } \\
\text { metodológica }\end{array}$ & $\begin{array}{l}\checkmark \text { Problematização } \\
\checkmark \text { Síntese } \\
\checkmark \text { Pesquisa } \\
\checkmark \text { Círculos de diálogo } \\
\checkmark \text { Integração de } \\
\text { saberes } \\
\checkmark \text { Jornadas } \\
\text { pedagógicas } \\
\checkmark \text { Grupos de estudo e } \\
\text { de trabalho }\end{array}$ & $\begin{array}{l}\checkmark \text { Educativos } \\
\checkmark \text { Instrumentais } \\
\checkmark \text { Operativos }\end{array}$ & $\begin{array}{l}\checkmark \text { Síntese } \\
\text { provisórias } \\
\checkmark \text { Síntese geral } \\
\checkmark \text { Mapeamento por } \\
\text { desenho } \\
\checkmark \text { Socialização dos } \\
\text { saberes } \\
\checkmark \text { Continua e } \\
\text { processual }\end{array}$ \\
\hline
\end{tabular}

Fonte: Autores (2020).

Como podemos visualizar a estrutura pedagógica dos cadernos do Programa ProJovem Campo - Saberes da Terra, se propõe vivenciar a dinâmica dos círculos de cultura propostos por Paulo Freire.

\section{TERRITÓRIO METODOLÓGICO ENUNCIATIVO}

O território arqueológico pode ser entendido como o lugar do primado do conhecimento que possibilitará escavações acerca do objeto investigado, a fim de que seja compreendido e apreendido este objeto e como ele se relaciona no lócus de sua existência, sendo, portanto, enunciado através da linguagem enquanto campo complexo.

Dialogar sobre a especificidade da análise arqueológica do discurso é adentrar no universo do desconhecido, para que somente após as escavações, enunciar os achados, sem fazer interpretações ou impregnar sentidos subjetivos aos achados, mas tão somente enuncia-los tal como foram encontrados.

O que é a AAD? É entendido aqui por Análise Arqueológica do Discurso (AAD) como um componente enunciativo, que nos faz lembrar o domínio científico da Arqueologia, como Ciência, que se ocupa do estudo de vestígios materiais passados e presentes (ALCÂNTRA e CARLOS, 2013). Significa dizer que é um procedimento metodológico de pesquisa operado metodologicamente como os arqueólogos fazem, escavam, para poder assim enunciar as coisas advindas da escavação, sendo assim 
enunciadas, evidenciadas, mostradas, sinalizadas.

Ao que concerne aos enunciados Foucault (2010, p. 36) menciona que "os enunciados, diferentes em sua forma, dispersos no tempo formam um conjunto, se referem a um único e mesmo objeto". O objeto enunciativo é a educação de jovens, adultos e idosos como direito para os povos do território camponês, que será escavado nos documentos supracitados. Logo, “o conjunto de enunciados está longe de relacionar com um único objeto, formado de maneira definitiva, e de conservá-lo indefinidamente como horizonte de realidade inesgotável" (FOULCAULT, 2010, p. 36). Isso porque os enunciados estão sempre em reelaboração, as causas da EJAI para os povos do campo são diversas e há uma realidade inesgotável e indefinida de problematizações, por isso que há regularidade enunciativa, pois em algum momento os enunciados se intercruzam.

Para Foucault (2010, p. 37) define um conjunto de enunciados no que ele tem de individual consistiria em descrever a dispersão desses objetos, apreender todos os interstícios que os separam, medir as distâncias que reinam entre eles - em outras palavras formular sua lei de repartição. Desta forma, não dá para abordar os mesmos sujeitos de duas modalidades educacionais sem considerar o conjunto de enunciados específicos de cada modalidade e dos seus sujeitos. Dentro do conjunto de enunciados existem o que Foucault (2010, p. 40) denomina de "uma unidade discursiva se a buscássemos não na coerência dos conceitos, mas em sua emergência simultânea ou sucessiva, em seu afastamento, na distância que os separa e, eventualmente em sua incompatibilidade". Desta feita, a unidade discursiva está presente no que emerge de forma simultânea ou sucessiva, distância e incompatibilidade, isto é, as dispersões.

A unidade discursiva acontece conforme também regular, a saber por regularidade Foucault (2010, p. 42) afirma que "uma ordem em seu aparecimento sucessivo, correlações em sua simultaneidade, posições assimiláveis em um espaço comum, funcionamento recíproco, transformações ligadas e hierarquizadas". É interessante, que a regularidade pode ocorrer na dispersão, isto é, a depender da posição que o sujeito ocupa em relação ao objeto. Como já fora enunciado, os objetivos que permeiam a presente reflexão é descrever a ordem do discurso enunciado nos documentos brasileiros da Educação de Jovens, Adultos e Idosos para os campone- 
ses; escavar nos documentos legais sobre as práticas pedagógicas específicas para contemplar a identidade a cultura dos camponeses e mapear os materiais didáticos necessários para a promoção do ensino-aprendizagens aos camponeses.

Assim sendo, a formação discursiva que se forma em relação aos objetivos supracitados conduz ao procedimento analítico e argumentativo acerca do objeto de estudo. Para Foucault (2010) há uma complexidade no procedimento da formação discursiva, pois

É assegurada por um conjunto de relações estabelecidas entre instâncias de emergência, de delimitação e de especificação (...) se define (pelo menos quanto a seus objetos) se se puder estabelecer um conjunto semelhante, se se puder mostrar como qualquer objeto do discurso em questão aí encontra seu lugar e sua lei de aparecimento, se se puder mostrar que pode dar origem, simultânea ou sucessivamente, a objetos que se excluem sem que ele próprio tenha de se modificar (FOUCAULT, 2010, p. 49-50).

Nesta perspectiva, a formação discursiva desempenha um papel fundamental no processo de escavação e mapeamento do objeto de estudo em análise arqueológica do discurso, tendo em vista que para Foucault (2000, p. 48) discurso é algo inteiramente diferente do lugar em que vem se depositar e se superpor, como em uma simples superfície de inscrição, objetos que teriam sido instaurados anteriormente. Daí a importância do procedimento de escavar os enunciados que estão para além da superfície dos enunciados pronunciados.

\section{EXPLORANDO O TERRITÓRIO DOS ENUNCIADOS}

Ao identificar os enunciados acerca da qualificação profissional para os jovens do campo nos cadernos do Programa Projovem Campo - Saberes da Terra vamos identificar uma certa regularidade ao que concerne a qualificação profissional, como podemos assim visualizar:

O caderno 1 - Agricultura Familiar: Identidade, Cultura, Gênero e Etnia (ver figura 1) apresenta a diversidade brasileira, assim como faz jus a práxis da educação popular, baseada nos círculos de cultura idealizados por Freire, quando assim é enunciado que "o Currículo da Formação tanto do/a educador/a quanto do/a educando/a está alicerçado na Educação Popular como uma Pedagogia enquanto uma 
Teoria Crítica Geral da Educação" (AGRICULTURA FAMILIAR, 2010).

Para promover a qualificação profissional, um enunciado que aparece onze vezes no caderno do educador, como a qualificação de jovens voltada para a formação e o fortalecimento de espaços de organização social, oportunidades de qualificação técnica e tem como objetivo proporcionar um certificado de qualificação profissional nas cinco ocupações do arco ocupacional produção rural familiar (AGRICULTURA FAMILIAR, 2010). As cinco ocupações que permeiam o arco ocupacional são "Sistemas de Cultivo, Sistemas de Criação, Extrativismo, Aquicultura e Agroindústria" (AGRICULTURA FAMILIAR, 2010, p. 17).

Figura 1 - Caderno Pedagógico Educadoras e Educadores 1

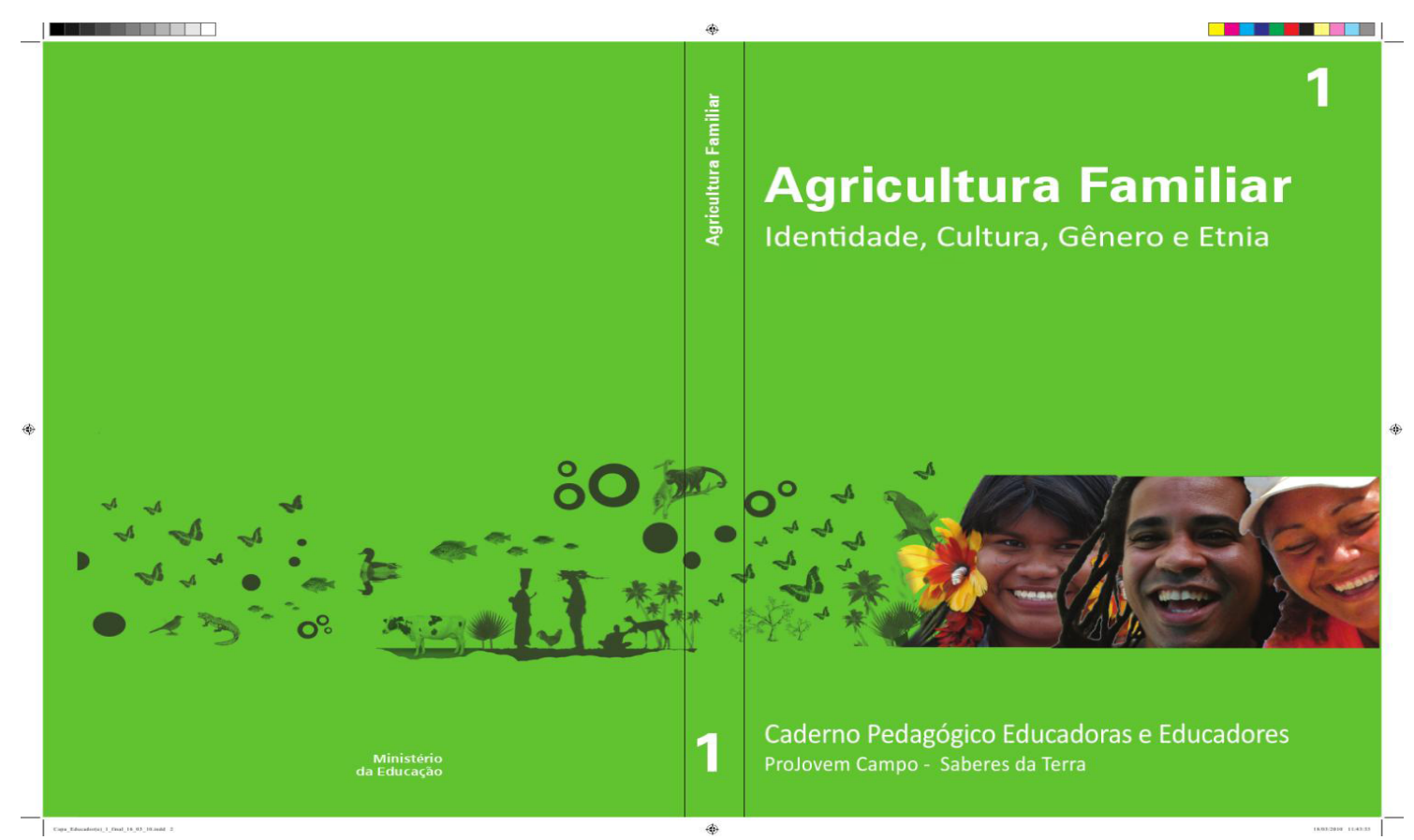

Fonte: BRASIL, 2010.

No caderno 2 Caderno Pedagógico Sistemas de Produção e Processos de Trabalho no Campo (ver figura 2) o mesmo enunciado qualificação profissional aparece com regularidade de nove vezes, destacando a importância da integração de saberes, para tal "São apresentadas propostas de saberes escolares, focadas na qualificação profissional, que articuladas aos saberes prévios dos/as educandos/as e da comunidade, possibilitarão a integração de saberes diversos e construção de novos saberes" (SISTEMA DE PRODUÇÃO, 2010, p. 114). 
Figura 2 - Caderno Pedagógico Educadoras e Educadores 2

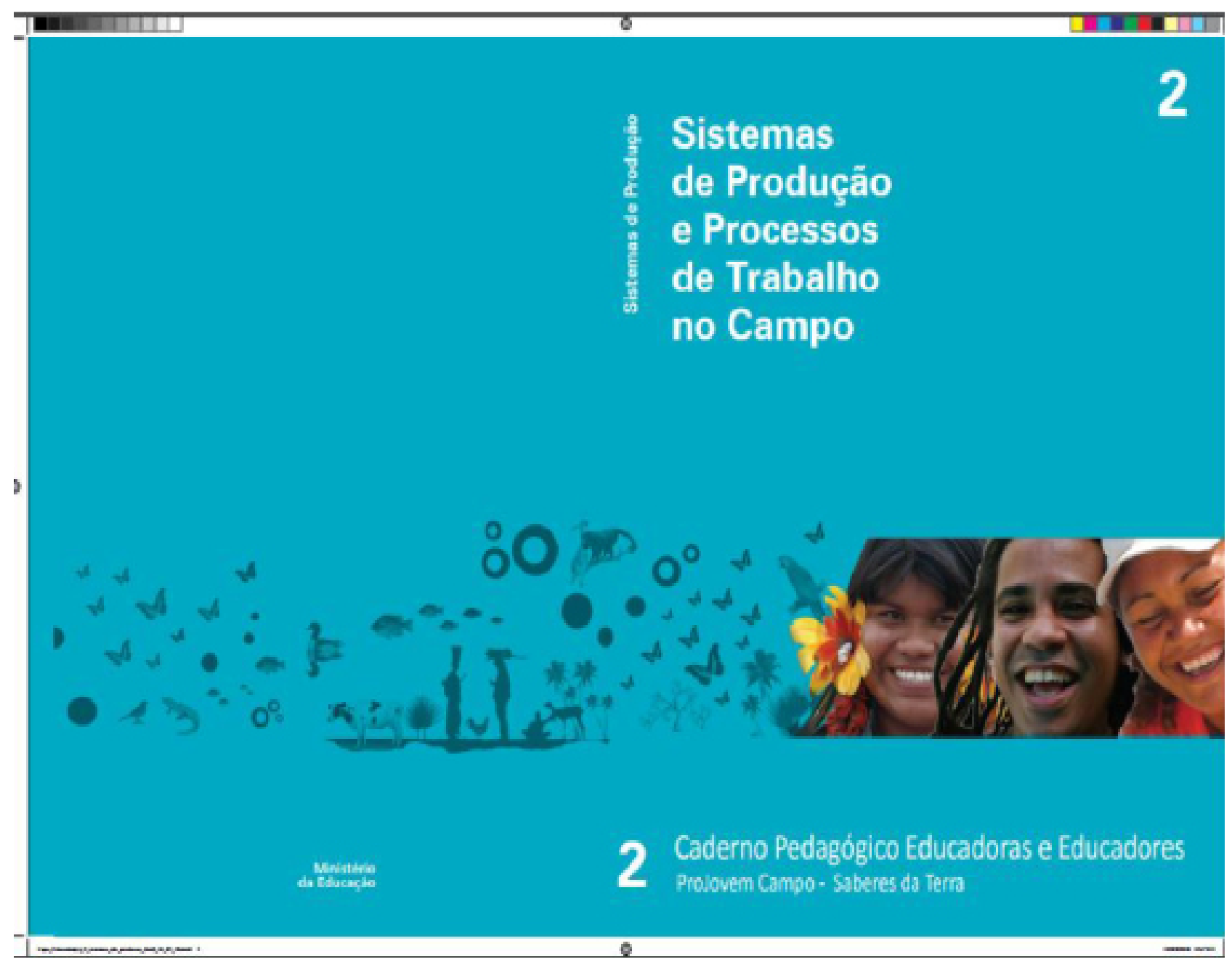

Fonte: BRASIL, 2010.

No caderno 3 Cidadania, Organização Social e Políticas Públicas (ver figura 3) do educador o enunciado qualificação profissional aparece sete vezes, já no caderno do educando, qualificação profissional aparece assim destaca-se esta passagem "estudar as áreas de conhecimento necessárias para compreender e aprofundar o processo de elevação de escolaridade e, paralelo a isso, da qualificação profissional, com seus Arcos Ocupacionais" (CIDADANIA, 2010, p. 111). 
Figura 3 - Caderno Pedagógico Educadoras e Educadores 3

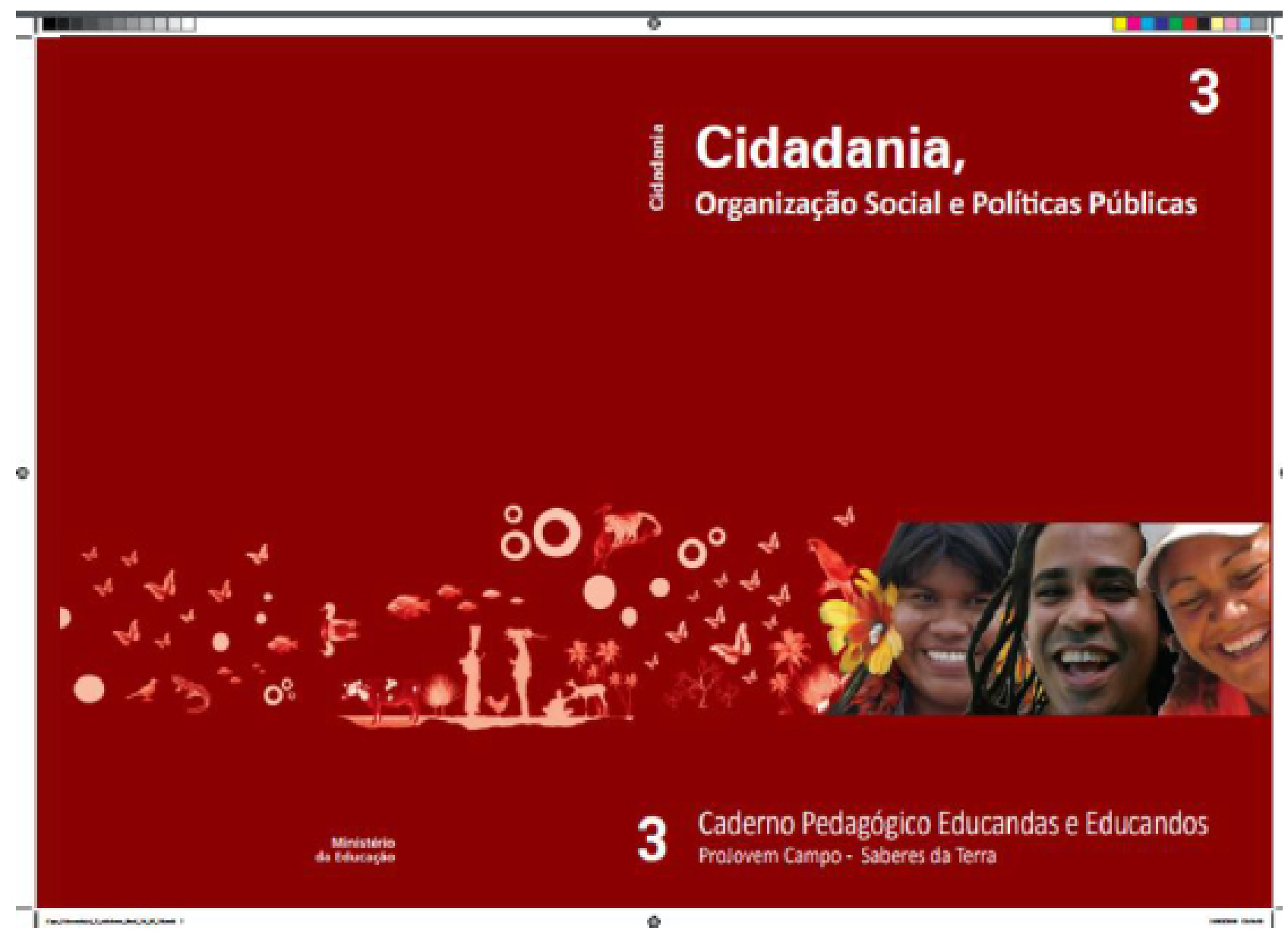

Fonte: BRASIL, 2010.

Ao escavar o caderno 4 Economia solidária (ver figura 4) o enunciado qualificação profissional sofre uma refração, ou seja, não foi possível constatar nenhum enunciado ou correlatos em relação a qualificação profissional, apenas constata-se sobre, Desenvolvimento Sustentável e Solidário com Enfoque Territorial quando se afirma "o grande desafio que é construir a sustentabilidade da Agricultura Familiar, ao mesmo tempo em que se qualifica social e profissionalmente" (ECONOMIA SOLÍDÁRIA, 2010, p. 13).

Por último no caderno 5 Desenvolvimento Sustentável e Solidário com Enfoque Territorial (ver figura 5), o enunciado qualificação profissional aparece apenas quatro vezes, a saber "Assim, este Caderno aborda conteúdos formativos que apontam para a conclusão do ensino fundamental integrado com a qualificação profissional inicial em Produção Rural Familiar" (DESENVOLVIMENTO SUSTENTÁVEL, 2010, p. 14). 


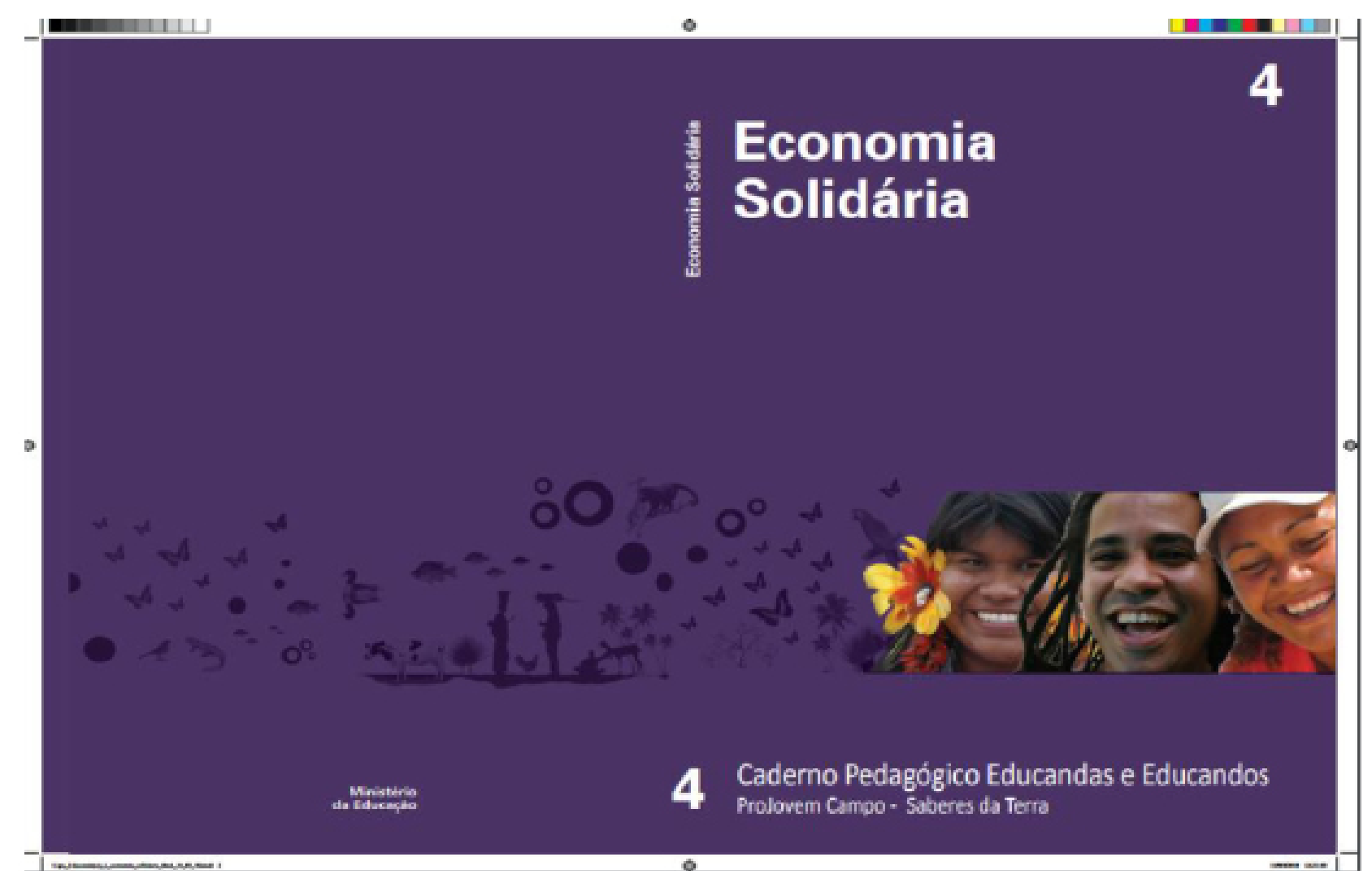

Fonte: BRASIL, 2010.

Como podemos constatar o Programa ProJovem Campo-Saberes da Terra é um programa voltado para os jovens e adultos, os quais são os sujeitos da modalidade da educação básica: educação de jovens e adultos (EJA), tal como está enunciado em seu artigo $37^{\circ}$., a saber: "A educação de jovens e adultos será destinada àqueles que não tiveram acesso ou continuidade de estudos nos ensinos fundamental e médio na idade própria e constituirá instrumento para a educação e a aprendizagem ao longo da vida" (BRASIL, 2018). Pois, o ProJovem Campo - Saberes da Terra é um programa de escolarização de jovens agricultores/as familiares em nível fundamental na modalidade de Educação de Jovens e Adultos (EJA), integrado à qualificação social e profissional, estando assim centrado nos jovens camponeses de 18 a 29 anos. Mediante este dado, há uma refração no acesso a educação básica quando se faz jus a um tempo cronológico de idade, assim somente os jovens de 18 a 29 anos podem acessar ao ProJovem Campo, os de idade menos e mais, ficam impedidos de elevar o nível de escolarização e se qualificar social e profissionalmente, tal como é o objetivo maior deste Programa. Nesta perspectiva, enquanto modalidade de jovens e adultos não se pode fazer jus a educação e a aprendizagem ao longo da vida. 
Figura 5 - Caderno Pedagógico Educadoras e Educadores 5

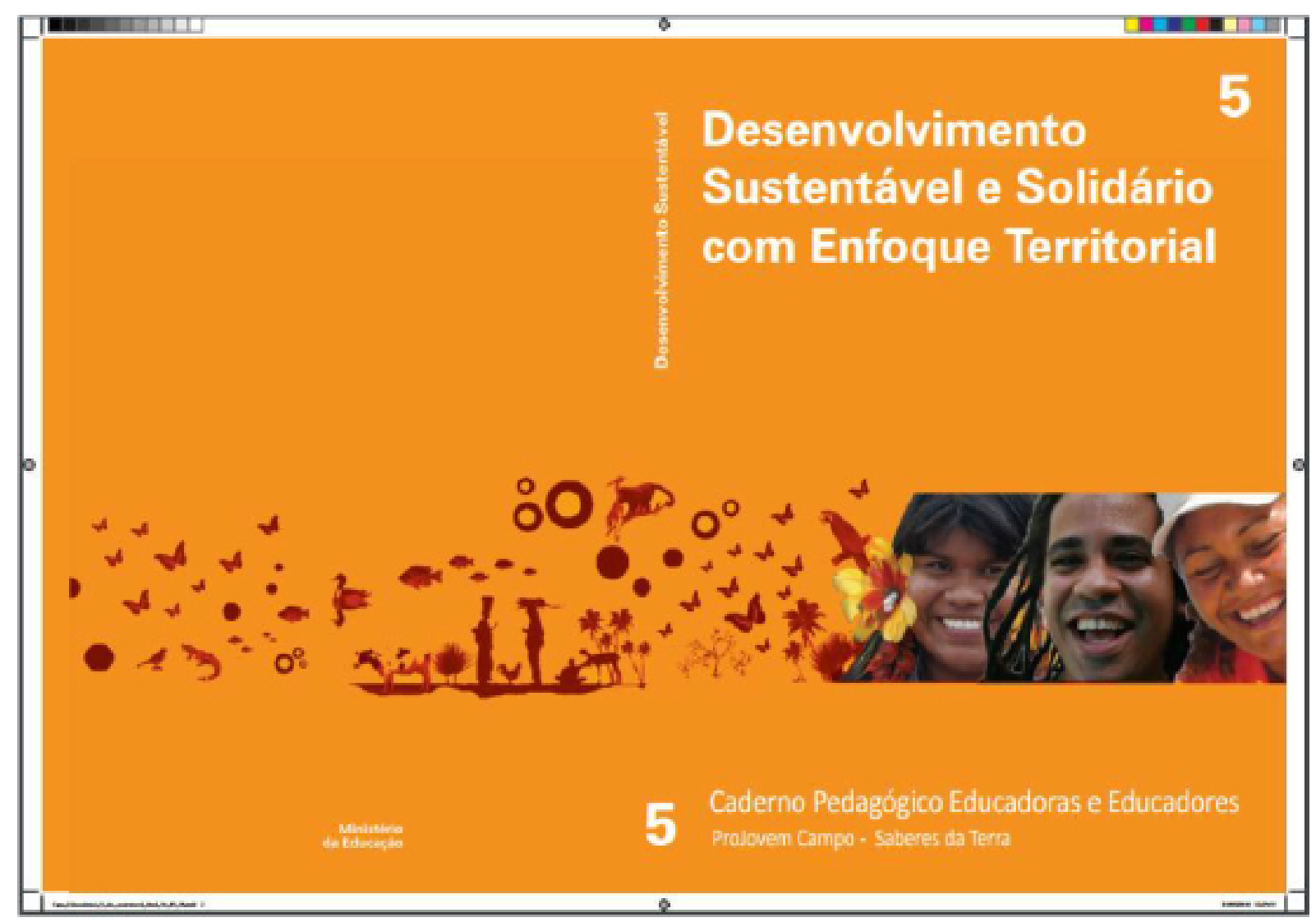

Fonte: BRASIL, 2010.

É importante ressaltar que o ProJovem Campo - Saberes da Terra é um programa intersetorial, pois é uma ação integrada entre o Ministério da Educação, por meio da Secretaria de Educação Continuada, Alfabetização e Diversidade (SECAD) e da Secretaria de Educação Profissional e Tecnológica (SETEC); o Ministério do Desenvolvimento Agrário por meio da Secretaria de Agricultura Familiar (SAF) e da Secretaria de Desenvolvimento Territorial (SDT); o Ministério do Trabalho e Emprego por meio da Secretaria de Políticas Públicas de Emprego (SPPE) e da Secretaria Nacional de Economia Solidária (SENAES); o Ministério do Meio Ambiente por meio da Secretaria de Biodiversidade e Floresta (SBF); o Ministério do Desenvolvimento Social e Combate à Fome (MDS) e a Secretaria Nacional de Juventude (SNJ) vinculada à Presidência da República (MEC/SECAD, 2018). Desse modo, só tende a se fortalecer e torna-se uma política pública para os jovens camponeses que não tiveram a escolaridade na idade própria e agora pode ter acesso a uma formação dupla, a elevação da escolaridade e a qualificação social e profissional. 
A Educação popular é um movimento próprio que enseja na atuação dos movimentos sociais que prima pelos processos de transformação social. Nesta perspectiva, importa ressaltar que a Educação popular contribui para a atuação de forma protagonista dos sujeitos que antes eram narrados pelos quem detinham o poder $e$ hoje o jargão dos processos educativos está nas mãos dos coletivos de direito. Deste modo é assinalado por Xavier (2019, p. 2) assinala sobre o discurso, pois

\begin{abstract}
A Educação Popular (EP), especialmente aquela realizada no âmbito dos movimentos sociais populares incorpora princípios filosóficos, políticos, sociológicos, culturais entre os quais destacamos: a origem e finalidade nos interesses das classes populares, dos setores oprimidos organizados nos movimentos sociais; o respeito às suas culturas; os conhecimentos voltados para compreensão crítica da realidade social, econômica e política; o respeito às visões de mundo que são resultantes das experiências vividas por esses segmentos como ponto de partida para uma reflexão crítica da realidade, que se dá através do diálogo. Também são traços presentes na EP a busca da constituição de relações sociais calcadas na solidariedade, igualdade, participação, na emancipação, colaboração, com vistas à formação de sujeitos autônomos e livres.
\end{abstract}

A complexidade da Educação popular está acionada nos campos de domínios distintos, como a filosofia, sociologia e a política, já que todo ato pedagógico é um ato político, pois, cada princípio da educação popular aciona uma prática discursiva nos diversos campos que lhe constitui em ser o que é.

A Educação popular é uma pedagogia essencialmente contestadora do projeto da modernidade ocidental, haja vista que promove a emancipação social dos sujeitos de direito enquanto produtores de conhecimento legítimo partindo de sua realidade. Desse modo, tudo isso somente é possível através do diálogo, pois o diálogo elemento essencial nos movimentos sociais é um processo de comunicação e intercomunicação entre sujeitos em busca de uma transformação, em busca de uma ação de emancipação e de libertação. Ele é potencializador da discussão dos temas que envolvem as demandas, as análises, a definição de táticas e estratégias de mobilização, de ação dos movimentos. Como princípio pedagógico ele é fundamental no processo ensino-aprendizagem, no processo de problematização, de reflexão e apreensão dos conteúdos e do mundo (XAVIER, 2019). 
Ao escavar o Documento base nacional de preparação a VI CONFINTEA(2008), houve uma ressalva importante sobre o ProJovem Campo - Saberes da Terra, pois ficou enunciado que, a:

Execução da proposta pedagógica e curricular se desenvolve em sistema de alternância, ou seja, em diferentes tempos e espaços formativos: tempo-escola e tempo comunidade. Atualmente o Programa integra a Política Nacional de Inclusão de Jovens (PROJOVEM) com a denominação de ProJovem Campo - Saberes da Terra. A meta para 2008 é atender, em parceria com 21 estados, 35 mil jovens agricultores entre 15 e 29 anos de idade e até 2011, 275 mil jovens. A formação continuada dos profissionais que atuarão no Programa será de responsabilidade das instituições de ensino superior públicas, em parceria com os sistemas públicos de ensino estaduais e municipais que a ele aderirem. Este Programa é compreendido como EJA enquanto modalidade de ensino e pode ser financiado pelos recursos do FUNDEB, nas ações que se enquadram na previsão do art. 70 da LDBEN (MEC/SECAD, 2008 , p. 10, grifos nossos).

Dois pressupostos são importantes de serem mencionados, primeiro a metodologia do programa por ser a pedagogia da alternância (tempo escolar e tempo comunidade), um currículo diferenciado, assim como suscita um calendário escolar também diferenciado, e o segundo pressuposto é a formação continuada dos professores por ser de responsabilidade da universidades, sistemas estaduais e municipais, significa dizer que é preciso muita vontade política para aderir ao ProJovem, haja vista que é um programa e por ser desta natureza aderi a ele quem quer, como demanda muito trabalho, sobretudo ao que concerne ao processo formativo dos professores neste regime de colaboração, o primeiro impasse é quem faz o quê? Uma política pública de natureza de programa é ainda muito frágil e a qualquer momento pode acabar, como de fato, estamos falando de um programa que surgiu em 2005. Atualmente o Projovem Campo - Saberes da Terra:

Estará presente em 11 estados da federação e em 25 cidades e municípios, com destaque para a Bahia, que irá concentrar 4.400 das 11 mil vagas destinadas à modalidade, para Paraíba, com 1.125, e para o Amazonas, com 1.100. A metas de atendimento em Recife são as maiores do país, com 3.200 vagas, seguido de Manaus, com 2.800 e de São Luís e Rio de Janeiro, com 1.200 vagas, ambos (SECRETARIA NACIONAL DE JUVENTUDE, 2018). 
Ressalta-se que geograficamente os estados da região Nordeste se destacam com as demandas dos jovens e adultos do campo, a interrogação que fica é: todas as vagas disponíveis são ocupadas, ou seja, a matrícula é efetivada? Como erradicar o analfabetismo com números expressivos de vagas disponíveis? A realidade política pode ter implicações nestes dados, pois é preciso fazer valer a intersetorialidade do programa para que de fato tenha êxito e que a elevação do nível de escolarização e a qualificação profissional possam subsidiar a transformação e a emancipação social dos jovens e adultos que compõem a EJAI.

\section{Assinalações conclusivas}

A presente pesquisa possibilitou escavar nos cadernos do Programa ProJovem Campo Saberes da Terra a regularidade enunciativa sobre qualificação profissional voltada para os jovens do campo que integram também a modalidade da educação de jovens e adultos, assim a formação técnica se destaca em todos os cadernos, com menos regularidade no caderno 3 , este trata do exercício da cidadania dos jovens, bem como da inserção dos jovens nas políticas públicas.

A estrutura pedagógica dos cadernos escavados foi possível identificar que está concernente com o círculo de cultura vivenciado no movimento da educação popular, uma pedagogia essencialmente democrática, onde os que ensinam e aprendem são conectados pelo diálogo, tendo assim o respeito expressivo as culturas e identidades dos sujeitos envolvidos no círculo de cultura, é um movimento onde os alunos falam, escrevem, desenham, vão a aulas de campo, fazem pesquisas, intervenções técnicas, aulas práticas, buscam, criam e são protagonistas do conhecimento no movimento duplo de socializar o que sabe e de saber o que ainda não sabia.

Nesta pesquisa, de/enunciamos um achado importante neste programa, pois ele não promove o acesso e a permanência de todos os sujeitos que não tiveram a escolarização na idade própria, por ser um programa voltado aos jovens de 18 aos 29 anos, inviabilizando assim a universalização da educação e a erradicação do analfabetismo.

Vale salientar que por se tratar de um programa, não chega a todos os municípios e estados, uma vez que é por aderência, e deste modo, nem todas as autoridades políticas estão voltadas para as especificidades do campo, é tanto que o 
ProJovem urbano sempre tem mais matrículas disponíveis do que o ProJovem rural.

A formação técnica é destacada com ênfase nos cadernos 1, 2, 4 e 5, sobretudo no 5 caderno que trata especificamente do Desenvolvimento Sustentável e Solidário com Enfoque Territorial, no nosso modo de entender sobre as práticas dos cultivares, das criações e de todo o labor que permeia a vida do homem e da mulher do campo. Desse modo, a ordem do discurso da qualificação profissional para os camponeses, evidencia a necessidade para além do ler e escrever, dando ênfase a qualificação profissional para o desenvolvimento de uma agricultura familiar e sustentável. Assim sendo, a educação dos jovens e adultos que vivem no campo brasileiro é viabilizada pelo programa ProJovem Campo - Saberes da terra com dupla finalidade a elevação do nível de escolaridade e a qualificação profissional e social destes sujeitos de direito, fomentando uma formação integral por meio da prática da educação popular e seus círculos de cultura, com diálogo, respeito aos múltiplos sujeitos e aos múltiplos saberes.

\section{REFERÊNCIAS}

ALCÂNTRA, Marcos Angilus Miranda de; CARLOS, Erenildo João. Análise arqueológica do discurso: uma alternativa de investigação na educação de jovens e adultos (EJA). Intersecções (Jundiaí), v. 6, p. 59-73, 2013.

BRASIL. Lei de diretrizes e bases da educação nacional. Disponível em https:// www.planalto.gov.br/ccivil_03/Leis/L9394.htm Acesso em 05 ago. 2018b.

BRASIL. Agricultura familiar: identidade, cultura, gênero e etnia: caderno pedagógico educadoras e educadores / Coordenação: Armênio Bello Schmidt, Sara de Oliveira Silva Lima, Wanessa Zavarese Sechim. Brasília: Ministério da Educação, Secretaria de Educação Continuada, Alfabetização e Diversidade, 2010.

BRASIL. Cidadania, organização social e políticas públicas: caderno pedagógico educadores e educadoras / Coordenação: Armênio Bello Schmidt, Sara de Oliveira Silva Lima, Wanessa Zavarese Sechim. Brasília: Ministério da Educação, Secretaria de Educação Continuada, Alfabetização e Diversidade, 2010.

BRASIL. Desenvolvimento sustentável e solidário com enfoque territorial: caderno pedagógico educadoras e educadores / Coordenação: Armênio Bello Schmidt, Sara de Oliveira Silva Lima, Wanessa Zavarese Sechim. - Brasília: Ministério da Educação, Secretaria de Educação Continuada, Alfabetização e Diversidade, 2010. 
BRASIL. Economia solidária: caderno pedagógico educadoras e educadores / Coordenação: Armênio Bello Schmidt, Sara de Oliveira Silva Lima, Wanessa Zavarese Sechim. - Brasília: Ministério da Educação, Secretaria de Educação Continuada, Alfabetização e Diversidade, 2010.

BRASIL. Sistema de produção e processos de trabalho no campo: caderno pedagógico educadoras e educadores / Coordenação: Armênio Bello Schmidt, Sara de Oliveira Silva Lima, Wanessa Zavarese Sechim. - Brasília: Ministério da Educação, Secretaria de Educação Continuada, Alfabetização e Diversidade, 2010.

FOUCAULT, Michel. A arqueologia do saber. Trad. Luiz Felipe Baeta Neves. 6. ed. Rio de Janeiro: Forense Universitária, 2010.

FREIRE, Paulo. Educação como prática da liberdade. São Paulo: Paz e Terra, 1967.

MEC/SECADI. Documento base nacional preparatório à VI Conferência Internacional de Educação de Adultos. 1․ Brasília: MEC. 2008.

SECRETARIA NACIONAL DE JUVENTUDE. Projovem 2018 atuará em 17 Estados e 70 Municípios. Disponível em http://juventude.gov.br/juventude/noticias/projovem-2018-atuara-em-17-estados-e-70-municipios Acesso em 05 ago. 2018.

XAVIER. M. S. B. Os movimentos sociais cultivando uma educação popular do campo. Disponível em: <http://29reuniao.anped.org.br/trabalhos/trabalho/GT06-1780-Int.pdf>. Acesso em 01 de out. de 2019. 


\subsection{9/978-24-CAMPO6-7-2}

\section{A POTENCIALIDADE PEDAGÓGICA}

E DE TRANSFORMACAO HUMANA NAS VIVÊNCIAS DE FABRICACAO ARTESANAL DE ERVA-MATE

Moisés da Luz ${ }^{92}$ Marcelo Vaz Pupo ${ }^{93}$

92 Educador e carijeiro, biólogo e mestre em Desenvolvimento Rural, moisesdaluz2018@ gmail.com.

93 Educador e professor doutor da Educação do Campo pela Universidade Federal do Pampa, Campus Dom Pedrito-RS, marcelopupo@unipampa.edu.br. 
A erva-mate (Ilex paraguariensis St. Hil.) é uma espécie arbórea nativa das matas com araucária e matas estacionais. No Brasil abrange especialmente os estados do sul e o Mato Grosso do Sul; na Argentina, as províncias de Misiones e Corrientes, além de partes do Paraguai e Uruguai. A sua área natural de distribuição coincide com a presença das populações indígenas guaranis, kaingangs, xocklengs, entre outras.

A erva-mate, caá em guarani, já era consumida pelos povos originários destes rincões bem antes da vinda dos exploradores europeus. Muitos ervais existem hoje devido ao cultivo e domesticação que guaranis e possivelmente kaingaings efetuaram. Vale mencionar igualmente, que os ervais também foram implantados pelos guaranis, através das missões jesuíticas nos séculos XVII e XVIII. O avanço comercial da erva-mate se desenvolveu através das colônias espanholas, depois que um exército de Asunción teria presenciado uma comunidade guarani fazendo uso da bebida, em alguma localidade de Guairá, atual estado do Paraná, por volta do ano 1554 (LINHARES, 1969).

A partir dessa árvore se prepara o mate ou chimarrão, tomado com água quente, e o tererê, tomado frio ou gelado, assim como se prepara o chá-mate e outras bebidas menos famosas. A cultura de tomar mate se expandiu além da área de ocorrência natural da erva-mate, por exemplo, na Argentina e no Uruguai são bebidas nacionais, abrangendo todo o território desses países. Na Argentina, inclusive, tornou-se componente da cesta básica.

No Rio Grande do Sul tornou-se também a bebida típica e a árvore símbolo do estado, tendo como histórico a presença da bebida muito atrelada aos costumes de um grupo social, denominados "gaúchos", que já seria a miscigenação entre portugueses, espanhóis, indígenas e negros, constituindo famílias e homens solitários que trabalhavam com o gado, indo de um campo a outro no território do pampa.

Posteriormente, foi a vez de imigrantes alemães, italianos, entre outros, a aprenderem com os povos originários e com a população que aqui estava, a saborear o mate e outros alimentos daqui, favorecendo o estabelecimento de suas comunidades no território e de seus empreendimentos. A erva-mate, que já era um produto comer- 
cial desde os tempos das colônias espanholas e portuguesas, é então incorporada ao modo de vida desses imigrantes, que passam a manejá-la e processá-la artesanalmente, ampliando assim a rede de relações socioeconômicas em torno do mate.

A reprodução de práticas de conhecimento necessárias para a qualidade de vida das comunidades humanas é um traço do campesinato latino americano. $O$ exemplo da erva-mate ilustra bem essa afirmação, de modo que buscamos evidenciar, neste capítulo, a importância pedagógica das vivências com a fabricação artesanal da erva-mate. Tratando-se de um bem com valor de uso histórico e culturalmente dado, o estudo integrado do mate apresenta grande potencial de correlação entre conhecimento, identidade e experiência, elemento indispensável para ações interdisciplinares e emancipatórias no âmbito escolar e não escolar.

Defendemos que o processo educativo de crianças e adolescentes e a formação de docentes deve alinhar-se definitivamente aos esforços sociais de manutenção e aperfeiçoamento de práticas locais com esse caráter.

\section{ERVA-MATE, ECONOMIA E AGRICULTURA}

A partir dos anos 1960 avança a modernização na agricultura e a industrialização. Os monocultivos com base em um pacote tecnológico, composto de máquinas, adubos químicos e agrotóxicos, agências de pesquisa e formação de técnicos, são expandidos, ocasionando um período intenso de desmatamento e inclusive derrubada de ervais, uma vez que os preços dos grãos começaram a ser mais cotados para os negócios. Ao mesmo tempo, a industrialização chega para a fabricação de erva-mate, desestimulando aqueles que a processavam artesanalmente.

Pode-se pensar esse período histórico como um processo dominante de modernização e produção em larga escala, sendo implementado pelos Estados Nacionais a partir de uma onda global, pós segunda guerra mundial, tendo a indústria do petróleo como catalisador (BRUM, 1988, PLOEG, 2006). Assim, a partir de todo um aparato estatal, que também engloba a cultura e a educação, esses valores modernos são amplamente incentivados. Isso também se aplica à implementação das agências reguladoras das normas sanitárias, o que inviabilizou muito os empreendimentos artesanais, pois elas seguem uma estandartização industrial (CRUZ, 2007; VILLANUEVA et al. 2008). Enfim, a lógica da industrialização em larga escala não 
contempla as experiências de fabricações artesanais, que igualmente poderiam ter incentivos para uma industrialização de pequena escala ou adequada ao processo artesanal.

Por contradição, desse período até o presente, o Rio Grande do Sul hoje importa em torno de $50 \%$ da matéria-prima para processar a erva-mate, e permitiu a derrubada dos antigos ervais mesmo tendo o chimarrão como parte intrínseca de sua tradição. Consequentemente, apenas algumas regiões ficaram dedicadas para o cultivo da erva-mate, considerando seus relevos mais íngremes, que não foram propícios para o avanço da agricultura industrializada, o que mobilizou a implantação de polos industriais ervateiros.

\section{CARIJO: FABRICAÇÃO ARTESANAL DE ERVA-MATE}

A fabricação artesanal de erva-mate está entre uma das inúmeras atividades camponesas e indígenas, que está presente em seus territórios. Dentro do contexto da pressão do agronegócio e da industrialização, pode-se depreender um processo de resistência dos povos do campo. No tocante à agricultura familiar, a resistência para seguir com a terra, mantendo seu modo de vida e conservando a natureza é bastante delicado, haja vista que esse setor, por ausência de políticas públicas específicas, já encontra-se muito comprometido com atividades do agronegócio. Além disso, ela encontra grande dificuldade em manter a sucessão familiar conforme o estilo de vida camponês, como é discutido por Ploeg (2006). Sendo assim, entre esse setor, deduz-se que a prática da fabricação artesanal da erva-mate continua em declínio.

Em linhas gerais, o que se testemunha na área rural do estado é a disputa territorial entre dois modos antagônicos de apropriação dos ecossistemas, que Toledo e Barrera-Bassols (2015) arquetipicamente chamam de modo tradicional ou camponês em contraste com o modo moderno ou agroindustrial, este último como resultado do desenvolvimento capitalista de produção.

Conforme Luz et al. (2017), a continuidade da fabricação artesanal de erva-mate, que está atrelada à continuidade do estilo camponês de agricultura, em vista da possibilidade de haver sucessão familiar, está acontecendo em famílias, que estão no ramo da agroecologia e vinculadas à redes de cooperação. A tradição é um fator 
intrínseco a todas as famílias que fabricam erva-mate artesanalmente, somado a um histórico de manutenção e incremento da base de recursos, retroalimentando-se com a entrada no ramo agroecológico e em cooperação. Como parte fundamental da base de recursos está a mata nativa e os ervais, sendo que em alguns casos a erva-mate é nativa da floresta. Dessa forma, essas famílias puderam investir na atividade, tornando-se a principal fonte de renda.

Enquanto base conceitual, a agroecologia proporciona uma estrutura de análise e interpretação do ecossistema manejado, levando em conta o trabalho humano e a tecnologia empregada nesse manejo. Enquanto ação social e coletiva, a agroecologia estabelece uma rede de relações, com base na cooperação e na reciprocidade, que sustentam práticas, conhecimentos, técnicas e métodos que dinamizam as relações ecológicas, econômicas e culturais de uma determinada região (VAZ PUPO, 2018).

Em boa medida, essa rede de relações - que organiza o modo camponês de apropriação da natureza — representa a resistência exercida pela agricultura familiar e camponesa para que siga existindo, mesmo sob condições adversas, que continuamente são impostas pelo sistema capitalista. Ao manter vivos valores de uso com base histórica e cultural, a agricultura familiar e camponesa se torna o segmento social com melhor capacidade de explorar, de maneira sustentável, o potencial endógeno dos ecossistemas.

Através de um projeto sobre patrimônio imaterial, executado pela cooperativa Catarse, de Porto Alegre, e financiado pelo Instituto do Patrimônio Histórico e Artístico Nacional (IPHAN), entre 2012 e 2014, essa prática ancestral foi amplamente popularizada por meio de um filme ${ }^{94}$ documentário e a realização de eventos para a produção de erva-mate artesanal. Além do filme, produziu-se um livro (LUZ, 2014), onde se descreve detalhadamente a prática do carijo e fatores relacionados à resistência camponesa entre guaranis, quilombolas e famílias agricultoras.

O carijo é a estrutura de secagem da erva-mate, por vezes também mencionado como a totalidade desse método de fabricação artesanal. Ao que tudo parece, ele se constitui como um primeiro salto produtivo, conjugando-se a prática guarani com o interesse comercial e de acúmulo dos primeiros colonizadores estrangeiros. Pois 
os guaranis, segundo diversos relatos, quando não utilizam o carijo, costumam secar um feixe de erva-mate pendurado acima de um fogo de chão, o denominado "macaco", desta forma, secando as folhas e macerando-as para o mate, à medida de suas necessidades, sem haver uma produção para acúmulo.

O carijo proporciona aumentar a produção de erva-mate sem perder determinadas dimensões culturais, espirituais e de contato com a natureza (figura 1), que não aparecem no barbaquá, um método também artesanal, porém de maior produção, mas que para a secagem, o fogo é acendido a uma distância ao redor de $10 \mathrm{~m}$, o que não exige o cuidado permanente da combustão, e por sua vez retira o risco de incêndio, que está presente no carijo. A seguir, apresenta-se uma descrição das etapas do carijo.

Figura 1. Sequência das etapas da fabricação artesanal de erva-mate, através do método do carijo: a) poda, b) sapeco, c) desgalha e enfeixamento, d) secagem no carijo, e) cancheamento, f) soque.
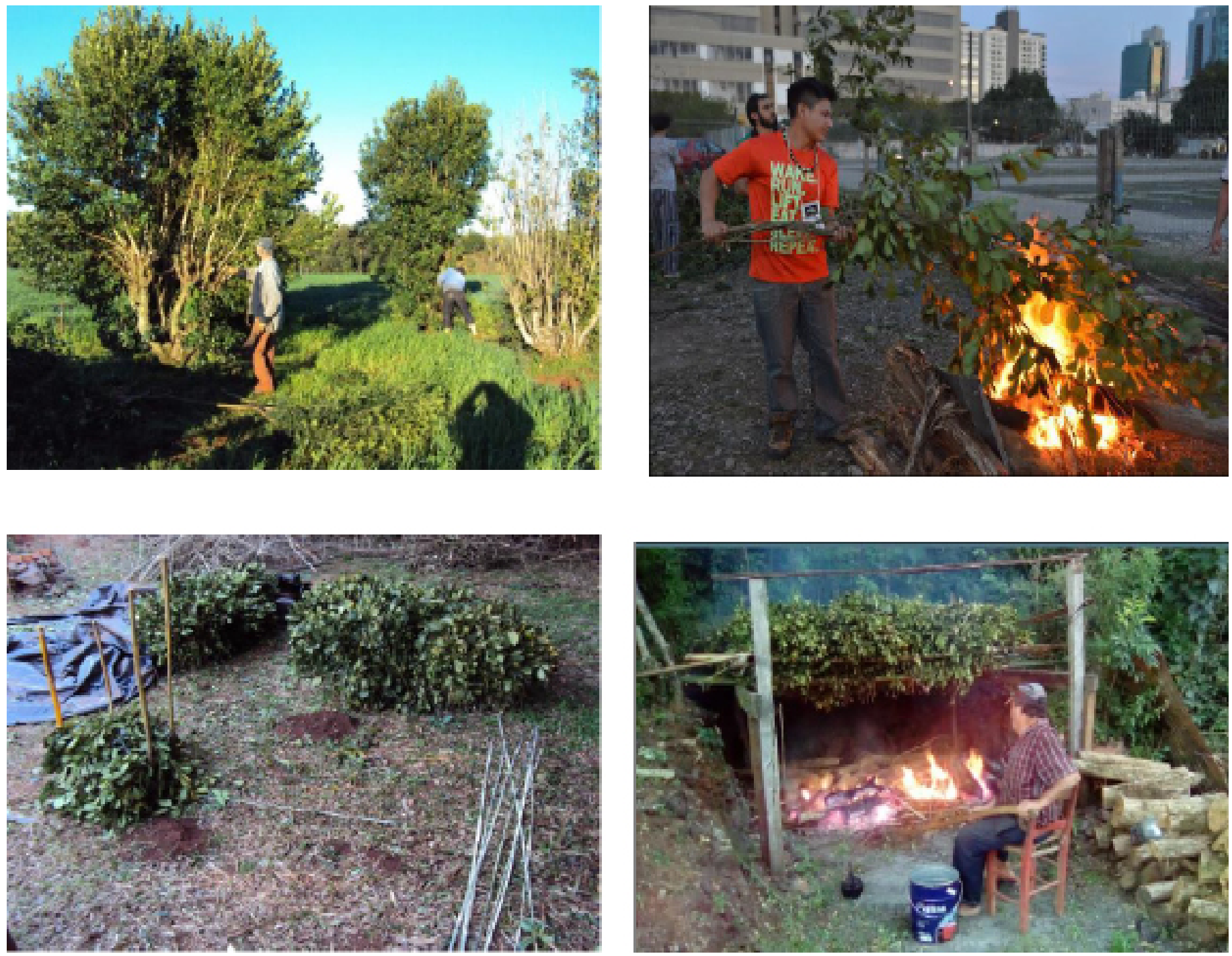

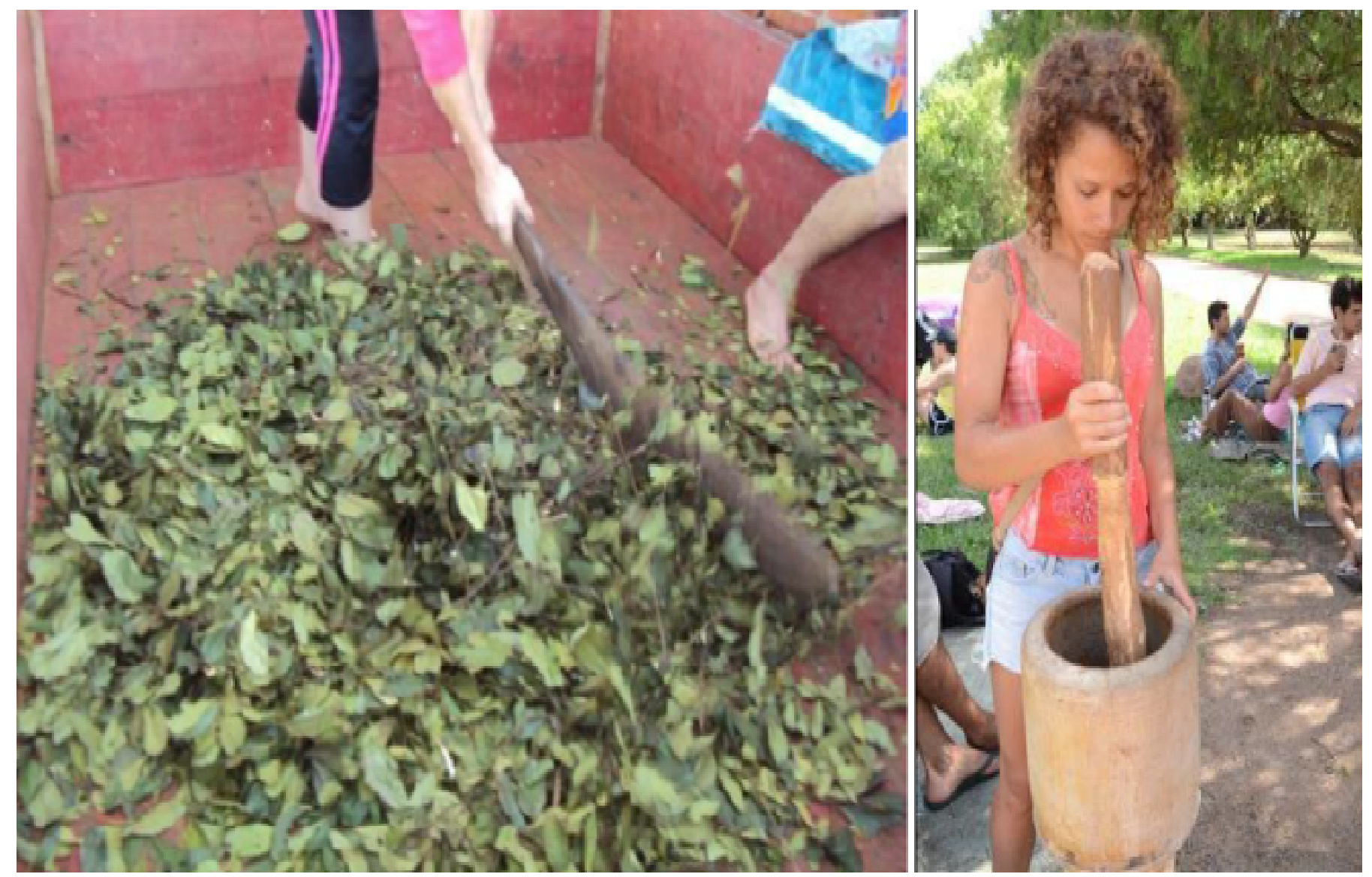

Fonte: acervo do primeiro autor (a,c,d,e). Cooperativa Catarse http://carijoofilme.blogspot.com/ (b, f).

\section{Poda}

A poda da erva-mate é realizada em ervais nativos e cultivados, sendo que estes existem em sistema de monocultivo ou em sistema agroflorestal. Historicamente existe a figura chamada "tarefeiro", que é o trabalhador contratado por patrões ou ervateiras, responsável por essa atividade. Em determinados contextos, como há em Misiones, na Argentina, fazem parte do grupo social mais excluído da população (MARCONE, 2018), já que não possuem posse ou título de terra. Diferente da situação da agricultura familiar ou de populações tradicionais, que por possuírem seus territórios, manejam a erva-mate com autonomia.

A poda acontece com o uso de facão, respeitando-se a lua, que não pode ser durante a lua Nova, mas preferencialmente as melhores fases são a Cheia e a Crescente. Também o ideal é seguir a melhor época do ano, em que as árvores não estejam em fase reprodutiva, por isso, as podas se concentram mais entre maio e setembro. Cada árvore podada volta a ser podada a cada 2 ou 3 anos, para que os galhos fiquem compridos, facilitando a segunda etapa - o sapeco, e assim também 
as folhas vão estar mais maduras. Em geral, costuma-se tirar toda a ramagem da árvore, deixando-se apenas galhos pequenos.

\section{Sapeco}

O sapeco é a passagem dos galhos sobre uma fogueira alta, pelo tempo de alguns segundos, gerando a crepitação das folhas. Com isso se preserva a cor verde e se quebram substâncias químicas naturais que deixariam um gosto muito amargo no produto. Após o sapeco, é realizada a "quebra" ou "desgalha", em que são separados os galhos finos com as folhas, formando-se feixes ou amontoando-os sobre o chão, para depois serem levados para cima do carijo.

\section{Secagem}

O carijo consiste em uma armação de madeira, com quatro moirões sustentando varas roliças ou de bambu, distanciadas paralelamente entre 10 a $15 \mathrm{~cm}$ uma da outra, e a uma altura do chão em torno de 1,30 m. Uma espécie de estrado. São construídos no interior da selva, junto aos ervais, ou perto de casa, comumente próximo de algum curso d'água.

A secagem da erva-mate é um momento de folclore, de confraternização, de convivência com a natureza, especialmente a dimensão noturna, considerando os corpos celestes. Pois por tradição e coerência ao manejo do fogo, a secagem geralmente inicia no final da tarde, seguindo noite adentro. Pelo folclore gauchesco chama-se a "ronda do carijo". A motivação para seguir desperto pela madrugada depende da companhia e da animação das pessoas presentes, pois é um momento propício para cantar e praticar instrumentos musicais.

\section{Cancheamento}

No outro dia pela manhã, a erva estará seca, estando pronta para o cancheamento, que é a fragmentação dos ramos, o que facilita a última etapa, o soque. $O$ cancheamento mais rústico é o realizado com facões de madeira sobre uma "cancha", que pode ser uma prancha de madeira, um reboque de madeira, ou uma estrutura de madeira em formato "V". A erva cancheada, então, fica com os galhinhos quebrados e as folhas em pedaços, que em parte já está em estilo "pura folha" ou tererê. Com o cancheamento, a erva pode ser ensacada, para fins de transporte. 


\section{Soque}

A moagem da erva pode ser realizada no pilão, manualmente, ou em soques mecânicos, com duas ou mais mãos de pilão, sendo movidos através de motores a eletricidade, combustão ou pela força da água (roda d'água, turbina d'água).

\section{AS VIVÊNCIAS DO CARIJO}

As vivências a que nos referimos são as realizadas com intencionalidade pedagógica, de troca de saberes e de mobilização social, entendendo-as como a passagem por uma experiência em geral fora do cotidiano da vida dos estudantes, tanto em suas comunidades, como em outras realidades, interagindo com as pessoas dos lugares. Uma vivência, segundo a cartilha preparatória do V Estágio Interdisciplinar de Vivência (EIV) de Minas Gerais, realizado em 2008, "é um encontro de pessoas", onde, no espaço de vida das comunidades, os estudantes irão conviver com elas em seu mundo, em seu dia a dia, seguindo uma concepção e metodologia dialógicas, onde ambos serão educador-educandos (FREIRE, 2006).

As vivências do Carijo no RS têm sido mobilizadas a partir do ano 2005, iniciando com o protagonismo de estudantes de Biologia e Agronomia da UFRGS, proporcionando a experiência de aprender a prática de fabricação artesanal de erva-mate, junto ao agricultor Luís Pires, de Panambi, RS. A partir desse ano, as vivências se tornaram recorrentes, acontecendo em quase todos os anos ${ }^{95}$. Entre as vivências, citam-se as que aconteceram na forma de eventos, a partir de projetos executados pela cooperativa Catarse, de Porto Alegre, RS, sendo realizadas nos municípios de Panambi, ljuí, São Miguel das Missões, Soledade e Porto Alegre, a que foi organizada em um assentamento da reforma agrária no município de Nova Santa Rita, e as da Universidade Federal do Pampa, nas cidades de Dom Pedrito e Alegrete. Com as vivências, algumas pessoas se tornaram multiplicadoras da prática, levando a experiência para distintos contextos no RS. Inclusive a partir delas houve o resgate da prática por comunidades guaranis.

As vivências, que inicialmente tiveram a intenção de aprender a fazer a erva-mate, de valorizar o processo e proporcionar uma experiência de troca de saberes,

$95 \quad$ Mobilizada pelo primeiro autor em sua carreira, como estudante de Biologia, profissional docente do ensino básico, técnico e universitário, estudante de mestrado em Desenvolvimento Rural, e como integrante dos projetos executados pela cooperativa Catarse, de Porto Alegre, RS. 
de encontro e mobilização, foram ao longo do tempo mostrando sua riqueza entre aspectos da construção do conhecimento, da cultura, da autonomia, da biodiversidade, da saúde, da segurança alimentar, e inclusive como dimensão pedagógica.

As vivências foram realizadas pelo tempo entre 2 a 4 dias, geralmente na forma de acampamento, quando estudantes universitários tiveram que se deslocar para as comunidades rurais ou montaram o acampamento no próprio espaço da universidade, caso do Carijo organizado no campus da UNIPAMPA, em Dom Pedrito, como parte das atividades acadêmicas do curso de licenciatura em Educação do Campo e do Encontro Internacional dos Povos do Campo.

O Carijo é uma atividade coletiva, onde todas as pessoas participam de todas as etapas do processamento da erva-mate, culminando com a degustação do chimarrão. Também é uma vivência pedagógica, em que estudantes saem da sala de aula, para realizarem um conjunto de atividades práticas, em interação com pessoas das comunidades rurais, como agricultores, quilombolas e indígenas, ou mesmo a interação com a comunidade acadêmica da universidade e seus visitantes, quando o Carijo é realizado dentro do campus. O aprendizado e a troca de saberes se processa a partir de um trabalho ou prática coletiva, entremeado de atividades culturais e em contato com a natureza envolvente.

Em geral a agenda de atividades do Carijo segue a sequência das etapas da fabricação artesanal. Para ilustrar a programação, apresenta-se um roteiro para três dias de evento:

$1^{\circ}$ dia: Manhã: - Poda da erva-mate

- (roda de conversa)

Tarde: - Sapeco

- Roda de conversa/visita guiada/atividade extra

Noite: - Atividade cultural

$2^{\circ}$ dia: Manhã: - Desgalha e enfeixamento, colocação dos feixes no carijo

- Roda de conversa/atividade extra

Tarde: - Secagem da erva-mate

- Roda de conversa/atividade extra 
Noite: - Secagem da erva-mate (ronda do carijo)

$3^{\circ}$ dia: Manhã: - Cancheamento e soque, degustação da erva cancheada

Tarde: - Soque e degustação, distribuição da erva-mate

- Roda de conversa/finalização da vivência

A vivência em um período de três dias ou mais proporciona uma imersão maior no contexto vivenciado e maior troca de experiências, desta forma é possível realizar rodas de conversa e outras atividades complementares, como visitas guiadas aos cultivos, às agroflorestas, trilhas na mata, e debate de assuntos diversos, conforme a proposição de temas. Houve situações em que acrescentou-se um dia prévio a mais na agenda, necessário para montar a estrutura do carijo.

Quanto aos aprendizados, a fabricação artesanal de erva-mate, além das técnicas em cada etapa, carrega um conjunto de conhecimentos e significados relacionados, considerando que a vivência, como um fenômeno, está acontecendo em um determinado contexto (social, econômico, ambiental, etc). Então além dos temas que certamente ou provavelmente são discutidos durante a vivência, existem outras dimensões que mobilizam a experiência pedagógica.

Entre uma relação de temas das diversas áreas do conhecimento, para exemplificar, citam-se os seguintes:

- Conhecimentos biológicos, ecológicos e agronômicos: época de poda, fases da lua, manejo da erva-mate, sistemas agrícolas, variedades de erva-mate, clonagem, produção de mudas, conservação da mata, plantas medicinais, espécies florestais para lenha e madeira, biodiversidade e agrobiodiversidade.

- Conhecimentos de contexto socioeconômico: povos do campo (agricultura familiar, quilombolas, guaranis, entre outros), sucessão familiar na atividade agrícola, mão-de-obra, assistência técnica, cooperativismo, acesso à água e à energia, acesso à informação, mercado, organização comunitária.

- Conhecimentos de contexto territorial, geográfico: commodities, agrotóxicos, distribuição da terra, educação, geomorfologia, clima.

- História, cultura, artes: origem da erva-mate, povos originários, colonização, 
imigração, hábitos, folclore, economia. Poesia, música, contos. Habilidades artísticas. Conhecimentos espirituais, místicos.

- Linguística: idioma guarani, kaingang, origem dos nomes de alimentos, plantas, lugares e termos relacionados à erva-mate.

- Conhecimentos astronômicos: universo, estrelas, planetas, fases da lua.

- Conhecimentos de química e culinária: o fenômeno da manutenção da cor verde após o sapeco da erva-mate, óleos essenciais, hidrolato, erva-mate na alimentação e na cosmética.

A citação de temas potencialmente presentes em uma vivência do Carijo é apenas a "superfície do oceano" de um processo educativo. Pois longe de se deter em uma visão conteudista, a vivência se potencializa por um processo transdisciplinar e participativo. O diálogo e a prática levam a uma experiência ilimitada de questões que surgem espontaneamente no encontro, o que também vai depender da proposição prévia de temas a serem desenvolvidos durante a vivência.

Quanto as outras dimensões do processo vivencial, abre-se caminho para questões de contexto e subjetividade. A vivência, pelo aspecto de ser coletiva, compreendendo que uma turma de estudantes estarão indo com o mesmo fim, compartilhando essa experiência, catalisa o processo de trocas e construção do conhecimento. Mais gente aprendendo, em processo de diálogo com os anfitriões, mestres carijeiros, mais leva a reflexões sobre as práticas e técnicas realizadas. Pois a criatividade e a inventividade fazem parte das habilidades intelecto-motoras, especialmente falando sobre os povos do campo, que vem trazendo habilidades ancestrais e tem que lidar com autonomia para alcançarem objetivos.

Em termos de organização coletiva do grupo de acampamento, acontecem diversos aprendizados, uma vez que todos são sujeitos do processo educativo. É possível fazer uma divisão de tarefas de acampamento, de forma que todas as pessoas participem de todas as atividades, como equipes diferentes para preparar cada refeição, cuidar da limpeza, entre outros aspectos. Geralmente o espaço cultural é deixado para o período da noite, onde também é possível convidar ou dividir determinados grupos a organizarem expressões artísticas. A noite da secagem da erva é especial, pois compreende o cuidado do fogo do carijo, fato que é tradicional para a 
confraternização, a observação do fogo, do céu e seus corpos celestes, a atenção para os ruídos noturnos, como da fauna.

A vivência de passar pelo menos algumas horas da noite cuidando do fogo do carijo ou estando em confraternização nesse momento, permite essa experiência noturna, que em geral está muito escassa nos dias de hoje. O passar à noite proporciona a percepção de dinâmica da rotação da Terra e simbolicamente a existência de dois mundos naturais, o dia e a noite, mudando a percepção, e mudando de fato a presença de outros representantes da fauna, ou seja, nichos ecológicos diferentes.

$\mathrm{O}$ fato dos estudantes se retirarem de seus cotidianos e imergirem alguns dias em uma outra realidade estimula os órgãos dos sentidos, pois se configura em muitas novidades, estimulando a inteligência. É sinônimo de aventura, ao mesmo tempo organizada pela intencionalidade pedagógica da vivência. Sair da "zona de conforto" e abrir-se a novas experiências, conhecendo realidades e pessoas diferentes, tem um efeito transformador na vida dos estudantes. Muitos(as) educandos(as) relataram que as vivências do carijo foram transformadoras para suas vidas. Assim como o carijo, outras vivências pedagógicas são vividas com intensidade, podendo ser marcantes pessoalmente, e mais além, tudo que marca tem um efeito posterior à vivência, que é voltando ao cotidiano de cada pessoa, a reflexão sobre o vivido. Conforme Maturana (2002), o aprender tem a ver com as mudanças estruturais que ocorrem em nós de maneira contingente com a história de nossas interações.

$O$ vivido e refletido tem um efeito sobre a formação de valores e visões de mundo de cada pessoa. É um processo dinâmico e que influencia as escolhas pessoais em cada ser humano. Nesse aspecto, os escritos de Dilthey (1992), numa perspectiva filosófica e psicológica, parecem se aproximar do que entendemos como potencial transformador das vivências, que para ele, elas são momentos carregados de significado para a vida pessoal, o que terá influência nas visões de mundo.

Conhecer as realidades, as injustiças, "os paraísos", aproximar-se e vincular-se a pessoas de outras culturas, faz crescer o sentido humanista, cosmopolita, faz diminuir as ignorâncias e divisões que a sociedade incentiva, devido a interesses em jogo. Por exemplo, o mercado muitas vezes nos apresenta uma cultura/ancestralidade da Índia, de tão longe, não menos importante, porém na nossa mesma cidade ou estado, estão comunidades guaranis, em processo de reivindicação por território, 
muitas vezes vivendo insalubremente nas beiras das rodovias. Essas pessoas também possuem sua ancestralidade, espiritualidade, seu idioma, enfim, outra cultura.

Segundo Maturana e Varela (1995), o processo do aprender está ontologicamente ligado ao viver, então, conhecer é fazer, fazer é conhecer. Seguindo esses autores, o processo do aprender é social e se efetua através da linguagem. A linguagem no histórico da evolução humana, é o que desenvolveu a (auto)consciência, e por sua vez a noção de visões de mundo, de valores cultivados (MATURANA; VARELA, 1995). Dialogando com esta proposição, o trabalho artesanal com a erva-mate pode ser interpretado como um conjunto de ser e fazer camponês, indígena, que organiza e oferece significado para o trabalho no campo. Pode-se então assumir que trata-se de conceber o trabalho como princípio educativo, uma vez que os conhecimentos associados a esse trabalho configuram um domínio comportamental de grande interesse para a educação em geral e para a Educação do Campo, em específico (FRIGOTTO; CIAVATTA, 2012).

A evolução de comportamentos sociais nos animais e especialmente na humana compreende um processo de cooperação, essencial à sua sobrevivência. Por isso, a educação, implicitamente um fenômeno social processado através da linguagem, só pode ser entendida como profícua em uma relação de cooperação, que em outras palavras é fundada no amor. Ao ressaltar o amor como a emoção que fundamenta a legitimação do outro na convivência, Maturana e Varela (1995) subsidiam ações educativas com base no associativismo e cooperativismo como uma necessidade do existir humano.

\section{CONCLUSÃO}

A realização das vivências do Carijo remetem para o campo da Educação a potencialidade pedagógica dessas atividades organizadas com os povos do campo e demais realidades do cotidiano das pessoas. Elas configuram um rechaço à educação bancária, criticada por Freire (2011), e vem ao encontro de várias abordagens que vêm reivindicando e pondo em prática uma educação contextualizada às realidades locais (MOLINA, 2014).

As vivências do Carijo demonstram o que se compreende como um processo educativo coletivo, em que todas as pessoas envolvidas participam, constroem co- 
nhecimento, numa concepção e metodologia dialógicas.

As vivências proporcionam aos estudantes conhecerem as realidades, que muitas vezes lhes são negadas ou parcializadas através dos atravessadores de informação (mídia). O fato de conhecer realidades, compreende conhecer outras pessoas em situações diferentes, e por sua vez, diferentes necessidades, características, cosmovisões e místicas em relação ao estar no mundo. Também, dessa maneira se constrói o senso crítico tão necessário à civilidade.

Além de conhecer outras realidades, a imersão vivencial proporciona a (trans) formação pessoal em termos de valores, visões de mundo ou cidadania. Esse aspecto é uma necessidade urgente para a formação humana, em termos de valores universais, de vida em comum, de cuidado da nossa casa comum, como colocado nessas palavras pela encíclica papal atual, em relação ao planeta Terra ou a Pachamama. Em outras palavras a necessidade de formação e aplicação de valores conforme a noção de Suma Qamaña (Buen vivir, bem viver) dos povos originários dos Andes.

Os valores de bem viver não se aplicam apenas ao cuidado da natureza, mas aos cuidados entre nós pessoas e comunidades, em que cada ser humano se reconheça no outro a possibilidade de existência digna e mútua. E para isso, é necessário transpor as barreiras colocadas pela sociedade, haja vista o distanciamento entre as pessoas, por uma série de aspectos, como de classe, cor, religião, ideologias, orientação sexual, entre outros. Essas separações e a não oportunização de experiências que proporcionam o "encontro de mundos" (pessoas) observamos como prejudiciais à formação de valores comuns e para o bem comum. Como disse Maturana (2002), para formar valores, há que vivê-los.

Enfim, as vivências do Carijo realizadas com estudantes universitários têm nos provocado a refletir sobre o processo do aprender, da construção e troca de conhecimentos, e mais além sobre o processo de transformação humana/cidadã. Vemos sua potencialidade pedagógica para o público universitário, e em especial para a formação de estudantes dos cursos de licenciatura, e por sua vez, para a educação básica. Afinal, para que a escola supere a educação bancária, é necessário que isso comece pela formação de professores(as). 
BRUM, A. J. Modernização da agricultura: trigo e soja. Petrópolis: Vozes. FIDENE. 1988.

CRUZ, F. T. Qualidade e boas práticas de fabricação em um contexto de agroindústrias rurais de pequeno porte. 2007. 111f. Dissertação (Mestrado em Agroecossistemas). Centro de Ciências Agrárias. Universidade Federal de Santa Catarina. Florianópolis.2007.

DILTHEY, W. Os tipos de concepção de mundo. Tradução: Artur Morão. Lusosofia: Press. Portugal. 1992. Disponível em: <www.lusosofia.net/textos/dilthey_tipos_de_ concep_ao_do_mundo.pdf>. Acesso em: 11 de mar 2021.

FREIRE, P. Pedagogia do oprimido. 50. ed. Rio de Janeiro: Paz e Terra. 2011. 253 p.

FREIRE, P. Extensão ou comunicação? 13. ed. Rio de Janeiro: Paz e Terra. 2006. 93 p.

FRIGOTTO, G.; CIAVATTA, M. Trabalho como princípio educativo (R. S. Caldart et al., Eds.) Dicionário da educação do campo. Rio de Janeiro : São Paulo: Escola Politécnica de Saúde Joaquim Venâncio/Fiocruz ; Expressão Popular, 2012.

LINHARES, T. História econômica do mate. Rio de Janeiro: José Olympio. 1969.

LUZ, M. Carijo: saber cultural do Rio Grande do Sul, símbolo da resistência e conhecimento indígena e camponês na fabricação artesanal de erva-mate. Porto Alegre: CATARSE. 2014. 148p.

LUZ, M; DAL SOGLIO, F. K, KUBO, R. R. Resistência camponesa no âmbito da fabricação artesanal de erva-mate, Rio Grande do Sul, Brasil. Revista Brasileira de Agroecologia. 12(1): p. 068 -080. 2017.

MARCONE, D. (dir.) Raídos. Documental. Película. 2018. (1h 14 min). Disponível em: https://play.cine.ar/INCAA/produccion/5171. Acesso em: 07 de abr 2021.

MATURANA, H. Emoções e linguagem na educação e na política. Belo Horizonte: UFMG. 2002. 98 p.

MATURANA, H.; VARELA, F. A árvore do conhecimento: as bases biológicas do entendimento humano. Campinas, SP: Editorial Psy II. 1995. 281 p. 
MOLINA, M.C. (org.) Licenciaturas em Educação do Campo e o ensino de Ciências Naturais: desafios à promoção do trabalho docente interdisciplinar. Brasília: MDA, 2014. 268 p. (Série NEAD Debate; 23).

TOLEDO, V. M.; BARRERA-BASSOLZ, N. A memória biocultural: a importância ecológica das sabedorias tradicionais. São Paulo: Expressão Popular. 2015.

VAZ PUPO, M. Por uma Ciência Popular da Vida: Educação do Campo, Agroecologia e Tradição Biocultural. 2018. 286 p. Tese de doutorado (Doutorado em Ensino de Ciências e Matemática). Instituto de Física Gleb Wataghin. Universidade Estadual de Campinas. Campinas, SP. 2018.

VILLANUEVA, A. C. et al. Alimentos artesanales y tradicionales: variabilidad versus estandarización. In: CONGRESO INTERNACIONAL DE LA RED SIAL, 4. 2008. Mar del Plata. Anais...Mar del Plata: Alfater. 2008. 1 CD ROM. 


\section{PROCESSOS RESISTENTES NA} PERSPECTIVA DA EDUCAÇA QUILOMBOLA

Dilmar Luiz Lopes ${ }^{96}$ 
Este artigo é resultado de pesquisas sobre a Educação do Campo e o desafio de práticas pedagógicas que acontecem nos territórios das comunidades dos quilombos $^{97}$. Uma reflexão de saberes em torno da dimensão ontológica, epistemológica da educação e a diversidade cultural dos povos da diáspora.

Ao entender a educação como processos formativos que se desenvolvem na vida familiar, na convivência humana, no trabalho, nas instituições de ensino e pesquisa, nos movimentos sociais e organizações da sociedade civil e nas manifestações culturais (Art. $1^{\circ}$ da LDB, 1996). Já a educação escolar quilombola é compreendida como uma modalidade educativa inscrita em suas terras e cultura, requerendo pedagogia própria em respeito à especificidade étnico-cultural da comunidade. $E$ com a elaboração das Diretrizes Curriculares Nacionais para a Educação Escolar Quilombola busca-se desenvolver uma pedagogia que respeite à diversidade étnica, saberes, conhecimentos de cada comunidade. Ou seja, a Educação Escolar Quilombola no seu artigo $9^{\circ}$, compreende: I - escolas quilombolas; II - escolas que atendem estudantes oriundos de territórios quilombolas. Parágrafo Único Entende-se por escola quilombola aquela localizada em território quilombola (DCNEEQ, 2012). A partir disto, descrevo alguns achados da educação quilombola fundamentados na memória histórica, em experiências das comunidades localizadas no Rio Grande do Sul.

$\mathrm{Na}$ abordagem metodológica destaca-se a perspectiva qualitativa, com os recursos da observação participante, na aplicação de um questionário semi-estruturado sobre a educação quilombola com 21 participantes, no decorrer do ano de 2015 e 2016. Procurei dar centralidade às lideranças que tinham mais experiência de vida $e$ exerciam um papel importante para a memória das comunidades de São Miguel e da Palma, nos municípios de Restinga Seca e Santa Maria. A partir da seguinte questão: que processos educativos emergem destes territórios que representam resistências? As análises e interpretação possuem as contribuições teóricas (MUNANGA, 2001; BENJAMIN, 1985; GILROY, 2001; GOMES, 2017; FREIRE, 1996). Os resultados ora apresentados se traduzem em experiências de pesquisa na educação com as

97 Conforme Decreto 4887/20/11/2003, artigo $2^{\circ}$. Consideram-se remanescentes das comunidades dos quilombos, para os fins deste Decreto, os grupos étnico-raciais, segundo critérios de auto-atribuição, com trajetória histórica própria, dotados de relações territoriais específicas, com presunção de ancestralidade negra relacionada com a resistência à opressão histórica sofrida. 
comunidades remanescentes dos quilombos (LOPES, 2004, 2012). Sua dinamicidade potencializa os valores civilizatórios da cultura afro-brasileira onde o quilombola reconstrói de maneira criativa seu mundo existencial em sintonia com suas memórias ancestrais.

E esta pequena exposição objetiva buscar as origens e conceitos, modos de organização dos quilombos, processos de disputas territoriais, as formas como ensinavam por meio das rodas de conversas e narrativas que servem como fundamento da atividade educativa camponesa e direitos étnicos.

\section{O QUILO MBO: ORIGEM E CONCEITOS}

Como é de conhecimento, o uso do termo quilombo remonta ao período colonial, tendo se constituído em um instrumento de repressão ao que se apresentava como uma das principais formas de resistência à escravidão: a fuga do cativeiro e esconderijo em locais de difícil acesso às forças repressivas. A grande referência simbólica da ancestralidade negra nas Américas se deu com o quilombo de Palmares que sintetizou um alto grau de organização política e social.

Enquanto categoria jurídica designava, portanto, uma afronta à ordem instituída. Este significado se confrontava com o conteúdo semântico do idioma da matriz lingüística africana banta: povoação e união, acampamento guerreiro na floresta ou divisão administrativa (BANDEIRA, 2002, p. 217). A compreensão atual, porém, é de que tais comunidades podem ter outras origens, tais como terras que tenham sido compradas ou recebidas como herança por ex-escravos e seus descendentes.

Tanto no meio acadêmico quanto na sociedade civil organizada, o conceito colonial de quilombo desconsidera "as várias possibilidades de enfrentamento de um mesmo processo de espoliação racial, social e cultural esquece e escamoteia toda uma gama variada e matizada de situações sutis, mas concretas, que se fizeram em face de um processo injusto" (SILVA e BITTENCURT JR, 2004, p. 29). Tais confrontos foram relativizados com a ordem escravocrata e pelo cativeiro da terra estabelecida pela Lei de Terras de 1850. Como consequências, as comunidades quilombolas, os agrupamentos negros que viviam em áreas periféricas ou em pequenas glebas doadas por seus antigos senhores viram-se, com a lei de 1850, impossibilitados de legalizarem suas apropriações, e passaram a ser considerados como ocupantes irre- 
gulares de terras devolutas. Só as terras pouco produtivas e de difícil acesso ficaram preservadas da ganância expansionista de grandes latifúndios.

Por remanescente de quilombos se entende hoje todo o agrupamento negro, rural ou urbano, constituído durante o regime escravocrata ou logo após a abolição, e que consolidou um "território como forma de construção de um espaço mínimo de autonomia, no interior do qual lograram a reprodução econômica, biológica e social em condições adversas" (Associação Brasileira de Antropologia - ABA,1994). Além da ênfase à particularidade de tal historicidade e territorialidade, considera-se que "quilombo vem a ser, portanto, o mote principal para se discutir uma parte da cidadania negada" (LEITE, 1999: 141), a inserção de fato de determinados segmentos em uma sociedade fortemente marcada por hierarquias raciais.

Várias pesquisas realizadas até aqui apontam que a constituição de territórios negros, no transcorrer e após o desmantelamento do regime escravocrata, se deu a partir das mais variadas estratégias de resistência mediadas entre conflito e negociação: o tradicional esconderijo/refúgio; doação testamental por parte do antigo senhor/ estancieiro (chamadas de dádivas ou deixas); compra com pagamento não só em dinheiro, mas também com trabalho e/ou outros bens; posse de terrenos 'devolutos' e impróprios às atividades produtivas dominantes; recompensa por participação em revoluções. Tais estratégias de territorialização não são mutuamente excludentes. Pesquisas mais aprofundadas já realizadas em comunidades do Rio Grande do Sul e o restante do Brasil indicam que áreas recebidas como 'deixa', além de abrigarem negros libertos e alforriados, se constituíam em esconderijos preferenciais para escravos fugidos (LEITE, 2002: 95; ANJOS, 2004: 39).

O processo de resistência de africanidades negra retoma sua força com o surgimento do quilombismo, conjunto de proposições lançado pelo ativista negro Abdias do Nascimento, o qual permeia o movimento negro a partir dos anos 80 . Tal conjunto de proposições é impulsionado pelas críticas intelectuais ao mito da democracia racial vigente no Brasil, pelo movimento dos negros americanos por direitos civis e pelas lutas anticoloniais da África meridional.

Porém, somente na esteira da intensa mobilização ocorrida por ocasião do Centenário da Abolição da Escravatura, no ano de 1988, aprova-se na nova Constituição Federal o Art. 68 - Ato das Disposições Constitucionais Transitórias - onde 
se inscreveu que "Aos remanescentes das comunidades dos quilombos que estejam ocupando suas terras é reconhecida a propriedade definitiva, devendo o Estado emitir-lhes os títulos respectivos". O que representa um grande avanço no processo de reparações dos territórios de povos tradicionais no país, em consonância com o decreto 4.887/03 que regulamenta o procedimento para identificação, delimitação, demarcação e titulação das terras ocupadas por remanescentes dos quilombos.

É importante ainda destacar a concepção de reparações que orientou a intervenção dos movimentos antirracismo internacional e brasileiro nos últimos anos, o que significou o reconhecimento pelo Estado - baseado nas decisões da III Conferência Mundial Contra o Racismo, a Discriminação Racial, a Xenofobia e Formas Correlatas de Intolerância, realizada em Durban (RSA), no ano de 2001. Naquela conjuntura, o colonialismo e a escravidão cometidos no passado, foram considerados crimes de lesa-humanidade e que as novas gerações de negros que trazem na pele as marcas mais evidentes da sua descendência africana, sofrem ainda hoje as consequências desse crime. A partir dessa conjunção de fatores iniciam alguns movimentos reparatórios que tem como mote a questão racial e uma agenda efetiva que reconheçam a importância das comunidades remanescentes quilombolas no país.

\section{QUILOMBOS NO SUL E A DISPUTAS POR TERRITÓRIOS}

A história social da colonização no Rio Grande do Sul se caracteriza pela constante destruição dos territórios de resistência das comunidades negras pela estrutura fundiária ora dominante.

Destaca-se então que regimes diferenciados de apropriação de recursos consolidaram fronteiras étnicas e territorializaram o Rio Grande do Sul. O esvaziamento com que a literatura sul-rio-grandense apresenta as terras a serem ocupadas por essas ondas migratórias, sob o termo "apropriação de terras devolutas" registra a forma como os euro descendentes varreram agrupamentos indígenas e negros do mapa étnico do Estado. No contexto das disputas pela posse da terra no Rio Grande do Sul, a população africanizada, no nosso entender, propulsora e precursora do desenvolvimento da economia gaúcha, através de sua utilização no trabalho compulsório das charqueadas e nas fazendas gaúchas é uma das principais responsáveis pela demarcação e guarda das fronteiras limítrofes do país. Ocorre que em poucos 
momentos da historiografia oficial tem a comunidade negra reconhecida a sua importância estratégica no processo de formação do Estado.

Os africanos trazidos a região sul eram provenientes de várias nações africanas (Angola, Benguela, Cabinda, Congo, Mina, Moçambique, Monjolo, Nagô, Oyó e outros), eles trouxeram consigo uma cultura rica e diversificada: religiosidade, prática de artesanato, cultivo da terra, manufatura, artes, construção. Bem como os saberes e fazeres na pecuária e em diversos outros ofícios rurais e urbanos. Os seus territórios passam a se constituir desde as primeiras fugas até os processos de emancipação que começaram em 1884 ( MAESTRI, 2006).

Somente entre os anos 1998 e 2002, foi desenvolvido o primeiro laudo antropológico na comunidade quilombola de Casca, município de Mostardas ${ }^{98}$. Desta primeira pesquisa exitosa foi assinado o convênio entre a Fundação Cultural Palmares e a Secretaria do Trabalho, Cidadania e Assistência Social no governo gaúcho para elaboração de estudos técnicos em: Morro Alto, município de Maquiné e Osório, São Miguel e Rincão dos Martimianos, em Restinga Seca; Arvinha e Mormaça, em Sertão.

Esses estudos acabaram produzindo uma densa bibliografia publicada através da linha editorial da UFRGS: comunidades tradicionais ${ }^{99}$.

Posteriormente, foi criada a legislação estadual que reconhece os direitos quilombolas por dentro da constituição estadual ${ }^{100}$. O que representou um marco importante para os procedimentos administrativos e judiciais com o apoio científico, por meio de etnografias e grupos de pesquisas antropológicos das universidades federais. Observa-se que o envolvimento destes pesquisadores com os povos tradicionais permitiu, especialmente a partir da utilização da história oral ${ }^{101}$, cartografias como fonte de pesquisas, que as comunidades tradicionais se tornassem protagonistas em processos emancipatórios. Segundo os últimos dados do Incra/RS temos no

98 Vide: Leite, Ilka Boaventura. O legado do testamento: a Comunidade de Casca em perícia. Porto Alegre: Editora da UFRGS; Florianópolis: NUER/UFSC, 2004.

99 Barcellos, Daisy Macedo de [et al.]. Comunidade negra de Morro Alto: historicidade, identidade e territorialidade. Porto Alegre: Editora da UFRGS/Fundação Cultural Palmares, 2004; Anjos, José Carlos Gomes dos [et al]. São Miguel e Rincão dos Martimianos: ancestralidade negra e direitos territoriais. Porto Alegre: Editora da UFRGS, 2004.

100 Lei $n^{\circ} 11.731$, de 09 de janeiro de 2002 e Decreto 41.498 de 25 de março de 2002.

101 A oralidade tem sido veículo de resgate da história africana e dos quilombos. Muito embora também devamos considerar a possibilidade da história oral funcionar como um elemento da africanidades haja vista que a população negra também teve negado o acesso a escolarização e ao aprendizado da escrita. 
momento noventa e nove processos abertos para reconhecimento dos territórios negros. Quatro territórios titulados e referidos acima. Treze com Portarias de Reconhecimento da Presidência do INCRA, vinte e dois Relatórios Técnico de Identificação e Delimitação. E possui trinta e quatro Relatórios Antropológicos produzidos, com doze Relatórios esperando elaboração de RTIDs, e sessenta e cinco processos parado aguardando condições financeiras, operacionais. O que demonstra que a temática permanece em disputa política e conceitual. Sob a perspectiva da ciência sua contribuição é no sentido de alargar o espaço de representação política, tanto nos sensos de justiça, como na emergência das experiências quilombolas como mais uma modalidade educativa a contribuir nas arenas de políticas públicas.

$\mathrm{Na}$ contemporaneidade, podemos afirmar que esse movimento da relação entre os processos de territorialização e a demarcação/reconhecimento da identidade quilombola constitui um "campo" de pesquisa (BORDIEU, 2004). Ou ainda, a identidade emerge a partir da afirmação dos sujeitos políticos que se organizam, como forma de reação a processos de violência física e simbólica que colocam coletividades em ameaça. Ao analisar essa temática, geralmente parte-se da premissa de que temos um passado glorioso que testemunha nossa humanidade. Por exemplo, as pessoas pensam que todos os quilombos foram resultados de lutas históricas. E esta é apenas uma perspectiva que ficou presa no passado colonial. Para ser exato, não há nenhuma identidade quilombola que possa ser designada por um único termo, ou que possa ser nomeada por uma única palavra; ou que possa ser subsumida a uma única categoria. Ela é constituída, de variantes formas, através de uma série de práticas subjetivo-objetivas como um campo de batalha operando com base nas relações de força manifestadas dentro dos grupos de poder e de decisão, níveis de discurso, imagem que informam o campo ideológico de uma dada cultura (BORDIEU, 2007). A crítica até aqui não é contra o pertencimento, mas contra o preconceito que designa a esse grupo um status inferior.

$\mathrm{Na}$ atualidade, esta identidade é bastião de suas lutas pelo reconhecimento de direito ao território via ancestralidade. Ela afirma-se na representação política forjada nas organizações que presidiram seus pleitos de estudos pela demarcação e titulação dos territórios quilombolas. Assim, os usos de recursos e os saberes desenvolvidos sobre o território e elaborados ao longo do tempo constroem sua representação 
de territorialidades negras (ACEVEDO e CASTRO,1993).

O que nos cabe enquanto pesquisador é captar os elementos de africanidades resistentes que constituem o espaço vivido nestes territórios. Na pesquisa de doutoramento, pude entender os significados, os recursos, as estratégias de resistência que vão emergindo no campo. Ao retomar a memória quilombola como pano de fundo, destaco alguns aspectos de suas resistências.

\section{MEMÓRIAS QUILOMBOLAS: AFRICANIDADES EM RESISTÊNCIAS}

O estudo da cultura quilombola com dinâmicas africanas nos reporta a metáfora da casa, onde a porta funciona como um percurso de entrada/saída para as várias dimensões de uma construção ontológica. Os elementos de africanidades que vão se constituindo ao longo do percurso histórico que tem início em África e se prolonga nas várias experiências negras pelo mundo. Uma perspectiva diaspórica que considera os elementos da epistemologia, da política, cultura e história que nos formam. E constitui outras narrativas que estão ligadas a natureza material, cultural, espiritual, no espaço vivido da comunidade. Uma dinâmica que representa elementos das africanidades que estão na origem da memória quilombola e se dá por meio de: a) rodas de conversa: rodar, circular, dialogar, ouvir/falar, aprender/ensinar, enquanto ferramenta de compreensão, interpretação do mundo das coisas, das narrativas e metáfora contadas que são passadas de geração em geração. Funciona como caminho para reatar o fio da história que foi rompido pela colonização. O caminho é através do diálogo de sabedoria, pelos mais velhos, adultos, jovens e crianças que se encontram presentes nas rodas de conversa. Muitas vezes, pode ser utilizado como recurso metodológico para avançar na pesquisa, e assim, estabelecer os vínculos necessários à dimensão existencial, social, educacional da comunidade quilombola.

A ponta do fio está com os mais velhos, agora será preciso passar às gerações mais novas para que a memória não se perca, a história quilombola não se esvazie. Será necessário retornar ao passado para reencontrar os pontos que ligam o fio e não se perder no labirinto de informações do presente, tendo como linha condutora a memória histórica. Paulinho da Viola atualiza essa relação com a seguinte rima: "Não sou eu que vivo no passado / é o passado que vive em mim". 
A roda de conversa serve também como uma tática política para constituir o acesso a uma educação que vem de casa e se prolonga na escola. Ao considerar a educação enquanto processo de aprendizagem que brota da casa e território quilombola por meio das práticas, saberes que se fortalecem através da "roda de conversa". Paulo Freire conceitua de círculo de cultura em suas diversas experiências educativa (FREIRE, 1978). Numa dimensão educativa que relaciona os tempos/espaços da casa/escola; ensino/aprendizagem; professor/aluno, história/vida no qual a dinâmica de estudo se faz com o protagonismo das comunidades estudadas. Em que a educação é organicamente ligada à cultura quilombola do campo, e pode emergir numa nova relação de forças e servir como instrumento eficaz para formulação do projeto político pedagógico e formação continuada de professores. O ponto de partida e chegada da educação passa necessariamente pela experiência da comunidade, com suas práticas pedagógicas e sociais. Em síntese, um percurso pedagógico capaz de retroalimentar esta memória, através das rodas ${ }^{102}$ que recupera uma das direções das africanidades. b) A dimensão das narrativas ${ }^{103}$ : torna-se um recurso pedagógico em que as comunidades quilombolas têm buscado recuperar um saber historicamente sedimentado pela memória e que passa de geração em geração. Não de maneira estática, mas dialeticamente, articulado aos aspectos culturais e simbólicos que orientam suas vidas. É um processo fazedor do mundo, bem como um recurso revelador do mundo. A realidade e o significado das histórias contadas geram a busca por uma nova voz que tem no horizonte a justiça.

Pedagogicamente falando, essas narrativas e metáforas não são respostas prontas para pensar uma educação quilombola, mas se tornam insights para trazer à tona a memória rebelde do grupo que se orienta pelos elementos de eticidade $\mathrm{e}$ liberdade. Também se apresentam na forma de novos saberes que operam na perspectiva de africanidades e potencializam novas teorias pedagógicas, no intuito de materializar a educação.

102 A roda é um dos elementos dinâmicos da cultura africana: roda de conversas, roda de samba, roda de batuque e outras rodas de saberes.

103 História contada por alguém. Narração de acontecimentos, ações, fatos ou particularidades relativas a um determinado assunto. (Dicionário Aurélio, Editora Positivo,2010). 
Para José Carlos dos Anjos, a premência primeira que rege a estruturação dessas narrativas é uma tentativa de recolocar em ordem o mundo vivido.

Efetivamente, todo o conjunto de narrativas pertinente à fundação de quilombos nos remete para a polarização entre o tempo do cativeiro e o tempo pós-abolição. Essas narrações nos apresentam um passado amorfo, no qual se cristaliza um único acontecimento - desafio à ordem escravista. Esse desafio constitui o fundamental da esquematização da concepção de justiça e caráter do povo. [...] a memória coletiva cristaliza uma série de ícones que opõem a liberdade ao cativeiro, a bondade à injustiça, a submissão ao caráter (ANJOS, 2004, p. 64).

Essas narrativas nos ajudam a entender a origem do território, configurada pelo mulato e o desafio da hierarquia racial; o negro negociando na escravidão; e os senhores brancos seduzindo o grupo ora com regras de justiça, ora como representação da injustiça. Do ponto de vista pedagógico, o fator determinante é a reflexão que tal fato provoca. Essas histórias narradas reforçam as experiências coletivas e práticas de resistência na manutenção de seus modos de vida característicos num determinado lugar.

Em síntese, ao recontar a história de comunidades quilombolas procura-se territorializar as africanidades insurgentes que garantem direitos.

\section{CONSIDERAÇÕES FINAIS}

Do quilombo como sinônimo de fuga de escravos ao quilombo como símbolo resistência, expressão cunhada pelas proposições ativistas de Abdias do Nascimento. O aquilombamento remete para os processos de resistência cotidiana, para possibilidades de negociação dos africanos e seus descendentes. Assim procurei resgatar processos organizativos dos descendentes de africanos que atualizam, ainda hoje, diversas formas de reprodução no território direcionada para a sustentabilidade e sociabilidades fortalecidas pelo parentesco.

Em que a memória coletiva é mantida por meio de narrativas que vão se constituindo como amálgama para enfrentar os desafios deste contexto de exclusão racial. Ao contar histórias, mais importante que o seu conteúdo é o fato de que durante o processo de interpretação, a força dramática da narrativa é celebrada como forma. $O$ conteúdo simples das histórias é dominado pelo ato ritual da narrativa em si mesma. 
Todavia, esses relatos do cotidiano também são formas políticas de expressar espaços vividos da cultura quilombola. Elas enfatizam os pontos de interseção e a constituição de um pensamento plural em contraposição a um pensamento único; ao tratar da cultura negra e a negritude. Tudo isso para compreender as africanidades como um repositório no qual a consciência da cultura tradicional possa ser condensada em formas ainda mais potentes.

Nos quilombolas, o status de escravizados para o status de cidadãos os levou a indagarem quais seriam as melhores formas possíveis de existência social e política. A memória da escravidão, ativamente preservada como recurso intelectual vivo em sua cultura expressiva, ajudou-os a gerar um novo conjunto de respostas para essa indagação. Eles tiveram de lutar, muitas vezes por meio de sua fé, para manterem a unidade entre a ética e a política (GILROY, 2001, p. 99). O artigo aponta para uma história quilombola que tem sua raiz nas africanidades resistentes, mas não se apresenta como única. Os processos de enunciação fortalecem experiências coletivas na manutenção de suas culturas, reivindicações e lutas sociais em reconhecimento de seus territórios.

Com estas considerações, as narrativas atualizadas continuam tendo funções importantes a cumprir na constituição dos territórios negros. Hoje podemos afirmar que é para não perder essa memória que constituem valores civilizatórios africanos que são incorporados pela educação em diferentes espaços da sociedade brasileira.

\section{REFERÊNCIAS}

ACEVEDO, Rosa; CASTRO, Edna. Negros do Trombetas: guardiães de matas e rios. Belém. Ufpa/Naea. 1995.

ALMEIDA, Alfredo Wagner Berno de. Terras Tradicionalmente Ocupadas: processos de Territorialização e Movimentos Sociais. Revista Brasileira de Estudos Urbanos e Regionais, v.6, n.1, maio/2004. Pp. 9-30.

ANJOS, José Carlos G.; LOPES. Dilmar Luiz. Organizações locais e conformação de pleitos. In: ANJOS, José Carlos Gomes dos; SILVA, Sergio Baptista da (org.). São Miguel e Rincão dos Martimianos: ancestralidade negra e direitos territoriais. Porto Alegre: UFRGS, 2004

BRASIL. Lei de Diretrizes e Bases da Educação Nacional, LDB. 9394/1996. 
. Diretrizes Curriculares Nacionais para a Educação das Relações Étnico-Raciais e para o Ensino de História e Cultura Afro-Brasileira e Africana. Ministério da Educação. Brasília, outubro, 2005.

. Parecer CNE/CEB No 16/2012. Diretrizes Curriculares Nacionais para a Educação Escolar Quilombola. Ministério da Educação. Conselho Nacional de Educação. Relatora: Nilma Lino Gomes Aprovado em: 5/6/2012. Brasília, DF, 2012

ANJOS, José Carlos Gomes e SILVA, Sergio Baptista da. São Miguel e Rincão dos Martimianos: ancestralidade negra e direitos territoriais. Porto Alegre, Editora da UFRGS, 2004.

ANJOS, Rafael S. A. Territórios Étnicos: o espaço dos quilombos no Brasil. Editora da UNB, 2010.

BANDEIRA, Maria de Lourdes. Terras Negras: invisibilidade expropriada. Nucleo de Estudos sobre identidade e relações interétnicas, Florianópolis, ano 1, n², 1991. Textos e Debates.

BENJAMIN, Walter. O Narrador. In: Obras Escolhidas I: Magia e Técnica, arte e política. Ensaios sobre literatura e história da cultura. 3. ed. Trad. Sérgio Paulo Rouanet. São Paulo: Brasiliense, 1985.

BOURDIEU, Pierre. Os usos sociais da ciência. Por uma sociologia clínica do campo científico. Tradução Denice Barbara Catani. São Paulo: Editora Unesp, 2004.

BOURDIEU, Pierre. A economia das trocas simbólicas. Introdução, organização e seleção Sergio Miceli. São Paulo, Perspectiva, 2007.

FREIRE, Paulo. Cartas à Guiné-Bissau: registros de uma experiência em processo. 2. ed. Rio de Janeiro: Paz e Terra, 1978.

Pedagogia da autonomia: saberes necessários à prática educativa. São Paulo: Paz e Terra, 1996.

GILROY, Paul. O Atlântico Negro: Modernidade e dupla consciência. Trad. Cid Knipel Moreira - São Paulo: Editora 34; Rio de Janeiro: Universidade Candido Mendes, Centro de Estudos Afro-Asiáticos, 2001.

GOMES, Nilma Lino. O Movimento Negro educador: saberes construídos nas lutas por emancipação. Petrópolis,RJ: Vozer, 2017.

GUSMÃO, Neusa Mendes. Terra de pretos, terra de mulheres - terra, mulher e 
raça num bairro rural negro. Brasília: Fundação Cultural Palmares/Ministério da Cultura,1991.

HENRIQUES, R. Desigualdade Racial no Brasil: Evolução das Condições de Vida na Década de 90. Texto para Discussão n 807. Brasília: IPEA, 2001.

LEITE,Ilka Boaventura. Quilombos e quilombolas: cidadania ou folclorização? Horizontes Antropológicos, Porto Alegre, ano 5, n¹0, p. 123-149, maio 1999.

Comunidade de Casca: Territorialidade, direitos sucessórios e de cidadania. Laudo Antropológico. Departamento de Antropologia - UFSC,2002.

LOPES, Dilmar Luiz. Rodas de Conversa e Educação Escolar Quilombola: a arte do falar saber fazer. O Programa Brasil Quilombola em Restinga Seca/RS. Tese de doutorado. PPGEDU, Universidade Federal do Rio Grande do Sul. Porto Alegre, 2012.

Territorialidade como processo de organização social, política e cultural. In: MELO, Ana Lúcia Aguiar et al. (org.). "Palmas" para o quilombo: processo de territorialidade e etnicidade negra. Santa Maria: UFSM, 2011.

MAESTRI, Mário.O escravo no Rio Grande do Sul: trabalho, resistência e sociedade. Porto Alegre, Editora UFRGS, 2006.

MUNANGA, Kabengele. (org.) Superando o racismo na escola. Ministério da Educação, Secretaria de Educação Fundamental, Brasília, 2001

SILVA, Sergio Baptista da \& BITTENCOURT JR, losvaldyr Carvalho. Etnicidade e Territorialidade: o quadro teórico. In: São Miguel e Rincão dos Martimianos: ancestralidade negra e direitos territoriais. Porto Alegre: Editora da UFRGS, 2004.

SILVA, Petronilha Beatriz Gonçalvez. Aprendizagem e ensino de africanidades brasileiras. In: Superando o racismo na escola. Brasília: Ministério da Educação, Secad, 2001. 


\title{
10.48209/978-26-CAMPO6-7-2
}

\section{A BNCC E A GEOGRAFIA NA}

\section{EDUCAÇÃO BÁSICA:}

AS ESCOLAS DE COMUNIDADES

RURAIS DE RESTINGA SECA/RS

\author{
Altair Groff ${ }^{104}$ \\ Angelita Zimmermann ${ }^{105}$ \\ Ane Carine Meurer ${ }^{106}$
}

104 Doutorando em Geografia pelo Programa de Pós-Graduação em Geografia - PPGGEO/ UFSM. E-mail: altairgroff2@gmail.com.

105 Doutora em Geografia pelo Programa de Pós-Graduação em Geografia - PPGGEO. E-mail: angelitazd@gmail.com

106 Doutora em Educação, Docente no Programa de Pós-Graduação em Geografia - PPGGEO/UFSM. E-mail: anemeurer@gmail.com. 
A Base Nacional Comum Curricular (BNCC, 2017), como documento estruturante da matriz curricular do ensino fundamental e médio, tem um papel fundamental no currículo de escolas do campo ou da cidade. Este texto ${ }^{107}$ objetiva discutir a resolução em vigor, desde 2017, e sua relação com os processos de ensino e de aprendizagem da área das ciências humanas, mais especificamente da Geografia, com base em duas escolas do campo do município de Restinga Seca, no Rio Grande do Sul.

Em abordagem qualitativa, fundamenta-se em teóricos e dados da pesquisa de campo realizada na Escola Estadual de Ensino Fundamental Olmiro Pulmann Cabral $(E E E F)$ e a na Escola Municipal de Ensino Fundamental Manuel Albino Carvalho (EMEF), as quais funcionam nas localidades do Silêncio e São Miguel dos Carvalhos, respectivamente, além do uso de fotografias e entrevistas em forma de diálogo.

Entre os principais fundamentos de análise estão os de Luiz Carlos de Freitas, por meio do livro A Reforma Empresarial da Educação, Nova direita, velhas ideias (2019); a Resolução ${ }^{108}$ CNE/CP No 2, publicada no dia 22 de dezembro de 2017, que institui e orienta a implantação da Base Nacional Comum Curricular; o livro de lara Vieira Guimarães, intitulado Ensinar e aprender Geografia na Base Nacional Comum Curricular (BNCC) (2018); e os argumentos de José Gimeno Sacristán, discutidos na obra O que significa o currículo? (2013). Embora seja um ensaio, com reflexões iniciais, a consistência do conteúdo aqui desenvolvido poderá dar suporte e incentivar a busca por mais estudos e outras perspectivas para o ensino da Geografia no Ensino Fundamental e Médio.

Compreendemos a problemática educacional que envolve o fechamento de escolas rurais como consequência das políticas públicas implementadas no país, uma delas a BNCC para a Educação Básica que, em suas entrelinhas, reduz a Geografia ao todo que engloba as Humanas (Sociologia, Filosofia, Geografia e História) em um componente curricular só, ou seja, desvaloriza a amplitude de conhecimentos já

107 Este artigo se originou das discussões ocorridas na disciplina de Tópicos Especiais em Geografia D (2020), ministrada pela Professora Ane Carine Meurer, no Curso de Doutorado em Geografia, do Programa de Pós-Graduação em Geografia (PPGGEO), da Universidade Federal de Santa Maria, a qual teve como base a BNCC - Base Nacional Comum Curricular.

108 Ver em: http://portal.mec.gov.br/index.php?option=com_docman\&view=download\&alias=79631-rcp002-17-pdf\&category_slug=dezembro-2017-pdf\&ltemid=30192. Acesso em 10 de mar. 2021). 
sistematizados, assim como o ensino e o trabalho de educadores que tiveram uma formação e profissionalização especifica que possa constituir a articulação com as demais. Portanto, a partir do olhar dos autores mencionados, defendemos a disciplina de Geografia, no Ensino Fundamental e Ensino Médio, argumentando em favor da manutenção das escolas do campo e do trabalho destes profissionais da educação.

\section{FICOU A RESISTÊNCIA: DUAS DAS SETE ESCOLAS NO CAMPO DE RETINGA SECA/RS}

As Escolas do Campo constituem resistências nas comunidades que dela participam. São apropriadas ao acolhimento da cultura de crianças e juventudes que ainda trazem o brilho de uma perspectiva de vida condizente à de seus pais, irmãs, irmãs, vizinhos, vizinhas, amigos e amigas. Estas escolas são fontes objetivas e subjetivas que alimentam, valorizam e materializam o saber constituído pelas pessoas do lugar. São espaços de ensino e de aprendizagem recíproca de conhecimentos e discernimentos ao compartilharem desafios, anseios, brincadeiras, canções, danças, festas, amizades e tradições.

Contudo, no município de Restinga Seca, no centro do Rio Grande do Sul, somente sete, das 62 (sessenta e duas) escolas que existiam, continuam em funcionamento no campo. Neste texto, destacaremos duas: Escola Estadual de Ensino Fundamental Olmiro Pulmann Cabral e a Escola Municipal de Ensino Fundamental Manuel Albino Carvalho.

Quais as justificativas da gestão pública federal, estadual e municipal para o progressivo fechamento destas instituições?

Freitas (2017) defende que fechar escolas é um projeto deflagrado nas legislações do país, a começar pela BNCC (2017), que orienta a educação básica brasileira, destacando o modo sutil e progressista colocado na lei, "[...] é esta visão social que também embasa as "soluções" propostas pela engenharia da reforma empresarial na educação. Pensando a escola como uma "empresa", as escolas de menor qualidade devem sucumbir às de maior qualidade, sendo fechadas." (FREITAS, 2017, p. 28). Segundo o autor, as formas de manipulação institucionalizadas nos documentos legais levam ao fechamento e são contundentes: 
distribuição de renda; destruir a organização dos trabalhadores, a atuação dos sindicatos e confederações; destruir a atuação e organização dos movimentos que lutam pelos direitos humanos; atuar contra os imigrantes e contra ações de preservação do meio ambiente; desregulamentar a atuação das corporações; privatizar tudo que for possível; propor formas de proteção constitucional quase que irrevogáveis, que evitem o impacto de eventuais decisões contrárias ao livre mercado, entre outras. Tudo isso em alto e bom som (FREITAS, 2017, p. 28).

Em concordância e decorrência, os decretos municipais instituíram em sua ação - Decretos de desativação e extinção das escolas do campo - o Decreto N 26/2002 delineou a extinção de 43 escolas no Município de Restinga Seca/RS. Desde os decretos de 1987, e nos anos sucessivos, vem sucedendo um processo legislativo de desativação das escolas neste município, bem como em todo o país e América Latina. O estudo de mestrado de Groff (2016) sistematizou uma histórica desterritorialização que comprova essa política de fechamento, conforme a discussão feita por Freitas (2017).

A pesquisa de Groff (2016) demonstra a desativação de 55 escolas do campo que deixaram de existir nas comunidades do município de Restinga Seca/RS, e as consequências à vida camponesa destes lugares, entre elas, a Escola Cândido A. Fagundes, como podemos ver na Figura 1, a seguir:

Figura 1 - Escola Desativada Cândido A Fagundes - Rincão dos Martimianos

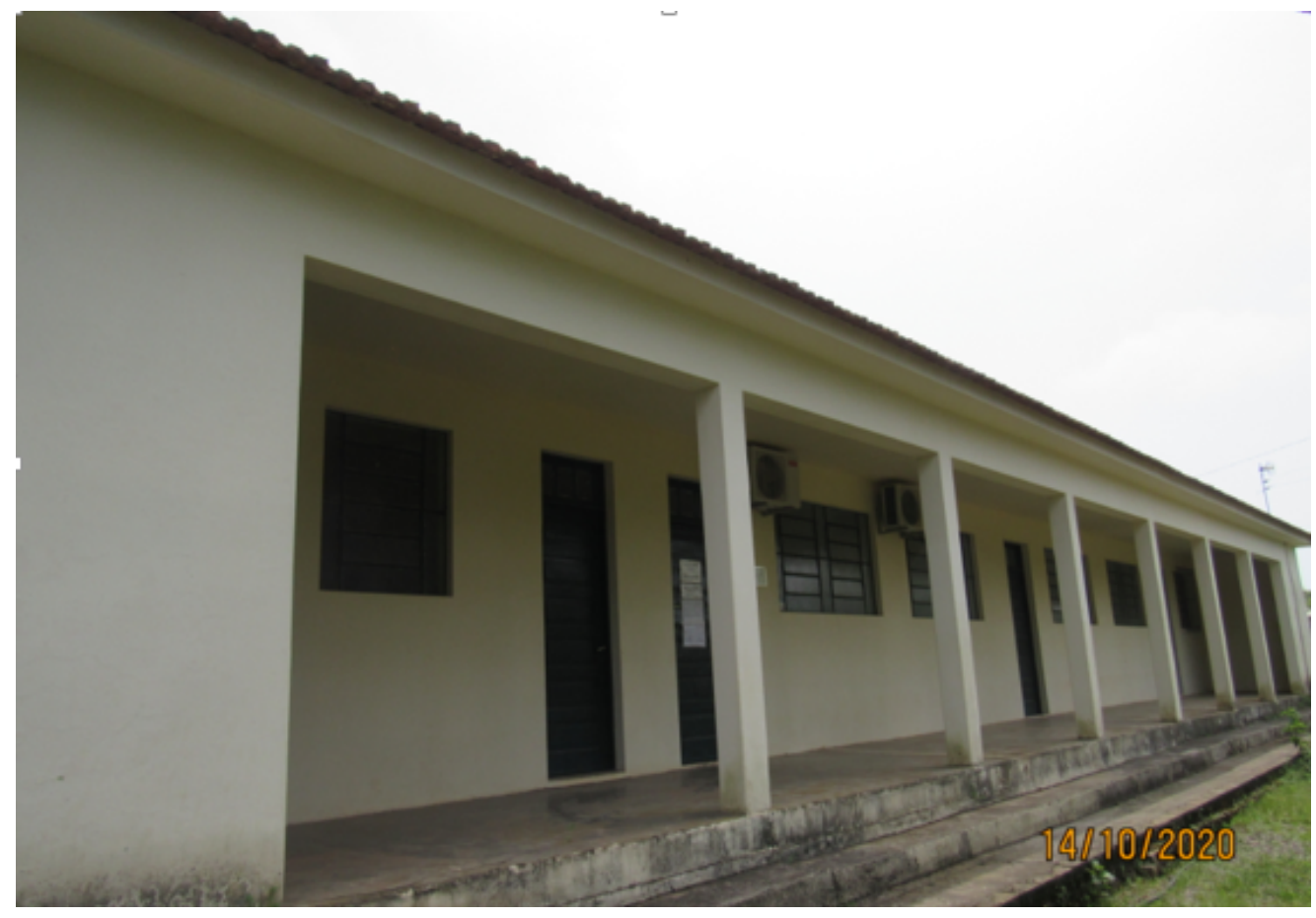

Fonte: autor, 2020 
O prédio da Escola Cândido A. Fagundes, localizado no Rincão dos Martimianos, constituía um território escolar e comunitário, cujo o fechamento ocasionou a necessidade de transporte a outros lugares onde funcionam escolas, inclusive de crianças da Educação Infantil, com idades entre 4 anos a 5 anos e 11 meses. Esta escola com infraestrutura adequada, quatro salas aula, próxima à área urbana, poderia estar ativa pelo menos até o $4^{\circ}$ ano de escolarização destes estudantes.

Como mencionamos, das 62 escolas do perímetro rural do município, permanecem em funcionamento apenas 07 escolas, sendo duas estaduais e cinco municipais. Neste texto, referendamos somente duas (Figuras 02 e 03) em atividade, sendo uma municipal e outra estadual. Em 2019, salienta-se que $40 \%$ da população de Restinga Seca estava assentada no campo, ou seja, do total de habitantes, 6.745 no âmbito rural e 8.669 na área urbana (SEBRAE, 2020, p. 10).

Significa dizer, sobretudo, que para que o poder público concretize as imposições legais para a educação brasileira tem recorrido às políticas que possam remediar os problemas, isto é, o transporte escolar torna-se uma necessidade aos municípios do país e, ao mesmo tempo, precisa ser batalhado pelas populações camponesas como um direito das crianças, jovens e adultos. Portanto, há uma inversão de valores já que este não deveria se constituir em direito substitutivo das escolas que existiam nestes territórios.

Ferreira e Brandão (2017) advertem sobre o transporte de estudantes para os centros urbanos.

Não seria menos desgastante, física e psicologicamente, para os alunos do campo, estudar nas escolas do campo, próximas às suas residências, desenvolvendo conhecimento sobre a realidade nacional, regional e local, respeitando suas peculiaridades - terra, produção e comercialização - do que se deslocarem por muitos quilômetros, desde a madrugada, cansados, em veículos muitas vezes inaptos, para estudarem em local distante de seu território? (FERREIRA e BRANDÃO, 2017, p. 81).

Em Restinga Seca, observamos que as escolas que permanecem com atividades escolares estão centradas num perímetro rural em que circunvizinham comunidades como São Miguel Novo, São Miguel dos Carvalhos, Santa Rosa, Lomba 
Alta e Silêncio, o que dinamiza um movimento de resistência entre os sujeitos e as instituições de formação. Nas demais localidades, duas das escolas que estão em atividade, localizam-se em pontos mais distantes da cidade, ou seja, na comunidade do Jacuí e da Colônia Borges.

O território camponês é o espaço de vida do camponês. É o lugar ou os lugares onde uma enorme diversidade de culturas camponesas constrói sua existência. O território camponês é uma unidade de produção familiar e local de residência da família, que muitas vezes pode ser constituída de mais de uma família. Esse território é predominantemente agropecuário, e contribui com a maior parte da produção de alimentos saudáveis, consumidos principalmente pelas populações urbanas. (FERNANDES, 2012, p. 744).

As escolas do campo de Restinga Seca buscam incentivar os jovens à construção dos conhecimentos e oportunidades de escolha em dar continuidade às atividades da agricultura. Nas duas em abordagem, existem muitas dificuldades, porém o sentimento da equipe de professores em realizar um trabalho significativo é contínuo e motivador.

Reconhecemos a vivência de um ano atípico, histórico de pandemia, em decorrência da Covid-19, em que as restrições são inerentes aos processos de ensino e de aprendizagem das escolas. Porém, são sete escolas no campo nestes municípios, algo a ser considerado e defendido para a manutenção destas e das crianças e dos profissionais da educação em suas comunidades.

Explicitamos a seguir duas escolas que seguem ativas nas comunidades, como mencionamos, a Escola Municipal de Ensino Fundamental Manuel Albino Carvalho ${ }^{109}$, conforme a figura (2):

109 Durante a pesquisa de campo tivemos a satisfação em encontrar um aluno egresso da Universidade Federal de Santa Maria/RS, que residiu na Casa do Estudante (CEU/02) no mesmo período em que um dos autores deste artigo, sendo atualmente professor e diretor da EEEF Olmiro Pohlmann Cabral do Silêncio, e com atuação constante e comprometida com os estudantes, com a escola e com a comunidade, com o território. 
Figura 2 - Escola Municipal de Ensino Fundamental Manuel Albino Carvalho

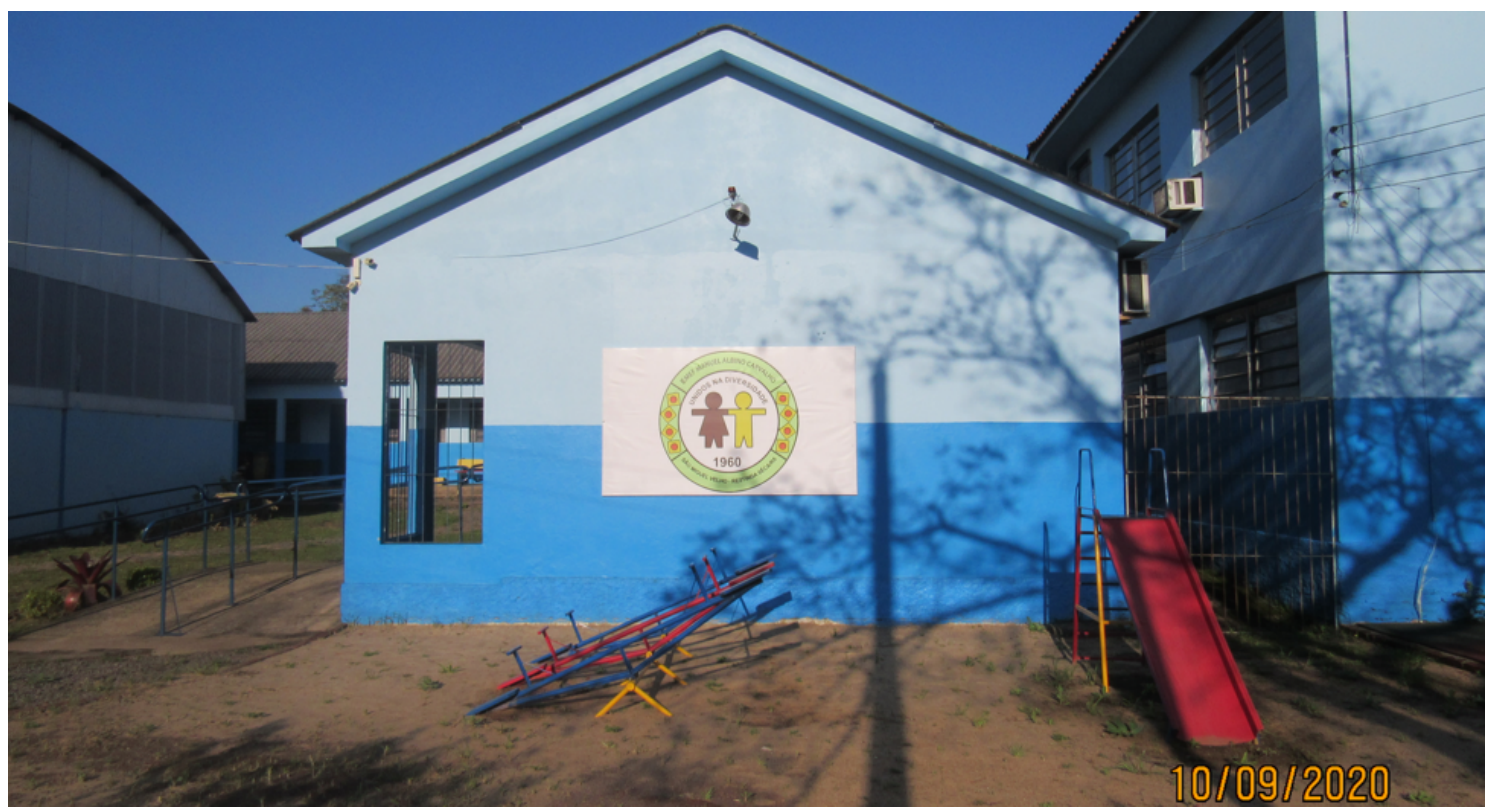

Fonte: autor, 2020

Nesta escola estiveram matriculados 103 (cento e três) estudantes em 2020, nos turnos manhã e tarde, na Educação Infantil e Ensino Fundamental, conforme o Quadro 1, abaixo:

Quadro 1: Matrículas da EMEF Manuel Albino Carvalho

\begin{tabular}{|c|c|c|c|c|c|c|c|c|c|c|c|}
\hline Modalidades & PRÉ A & PRÉ B & $1^{\circ}$ & $2^{\circ}$ & $3^{\circ}$ & $4^{\circ}$ & $5^{\circ}$ & $6^{\circ}$ & $7^{\circ}$ & $8^{\circ}$ & $8^{\circ}$ \\
\hline $\begin{array}{c}\text { Números de } \\
\text { alunos }\end{array}$ & 10 & 05 & 17 & 07 & 10 & 08 & 11 & 06 & 07 & 10 & 11 \\
\hline \multirow{2}{*}{ Turno } & $\mathrm{T}$ & $\mathrm{T}$ & $\mathrm{M}$ & $\mathrm{M}$ & $\mathrm{M}$ & $\mathrm{T}$ & $\mathrm{T}$ & $\mathrm{T}$ & $\mathrm{T}$ & $\mathrm{M}$ & $\mathrm{M}$ \\
\hline
\end{tabular}

Fonte: EMEF Manuel Albino Carvalho e Secretaria Municipal de Educação do município, 2020.

Conforme a Figura 3, trazemos a segunda instituição em atividade, a Escola Estadual de Ensino Fundamental Olmiro Pohlmann Cabral, da localidade de Silêncio, em Restinga Seca/RS. Nesta estiveram matriculados somente 13 (treze) alunos em 2020, como podemos ver em posterior Quadro 2. 
Figura 3 - Escola Estadual de Ensino Fundamental Olmiro Pohlmann Cabral

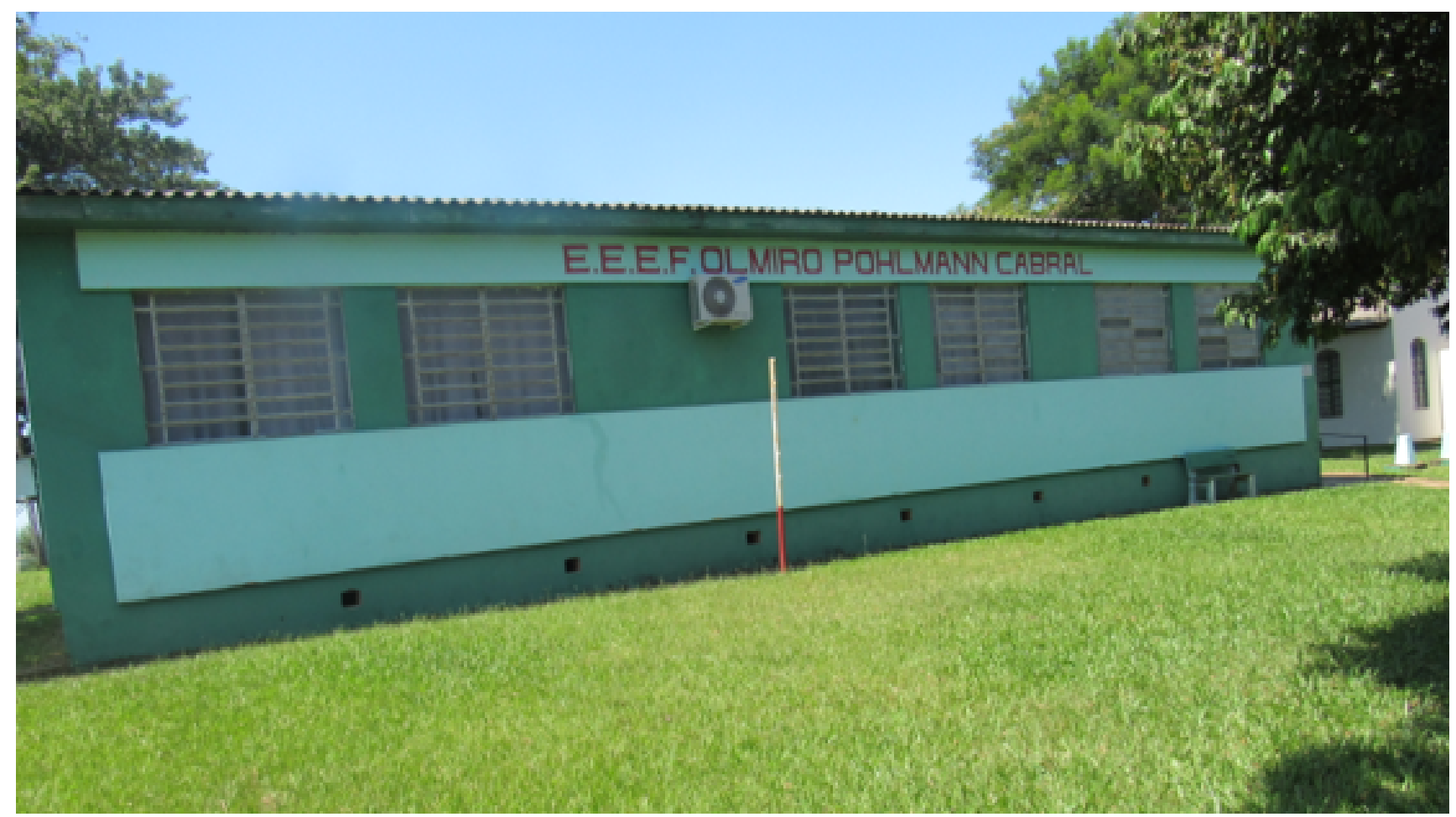

Fonte: autor, 2020

Quadro 2: Matrículas da EEEF Olmiro Pohlmann Cabral

\begin{tabular}{|c|c|c|c|}
\hline Modalidades & $2^{\circ}$ ANO & $3^{\circ}$ ANO & $4^{\circ}$ ANO \\
\hline Números de alunos & 03 & 07 & 03 \\
\hline Turno & M & M & M \\
\hline
\end{tabular}

Fonte: Direção da EEEF Olmiro Pohlmann, 2020

A figura 4, abaixo, mostra a entrega do material pedagógico escolar feita pelo Professor João Carlo Dias Trindade e a equipe de trabalho da Escola Municipal Manuel Albino Carvalho nas casas dos estudantes, em tempo de distanciamento social, decorrente da Pandemia. 
Figura 4 - Entrega de material aos estudantes, durante a Pandemia

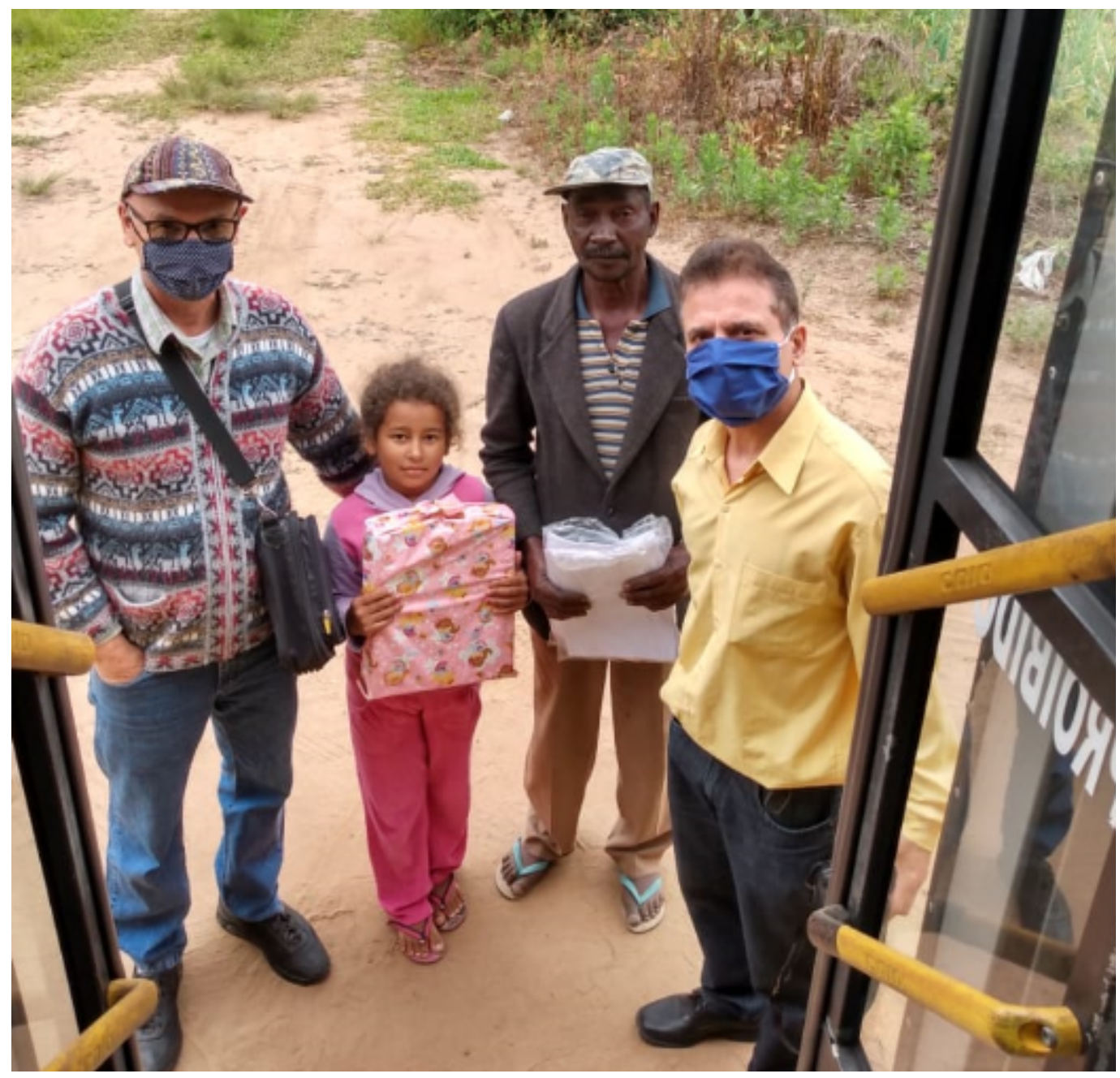

Fonte: autor, 2020

$E$, junto à equipe de professores que entregava os materiais, estava mais um egresso da UFSM, do Curso de Educação Especial, o Professor Adriano Zinn. Este educador relatou que trabalhar na escola do campo, especificamente na EMEF Manuel Albino Carvalho, "é agradável e significativo", pois os pais são interessados, os alunos estão constantemente buscando auxílio, ajudando nas atividades propostas e que, inclusive durante a Pandemia, mesmo que em muitas localidades não haja sinal de telefonia e internet, os responsáveis receberam o material com atividades escolares em casa com entusiasmo e interesse.

Freitas (2017) disserta que o Estado mínimo está na base das atuais legislações, e que mesmo que o teor legal se pareça defensável dos alunos, dos trabalhadores, dos oprimidos da sociedade capitalista, o que se visualiza são políticas de restrição de recursos destinados à educação superior que teve suas vagas estagnadas 
durante mais de 30 anos, isto é, de 1964 a 2005, foi impossibilitado que mais estudantes, especialmente os camponeses, concorressem às vagas nas universidades.

Freitas (2017) vem e se manifestando, juntamente com profissionais da educação, sociólogos, entre outros, em defesa do contraditório em relação ao fechar escolas no campo. Ao analisar a BNCC, este autor tem contribuído com elucidações e proposto alterações, inclusive na elaboração de uma outra BNCC mais comprometida e voltada aos interesses da população estudantil, especialmente aos que estudam em escolas públicas.

Neste caminho, o indivíduo cria para si uma narrativa na qual se vê como parte do mercado e, portanto, competindo com seus semelhantes pelo seu próprio sucesso, que só dependeria dele mesmo. Empurrado pelas alterações nas regras das relações trabalhistas, o livre mercado passa a ser a única possibilidade de que ele exercite a sua "liberdade" de ser bem-sucedido - em confronto com seus semelhantes - sem interferências do Estado (e dos sindicatos). Ao eliminar direitos sociais, transformando-os em "serviços a serem adquiridos", o neoliberalismo derruba a proteção social, que tornou o trabaIhador mais exigente (e mais caro) frente ao empresário - exatamente por contar com proteção social do Estado (p. ex. saúde, educação, previdência, leis trabalhistas). Desprotegido, o trabalhador acaba por ser obrigado a aceitar as imposições do mercado. (FREITAS, 2017, p. 24110)

Quais alternativas tem a classe trabalhadora frente a essa realidade? Compreendemos que haja comprometimento de intelectuais orgânicos, pensadores e instituições públicas que buscam a defesa de uma educação pública, gratuita e de qualidade que seja dos (e para os) povos tradicionais e filhos de trabalhadores que estão subjugados pelo capital. Contudo, essa luta, que é também dos sujeitos sociais do campo, precisa ser contínua e coletiva com o propósito de fecundar e desenvolver um projeto social emancipatório e sustentável, sem o comprometimento com o mercado e sua competitividade.

É importante salientarmos os diversos movimentos contínuos de luta e resistência de povos tradicionais existentes no Brasil e América Latina que articulam projetos buscando condições de vida digna para coletivos e para o planeta, por exemplo, o Movimento dos Trabalhadores sem Terra (MST) que luta por terra, educação e vida,

110 Conforme Freitas (2017), isso, associado às alterações tecnológicas no interior da produção e à guerra contra as centrais sindicais e movimentos sociais, compõe o cenário de contraposição à queda nas taxas de acumulação de riqueza. 
e a ASSESSOAR - Associação de Estudos, Orientação e Assistência Rural (2020), com sede em Francisco Beltrão/PR, que sem movimenta em defesa do não fechamento de escolas no campo, como podemos observar na figura 05 :

Figura 5 - Campanha do Assessoar juntamente com os MST

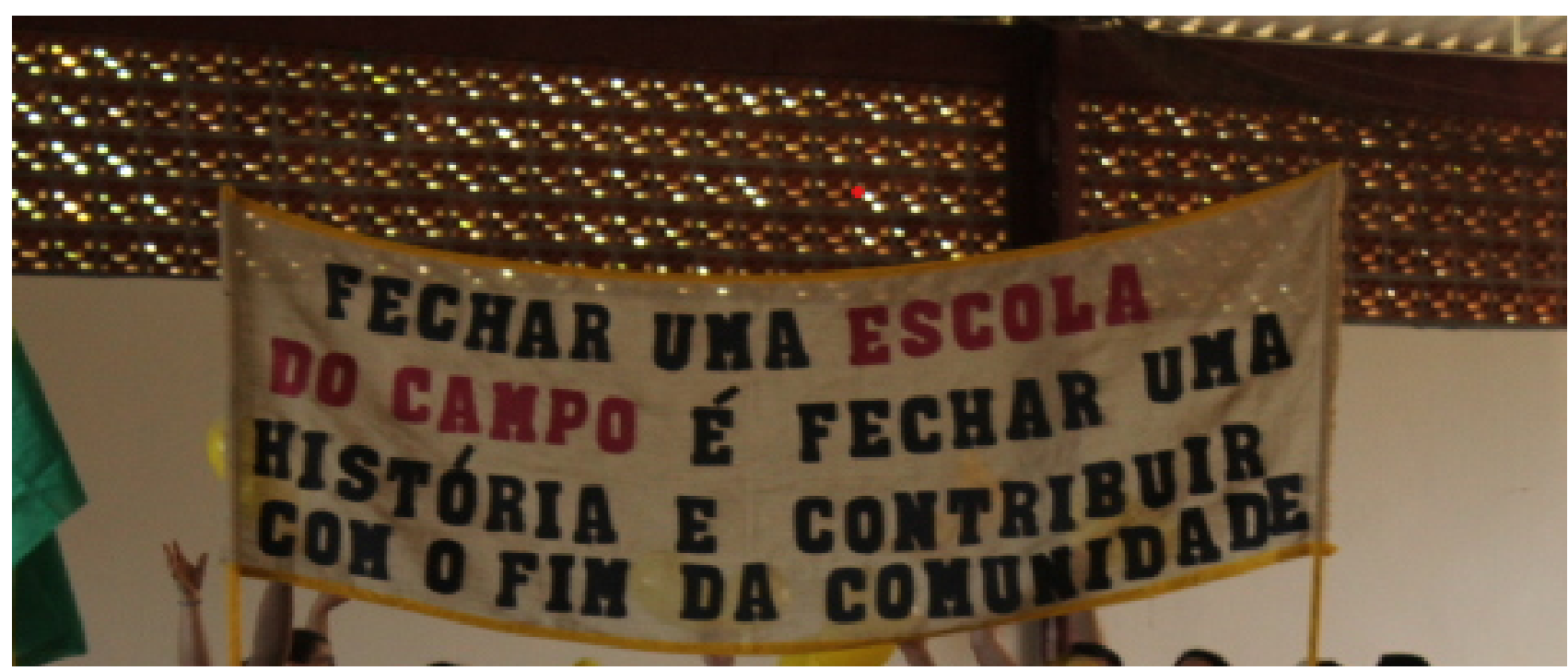

Fonte: Assessoar, 2020

Freitas (2017, p. 12) questiona sobre "qual agenda está embutida na BNCC? O que significa este movimento mundial que proclama reformas para que a educação seja de qualidade para todos? Qual qualidade? Quem são estes reformadores?". Em relação à aplicabilidade dos recursos públicos, o autor critica as chamadas escolas charter, salientando que "quando um aluno deixa uma escola da comunidade e vai para uma escola charter, sua parcela de financiamento proporcional vai com ele, enquanto o distrito continua sendo responsável por muitos custos que esses fundos apoiavam" (FREITAS, 2017, p. 55).

Conforme o autor, as escolas charter estão em ação em algumas cidades do nordeste brasileiro, cuja ideologia se origina dos Estados Unidos. Ocorre que as empresas americanas (ou de países em que elas estiverem implantadas) se beneficiam dos recursos públicos do nosso país, levando para as escolas charter alunos das escolas públicas, através da oferta de bolsas de estudos, para então tais empresas multinacionais obterem recursos públicos ou amortizações nos Impostos de Renda. 
Como dissemos, a Geografia sistematizada como ciência humana e componente curricular está colocada na Base Nacional Comum Curricular (2017) no âmbito que envolve as Humanas (Sociologia, Filosofia, Geografia e História).

Conforme Sacristán (2013), a intencionalidade de desenvolver uma educação emancipatória fica comprometida e difícil de se realizar perante às contradições e os interesses de corporações financeiras e empresas multinacionais empenhadas usufruir da sociedade dividida em classes e em manter uma parcela significativa com o papel de trabalhar para a classe hegemônica. Nesta perspectiva, tem-se que as eleições continuam sendo vencidas por partidos que defendem o capital, em detrimento daqueles que poderiam projetar e desenvolver políticas públicas advindas das necessidades e significados dos sujeitos que se movimentam, resistem e lutam por educação e pela produção de bons alimentos e em defesa da biodiversidade e da soberania alimentar nos territórios em que (re)produzem suas vidas.

A persistência e o aumento das desigualdades entre indivíduos e os povos, a
degradação do meio ambiente, o esgotamento dos recursos não renováveis,
os perigos impostos pela técnica e pela ciência desvinculada de valores, mo-
rais (o desenvolvimento de armas, a manipulação genética) começam a pôr
em dúvida a ideia de progresso na qual o binômio tecnologia-ciência se apoia
(SACRISTÁN, 2013, p. 33).

Retomando as indagações iniciais, precisamos articular a estas, as questões que fundamentam a Base Nacional Comum Curricular. Na BNCC (2017) e o ensino da Geografia, dispostas nesta resolução, visto que, conforme demonstrado nas páginas 359 a 394 do documento, do $1^{\circ}$ ano ao $9^{\circ}$ do Ensino Fundamental, as unidades temáticas são todas com o mesmo formato, colocadas conforme a Figura 6, abaixo: 
Figura 6 - Relação Unidades Temáticas e Objetos do Conhecimento da Geografia $7^{\circ}$ ano

\begin{tabular}{|c|c|c|}
\hline UMLABES TEMATICAS & cButros of con-saAENTO & HAEUDLES \\
\hline O wieite e seu ugar no manso & 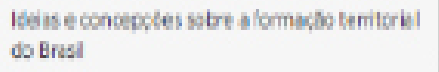 & 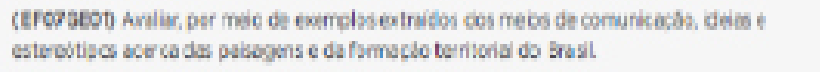 \\
\hline \multirow[t]{3}{*}{ Conwbes t evendis } & Fornaclo teritaid do Bral & 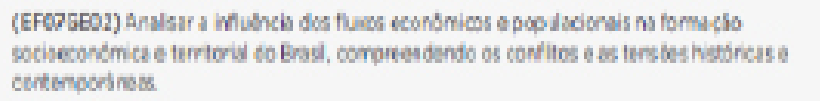 \\
\hline & & 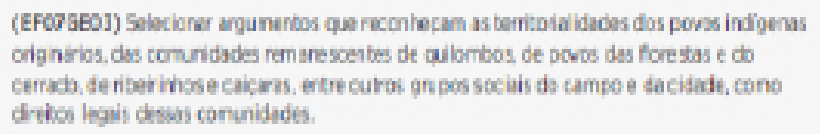 \\
\hline & 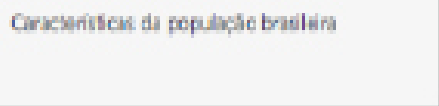 & 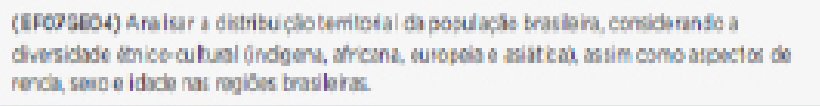 \\
\hline \multirow[t]{4}{*}{ Munde do trabulto } & Froducla, ckicua,jo s consurve demercadsrias & 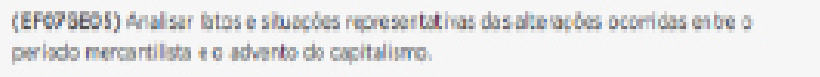 \\
\hline & & 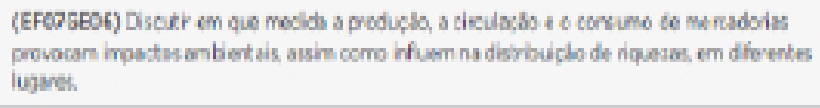 \\
\hline & Desiguabede social e o trabalio & 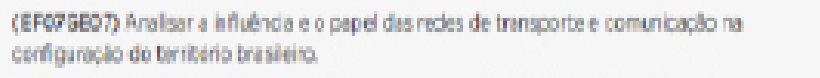 \\
\hline & & 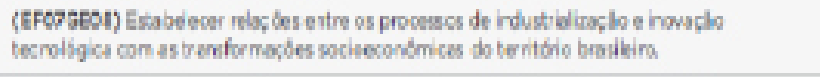 \\
\hline $\begin{array}{l}\text { Formas de representacto e pens amerto } \\
\text { elpacial }\end{array}$ & Napas tem\&icos do Brasi & 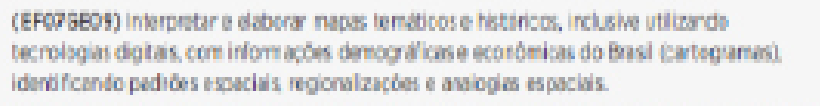 \\
\hline & & 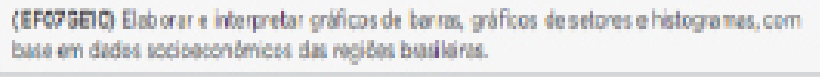 \\
\hline 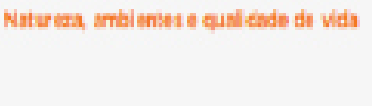 & Bedveridade brislera & 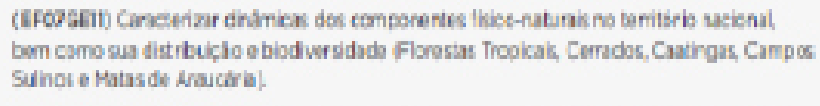 \\
\hline & & 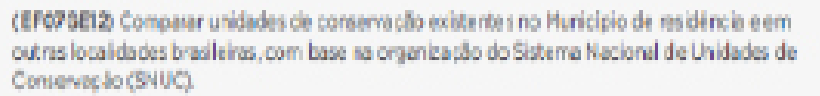 \\
\hline
\end{tabular}

Fonte: BNCC, 2017, p. 386.

Como podemos observar, em cada unidade temática apresentada consta o objeto de conhecimento a ser desenvolvido em cada ano escolar. Entretanto, como podemos verificar, esse objeto se repete da mesma forma às demais disciplinas, trocando-se somente o conteúdo do Componente Curricular e as Habilidades correspondentes. Isso comprova a desvalorização dos conhecimentos específicos e das particularidades interdisciplinares que possam possibilitar uma transdisciplinaridade do saber/conhecimento.

As incongruências e inconsistências encontradas na BNCC, destacadas por estes estudiosos, compreendem o todo do documento, como indica Guimarães (2018). A autora ressalta que o texto inicial que apresenta a proposta é demasiado curto, não chegando a dez páginas, e que embora seja destinado a evidenciar os fundamentos, os objetivos, os conceitos e as unidades temáticas que sustentam a estrutura 
curricular apresentada, demonstra somente um tecnicismo exacerbado. Afirma ainda que, embora o documento tenha sinalizado um importante problema como o da desigualdade social que, de acordo com a UNICEF (2018), 32 milhões (61\%) de crianças e adolescentes brasileiros são afetados de alguma forma com a pobreza, seria necessário ultrapassar a necessidade de mudanças técnicas do ensino, mas planejar a realização de mudanças políticas no país.

Em concordância, Freitas adverte que é preciso resistir por uma BNCC que seja pensada pela base.

Lutar pela revogação da Base Nacional Comum Curricular atual (fundamental e médio), substituindo-a por outra, que seja uma referência para os Estados, construída com os educadores e com os pais, bem como revogar a Lei da Reforma do Ensino Médios (FREITAS, 2017, p. 144).

O autor defende que a BNCC (2017) foi discutida por alguns anos, porém quando o Vice-Presidente Michel Temer assumiu o governo federal, a comissão encarregada de organizar o processo, no Governo Dilma, foi destituída e uma nova constituída. A partir disso, em num período bastante exíguo, a Resolução foi publicada atendendo às políticas do Ministério da Economia: privatizar instituições públicas o máximo possível, destituir as instituições públicas, implantar o estado mínimo, buscar modelos e formas em outros países, como o Chile e os Estados Unidos, sem considerar a realidades educacional e social do Brasil.

Faz-se urgente e necessário confrontarmos, contradizermos e buscarmos uma Educação Pública com uma BNCC condizente ao proposto pela Lei 9394/1996, ou seja, que possa dar suporte para cada componente e área do conhecimento, assim como à disciplina de Geografia e que possa ser ministrada dentro da área humana correspondente em conjunto com as demais.

\section{CONSIDERAÇÕES FINAIS}

A Base Nacional Comum Curricular destinada à Educação Básica tem um papel preponderante no currículo do Ensino Fundamental e Médio, seja em escolas do campo ou da cidade. Em análise reflexiva este foi um ensaio sobre o tema, mas que pretende abrir novas discussões em relação a esta resolução, em vigor desde 2017, e sua relação com os processos de ensino e de aprendizagem da Geografia. 
As duas escolas do campo do município de Restinga Seca, no Rio Grande do Sul, em destaque no texto, continuam em atividade como resistência camponesa contra as incisivas imposições do mercado que não mede esforços para fechá-las. Desse modo, a continuidade da Escola Olmiro Pulmann Cabral e da Escola Manuel Albino Carvalho faz parte do grande desafio que se impõe no sentido de uma educação que possa atender efetivamente os sujeitos em seus lugares de vida.

O conhecimento geográfico tem sido uma epistemologia fundamental para possibilitar que os sujeitos em formação reconheçam o território como um espaço a ser produzido pela luta coletiva, conforme as necessidades comuns de camponeses, que seguem resistindo aos desafios e contradições do agronegócio. A apropriação destes conhecimentos, em processos de ensino e de aprendizagem em escolas do campo, pode ser um modo efetivo para que as comunidades em movimento possam fortalecer o lugar e a função social da escola, na direção da continuidade e do não fechamento de escolas como estas, em Restinga Seca/RS.

Mais que pedagógica, a Base Nacional Comum Curricular precisa assegurar politicamente quais epistemologias específicas da Geografia serão capazes de contribuir para a territorialização das escolas e dos sujeitos do campo. Compreendemos a questão educacional que envolve o fechamento de escolas e a consequente desterritorialização de saberes, conhecimentos, valores comunitários, produção de bons alimentos e continuação da humanidade, como consequência das políticas públicas implementadas no país.

Defendemos a Geografia como disciplina a ser ministrada no Ensino Fundamental e Ensino Médio e que seja tema de discussão nas abordagens das instituições de ensino superior de modo a potencializar espaços públicos que articulam território, educação e dignidade humana. A luta continua, a começar pela revogação da BNCC em vigor e a constituição de outra que seja produzida pela base, pela classe trabalhadora.

\section{REFERÊNCIAS}

BNCC - Base Nacional Comum Curricular. Resolução CNE/CP n ${ }^{\circ}$ 2. Ministério da Educação. Publicada a. dia 22 de dezembro de 2017. Disponível em: http://portal.mec.gov.br/index.php?option=com docman\&view=download\&alias=79631-rcp002-17-pdf\&category_slug=dezembro-2017-pdf\&ltemid=30192. Acesso em: 10 de 
mar. 2021.

ASSESSOAR, FEDEL, André de Souza et al. Educação do Campo: direito nosso, dever do Estado! ASSESSOAR, Francisco Beltrão, Paraná. 2020. Disponível em: https://assesoar.org.br/ educação-do-campo-direito-nosso-dever-do-estado/. Acesso em: 22 de Jan. 2020.

FERREIRA, F. de J.; BRANDÃO, E. C. Fechamento de Escolas do Campo no Brasil e o Transporte Escolar entre 1990 e 2010: na contramão da Educação do Campo. Imagens da Educação, v, 7, n. 2, p. 76-86, 2017.

FERNANDES, Bernardo Mançano. Território camponês. In: CALDART, Roseli Salete; PEREIRA, Isabel Brasil; ALENTEJANO, Paulo; FRIGOTTO, Gaudêncio. (Orgs.). Dicionário da Educação do Campo. São Paulo: Expressão Popular, p. 744-747, 2012. FREITAS, Luiz Carlos de. A REFORMA EMPRESARIAL DA EDUCAÇÃO: Nova direita, velhas ideias. São Paulo: Expressão Popular, 2018.

GROFF, A. Desterritorialização das Escolas do Campo no município de Dona Francisca/RS. Dissertação (Mestrado), Universidade Federal de Santa Maria, Programa de Pós-Graduação em Geografia - PPGGEO, 2016.

GUIMARÃES, lara Vieira. Ensinar e aprender Geografia na Base Nacional Comum Curricular (BNCC). Ensino Em Re-Vista, Uberlândia, MG, v. 25, $n^{\circ}$ Especial, p. 1036-1055, 2018

BRASIL. Secretaria de Educação. Parâmetros curriculares nacionais: geografia Secretaria de Educação Fundamental. Brasília: MEC/ SEF, 1998.

SACRISTÁN, José Gimeno. O que significa o currículo? In: Saberes e Incertezas sobre o Currículo (recurso eletrônico). Org.: José Gimeno Sacristán. Porto Alegre: Penso, 2013.

SEBRAE: Perfil_Cidades_Gauchas-Restinga_Seca.pdf - SEBRAE 2019. Disponível Inhttps://datasebrae.com.br/municipios/rs/Perfil Cidades Gauchas-Restinga Seca. pdf, Acesso em: 14 nov 2020 


\section{NOTAS DE UMA ETNOGRAFIA} DA PEDAGOGIA DOS POVOS ATINGIDOS POR BARRAGEM: UMA EXPERIÊNCIA DE EDUCACÁO DO CAMPO NO AGRESTE PARAIBANOM

Givanilton de Araújo Barbosa ${ }^{112}$

111 Apresentei este estudo no "I seminário nacional de educação popular e movimentos sociais do campo: $V$ encontro de pesquisas e práticas em educação do campo da Paraíba" realizado no Centro de Educação da UFPB, no ano de 2019. Sua primeira versão teve o título:estudo antropológico acerca da "pedagogia dos povos atingidos" por barragem. Já o presente conteúdo se refere ao relatório desta pesquisa onde ampliei a sistematização de dados etnográficos, configurando uma nova versão dos resultados preliminares.

112 Mestrando em Antropologia e Licenciado em Ciências Sociais pela UFPB. givaniltonbarbosa10@gmail.com 
Antes de falar da Pedagogia dos povos atingidos por barragem, gostaria de destacar brevemente a noção de cultura local neste processo. Um território é construído socialmente, onde culturas e políticas são produzidas constantemente, isto é, atividades produtivas à manutenção social resultam numa dinâmica social que pode modificar tanto os modos de vida social quanto da localidade (GLUKCMAN, 1987).

Quanto ao estudo interpretativo da cultura local, representa um esforço social para "aceitar a diversidade entre várias maneiras que seres humanos têm de construir suas vidas no processo de vivê-las” (GEERTZ, 1997, p. 29). Os povos ribeirinhos, por exemplo, podem apresentar seus próprios modos de vida. No entanto causas e efeitos permitem criar novas configurações sociais e territoriais.

Geertz (1997, pp. 13-15) afirma que ao abandonar a tentativa de explicar fenômenos sociais através de uma metodologia que os tece em redes gigantescas de causas e efeitos, teria que tentar explicá-los colocando-os em estruturas locais de saber, isto é, " a cultura é adquirida, os costumes variam, o mundo é composto por uma variedade de tipos humanos". Ou seja, a compreensão da diversidade de culturas implica em considerar um princípio norteador: o da alteridade.

Segundo Geertz (1997, p. 115) o conceito de cultura "implica em analisar o senso comum e não necessariamente seu exercício, deve, portanto, iniciar-se por um processo em que se reformule esta distinção com reflexão prévia aos problemas sociais cotidianos". E para Velsen (1987):

"A cultura não é meramente um sistema de convicções e práticas formais. É essencialmente formada por reações individuais a um padrão tradicionalmente determinado e por variações deste padrão; e, realmente, nenhuma cultura jamais poderá ser entendida se a atenção especial não for dedicada a esta variação de manifestações individuais" (p. 355).

Dessa maneira, o estudo antropológico pode permitir identificar as mudanças em sociedade, ao mesmo tempo leva em conta a alteridade e particularidades das relações socioculturais e ambientais que foram estabelecidas em um território. Isto posto, o presente conteúdo se refere a um relatório de pesquisa sobre a Pedagogia dos Povos Atingidos Por Barragem do Brasil. 
Trata-te de um estudo etnográfico que analisará a criação e finalidade da pedagogia dos povos atingidos por barragem; traçará o seu percurso; mapeará as práticas pedagógicas articuladas ao movimento social, desde seu ponto de vista histórico, e contextualizará a condição dos atingidos por barragem.

Adotei a abordagem qualitativa como caminho metodológico e sistematizei os dados etnográficos prévios por meio de uma revisão bibliográfica. Considero como teoria antropológica para o estudo da cultura local os seguintes autores: (CLIFFORD, 2002), (MALINOWSKI,1978) e (GEERTZ, 1989).

Já o percurso da história do Movimento dos Atingidos por Barragem no Brasil (MAB, 2005) também faz parte dos passos metodológicos, visando caracterizar tanto a criação da "Pedagogia dos Povos Atingidos" (MEDEIROS, 2010) quanto a formação da Política Educacional do MAB (2005).

Outro passo metodológico importante é o estudo dos princípios da Educação do Campo (BRASIL, 2010), (CALDART, 2004) e (MANÇANO e MOLINA, 2004), articulados ao conceito de Movimentos Sociais (GONH, 1995), enquanto ações coletivas para entendimento da realidade social da população pesquisada. Em suma, aponto três terrenos etnográficos (BARBOSA, 2017) que são aspectos sociais de cada contexto da pesquisa, identificados nesse primeiro momento.

Ao assinalar a pedagogia dos povos atingidos do MAB (2005) aponto a questão local da implantação do Movimento dos atingidos por barragem nas comunidades atingidas pela barragem de Acauã no ano de 2000, que envolve as comunidades Cajá e Melancia do município de Itatuba, comunidade da Costa de Natuba e Pedro Velho de Aroeiras, agreste do Estado da Paraíba.

Há também investigação da abordagem do uso pelo MAB da concepção de Educação do Campo (CALDART, 2009), adotada pelo Movimentos dos Atingidos por Barragem (2005) para a formação e organização coletiva do movimento da população atingida de Acauã.

A justificativa desta pesquisa se concentra na identificação de novas práticas educativas associadas aos movimentos sociais na cultura local, se configurando em uma região enquanto demanda. Haja vista, tais novas práticas educativas, ligadas à políticas educacionais, resultam de novas demandas sociais, diante de uma sociedade cada vez mais globalizada e em constante mudança, especialmente atreladas às 
populações do campo atingidas por barragem.

Diante do exposto, resta saber: enquanto política pública de educação do movimento dos atingidos por barragem do Brasil, como se constituiu a Pedagogia dos povos atingidos por barragem nos reassentamentos atingidos de Acauã?

\section{MOVIMENTOS SOCIAIS E EDUCAÇÃO}

Conforme discutido em Gohn (2011, p. 333) os movimentos sociais sempre fizeram parte da construção das sociedades, pois são mecanismos vitais ao processo de mudança do meio social. São, portanto, um dos meios de conversão de uma sociedade em uma nova realidade a partir da ação coletiva:

"Movimentos sociais são ações coletivas de caráter sociopolítico, construídas por atores sociais pertencentes a diferentes classes e camadas sociais. Eles politizam suas demandas e criam um campo político de força social na sociedade civil. Suas ações estruturam-se a partir de repertórios criados sobre temas e problemas em situações de conflitos, litígios e disputas. As ações desenvolvem um processo social e político-cultural que cria uma identidade coletiva ao movimento, a partir de interesses em comum. Esta identidade decorre da força do princípio da solidariedade e é construída a partir da base referencial de valores culturais e políticos compartilhados pelo grupo" (GOHN, 1995, p. 44).

Neste sentido os movimentos sociais se caracterizam, sobretudo, pelo sentimento de coletividade voltado à resolução de problemas, seja de ordem política, econômica ou sociocultural, que são de interesse compartilhado do grupo. Há, então, a criação de uma percepção acerca de movimentos sociais, a Educação, podendo agir de maneira pedagógica no "processo formativo libertário emancipatório" nos espaços de vivências (FREIRE, 1984).

Para Gohn (1995) é importante perceber o viés marxista de análise crítica sobre as mudanças sociais, isto é, os movimentos sociais podem possibilitar a organização de um grupo social insatisfeito com mudanças impostas pelo sistema capitalista.

Portanto é importante perceber os movimentos sociais do ponto de vista da cultura local; neste caso, a análise também pode partir da relação entre comunidade e escola observando suas particularidades e finalidades; se há articulações entre proposta de educação contextualizada e da politização ou sistematização das demandas sociais locais. 
Da politização das demandas pelos movimentos sociais podem surgir diversas propostas de políticas públicas articuladas à direitos sociais da Constituição Federal do Brasil (1988). A Política de Educação do Campo é uma demanda social oriunda das experiências históricas dos povos do campo (FERNANDES e MOLINA, 2004).

Conforme Caldart (2009, p.36) discutir sobre a Educação do Campo hoje, buscando ser fiel aos seus objetivos de origem, nos exige um olhar de totalidade, em perspectiva, com uma preocupação metodológica, sobre como interpretá-la, combinada a uma preocupação política, de balanço do percurso e de compreensão das tendências de futuro para poder atuar sobre elas.

Segundo Caldart a "Educação Rural" situa-se em uma educação eurocêntrica colonizadora, onde seu objetivo principal é de colonizar o outro para que possa atender suas necessidades para a manutenção do capital estrangeiro e nacional, sobretudo desconsiderando os modos de vida dos trabalhadores do campo e tornando-os assalariados, por sua vez, acarretando a desvalorização dos modos de vida do Campo:

\begin{abstract}
"Pensar a Educação do Campo é estar junto com uma concepção de Campo de significados e assumir uma visão de totalidade dos processos sociais, é reconhecer os processos históricos brasileiros que formou o modelo de sociedade, é garantir avanços institucionais que percebam a valorização da vida cultural e social do Campo, é perceber a exploração da força de trabalho que resultou na pobreza extrema e desvalorização do campo" (CALDART, 2004, p. 5).
\end{abstract}

Dessa maneira, os modos de vida são revistos por meio da perspectiva da Educação, porém, levando em consideração todas as esferas da vida social [cultura, economia local, trabalho e renda, saberes tradicionais, território e outros] que abrangem direta e indiretamente as populações do campo em questão.

Trata-se também de acionamentos de dispositivos institucionais do campo jurídico que regulam políticas sociais locais do cenário social em questão, uma vez que envolve a comunidade em sua totalidade considerando seus conflitos e saberes no processo de vivê-los, considerando tanto seu passado quanto o presente. 
Dito isto, as especificidades da Educação do campo são formas de reaver os modos de vida das famílias, e de que essa população se reconheça como tal, podendo permitir a valorização e pertencimento de sua própria organização:

A Educação do Campo é uma Política Pública que propõe reaver a trajetória dos modos de vida de comunidades, saberes e fazeres do Campo. Revisitar as trajetórias de vida da população camponesa, atenuando para as mudanças sociais devido a inserção da industrialização e que distanciou o Camponês de sua própria identidade e pertencimento enquanto camponês (CALDART, 2004, p. 7).

É necessário reconhecer essas transformações sociais do ponto de vista capitalista e de projeto internacional, por outro lado, requer formação humana para situar as pessoas a reconhecer seu contexto social e possibilitar o acesso da população do Campo à Universidade, e construir o diálogo entre esses espaços na produção de conhecimento.

Portanto, ao falar de Educação do Campo, enquanto Política Pública, Nascimento (2009, p. 189) considera "um processo de construção de um projeto Popular Alternativo de desenvolvimento para o Brasil e para a realidade camponesa", especificando novos valores éticos e culturais.

Ou seja, a Educação do Campo ocupa-se em pensar o campo e sua gente; seu modo de organização social; do trabalho; espaço geográfico; da organização política; de suas identidades culturais; celebrações e seus conflitos.

Segundo Fernandes e Molina (2004), de 1997 a 2004, ocorreu a especialização da Educação do Campo através de diversos movimentos sociais, discutindo a escolarização das populações do campo; construção de materiais didáticos apropriados, valorizando as práticas dos educandos e permitindo maior participação nos seminários locais, regionais e nacionais:

"A ideia de criação da Política Educacional de Educação do Campo nasceu em julho de 1997, quando da realização do Encontro Nacional de Educadores da Reforma Agrária - ENERA, na Universidade de Brasília (UnB) promovido pelo Movimento dos Trabalhadores Rurais Sem Terra - MST, em parceria com a UnB, Fundo das Nações Unidas para a Infância - UNICEF, a Organização das Nações Unidas para a Educação, Ciência e Cultura - UNESCO e a Conferência Nacional dos Bispos do Brasil - CNBB no processo de construção partindo de estudos, pesquisas e reflexões realizadas a respeito das diferentes realidades do campo" (FERNANDES e MOLINA, 2004, p. 4). 
Com base em muitos estudos e pesquisas, professores e pesquisadores de diferentes áreas de conhecimento possibilitaram a legalização da modalidade de ensino, a educação do campo, pelo decreto $n^{0} 7.352$, de 4 de novembro de 2010 (BRASIL, 2010), aprovando a Política de Educação do Campo, que por sua vez representa todas as experiências dos povos do campo, sendo indispensável seu Art: $2^{\circ}$, em que constam seus princípios, a saber: Respeito à diversidade do campo; Incentivo à formulação de projetos político pedagógicos específicos para as escolas do campo; Desenvolvimento de políticas de formação de profissionais da educação do campo; Valorização da identidade da escola do campo por meio de projetos pedagógicos com conteúdo curriculares e metodologias adequadas às reais necessidades dos discentes do campo; Controle social da qualidade da educação escolar, mediante a efetiva participação da comunidade e dos movimentos sociais do campo (BRASIL, 2010).

Segundo Fernandes e Molina (2004, p. 4-7) a área da Educação do Campo é analisada a partir do conceito de território como espaço político, onde se realizam determinadas relações sociais, que se transformam em projeto de desenvolvimento socioeconômico, cultural e ambiental, e contribuem para transformar a realidade. De tal modo que "trabalhar na terra, tirar da terra a sua existência, também exige conhecimentos que são construídos nas experiências cotidianas e como também na escola".

Quanto às experiências cotidianas, o território é um espaço de relações socioculturais, de disputas e de ligações afetivas, também construído entre grupo sociais, isto é, "compreender a territorialidade como o conjunto daquilo que se vive pelo conjunto no cotidiano", as relações de trabalho, familiares, comunitárias, de consumo, de tal modo a não homogeneizar a sociedade (SOUZA e PEDON, 2007, p. 136).

Souza e Pedon (2007) discutem que a construção da identidade no território é um processo que se constrói ao longo do tempo, tendo como principal elemento o sentimento de pertencimento do indivíduo ou grupo com seu espaço de vivência; e pertencer ao espaço em que se vive; conceber o espaço como lócus das práticas sociais e culturais, ou seja, onde se tem o enraizamento de sociabilidade, há o espaço com caráter de território. 
De modo geral, a educação do campo faz parte da política educacional brasileira como modalidade de ensino e aprendizagem para além dos muros da escola, e implanta cursos de graduação e pós-graduação nos diferentes territórios brasileiros.

A Educação do Campo é resultado de um longo processo histórico dos povos do campo, de suas lutas sociais por direitos, especialmente, em resposta às desigualdades educacionais, e da ausência de escolas de qualidade, que garantem o direito desses povos à educação e contemplam suas culturas e modos de vida.

\subsection{Terreno etnográfico I}

\section{A história dos atingidos por barragem}

O Movimento dos Atingidos por Barragem (MAB) vem constituindo uma história de luta e resistência social junto de populações ribeirinhas e outras. De acordo com Maria José Reis (2007, p. 473), estudiosa da área, no Brasil o movimento dos atingidos por barragens teve início por volta do final da década de 1970, na região do alto Uruguai RS/SC, devido aos prejuízos de grandes implantações de hidrelétricas em busca da produção de energia elétrica.

De maneira simultânea, comunidades ribeirinhas, como agricultores, pescadores e indígenas vêm sendo deslocadas de seus lugares e reassentadas distantes do rio, de modo que passam a ter seus direitos violados.

O MAB como um movimento de luta constante junto aos atingidos atua na assessoria de organização e pautas de reivindicação diante de órgãos oficiais do Estado brasileiro, objetivando a fim de reconstruir a infraestrutura de educação, saúde e habitação dignas para exercício de uma plena cidadania das populações atingidas. Elaboraram sua própria política de mobilização ao longo do tempo de sua atuação junto às populações para consolidação desta causa (REIS, 2007).

Segundo Santos (2015, pp.115-117), ao discutir o tema com base na teoria de Carlos Wainer, o "conceito de atingido" diz respeito ao reconhecimento e legitimação de direitos de seus detentores. Ou seja, é estabelecer que determinado grupo social, família ou indivíduo é atingido por certo empreendimento; significa reconhecer a violação de direitos, o legítimo direito de ressarcimento, indenização, reabilitação ou 
reparação.

Em meio a isso, acontece a realocação de populações ribeirinhas em reassentamentos, na maioria, em lugares áridos, tornando sua principal característica a perda da qualidade de vida, e ao mesmo tempo, a perda de qualidade ambiental.

Portanto, o surgimento da categoria social de "atingidos por barragem" está relacionada à construção de identidades individuais e coletivas de interações sociais, políticas, e produção de cultura de um povo; isso se constrói ao longo da vida social se configurando numa resistência coletiva (SANTOS, 2015).

\subsection{Terreno etnográfico III}

\section{A pedagogia dos povos atingidos por barragem}

Ao considerar o período de redemocratização do Brasil, que favoreceu a construção e fortalecimento de lutas sociais, houve também a organização de novos movimentos e demandas (GOHN, 1995). Com base nisso, destaco a construção da "Pedagogia dos povos atingidos" por barragem (MEDEIROS, 2010).

Em meio a tantas contribuições destaco a organização do $1^{\circ}$ Encontro "Coletivo de Educação", realizado entre os dias 07 a 10 de agosto de 2004, na Cidade de Luziânia no Estado de Goiás. O seminário contou com a participação de 30 colaboradores ligados à Educação de 14 Estados brasileiros, incluindo Estados nordestinos, como Sergipe, Ceará e Paraíba.

Outro levantamento foi a mobilização diante da proposta, de forma coletiva, dos coordenadores Estaduais que se integraram ao Coletivo de Educação, em traçar o Projeto inicial de Educação do Movimento dos Atingidos por Barragem do Brasil. Dessa maneira, a proposta de pensar uma "Pedagogia dos Povos Atingidos por Barragem" consiste substancialmente em:

"qualificar por meio de práticas educativas o processo de conscientização, participação e organização das pessoas, que direta ou indiretamente sofreram modificações nas condições de vida em consequência da implementação de barragens, e também realizando planejamento para a capacitação nos Estados com viabilidade para o desenvolvimento do processo de formação dos Educadores à nível nacional” (MAB, 2005, pp. 25-36). 
A partir deste encontro um projeto de educação foi elaborado com as demandas recolhidas e lançado naquele mesmo ano, denominado "A Pedagogia dos Povos Atingidos", a fim de adotar os princípios da Educação do Campo para o entendimento da população local. A coordenação Nacional do Movimento de Atingidos por Barragem do Brasil sistematizou uma proposta de educação ampla e consistente para ser implantada nas comunidades reassentadas.

Assim, os coordenadores estaduais se articularam com os coordenadores nacionais para a implantação do projeto de educação nas respectivas regiões foram viabilizadas parcerias com as secretarias dos Estados e Municípios na elaboração de políticas sociais voltadas às populações atingidas.

Um aspecto importante foi a vinculação da proposta educativa do MAB (2005) às questões, desafios e mobilizações em prol também da Educação do Campo (2010), mas com diretrizes e perspectivas próprias, dando respaldo às reivindicações de políticas públicas de desenvolvimento e de educação específicas, direcionadas aos camponeses com identidade, trabalho, cultura, história e suas formas e estágios de organização, visando a abrangência de todos os níveis de escolaridade.

Diante da uma proposta formulada enquanto política pública de educação foram realizados acordos e convênios entre o Movimento dos Atingidos por Barragem e instituições públicas. Passa, então, a ser constituída uma rede de articulação estadual para mobilizar as comunidades atingidas para o enfrentamento e reivindicações no processo de solucionar os problemas socioeconômicos e ambientais vividos por elas.

Reincide também na proposta de Educação do MAB Brasil (2005) o reconhecimento do campo como espaço de vida, moradia e trabalho, resultando na necessidade de justiça e humanização dos povos atingidos que vivem nesse espaço e que foram historicamente excluídos do direito à Educação e à Cultura eruditas. Tal proposta educativa lista uma série de diretrizes, dentre elas: diagnosticar as necessidades de Educação dos povos atingidos; fortalecer sua história e cultura; mapear financiamentos, editais, convênios e parcerias; elaborar projetos específicos e materiais didático-metodológicos para o trabalho pedagógico (MAB, 2005).

Um aspecto importante nesse processo são as articulações político-educacionais; iniciativas do MAB diante de instituições públicas e privadas. A ocorrência mais emblemática foi com o Ministério de Educação e Cultura - MEC, para a aquisição de 
convênios, especialmente no período de 2004 a 2016, com muitas intermitências. Conforme discutido por Medeiros (2010), este tipo de convênio possibilitou às entidades adotar uma linha teórico-metodológica própria, principalmente para a Alfabetização de Jovens e Adultos.

Dessa forma, tendo sido garantidas as condições básicas de financiamento do Projeto, o MAB seguiu a linha própria do Movimento (MEDEIROS, 2010). Com essas iniciativas e reivindicações do MAB nacional foram adquiridos convênios com estatais e desenvolvidas atividades através das políticas educacionais, garantindo as especificidades que o movimento defende.

A Educação de jovens e Adultos (EJA) foi uma das principais pautas da Pedagogia dos Povos Atingidos por Barragem, através de um convênio do MAB nacional com o MEC e ELETROBRAS. Neste projeto houve duas etapas, de 8 meses cada, contemplando todos os reassentamentos atingidos por barragem.

Diante de uma questão social tão complexa há nesse processo a criação da Pedagogia dos Povos Atingidos por Barragem: de inspiração Freiriana (1983: 1984), considera o índice de vulnerabilidade socioeconômica, de analfabetismo e escolaridade incompleta das populações que são atingidas por implantação de barragens, tanto de hidrelétricas quanto barragens de abastecimento de centros urbanos:

"[...] os atingidos precisam conhecer a História do Brasil dentro do cenário mundial, a organização da estrutura da sociedade para compreender sua conjuntura local, o funcionamento do capitalismo internacional para entender o capitalismo nacional, o poder político das esferas nacional e internacional para compreender o poder político local, dessa maneira, levando em conta o conhecimento por meio da interdisciplinaridade, complementaridade e totalidade" (MAB, 2005, pp. 37-40).

Seu currículo contempla uma estrutura na perspectiva de circunscrever o indivíduo atingido. Medeiros (2010, p. 209), ao observar os objetivos da pedagogia do MAB, afirma que sua proposta contém: I. Fonte sociocultural; II. Fonte Políticoorganizativa; III. Fonte epistemológica e IV. Fonte Psicossocial.

Já no ano de 2015 foi desenvolvido o projeto Brasil Alfabetizado, convênio entre o MAB e o Governo do Estado da Paraíba. Desta vez, o projeto também contempla a Educação de Jovens e Adultos nos reassentamentos, agenciadas pela secretaria 
de Educação do Estado e o Movimento dos Atingidos por Barragem; o segundo encarregando-se de fazer a mobilização em cada reassentamento.

De modo geral a coordenação do MAB Nacional (2005) considerou um avanço como movimento social organizado, inserindo a Educação na sua agenda política como um direito social a ser conquistado (MEDEIROS, 2010).

Ao mesmo tempo, o MAB preocupou-se em conquistar espaços próprios de Educação Formal, garantindo certificação oficial e práticas educativas que consolidem a conscientização dos atingidos num contexto de resistência, organização e luta com populações atingidas por barragens em diferentes territórios do Brasil.

\subsection{0 terreno etnográfico III}

\section{Os atingidos de Acauã}

A pesquisa de campo ocorre em uma área territorial considerando três reassentamentos agrovilas: Sítio Cajá e Sítio Melancia, localizados no município de Itatuba, e do distrito de Pedro Velho, do município de Aroeiras, todos no agreste do estado da Paraíba.

Medeiros (2010) e Barbosa (2017) discutem os efeitos nas comunidades ribeirinhas desde o ano 2000, período em que aconteceu a implantação da barragem de Acauã, na bacia hidrográfica do rio Paraíba, também sinalizam o profundo rompimento com o lugar junto do rio, além de perdas de terras, atividades produtivas e deslocamentos para reassentamentos em agrovilas.

Ao analisar o levantamento do dossiê organizado pelo MAB sobre os efeitos causados nas comunidades atingidas por Acauã (Dossiê sobre a situação da população atingida por Acauã 2005: 2007) constatei que há em média 5 mil habitantes atingidos pela represa. Com base nesse levantamento optei por continuar a estudar esta região, pois também residi em uma das comunidades atingidas por Acauã, no sítio Cajá. Com minha inserção no curso de Licenciatura em Ciências Sociais na UFPB passei a estudar o tema atingidos por barragem, resultando em ações extensionistas e em meu trabalho de conclusão de curso.

Nesta perspectiva, ao identificar um fator crucial na localidade pesquisada, que foi a existência da Pedagogia dos povos atingidos, venho sistematizando a 
pesquisa para levantar essa demanda local provocada pela questão educacional e socioambiental.

Portanto, as contribuições principais da pedagogia dos povos atingidos por barragem nos reassentamentos atingidos pela barragem de Acauã são: a experiência de implantação da educação de jovens e adultos (EJA) (MEDEIROS, 2010), do acionamento da política de educação do campo e de articulações com prefeituras municipais locais e governo do Estado. Resta saber como estão essas ações, as quais pretendo apresentar nos próximos resultados.

\section{ALGUMAS CONSIDERAÇÕES}

O estudo preliminar analisou os primeiros resultados de um relatório de pesquisa sobre a "Pedagogia dos Povos Atingidos por Barragem" do Movimento dos Atingidos por Barragem do Brasil. Foram discutidos aspectos teóricos e metodológicos que permitiram iniciar o mapeamento sobre os processos educacionais referentes ao movimento dos atingidos por barragem e da educação do campo em um terreno etnográfico.

Por conseguinte, identifica-se que há uma articulação nacional do Movimento dos Atingidos por Barragem com a política de educação, imbricada com a realidade social dos povos do campo e seus efeitos causados por implantação de barragens de Acauã no Estado da Paraíba.

$\mathrm{Na}$ região da barragem de Acauã vem se configurando um contexto social de luta e resistência social dos povos do campo: ribeirinhos em reassentamento, agricultores e pescadores, com um expressivo caráter protagonista, diante de políticas educacionais com direcionadas à Educação do Campo, enquanto papel revitalizador da população local.

Portanto, a Pedagogia dos Povos Atingidos por Barragem demonstra um caráter democrático, pois leva em conta os modos de vida dos atingidos e suas demandas articuladas à política de Educação do Campo. Também permite compreender a importância e o significado dos movimentos sociais, no papel de assegurar às populações atingidas por barragem o direito à Educação, bem como o potencial nas articulações para reconstrução social em reassentamento. 
BARBOSA, G. A. Educação ambiental crítica: experiência em escola de um reassentamento de atingidos por barragem na Paraíba. Orientadora: Profa. Dra. Maristela Oliveira de Andrade. Trabalho de conclusão de curso (Licenciatura em Ciências Sociais). João Pessoa, CCHLA-UFPB, 2017. 92pp.

BRASIL. Decreto 7.352, de 4 de novembro de 2010. Política de educação do campo. Brasília, DF, 2010.

BRASIL. Constituição federal de 1988. Brasília, DF.

BARTH, Fredrik. A análise da cultura nas sociedades complexas. In.:O guru, o iniciador e outras variações antropológicas. Rio de Janeiro. Contracapa Livraria. 2000.

CALDART, Roseli Salete. Educação do campo: notas para uma análise de percurso. In.: Trab. Educ. saúde [online], v. 7, n. 1p. 35-64, 2009. Disponível em: http://www. epsjv.fiocruz.br/upload/d/Caldart.pdf

. Elementos para construção do projeto político e pedagógico da Educação do Campo. Trabalho Necessário. ano 2 - número 2 - 2004.

CLIFFORD, James. A experiência etnográfica. Antropologia e literatura no século XX. Rio de Janeiro: Editora da UFRJ, 2002.

Dossiê sobre a situação da população atingida por Acauã. Org. Movimento dos atingidos por barragem, Campina Grande, dezembro de 2005. In.: Conselho de Defesa dos Direitos da Pessoa Humana Comissão Especial "Atingidos por Barragens. Brasília, DF. 2007.

FREIRE, Paulo. Extensão ou comunicação? Tradução de Rosisca Darcy de Oliveira. prefácio de Jacques Chonchol. $7^{\text {a }}$ ed. Rio de Janeiro, Paz e Terra, 1983.

. Pedagogia do oprimido. Rio de Janeiro. Paz e Terra, 1984.

FERNANDES, Bernardo Mançano; MOLINA, Mônica Castagna. O Campo da educação do campo. In: MOLINA, Mônica Castagna; JESUS, Sônia Mary Azevedo de (Ogs). Contribuições para a construção de um projeto de Educação do Campo. Brasília, DF: 'Articulação Nacional Por Uma Educação do Campo', 2004. (Coleção por uma Educação Básica do Campo, Nº 5). 
GEERTZ, C. A interpretação das culturas. Rio de Janeiro. Editora LTC, 1989.

O saber local. Novos ensaios em Antropologia interpretativa. Tradução de Vera Mello Joscelyne. 9ª ed. Petrópolis, RJ, Vozes, 1997.

GOHN, Maia da Glória. Movimentos e lutas sociais na história do Brasil. São Paulo, Loyola, 1995.

Movimentos sociais na contemporaneidade. Revista Brasileira de Educação v. 16 n. 47, maio-ago. 2011.

Educação, trabalho e lutas sociais. CLACSO, Consejo Latinoamericano de Ciencias Sociales 2000.

INGOLD, Tim. Estar Vivo: ensaios sobre movimento, conhecimento e descrição. Petrópolis: Vozes, 2015. Cap. 1 (pp. 25-41) e 19 (pp. 327-347).

MALINOWSKI, Bronislaw Kasper. Argonautas do pacífico ocidental: um relato do empreendimento e da aventura dos nativos nos arquipélagos da Nova Guiné-Melanésia. Prefácio de Sir james George Frazer. Traduções Anton P. Carr e Lígia Aparecida Cardieri Mendonça. Revisão de Eunice Ribeiro Durham. $2^{a}$ edição. São Paulo: Abril Cultural,1978.

MALINOWSKI, B. K. 1986 [1954]. "A coleta e a interpretação dos dados empíricos". In. E. R. DUHRAN (comp.), Malinowski, Coleção grandes Cientistas Sociais, SP., Ed. Ática, pp. 143-158.

MARCUS, George. "Etnografía en/del sistema mundo. El surgimiento de la etnografía multilocal." ALTERIDADES, 11 (22): pp. 111-127. 2001.

MEDEIROS, Edileuza Custódio Rodrigues de. Registro da atuação do movimento dos atingido por barragens nos reassentamentos de Acauã: a alfabetização de jovens e adultos. Natal, 2010.

MOVIMENTO DOS ATINGIDOS POR BARRAGEM. Org: Movimento dos Atingidos por Barragem. In: MAB. $1^{\text {a }}$ ed., Secretaria Nacional do MAB, Brasília, DF, janeiro de 2005.

NASCIMENTO, Claudemiro Godoy do. Políticas públicas e educação do campo: em busca da cidadania possível. Revista Travessia, v3, n.3. 2009.

REIS, Maria José. O Movimento dos Atingidos por Barragem: atores, estratégias de luta e conquistas. In.:Anais do II seminário nacional: Movimentos Sociais, Parti- 
cipação e Democracia, Florianópolis, 2007.

SOUZA, Edevaldo Aparecido. PEDON, Nelson Rodrigo. TERRITÓRIO E IDENTIDADE. Revista Eletrônica da Associação dos Geógrafos Brasileiros - Seção Três Lagoas Três Lagoas - MS, V 1 - n. ${ }^{\circ} 6$ - ano 4, novembro de 2007.

SANTOS, Mariana Corrêa dos. O conceito de "atingido" por barragens - direitos humanos e cidadania. Revista Direito e práxis. Rio de Janeiro, Vol. 06, N. 11, 2015, p. 113-140.

TRINDADE, G. C. MOVIMENTO DOS ATINGIDOS POR BARRAGEM. Caderno pedagógico. $2^{a}$ Edição. Org. Gestine Cássia Trindade et. Al. Tamandaí: Ísis. Brasília, DF, janeiro de 2005 .

VELSEN, J. Van. A análise situacional e o método de estudo de caso detalhado. In Antropologia das sociedades contemporâneas. São Paulo: Global, 1987. 


\title{
OS CENTROS EDUCATIVOS FAMILIARES DE FORMACAO EM ALTERNÂNCIA E A EDUCAÇO DO CAMPO
}

\author{
Aline Guterres Ferreira ${ }^{113}$ \\ José Vicente Lima Robaina ${ }^{114}$ \\ José Geraldo Wizniewsky ${ }^{115}$
}

113 Doutoranda em Educação em Ciências: química da vida e saúde (UFRGS). Mestra em Extensão Rural, Especialista em Educação Ambiental, Licenciatura Plena em Formação de Professores para Educação Profissional, Zootecnista (UFSM). Licenciada em Educação do Campo - ciências da natureza (UFRGS). alinegufe@gmail.com

114 Pós Doutorado em Educação e Educação do Campo (UFRGS), Doutor em Educação (UNISINOS), Professor do Departamento de Ensino e Currículo (FACED/UFRGS). joserobaina1326@ gmail.com

115 Doutor em Agroecología, Sociología y Estudios Campesinos, (UCO-ES), Mestre em Extensão Rural (UFSM), Professor Titular do Departamento de Educação Agrícola e Extensão Rural (CCR/UFSM).zecowiz@gmail.com 
Historicamente as populações do campo, quando não eram excluídas, sofreram para acessar o sistema educacional ofertado pelo poder público, pois a orientação pedagógica do referido sistema não contemplava as realidades e necessidades das comunidades rurais. No decorrer dos anos o sistema educacional foi disposto e orientado a transmitir e reproduzir os conteúdos programáticos urbano-centrado, ou seja, não contextualizados ao campo, sendo assim nomeado de Educação Rural. Uma educação que servia apenas como forma de alienação e dominação das populações do campo, que incentivava o êxodo rural e a desvalorização da cultura e tradições destes povos. A autora Roseli Caldart afirma que as populações do campo sempre foram reféns de políticas públicas referentes à educação de formas negligentes e que desvalorizasse o lugar e seus atores sociais. Como podemos identificar em suas palavras.

\begin{abstract}
Se levarmos em conta que na história do Brasil, toda vez que houve alguma sinalização de política educacional ou de projeto pedagógico específico isto foi feito para o meio rural e muito poucas vezes com os sujeitos do campo. Além de não reconhecer o povo do campo como sujeito da política e da pedagogia, sucessivos governos tentaram sujeitá-lo a um tipo de educação domesticadora e atrelada a modelos econômicos perversos. (CALDART, 2002, p. 19).
\end{abstract}

Nas últimas décadas, do século passado e nas primeiras do atual, a discussão sobre uma educação contextualizada, que conheça a realidade dos seus estudantes, que respeite sua cultura e que valorize suas tradições, tomou notoriedade a partir das populações do campo e se tornou presente nas instituições de ensino e pesquisa, e ainda, no poder público. Uma Educação do Campo presente fisicamente no campo e realizada em conjunto com suas populações. Não aquela educação pensada para/ na zona urbana e transferida para o meio rural, ainda, de acordo com Caldart (2002, p. 19): "trata-se de uma educação dos e não para os sujeitos do campo. Feita sim através de políticas públicas, mas construídas com os próprios sujeitos dos direitos que as exigem.".

116 Este capítulo é originário da Dissertação de Mestrado do Programa de Pós-graduação em Extensão Rural defendida em 2014 na Universidade Federal de Santa Maria (UFSM). 
Entende-se que a Educação do Campo não está restrita a uma determinada população, mas sim deve ser desenvolvida com todos os povos que se expressam no campo, como camponeses, quilombolas, indígenas, pescadores artesanais, assentados da reforma agrária, trabalhadores assalariados e tantos outros que lutam pela sua identidade cultural, humana, social, política e ambiental. Povos que possuem pluralidade étnica, geográfica, organizativa, religiosa, entre outras diversidades que se constroem as características locais e ambientais. Trazemos os traços e identidade da Educação do Campo como expressa a autora Roseli Caldart:

\begin{abstract}
Nossa proposta é pensar a Educação do Campo como processo de construção de um projeto de educação dos trabalhadores e das trabalhadoras do campo, gestado desde o ponto de vista dos camponeses e da trajetória de luta de suas organizações. Isto quer dizer que se trata de pensar a educação (política e pedagogia) desde os interesses sociais, políticos, culturais de um determinado grupo social; ou trata-se de pensar a educação (que é um processo universal) desde uma particularidade, ou seja, desde sujeitos concretos que se movimentam dentro de determinadas condições sociais de existência em um dado tempo histórico. A Educação do Campo assume sua particularidade, que é o vínculo com sujeitos sociais concretos, e com um recorte específico de classe, mas sem deixar de considerar a dimensão da universalidade: antes (durante e depois) de tudo ela é educação, formação de seres humanos. (CALDART, 2004, p.12).
\end{abstract}

Portanto, é importante desenvolver uma Educação do Campo que consiga junto aos seus estudantes problematizar a realidade, aliar a reflexão com ação tornandoos atores do seu desenvolvimento local, familiar, comunitário e que consigam unir conhecimentos escolares e técnicos com saberes empíricos.

Os Centros Educativos Familiares de Formação em Alternância (CEFFA's), em todos esses anos de atuação no Brasil e pelo mundo, possuem esses princípios e respeitam as especialidades das populações do campo. É uma alternativa de educação para os estudantes, oriundos do meio rural, suas famílias e comunidade onde as escolas estão inseridas. Visto que muitos movimentos sociais do campo não aceitam a educação descontextualizada disponível pelo poder público, e dessa forma podem constituir-se em atores dos processos de ensinos e aprendizagens de seus filhos, (FERREIRA, 2014). 
Neste capítulo, abordaremos a origem das CEFFA's, os pilares que as compõem e ainda seus princípios que caracterizam a Educação do Campo, a partir de uma apreciação bibliográfica.

\section{DA FRANCCA AO BRASIL: O CAMINHO DA MAISON FAMILIALE RURALE AO CENTRO EDUCATIVO FAMILIAR DE FORMAÇÃO EM ALTERNÂNCIA}

No interior da França, na década de 30, nascem as primeiras Maisons Familiales Rurales (MFR), a partir do diálogo entre agricultores familiares e os representantes religiosos e sindicais da região, ao perceberem o desinteresse de seus filhos à educação escolar da época, caracterizada como urbanizante e excludente. Os agricultores familiares em conjunto a esses representantes construíram uma proposta educacional de formação "fundamentada em conhecimentos da vida quotidiana e no saber que se encontra nas escolas, ou seja, enraizados pela relação entre o empírico e o científico" (Cristina Vergutz, 2013, p. 29). Livre das amarras burocráticas e não sendo refém das teorias pedagógicas tradicionais, esse grupo pensou uma formação que compartilhava responsabilidades educacionais entre os pais e as forças sociais locais. Assim construíram uma fórmula de escola baseada na Pedagogia da Alternância que promove uma partilha do poder educativo entre os atores do meio, pais e os formadores da escola, (GIMONET, 1999).

Este novo sistema educacional, portanto, aliava os estudos escolares com os afazeres da propriedade familiar. Era uma experiência educacional voltada para as necessidades dos agricultores familiares, que teria como partida os conhecimentos já existentes nas comunidades rurais e se somariam a esses os saberes escolares, sem que os filhos dos agricultores familiares fossem viver na cidade para dar continuidade aos seus estudos. O processo educacional dos estudantes estava organizado em alternar um período na Paróquia Católica da comunidade rural, tutelados pelos representantes religiosos e sindicais, e outro período retornavam às propriedades familiares, dando continuidade aos seus estudos a partir da prática e dos seus saberes cotidianos. Caracterizando uma formação em alternância e sob a responsabilidade das famílias e das organizações sociais locais, que estaria pautada na formação técnica, geral e humana em ambos os ambientes educacionais, (FERREIRA, 2014). 
A partir da década de 40 houve uma expansão das MFR's pelo território Francês e abertura da primeira Escola de Monitores, professores dessas instituições, e também da União Nacional das Maisons Familiales Rurales. Já na década de 60 este modelo educacional chega à Itália e lá são criadas as Scuola Della Famiglie Rurali, as primeiras Escolas Famílias Agrícolas. Na América Latina essas instituições escolares irmãs são reunidas pelos Centros Educativos Familiares de Formação por Alternância, que segundo o autor Costa.

A sigla CEFFA significa: Centros Educativos Familiares de Formação em Alternância. Que nesse caso congregam várias instituições que trabalham com a Pedagogia da Alternância. No caso do Brasil: As Escolas Família Agrícola, as Casas Familiares Rurais e outros Centros de Formação que se utilizam da Pedagogia da Alternância e observam seus quatro pilares: Associação Local, Alternância, Formação Integral e Desenvolvimento do Meio. (COSTA, 2012, p. 43).

Sobre as CEFFA's, a autora Luci Mary Pacheco, discorre sobre os objetivos da rede e ainda os percursos formativos dos estudantes alternantes e os ambientes percorridos no processo de aprendizagem.

Os CEFFA's são associações de famílias, profissionais e instituições que assumem a responsabilidade do desenvolvimento e da promoção do mundo rural através de ações educativas integrais e de formação profissional, como resposta a um problema comum. Para isso se baseiam na pedagogia da alternância, que implica uma aprendizagem prática a partir da experiencia no ambiente de trabalho e na sala de aula, portanto, uma continuidade de aquisição de conhecimentos obtidos através da alternância de espaço e tempo entre o mundo rural socioprofissional e a escola. (PACHECO, 2010, p. 89).

A nomenclatura CEFFA nasce em 2001 em um evento sobre Pedagogia da Alternância (PA) na Argentina, para referenciar e reunir as experiências educacionais que desenvolvem seu processo formativo a partir desta, entre elas, são as Casas Familiares Rurais (CFR's), as Escolas Famílias Agrícolas (EFA's), as Escolas Comunitárias Rurais, entre outras.

Nos anos seguintes, essas experiências educacionais são difundidas pelos cincos continentes e em 1975 em Dacar no Senegal é criada a Associação Internacional dos Movimentos Familiares de Formação Rural (AIMFR). Uma instituição representativa 
que possui objetivo de fomentar e desenvolver as instituições escolares e estabelecer relações com organismos internacionais, difundindo os princípios dos CEFFA's definidos em seus estatutos e velando por sua correta aplicação, de acordo com García-Marirrodriga e Puig-Calvó (2010).

No Brasil, em meados da década de 60 , em uma conjuntura política que se caracteriza como um governo militar-civil-empresarial, chegam as primeiras experiências de EFA's pelo sul do Estado do Espírito Santo, vinculadas ao Movimento de Educação Promocional do Espírito Santo (MEPES). Com intuito de acolher e oportunizar educação aos agricultores familiares empobrecidos pela política do intervencionismo econômico estatal que excluía a agricultura familiar em detrimento da grande empresa agrícola moderna, segundo Begmani (2002). A partir da década de 70 essas experiências são difundidas em alguns Estados brasileiros na tentativa de sanar a indisponibilidade histórica de escolas no meio rural para a população do campo. A primeira Casa Familiar Rural (CFR) nasce em solo brasileiro pelo Estado de Pernambuco, no município de Riacho das Almas, em meio a uma população do campo abandonada e esquecida pelo poder público e assolada pelos longos períodos de secas. Ainda, existem registros que experiencias pioneiras no Estado de Alagoas no início da década de 80.

Na região Sul do Brasil, as CFR's se disseminam através do Estado do Paraná no final dos anos 80 e hoje estão presentes nos três Estados do Sul. Essas instituições unificam-se através da rede da Associação Regional das Casas Familiares Rurais (ARCAFAR). Atualmente, a rede ARCAFAR é constituída pela ARCAFAR/NORTE e NORDESTE, que compreende os Estados do Pará, Amazonas e Maranhão e a ARCAFAR/Sul, que compreende os Estados do Paraná, Santa Catarina e Rio Grande do Sul. A autora Lucy Mari Pacheco destaca os objetivos que embasam essa proposta educacional no Rio Grande do Sul (RS).

Entre outros objetivos, os centros surgem como uma possibilidade de educação apropriada às necessidades sociais e históricas para conter o êxodo, desenvolver o campo, superando as condições de pobreza, abandono, entre outras mazelas existentes no campo, através de uma formação integral dos alunos e de suas famílias. (PACHECO, 2010, p. 91). 
Podem ser constatados a fidelidade aos valores e princípios das experiências precursoras do velho mundo. Mas ao chegar em terras latinas, são inevitáveis as adaptações nessas instituições escolares à realidade da construção histórica, social, econômica, cultural e ambiental do país e do continente.

As EFA's, chegam ao RS no final da primeira década do século 21, a partir da Associação Gaúcha Pró- Escolas Famílias Agrícolas (AGEFA), associação local mantenedora, filiada a União Nacional das Escolas Família Agrícolas do Brasil (UNEFAB), que de acordo com Costa (2012, p. 46) "congrega todas as associações regionais e suas EFAs todo território nacional, capacitando técnicos agrícolas ou em agropecuária em nível médio, embora algumas EFAs funcionem com ensino fundamental também.”. Ambas instituições, as CFR's e as EFA's, são filiadas a Associação Internacional dos Movimentos Familiares de Formação Rural (AIMFR), que segundo García-Marirrodriga e Puig-Calvó (2010, p. 47) "representa as diferentes Instituições promotoras de Escolas de Formação por Alternância para jovens do meio rural. [...] tem como objetivo fomentar e promover o desenvolvimento dos CEFFA no mundo.".

Com mais de duas décadas no Estado Gaúcho essas instituições escolares já demonstram contribuições significativas para o desenvolvimento das populações do campo e para o avanço e fortalecimento das construções epistemológicas da Educação do Campo, como afirma Costa.

Não resta dúvida que essa unificação de bandeira, na luta pela Pedagogia da Alternância, entre CFRs e EFAs vem promovendo o desenvolvimento de uma educação do campo, cada vez mais qualificada e voltada para as comunidades onde os estudantes estão inseridos, oportunizando a esses jovens do meio rural e suas famílias, possibilidades concretas de uma maior qualidade de vida no campo. Gerando assim, renda e desenvolvendo da forma mais eficaz possível o meio rural, valorizando o conhecimento das famílias e vizinhos, fortalecendo a agricultura familiar e as relações comunitárias através da solidariedade. (COSTA, 2012, p. 47).

São necessárias e urgentes alternativas de educação escolar às populações do campo que historicamente foram excluídas dessa rede, e quando ofertadas escolas no meio rural pelo poder público, o sistema educacional não possibilita o comprometimento e a responsabilidade com os conhecimentos das populações do campo, sua emancipação e desenvolvimento. Instituições balizadas na Pedagogia 
da Alternância permitem a qualificação dos estudantes do campo pelo acesso à uma educação de qualidade pautada na realidade das comunidades rurais e atendendo suas reais necessidades a partir da compartilha e união dos saberes e conhecimentos, para além da transmissão de conteúdos programáticos tradicionais. Para esse caminho de sucesso, devem ser respeitadas os quatro pilares de sustentação da Pedagogia da Alternância, possibilitando a organicidade do seu desenvolvimento através dos seus Instrumentos Pedagógicos, que possibilita aos estudantes do campo a opção de permanecer no campo.

\section{OS QUATRO PILARES QUE COMPÕEM OS CENTROS EDUCATIVOS FAMILIARES DE FORMAÇÃO EM ALTERNÂNCIA}

Os quatro pilares que sustentam a rede CEFFA's, são a Associação Local, a Alternância, a Formação Integral e o Desenvolvimento do Meio. Na formação inicial das MFR's, seus criadores tinham como objetivos um projeto de desenvolvimento de uma região e um projeto educativo para os adolescentes (FORGEARD, 1999). Estes quatro pilares são essenciais para uma instituição ser caracterizada como Centro Educativo Familiar de Formação em Alternância, a qual possui objetivo institucional de promoção e desenvolvimento das pessoas e do meio, através da formação integral dos sujeitos em formação. Segundo Costa (2012) os pilares que regem os CEFFA's são inegociáveis e construídos cotidianamente, a Associação Local e a Alternância, entendidas como meios para chegar às finalidades, que são a Formação Integral e o Desenvolvimento do Meio.

Associação Local é formada por todos os atores do processo educativo, tais como pais ou responsáveis dos estudantes, egressos da rede, líderes das comunidades e todos aqueles que buscam uma educação diferenciada, parceiros das instituições públicas e privadas. De acordo com Calvó (2002, p. 127): "um instrumento de solidariedade, de trabalho em grupo, de participação local, de partilha de experiências a partir dos atores locais, beneficiários do sistema". A Associação Local representa judicialmente o CEFFA's, assim é a instância administrativa que responde legalmente e adota a função de regulação dos fatores da alternância dentro e fora deste movimento. É um espaço compartilhado de gestão com participação democrática, discutindo todos os assuntos relacionados à formação pedagógica, 
gestão econômica, e a vida cotidiana dentro do CEFFA's. Espaço de participação e diálogo entre os responsáveis dos estudantes com os demais membros, como Monitores e administradores, no que tange os rumos da formação pedagógica, bem como o conhecimento das suas realidades. Costa destaca a importância de uma Associação Local gestando o CEFFA's:

\begin{abstract}
A Associação Local representa a ligação entre as demandas familiares e comunitárias dentro da escola, tencionando sempre o CEFFAa estar conectado com a realidade, para buscar construir alternativas frente às necessidades do meio em que está inserido. Desta forma o poder de decisão numa EFA recai basicamente sobre a sua Associação Local, daí a importância de os agricultores/pais estarem na vanguarda dessa instituição, para que ela tenha compromisso com os principais interessados nesse processo de ensinoaprendizado, ou seja, as famílias, juntamente com os jovens. (COSTA, 2012, p. 124).
\end{abstract}

Em relação a promoção do diálogo e da corresponsabilidade entre os atores, o autor Calvó (1999), destaca que Associação é uma organização local de base participativa, na qual as famílias, as comunidades, as instituições locais, os profissionais do setor, junto aos promotores e as pessoas presentes no meio e comprometidas com o projeto, são os responsáveis pela gestão e o desenvolvimento do meio onde ocorre os processos educativos.

Um importante pilar da rede CEFFA's é a Alternância, a qual não deve ser resumida no deslocamento tempo-espaço dos estudantes, o(a) alternante. Abreviando em um tempo na escola, no qual aprende técnicas e um tempo em casa no qual aplica essas técnicas, isto é a maneira superficial de se pensar a Alternância. GarcíaMarirrodriga e Puig-Calvó (2010) afirmam que: "a formação por alternância não pode, nem deve reduzir-se, [...], a simples relações binárias do tipo; teoria e prática.". A Pedagogia da Alternância é um processo de aprendizagens e ensinos complexo, que se origina na problematização da prática, passa pelo nível teórico reflexivo e retorna a prática com novos questionamentos. Ou seja, parte do concreto (prática), para o abstrato (conhecimento) e retorna para a prática (concreto enriquecido pelos saberes e conhecimentos).

$\mathrm{Na}$ família e comunidade, os estudantes observam, realizam pesquisas participativas diagnósticas sobre a realidade, quando retornam ao CEFFA's é o 
momento de reflexão, da análise da realidade, de comparações, generalizações e sínteses, em conjunto com Monitores e, principalmente, com seus colegas. Quando retornam à família e comunidade, é o momento de experimentar, de transformar e também de novas interrogações e pesquisas. Portanto, os estudantes tornam-se atores principais dos seus processos de aprendizagens em conjunto com os Monitores, colegas, famílias e comunidade, assim ocorrendo à construção do conhecimento.

Aalternância como uma práxis educacional, permite que os estudantes aprendam a partir dos seus conhecimentos de origem e que não tenham que se afastar do seu seio familiar, evitando assim perder o vínculo com o campo. Daí a importância dos Instrumentos Pedagógicos enquanto ferramentas que permitem um compartilhamento direto e imediato de saberes entre a família e comunidade e o CEFFA's, que mantem o diálogo para promoção efetiva da construção do conhecimento. Podemos destacar, a abertura da família e da comunidade para aquele estudante, pois são ambientes pedagógicos e devem ser explorados físicos e culturalmente. Gimonet (2002) destaca a importância aos estudantes em adentrar na realidade ambiental, econômica e social da sua unidade produtiva familiar e comunidade.

A alternância permite ao adolescente entrar no mundo dos grandes, quer dizer, no mundo dos adultos. Ela lhe dá possibilidades de encontrar um lugar, uma posição social, uma consideração, um reconhecimento. [...] ela o ajuda a encontrar e construir seu presente e, por meio dele, vislumbrar o futuro. (GIMONET, 2002, p. 121).

Está inserção social dos estudantes é consequência também, segundo Calvó (1999) da práxis da Alternância Integrativa. Nesta Alternância existe uma verdadeira colaboração, cogestão, coabitação, coação, onde o meio social/profissional intervém na escola e está intervém no meio. Com intervenção na educação - formação dos estudantes pela alternância, que não se limitam a um ou a dois atores, mas se estendem a toda complexidade do mundo que envolve a vida destes (família, amigos, trabalho, economia, cultura, escola, política...), onde nenhum dos elementos que intervêm é passivo, todos são parceiros, coautores, corresponsáveis, comprometidos.

A formação que a rede CEFFA's proporciona não é resumida a formação do ensino básico ou profissionalizante, mas sim a Formação integral, a qual abrange 
aspectos técnicos-profissionais, intelectual, humano, social, econômico, ecológico, espiritual e de cidadania. Visto que, uma das prioridades dos CEFFA's é a Formação integral da pessoa humana e seu desenvolvimento com qualidade e dignidade da vida do campo, compondo mais um de seus pilares.

Segundo Calvó (1999), a Formação Integral considera a totalidade, a integralidade da pessoa como ser humano e tudo aquilo que pode enriquecer a sua formação, considerando todos os ângulos: formação escolar, formação profissional, formação social, educação, cidadania, projeto de vida, economia, família, meio. E os elementos que intervêm na Formação integral dos estudantes pela Alternância são: família; monitores; grupo de estudantes, amigos, capacidades, programa oficial, escola, cultura local, projetos, meio social, trabalho, economia e outros. Para o mesmo autor citado, essa formação que leva em conta a totalidade dos elementos formativos, influi e colabora também na formação de todos os aspectos da pessoa humana, tais como, intelectuais, técnicos, científicos, profissionais, humanos, sociológicos, artísticos, filosóficos, econômicos, espirituais, éticos, ecológicos e outros fatores.

García-Marirrodriga e Puig-Calvó (2010, p. 62), afirmam que a Formação integral se preocupa em, "Formar pessoas em valores humanos, promotoras do desenvolvimento pessoal e coletivo, com uma capacidade de compromisso social no meio onde se encontra.". A Formação integral não se resume apenas aos muros dos CEFFA's, pela Pedagogia da Alternância, e o uso correto dos seus Instrumentos Pedagógicos, o meio familiar e comunitário também são centros pedagógicos de construção do conhecimento, segundo Caliari (2002, p. 84), "efetivada a partilha da responsabilidade da família no processo educativo do jovem [...] todas as ações são compartilhadas em comum entre escola - família - comunidade.". É um movimento interligado dos conteúdos ministrados pelos Monitores e a realidade dos estudantes, ainda de acordo com o mesmo autor (2002, p. 83), "O jovem vai estudar tanto na família como na escola e a cada tema investigado há um encadeamento lógico do assunto com os conteúdos das outras disciplinas.". A Formação Integral se desenvolve em vários espaços junto a rede CEFFA's, em conjunto com os respectivos atores do processo educativo, tais como pais, familiares, comunidade, instituições, parceiros e sociedade, os quais também são responsáveis pela construção pedagógica e 
humana dos estudantes.

De acordo com Nascimento (2005), a educação e Formação Integral dos estudantes, além da formação geral e profissional leva em consideração todas as dimensões da pessoa humana, buscando descobrir, valorizar e desenvolver as capacidades de cada jovem, num tratamento personalizado, através do espírito da iniciativa, criatividade, trabalho de grupo, senso de responsabilidade e de solidariedade, ajudando a construir o projeto de vida/profissional junto com a família e o meio em que vive. E a partir desta Formação Integral, o egresso da rede CEFFA's é capaz de transformar sua realidade.

O último pilar que sustenta a rede CEFFA's, para assim caracterizá-la, é o Desenvolvimento do Meio. Este deve inicialmente resgatar as identidades dos estudantes como pertencentes àquele meio social, comunitário e familiar, bem como de todos os atores do processo educativo, como se observa na autora Vergutz (2013, p. 70): "traduz num trabalho de reconhecimento e valorização do sujeito, da sua família, da sua comunidade [...] de todas as relações que possibilitem este ou esta jovem atuarem e refletir valorizando os saberes locais." Desde o nascimento deste sistema educacional, uma de suas finalidades era o desenvolvimento de uma região através de um projeto educativo para os estudantes.

O Desenvolvimento do Meio respeita a abrangência da rede CEFFA's, no que tange ao meio geográfico, populacional, cultural, religioso, que possuem maior diversidade de culturas e a sua reprodução. Após o reconhecimento dos estudantes como pertencentes a este meio, é desenvolvido sua percepção do meio como um todo, não apenas o desenvolvimento econômico, quebrando o pensamento fragmentado e limitado apenas nas questões monetárias. O Desenvolvimento do Meio perpassa pelas questões sociais, ambientais, econômicas, culturais, ecológicas e religiosas daquela região. É distinto da lógica mercadológica de desenvolvimento, onde a degradação e contaminação ambiental pelo excessivo uso de maquinários, implementos agrícolas e o abuso de fertilizantes sintéticos e agrotóxicos é mitigado pelos altos índices de produtividade. Ainda, são refletidas a histórica exclusão das populações do campo pela negligência de políticas públicas e serviços básicos, (FERREIRA, 2014).

A rede CEFFA's preconiza o Desenvolvimento do Meio a partir da congregação 
dos saberes tradicionais de origem das populações do campo aos conhecimentos técnicos científicos escolares, dos parceiros e instituições que integram os atores do processo educativo e são responsáveis pela Formação Integral dos estudantes. Portanto, o desenvolvimento de uma agricultura responsável, que tenha menor impacto negativo no ambiente e na sociedade e que saiba harmonizar o desenvolvimento produtivo com a preservação ambiental. Como cita o autor Nascimento.

O CEFFA, através da educação, busca contribuir para o Desenvolvimento Local Sustentável Solidário, através da formação dos jovens, suas famílias e demais atores envolvidos, tendo como enfoque principal o fortalecimento da agricultura familiar e inserção profissional e empreendedora dos jovens no meio rural. (NASCIMENTO, 2005, p. 24).

Portanto, é entendido o Desenvolvimento do Meio em conjunto a formação pedagógica e humana dos estudantes dessas escolas do campo. Calvó (1999, p. 24) destaca "que o Desenvolvimento local através da ação educativa dos jovens e adultos, fazendo deles os verdadeiros atores do progresso, como elemento necessário, podemos encará-lo, como um meio, mas também como um fim, um objetivo.". A partir destes quatro pilares, pode-se definir um CEFFA e suas contribuições à realidade dos estudantes, famílias e comunidades. Esses quatro pilares devem ser respeitados e desenvolvidos interligados para conhecer e, se necessário, transformar a realidade ao seu redor.

\section{CONSIDERAÇÕES FINAIS}

Quando analisado a oferta escolar para as populações do campo, nos defrontamos com a exclusão escolar, currículos descontextualizados e o constante fechamento de escolas no meio rural. O debate sobre essas questões levou a inúmeros avanços, tais como a proposição teórico metodológico da Educação do Campo, a qual possui sua gênese na Pedagogia da Alternância, no Brasil. Nascida no velho mundo, na França, essa proposta educacional chega em terras Latinas em uma conjuntura inóspita aos contextos sociais e ambientais, apesar disso, sua difusão ocorre na maioria dos Estados brasileiro. Na atualidade, essas experiências propiciaram contribuições importantes à formação integral dos estudantes do campo e ao desenvolvimento do meio das comunidades onde estão inseridas, a partir da 
organização da associação local e a práxis teórico metodológico da pedagogia da alternância.

Essas são caracterizadas como Centros Educativos de Formação em Alternância que coadunam os conteúdos escolares aos conhecimentos das populações do campo, ressignificando a educação e tornando-a mais significativa aos estudantes, famílias e comunidades rurais. Ainda, compartilham a responsabilidade educacional entre os atores sociais que refletem a importância de uma educação contextualizada e compatível com as necessidades e realidades das populações do campo. Reconhecem outros espaços de educação para além dos muros da escola, valorizando e considerando os processos educacionais no ambiente familiar e comunitário.

Entendemos que essas experiências educacionais contribuem na oferta e desenvolvimento da educação às populações do campo, pois essas constituem seu processo educacional junto aos conhecimentos dessas, ressignificando e tornandoos curricular.

\section{REFERÊNCIAS}

BEGMANI, João Batista. Experiência das Escolas Famílias Agrícolas - EFAs do Brasil. In: Pedagogia da Alternância: Formação em Alternância e Desenvolvimento Sustentável. II Seminário Internacional da Pedagogia da Alternância. Brasília: União Nacional das Escolas Famílias Agrícolas-UNEFAB, 2002, p.106 - 117.

CALDART, Roseli Salete. Por uma Educação do Campo: traços de uma identidade em construção. In: KOLLING Edgar Jorge, CERIOLI Paulo Ricardo e CALDART, Roseli Salete, (Orgs.). Educação do Campo: identidade e políticas públicas. Brasília: Articulação nacional por uma educação do campo, 2002. (Coleção Por Uma Educação do Campo, n. $\left.{ }^{\circ} 4\right)$.

CALDART, Roseli Salete. Elementos para construção do projeto político e pedagógico da educação do campo. In: MOLINA, Mônica Castagna e JESUS, Sônia Meire Santos Azevedo (Orgs.). Contribuições para a construção de um projeto de Educação do Campo. Brasília: Articulação nacional por uma educação do campo, 2004. (Coleção Por Uma Educação do Campo, n 5).

CALIARI, Rogério Omar. Pedagogia da Alternância e Desenvolvimento Local. Lavras: UFLA, 2002. 
CALVÓ, Pedro Puig. Centros Familiares de Formação em Alternância. In: Pedagogia da Alternância: Alternância e Desenvolvimento. Primeiro Seminário Internacional. Salvador: UNEFAB, $2^{\mathrm{a}}$ ed. 1999.

CALVÓ, Pedro Puig. Formação Pessoal e Desenvolvimento Local. In: Pedagogia da Alternância: Formação em Alternância e Desenvolvimento Sustentável. Segundo Seminário Internacional da Pedagogia da Alternância. Brasília: União Nacional das Escolas Famílias Agrícolas do Brasil-UNEFAB, 2002.

COSTA, João Paulo Reis. Escola Família Agrícola de Santa Cruz do Sul - EFASC: uma contribuição ao desenvolvimento da região do Vale do Rio Pardo a partir da pedagogia da alternância. 225 f. Dissertação (Mestrado em Desenvolvimento Regional) - Universidade de Santa Cruz do Sul, 2012.

FERREIRA, Aline Guterres. A formação através da Pedagogia da Alternância em Agroecologia: um estudo de caso da Escola Família Agrícola de Santa Cruz do Sul, RS. 2014. Dissertação (Mestrado em Extensão Rural). Universidade Federal de Santa Maria, Santa Maria, 2014.

FORGEARD, Gilbert. Alternância e Desenvolvimento do Meio. In: Pedagogia da Alternância: Alternância e Desenvolvimento. Primeiro Seminário Internacional. Salvador: União Nacional das Escolas Famílias Agrícolas-UNEFAB. 2ª ed. 1999.

GARCÍA-MARIRRODRIGA, Roberto e PUIG-CALVÓ, Pedro. Formação em alternância e desenvolvimento local: o movimento educativo dos Ceffa no mundo. Belo Horizonte: O Lutador, 2010.

GIMONET, Jean-Claude. Nascimento e desenvolvimento de um movimento educativo: as Casas Familiares Rurais de Educação e Orientação. In: Pedagogia da Alternância: Alternância e Desenvolvimento. Primeiro Seminário Internacional. Brasília: União Nacional das Escolas Famílias Agrícolas-UNEFAB, $2^{a}$ ed. 1999.

GIMONET, Jean-Claude. Adolescência e alternância. In: Pedagogia da Alternância: Formação em Alternância e Desenvolvimento Sustentável. Segundo Seminário Internacional da Pedagogia da Alternância. Brasília: União Nacional das Escolas Famílias Agrícolas do Brasil-UNEFAB, 2002.

NASCIMENTO, Claudemiro Godoy. A educação camponesa como espaço de resistência e recriação da cultura: um estudo sobre as concepções e práticas educativas da Escola Família Agrícola de Goiás. Dissertação (Mestrado em Educação). Universidade Estadual de Campinas. Campinas. 2005. 
PACHECO, Luci Mary Duso. Práticas Educativas Escolares de Enfrentamento da Exclusão Social no Meio Rural: A Pedagogia da Alternância e a Casa Familiar Rural em Frederico Westphalen. Dissertação (Mestrado em Educação). Universidade do Vale do Rio dos Sinos (UNISINOS). São Leopoldo. 2010.

Vergutz, Cristina Luisa Bencke. Aprendizagens na Pedagogia da Alternância da Escola Família Agrícola de Santa Cruz do Sul. Dissertação (Mestrado em Educação). Universidade de Santa Cruz do Sul (UNISC). Santa Cruz do Sul, p. 174. 2013. 


\section{SOBRE OS ORGANIZADORES \\ ANE CARINE MEURER}

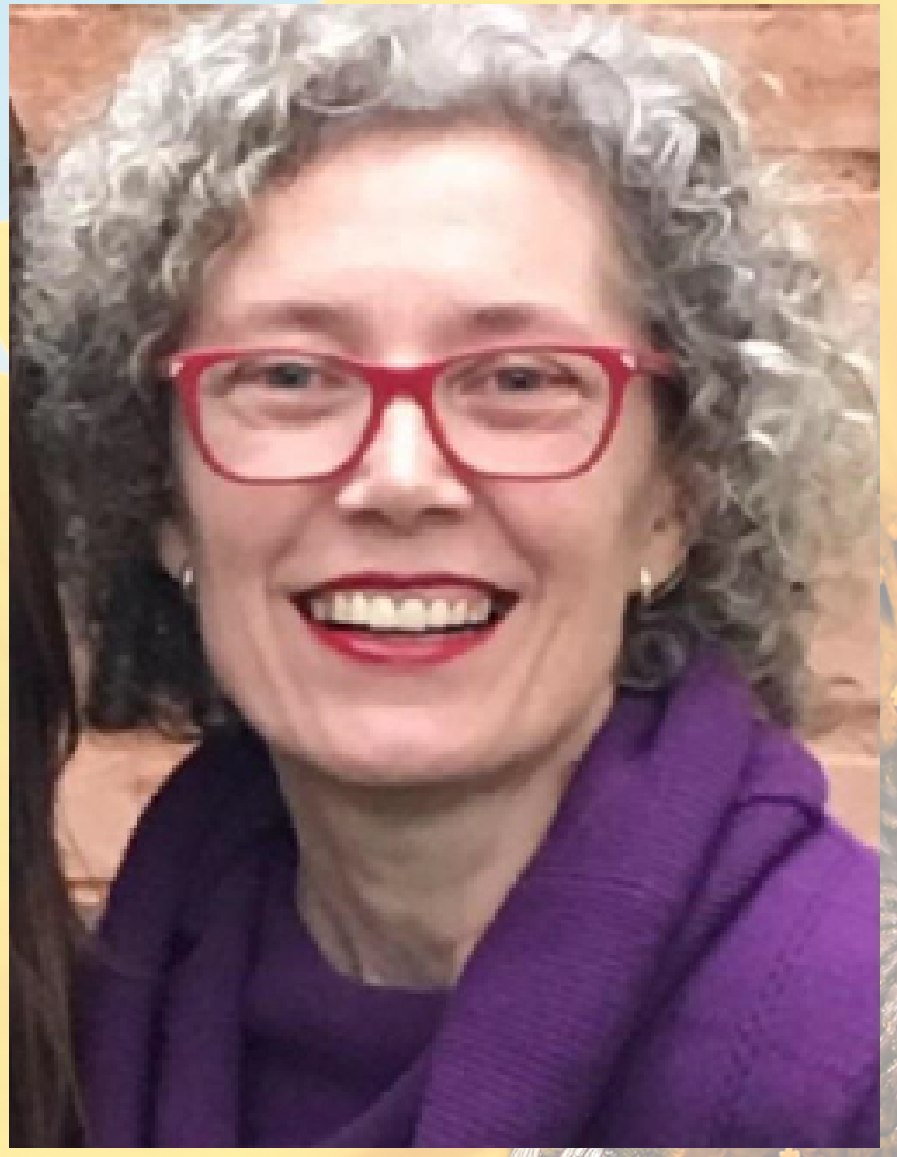

Possui Graduação em Pedagogia pela Faculdade de Filosofia Ciências e Letras Dom Bosco (1987), Mestrado em Educação nas Ciências pela Universidade Regional do Noroeste do Estado do Rio Grande do Sul (1997) e Doutorado em Educação pela Universidade Federal da Bahia (2003). Atualmente é professor da Universidade Federal de Santa Maria, atuando como Diretora do Centro de Educação da UFSM. Tem experiência na área de Educação, com ênfase em Educação e Movimentos Sociais, atuando principalmente nos seguintes temas: Educação, Educação do Campo, Projeto Político-Pedagógico, e Formação de Professores. 


\section{IVANIO FOLMER}

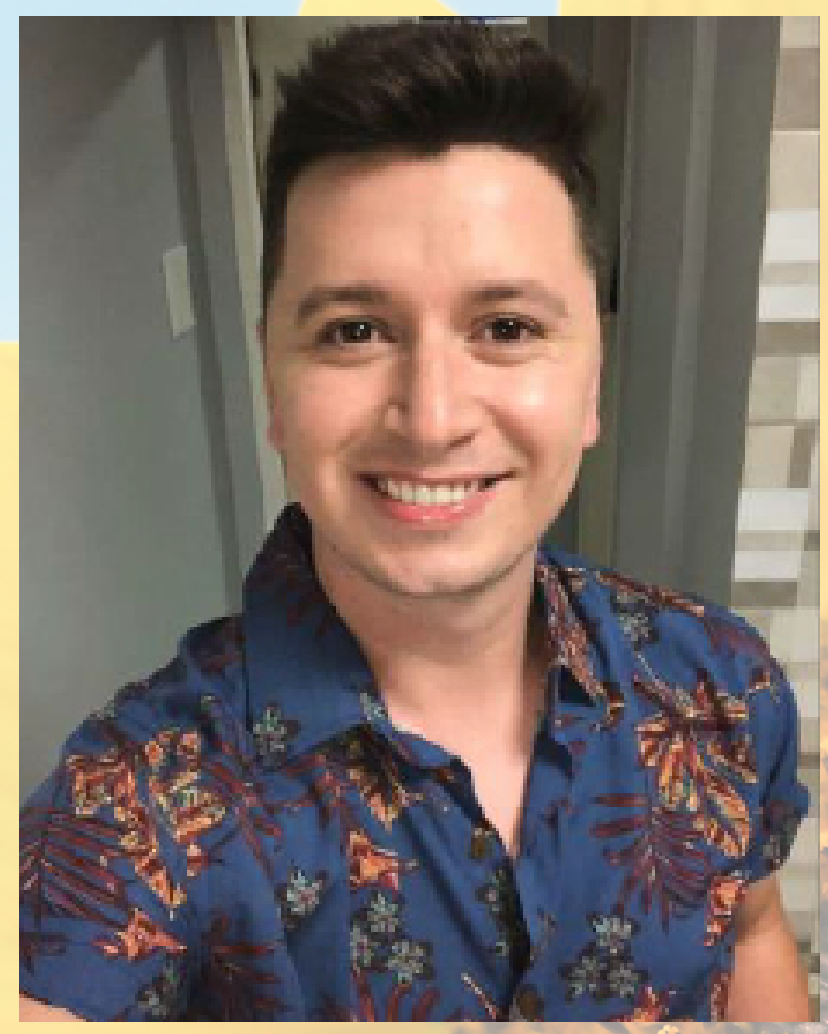

Graduado em Geografia Licenciatura pela Universidade Federal de Santa Maria (2014). Mestre em Geografia pelo Programa de Pós Graduação em Geografia-PPGGEO/UFSM (2018). Doutorando em Geografia-PPGGEO/UFSM com previsão de término em 2022. Participante de diversos projetos de pesquisa e extensão, com as temáticas de Educação no campo; Educação Ambiental; Gênero e sexualidade; Mortalidade Infantil; Catadores e Memória e Patrimônio Cultural. É professor da Rede Estadual do RS na Área das Humanas - Componente Curricular: Geografia. Tutor EAD no Curso Licenciatura em Educação do Campo UAB/UFSM desde 2018. Integrante do Grupo de Pesquisa em Educação e Território- GPET. 


\section{RICARDO SANTOS DE ALMEIDA}

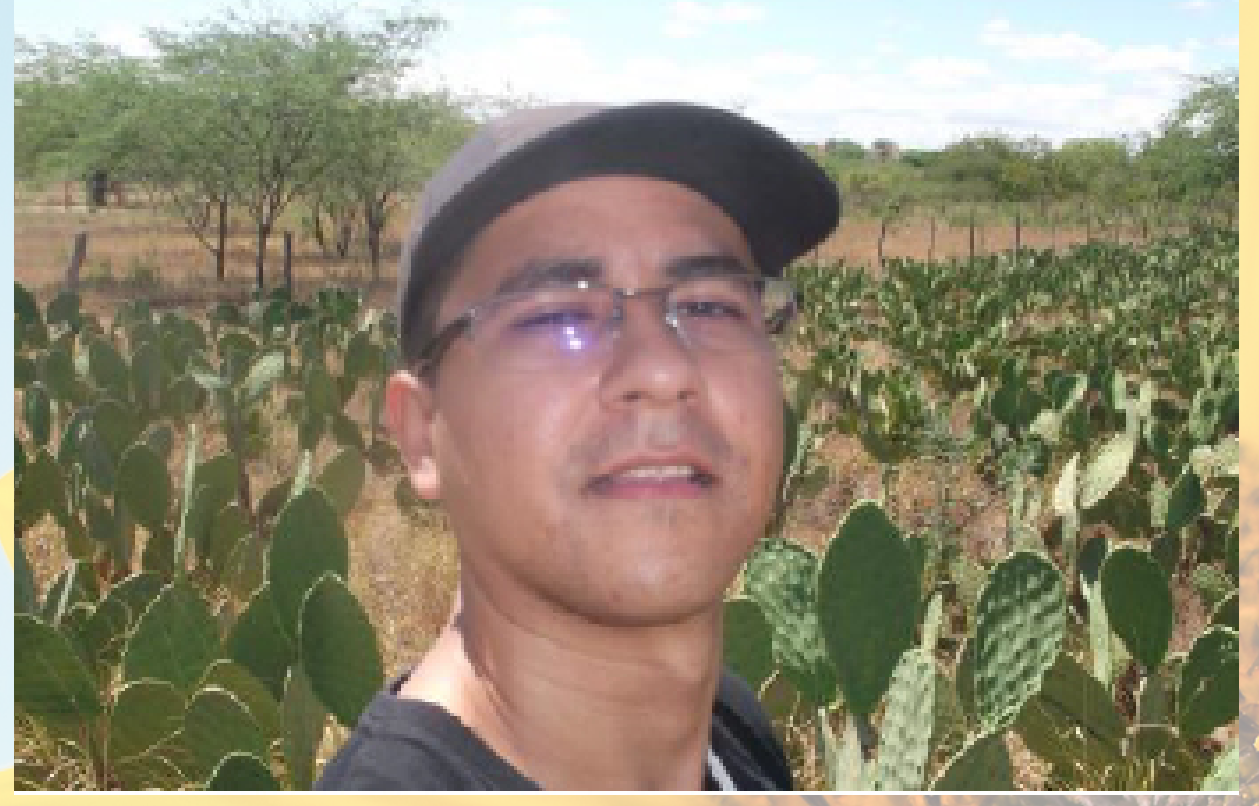

Mestrado: Geografia pela UFS (2016). Especializações: Práticas Assertivas da Educação Profissional Integrada à Educação de Jovens e Adultos - com Ênfase em Didática pelo IFRN (2020), Geografia Humana e Econômica pela UNINTER (2019), Administração Pública pela UCAM (2016); Geografia e Meio Ambiente pela UCAM (2014); Educação do Campo pela UCAM (2013); Formação para a Docência do Ensino Superior (2011). Graduações: Pedagogia pela UNINTER (2018), Geografia Licenciatura pela UFAL (2014), Gestão de Pequenas e Médias Empresas pela FAA (2009). Desenvolve pesquisas relacionadas às temáticas: agronegócio, território e territorialidades, processos de ensino-aprendizagem em Geografia e Educação do/no campo. Docente da rede pública de Porto Calvo/AL e da Educação Básica Técnica e Tecnológica Substituto de Geografia no Instituto Federal de Educação, Ciência e Tecnologia de Alagoas Campus Marechal Deodoro. Pesquisador do: Núcleo de Estudos Agrários e Dinâmicas Territoriais (NUAGRÁRIO/UFAL) desde 2009; Grupo de Estudos e Pesquisa em Análise Regional (GEPAR/UFAL); Geoprocessamento e a Cartografia no Ensino de Geografia (GCEG/UFAL) desde 2016; e Núcleo de Pesquisa e Extensão em Educação de Jovens, Adultos e Idosos e Campesinos (NUPEEJAIC/UNEAL) desde 2020. E-mail: ricardosantosal@gmail.com. 


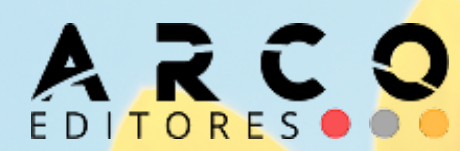

(i) an-

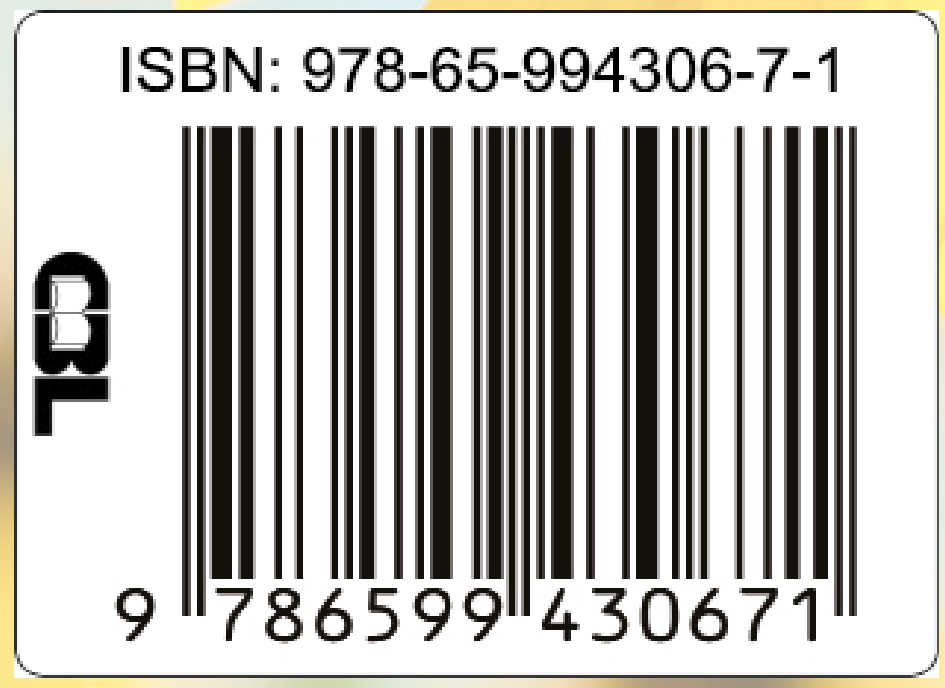

